\title{
Zorg voor zelfstandigheid : verslag van een studie over de zorg voor zelfstandigheid in verzorgingshuizen en het bevorderen van die zorg
}

Citation for published version (APA):

Kardol, M. J. M. (2004). Zorg voor zelfstandigheid : verslag van een studie over de zorg voor zelfstandigheid in verzorgingshuizen en het bevorderen van die zorg. [Doctoral Thesis, Maastricht University]. Universiteit Maastricht. https://doi.org/10.26481/dis.20041104mk

Document status and date:

Published: 01/01/2004

DOI:

10.26481/dis.20041104mk

Document Version:

Publisher's PDF, also known as Version of record

Please check the document version of this publication:

- A submitted manuscript is the version of the article upon submission and before peer-review. There can be important differences between the submitted version and the official published version of record. People interested in the research are advised to contact the author for the final version of the publication, or visit the DOI to the publisher's website.

- The final author version and the galley proof are versions of the publication after peer review.

- The final published version features the final layout of the paper including the volume, issue and page numbers.

Link to publication

\footnotetext{
General rights rights.

- You may freely distribute the URL identifying the publication in the public portal. please follow below link for the End User Agreement:

www.umlib.nl/taverne-license

Take down policy

If you believe that this document breaches copyright please contact us at:

repository@maastrichtuniversity.nl

providing details and we will investigate your claim.
}

Copyright and moral rights for the publications made accessible in the public portal are retained by the authors and/or other copyright owners and it is a condition of accessing publications that users recognise and abide by the legal requirements associated with these

- Users may download and print one copy of any publication from the public portal for the purpose of private study or research.

- You may not further distribute the material or use it for any profit-making activity or commercial gain

If the publication is distributed under the terms of Article $25 \mathrm{fa}$ of the Dutch Copyright Act, indicated by the "Taverne" license above, 


\section{ZORG VOOR ZELFSTANDIGHEID}

Verslag van een studie over de zorg voor zelfstandigheid in verzorgingshuizen en het bevorderen van die zorg 
Kardol, Martinus Josephus Maria

Ontwerp kaft: Adri Frigge, St.Oedenrode

Grafische vormgeving: Eva Frigge en Martijn van Lanen

Zorg voor zelfstandigheid: Verslag van een studie over de zorg voor zelfstandigheid in verzorgingshuizen en het bevorderen van die zorg.

Maastricht: Universiteit Maastricht, Faculteit Gezondheidswetenschappen

Proefschrift Universiteit Maastricht.

Met samenvatting in het Engels.

ISBN 90-9018593-3

Drukkerij: Gianotten B.V., Tilburg

Tinie Kardol, Maastricht, 2004. Alle rechten voorbehouden, Niets uit deze uitgave mag worden verveelvoudigd, opgeslagen in een geautomatiseerd gegevensbestand, of openbaar gemaakt, in enige vorm of op enige wijze, hetzij electronisch, mechanisch, door fotokopieën, opnamen, of op enige andere manier, zonder voorafgaande schriftelijke toestemming van de auteur. 


\section{ZORG VOOR ZELFSTANDIGHEID}

Verslag van een studie over de zorg voor zelfstandigheid in verzorgingshuizen en het bevorderen van die zorg.

\section{Proefschrift}

ter verkrijging van de graad van doctor aan de Universiteit Maastricht, op gezag van de Rector Magnificus, Prof. mr. G.P.M.F. Mols volgens het besluit van het College van Decanen, in het openbaar te verdedigen op donderdag 4 november 2004 om 16.00 uur

door

Martinus Josephus Maria Kardol 


\section{Promotoren:}

Prof. dr. G.A.M. Widdershoven

Prof. mr. F.C.B. van Wijmen

\section{Copromotor:}

Dr. N. Sijben

\section{Beoordelingscommissie:}

Prof. dr. C. Spreeuwenberg (voorzitter)

Dr. T.A. Abma

Prof. dr. J.J.M. van Delden (Universiteit Utrecht)

Mr. dr. J.C.J. Dute

Prof. dr. J.M.G.A. Schols (Universiteit van Tilburg) 


\section{Inhoudsopgave}

$1 \quad$ Inleidend hoofdstuk 9

1.1 Inleiding 9

$\begin{array}{lll}1.2 & \text { De anleiding voor deze studie } & 10\end{array}$

1.3 De opbouw van deze studie 11

$2 \quad$ Ouderdom: status of stigma? $\quad 18$

$\begin{array}{lll}2.1 & \text { Inleiding } & 18\end{array}$

2.2 Oud en ouderdom 20

$2.3 \quad$ Ouderen en hun gezondheid 21

$2.4 \quad$ Maatschappelijke participatie van ouderen 25

2.4.1 Arbeidsparticipatie 26

2.4.2 Participatie op sociaal, cultureel en recreatief gebied 30

2.4.3 Participatie en persoonlijke kenmerken van ouderen 31

2.5 De sociale positie van ouderen 33

2.6 Van ontparticipatie naar herparticipatie $\quad 37$

2.7 Beschouwing 40

$3 \quad$ Het verzorgingshuis: plaats voor zorg en voor zelfstandigheid 42

3.1 Ontstaan en positionering van het verzorgingshuis 42

$3.2 \quad$ Kenmerken van het verzorgingshuis 51

3.2.1 Het verzorgingshuis als instituut 51

3.2.2 Het verzorgingshuis als werkgever $\quad 54$

$3.3 \quad$ Verzorgingshuizen: capaciteit en vraag 56

3.3.1 Ontwikkeling van verzorgingshuiscapaciteit 56

3.3.2 Vraag naar het verzorgingshuis: wachtlijsten en wachttijden $\quad 59$

3.4 De bewoner van het verzorgingshuis 61

3.5 Beschouwing 65

$4 \quad$ Versterking van de positie van de bewoner in het verzorgingshuis $\quad 68$

4.1 Van aanbodgestuurde naar vraaggestuurde zorg 68

$\begin{array}{lll}4.2 & \text { Kwaliteit van zorg } & 71\end{array}$

4.3 De positie van de zorgvrager $\quad 74$

4.4 Verwachting en beleving van het verblijf van bewoners in $\begin{array}{ll}\text { verzorgingshuizen } & 80\end{array}$

4.4.1 Verwachting van het verblijf $\quad 80$

4.4.2 Beleving van het verblijf 83

$\begin{array}{lll}4.5 & \text { Beschouwing } & 86\end{array}$ 
$5 \quad$ Zorg voor zelfstandigheid: een begripsbepaling $\quad 88$

5.1 Zelfredzaamheid en zelfstandigheid 88

5.2 Zorg voor autonomie: een gezondheidsethische omschrijving 91

$\begin{array}{lll}5.2 .1 & \text { Autonomie en vrijheid } & 92\end{array}$

5.2.1.1 Autonomie als negatieve vrijheid 93

5.2.1.2 Autonomie als positieve vrijheid door kritische reflectie 97

5.2.1.3 Autonomie als positieve vrijheid door voorbewuste betekenisgeving 101

5.3 Zorg voor zelfbeschikking: een gezondheidsrechtelijke benadering 105

$\begin{array}{lll}5.4 & \text { Beschouwing } & 109\end{array}$

6 Zorg voor zelfstandigheid: een praktische invulling 112

6.1 Inleiding 112

6.2 Belevingsgerichte zorg en levensfasegeoriënteerde zorg: persoonsgerichte zorgbenaderingen 113

$\begin{array}{lll}\text { 6.2.1 Belevingsgerichte zorg } & 114\end{array}$

$\begin{array}{lll}6.2 .2 & \text { Levensfasegeoriënteerde zorg } & 118\end{array}$

6.3 Responsieve evaluatie: het opkomen voor zorg voor zelfstandigheid 122

6.3.1 Responsieve evaluatie: herkomst, uitgangspunten, methode en toepassingen 124

$\begin{array}{lll}6.4 & \text { Beschouwing } & 128\end{array}$

$7 \quad$ Zorg voor zelfstandigheid: probleemstelling en methode van $\quad 130$

$\begin{array}{lll}7.1 & 130\end{array}$

$\begin{array}{lll}7.2 & \text { Probleemstelling } & 131\end{array}$

$\begin{array}{lll}7.3 & \text { Methodologische context } & 132\end{array}$

7.3.1 Het onderzoeksontwerp: kwantitatief en kwalitatief onderzoek 135

$\begin{array}{lll}7.4 & \text { Het onderzoeksproces } & 138\end{array}$

$\begin{array}{lll}7.4 .1 & \text { Inleiding } & 138\end{array}$

$\begin{array}{ll}7.4 .2 & \text { Onderzoekslocatie en respondenten } \\ 7.4 .3\end{array}$

$\begin{array}{lll}7.4 .3 & \text { Onderzoeksopzet en -uitwerking } & 142\end{array}$

$\begin{array}{lll}7.4 .4 & \text { De gegevensverwerking } & 156\end{array}$

$\begin{array}{lll}7.5 & \text { Beschouwing } & 157\end{array}$

$8 \quad$ Zorg voor zelfstandigheid: "Ik wou dat ik wat mankeerde"! 159

8.1 Resultaten van interviews met bewoners 159

8.1.1 Motieven voor verhuizing naar het verzorgingshuis $\quad 159$

$\begin{array}{ll}8.1 .2 & \text { Verwachtingen van het verzorgingshuis } \\ 8.3 & 160\end{array}$

$\begin{array}{lll}8.1 .3 & \text { Informatievoorziening } & 162\end{array}$ 
8.1.4 Kwaliteit van leven in het verzorgingshuis 165

8.1.5 Zorgvragen en beoordeling van het zorgaanbod 167

8.1.6 Houding van de verzorgenden 168

8.1.7 Keuzevrijheid bij regels en gewoonten van het verzorgingshuis 169

$\begin{array}{lll}\text { 8.1.8 De resultaten nader beschouwd } & 170\end{array}$

8.2 Resultaten van het enquête-onderzoek onder het verzorgend personeel 174

$\begin{array}{lll}\text { 8.2.1 Verwachtingen van het verzorgingshuis } & 174\end{array}$

$\begin{array}{lll}8.2 .2 & \text { Informatievoorziening } & 175\end{array}$

$\begin{array}{lll}\text { 8.2.3 Kwaliteit van leven in het verzorgingshuis } & 177\end{array}$

8.2.4 Zorgvragen en beoordeling van het zorgaanbod $\quad 177$

$\begin{array}{ll}\text { 8.2.5 Houding van de verzorgenden } & 178\end{array}$

8.2.6 Keuzevrijheid bij regels en gewoonten van het verzorgingshuis 179

$\begin{array}{lll}\text { 8.2.7 De resultaten nader beschouwd } & 180\end{array}$

8.3 Vergelijking van de resultaten van de interviews met bewoners met de resultaten van de enquête onder het verzorgend personeel 182

$\begin{array}{lll}\text { 8.3.1 Verwachtingen } & 182\end{array}$

$\begin{array}{lll}\text { 8.3.2 Informatievoorziening } & 184\end{array}$

8.3.3 Kwaliteit van leven in het verzorgingshuis 185

8.3.4 Zorgvragen en beoordeling van het zorgaanbod 187

$\begin{array}{lll}\text { 8.3.5 Houding van de verzorgenden } & 187\end{array}$

$\begin{array}{lll}\text { 8.3.6 Keuzevrijheid bij regels en gewoonten } & 191\end{array}$

8.4 De resultaten nader beschouwd 193

9 Responsieve evaluatie en een persoonsgerichte zorgregistratie voor een dialogische zorgrelatie

$\begin{array}{lll}9.1 & 197\end{array}$

$\begin{array}{lll}9.2 & \text { Responsieve evaluaties } & 198\end{array}$

9.2.1 Verloop van de eerste ronde responsieve evaluatie 199

9.2.2 Verloop van de tweede ronde responsieve evaluatie 204

$\begin{array}{lll}9.3 & \text { Persoonsgerichte zorgregistratie } & 211\end{array}$

9.3.1 Overzicht Zorgafspraken: blauwdruk of persoonsgericht document? 212

$\begin{array}{lll}9.3 .2 & \text { Invoering van persoonsgerichte zorgregistratie } & 214\end{array}$

$\begin{array}{lll}9.4 \text { Beschouwing } & 219\end{array}$

10 Zorg voor zelfstandigheid in verzorgingshuizen: resultaten na interventies

10.1 Opvattingen van verzorgenden over afdelingsomstandigheden 224

10.1.1 Toename van de behoefte aan zorg: opvattingen en feiten 225

10.2 Informatievoorziening 229

$\begin{array}{lll}10.3 & \text { Regievoering in het verzorgingshuis } & 234\end{array}$ 
10.4 Houding van de verzorgenden 242

10.5 De resultaten nader beschouwd 251

11 Beschouwing, conclusies en aanbevelingen 256

$\begin{array}{lll}11.1 & \text { Inleiding } 256\end{array}$

$\begin{array}{ll}11.2 & \text { Literatuurbevindingen } \\ 11.3 & 256\end{array}$

$\begin{array}{lll}11.3 & \text { Onderzoeksbevindingen } & 260\end{array}$

$\begin{array}{lll}11.4 & \text { Beperkingen van de studie } & 267\end{array}$

$\begin{array}{lll}11.5 & \text { Aanbevelingen } & 268\end{array}$

$\begin{array}{ll}\text { Summary } & 271\end{array}$

$\begin{array}{ll}\text { Samenvatting } & 276\end{array}$

Dankwoord 282

$\begin{array}{ll}\text { Curriculum Vitae } & 284\end{array}$

$\begin{array}{ll}\text { Literatuurlijst } & 285\end{array}$

Bijlagen:

1 Vragenlijst voor de bewoners van verzorgingsafdelingen 299

$2 \quad$ Vragenlijst voor het verzorgend personeel 311

3 Overzicht Zorgafspraken en handleiding $\quad 319$ 
"Bent U streng meneer?" Met deze vraag werd ik enige jaren geleden geconfronteerd tijdens mijn kennismaking met de cliěntenraad van een zorginstelling voor ouderen. De mevrouw die deze vraag stelde, wilde zien te achterhalen wie die meneer was die solliciteerde naar de functie van algemeen directeur. De vraag overviel me. "Hoe bedoelt u, mevrouw ?", reageerde ik. "Nou gewoon", was het antwoord, "wat mogen we van u wel en wat niet; waar vindt u dat wij ons aan te houden hebben?" "Maar dat bepaalt u toch zelf", zei ik met een licht verontwaardigde ondertoon, "de mensen wonen hier toch in deze huizen en zij geven toch zelf richting aan hun leven. $\mathrm{U}$ als cliêntenraad en de mensen die hier werken kunnen hen daarbij helpen". De instemmende blikken die ik verwachtte, bleven uit. Veeleer bespeurde ik aarzelingen om verder op dit onderwerp in te gaan.

\section{$1.1 \quad$ Inleiding}

De tijd dat de zorgaanbieder bepaalt wat goed is voor de zorgvrager zou achter ons moeten liggen. Vraaggestuurd en vraaggericht werken zijn sinds enige jaren de slogans geworden: de zorgvrager regisseert de zorg en de zorgaanbieder zal zich moeten inspannen de kwaliteit van zorg op een dusdanig peil te brengen dat hij zich in de markt prijst en de strijd om de klant in zijn voordeel beslist; de zorg zal ook op maat van de individuele vrager gesneden moeten zijn. Maar zorg is vooralsnog een schaars goed. Zolang er lange wachtlijsten bestaan heeft de zorgvrager niet de mogelijkheid een vrije keuze uit aanbieders te maken en wordt de zorgaanbieder niet geprikkeld zijn concurrenten de loef af te steken. Zolang de kosten voor intramurale ouderenzorg collectief gefinancierd blijven, zal, zeker ook met het oog op de sterke vergrijzing van onze samenleving, het beroep op deze zorg alleen maar toenemen. Van overheidswege zijn en worden initiatieven genomen om deze 'bezwaarlijke' omstandigheden weg te nemen. De zorgarrangementen die ouderen thuis kunnen krijgen, en die zij met een persoonsgebonden budget zouden kunnen inkopen, zijn verder gedifferentieerd. De noodzaak van plaatsing van ouderen in een verzorgingshuis wordt hierdoor enigszins weggenomen. Om de kosten te beteugelen wordt tegelijkertijd bezien of bepaalde diensten collectief gefinancierd moeten blijven. Ook de regulering van zorg en aan zorg gerelateerde diensten gaat veranderen door de Wet Maatschappelijke Ondersteuning. Een wet waarmee de lokale overheden een belangrijke verantwoordelijkheid krijgen toebedeeld ten aanzien van de zelfstandigheid van haar burgers.

Aan de zorg voor zelfstandigheid van de ouderen die in verzorgingshuizen verblijven, heeft de overheid ook impulsen gegeven, namelijk door wetgeving die voorschrijft aan welke eisen de kwaliteit van intramurale zorg moet voldoen en door wetgeving die de rechtspositie van de zorgvrager versterkt. Deze studie richt zich op de vraag welke invulling hieraan gegeven wordt en gegeven zou kunnen worden. 
In dit inleidend hoofdstuk wordt achtereenvolgens ingegaan op de aanleiding voor en de opbouw van deze studie. Tegen de achtergrond van de ontwikkelingen die hierboven kort zijn geschetst, wordt in paragraaf 1.2 de vraag opgeworpen waarom ouderen in verzorgingshuizen niet de regie over de zorg in handen nemen, zoals uit de inzet van dit hoofdstuk naar voren komt. Tevens wordt de probleemstelling van deze studie geformuleerd. In paragraaf 1.3 worden de verschillende hoofdstukken van deze studie beknopt toegelicht.

\subsection{De aanleiding voor deze studie}

Hoe komt het dat een bewoner van midden tachtig jaar zich zo afhankelijk opstelt en dat haar vraag naar instellingsregels begrip ontmoet bij haar medebewoners? Hoe kan iemand met zoveel levenservaring willen weten wat zij wel en niet mag doen in haar eigen woonen leefsituatie? In het verzorgingshuis worden ouderen geplaatst die ondersteuning nodig hebben bij algemeen dagelijkse levensverrichtingen, of bij huishoudelijk werk, maar die wilsbekwaam zijn en het recht hebben over hun eigen leven te beschikken. Maken zij geen gebruik van dit recht, staan zij niet op hun strepen, of treden zij niet in overleg met de zorgverlener of met de zorgaanbieder over zaken die hen aangaan? In het verzorgingshuis werken verzorgenden die dicht bij de bewoners staan, die er een zorgrelatie mee hebben opgebouwd. Hoe geven verzorgenden en bewoners invulling aan deze relatie? Tonen zij belangstelling voor het levensverhaal van de ouderen die zij dagelijks ontmoeten; zijn ze op de hoogte van hun behoeften, wensen of dagelijkse gewoonten? Informeren de verzorgenden de bewoners over hun rechten en over de mogelijkheden en beperkingen van het verzorgingshuis; bieden zij bewoners keuzemogelijkheden aan en dragen zij er zorg voor dat de bewoners zich zelfstandig kunnen opstellen? Communiceren bewoners op hun beurt met de verzorgenden over de dingen die hun bezig houden; vragen zij om aandacht voor hun behoeften en maken zij kenbaar of op hun vragen wordt ingegaan; vinden zij dat zij zichzelf kunnen zijn en voldoende tot hun recht komen en als zij dat niet vinden hoe reageren zij daar dan op? Kenmerkt het verzorgingshuis zich als een inspirerend samenlevingsverband, waar mensen elkaar ontmoeten, bewoners en verzorgenden de dialoog aangaan en waar het leven de moeite waard gevonden wordt?

In het beleidsplan van de stichting waar ik inmiddels een aantal jaren werkzaam ben, is het allemaal geregeld. Vermeld staat dat in onze verzorgingshuizen wordt ingegaan op persoonlijke en gemeenschappelijke behoeften van de bewoners. Daarbij moet, zo wordt 
gesteld, worden uitgegaan van de zelfstandigheid van de oudere: hij moet de ruimte hebben om keuzes te maken, mogelijkheden te benutten en op eigen wijze invulling te geven aan zijn leven; de zorgverlening moet recht doen aan de eigenheid van de bewoner.

Het staat er mooi beschreven en veel collega - instellingen sluiten zich bij een dergelijke visie aan, temeer omdat de intramurale zorgaanbieder door haar financier contractueel verplicht gesteld wordt bewoners keuzevrijheid te verschaffen en hun zelfstandigheid of autonomie te respecteren en beschermen. Maar betekent dit dat het praktijkvoorbeeld uit de inzet van dit hoofdstuk verleden tijd is en dat verzorgingshuizen weten hoe zij, gespeend van paternalisme, invulling dienen te geven aan de zorg voor zelfstandigheid van de ouderen die er wonen?

De confronterende reactie van de bewoner over de regels van het verzorgingshuis en mijn vraag of het overnemen van de regie van het leven van bewoners in het verzorgingshuis niet op gespannen voet staat met het streven recht te doen aan keuzes die ouderen maken of aan besluiten die zij willen nemen, hebben mij tot deze studie aangezet. Daarbij heb ik me de vraag gesteld op welke wijze een concrete invulling gegeven kan worden aan de algemeen geformuleerde opdracht van de zorgfinancier om de zelfstandigheid van bewoners te respecteren en beschermen. De volgende probleemstelling is geformuleerd:

Wat wordt door bewoners en verzorgenden van verzorgingshuizen onder zorg voor zelfstandigheid verstaan en beantwoordt de dagelijkse praktijk daar naar hun mening aan; hoe kan zorg voor zelfstandigheid worden bevorderd en hebben interventies hiertoe tot gevolg dat de zorg voor zelfstandigheid toeneemt?

Bewoners en verzorgenden van de verzorgingshuizen zijn ondervraagd over het thema 'zorg voor zelfstandigheid'. Zij hebben het onderzoeksmateriaal verschaft en een deel van hen heeft aan interventies deelgenomen om de zorg voor zelfstandigheid te bevorderen.

\subsection{De opbouw van deze studie}

In de hoofdstukken 2 tot en met 4 worden onderwerpen behandeld die een licht werpen op de vraag waarom 'zorg voor zelfstandigheid' een belangrijk thema is. In hoofdstuk 2 brengt een analyse van literatuur over ouderdom en ouderen in Nederland aan het licht dat aan ouderdom een sterk negatief beeld kleeft. De mening overheerst dat ouderen zich terug dienen te trekken uit de maatschappij. Wanneer zij op basis van hun leeftijd geen betaalde arbeid meer verrichten, verliezen mensen hun economisch nut en leveren zij maatschappelijke status en verantwoordelijkheid in. Het laat zich begrijpen dat ouderen 
geen zelfbewuste houding aan de dag leggen als zij worden beschouwd als kwetsbare mensen die geen plichten meer hebben te vervullen en die afscheid van het leven aan het nemen zijn. Wanneer ook de zelfredzaamheid afneemt en ouderen voor het verrichten van dagelijkse bezigheden afhankelijk worden van anderen bestaat de kans op mentale afhankelijkheid, op het uit handen geven van de regie over het leven.

De bouw van bejaardenhuizen is aanvankelijk een gevolg van de opvatting dat ouderen geen maatschappelijk engagement meer hebben. In een tijdperk van woningnood heerst bij de overheid de opvatting dat oudere mensen hun woningen beschikbaar moeten stellen aan volwassenen die nog een arbeidzaam leven voor de boeg hebben. In de bejaardenhuizen worden de ouderen geacht een zelfstandig bestaan te leiden, met dien verstande dat enige hulp bij de zelfredzaamheid beschikbaar wordt gesteld. De demografische ontwikkeling in de twintigste eeuw is van dien aard dat het aantal ouderen in de Nederlandse samenleving sterk stijgt. De bemoeienis die de overheid op zich heeft genomen met de bouw van bejaardenhuizen en met de financiering van de ondersteuning van de ouderen die er wonen, wil zij beter reguleren; de drempel tot plaatsing of verhuizing naar een bejaardenhuis wordt opgehoogd en een indicatie-orgaan krijgt de functie van poortwachter. In hoofdstuk 3 wordt, tegen die achtergrond, de opkomst van het verzorgingshuis beschreven. In de vijfentwintig jaar dat het verzorgingshuis oud is, is waarneembaar dat de behoefte aan zorg van ouderen die er komen te wonen een stijgende lijn vertoont. Dit doet geen afbreuk aan de eis die de overheid aan het verzorgingshuis en haar bewoners is blijven stellen om de bewoner de regie over het eigen leven te laten behouden. Van het verzorgingshuis wordt tevens verwacht dat optimaal tegemoet wordt gekomen aan de zelfredzaamheid van de bewoners. Dit laatste lijkt een onderstreping van het belang dat moet worden toegekend aan de zorg voor zelfstandigheid van de bewoners. Maar geconstateerd wordt dat deze eisen conflicterend kunnen zijn. Literatuur wordt aangehaald waaruit blijkt dat het verzorgingshuis institutionele kenmerken vertoont; het is sterk geneigd het leven voor de bewoners te bepalen, weinig ruimte te geven aan de eigenheid van bewoners en meer de zelfredzaamheid dan de zelfstandigheid van bewoners centraal te stellen.

Hoofdstuk 4 beschrijft dat onder invloed van nieuwe wetgeving de laatste twee decennia een ontwikkeling gaande is waarin de aandacht uitgaat naar de positie van de zorgvrager en naar de kwaliteit van zorg in verzorgingshuizen. Dit hoofdstuk geeft een beeld van de wijze waarop de zorg voor zelfstandigheid in verzorgingshuizen er uit zou moeten zien. De medezeggenschap van bewoners is formeel geregeld en de rechtspositie van de bewoner is met name het laatste decennium beschermd en versterkt. De bewoner van het verzorgingshuis heeft, analoog aan de Wet op de geneeskundige behandelingsovereenkomst 
(Wgbo), recht op informatie; hij moet instemmen met de inhoud van het zorgplan dat over hem wordt opgesteld en hij heeft het recht zijn zorgdossier en de gegevens over zijn persoon in te zien. Het verzorgingshuis is om die reden verplicht een zorgdossier bij te houden. Met het zorgkantoor tekent het verzorgingshuis ieder jaar een contract waarin wordt toegezegd dat de autonomie van de bewoners wordt gerespecteerd en beschermd, dat rekening gehouden wordt met de persoonlijke levenssfeer van bewoners en met hun keuzevrijheid. Ondanks deze wetten en maatregelen is het verzorgingshuis voor 'buitenstaanders' geen woonomgeving die geassocieerd wordt met vrijheid en zelfstandigheid. Onderzoeken worden aangehaald waaruit blijkt dat mensen van mening zijn dat het gaan wonen in een verzorgingshuis verder afbreuk zal doen aan hun zelfstandigheid en dat zij verwachten dat zij zich zullen moeten aanpassen aan het ritme en de regels van de instelling. Ouderen die reeds in een verzorgingshuis wonen, hebben zich ook uitgesproken over het verblijf in het verzorgingshuis, zij het dat zij meer hebben aangegeven hoe de zorg en aandacht er zouden moeten uitzien dan dat zij hun opvattingen hebben gegeven over de kwaliteit van zorg die aan hen daadwerkelijk geboden wordt.

In de hoofdstukken 5 en 6 wordt het begrip zelfstandigheid nader uitgediept. Hoofdstuk 5 gaat vooral in op de theoretische betekenis van zorg voor zelfstandigheid en hoofdstuk 6 laat zien welke praktische toepassingen hieraan gegeven (kunnen) worden.

Zorg voor zelfstandigheid (door de zorgfinancier verengd tot 'het beschermen en respecteren van de autonomie'), waar het verzorgingshuis zich op dient te richten, is door de zorgfinancier niet geconcretiseerd in termen van taken die moeten worden verricht, houdingsaspecten die de aandacht moeten hebben of doelstellingen die gehaald moeten worden. Evenmin vraagt de zorgfinancier aan de zorgaanbieder verantwoording af te leggen over de activiteiten die hij op dit gebied heeft ondernomen. Het staat zorgaanbieders kennelijk vrij daar een eigen invulling aan te geven. Op basis van literatuurstudie is in hoofdstuk 5 het begrip 'zelfstandigheid' uitgewerkt. Omdat in een verzorgingshuis alleen ouderen worden geplaatst die voor de rest van hun leven in meer of mindere mate zijn aangewezen op de zorg van anderen is daarbij de vraag behandeld of afhankelijkheid en inmenging van zorgverleners in het leven van de zorgvrager inbreuk doen op zijn zelfstandigheid.

In een gezondheidsrechtelijke benadering over zelfstandigheid van de zorgvrager neemt het recht op zelfbeschikking een centrale plaats in. Uitwisseling van informatie tussen de zorgvrager en de zorgverlener is een belangrijk onderdeel van de zorgrelatie. Het recht op zelfbeschikking van de zorgvrager hoeft een inmenging door de zorgverlener niet uit te sluiten, maar inmenging gebeurt alleen met toestemming van de zorgvrager. Om zich te mengen in het leven van de zorgvrager moet de zorgrelatie van dien aard zijn dat de 
zorgvrager en zorgverlener gezamenlijk, op basis van ieders verantwoordelijkheid, rechten en plichten, tot keuzes, handelingen of beslissingen komen, die gericht zijn op de zelfstandigheid van de zorgvrager.

In een zorgethische benadering kan de zorgverlener zich mengen in het leven van de zorgvrager en tot handelingen of beslissingen voor de zorgvrager komen waarvoor hij geen toestemming heeft gekregen. De zorgverlener wordt geacht de zorgvrager zo nabij te zijn dat hij weet welke keuzes en beslissingen het meest recht doen aan de zorgvrager. Dit kan zelfs betekenen dat de zorgverlener het nodig vindt en de ruimte neemt de zorgvrager te overreden of beslissingen van hem over te nemen als de zorgvrager onvoldoende in staat is om zelf beslissingen te nemen. Zorg voor zelfstandigheid vraagt een op de persoon van de zorgvrager gerichte benadering, diens levensverhaal moet er in doorklinken en zijn gevoel van eigenwaarde en zelfrespect moeten overeind blijven. Oog hebben voor de behoeften van de zorgvrager (attentiviteit), bereid zijn verantwoordelijkheid te nemen voor de zorg, op een deskundige, competente manier zorg verlenen en nagaan of verleende zorg aan de behoefte heeft beantwoord (responsiviteit), zijn belangrijke deugden of eigenschappen die de zorgverlener moet bezitten om van zorg voor zelfstandigheid te kunnen spreken.

'Belevingsgerichte zorg' en 'levensfasegeoriënteerde zorg' worden gezien als persoonsgerichte zorgbenaderingen, waarin aan deze deugden geappelleerd wordt. In hoofdstuk 6 komen ze aan de orde met het doel na te gaan of het praktisch toepassen van deze benaderingen de zorg voor zelfstandigheid zou kunnen bevorderen. Belevingsgerichte zorg, die voornamelijk is toegepast bij ouderen met verschijnselen van dementie, pretendeert dat de eigenheid en individualiteit van de oudere wordt beschermd wanneer de zorgverlener uitgaat van en zich inleeft in de belevingswereld van de oudere. De methodiek van belevingsgerichte zorg omvat onder meer een set van registratieformulieren waarop de beleving van de oudere wordt gerapporteerd en de daarop gebaseerde werkwijzen voor de zorgverleners zijn aangegeven. Levensfasegeoriënteerde zorg stelt de aandacht voor het levensverhaal van de zorgvrager voorop. Zorg voor zelfstandigheid betekent ook in die benadering er voor zorgdragen dat de persoon of eigenheid van de zorgvrager doorklinkt in de zorg. Om dit te waarborgen dient de zorgverlener het levensverhaal van de zorgvrager te kennen en is de dialoog tussen zorgvrager en zorgverlener van belang om keuzes te kunnen maken en op behoeften te kunnen ingaan die passen in het leven van de zorgvrager. De benadering 'levensfasegeoriënteerde zorg' is niet uitgewerkt in een methodiek of instrument voor praktische toepassing.

Zorg voor zelfstandigheid vraagt om samenspraak tussen zorgvrager en zorgverlener, niet alleen in de directe zorgrelatie maar ook in het samenlevingsverband van het verzorgingshuis. De rol die het verzorgingshuis speelt en de activiteiten die door haar 
worden ontplooid, kunnen een bevorderende of belemmerende invloed hebben op de zorg voor zelfstandigheid in de zorgrelatie. Om de opvattingen van groepen bewoners en verzorgenden hierover te peilen, maar ook om de gezamenlijke verantwoordelijkheid te benadrukken voor het leven en wonen in het verzorgingshuis, wijdt hoofdstuk 6 een paragraaf aan responsieve evaluatie, een vorm van evaluatie-onderzoek waarin de deelnemers hun standpunten over zorg voor zelfstandigheid kenbaar kunnen maken en die de mogelijkheid biedt tot gezamenlijke keuzes te komen voor verbeteringen.

In de hoofdstukken 7 tot en met 10 van de studie staan het onderzoek naar zorg voor zelfstandigheid en het bevorderen van die zorg centraal. Bij bewoners en verzorgenden van een drietal verzorgingshuizen is in twee perioden onderzoek gedaan naar de zorg voor zelfstandigheid van bewoners. Tussen de eerste en tweede meting heeft een deel van de respondenten deelgenomen aan een interventieprogramma. In hoofdstuk 7 zijn de onderzoeksopzet en het onderzoeksproces beschreven. Het onderzoek is gestart met een concept mapping waarin betrokkenen naar voren brachten welke kernpunten naar hun mening van belang zijn bij de zorg voor zelfstandigheid in het verzorgingshuis. Informatievoorziening, invloed of keuzevrijheid van bewoners ten aanzien van het programma en de regels van het verzorgingshuis, alsmede de houding van verzorgenden zijn de punten die het meest van belang geacht worden in de contacten tussen bewoners en verzorgenden. Op basis van de reacties bij de concept mapping zijn vragenlijsten opgesteld. Door middel van een vraaggesprek en door middel van een enquête hebben de bewoners respectievelijk de verzorgenden vervolgens de gelegenheid gekregen aan te geven hoe het verzorgingshuis met die kernpunten omgaat. Het peilen van opvattingen is te typeren als kwalitatief onderzoek, terwijl de inventarisatie van de mate waarin opvattingen voorkomen kwantitatief van aard is. De manieren waarop opvattingen gepeild of geïnventariseerd zijn, laat zien dat gebruik is gemaakt van verschillende vormen van triangulatie. Hoofdstuk 7 beschrijft ook de aard van de interventies die tot doel hebben de zorg voor zelfstandigheid te bevorderen alsmede de methodologische wijze waarop er mee is omgegaan. Door middel van responsieve evaluaties zijn de resultaten van de geïnventariseerde opvattingen besproken en zijn de deelnemers tot voorstellen gekomen voor de bevordering van zorg voor zelfstandigheid. Vervolgens hebben verzorgenden en bewoners, in één-op-één gesprekken, afspraken gemaakt over de zorg die moet worden geleverd om recht te doen aan de zelfstandigheid van de bewoner. Deze afspraken zijn geregistreerd in een zogenoemd 'Overzicht Zorgafspraken'. De responsieve evaluaties en de opgestelde overzichten zorgafspraken zijn aangeduid als interventies.

Hoofdstuk 8 doet verslag van de onderzoeksresultaten van de eerste meting. Het laat zien dat opvattingen over en belevingen bij de zorg voor zelfstandigheid in meer of mindere 
mate uiteenlopen, zowel tussen als binnen de twee groepen respondenten. Duidelijk wordt dat verzorgenden geen goede inschatting maken van de verwachtingen en motieven waarmee bewoners naar het verzorgingshuis komen; de behoeften van bewoners worden niet voldoende onderkend en de informatievoorziening is van dien aard dat verschillen in opvattingen of belevingen niet worden overbrugd. De bewoners ondergaan die situatie; zij claimen niet hun rechten en treden niet uit eigen beweging in overleg met de verzorgenden, misschien wel omdat het verzorgingshuis voldoende veiligheid biedt, men zich op zijn gemak voelt en van mening is dat het verzorgend personeel hen vriendelijk, deskundig en met respect tegemoet treedt.

Om de onderzoeksresultaten nader te exploreren en zo mogelijk tot een verbetering van de zorg voor zelfstandigheid te komen, zijn de ondervraagde groepen in tweeën gesplitst: een controlegroep en een experimentele groep. Deze laatste is gevormd door bewoners en het verzorgend personeel van een drietal verzorgingsafdelingen. Zij zijn in afzonderlijke groepen met behulp van responsieve evaluatie nader op de resultaten van het onderzoek ingegaan. Deze nauwe betrokkenheid van de groepen respondenten bij de vraagstukken over de zorg voor zelfstandigheid is op zichzelf al een uiting van het willen nemen van verantwoordelijkheid voor zelfstandigheid. Hoofdstuk 9 beschrijft het verloop van de responsieve evaluatie. Daarnaast wordt in dat hoofdstuk ingegaan op het verloop van de tweede interventie: de bijstelling van de rapportage van het zorgproces. Uit de eerste meting blijkt dat veel respondenten niet tevreden zijn over de kwaliteit hiervan. Om die reden is het registratieformulier 'Overzicht Zorgafspraken' ontwikkeld dat aan eisen of verwachtingen terzake het inzagerecht en het toestemmingsvereiste voldoet en waarin ruimte is opgenomen om er die passages uit het levensverhaal van de bewoner in op te nemen die voor de zorg voor zelfstandigheid van belang zijn.

$\mathrm{Na}$ de interventieperiode is een tweede meting verricht naar de zorg voor zelfstandigheid. In hoofdstuk 10 is aangegeven in hoeverre de opvattingen van respondenten van controlegroepen en van experimentele groepen van elkaar verschillen, wat de invloed van de interventies is en welke verschillen geconstateerd kunnen worden tussen meting één en meting twee.

Deze studie eindigt met een weergave van de belangrijkste conclusies. Gesteld wordt dat het te begrijpen is dat ouderen die in een verzorgingshuis wonen zich afhankelijk opstellen als zij, in de jaren die aan de plaatsing in een verzorgingshuis voorafgingen, geen sociale rol van betekenis meer hebben gespeeld, nauwelijks deel hebben genomen aan het maatschappelijk leven, afhankelijk zijn geweest van materiële voorzieningen en van de beschikbaarheid en bereidheid van informele en professionele hulpverleners. Het gevoel 
van eigenwaarde van ouderen is daarmee zwaar op de proef gesteld. De zorg voor zelfstandigheid, die juist tot doel heeft de eigenheid en het zelfrespect van ouderen overeind te houden, is tegen die achtergrond een maatschappelijke verantwoordelijkheid die ouderen en de Nederlandse samenleving op zich dienen te nemen, en die niet kan worden afgewenteld op zorginstellingen. Verzorgenden zeggen hun handen al meer dan vol te hebben aan de bewoners. De behoefte aan zorg in de verzorgingshuizen stijgt sterk en de hoeveelheid tijd die elke bewoner vraagt, is niet beschikbaar. Dit gaat ten koste van de zorg voor zelfstandigheid: aan bewoners wordt niet gevraagd wat hun verwachtingen, behoeften of wensen zijn, laat staan dat hun levensgeschiedenis of levensverhaal de basis vormt van waaruit zorgafspraken worden gemaakt; de aanwezige zelfredzaamheid van bewoners moet naar de mening van verzorgenden worden benut ook al heeft de bewoner redenen om dat niet te doen. De vraag of de verzorgende die zorg heeft gegeven die de bewoner nodig had, wordt niet gesteld. Daarmee wordt voorbijgegaan aan de rechten en de rechtspositie van de bewoner, maar zeker ook aan zijn eigenheid en eigenwaarde.

$\mathrm{Na}$ een interventieprogramma is geconstateerd dat beduidend meer bewoners van experimentele verzorgingsafdelingen dan van controleafdelingen aangeven dat de informatievoorziening is verbeterd, met name rondom de zorgafspraken, dat zij invloed kunnen uitoefenen op de regels en het programma van het verzorgingshuis en dat meer verzorgenden een attentieve en een op responsiviteit gerichte houding tonen. Mogelijk dat het proces dat de experimentele afdelingen hebben doorlopen, waarbij verzorgenden en bewoners veel nauwer met elkaar in contact zijn gekomen dan doorgaans het geval is en tijd voor elkaar hebben genomen, in belangrijke mate heeft bijgedragen aan de bevordering van de zorg voor zelfstandigheid. 


\section{Hoofdstuk 2 Ouderdom: status of stigma?}

\section{$2.1 \quad$ Inleiding}

"Mensen willen graag oud worden, maar niet graag oud zijn" is een bekend gezegde. Voor iemand die oud wil worden, is het leven blijkbaar de moeite waard. Niet oud willen zijn geeft te denken. Aan ouderdom worden in de Nederlandse samenleving klaarblijkelijk status en kenmerken toegekend die niet aantrekkelijk zijn. Wellicht om die reden schuift de mens de beleving van ouderdom voor zich uit, ongeacht het aantal jaren dat men oud is.

Simone de Beauvoir (1975) liet ouderen aan het woord over hun beleving van ouderdom. In haar essay over 'De Ouderdom' stelt zij dat veel mensen en vooral bejaarde mensen, haar herhaaldelijk verzekerd hebben dat de ouderdom helemaal niet bestaat. "Sommige mensen zijn minder jong dan andere, dat is alles". Ook Munnichs (1989) onderzocht de beleving van ouderdom. Aan 1000 personen van verschillende leeftijden stelde hij de vraag tot welke leeftijdscategorie men zich rekende. Personen tussen 30 en 60 jaar noemden zich overwegend van middelbare leeftijd, maar beginnend bij 60 jaar noemde zich slechts een klein gedeelte oud. Zelfs bij 80 jaar en ouder bleef elf procent zich jong noemen en zesendertig procent vond zich van middelbare leeftijd. Uit de uitspraken van ouderen die door Simone de Beauvoir en Munnichs worden weergegeven, valt op te maken dat ouderdom niet wordt beleefd als een apart verschijnsel in de levensloop, als een levensfase die vanaf een bepaalde leeftijd begint of waarin mensen gemeenschappelijke kenmerken delen. Deze beleving komt in het geheel niet overeen met het beeld in de Nederlandse samenleving dat rond 1980 werd opgetekend (Braam, 1981):

Mensen van 65 jaar en ouder worden oud genoemd; kenmerkend voor ouderen is dat ze geholpen en verzorgd moeten worden en in bejaardenhuizen wonen.

Voor Munnichs (1990) is dit aanleiding te concluderen dat het Selbstbild, het beeld dat de oudere van zichzelf heeft, contrasteert met het Fremdbild, het beeld dat de omgeving van de oudere heeft. In het Selbstbild wordt oud en ouderdom pas ervaren als men de greep over zichzelf verliest, de eindigheid van het leven gewaar wordt en afhankelijk van de omgeving wordt. In het Fremdbild wordt de kalenderleeftijd geassocieerd met ouderdom.

In dit hoofdstuk wordt beschreven hoe ouderdom zich manifesteert op het gebied van gezondheid, maatschappelijke participatie en de sociale positie van ouderen.

Of de beschrijving van deze thema's over ouderen recht doet aan de werkelijke situatie is de vraag. Beschrijving en werkelijkheid komen volgens Braam (1981) het meest overeen als de afstand tot de groep of het fenomeen waarover geschreven wordt klein is. In de analyse van 
ouderdom die in dit hoofdstuk wordt weergeven, is geprobeerd die afstand met behulp van literatuurstudie te overbruggen, met de restrictie dat ook het wetenschappelijk oog voor de werkelijkheid in de loop van de tijd anders gaat zien. Zo blijkt dat de gerontologie in haar eigen ontwikkeling de levensfase ouderdom steeds minder is gaan problematiseren, minder is gaan beschouwen als een periode van verval en meer als een fase met eigen karakteristieken.

Alvorens in te gaan op de drie genoemde thema's zal eerst het vraagstuk 'oud' worden behandeld. Wie mag zich oud noemen en wie niet, welke criteria worden daarbij in acht genomen? Duidelijk is dat ouderdom gepaard gaat met lichamelijke veranderingen. Maar deze zijn niet exclusief voorbehouden aan deze levensfase; het tempo of tijdsverloop waarin ze optreden is individueel verschillend, zo goed als ook de omstandigheden waarin mensen leven uiteenlopend en aan verandering onderhevig zijn.

De leeftijdsgrens die "de levensfase oud" markeert en die in Nederland op 65 jaar is gesteld, is door mensen getrokken. $\mathrm{Zij}$ is derhalve arbitrair, maar zeker niet zonder betekenis. Met name op het gebied van de maatschappelijke participatie c.q arbeidsparticipatie is het bereiken van de 65 -jarige leeftijd een belangrijke gebeurtenis.

De sterke stijging van de levensverwachting van mensen in de afgelopen eeuw vraagt om een genuanceerd beeld van ouderdom; van gezondheid, maatschappelijke participatie en de sociale positie van ouderen in onze samenleving. In literatuur waarin opvattingen over de sociale positie van ouderen worden weergegeven, liggen de gewenste nuanceringen niet voor het oprapen. Zo wordt overwegend een generaliserend beeld geschetst van de oudere die niet meer wordt aangesproken op het dragen van enige maatschappelijke verantwoordelijkheid en die niet uitstijgt boven de positie van 'drop-out'. Literatuur over maatschappelijke participatie van ouderen draagt daarentegen feiten aan. We treffen er een indeling in aan in leeftijdscategorieën binnen de levensfase ouderdom en op basis van die feiten wordt de conclusie getrokken dat maatschappelijke participatie afneemt naarmate de leeftijdscategorie hoger is (Van Rijsselt (1991); Bijsterveld (2001); Braam (2001)). Mensen in de leeftijdscategorie 80-plus, en binnen die leeftijdsgroep met name alleenstaande vrouwen, nemen beduidend minder deel aan verschillende vormen van het maatschappelijk leven dan ouderen uit lagere leeftijdscategorieën. Het inkomen van veel 80-plussers is laag; het merendeel van hen heeft niet meer dan een lagere opleiding en in hun woningen moeten aanpassingen worden aangebracht. Feiten tonen dat ook lichamelijke kwetsbaarheid zich in sterke mate openbaart vanaf het tachtigste levensjaar. Gezondheidsproblemen zijn evenwel van alle levensfasen; ze stapelen zich op naarmate mensen ouder worden en manifesteren zich bij veel ouderen vanaf de vijfenzeventig-, tachtigjarige leeftijd. Vanaf hun negentigste jaar blijken vier tot vijf op de tien ouderen aangewezen op een verblijf in het verzorgingshuis (Huijsman (1990); WRR (1993); Arcares (1997; 20001); SCP (2001)). 
Om uitspraken te kunnen doen over de plaats die ouderen innemen in de samenleving zal allereerst bepaald moeten worden welke mensen oud genoemd mogen worden.

Literatuur over dit vraagstuk laat zien dat de kwalificaties oud en ouderdom door de samenleving willekeurig worden toegekend; dat ze sociaal geconstitueerd zijn (Knipscheer/Baars, 1988). De kalenderleeftijd heeft een belangrijke, maar niet altijd dominante rol gespeeld. Van het antieke Rome is bekend dat de levensfase ouderdom op verschillende leeftijden kon beginnen. Sommige mensen waren oud op hun $42^{\mathrm{e}}$ levensjaar en andere wanneer ze 77 werden. Niet zozeer hun leeftijd als wel het vermogen om arbeidstaken uit te voeren was doorslaggevend (Bijsterveld, 2001; Turksma, 1982). Niet vermeld wordt wie tot de vaststelling kwam van dit al dan niet aanwezige vermogen, de betrokkene of diens omgeving. Veel later in onze geschiedenis worden kalenderleeftijd en ouderdom aan elkaar verbonden, zij het nog op indirecte wijze. Zo beschrijft Baars (2001) dat het Napoleontisch bewind van het einde van de $18^{\mathrm{e}}$ en het begin van de $19^{\mathrm{c}}$ eeuw in veel Europese landen, waaronder Nederland, een bureaucratisch toezicht op de bevolking organiseert, waardoor aan verschillende leeftijden verschillende kenmerken worden toegekend. Leeftijden worden gebruikt bij het chronologisch beheer van de bevolking en chronologisch beheer krijgt de functie het gedrag van de bevolking te beïnvloeden door aan leeftijd gerelateerde maatregelen te treffen of hindernissen op te werpen. De levensloop wordt aldus gechronologiseerd en krijgt een categoriserende inwerking op de samenleving. In het verdere verloop van de negentiende en twintigste eeuw zien we dat voor tal van maatschappelijke activiteiten leeftijdsgrenzen worden getrokken, zoals de leeftijd waarop een kind met onderwijs begint of waarop betaalde arbeid mag worden verricht. Ook de hoeveelheid tijd die voor bepaalde activiteiten of gebeurtenissen beschikbaar wordt gesteld, wordt gestandaardiseerd, zoals het aantal verlofdagen bij overlijden in de familie, de duur van zwangerschapsverlof en het aantal jaren waarbinnen een hypotheek moet worden afgelost.

Een volkstelling van 1869 stelt vast dat $5.5 \%$ van de Nederlandse bevolking 65 jaar of ouder is. Deze vaststelling heeft niet meer dan statistische betekenis en zegt in die tijd nog niet dat 65 jaar de leeftijdsgrens markeert waarop de levensfase ouderdom intreedt. Pas op het eind van de negentiende eeuw zien we een expliciete koppeling van leeftijd aan ouderdom. Onder invloed van Bismarck wordt bepaald dat mensen van een bepaalde leeftijd moeten stoppen met het verrichten van betaalde arbeid en met pensioen moeten gaan, vanuit de overwegingen dat de gezondheid van ouderen kwetsbaar is en het prestatievermogen en de productiviteit verminderen. In eerste instantie wordt 70 jaar 
(Knipscheer/Baars, 1988) genoemd als leeftijd waarop mensen te oud zijn om nog betaalde arbeid te verrichten en spoedig daarna wordt de 65 jarige leeftijd aangehouden (Reestman, 2000; Turksma, 1982).

Ouderdom is sindsdien aan leeftijd gekoppeld; 65 jaar is de leeftijd waarop de levensfase ouderdom intreedt. Een levensfase die wordt geassocieerd met tekortkomingen. De overheid ziet het als haar taak maatregelen te nemen om ouderen te beschermen tegen gezondheidsrisico's en het recht op pensioen dat aan 65 -jarigen wordt toebedeeld is hier het gevolg van. Voor het eerst in de Nederlandse geschiedenis worden ouderen sociaal gepositioneerd. Ze gaan in de samenleving een bepaalde plaats innemen, namelijk die van uittreders van de arbeidsmarkt. Zij krijgen de plicht tot stoppen met werken op 65-jarige leeftijd en verwerven dan ook het recht op een ouderdomsuitkering.

\section{$2.3 \quad$ Ouderen en hun gezondheid}

Tegen de achtergrond van een maatschappelijke omgeving en beeldvorming waarin de oudere medemens geassocieerd wordt met uitgeschakeld en overtollig zijn, worden ouderen uitgenodigd de rol van hulpbehoevende aan te nemen om het beroep op hulp dat zij doen te rechtvaardigen. Daarmee bevestigen zij het beeld dat ouderen object van zorg zijn (Aakster, 1987).

Aan het eind van de negentiende eeuw worden mensen niet oud. In de periode rond 18701880 sterft één op elke drie kinderen voor het vierde levensjaar. Slechts 28 procent van de mannen en 31 procent van de vrouwen sterft na het bereiken van de 65 -jarige leeftijd. Honderd jaar later sterft 74 procent respectievelijk 85 procent van de mensen na het $65^{\circ}$ levensjaar (Matse, 1977). In een tijdperk als het einde van de negentiende en het begin van de twintigste eeuw, waarin de levensverwachting laag is, nog veel fysieke arbeid moet worden verricht en onder slechte arbeidsomstandigheden moet worden gewerkt, is het te begrijpen dat de overheid ouderen beschermt omwille van hun gezondheid. Maar het stigma van een kwetsbare gezondheid is aan ouderdom blijven kleven ondanks een sterke stijging van de levensverwachting en het gegeven dat mensen een steeds groter deel van hun leven oud zijn. De Wetenschappelijke Raad voor het Regeringsbeleid (WRR, 1999) komt met de volgende cijfers aangaande de stijgende levensverwachting:

- mannen die in het tijdvak 1901-1910 zijn geboren worden gemiddeld bijna 56 jaar, tegen vrouwen 62 jaar;

- mannen en vrouwen uit het cohort 1961-1970 zullen gemiddeld op 77-jarige, respectievelijk 81 -jarige leeftijd sterven.

Andere bronnen geven aan dat vrouwen van 80 een gemiddelde levensverwachting hebben 
van acht jaar, mannen van zes jaar (Westendorp, 2001).

Ondanks de sterk toegenomen levensverwachting van ouderen, met name in de loop van de twintigste eeuw, wordt ouderdom geassocieerd met mortaliteit. Baars (2001) omschrijft dit als volgt :

De verbinding tussen ouderen en dood is paradoxaal genoeg nauwer geworden door de toegenomen gemiddelde levensduur. De dood, die ook in West - Europa tot in de eerste helft van de twintigste eeuw midden in het leven stond en mensen van alle leeftijden neer maaide, concentreert zich tegenwoordig in toenemende mate op de oudsten.

Sterven wordt dan ook geassocieerd met ouderen, hetgeen statistisch gezien een realiteit is maar niet wegneemt dat iedereen nog steeds op elke leeftijd kan sterven.

Van der Maas (1997) komt in 1982, in zijn poging mythen over vergrijzing en volksgezondheid door te prikken, tot de volgende conclusie:

Op dit moment heeft een gemiddelde Nederlander gegeven zijn/haar leeftijd minder kans dan ooit in het dagelijks leven geïnvalideerd of dood te zijn, hoewel hij/zij meer kans heeft dan ooit om onder doktershanden te zijn, waarbij het aardigste is dat het één weinig met het ander uitstaande heeft.

Deze waarschuwing kan niet voorkomen dat ouderdom wordt geassocieerd met fysiek en geestelijk verval; ze wordt gestigmatiseerd en gemedicaliseerd (Knipscheer/Baars, 1988; Aakster, 1987; Missine, 1996; Reestman, 2000; Munnichs, 1989). Met haar beschrijving van het deficitparadigma (Brugman, 2001) draagt de psychogerontologie, de wetenschap die in het midden van de twintigste eeuw ontstaat en die de beschrijving van het gedrag van ouderen tot object van wetenschap maakt, ongewild bij aan dit beeld van ouderen in de samenleving. Het deficitparadigma of deficitmodel belicht de tekortkomingen van ouderen en spreekt van een privatieve generatie (Baars, 2001). Deze bezit een tekort tegenover een andere generatie. Verschillende 'tekorten' van ouderen worden door de gerontologie blootgelegd. De vraag die in de eerste decennia na de Tweede Wereldoorlog centraal wordt gesteld is de mate van competentie bij ouderen. Munnichs (1989) verwijst naar een proefschrift van Verhage uit 1964, waaruit blijkt dat 65-plussers intellectueel minder kunnen dan hun twaalfjarige kleindochters, en naar een onderzoek van Lehman uit 1953 dat ondubbelzinnig aantoont dat met het klimmen der jaren de creativiteit achteruit gaat. Preventie en het verzachten van symptomen van de ouderdom zijn voor de gerontologie in het begin van haar ontwikkeling belangrijke aandachtsgebieden (Prétat, 1995).

Het beeld dat ouderdom onvermijdelijk leidt tot cognitieve achteruitgang wordt voor Jelicic (2001) niet overtuigend door onderzoek gestaafd. Hij werpt de these op dat een willekeurige groep voorbijgangers op straat, aan wie de vraag wordt gesteld of veroudering gepaard gaat met een vermindering van het geheugen en andere cognitieve functies, bevestigend antwoordt. Jelicic stelt dat veranderingen die met het ouder worden optreden in de frontale 
hersengebieden er toe leiden dat veel ouderen op taken die een sterk beroep doen op gecontroleerde cognitieve processen minder presteren dan jongeren. Daartegenover stelt hij dat sommige ouderen zelfs beter scoren en dat niet de kalenderleeftijd de oorzaak hoeft te zijn van een verminderde prestatie. Ook voor Brugman (2001) is leeftijd niet de verklarende variabele voor kenmerken of tekorten van ouderen:

Ons hele leven vergeten we, maar in de tweede levensfase schrijven we dat toe aan ouderdom.

Aakster (1987) stelt dat ouderen de enige generatie vertegenwoordigen die haar gezondheid moet laten blijken uit onderzoek naar wat haar mankeert. Hij spreekt dan ook van een medicalisering van de ouderdom. Medici hebben de neiging het proces van ouderdom vanuit een ziektebehandelingsmodel onder controle te krijgen (Knipscheer/Baars, 1988; Kardol, 1997). Ontegenzeglijk neemt de kans om chronische aandoeningen te krijgen toe met het toenemen van de leeftijd. Cardiovasculaire ziekten, kanker, respiratoire aandoeningen, reumatoïde arthritis en diabetes zijn de ouderdom niet vreemd. Vermindering van spierkracht, verandering in mobiliteit en flexibiliteit van de gewrichten en een daling in de fysieke belastbaarheid zijn prevalenties van mensen van hogere leeftijd, met name van ouderen van boven tachtig jaar. Dat aandoeningen zich manifesteren bij ouderen betekent overigens niet dat ze ook veroorzaakt worden door ouderdom (Bosscher en Deeg, 1996; Deeg en Zonneveld, 1987). Vanaf de geboorte is het lichaam aan degeneratie onderhevig en het bereiken van de 65 -jarige leeftijd luidt niet abrupt een periode van lichamelijk verval in.

De Wetenschappelijke Raad voor het Regeringsbeleid (WRR, 1993) en Arcares (1997; 2000) gaan nader in op de gezondheidssituatie van mensen gedurende hun levensloop. Zij stellen dat van alle mannen van 55 jaar en ouder vierendertig procent hulpbehoevend blijkt te zijn, van alle vrouwen vijfendertig procent:

leder jaar dat men ouder wordt stijgt de kans met 1,4 procentpunt voor de mannen en 2,4 procentpunt voor de vrouwen. Over de periode tussen 55 en 85 jaar stijgt de kans op hulpbehoevendheid met enige tientallen procenten.

Arcares geeft aan dat de verwachting is dat ouderen een langere periode zullen kennen met relatief lichte klachten die nog geen verpleging en verzorging noodzakelijk maken. Betere geneeskundige voorzieningen dragen er toe bij dat professionele zorg en eventuele opname in een zorginstelling in veel gevallen langer worden uitgesteld. Na opname is wel meer zorg nodig dan nu het geval is. De zorgzwaarte van de verschillende intramurale cliëntengroepen neemt verder toe en ook het antal jaren in ernstige ongezondheid neemt gemiddeld toe. Ongezonde jaren zijn vooral toe te schrijven aan chronische aandoeningen als reuma, gewrichtsslijtage, rugklachten, ziekten van luchtwegen en hart - en vaatziekten en aan 
suikerziekte, zintuigstoornissen, CARA, verschillende soorten kanker en aandoeningen van het bewegingsapparaat. Van de zelfstandig wonende 75-plussers heeft volgens Arcares ruim vijftig procent twee of meer chronische aandoeningen; één op de vier voelt zich daarbij beperkt in het verrichten van de algemeen dagelijkse levensverrichtingen (ADL). De ADL, waaronder het zich volledig zelfstandig kunnen wassen, valt het eerst uit bij ouderen, daarna volgt het zich aan- en uitkleden en pas dan het zelfstandig eten en drinken. Ook bij het verrichten van algemeen huishoudelijke functies (HDL), zoals de zorg voor de huishouding en voor de maaltijdbereiding, worden beperkingen ondervonden (Huijsman,1990).

\section{Gebruik van (zorg)voorzieningen door ouderen}

Door een divers aanbod aan zorgdiensten en -arrangementen probeert de overheid de onafhankelijkheid en zelfstandigheid van ouderen zolang mogelijk overeind te houden. $\mathrm{Om}$ economische redenen is zij in het begin van de jaren tachtig ook genoodzaakt een restrictief volumebeleid te voeren ten aanzien van het aantal intramurale plaatsen (Knipscheer,1999). Diensten als tafeltje-dek-je, sociale alarmering en voorzieningen als de WVG (Wet voorzieningen gehandicapten) en het persoonsgebonden budget (PGB) ontstaan. Zij hebben mede tot doel formele hulp te beperken en verhuizing van ouderen naar een intramurale setting te voorkomen of uit te stellen. Sinds de introductie van de WVG in 1994 was eenderde van de gebruikers van deze voorziening 65 jaar en ouder. Tachtig procent van hen geeft aan dat ze door de WVG een onafhankelijk leven kunnen blijven leiden. Eind 1999 kon worden vastgesteld dat door de WVG 135.000 vervoersvoorzieningen waren geregeld en 47.000 rolstoelen waren verstrekt. Ook met de bouw van aparte woningen voor ouderen heeft de overheid ten doel deze generatie een zelfstandig bestaan te verschaffen in een omgeving waarin men zich thuis voelt. In het laatste decennium van de vorige eeuw verdubbelde de overheid het antal woningen voor ouderen met 450.000 (SCP, 2001). Daarbij worden (domotica)woningen ontwikkeld die met behulp van technologie zodanig zijn toegerust dat minder valide ouderen zonder veel fysieke inspanningen in hun eigen huis kunnen blijven wonen. Met haar woningbouwbeleid komt de overheid volgens het Sociaal Cultureel Planbureau (2001) tegemoet aan de voorkeur van ongeveer tachtig procent van de 75-plussers om in de eigen woning te blijven wonen.

Elf tot dertien procent van de mensen van 65 jaar en ouder krijgt informele hulp. Van de mensen die thuis professionele zorg ontvangen is tachtig procent 65 jaar of ouder. Niet iedereen die voor thuiszorg in aanmerking komt wordt direct geholpen; in het jaar 2000 stonden meer dan 54.000 geïndiceerden op een wachtlijst met een gemiddelde wachttijd van 30 weken. Sinds de introductie van het persoonsgebonden budget in 1995 bleken in het jaar 2000 ruim 16.000 mensen van deze regeling gebruik gemaakt te hebben. Het merendeel van 
deze gebruikers was tussen de 45 en 55 jaar oud (Arcares, 2000).

Beperkingen van ouderen kunnen uiteindelijk leiden tot plaatsing in een verzorgingshuis. Van alle 65 -plussers woont $7.3 \%$ in een verzorgingshuis; van de ouderen boven 80 jaar is dat twintig tot dertig procent en van ouderen boven 90 jaar gemiddeld meer dan veertig procent. Een kwart van hen is geheel hulpbehoevend. De voornaamste zorgvragen van ouderen in verpleeg- en verzorgingshuizen komen voort uit aandoeningen als dementie, met name de ziekte van Alzheimer, CVA's, neurologische aandoeningen en kanker (SCP, 2001)

\subsection{Maatschappelijke participatie van ouderen}

De vorige paragraaf heeft laten zien dat zich gaandeweg het ouder worden gezondheidsproblemen kunnen manifesteren. De levensverwachting is daarentegen zodanig gestegen dat ouderdom een groter deel van het leven beslaat. De arbeidsomstandigheden en arbeidstijden zijn sterk verbeterd, het maatschappelijk leven is verbreed, kennis op het gebied van gezondheid is toegenomen en tal van sociale en gezondheidsvoorzieningen maken mogelijk dat veel mensen nog tot op hoge leeftijd allerlei rollen in de samenleving kunnen vervullen. Op ouderen zal een toenemend beroep worden gedaan om maatschappelijk te participeren. 'Participatie' wordt door Van Rijsselt (1991) gedefinieerd als het geheel van sociale relaties die mensen onderhouden en de deelname aan verschillende vormen van het maatschappelijk leven'. Deze deelname van ouderen aan de Nederlandse samenleving zal om meerdere redenen steeds minder een vrijblijvende zaak zijn. Als gevolg van de gestegen levensverwachting is het aantal ouderen in de twintigste eeuw sterk vermeerderd en de stijging zal zich in de eerste helft van de eenentwintigste eeuw voortzetten.

Van een in kwantitatieve zin beperkte groep in het begin van de twintigste eeuw, in 1900 was maar zes procent van de bevolking 65 jaar en ouder en tot 1930 bleef het percentage rond zes procent hangen (Turksma, 1982), stijgt het aandeel ouderen naar negen procent in 1960, elf procent in 1980 en ongeveer twintig procent in het jaar 2000. Een stijging in een eeuw tijd van dertien tot veertien procent (Braam, 1981; Knipscheer, 1985; Bijsterveld, 2001). Ondanks het hoge aantal 65-plussers in onze huidige samenleving heeft ons land ten opzichte van landen als Duitsland en Frankrijk nu nog een relatief jonge bevolking (VWS, 2003). Naar de mening van de Wetenschappelijke Raad voor het Regeringsbeleid (1999) zal het verouderingsproces zich de komende decennia versterkt voortzetten. Bovenop de structurele veroudering van de bevolking, als gevolg van de ingezette daling van het vruchtbaarheidscijfer, zal zich namelijk ook nog de vergrijzing aandienen van de grote 
geboortecohorten van na de Tweede Wereldoorlog. In 2000 is één op de vijf mensen 65 jaar of ouder; in 2035 één op de vier (Aakster, 1987; Van der Maas, 1999), meer dan een verdubbeling van het aantal ouderen ten opzichte van 1980 (Visser, 1990; Knipscheer, 1995). Binnen de groep van 65-plussers neemt het aandeel oudste ouderen ( 80 jaar en ouder) snel toe (Aakster, 1987). Het Sociaal Cultureel Planbureau (2001) gaat bij ouderen uit van de leeftijdsgroep vanaf 55 jaar en concludeert dat in 200023 procent van de Nederlanders, oftewel 3.7 miljoen inwoners, 55 jaar of ouder is. De komende 30 jaar zal het aantal 55 -plussers met 63 procent stijgen.

De aanwezigheid van een grote groep van ouderen in de Nederlandse samenleving zorgt er volgens Bijsterveld (2001) voor dat individuele verschillen tussen ouderen toenemen en dat gesproken kan worden van een 'amalgaam van individuen onderscheiden naar generatie, gender, klasse, rijkdom, macht, religie en ras'. Braam (2001) concludeert dat de verschillen binnen de categorie ouderen groter zijn dan in welke andere leeftijdscategorie ook. Visser (1990) karakteriseert de pensionering als een gebeurtenis die leidt tot een verandering van dagindeling, van sociale contacten, van de financiële situatie en van de hoeveelheid vrije tijd. Ze luidt een periode in waarin ouderen op zoek gaan naar nieuwe perspectieven.

In de paragrafen 2.4.1 tot en met 2.4.3 wordt beschreven hoe de deelname van ouderen aan de Nederlandse samenleving er uit ziet op het gebied van arbeid en op sociaal, cultureel en recreatief gebied, hoe verschillen tussen ouderen tot uiting komen en wat de perspectieven van ouderen zijn ten aanzien van maatschappelijke participatie.

\subsubsection{Arbeidsparticipatie}

In paragraaf 2.2. is beschreven dat de overheid op het eind van de negentiende eeuw mensen in bescherming neemt door hen op 65-jarige leeftijd te laten uittreden uit het arbeidsproces. Door (aanvankelijk een deel van) hen recht op pensioen te geven worden zij beschermd tegen de financiële gevolgen van het stoppen met betaalde arbeid. In de loop van de twintigste eeuw neemt de overheid met een stelsel van sociale zekerheid verdere maatregelen die de bescherming tegen risico's en gevolgen van ouderdom van grotere groepen ouderen moeten waarborgen:

- in 1913 wordt de Invaliditeitswet van kracht met het doel arbeiders te verzekeren tegen de geldelijke gevolgen van invaliditeit en ouderdom;

- de Pensioenwet van 1922 geeft een wettelijk kader aan de leeftijdsgrens van 65 jaar en waarborgt een inkomen voor een deel van de Nederlandse beroepsbevolking bij het bereiken van de pensioengerechtigde leeftijd;

- de Algemene ouderdomswet van 1956 regelt een basisinkomen voor alle mensen 
van 65 jaar en ouder;

- de Algemeen burgerlijke pensioenwet van 1996 vervangt de Pensioenwet van 1922;

- de Arbeidsongeschiktheidsverzekering van 1967 vervangt de Invaliditeitswet en geeft een aparte regeling voor invaliditeit en ouderdom (Huijsman, 1990). Daarmee wordt uitdrukking gegeven aan de gegroeide feitelijkheid dat ouderdom en invaliditeit niet noodzakelijk samenhangen.

De overheidsregelingen bewerkstelligen dat de deelname van ouderen aan het arbeidsproces in de loop van de twintigste eeuw sterk afneemt: in 1947 neemt nog 35 procent van de 65plussers deel en in het midden van de jaren tachtig is nog slechts 4 procent betaald actief (Aakster, 1987). Door de decennia van de twintigste eeuw heen blijkt het bereiken van de pensioengerechtigde leeftijd voor de betrokkenen steeds minder een gebeurtenis te zijn die samengaat met fysiek ongemak. Waar ouderen in het begin van de twintigste eeuw nog worden beschermd tegen het verrichten van betaalde arbeid en ze niet meer hoeven deel te nemen aan het arbeidsproces, zien we vanaf de tweede helft van die eeuw dat ze worden afgeschermd van de arbeidsmarkt; ze mogen niet meer deelnemen (Braam, 1981).

Baars (2001) schertst:

Slechts nog in een 'grijs' circuit wordt geschnabbeld en geklust tot op hoge leeftijd.

Het pensioenrecht wordt een pensioenplicht. Reestman (2000) gaat zo ver dat hij spreekt van een 'dwangpensioen', omdat de individuele 65 -jarige niet de vrijheid heeft om betaalde arbeid te blijven verrichten, ongeacht zijn fysieke en mentale gesteldheid. Voor Evenhuis (2001) is dit aanleiding te stellen dat sprake is van leeftijdsdiscriminatie en zij pleit voor de ontwikkeling van een rechtstheoretisch kader dat de grondslagen van het gelijke behandelingsrecht ook voor de non - discriminatiegrond leeftijd vastlegt en uitdraagt.

Voor de 65-jarige krijgt het pensioen naast financiële vooral psychologische en sociale betekenis. De generaties mannen en vrouwen die in de periode van de Tweede Wereldoorlog oud worden en die bovendien de zware crisis in de dertiger jaren hebben beleefd, genieten van de verworvenheden van het pensioenrecht (Munnichs, 1990). Maar in de jaren na 1945 wordt het pensioenrecht voor velen als een pensioendwang beschouwd, waardoor een belangrijke maatschappelijke rol niet meer vervuld kan worden. Voor de overheid is dit geen reden om de leeftijd voor ouderdom naar boven toe bij te stellen. In de loop van de twintigste eeuw gaat zij de leeftijd van 65 jaar in toenemende mate als economisch stuurmechanisme hanteren, waarbij werkgelegenheid of arbeidsbehoefte en financiering van 'oudedagvoorzieningen' centraal komen te staan. Dit komt evident aan het licht bij de economische crisis van de midden zeventiger jaren waarin werk een schaars 
goed wordt. Voor de jongere beroepsbevolking moet emplooi gevonden worden en ouderen krijgen massaal de gelegenheid vervroegd uit te treden. Prestatievermogen, productiviteit en lichamelijke gesteldheid spelen geen doorslaggevende rol in de beslissing om van die gelegenheid gebruik te maken. Pensioen wordt mogelijk vanaf 55 jaar, hier en daar zelfs vanaf 50 jaar. De effecten laten niet op zich wachten. Waar de arbeidsparticipatie van mannen van $50 \mathrm{t} / \mathrm{m} 64$ jaar tussen 1899 en 1960 ongeveer $90 \%$ bedraagt, gaat de uittredingsleeftijd na 1960 aanmerkelijk dalen (de deelname van oudere vrouwen aan het arbeidsproces is overigens maar beperkt van invloed op de gemiddelde uittredingsleeftijd, omdat het aandeel vrouwen van $50 \mathrm{t} / \mathrm{m} 64$ jaar in de beroepsbevolking veel kleiner is dan het aandeel mannen). Rond 1980 is nog slechts $41 \%$ van de leeftijdsklasse van 60-65 jaar full-time aan het werk. De Wetenschappelijke Raad voor het Regeringsbeleid (WRR, 1999) schrijft de drastische verlaging van de uittredingsleeftijd toe aan 'de beschikbaarheid van genereuze uitkeringsregelingen en een tolerante uitvoeringspraktijk'.

Het Sociaal Cultureel Planbureau (2001) constateert dat vanaf 1993 een lichte kentering plaats heeft. Mensen verlaten minder snel het arbeidsproces. De leeftijd waarop de meeste mannen uittreden verschuift van 60 naar 61 jaar en voor het merendeel van de vrouwen blijft 60 jaar de leeftijd om te stoppen met betaalde arbeid. In 2000 blijkt gemiddeld één op de drie 55-tot 64 jarigen nog betaalde arbeid te verrichten: de helft van de mannen en twintig procent van de vrouwen. Door de vervroegde uittreding ontstaat een nieuwe ouderdomscategorie: de 'jongere ouderen' genoemd. Nieuwe aanduidingen voor ouderdom volgen, zoals de "derde leeftijd" (Munnichs, 1989) en "het derde kwartiel van het leven" (Knipscheer/Baars, 1988), benamingen voor groepen van mensen die de arbeidsmarkt vroegtijdig de rug toekeren. Aanduidingen die niet kunnen verhullen dat met het verlies van arbeid ook maatschappelijk aanzien verloren gaat. Gaandeweg de twintigste eeuw wordt duidelijk dat de kwaliteit van het menselijk leven in de Nederlandse samenleving wordt afgemeten aan haar 'ruilwaarde', haar economisch nut. Uittreding uit de arbeidsmarkt reduceert dit nut tot nul en de beeldvorming van de generatie ouderen wordt er door gevormd (zie paragraaf 2.5). Met een verplichte uitsluiting uit het arbeidsproces gaat ook een verplichte uittreding uit andere maatschappelijke verbanden gepaard. Zo was tot voor kort 65 jaar de leeftijd waarop mensen in organisaties, bedrijven en verenigingen statutair moesten aftreden als commissaris of bestuurslid. Ook aan deze regeling lag de veronderstelling ten grondslag dat het prestatievermogen en rendement het niet langer toelaten verantwoordelijkheid te dragen en dat ouderen tegen zichzelf in bescherming moeten worden genomen. Voor Westenterp reden om te fulmineren (Reestman, 2000):

Alleen in Nederland dwingt de wet commissarissen tot aftreden. In Azië kom je op die leeftijd pas kijken. 
Ondanks de ruilwaarde die kennelijk aan arbeidsparticipatie is opgehangen en een vermeend verlies van maatschappelijk aanzien bij non-participatie, kent Nederland een omvangrijke groep die niet gebukt gaat onder het verlaten van het arbeidsproces. Veel mensen verlaten vrijwillig het arbeidsproces voor zij de leeftijd van 65 jaar bereiken. Zij kiezen er weloverwogen voor gebruik te maken van het recht op pensioen in plaats van de pensioenplicht af te wachten. Vele ouderen die deze keus maken doen dat omdat de arbeidstaken die zij verrichten onvoldoende voldoening bieden; zij verrichten laaggekwalificeerde arbeid en vrije tijd heeft hun voorkeur. Van een gevoel van uitstoting uit de arbeidsmarkt is geen sprake. Daarnaast wenst maar liefst negentig procent van de ouderen na het $65^{\mathrm{e}}$ levensjaar niet meer te werken. Dit percentage is tevreden met een definitieve uittreding uit de arbeidsmarkt (Braam, 1981).

Voor de nog beperkte groep van ouderen die ervaart dat het pensioen een vroegtijdig einde maakt aan de aspiratie om op de arbeidsmarkt actief te blijven, treffen we nu, in het prille begin van de eenentwintigste eeuw, de kiemen aan van een nieuwe ontwikkeling. De sterke vergrijzing drukt op de overheidsfinanciën en heeft tot gevolg dat de overheid initiatieven neemt om ouderen te behouden voor de arbeidsmarkt en hen door (extra) premieafdracht medebetaler te maken voor sociale zekerheid; voor pensioen - en zorgvoorzieningen. Voor de overheid is het economisch niet langer verantwoord grote groepen ouderen vervroegd of met 65 jaar te laten uittreden uit de arbeidsmarkt. Uit lange termijn berekeningen van de Sociale Verzekeringsbank blijkt dat op het hoogtepunt van de vergrijzing, in de jaren tussen 2035 en 2040, het Rijk meer dan de helft van de AOW-uitkering moet opvangen, wat neerkomt op ruim zeven procent van het nationaal inkomen, tegen vijf procent nu (ANP, 5$8-2003$ ). De noodzaak tot het oprekken van de geïnstitutionaliseerde grens van 65 jaar is daarmee na 110 jaar onderwerp van discussie geworden en stemmen gaan op om de grens voor uittreding bij 67 jaar neer te leggen. Tot nu toe is verlate uittreding in Nederland slechts voorbehouden (geweest) aan hoogleraren en rechters, die tot hun $70^{c}$ mogen aanblijven en aan PTT-medewerkers voor wie een uitloop tot het $67^{\mathrm{C}}$ levensjaar mogelijk is. Nu worden scenario's ontwikkeld voor flexibele uittreding, voor en na de 65 -jarige leeftijd voor iedereen. Het Verbond van Verzekeraars pleit voor een deeltijdpensioen in een levensloopregeling (ANP, 9-9-2003); anderen bepleiten een functionele flexibilisering van de arbeid en een zogenoemde transitionele arbeidsmarkt (Muffels, 2001). Het zijn scenario's die de werknemer respectievelijk de ruimte bieden op een zelfgekozen moment uit te treden, arbeidstaken te verrichten die zijn toegesneden op individuele kwaliteiten en loon en uitkering te combineren. 


\subsubsection{Participatie op sociaal, cultureel en recreatief gebied}

Participatie in de samenleving wordt door de overheid als een belangrijke voorwaarde gezien voor het behoud van onafhankelijkheid en zelfstandigheid (Knipscheer,1999). Volgens Braam (1981) geeft participatie aan dat sprake is van maatschappelijke integratie en hij constateert dat het verlies van de arbeidsrol c.q. van arbeidsparticipatie tot afnemende integratie leidt, die gecompenseerd wordt door tal van andere activiteiten. Hij merkt op dat verschillen in participatie groot zijn tussen de jongbejaarden en de hoogbejaarden en minder groot zijn tussen de jongbejaarden en mensen van middelbare leeftijd. Vijftig tot zestig procent van de 50 - tot 64 - jarigen zet zich in voor vrijwilligerswerk of informele zorg. Binnen die categorie zijn het met name de 55 - tot 59-jarigen die informele zorg verlenen binnen hun sociale netwerk, waaronder de opvang van kleinkinderen. Ouderen tussen 50 en 59 die geen betaalde arbeid meer verrichten en die een hoger opleidingsniveau hebben, scoren hoog op het gebied van vrijwilligerswerk, terwijl vrijwilligerswerk en informele zorg afnemen bij het stijgen der jaren (SCP, 2001). Ouderen hebben meer contact met familie en buren dan met vrienden; dit geldt met name voor de groep van 80 - plussers. Ongehuwde, alleenstaande en gescheiden ouderen, met name vrouwen, hebben daarentegen veel minder contacten met de familiekring of met anderen in hun omgeving. Cijfers van het CBS (Braam, 1981) wijzen uit dat in de leeftijdscategorie 65-74 jaar veertien procent van de mannen en zeven procent van de vrouwen minder dan éénmaal per week contact hebben; in de leeftijdscategorie $75+$ zijn de percentages zeventien respectievelijk achtentwintig procent. Het gaat hier om een aanzienlijke groep: meer dan veertig procent van de $75-$ plussers is alleenstaand; van ouderen die gebruik maken van intramurale voorzieningen is zelfs negentig procent alleenstaand (Huijsman, 1994). Braam (1981) merkt op dat met het toenemen van de leeftijd ouderen een zwakkere verbondenheid krijgen met primaire relaties. Burenrelaties zijn belangrijk voor ouderen. Buurtcontacten vinden eerder plaats wanneer sprake is van een homogeen woonmilieu, een woonomgeving waarin mensen van ongeveer dezelfde leeftijd wonen, dan in een heterogeen woonmilieu. Vooral wanneer veel oudere vrouwen bij elkaar in de buurt wonen zijn de contacten het sterkst. Burenrelaties van ouderen hebben vaak het karakter van onderlinge ondersteuning op het gebied van het huishouden, boodschappen en klusjes (Braam, 1981).

Ouderen in verschillende leeftijdscategorieën vullen hun vrije tijd in met tal van activiteiten. Wanneer ze dat samen met anderen doen, zijn het overwegend leeftijdgenoten die aan hun zijde staan (Turksma, 1982). Vierenveertig procent van de 55-plussers doet aan sport. Gemiddeld een half uur per dag wordt gezwommen, gefietst, getennist of gewandeld. Er wordt niet vermeld of het sporten afneemt of minder intensief wordt beoefend met het 
stijgen van de leeftijd (SCP, 2001). Cramer-Cornelissen (1998) neemt de intentie van de lichamelijk actieve ouderen als volgt op de korrel:

We joggen, fitnessen en lijnen dat het een lieve lust is, met als voornaamste doel de sporen uit te wissen die ons aan het verstrijken van de tijd herinneren.

Ongeveer één op de tien ouderen van 65-74 jaar zegt vaak aan de activiteiten van een vereniging deel te nemen; bij ouderen van $75+$ is één op de twintig vaak actief. Op het gebied van clubs en sociëteiten is de participatiegraad van deze leeftijdscategorieën minder uiteenlopend: tien procent van de laagste en acht procent van de hoogste leeftijdscategorie bezoeken deze gelegenheid vaak (Braam, 1981).

Tisser (1999) bevestigt dat ouderen in de leeftijd van 65-79 jaar met het stijgen van de leeftijd minder aan activiteiten deelnemen. Omstreeks het 80 ste levensjaar neemt ook de variatie in activiteiten waaraan wordt deelgenomen duidelijk af. Activiteiten die ouderen op hogere leeftijd blijven doen, zijn het beoefenen van een denksport, het bezoeken van een middag- of avondactiviteit, het kijken naar het televisiejournaal en het lezen van een krant. In hoeverre deze keuzes beïnvloed of gestuurd worden door belemmeringen op het terrein van gezondheid, mobiliteit of bestedingsmogelijkheden wordt niet vermeld. De mate waarin ouderen lid zijn van maatschappelijke organisaties neemt volgens Tisser sterk af met de leeftijd, uitgezonderd het lidmaatschap van een politieke partij. Wat hem opvalt is de relatief grote groep van 65 tot 79 jaar en ouder met een lidmaatschap van de bibliotheek.

\subsubsection{Participatie en persoonlijke kenmerken van ouderen}

De hierboven gepresenteerde cijfers over de participatie van mensen van 55 jaar en ouder aan sociale, culturele en recreatieve activiteiten geven het beeld van een actieve invulling van hun leven door 'jongere ouderen' en een overwegend teruggetrokken bestaan van mensen van 80 jaar en ouder, de zogenoemde 'oudere-ouderen' of hoogbejaarden. De positie die ouderen in de maatschappij innemen en de mate waarin ze actief participeren worden beïnvloed door zowel hun persoonlijke situatie of individuele kenmerken als door de wijze waarop zij door de samenleving bejegend worden. Voor Braam (1981) hangen kenmerken van ouderen en hun participatie samen. Hij constateert dat participatie van ouderen geen rechtstreekse afspiegeling is van de afnemende integratie in de samenleving, zoals die door het verlies van met name de arbeidsrol verwacht mag worden. Voor wat betreft participatie lijken de scheidslijnen naar zijn mening niet primair te lopen tussen de wel- en niet-ouderen, maar veeleer binnen de categorie van ouderen. Met het verenigingsleven wordt bijvoorbeeld niet gestopt rondom de pensionering, maar in een latere fase van de ouderdom, op een leeftijd van 70 of 75 jaar. De reden waarom men stopt 
is vaak gelegen in de gezondheidssituatie. Achteruitgang in de mobiliteit, die zoals hiervoor beschreven vooral vanaf 80-plus optreedt, heeft tot gevolg dat de sociale omgeving kleiner wordt en dat ouderen er minder op uit gaan. Door het verlies van naaste verwanten en het risico van een plotselinge verslechtering van de gezondheid lopen met name ouderen van hoge leeftijd de kans op verlies van sociale participatie en het optreden van isolement. Op basis van een cohortstudie over de periode 1974-1986 naar veranderingen in de inkomenspositie, waardenoriëntaties en participatieniveaus van ouderen bevestigt Van Rijsselt (1991) zijn "socio-economic breakdown hypothese": naarmate ouderen in een hogere leeftijdscategorie vallen, is het opleidingsniveau lager, verslechtert de inkomenspositie en nemen politieke, sociale, culturele en recreatieve activiteiten geleidelijk af; ouderen komen in steeds zwakkere maatschappelijke posities terecht.

Het Sociaal Cultureel Planbureau (2001) bevestigt in haar vergelijking van verschillende groepen ouderen deze opvatting. Zij heeft becijferd dat in 1971 maar liefst 59 procent van het aantal mannen en 72 procent van het aantal vrouwen van 65 jaar en ouder enkel lager onderwijs heeft genoten; in 2000 is dit percentage 25 bij mannen en 44 bij vrouwen en in 2015 zal het 17, respectievelijk 25 zijn. Bij splitsing van leeftijdscategorieën kan geconstateerd worden dat in 2000 circa 40 procent van de 65 - tot 74 -jarigen alleen lager onderwijs heeft gevolgd (mannen $38 \%$, vrouwen $55 \%$ ) en van de 75 -plussers heeft 50 procent alleen lager onderwijs gevolgd. Het SCP concludeert dat met het stijgen van de leeftijd het opleidingsniveau afneemt. Voor de ouderen die na de Tweede Wereldoorlog geboren zijn, is een kentering in dat beeld te zien. Het aantal ouderen met alleen lager onderwijs zal, vergeleken met nu, in het jaar 2010 zijn gehalveerd, terwijl het aantal ouderen met een HBO- of academische opleiding dan sterk is gestegen. Het SCP verwacht dat binnen 25 jaar nog slechts één op de tien ouderen alleen het lager onderwijs heeft gevolgd.

Terwijl de gemiddelde inkomsten van met name de 'jongere ouderen' tussen de 55 en 70 jaar volgens het SCP de komende jaren stijgen als gevolg van de opbouw van pensioenrechten, het eigen huisbezit, lijfrentes en kapitaalverzekeringen moeten ouderen zonder aanvullend pensioen, waartoe vooral de hoogbejaarden gerekend moeten worden, met een relatief beschouwd laag inkomen zien rond te komen. Een steeds grotere groep ouderen vult door het eigen woningbezit de AOW aan. Van de leeftijdscategorie 75 - 79 bezit 29.3 procent een eigen woning. Van de groep 80-plussers is dit 27.6 procent. In 2010 is dit percentage gestegen naar 33.1 respectievelijk 32.2 procent. Of een en ander betekent dat de levensstandaard van toekomstige ouderen sterk verbetert, is de vraag. De WRR (1999) concludeert dat de verwachtingen omtrent de aanvullende pensioenregelingen te 
hoog zijn en dat deze regelingen in de huidige vorm niet kunnen blijven voortbestaan. De demografische effecten op de financiering van de AOW en de aanvullende pensioenen blijken op lange termijn aanzienlijk. Een sterk groeiend deel van de loonsom is nodig voor de oudedagsvoorziening. De overheid zal, zoals ook in paragraaf 2.4 .1 is opgemerkt, genoopt worden tot ingrepen in de AOW of de aanvullende pensioenen, hetgeen de inkomensontwikkeling van ouderen negatief zal beïnvloeden. Op dit moment is de inkomenspositie van ouderen met matige tot ernstige beperkingen ongunstig; ouderen zijn oververtegenwoordigd in de lage inkomensgroepen. Van de zelfstandig wonende ouderen hebben alleenstaande vrouwen die ouder zijn dan 75 jaar het minst te besteden. Twintig procent kan moeilijk de eindjes aan elkaar knopen. Het inkomen van bewoners van verzorgingshuizen en verpleeghuizen steekt nog ongunstiger af bij dit beeld. Veertig procent van de bewoners van verzorgingshuizen ontvangt een aanvullend pensioen, tegenover tachtig procent van alle ouderen tezamen (Timmermans, 1993). In verzorgingshuizen wordt dit verschil bepaald door de samenstelling van de populatie bewoners: het merendeel van de bewoners is boven de tachtig en alleenstaand en vier van de vijf bewoners zijn vrouw. Voor wat betreft het gebruik van zorgvoorzieningen geeft de WRR aan dat dit afneemt naarmate het opleidingsniveau toeneemt. Gezien de ontwikkeling van het opleidingsniveau van ouderen wordt algemeen aangenomen dat het gebruik van zorgvoorzieningen naar verhouding zal gaan dalen (RIVM, 1997; SCP, 1997; WRR, 1999). In paragraaf 3.4. van het volgend hoofdstuk wordt deze aanname ter discussie gesteld. De dubbele vergrijzing zal evenwel in absolute zin een forse toename van het gebruik van zorgvoorzieningen te zien geven.

\subsection{De sociale positie van ouderen}

"Ze stonden het hoogst in aanzien toen er het minst van waren" (Midas Dekkers)

Sociale positie wordt door Braam (1981) gedefinieerd als 'de plaats die ouderen in de samenleving innemen en waaraan rechten en plichten zijn verbonden'. Met het begrip 'sociale positie' hangt volgens Braam nauw samen welke sociale rol vervuld mag worden en wat het maatschappelijk aanzien is. In de paragraaf over arbeidsparticipatie zagen we dat van ouderen wordt verwacht dat ze niet meer aan het arbeidsproces deelnemen. Vanaf hun 65-levensjaar vervalt de plicht om door middel van betaalde arbeid in eigen levensonderhoud te voorzien en heeft de oudere recht op pensioen. Aan eventuele ambities van ouderen om aan het arbeidsproces te blijven deelnemen, ook na het bereiken van de 65 jarige leeftijd, komt de overheid niet tegemoet; anno 2003 is dit wettelijk nog niet 
toegestaan. Als arbeid een schaars goed is, wordt van jongere-ouderen verwacht dat zij nog voor hun 65 jaar plaatsmaken op de arbeidsmarkt voor mensen die nog een toekomst moeten opbouwen, en waarvan verwacht wordt dat hun arbeidsrendement hoger en de kans op uitval kleiner is. Ouderen die voor of vanaf de 65 -jarige leeftijd stoppen met werken hebben de vrijheid te kiezen voor andere vormen van maatschappelijke participatie waaraan geen formele verplichtingen vastzitten of formele rechten aan kunnen worden ontleend.

Terwijl deelname aan het arbeidsproces omgeven is door rechten en plichten, rust op de schouder van de oudere in onze samenleving niet meer de plicht om maatschappelijke verantwoordelijkheid te dragen. Tegenover het recht op sociale zekerheid staat niet de plicht tot deelname aan politieke, sociaal-culturele, educatieve en/of recreatieve activiteiten, die bijvoorbeeld tot doel zou kunnen hebben om integratie van ouderen in de Nederlandse samenleving te behouden, of om de maatschappij gebruik te laten maken van de kennis en ervaring van ouderen. Of de kennis en ervaring van ouderen ook 'wijsheid' genoemd kunnen worden en of de samenleving er toe moet worden verplicht hiervan gebruik te maken, kan Brugman (2001) in zijn artikel 'demasqué van de wijze oudere' niet zonder meer beamen. Wijsheid veronderstelt naar zijn mening het zich bewust zijn van de beperktheid van menselijke kennis, het accepteren van die beperking en het niet vervallen in inertie. Wijsheid hangt niet samen met leeftijd, maar met persoonlijkheid. Open staan voor de wereld, emotioneel stabiel zijn, goed opgeleid zijn en het 'goede leven' leiden, staan symbool voor wijsheid. Uit de beschrijving van persoonlijke kenmerken en de maatschappelijke participatie van de hedendaagse ouderen in de Nederlandse samenleving, die in de vorige paragraaf werd gegeven, moet met Brugman worden gesteld dat wijsheid geen exclusieve eigenschap is van ouderen.

Als rechten en plichten niet met elkaar in evenwicht zijn en niet een duidelijke sociale rol vervuld wordt, schaadt dit het aanzien van een generatie. Zonder arbeidsparticipatie kan volgens Baars (2001) geen rol van betekenis worden gespeeld:

Terugtreding uit de arbeidsmarkt ontneemt ouderen de meest centrale vorm van maatschappelijke participatie en plaatst ouderdom in een negatief perspectief.

Jonker (1970) onderschrijft die mening door te vermelden dat in de Nederlandse samenleving van de negentiende eeuw 'ouden van dagen' aanzien genieten wanneer ze nog volop actief zijn in de samenleving. Een oude boer blijft de leiding van het bedrijf in handen houden tot aan zijn dood, evenals zijn vrouw die soms zelfs vanuit het ziekbed het huishouden regelt. Maar het aanzien van ouderen gaat naar zijn mening verder:

De oudsten van het volk nemen besluiten over kerkelijke zaken, hebben intensief deel aan het maatschappelijk leven en hun invloed is groot. 
Braam (1981) en ook Turksma (1982) plaatsen kanttekeningen bij dit beeld. Het aanzien van ouderen is naar hun mening in dat tijdvak betrekkelijk. In enkele gevallen is het gestoeld op bezit of financiële rijkdom en voor niet-bezitters is armoede en gebrek het lot. Het aanzien van ouderen in de sociale sfeer is gekoppeld aan religie, kennis en wijsheid. Het geven van 'zegen' aan de kinderen wordt van betekenis geacht en in een tijdperk waarin het grootste gedeelte van de bevolking niet kan lezen en schrijven wordt aan 'ervaring' grote betekenis toegekend. De opkomst van de industriële samenleving, de massale migratie naar de grote steden, waardoor grote gezinnen uit elkaar vielen, maar bovenal de opkomst van het onderwijs, die al snel tot gevolg heeft dat jongeren beter geschoold worden dan ouderen, verslechteren het maatschappelijk aanzien van ouderen.

Dit aanzien wordt niet verbeterd door uittreding uit de arbeidsmarkt. Het bereiken van de pensioengerechtigde leeftijd wordt negatief gewaardeerd, omdat ze geassocieerd wordt met een verlies van arbeidsrendement. Braam (1981) stelt dat mensen tot op zekere hoogte als machines worden gezien en als machines worden afgeschreven.

Terwijl ouderen vanaf de tweede helft van de twintigste eeuw niet om fysieke redenen, maar overwegend om economische motieven er voor kiezen of verplicht worden het arbeidsproces te verlaten, blijft hardnekkig het beeld bestaan van ouderdom als een lichamelijk en mentaal kwetsbare levensfase. In dit denken wordt het dragen van maatschappelijke verantwoordelijkheid niet meer verwacht van ouderen. Zij moeten zich terugtrekken, geen rol van betekenis meer spelen en zich stilaan voorbereiden op een afscheid van het leven. De disengagementtheorie (Knipscheer/Baars, 1988) en onthechtingstheorie (Prétat, 1995) zijn op dit denken gebaseerd. Zij stellen dat het goed en naturlijk is wanneer ouderen zich terugtrekken uit maatschappelijke verbanden. De oudere en de samenleving nemen volgens Van Rijsselt (1991) langzaam distantie ten opzichte van elkaar; ze vertonen wederkerige terugtrekkingstendensen. De samenleving verwacht van de oudere niet meer het engagement dat zij van anderen verwacht en ouderen hebben ook niet typisch een eigen rol; ze hebben een 'roleless role'; ze zijn buitenspel geplaatst (Turksma, 1982) en maatschappelijk uitgestoten (Braam, 1981; Franssen, 1995). De oudere staat in de schaduw van de dood (Baars, 2001; Prétat, 1995) en heeft nog slechts marginale betekenis voor de samenleving. Knipscheer (1985) drukt het als volgt uit:

Het marginaal worden is iets dat de oudere overkomt en dat hij in zijn leven zal moeten integreren.

Uit analyses van Rosow in 1973 en 1985 van de maatschappelijke situatie van ouderen blijkt dat disengagement feitelijk geconstateerd wordt. Er is daadwerkelijk sprake van rolverlies; ouderen worden uitgesloten van een betekenisvolle deelname aan het sociale 
leven. Omdat de maatschappij geen rollen specificeert voor ouderen zijn hun levens in sociaal opzicht niet gestructureerd en is geen sprake van een sociale identiteit (L. Claessens en F. Mertens, 1988). De kans op sociale isolatie is aanwezig (Prétat, 1995):

's Morgens trek ik de gordijnen open en 's avonds trek ik ze dicht, en daartussen zit alleen maar een schrijnend besef hoeveel ik heb verloren en hoe stom en onnozel mijn leven is geworden.

Ofschoon veel ouderen op velerlei gebied maatschappelijk participeren, zoals in de vorige paragraaf beschreven is, en mensen wel twintig, dertig jaar van hun leven oud kunnen zijn, wordt op de levensfase ouderdom een stigma geplakt dat haar associeert met incompetentie, tekortkomingen, sociale isolatie en eindigheid van het leven. Ouderdom heeft een negatieve beeldvorming. De sociale positie van ouderen is er een van een uitgerangeerde groep in de samenleving. Een groep die volgens Prétat (1995) in de wachtkamer van de dood zit en die op een goede dag zal ervaren dat ouderdom op de symptomenlijst van karakterstoornissen geplaatst is. In het begin van de jaren zeventig van de vorige eeuw stelt de Amerikaanse auteur Vonnegut (1971) in zijn roman Welkom op de apenrots dit beeld van ouderen in de westerse samenleving indringend aan de orde. Hij beschrijft hoe 65 -jarigen samenkomen in een restaurant waar ze hun vrienden en verwanten een groot afscheidsdiner aanbieden. $\mathrm{Na}$ afloop verlaten de gasten de zaal door de ene deur, de 65 -jarige gastheren en -dames via een andere deur waar zij de dood van hun keuze tegemoet treden. Vonnegut vraagt zich af of deze moedige mensen de gemeenschap geen dienst bewijzen door op die manier niemand tot last te zijn. Munnichs (1990) haalt een passage uit de Japanse roman Narayama aan, waarin een nog vitale zeventigjarige vrouw, die naar haar gevoel sociaal overbodig is geworden, zich door haar zoon op de berg laat brengen om te sterven.

Minder confronterend, maar vanuit een vergelijkbare overweging, is in Nederland de vraag gesteld of bij de besteding van overheidsmiddelen voor de gezondheidszorg in verhouding niet meer geld besteed zou moeten worden aan mensen met een lange levensverwachting. Voor Reestman (2000) is dit principe, dat ouderen dienen te wijken voor jongeren, uiterst gevaarlijk. Hij roept de vraag op bij welke leeftijd dat principe moet worden toegepast en of een 40-jarige moet wijken voor een 30-jarige. De "plaatsmaaktheorie" is naar zijn mening in strijd met de mensenrechten, met de grondwettelijke rechtsgelijkheid van alle burgers, met de solidariteit tussen de generaties en met de waardigheid en evenwaardigheid van de mens. Aan ouderen wordt geen maatschappelijke rol toegedicht, omdat zij economisch niet nuttig of nodig zijn. "Alleen een bedrijvig mens is een waardevol mens", waarschuwt Simone de Beauvoir in haar boek De Ouderdom (1975). Ook Missine (1996) en Hesschel (1983) bestrijden de opvatting dat zonder efficiënt handelen het leven zinloos is. Volgens hen is de mens nooit afgeschreven en uitgerangeerd, hoe oud hij ook is. 
'Zoals elke bloesem verwelkt en elke jeugd wijkt voor de ouderdom, zo bloeit elke levensfase...' (Herman Hesse)

Op hoge leeftijd draagt de mens volgens Missine (1996) nog heel wat mogelijkheden in zich. De Nederlandse overheid deelt blijkbaar een dergelijke opvatting, getuige de opdracht die zij aan instellingen voor ouderenzorg geeft om ouderen die een beroep op hen doen het recht op zelfbeschikking te geven, hun zelfstandigheid en zelfredzaamheid te ondersteunen, hun autonomie te respecteren en te beschermen en hen keuzevrijheid te verschaffen. Wanneer mensen met fysieke beperkingen een dergelijke verantwoordelijkheid krijgen toebedeeld, kan ook van lichamelijk gezonde ouderen gevraagd worden om een maatschappelijke rol te vervullen. De literatuur die in dit hoofdstuk is behandeld over de positie van ouderen in onze samenleving en over hun maatschappelijke rollen, laat evenwel een beeld zien van ontparticipatie, van verlies van deelname an maatschappelijke verbanden. Braam omschrijft deze positie met niet mis te verstane woorden (1981):

Met een variant op de 'disengagementtheorie' zou men wellicht kunnen stellen dat nogal wat oudere bejaarden sociaal zijn afgestorven, alvorens biologisch dood te gaan.

De omschrijving van Braam komt sterk overeen met die van Braudillard in 1976, die de oudere mens beschrijft als een 'sociale dode' die slechts een plaats heeft in de marge van de samenleving waar hem niets anders rest dan de te wachten op zijn tweede dood, de biologische (Hertogh,1999). Het zijn boute uitspraken. Ze onderstrepen de gedachte dat een bepaalde groep in onze samenleving niet van betekenis is; ze sluiten het risico in dat het verlies van engagement en een beperking van sociale contacten enkel gezien worden als bewuste, onontkoombare keuzen van ouderen; ze ontnemen de prikkel om een appèl te doen op deze ouderen en op de samenleving om het proces van ontparticiperen ter discussie te stellen en een halt toe te roepen; ze gaan er van uit dat de realiteit van een nog beperkte leef-tijd mogelijkheden, verwachtingen en aspiraties van mensen uitsluiten. De maatschappelijke discriminatie van ouderen, die wordt aangeduid met 'ageism', heeft zijn doorwerking in de geneeskunde, waar volgens Hertogh (1999) potentieel reversibele gezondheidsproblemen van ouderen over het hoofd worden gezien of inadequaat worden aangepakt, omdat ze worden toegeschreven aan ouderdom.

In een samenleving waarin de ouderen een in aantal steeds belangrijkere groep vertegenwoordigen, is participatie en herparticipatie gewenst, noodzakelijk en onontkoombaar zowel uit sociaal als uit financieel-economisch oogpunt. De laatste decennia heeft de gerontologie een theoretisch kader voor herparticipatie geschapen. 
Ouderdom is benaderd vanuit een ontwikkelings- en activiteitentheorie (Braam, 1981, 1995). De ontwikkelingstheorie geeft aan dat elke levensfase ontwikkelingsmogelijkheden heeft en de activiteitentheorie adviseert ouderen om lang actief te blijven en de eigen vertrouwde manier van leven zo lang mogelijk te handhaven. Voorwaardelijk voor een appèl op herparticipatie, vanuit welk theoretisch beginsel dan ook, is de erkenning van de ouderdom als een waardevolle en verantwoordelijke levensfase die, zoals Cicero 2000 jaar geleden al stelde, in belang niet onderdoet voor andere levensfasen en waarvan de kenmerken 'goed' zijn, omdat ze door de natuur worden voortgebracht (Van Heeswijk, 1995).

Ontparticipatie is een gevolg van de opvatting dat ouderen niet meer mogen deelnemen, dat zij niet meer hoeven deel te nemen en dat zij niet meer kunnen deelnemen aan de samenleving, met name aan het verrichten van betaalde arbeid. Aan ouderen worden geen eisen gesteld, of verplichtingen opgelegd; zij moeten niet meer deelnemen. Dit betekent niet dat het hen aan mogelijkheden ontbreekt om dienstig te zijn aan de maatschappij en dat zij niet willen deelnemen. De ontwikkelingstheorie dicht ouderen het exclusieve vermogen toe dat zij volgende generaties op weg kunnen helpen, kunnen begeleiden en dat zij ervaringen kunnen overdragen (Prétat). Kunnen, zo vraagt Knipscheer (1995) zich af, ouderen niet meer expliciet een taak krijgen of claimen bij het behoud, onderhoud en uitdragen van het culturele erfgoed van de samenleving en hun visie geven op datgene wat het leven echte kwaliteit geeft? De vraag is of volgende generaties om deze kwaliteiten verlegen zitten. Ter Borg (1998) denkt van niet. Volgens hem regeert heden ten dage een lineaire tijdsopvatting, waarin alleen het vooruitgangsgeloof telt en levenservaring minder belangrijk is, omdat kennis snel veroudert. Ouderen zijn, in een dergelijke opvatting, mensen die hun tijd gehad hebben en die hun 'zelf', hun eigenheid zijn kwijtgeraakt. Er wordt althans geen aanspraak op gemaakt. Hun aanwezigheid bewijst dat de wetenschap een grote levensverwachting garandeert en getuigt van humaniteit, omdat de lasten worden gedragen van de voorzieningen waarop zij zijn aangewezen.

De activiteitentheorie gaat er niet alleen van uit dat ouderen willen participeren, dat ze bezig en productief willen zijn en dat hen de mogelijkheid daartoe moet worden geboden (Prétat, 1995). Er schuilt ook een normatief element in: de oudere moet actief blijven. Knipscheer (1995) brengt in dit verband de legitimiteit van de AOW ter sprake en vraagt zich af of ouderen aanspraak kunnen blijven maken op de financiering van hun laatste twintig levensjaren, ook als dat op den duur betekent dat jongeren 25 procent van hun salaris daarvoor moeten afstaan. Om de legitimering van financiële afhankelijkheid te vergroten of om deze afhankelijkheid te verkleinen, zouden ouderen actief moeten bijdragen aan de samenleving en zou uittreding uit de arbeidsmarkt moeten worden uitgesteld. Braam (1981) 
ziet hierin het risico dat de oudere wordt opgejaagd tot deelname aan het maatschappelijk leven of tot zelfstandig wonen en dat hij zich wil meten met de jongere generatie terwijl dat niet verantwoord is. Carl Gustav Jung heft bij dit beeld de waarschuwende vinger op (Prétat, 1995):

Bij het ouder worden moet men zijn best doen om zich niet onnodig dood te werken. $Z_{0}$ is het tenminste met mij. Ik kan mezelf haast niet intomen en moet oppassen dat de creatieve krachten me niet in galop het universum rond jagen. Ik moet mezelf kalmerend toespreken, met grote volharding en oplettendheid, om te zorgen dat ik niet teveel doe.

Herparticipatie aan het maatschappelijk leven zal worden bevorderd of afgeremd, afhankelijk van de vraag om arbeidskrachten en van de financierbaarheid van voorzieningen op het gebied van de sociale zekerheid. Bij afwegingen die daarbij gemaakt worden, zullen ouderen nauw betrokken moeten worden en hun stem moeten laten horen. Waar een wettelijke leeftijdsgrens nu nog vormen van maatschappelijke participatie blokkeert, zal diezelfde leeftijdsgrens ouderen een stem moeten gaan geven in de keuze voor en inrichting van allerlei samenlevingsverbanden. Los van wijsheid die aan ouderen wel of niet wordt toegedicht, kan levenservaring niet worden ontkend en kan ook een lineaire tijdsopvatting niet om het gegeven heen dat voor betekenisgeving aan vooruitgangsgeloof een grote groep gelovigen nodig is. Om herparticipatie veilig te stellen, om ouderdom een eigen gezicht te geven, stelt Missine (1996) voor om rond een bepaalde leeftijd een religieus ceremonieel te laten plaatsvinden. Dit ceremonieel luidt de periode in waarin de ouder wordende mens wordt uitgenodigd nieuwe taken en nieuwe levenswaarden op zich te nemen. Door dienstig te zijn aan de samenleving zal de oudere zich volgens Missine ook vrijer en waardiger voelen.

Een belangrijke rol voor de bevordering van herparticipatie lijkt weggelegd voor de ouderenbonden. Na de Tweede Wereldoorlog hebben ouderen zich verenigd in ouderenbonden, aanvankelijk om meer sociale zekerheid te bewerkstelligen en een stem te hebben in de discussie over de hoogte van de ouderdomsvoorziening. Vanaf de jaren vijftig van de vorige eeuw, toen verschillende bonden de krachten gingen bundelen en het Centraal Orgaan Samenwerkende Bonden van Ouderen (COSBO) ontstond, zijn de bonden hun functie en invloed gaan vergroten. Naast het behartigen van belangen treden ouderenbonden als $\mathrm{ANBO}$, Unie $\mathrm{KBO}$ en $\mathrm{PCOB}$ onder meer op als voorlichter, adviseur en organisator van sociale, recreatieve en educatieve aktiviteiten. Hun gezamenlijk ledenaantal is meer dan 400.000. De ouderenbonden zijn zich meer en meer gaan richten op thema's als emancipatie en participatie van ouderen. De democratisering in zorginstellingen, de oprichting van bewonerscommissies en later cliëntenraden, zijn een rechtstreeks gevolg van hun inspanningen (Huisvesting en verzorging van Ouderen, 1993; Handboek Lokaal Ouderenbeleid, 1993; Regelingen en Wenken Ouderenbeleid, 1977). 


\section{$2.7 \quad$ Beschouwing}

Steeds meer mensen worden oud. Wanneer 65 jaar de leeftijd blijft waarop mensen oud zijn, zal als gevolg van een stijgende levensverwachting de levensfase ouderdom een steeds groter deel van het leven beslaan. De sterke vergrijzing maakt dat de samenleving steeds meer rekening heeft te houden met de levensfase ouderdom. De diversiteit in opleiding, inkomen en gezondheid van ouderen, in relatie tot de economische ontwikkeling van de Nederlandse samenleving, maakt dat een toenemend beroep gedaan zal worden op participatie van ouderen, op hun arbeidspotentieel en financiële inbreng. Financieeleconomische motieven zetten de overheid aan tot beleid waarin ouderen zo lang mogelijk behouden blijven voor het arbeidsproces. De tijd dat 65 -jarigen pensioenplichtig worden, ligt binnen afzienbare tijd achter ons en daarmee komt de fixatie van de levensfase ouderdom aan de leeftijd van 65 jaar ter discussie te staan. Ofschoon de Nederlandse samenleving arbeidsparticipatie beschouwt als vorm van maatschappelijke deelname die aanzien geeft, is de vraag gewettigd hoeveel ouderen zitten te wachten op langere deelname aan het arbeidsproces. Het aantal mensen dat voor de 65 -jarige leeftijd vrijwillig stopt met werken blijkt namelijk veel hoger te zijn dan het aantal mensen dat verplicht moet uittreden. Degenen die uitgetreden zijn keren de samenleving niet de rug toe, zoals de disengagementtheorie beweert. Op vele verschillende manieren nemen ouderen van verschillende leeftijdsgroepen deel aan het maatschappelijk leven. Zo worden sociale relaties onderhouden met familie en buurtgenoten; vrijwilligerswerk wordt verricht; ouderen nemen deel aan het verenigingsleven en aan tal van recreatieve en culturele activiteiten. De maatschappelijke waardering hiervan door niet-ouderen is laag; ouderen worden althans geen sociale positie, sociale rol of hoog maatschappelijk aanzien toegedicht.

De groep van ouderen blijkt heterogeen van samenstelling te zijn: het inkomen hangt af van de leeftijdscategorie waartoe de ouderen behoren; het opleidingsniveau is hoger bij 'jongere ouderen' dan bij hoogbejaarden; de woonsituatie is meer en meer aangepast aan individuele (zorg) behoeften; de gezondheid gaat over het algemeen achteruit naarmate de leeftijd toeneemt en het gebruik van zorgvoorzieningen sluit daar op aan. Leeftijd, binnen de levensfase ouderdom, blijkt een belangrijke factor te zijn voor wat betreft de mate van participatie van ouderen aan het maatschappelijk leven. Maar ook zogenoemde 'verworven kenmerken' beïnvloeden de participatie van ouderen: een lager inkomen, een slechtere gezondheid en het verlies van dierbare relaties leiden tot een verminderde participatie. Vanaf de 75-jarige leeftijd krijgt menig oudere gezondheidsproblemen. Na de 80 jaar neemt de kans op meervoudige aandoeningen toe en de gezondheid van 90 -jarigen is zodanig dat 
minstens vier van de tien mensen voor plaatsing in een verzorgingshuis in aanmerking komen. Voor sommige ouderen komt dat perspectief al eerder in beeld.

Het merendeel van de ongehuwde of gescheiden, alleenstaande vrouwen van 80 jaar en ouder blijkt niet meer dan lager onderwijs te hebben gevolgd, zit in een lage inkomensgroep, heeft weinig sociale contacten en een kwetsbare gezondheid. Bij deze groep is sprake van een "kumulative Benachteiligung" (Van Rijsselt, 1991). Veel van de eerder beschreven stereotype beelden over ouderen worden met name op deze groep van toepassing geacht: zij zijn sociaal afgestorven, maatschappelijk uitgestoten en tellen niet meer mee voor de samenleving; ze hebben een roleless-role; er is sprake van ontparticipatie. Veel van deze ouderen komen in aanmerking voor plaatsing in het verzorgingshuis. Terwijl zij vóór plaatsing een anoniem en teruggetrokken bestaan leiden, met beperkte financiën rond moeten zien te komen, afhankelijk zijn van anderen en de regie over hun leven verloren lijken te hebben (Van Houten, 1999), dienen zij in het verzorgingshuis hun zelfstandigheid, hun eigenwaarde en zelfrespect veilig te stellen. Dat dit niet eenvoudig is mag blijken uit de vraag van de bewoner, in de inzet van het inleidend hoofdstuk, aan welke regels zij zich te houden heeft. 
In dit hoofdstuk wordt de ontwikkeling beschreven die het verzorgingshuis heeft doorgemaakt en nog doormaakt. Doel, functie en taken van de verzorgingshuiszorg worden aangestipt, alsmede de werkzaamheden die in en vanuit het verzorgingshuis voor zorgbehoevende ouderen worden verricht. Vervolgens wordt een beeld geschetst van het verzorgingshuis als instelling; haar institutionele karakter maakt het lastig om zelfstandigheid, keuzevrijheid, privacy en het uitdrukken van competenties van bewoners voldoende ruimte te geven.

Daarna wordt een poging gedaan het personeel dat in verzorgingshuizen werkzaam is te karakteriseren. Opvallend is dat het tekort aan gekwalificeerde verzorgenden wordt opgeheven door functiedifferentiatie en flexibele arbeidscontracten, waardoor de continuiteit van de zorgrelatie tussen zorgvrager en zorgverlener onder spanning komt te staan.

Vervolgens wordt ingegaan op de ontwikkeling van capaciteit van verzorgingshuizen met inbegrip van de problematiek van de wachtlijsten. Aansluitend wordt 'de bewoner' van het verzorgingshuis getypeerd, waarbij met name de parameters zorgbehoevendheid en zorgzwaarte als uitgangspunt gelden. Het hoofdstuk eindigt met de constatering dat in de loop der jaren sprake is van een forse toename van de behoefte an fysieke zorg van bewoners in verzorgingshuizen. Daarnaast eist de behoefte van bewoners aan sociale contacten aandacht op, terwijl de verzorgingshuizen niet voldoende lijken toegerust om zich van die taak te kwijten.

\subsection{Ontstaan en positionering van het verzorgingshuis}

Het verzorgingshuis, als plaats waar ouderen naar toe gaan die een bepaalde mate van zorg behoeven, kent nog geen lange historie. In het begin van de vorige eeuw is ouderenzorg niet meer dan armenzorg, waarbij de overheid zorgdraagt voor armen- en oudeliedenhuizen voor ouden van dagen die geen familie (meer) hebben om voor hen te zorgen en die niet in hun levensonderhoud kunnen voorzien. De bewoners ervan zijn afhankelijk van de liefdadigheid van hun medeburgers. Daarnaast bestaan er voor de beter gesitueerden pensiontehuizen. Het antal woonvoorzieningen voor ouderen is echter lang niet voldoende om het toenemend aantal ouderen, dat na 1945 een beroep op huisvesting en verzorging doet, onderdak te verschaffen. De naoorlogse woningnood makt de situatie nog eens extra nijpend (Van Loveren, 1995). In de vijftiger en zestiger jaren van de twintigste eeuw is het 
overheidsbeleid er duidelijk op gericht de ouderen te stimuleren zo spoedig mogelijk na het bereiken van de 65 -jarige leeftijd te verhuizen naar pensionhuizen, bejaardenoorden of kleine, aangepaste woningen. Op deze wijze komt er versneld woonruimte beschikbaar om de vele woningzoekenden te kunnen huisvesten en de woningnood te ledigen (Ouderenbeleid, 1994). Het aanmoedigen van ouderen om voor residentiële zorg te kiezen en te verhuizen naar bejaardenhuizen sluit ook aan bij de in die tijd heersende disengagementtheorie; voor de ouderen wordt bepaald dat het hun wens is zich uit het sociale leven terug te trekken (De Keyzer en Hertogh, 1999). Dit leidt tot een explosieve groei van woonvoorzieningen voor ouderen en met name van bejaardenoorden. In de periode 1945-1969 komen er 56.500 bedden bij in 546 nieuwe bejaardenhuizen en nog eens 15.000 in al bestaande huizen. In 1962 telt Nederland al bijna 80.000 plaatsen in tehuizen; in 1950 woont vijf procent en in de jaren zeventig tien procent van de 65-plussers in een bejaardenoord. De snelle toename kent ook haar schaduwkanten. Soms worden te hoge pensionprijzen berekend, dan weer te veel ouderen in de beschikbare ruimte ondergebracht. Daardoor groeit de behoefte van de overheid aan toezicht op de instellingen en bescherming van de bejaarden. In 1963 wordt om die redenen de Wet op de bejaardenoorden aangenomen (WBO,1963; Huijsman, 1990).

\section{Wet op de bejaardenoorden}

In de Wet op de bejaardenoorden, kortweg WBO genoemd, wordt een bejaardenoord omschreven als een inrichting waarin aan minimaal vijf personen van 65 jaar en ouder duurzame huisvesting wordt verschaft, gepaard met gehele of gedeeltelijke verzorging. De WBO heeft tot doel toezicht te houden en bescherming te bieden aan bewoners van bejaardenoorden (VNG, 1988). Provinciale Staten en de vier grote steden krijgen de verantwoordelijkheid voor financiering, toezicht en inspectie van de bejaardenoorden en voor het maken van richtlijnen en regels waarmee de kwaliteit van het wonen en de zorg in bejaardenoorden gewaarborgd kan worden. Tevens krijgen zij de bevoegdheid regels te stellen met betrekking tot de vrijheid van bewoners om hun leven naar eigen inzicht in te vullen. De WBO, artikel 7 lid 1 en 2, bepaalt hierover het volgende:

(WBO,1963, art.7;Ouderenbeleid 1994;VNG: Indicatiecommissie bejaardenoorden, 1988).

De staten der provincie stellen een verordening vast ten aanzien van de bejaardenoorden. Deze verordening heeft in ieder geval betrekking op de vrijheid van de bewoners hun leven naar eigen inzicht te regelen en de plicht van de houder zodanige voorwaarden te scheppen dat de keuzemogelijkheden voor de bewoners ten aanzien van hun eigen leefsituatie zo ruim mogelijk zijn.

Het bejaardenoord verplicht zich derhalve om na opname de zelfstandigheid van de oudere zoveel mogelijk in stand te houden en waar nodig ondersteuning en verzorging op maat te 
bieden. De WBO schrijt tevens voor dat een commissie wordt ingesteld die aan de bejaarde en aan het bejaardenoord advies uitbrengt over de aard en mate van de verzorging die voor de bejaarde noodzakelijk is (WBO, art 6j). Daarmee wordt de instroom van ouderen in bejaardenoorden voor het eerst gereguleerd op basis van zorgbehoevendheid.

Het algemene beeld van de vijftiger en zestiger jaren dat oude mensen in een bejaardenoord thuishoren die niet meer zelfstandig willen blijven wonen, maar die nog gezond zijn, houdt niet langer stand. Mensen verhuizen naar bejaardenoorden vanwege aandoeningen waarvoor ze lichamelijke verzorging nodig hebben. De groei van het aantal huizen neemt sterk toe en van overheidswege wordt een Centrale Commissie Bejaardenoorden (CCB) ingesteld die moet adviseren over de taak en functie van het bejaardenoord. De CCB (1979) spreekt in haar advies van 'verzorgingshuis', en niet van bejaardenoord, en omschrijft de taak en functie als volgt:

Het verzorgingshuis biedt een ondersteunend woonmilieu voor verzorgingsbehoevende bejaarden. Daarin kan de bejaarde dankzij de personele - en individuele voorziening weer zijn eigen leefwijze in zijn eigen milieu (appartement) en temidden van andere oudere mensen in soortgelijke omstandigheden geheel overeenkomstig zijn eigen inzichten voortzetten. Ter realisering van de doelstelling verricht het verzorgingshuis, naast taken ten behoeve van alle personen in het tehuis, waaronder huishoudelijke taken en taken op het terrein van voeding, wonen en huisvesting, ook taken die gericht zijn op de behoefte van het individu, met name op het gebied van verzorging en begeleiding. Het verzorgingshuis levert een verantwoorde en goede verzorging als die is gebaseerd op een weloverwogen beoordeling van de omstandigheden van iedere bejaarde, mede gesteund op het eigen inzicht en de verlangens en wensen van de bejaarde zelf.

De indicatiecommissies, die ingevolge artikel $6 \mathrm{j}$ van de WBO zijn ingesteld om ouderen voor het juiste zorgaanbod te indiceren, blijken niet naar verwachting te functioneren. Ouderen worden in verpleeginrichtingen geplaatst, terwijl zij verzorgingsbehoevend zijn of kiezen voor een verzorgingshuis, terwijl zij verpleegbehoevend zijn. In de nota Zorg voor Ouderen (Kamerstukken II, 1985-1986, 19434, nrs.1 en 2) wordt in dit verband gesteld dat indicatiecommissies verschillende interpretaties geven aan de indicatiecriteria; er wordt te veel rekening gehouden met de bestaande hulpverleningsmogelijkheden in de naaste omgeving en ondanks verschillende indicatiecriteria voor verpleeginrichtingen en bejaardenoorden of verzorgingshuizen krijgen ouderen de gelegenheid om de door hen gewenste intramurale voorziening te kiezen. In de keuze van ouderen spelen ook financiële motieven een rol. Het verzorgingshuis en het verpleeghuis worden vanuit verschillende geldstromen gefinancierd. Voor de ouderen is het financieel aantrekkelijker om in een verpleeghuis geplaatst te worden dan in een verzorgingshuis, omdat voor de berekening van de eigen bijdrage van bewoners voor verzorgingshuizen een vermogenstoets wordt toegepast, die tot gevolg kan hebben dat mensen eerst 'hun eigen huis moeten opeten' 
alvorens zij van sociale verzekeringen gebruik kunnen maken. Dit leidt ertoe dat ouderen in een verpleeginrichting geplaatst worden die op grond van hun zorgbehoefte ook in het verzorgingshuis geplaatst hadden kunnen worden. Het maakt ook duidelijk dat de indicatiestelling meer gebaseerd is op de mogelijkheden van de instelling en de wensen van de bejaarde dan op de feitelijke zorgbehoefte (VNG 1988).

Haar toenemende financiële betrokkenheid noopt de overheid in de jaren tachtig tot een ouderenbeleid dat op andere uitgangspunten is geschoeid. Het bevorderen van de zelfstandigheid en zelfredzaamheid van ouderen en een vermindering van hun afhankelijkheid van professionele zorg, en met name van de duur geachte intramurale zorg zoals het verzorgingshuis, worden van belang geacht (Bouwstenen van een ouderenbeleid, TK, 1981/1982; Flankerend ouderenbeleid, WVC, 1983; Nota volksgezondheid bij beperkte middelen, TK 1983/1984b; Nota Zorg voor Ouderen, TK, 1985/1986; Knipscheer, 1999). Met die uitgangspunten leunt de overheid aan tegen de ideologische motieven uit de Nota Bejaardenbeleid van 1970 en 1975: de materiële en immateriële positie van de ouderen in de Nederlandse samenleving moeten worden verbeterd; zij moeten optimaal integreren en participeren en zo lang mogelijk zelfstandig zijn (Nota Bejaardenbeleid (TK, 1970, 1974/1975). De Nota Ouderenbeleid, Voortgangsrapportage 1982-1988 (TK, 1987/1988, p.47), doet daar nog een schepje bovenop met de zinsnede:

In het toekomstig ouderenbeleid zal rekening gehouden moeten worden met het feit dat ouderen niet één homogene groep vormen. Hiermee kan op den duur tevens het zelfbeeld en de beeldvorming van ouderen in het algemeen in meer positieve zin worden omgebogen.

Om te komen tot een objectieve beoordeling van de opnamebehoefte van de oudere, tot een onderscheid tussen verpleeginrichtingen en bejaardenoorden en tot een selectiever gebruik van de intramurale zorg, wordt in 1984 de Wet op de bejaardenoorden bijgesteld. Het Besluit Indicatieadvisering bejaardenoorden en verpleeginrichtingen (1988) moet vervolgens leiden tot een objectievere indicatiestelling, tot meer samenhang in het indicatiebeleid voor bejaardenoorden en verpleegtehuizen en tot gestructureerde samenwerking tussen verpleeginrichtingen en bejaardenoorden. De functie van deze instellingen voor ouderen wordt onderscheiden (VNG 1988):

In verpleeginrichtingen moeten mensen worden geplaatst die niet (langer meer) aangewezen zijn op specialistische hulpverlening, maar wel op behandeling, intensieve verpleging en verzorging die in de thuissituatie niet geboden kan worden. De verpleeginrichting geeft een integrale behandeling aan die mensen die reactivering, terminale zorg of andere continue en multidisciplinaire zorg behoeven. Bejaardenoorden zijn voor ouderen die minder hulpbehoevend zijn dan degenen die in de verpleeginrichting verblijven; ze hebben primair de functie van vervangend woonmilieu met verzorging, begeleiding en eventueel verpleegkundige zorg. 
Het aantal bejaardenoorden loopt tussen 1965 en 1984 terug van 1528 naar 1489 . Het aantal plaatsen groeit daarentegen van 73.000 in 1965 tot 133.500 in 1988 en neemt vervolgens af tot 127.000 in 1992 (CBS, 1994). De taken van het verzorgingshuis breiden zich uit. Vanaf het midden van de jaren tachtig biedt de gewijzigde WBO het bejaardenoord de mogelijkheid bredere taken te verrichten, zoals dagverzorging en nachtopvang. Gestructureerde samenwerkingsverbanden tussen verpleeginrichtingen (verder aangeduid als verpleeghuizen) en bejaardenoorden (verder aangeduid als verzorgingshuizen) maken mogelijk dat in verzorgingshuizen kleine groepen bewoners worden verpleegd, hetgeen wordt aangeduid als 'substitutie verpleeghuiszorg'. Semimurale en extramurale activiteiten worden ontplooid, waaronder flankerend ouderenbeleid en reikwijdteverbreding (flankerend beleid is een maatregel die ouderen in staat stelt tijdelijk in het verzorgingshuis te verblijven; door reikwijdteverbreding krijgt het verzorgingshuis de mogelijkheid om, eventueel in samenwerking met een thuiszorgorganisatie, zorg te leveren in (aanleun)woningen van ouderen; substitutie verpleeghuiszorg maakt mogelijk dat verpleegbehoevende ouderen in het verzorgingshuis kunnen blijven wonen, doordat het verpleeghuis en het verzorgingshuis samen de benodigde deskundigheid inbrengen) (Ouderenbeleid, 1994; Brancherapport, 2000).

De doelen die de overheid nastreeft met het flankerend beleid en met substitutie van verpleeghuiszorg zijn het terugdringen van intramurale verzorgingscapaciteit, respectievelijk het voorkomen van overlappingen in de zorg, omdat de kosten moeilijk te beteugelen zijn.

In 1975 woont $9.5 \%$ van de 65 -plussers in een bejaardenoord; in 1980 is dit percentage $8.9 \%$. Volgens Turksma (1982) zijn de invoering van de sociale bijstand en de wervende werking van de bouw van moderne verzorgingshuizen verantwoordelijk voor de hoge percentages. De Nota Bejaardenbeleid van 1975 stelt dat het percentage moet worden teruggedrongen naar 7\%. De Algemene Rekenkamer komt tien jaar later in haar nota Basisvoorzieningen voor bejaarden (TK, 1985/1986) tot de conclusie dat de 7\%-norm niet gebaseerd is op inzicht in het werkelijk benodigd aantal bedden voor verzorgingsbehoevende bejaarden (Huijsman, 1990). Los van deze verschillende meningen kan worden geconstateerd dat in 1996 5.4\% van de ruim twee miljoen 65-plussers in een verzorgingshuis woont, een afname van meer dan $4 \%$ in twintig jaar. Toegespitst op het percentage 75-plussers in verzorgingshuizen wordt geconstateerd dat dit is afgenomen van $25 \%$ in 1970 tot $14 \%$ in 1995 (Nies, 1999).

De functies van het verzorgingshuis op het gebied van intramurale zorg, tijdelijke opname, 
dagverzorging, nachtopvang en reikwijdtezorg breiden verder in omvang uit. Ook de externe dienstverlening door het verzorgingshuis neemt een vlucht, mede door de bouw van aanleunwoningen bij verzorgingshuizen. Op basis van instellingsregistraties in 1995 concludeert het Sociaal en Cultureel Planbureau (1997) dat in totaal 180.000 mensen van deze diensten gebruik maken. Daarbij moet worden aangetekend dat veel ouderen verschillende diensten afnemen. In 2000 registreert het CBS (Arcares, 2002) dat het verzorgingshuis aan bijna 60.000 mensen maaltijden verstrekt; meer dan 67.000 ouderen zijn aangesloten op alarmsystemen van het verzorgingshuis en het verzorgingshuis biedt kortdurende opname aan voor ruim 27.500 ouderen. Bij kortdurende opname wordt gedurende een periode van maximaal zes tot acht weken opvang en verzorging geboden aan ouderen die ziek zijn en thuis geen hulp hebben, of ouderen die na ontslag uit het ziekenhuis nog niet voldoende hersteld zijn om weer zelfstandig te wonen. Ongeveer 21.000 ouderen maken gebruik van dagverzorging en dagopvang.

Volgens het SCP (1997) is geen onderzoek gedaan naar de daadwerkelijke effecten van voorzieningen als kortdurende opname of dagverzorging op de behoefte aan opname in het verzorgingshuis. Aangenomen wordt dat deze voorzieningen de opname in een tehuis kunnen uitstellen. In ieder geval ontlasten deze zogenoemde respijtvoorzieningen de informele zorgverleners of mantelzorgers.

Door de extramurale diensten van het verzorgingshuis, de groeiende verpleegfunctie in het verzorgingshuis en de bouw van aanleunwoningen bij het verzorgingshuis verandert ook het beeld en de positie van het verzorgingshuis. Het verzorgingshuis wordt meer en meer een centrum van zorg en menig verzorgingshuis verandert haar naam in zorgcentrum.

De verpleegfunctie in het verzorgingshuis krijgt steeds meer inhoud en de behoefte aan zorg van de ouderen in het verzorgingshuis differentieert meer en meer.

De behoefte aan harmonisering van de regelgeving voor verpleeghuizen en verzorgingshuizen op het gebied van indicatiestelling en op het gebied van financiering groeit. Bij brief van 7 maart 1988 kondigt het Kabinet aan tot een gelijke financiering te komen van verpleeghuizen en verzorgingshuizen, c.q ook verzorgingshuizen op te nemen in de basisverzekering en te komen tot een 'functionele' pakketomschrijving in plaats van een 'institutioneel'. Beoogd wordt die zorg te bieden die de gebruiker in zijn specifieke situatie behoeft en gestreefd wordt de zorg zoveel mogelijk bij de gebruiker thuis aan te bieden.

\section{Modernisering ouderenzorg: van WBO naar AWBZ}

In 1993 stelt de overheid de Commissie Modernisering Ouderenzorg (CMO) in, die de minister moet adviseren over modernisering van het stelsel van ouderenzorg, als onderdeel van het zorgsysteem, waarbij de demografische ontwikkeling tot het jaar 2015 als 
uitgangspunt dient te worden genomen. Tevens moet worden nagegaan of en hoe 'zorg en wonen' gescheiden kunnen worden c.q. woonzorgprojecten tot ontwikkeling kunnen komen. De commissie adviseert in 1994 om een ruimtelijke en financiële scheiding aan te brengen tussen wonen en zorg en om alleen de zorgcomponent door de AWBZ te laten financieren; geadviseerd wordt om intramurale verzorgingshuiszorg te substitueren naar extramurale zorg en om intramurale verzorgingsplaatsen die vrijkomen te benutten voor substitutie van verpleeghuiszorg (CMO, 1994). De commissie vindt het, mede tegen de achtergrond van de nog bestaande verschillende financieringsvormen, ongepast dat ouderen met lichamelijke gebreken zowel voor het verzorgingshuis als voor het verpleeghuis geïndiceerd kunnen worden en stelt voor het verzorgingshuis en het verpleeghuis geleidelijk in elkaar te laten overgaan. De financiering van het verzorgingshuis moet om die reden worden overgeheveld van de WBO naar de Algemene Wet Bijzondere Ziektekosten. De $\mathrm{CMO}$ formuleert uitgangspunten voor een nieuwe regeling van de indicatiecommissie voor verpleeghuizen en verzorgingshuizen gebaseerd op de Algemene Wet Bijzondere Ziektekosten. Zij onderstreept het belang van een verantwoorde en patiëntgerichte zorgverlening en benadrukt de noodzaak van aandacht voor psychische en sociale problemen van ouderen $(\mathrm{CMO}, \mathrm{p} .75)$ :

Zorg voor ouderen omvat meer dan hulp bij dagelijkse en huishoudelijke activiteiten.

Een ontwerp van de Overgangswet verzorgingshuizen wordt opgesteld. De wet moet leiden tot intrekking van de Wet op de bejaardenoorden per 1-1-1997. Op 1 januari 1997 worden bij algemene maatregel van bestuur indicatiecommissies ingesteld die tot taak hebben de regels voor opname te (her)formuleren en aan de hand van de behoefte aan zorg de urgentie van de aanvragen vast te stellen. Zonder het advies van de indicatiecommissie is plaatsing voortaan uitgesloten. Voor indicatiestelling voor een verzorgingshuis worden vier dimensies van zorgbehoefte genoemd die getoetst worden: de lichamelijke toestand, huishoudelijke activiteiten, psychosociale omstandigheden en de huisvestingssituatie.

Op 1 januari 1997 wordt de Wet op de bejaardenoorden vervangen door de Overgangswet verzorgingshuizen (Stb. 1996, 476; Jaaroverzicht Zorg, 1997). In deze wet is opgenomen dat duurzaam verblijf en verzorging in een verzorgingshuis met ingang van 1 januari 2001 een aanspraak wordt in het kader van de AWBZ (artikel 26, juncto artikel 69, eerste lid).

Een AWBZ die, volgens het ministerie van VWS (Verzorgingshuiszorg als aanspraak in de AWBZ, 1999) gemoderniseerd wordt en zal worden omgebouwd tot een vraaggericht systeem, waarbij 'zorg op maat' het leidend principe is en waarbij de cliënt het heft zo lang mogelijk in eigen hand houdt. In het licht van de modernisering van de AWBZ wordt toegewerkt naar een in flexibele termen omschreven aanspraak voor verpleging en verzorging voor zowel intramurale als extramurale zorgverlening. In de Overgangswet 
periode worden de eigen bijdragen van bewoners van verzorgingshuizen en verpleeghuizen geharmoniseerd; de taken van de provincies en de vier grote steden worden overgedragen aan de zorgverzekeraar en een ontwerp wordt ontwikkeld over de inhoud van verzorgingshuiszorg in de AWBZ.

Vanaf 2001 is de Algemene Wet Bijzondere Ziektekosten (AWBZ) van toepassing voor verzorgingshuizen. De zorg te verlenen in een verzorgingshuis is in de AWBZ als volgt omschreven (AWBZ artikel 16, eerste lid):

Het doel van de verzorgingshuiszorg is het bieden van gecoördineerde planbare en onplanbare 24-uurs hulp bij zelfzorgtekorten op somatisch, psychogeriatrisch en psychosociaal gebied, waarbij verblijf in de instelling onlosmakelijk samenhangt met de ernst van zelfzorgtekorten als gevolg van veroudering en met de mate waarin de cliënt in staat is de regie over het eigen leven te voeren.

De zorg in het verzorgingshuis omvat de zorgonderdelen verzorging: het ondersteunen van ouderen bij activiteiten op huishoudelijk gebied (HDL-activiteiten) en op het gebied van de algemene dagelijkse levensverrichtingen (ADL-activiteiten); niet-complexe verpleging en begeleiding (activiteitenbegeleiding en recreatie), al dan niet gedurende het etmaal of een deel daarvan. Verblijf in het verzorgingshuis valt in artikel 16 van de AWBZ uiteen in beschutting/bescherming enerzijds en anderzijds in gelegenheid om te voorzien in eerste levensbehoeften, en in recreatieve mogelijkheden. Verblijf omvat meer dan huisvesting alleen; ook algemene menselijke levensbehoeften als veiligheid, privacy, en het zelf kunnen bepalen van een dagindeling behoren daartoe.

Opvallend in de omschrijving van de zorg in het verzorgingshuis is de verwijzing naar de mate waarin de cliënt in staat is de regie over het eigen leven te voeren. Voor het eerst in de definitie van verzorgingshuiszorg wordt impliciet aangeven dat ouderen die in staat zijn de regie over het eigen leven te voeren niet voor permanent verblijf in een verzorgingshuis in aanmerking komen. Dit zou betekenen dat de indicatiecommissie geen gehoor geeft aan de weloverwogen keuze van ouderen om vanwege de mogelijkheid tot sociale contacten en het gevoel van veiligheid voor een permanent verblijf in een verzorginghuis te kiezen (SCP, 1997). De omschrijving roept tevens de vraag op hoe een eventueel verlies van het vermogen om de regie over het eigen leven te voeren zich verhoudt tot de ruimte die de bewoner dient te krijgen om de dagindeling zelf te kunnen bepalen.

\section{Modernisering van de $A W B Z$}

In 2003 is de AWBZ gemoderniseerd. In essentie houdt dit in dat de aanbodgestuurde instellingsgebonden benadering is vervangen door een functiegerichte, vraaggestuurde benadering en dat instellingen meerdere functies kunnen leveren aan meerdere doelgroepen 
(VWS, 2003; aanpassingen WZV na modernisering AWBZ; Beleidsregels ex artikel 3 Wet ziekenhuisvoorzieningen). Verpleeg- en verzorgingshuizen worden niet langer onderscheiden als zorginstellingen waar ouderen met een verschillende mate van zorgbehoevendheid een beroep op kunnen doen. Zij worden voortaan beiden aangeduid als 'ziekenhuisvoorziening' ( VWS, 2003; Regeling DWJZ/SWW - 2370320). Zij vallen onder de WZV, omdat zij onder de functie 'verblijf' één of meer van de functies persoonlijke verzorging, verpleging, ondersteunende begeleiding, activerende begeleiding en behandeling leveren. De WZV gaat opmerkelijk genoeg niet zo ver dat verzorgings- en verpleeghuizen dezelfde verantwoordelijkheid krijgen toebedeeld. Zo wordt gesteld dat verzorgingshuizen wel de functies verblijf, verzorging, verpleging ( en niet meer de niet complexe verpleging) en ondersteunende begeleiding bieden, maar voor de organisatie en uitvoering van de functies behandeling en activerende begeleiding zijn zij aangewezen op andere zorgaanbieders, zoals het verpleeghuis en de geestelijke gezondheidszorg (VWS, 2003; Arcares, 2003).

In de gemoderniseerde AWBZ wordt de indicatiestelling verder gescheiden van de zorgtoewijzing en zorglevering. Voor wat betreft de indicatiestelling wordt door het Regionaal Indicatie Orgaan (RIO) bij de functies (exclusief 'behandeling') een klasse aangegeven die de intensiteit van de zorgbehoefte uitdrukt. Op basis van het indicatiebesluit wijst het Zorgkantoor de zorg toe. Op basis van zijn zorgplicht dient het Zorgkantoor een maximale inspanning te leveren om de aanspraak op zorg die is afgeleid uit het indicatiebesluit tijdig te leveren. Het Zorgkantoor vertaalt de aanspraken naar zorgproducten en maakt afspraken met zorgaanbieders over de zorglevering. In de zorgovereenkomst die de zorgaanbieder met de cliënt sluit dienen de inhoud en samenstelling van het zorgarrangement, alsmede de wijze waarop de zorg geleverd wordt, te worden vastgelegd. In het zorgplan wordt dit nader uitgewerkt en dienen de wensen en voorkeuren van de cliënt te worden opgenomen (Arcares, 2003). De gemoderniseerde AWBZ neemt de vraag van de cliënt als uitgangspunt van een proces van indicatiestelling, zorgtoewijzing en zorglevering. Schriftelijke afspraken tussen Zorgkantoor en zorgleverancier en vervolgens tussen zorgleverancier en zorgvrager dienen te waarborgen dat wordt ingegaan op deze vraag en op de wensen en voorkeuren van de cliënt.

De plaats die het verzorgingshuis in de Nederlandse gezondheidszorg inneemt, is tamelijk bijzonder. Vanderleyden (1989) geeft een overzicht van de woon-zorgvoorzieningen in Vlaanderen. Het beschut- of beschermd wonen zijn daar vormen van 'ondersteund zelfstandig leven' en bejaardenwoningen kunnen door ouderen worden betrokken 'voor zover er een grote mate van zelfstandigheid wordt gegarandeerd'. Het rusthuis is in Vlaanderen een residentiële voorziening voor ouderen die ook wel wordt aangeduid met 
verzorgingshuis. De hulpbehoevendheid van de ouderen in rusthuizen is evenwel dermate groot dat de voorziening rusthuis eerder de vergelijking met een verpleeghuis doorstaat dan met een verzorgingshuis.

In Groot-Brittannië benadert de 'sheltered housing' en met name de, wat wordt genoemd, maximaal beschutte wooncomplexen het Nederlandse verzorgingshuis. De bewoners van de beschutte wooncomplexen hebben een strak gemeenschappelijke levenswijze, maar er wordt slechts beperkt gebruik gemaakt van professionele zorg.

Vanwege het specifieke karakter van het verzorgingshuis in Nederland zijn in deze studie verder geen vergelijkingen gemaakt met buitenlandse zorginstellingen voor ouderen.

\subsection{Kenmerken van het verzorgingshuis}

\subsubsection{Het verzorgingshuis als instituut}

Spauwen-Micka (1975), Gallé en Luijten (1992), Van Loveren (1995) en Nies (1999) plaatsen kanttekeningen bij de vraag of in een intramurale instelling voor ouderen zorg voor zelfstandigheid mogelijk is. Zij schetsen een somber beeld van het verzorgingshuis en stellen dat het verzorgingshuis in veel opzichten het karakter heeft van een 'totale institutie', omdat het de volgende kenmerken bezit:

- het is bedoeld voor permanente bewoning en plaatsing in het verzorgingshuis is meer een noodzaak dan een vrije keus;

- de activiteiten die worden aangeboden zijn op de instelling georiënteerd in plaats van op individuele behoeften en ze worden op vaste tijden aangeboden;

- bewoners moeten afstand doen van veel persoonlijke bezittingen als ze in het verzorgingshuis komen wonen

Of het verzorgingshuis gezien kan worden als een totaal instituut hangt volgens Pincus en Wood (1970) af van de mate waarin bewoners een eigen domein hebben in de vorm van persoonlijke, fysieke en sociale leefruimte; de mate waarin bewoners zich moet aanpassen aan regels, respectievelijk worden gestimuleerd zelf keuzes te maken; de mate waarin bewoners de gelegenheid hebben mee te doen aan activiteiten en aan sociale interactie met verzorgenden en medebewoners; de mate waarin bewoners de gelegenheid hebben om communicatie met de maatschappij buiten het tehuis te onderhouden en de mate waarin verzorgenden een persoonlijke relatie onderhouden met de individuele bewoners. SpauwenMicka (1975) maakte op basis van deze criteria een analyse van de organisatiestructuur van 62 verzorgingshuizen in Nederland en zij concludeerde dat in ruim $70 \%$ van de onderzochte huizen sprake is van duidelijk institutionele kenmerken: 
Het contact met de buitenwereld is zeer beperkt. De activiteiten zijn met name intern georiënteerd. Participatie van bewoners aan de samenleving zagen de verzorgingshuizen niet als een na te streven doel en evenmin de continuering van de leefwijze van de bewoners. Bovendien wordt niet het wonen als het belangrijkste doel gezien, maar de verzorging van de bewoners. Het verzorgingshuis manifesteerde zich niet als een woonplaats of leefwereld maar als verzorgingsinstituut.

Hoewel het onderzoek van Spauwen-Micka reeds in 1975 is uitgevoerd, stelt Van Loveren (1995) dat vele uitkomsten twintig jaar later nog geldig zijn. Aan de hand van literatuur gaat zij nader in op kenmerken van verzorgingshuizen die institutionalisering bevorderen. Eén van de kenmerken van verzorgingshuizen is volgens haar 'onvoorspelbaarheid'. Nieteenduidige reacties van personeelsleden op vragen van bewoners, ondoorzichtige dienstroosters en toevallige omstandigheden die bepalen welke verzorgende op de kamer komt, hebben bij de bewoner een negatieve invloed op de beleving van het verblijf. Een ander kenmerk is 'controle'. Het verzorgingshuis legt de regels op en bepaalt wat wanneer gebeurt, zoals het tijdstip voor en de keuze van de maaltijden, het activiteitenprogramma en soms zelfs het tijdstip van naar bed gaan. Controle is van belang voor het welbevinden van bewoners. 'Restrictiviteit van de omgeving' is een volgend kenmerk. Hierbij wordt de gedragsvariantie van de bewoner door de omgeving kunstmatig laag gehouden waardoor diens zelfstandigheid sterk wordt ingeperkt. Het vierde kenmerk is 'prothetisering': taken, waarvoor de bewoner niet meer het initiatief neemt, worden automatisch door de omgeving overgenomen, ook wanneer het individu deze nog wel kan uitvoeren. Tot slot wordt 'depersonalisatie' genoemd. De bewoner wordt niet als individu benaderd maar als probleem of taak, waarbij vooral een gerichtheid op de lichamelijke hulpbehoevendheid centraal staat; een kenmerk wat ook in onderzoek naar de kwaliteit van zorg in verpleeghuizen wordt aangetroffen (Kardol, Hulsman ea.,1986; Gallé en Luyten, 1992). Verzorgenden benaderen de bewoners op onpersoonlijke wijze en passen zich in interactiestijl niet aan hen aan. In het verzorgingshuis is sprake van onderstimulatie; gedragingen die aan competentie zijn gerelateerd, worden actief ontmoedigd. Verzorgingshuizen zijn gericht op de minst competente mensen; zij die hulp nodig hebben krijgen de meeste aandacht. Bewoners doen de dingen niet meer die zij eigenlijk nog wel kunnen. $\mathrm{Zij}$ schatten hun competentie ook te laag in hetgeen het gevolg is van het gegeven dat de omgeving als niet beïnvloedbaar wordt gezien. Ook de omgeving van het verzorgingshuis speelt onvoldoende in op de mogelijkheden van de bewoners waardoor een beperkte interactie optreedt. Het personeel dat dagelijks met de bewoners omgaat heeft een pessimistische kijk op de mogelijkheden van de bewoners. Problemen die een bewoner vertoont, zijn, voor met name het lager geschoold personeel, inherent aan het ouder worden en worden toegeschreven aan persoonlijkheidskenmerken in plaats van aan situationele 
kenmerken. De aandacht die naar de bewoners uitgaat, is vooral gericht op hun lichamelijke hulpbehoevendheid.

Op basis van longitudinaal onderzoek in twee verzorgingshuizen constateert Van Loveren (1995) dat de omgeving van deze huizen niet zodanig is dat sociale contacten worden bevorderd en cognitieve problematiek wordt voorkomen, terwijl achteruitgang op lichamelijk, geestelijk en sociaal gebied door haar als een beïnvloedbaar proces beschouwd wordt. Wanneer bewoners geen afhankelijk gedrag meer hoeven te vertonen en zij door een toegenomen contingentie meer greep krijgen op de situatie zullen hun lichamelijke hulpbehoevendheid en psychosociale problemen afnemen en zullen zij in hun gedrag een groter deel van hun competentie realiseren. Door te interveniëren in de organisatie en werkwijze van het verzorgend personeel boekt Van Loveren verbeteringen. De afdelingen worden verkleind; afdelingen van 100 bewoners worden opgesplitst in eenheden van 50 bewoners. De taakgerichte werkwijze maakt plaats voor een bewonersgerichte, wat wil zeggen dat ieder personeelslid de verantwoordelijkheid krijgt voor een groepje bewoners en in overleg met die bewoners bepaalt wat er aan zorg nodig is. Bewoners krijgen niet langer het standaardpakket verzorging aangeboden, maar in onderling overleg met de bewoner wordt afgesproken welke zorg hij op een bepaald moment nodig heeft. Tevens zijn centraal op de afdelingen gelegen huiskamers ingericht, waardoor bewoners in staat worden gesteld ook buiten de dagelijkse koffie-uurtjes elkaar te ontmoeten. Geconcludeerd wordt dat de achteruitgang van verzorgingshuisbewoners door aanpassingen van de organisatie en werkwijze van het personeel doorbroken kan worden. Nieuw opgenomen bewoners hebben het meest profijt van de veranderingen; er is geen sprake van achteruitgang in het eerste verblijfsjaar. Ook bij bewoners die al langer in huis zijn en aan het onderzoek hebben deelgenomen, verbetert het lichamelijk en psychisch functioneren. De zorgverlening wordt minder gestandaardiseerd, de bewoner krijgt meer invloed op de situatie en er ontstaat een meer persoonlijke band tussen individuele bewoners en personeelsleden.

Te Wierik en Frederiks (1990) laten een ander geluid horen over het verzorgingshuis. Hun bevinding is dat de eenzaamheidsgevoelens van ouderen met een duidelijke 'eenzaamheidsindicatie' tijdens het verblijf in het verzorgingshuis afnemen. De Keyzer en Hertogh (1999) vinden evenwel dat de mogelijkheden van het verzorgingshuis op dit gebied niet moeten worden overschat en Janmaat (1970) stelt dat er bewoners zijn in het verzorgingshuis die zich nog eenzamer voelen dan ooit tevoren. Het verzorgingshuis moet naar zijn mening niet stil blijven staan bij alleen zorgverlening op lichamelijk gebied. Het heeft ook tot taak de oudere zoveel mogelijk zijn zelfstandigheid en gevoel van eigenwaarde te laten behouden of terug te geven. 


\subsubsection{Het verzorgingshuis als werkgever}

In 1998 zijn 87.000 en in het jaar 2000 ruim 91.000 mensen werkzaam in de verzorgingshuizen tegen 22.500 in 1965 en 74.000 in $1985 ; 75 \%$ heeft een deeltijdfunctie (Huijsman, 1990; Brancherapport, 2000; Arcares, 2002). Van de medewerkers heeft ruim $55 \%$ een verzorgende functie tegen $28.3 \%$ in 1965 en $38.3 \%$ in $1984 ; 85 \%$ is vrouw (Jaarboek ouderenzorg, 1997; Arcares, 2002). Voor wat betreft het kwalificatieniveau van het verplegend en verzorgend personeel heeft ruim $45 \%$ een verzorgende opleiding. Een kleiner deel heeft de opleiding van 'helpende' gevolgd. lets meer dan twintig procent heeft een toegevoegd deskundigheidsniveau als verzorgende, 'verzorgende I.G.' genaamd, en ongeveer tien procent heeft een verpleegkundige achtergrond. Door de diversiteit aan intramurale, semimurale en extramurale activiteiten van het verzorgingshuis, waaronder maaltijdverzorging, sociale alarmering en klussendienst, valt bijna $15 \%$ onder de categorie 'anders opgeleid'. De partime factor, die uitdrukt hoeveel mensen nodig zijn voor een functie, is voor het verplegend en verzorgend personeel in verzorgingshuizen 1.59 en voor het overig personeel 1.73 . In 2000 werkt $15 \%$ van de medewerkers full-time, $85 \%$ werkt part-time en 2\% werkt als oproepkracht (Arcares, 2000).

De leeftijdsopbouw van verplegend en verzorgend personeel wijkt in de ouderenzorg af van andere bedrijfstakken. Met name de categorie $45-64$ jaar is ondervertegenwoordigd en de categorie jongeren is ruimer vertegenwoordigd: $25 \%$ is jonger dan $26 ; 15 \%$ is tussen 26 en 30 jaar; $15 \%$ is tussen 31 en 35 jaar oud; $30 \%$ is tussen de 36 en 44 jaar en $15 \%$ is tussen de 45 en 64 jaar oud. Naast beroepskrachten zijn in de verzorgingshuizen veel vrijwilligers actief. In 1997 is een aantal van 56.699 geregistreerd; in 1998 is het aantal geregistreerden 57.529 (Ruimte voor zorg, 2000). Zij verrichten uiteenlopende werkzaamheden, met name ondersteuning van personeelsleden in ontmoetingsruimten, winkels, restaurant en bij de activiteitenbegeleiding. Ook het onderhouden van sociale contacten met bewoners zien vrijwilligers als een belangrijke taak.

Het ziekteverzuim in de verpleeg- en verzorgingshuizen is hoog. In 1997 is het verzuimpercentage $7.3 \%$; in 1998 is het $7.8 \%$ en in 2000 bijna $8.4 \%$. Als daarbij het verzuim vanwege zwangerschap wordt meegerekend, is het percentage nog $1.5 \%$ hoger (Samenvatting Gezondheidszorg in tel, 2001) Het verloop onder het personeel was in 1997 $12.8 \%$ hoog; ongeveer de helft van het vertrekkend personeel verlaat de sector en de andere helft verandert van instelling (Brancherapport, 2000). Bij de oudere werknemers is het verloop het kleinst, bij de jongere het grootst. Vertrekkende medewerkers geven aan dat vertrek te voorkomen was geweest wanneer er meer mogelijkheden tot ontplooiing en 
benutting van kansen was geweest, wanneer er een beter loopbaanperspectief was geweest, de mogelijkheden voor meer of minder werken beter hadden gepast, wanneer het klimaat op de afdeling beter was geweest, de werktijden/roosters beter hadden gepast en wanneer er meer gedaan was aan de werkdruk en opleidingsmogelijkheden. Voor degenen ouder dan 45 jaar spelen arbeidsomstandigheden en lichamelijke belasting sterk mee (Ruimte voor zorg, 2000; WRR, 1999). In het macrokader zijn de afgelopen jaren middelen opgenomen voor werkdrukvermindering en scholing. Vanaf 1999 zijn hier extra middelen aan toegevoegd.

Tegenover de uitstroom staat onvoldoende instroom. Er is vooral krapte op de arbeidsmarkt van verzorgenden IG. Voor de hele sector verpleging en verzorging wordt alleen al voor die functie een tekort geraamd van ruim $20 \%$ in het jaartal 2004. Ook het tekort aan helpenden scoort hoog met ruim 18.1\%. De rapportage Gezondheidszorg in Tel 8 (2000) gaat voor de periode 2000 - 2004 uit van een groei van de werkgelegenheid van $2.3 \%$.

Om de arbeidsmarkt te bewegen het personeelstekort op te heffen, zijn door de Brancheorganisatie voor Verzorging en Verpleging diverse beleidsmaatregelen voorgesteld: er ligt een instroomtaakstelling van 4000 allochtonen; herintreders worden gericht geworven; om verloop van het zittend personeel tegen te gaan wordt extra scholing geboden alsmede kinderopvang, verder worden mogelijkheden gecreěerd tot het combineren van arbeid en zorg en arbeidsomstandigheden worden verbeterd. Door verdere functiedifferentiatie wordt het loopbaanperspectief verruimd (Ruimte voor zorg, 2000). De Wetenschappelijke Raad voor het Regeringsbeleid (2001) sluit zich bij die voornemens aan. Het huidig stelsel van de gezondheidszorg is voor een belangrijk deel afhankelijk van de beschikbaarheid van voldoende personeel:

Arbeidscontracten moeten verder worden geflexibiliseerd, opdat het werk beter met zorgtaken thuis kan worden gecombineerd; binnen de instellingen zal, veel meer dan nu gebeurt, werk moeten worden gemaakt van loopbaanperspectieven en ontplooiingsmogelijkheden voor verplegenden en verzorgenden; de inzetbaarheid van personeeisleden zal veel meer dan nu het geval is gerelateerd moeten worden aan hun leeftijd en de mogelijkheden om de fysieke, emotionele en cognitieve aspecten van het werk aan te kunnen.

Aan verdere flexibilisering en scholing van zittend personeel zijn risico's verbonden. Flexibilisering brengt met zich mee dat een groeiende groep zorgverleners beperkt inzetbaar is, hetgeen de continuïteit van de zorgrelatie niet bevordert en de afstemming en coördinatie van de zorg bemoeilijkt. Ook de profielverbetering van zittende zorgverleners leidt tot ongewenste neveneffecten. Door huishoudelijke medewerkenden te scholen tot verzorgingsassistenten of helpenden en door meerdere deskundigheidsniveaus te introduceren, komt een zwaardere verantwoordelijkheid te liggen bij de kleine groep 
zorgverleners met de hoogste deskundigheid. Een krappe personele bezetting op afdelingen van verzorgingshuizen kan tot gevolg hebben dat medewerkers handelingen gaan verrichten, waartoe zij niet voldoende bevoegd of bekwaam zijn. De taaksplitsing die in het verzorgingshuis ontstaat, staat tevens op gespannen voet met een zorgvisie die menig verzorgingshuis uitdraagt en waarin aan de relatie tussen zorgvrager en zorgverlener veel gewicht wordt toegekend. Het hebben van 'volledige taken', oftewel verantwoordelijk zijn voor zowel de planning, de uitvoering als de evaluatie en bijstelling van de zorg wordt als een belangrijke voorwaarde gezien om die relatie gestalte te geven en om voldoende arbeidssatisfactie te verkrijgen, maar dit principe komt door de personeelssamenstelling in het gedrang.

\subsection{Verzorgingshuizen: capaciteit en vraag}

\subsubsection{Ontwikkeling van verzorgingshuiscapaciteit}

Het eerder genoemd beleid van de overheid om intramurale capaciteit af te bouwen, sorteert tot het eind van de jaren negentig effect, niet in de laatste plaats door de maatregel dat verbouw of renovatie van verzorgingshuizen budgettair neutraal dient te geschieden. Daardoor zijn ouderen meer en meer aangewezen op semimurale en extramurale diensten van verzorgingshuizen of thuiszorgorganisaties en komen nieuwe initiatieven tot ontwikkeling. Zo worden mantelzorgers ondersteund; logeerhuizen voor ouderen worden gebouwd; de bouw van zogenoemde steunpunten in een wijk of dorp waar eerste- en tweedelijns voorzieningen worden ondergebracht bij kleinschalige woonvoorzieningen krijgt gestalte, en als gevolg van de Wet voorzieningen gehandicapten krijgen ouderen en gehandicapten financiële ondersteuning voor noodzakelijke woonaanpassingen. Daarmee worden zij in staat gesteld langer in hun eigen huis te blijven wonen en plaatsing in een verzorgingshuis uit te stellen.

Het CBS registreert voor de periode 1992 tot en met 1995 als gevolg van deze maatregelen een afnemend gebruik van het verzorgingshuis door ouderen:

Tabel 3.1: Ontwikkeling van het aantal ouderen in verzorgingshuizen

\begin{tabular}{|l|c|c|c|c|}
\hline Jaartal & 1992 & 1993 & 1994 & 1995 \\
\hline Aantal ouderen & 127.000 & 124.000 & 121.000 & 117.500 \\
\hline
\end{tabular}

Deze afname zet zich verder door. In 1996 maken 112.000 ouderen gebruik van permanent 
verblijf in het verzorgingshuis (Jaaroverzicht Zorg, 1998), in 1998 zijn dat er nog 107.806 (Brancherapport, Verzorging en Verpleging, 2000). In de periode 1992 - 1998 vermindert het aantal verzorgingshuisplaatsen derhalve met bijna 20.000. Ook het aantal verzorgingshuizen loopt tussen 1984 en 1999 terug van 1489 naar 1380 (Brancherapport, 2000).

Op 1 januari 1997 wordt door het verzorgingshuis op 6376 plaatsen bij ouderen thuis zorg vertrekt in het kader van het reikwijdtebesluit. Het betreft zorgverlening aan ouderen met een indicatie voor een verzorgingshuisopname. Vanwege de forse terugloop van intramurale verzorging daalt de totale productie desondanks met $1.3 \%$ (Gezondheidszorg in Tel (GiT), 2000). (Het productievolume wordt bepaald door het aantal bewoners in combinatie met de zorgintensiteit).

De Commissie Van Veldhoven (Vraag aan bod, 1996) gaat voor een raming van de behoefte aan verzorgingshuiszorg in 2015 uit van een drietal scenario's:

1. de demografische variant. Uitgaande van de bevolkingssamenstelling in 1993 en van het gebruik in 1993 van verzorgingshuizen door $8.1 \%$ van de bevolking ouder dan 65 jaar zullen, bij ongewijzigd beleid, in 2015138.000 mensen gebruik maken van intramurale verzorging;

2. de maximale substitutievariant. Door, in navolging van het advies van de Commissie Modernisering Ouderenzorg, intramurale zorg zo maximaal mogelijk te verplaatsen naar de ouderen thuis kan voor de bepaling van de omvang van de totale beddencapaciteit van verzorgingshuizen, op voorstel van de commissie van Veldhoven, worden uitgegaan van een gebruikspercentage van 5,3\% van de bevolking van 65 jaar of ouder. $\ln 2015$ zullen dan 75.000 mensen in een verzorgingshuis verblijven;

3. het kabinetsstandpunt. Het Kabinet baseert zich op het advies van de Commissie Modernisering Ouderenzorg, maar gaat uit van een gebruiksnorm van $6,5 \%$ en een minder maximale substitutie van intramurale zorg naar extramurale zorg. De raming bedraagt hier 107.000 plaatsen in 2015 .

In 1998 blijkt het kabinetsstandpunt niet langer houdbaar. Er komt een einde aan de reductie van verzorgingscapaciteit. In de motie-Wallage (Tweede Kamer, vergaderjaar 1997 - 1999 25600 , nr.9; College Van Zorgverzekeringen) wordt geconstateerd dat de intramurale capaciteit van de verzorgingshuizen veel harder afneemt dan met het oog op de toenemende vergrijzing verantwoord werd geacht. Het macrokader wordt met negentig miljoen opgehoogd en beschikbaar gesteld voor het ongedaan maken van capaciteitsreducties, dan wel het verzachten van de gevolgen van deze reducties. Als gevolg van afnemende validiteit 
van verzorgingshuisbewoners en de toegenomen zorgintensiteit wordt aan het macrokader van 1998 tevens 65 miljoen gulden toegevoegd, bedoeld voor 'meer handen aan het bed'.

Door de toenemende zorgintensiteit stijgt het productievolume volgens Prismant met gemiddeld $0.9 \%$ per jaar (GIT, 2000). In Ruimte voor zorg (2000) wordt het beeld geschetst van een nominale stijging en een relatieve daling:

Tabel 3.2: Ontwikkeling van het aantal ouderen in verzorgingshuizen

\begin{tabular}{|l|c|c|c|}
\hline Jaartal & 2000 & 2005 & 2010 \\
\hline Aantal ouderen $(75+)$ & 117.000 & 124.000 & 130.000 \\
in verzorgingshuizen & $(12,2 \%)$ & $(12,0 \%)$ & $(11,9 \%)$ \\
\hline
\end{tabular}

In 2000 verblijven 117.000 mensen van 75 jaar en ouder in verzorgingshuizen $(12,2 \%$ van het aantal 75 plussers), in 2005 is dit aantal $124.000(12,0 \%)$ en in 2010 zijn 130.000 mensen van 75 jaar en ouder geplaatst (11.9\%). In haar Werkdocument 55 komt het SCP (1999) met cijfers die een gewenste toename van benodigde verzorgingshuiscapaciteit tonen. Gesteld wordt dat de capaciteit van de intramurale instellingen tussen 1996 en 2015 met een kwart zal moeten toenemen om aan de toenemende vraag tegemoet te komen. In 2015 zullen 141.000 ouderen in verzorgingshuizen verblijven. De toename van de belangrijkste gebruikers van (intramurale) verzorging en verpleging, de groep van 80 jaar en ouder die in 2020 met veertig procent is toegenomen, zal de druk op de capaciteit verder opvoeren (Branchegroep Verpleging en Verzorging, 2000). In het jaarverslag 2002 van Arcares is deze druk nog niet zichtbaar. In 2001 wordt een capaciteit gemeten van iets minder dan 111.000 plaatsen, verdeeld over 1353 verzorgingshuizen.

Volgens de Wetenschappelijke Raad voor het Regeringsbeleid (1999) zal door de absolute toename van het aantal ouderen de capaciteit van verzorgingshuizen naar verwachting met 1 procent per jaar toenemen. De veranderende samenstelling van de oudere bevolking zal van invloed zijn op de mate waarin ouderen lichamelijke beperkingen ondervinden en gebruik zullen maken van intramurale voorzieningen. Door het hogere opleidingsniveau zal het aantal ouderen met beperkingen afnemen, evenals het gebruik dat zij maken van intramurale voorzieningen. Omdat in absolute zin het aantal ouderen en het aantal ouderen met beperkingen de komende jaren sterk zullen stijgen, zal ook het gebruik van verzorgingshuizen toenemen. De raming van een toename van het gebruik met $1 \%$ is gebaseerd op de aanname dat het gebruik van informele hulp jaarlijks met $1.1 \%$ zal stijgen. (SCP, 1997) Gezien de sterke individualisering van de maatschappij, waardoor het aantal alleenstaanden toeneemt, is de vraag gewettigd of deze aanname houdbaar is. Wielink e.a. (1995) laten zich sceptisch uit over de stijging van informele hulp. Los van de vraag of 
informele hulp in voldoende mate beschikbaar zal zijn, tonen zij aan dat ouderen de voorkeur hebben voor professionele hulp in plaats van informele hulp indien zij kortdurend of langdurend persoonlijke verzorging nodig hebben. Huishoudelijke werkzaamheden en het doen van boodschappen worden gemakkelijker overgenomen door informele hulpverleners.

\subsubsection{Vraag naar het verzorgingshuis: wachtlijsten en wachttijden}

\section{Wachtlijsten}

De vraag naar verzorgingshuiszorg en het aanbod aan deze zorgvorm sluiten niet op elkaar aan. Er is een tekort aan aangeboden zorg, dat voor een deel zichtbaar wordt in het aantal mensen dat op de wachtlijst staat. Er bestaat ook een 'verborgen vraag'. Een aantal ouderen laat zich niet op de wachtlijst plaatsen, omdat toch geen plaats beschikbaar is. Tot het eind van de jaren negentig zijn geen betrouwbare gegevens bekend over de omvang van wachtlijsten.

De Stuurgroep Verstandig Vernieuwen 2 (1997) maakt in haar rapport gewag van "een persbericht waarin melding werd gemaakt van een recente, telefonische peiling, waaruit werd afgeleid dat rond de 15.000 mensen op de wachtlijst voor een verzorgingshuis staan, die gemiddeld bijna 10 maanden moeten wachten'. Over de wijze waarop de peiling heeft plaatsgevonden of over de herkomst van de gegevens wordt niets vermeld. In een in 1998 gepubliceerd onderzoek van de toenmalige koepelorganisatie voor verzorgingshuizen, de Woonzorgfederatie, wordt het aantal wachtenden in 1994 geschat op ongeveer 24.000, in 1996 op 29.000 en eind 1997 op circa 35.000. Over de wachttijd worden geen uitspraken gedaan (SCP, 1997; SCP, 1999). In het in 2000 gepresenteerde Brancherapport verpleging en verzorging wordt nader ingegaan op de resultaten van een onderzoek dat door Prismant is uitgevoerd. Geconcludeerd wordt dat ongeveer 20.000 ouderen wachten op plaatsing in een verzorgingshuis. Dit aantal is afgeleid uit verstrekte gegevens door $59 \%$ van de zorginstellingen die zijn geëxtrapoleerd en gecorrigeerd voor dubbeltellingen en andere vervuiling.

In 1999 wordt, in het kader van de meerjarenafspraken voor de sector Verpleging \& Verzorging, structureel een bedrag van 81 miljoen gulden beschikbaar gesteld met als doel de wachtlijsten in de sector terug te dringen. Uitbreiding van intramurale capaciteit wordt als mogelijkheid gezien. In 2000 onderzoekt de commissie 'Task force aanpak wachtlijsten' opnieuw de wachtlijsten. Nagenoeg alle zorgaanbieders nemen aan het onderzoek deel. Geconcludeerd wordt dat in mei 2000 in totaal 32.400 ouderen op verzorgingshuiszorg wachten. 
Het aantal wachtenden is dus aanzienlijk hoger dan uit het Prismant onderzoek naar voren komt. Dit wordt verklaard uit de respons op het Prismant onderzoek, die 59 procent bedraagt, tegen bijna 100 procent bij de Task Force. Daarnaast heeft het Prismant onderzoek alleen het wachten op intramurale verzorgingshuiszorg gewogen, terwijl de Task Force ook de wachtlijsten voor aanvullende verpleeghuiszorg in het verzorgingshuis heeft meegerekend. Bovendien is Prismant uitgegaan van dubbeltellingen op de wachtlijst, terwijl de Task force een opgeschoonde wachtlijst heeft gehanteerd (GIT, 2000). Arcares (2002) registreert eind 2000 ruim 33.000 wachtenden, maar niet duidelijk is hoe de berekening hiervan heeft plaatsgevonden.

Steverink (1996) geeft aan dat de aanmelding van een voor het verzorgingshuis geïndiceerde oudere niet steeds overeenkomt met de subjectieve behoefte van het moment zelf. Zij verwijst naar onderzoek van Penris en Van Steenbergen uit 1992 waaruit blijkt dat zestig procent van de bij het onderzoek betrokken positief-geïndiceerden niet naar het verzorgingshuis wilde toen zij daartoe de mogelijkheid kreeg. Veel ouderen blijken zich 'voor de zekerheid' op de wachtlijst te plaatsen, maar willen de tijd hebben om zich op plaatsing voor te bereiden. Dit verschijnsel vertroebelt het beeld van de wachttijd, omdat verzorgingshuizen in overleg met de wachtende kunnen besluiten de oudere onderaan de wachtlijst te plaatsen.

\section{Wachttijden}

Arcares stelt dat maar liefst $49 \%$ van de wachtenden voor verzorgingshuizen urgent en zeer urgent is (Brancherapport, 2000). Deze urgentie kan verklaard worden door de wachttijd. De wachttijd, de tijd die verstrijkt tussen het moment van plaatsing op de wachtlijst en het in zorg nemen van de oudere, bedraagt voor verzorgingshuizen 35 weken (Brancherapport, 2000). $31 \%$ heeft een wachttijd van meer dan 12 maanden (GIT, 2001; Arcares, 2002). Het op de wachtlijst staan voor het verzorgingshuis hoeft niet te betekenen dat men van zorg verstoken blijft. In de wachttijd krijgt 55\% van de ouderen zogenoemde overbruggingszorg door professionele instellingen. Ongeveer $60 \%$ van de wachtenden krijgt thuiszorg, $20 \%$ ontvangt geen professionele of formele zorg en van nog eens $20 \%$ is niet bekend of formele of informele zorg ontvangen wordt (GIT, 2001).

In het zogenoemde Treek-overleg tussen zorgaanbieders en zorgverzekeraars worden afspraken gemaakt over maximaal aanvaardbare wachttijden. $80 \%$ van de ouderen dient binnen drie weken na aanmelding uitsluitsel over de indicatie te krijgen. De zorgwachttijd voor het verzorgingshuis wordt gesteld op 8 tot maximaal 13 weken. Voorts wordt afgesproken dat aan alle acute cliënten binnen 24 uur zorg moet worden verleend en aan alle subacute cliënten binnen 7 dagen (Samenvatting GIT, 2000). 
Het Prismant onderzoek geeft een wachttijd aan van meer dan 8 weken voor $85 \%$ van de wachtenden en van meer dan 13 weken voor $75 \%$ van de wachtenden. Onderzoek van de Task force laat zien dat meer dan $90 \%$ langer wacht dan de Treek-normen (GIT, 2000).

In een rechterlijke uitspraak in het jaar 2000 worden cliënten die op een wachtlijst voor thuiszorg staan in het gelijk gesteld in hun eis zorg op tijd geleverd te krijgen.

De omvang van de wachtlijsten en de aanspraak die op zorg gemaakt kan worden, hebben de overheid er toe aangezet vanaf 2001 de door de commissie van Veldhoven gehanteerde gebruikspercentages voor intramurale capaciteit, die gebaseerd zijn op demografische ontwikkelingen, c.q. op percentages van het aantal 65 - en 75 plussers, minder stringent te hanteren. De overheid stelt in 2000 extra volumemiddelen beschikbaar om de druk op de wachtlijsten te verminderen. De zorgkantoren maken voor dit doel (extra) productieafspraken met zorgaanbieders, die al dan niet door uitbreiding van (intramurale) capaciteit nagekomen moeten worden.

\subsection{De bewoner van het verzorgingshuis}

\section{Criteria voor plaatsing}

Het merendeel van de ouderen die in het verzorgingshuis komen, is daar naar toe verhuisd vanuit hun eigen omgeving $(87 \%)$; een klein deel verruilt de aanleunwoning voor een appartement in het verzorgingshuis $(6 \%)$ en $7 \%$ komt van een andere intramurale voorziening voor ouderen (Arcares, 2002). De kans op het krijgen van een positieve indicatie voor het verzorgingshuis is groter naarmate mensen meer beperkingen hebben als gevolg van chronische aandoeningen en meer gevoelens van eenzaamheid. Ouderen die naast lichamelijke en psychische beperkingen ook met gedragsafwijkingen kampen, krijgen vaak een negatieve indicatie. Dit geldt ook voor ouderen die hulpbehoevend zijn, maar nog een goed sociaal netwerk hebben. Plaatsing in het verzorgingshuis wordt urgenter geacht naarmate de oudere slechter in staat is huishoudelijke activiteiten te verrichten, ouder is en zich onvoldoende veilig voelt. lemand die én in een slechte geestelijke toestand verkeert én slechte ADL-capaciteiten heeft, krijgt volgens het SCP een extra hoge urgentie toegewezen (SCP, Vraagverkenning, 1997). Of de oudere met een hoge zorgzwaarte ook daadwerkelijk wordt geplaatst in het verzorginghuis van zijn keuze is de vraag. In geval het verzorgingshuis beschikt over een voorziening voor ouderen met psychogeriatrische aandoeningen, een tarief voor 'meerzorg' ontvangt en personele mogelijkheden heeft, is de kans groter dat een oudere met een slechte geestelijke toestand wordt geplaatst dan wanneer het verzorgingshuis die mogelijkheden niet benut. Indien geen adequate accommodatie aanwezig is voor een dergelijke doelgroep en indien de werkdruk als hoog wordt ervaren, al 
dan niet door het niet tijdig kunnen invullen van vacatures, kunnen verzorgingshuizen de keuze maken ouderen op te nemen die een lage(re) urgentie hebben.

Het SCP verwacht een daling van het percentage ouderen dat matige en ernstige beperkingen heeft, van 36\% in 1996 naar 33\% in 2015. Dit wordt toegeschreven aan een stijging van het opleidingsniveau van ouderen. Verondersteld wordt dat een hoger opleidingsniveau tot een afname van de behoefte aan intramurale verzorging leidt. Door de sociale participatie van de hoger opgeleide oudere, de leefwijze en het bestedingsniveau wordt verondersteld dat minder gebruik gemaakt hoeft te worden van professionele zorginstanties. Indien zorgondersteuning nodig is, zal eerder een beroep gedaan worden op particuliere hulp, veronderstelt het Sociaal Cultureel Planbureau (1997). Onderzoek van Wielink e.a. (1995) weerspreekt deze opvatting. Aan een representatief samengestelde groep van 498 alleenwonende ouderen van 75 jaar en ouder met een gemiddelde leeftijd van 81 jaar stelden zij de hypothetische vraag of zij de voorkeur geven aan professionele hulp of aan informele hulp indien zij hulp nodig hebben. De mogelijke hulpbehoefte werd in de volgende vier hulpbehoefte-situaties onderscheiden: het nodig hebben van kortdurende huishoudelijke hulp, kortdurende persoonlijke verzorging, langdurende huishoudelijke hulp en langdurende persoonlijke verzorging. Geconcludeerd wordt dat slechts $16.5 \%$ van de respondenten bij kortdurende huishoudelijke verzorging de voorkeur geeft aan particuliere hulp en bijna $15 \%$ bij langdurende huishoudelijke hulp. Bij kortdurende huishoudelijke hulp zou veertig procent hulp willen hebben van de kinderen; bij langdurende hulp neemt dit percentage af naar eenendertig procent. Bij kortdurende en langdurende persoonlijke verzorging wil de meerderheid professionele hulp, namelijk 72 , respectievelijk $65 \%$. Er wordt een verschuiving geconstateerd van de preferenties naar formele en intramurale zorg, wanneer de zorg langdurend wordt en/of persoonlijke verzorging in plaats van huishoudelijke hulp betreft. Met name mensen met een hoge sociaal-economische status spreken hun voorkeur uit voor formele hulp; in nog sterkere mate geldt dit wanneer zij depressief zijn.

Steverink (1996) vraagt zich af waarom sommige ouderen naar opname in een verzorgingshuis vragen terwijl anderen, met een vergelijkbare mate van fysieke beperkingen, voor een ander zorgarrangement kiezen. Zij bevraagt 607 fysiek kwetsbare ouderen en komt tot de volgende conclusie: ouderen oriënteren zich eerder op het verzorgingshuis als zij zowel weinig comfort als affectie genieten. Wanneer zij er onvoldoende in slagen zelf te voldoen aan basisbehoeften als eten, drinken, rust, warmte en beschutting, pijn ervaren of zich ziek of hulpbehoevend voelen, oriënteren ouderen zich op het verzorgingshuis indien zij in hun sociale omgeving mensen missen die hen tot steun 
willen zijn. Steverink komt tot de verrassende conclusie dat het ontvangen van professionele hulp juist tot een sterkere oriëntatie op plaatsing in het verzorgingshuis kan leiden. Fysieke hulpbehoevendheid alleen is blijkbaar niet voldoende voor het zich oriënteren op het verzorgingshuis. Ook voor de hoog opgeleide oudere zal het sociaal netwerk van doorslaggevende betekenis kunnen zijn bij zijn keuze voor de meest gewenste zorgvorm. Over de vraag of hij een groter sociaal netwerk heeft dan de oudere met een laag opleidingsniveau zijn de meningen verdeeld (Huijsman 1990).

De opnamewens van de oudere speelt volgens Te Wierik en Frederiks (1990) ook een rol bij de indicatiestelling en de plaatsing. Zij merken op dat het verzorgingshuis voor redelijk vitale ouderen, ongeacht hun opleidingsniveau, geen aantrekkelijke woonvorm meer is, omdat de hulpbehoevendheid van zittende bewoners groot is en er om die reden weinig contact gemaakt kan worden.

Knipscheer (1999) maakt een onderscheid tussen de indicatiecriteria en de feitelijke behoefte aan hulp of zorg. Indicatiestelling identificeert naar zijn mening de 'rechthebbende', terwijl het aan de bewoner en de zorgverlener is om samen afspraken te maken over de invulling van de zorg. Dit onderscheid roept de vraag op of niet uit de indicatiestelling moet kunnen worden opgemaakt wat de range aan zorgbehoeften is. De kans bestaat dat aan behoeften die niet geïndiceerd zijn geen aandacht wordt besteed, omdat ze niet worden opgemerkt of niet de prioriteit krijgen.

\section{Leeftijd en geslacht}

Van alle 65 -plussers in Nederland woont $7.3 \%$ in een verzorgingshuis; van de ouderen boven de 80 is dat $30 \%$, van de ouderen boven de 90 jaar $40 \%$ van de mannen en $47 \%$ van de vrouwen. In 1994 is de gemiddelde leeftijd van de verzorgingshuisbewoners 84 jaar: $80 \%$ is ouder dan 80 jaar, $55 \%$ is ouder dan 85 jaar. In 2002 is de gemiddelde leeftijd van vrouwelijke bewoners ruim 86 jaar en de mannelijke bewoners zijn bijna 84.5 jaar.

Bijna $80 \%$ van de ouderen van 85 jaar en ouder is vrouw, van de 90-plussers in verzorgingshuizen is bijna $90 \%$ vrouw. $80 \%$ is alleenstaand. Driekwart van de hoogbejaarde bewoners zijn alleenstaande vrouwen. Bij opname is de gemiddelde leeftijd van de bewoners 81 jaar. Dit betekent dat hun levensverwachting op dat moment - statistisch gezien - ten hoogste vijf jaar bedraagt. Voor de meeste bewoners is het verzorgingshuis dan ook hun laatste woonplaats: bijna $80 \%$ overlijdt er, $15 \%$ gaat naar een verpleeghuis en de overige $5 \%$ verhuist naar elders of wordt opgenomen in een ziekenhuis en overlijdt daar (Huijsman, 1990; Van Loveren, 1995; Brancherapport, 2000; Ruimte voor zorg, 2000; Arcares, 2002). 


\section{Zorgbehoefte}

De behoefte van bewoners van verzorgingshuizen aan ondersteuning bij de zorg stijgt. In de periode van 1965 tot 1980 blijft het aantal bewoners in bejaardenoorden dat volledig hulpbehoevend is met een stijgingspercentage van $2.4 \%$ nagenoeg gelijk; het aantal bewoners dat gedeeltelijk hulpbehoevend is stijgt in die periode van 16.7 naar $32.8 \%$; het aantal mensen dat alleen huishoudelijke hulp nodig heeft, daalt van $69.3 \%$ naar $50.8 \%$ (Van Loveren, 1995). De reductie van het aantal bedden in verzorgingshuizen, bij een gelijktijdige toename van een aantal ouderen in de hoogste leeftijdscategorieën, alsmede de hoge wachtlijsten hebben geleid tot een toename van de zorgzwaarte van bewoners in verzorgingshuizen (Woonzorgfederatie, 1997; Verstandig vernieuwen; SCP, 1997). De WZF konstateert dat in de periode 1991 - 1994 alleen de 'incidenteel aanvullende zorg' met ruim $3 \%$ per jaar is afgenomen; de 'regelmatig aanvullende zorg', de 'aanvullende en overnemende zorg' en de 'veel overnemende zorg' stijgen jaarlijks met ruim drie procent, terwijl de 'totaal overnemende zorg' met $1.7 \%$ per jaar is gestegen (JOZ, 1998).

De zorgzwaarte, uitgedrukt in gemiddeld aantal zorgminuten per dag, neemt tussen 1994 en 1997 jaarlijks met ongeveer drie procent toe; ongeveer een kwart van de bewoners heeft begeleiding nodig wegens verhoogde kwetsbaarheid en ernstige psychosociale moeilijkheden (Arcares, 2000).

Westerhoven (1998) heeft berekend dat verzorgingshuisbewoners in 1998 gemiddeld 102,6 minuten directe zorg per dag krijgen, terwijl dit in 1996 nog 98,4 minuten is.

Zijn berekeningen zijn bepaald met EBIS, een landelijk informatiesysteem, waarbij de zorgzwaarte wordt gemeten aan de hand van vragen over de lichamelijke zorg en over onder meer geheugen en communicatie. Op grond van de scores worden cliënten ingedeeld in één van de vijf zorgzwaarte groepen. Aan elke zorgzwaarte groep zijn tijden gekoppeld. De EBIS scores, die verzorgingshuizen jaarlijks invullen, worden door het ministerie van VWS benut om de ontwikkeling van de zorgzwaarte in verzorgingshuizen te volgen.

In 1998 valt $38 \%$ van de verzorgingshuisbewoners onder zorgzwaarte categorie 1, de 'lichtste categorie' met een gemiddelde zorgtijd van 35 minuten; $21 \%$ onder zorgzwaarte categorie 2 met 75 minuten; $14 \%$ valt onder zorgzwaarte categorie 3 met 120 minuten; eveneens 14\% komt onder zorgzwaarte categorie 4 met 165 minuten en $13 \%$ valt in de hoogste zorgzwaarte categorie en krijgt 260 minuten zorgtijd per dag (Westerhoven, 1998). Arcares komt met vergelijkbare cijfers: Het aantal zorgminuten per dag loopt op van gemiddeld 95,25 in 1995 tot 104,03 in 1998 ( Brancherapport 2000). Hieronder zijn de cijfers van Van Westerhoven en Arcares samengevat. 
Tabel 3.3: Ontwikkeling van de zorgzwaarte van verzorgingshuisbewoners

\begin{tabular}{|l|c|c|c|}
\hline Jaar & 1995 & 1996 & 1998 \\
\hline $\begin{array}{l}\text { Gemiddeld aantal zorgmi- } \\
\text { nuten per bewoner per dag }\end{array}$ & 95,25 & 98,4 & $102,6^{*} \quad 104,03^{* *}$ \\
\hline
\end{tabular}

* meting voorjaar 1998 (V.Westerhoven)

** peildatum september 1998 (Arcares)

De toegenomen zorgzwaarte heeft gevolgen voor de doorstroming van en de wachttijd voor verzorgingshuisbewoners en beïnvloedt ook de verblijfsduur. In 1998 bedraagt de gemiddelde verblijfsduur in verzorgingshuizen bijna 4,5 jaar, terwijl in een verpleeghuis het gemiddelde op 1,3 jaar ligt. Door een verdere intensivering van zorg en toename van verpleegbehoevende bewoners in verzorgingshuizen neemt de gemiddelde verblijfsduur snel af. In vier jaar tijd daalt deze tot 3.85 jaar (Arcares, 2002). Circa $30 \%$ van de huidige populatie van verzorgingshuizen heeft inmiddels een ruwweg vergelijkbare zorgzwaarte als de meeste verpleeghuisbewoners (Kardol en Masselink, 1999).

Het EBIS-systeem, dat de zorgzwaarte registreert, is voornamelijk gericht op het meten van tijd die benodigd is voor verzorgende handelingen. Daarmee schiet dit systeem tekort, omdat begeleidende werkzaamheden, die een wezenlijk deel uitmaken van het zorgaanbod van het verzorgingshuis (Commissie Modernisering Ouderenzorg, 1994; AWBZ, 2001, artikel 16, eerste lid; VWS, 2003, Beleidsregels ex. Art. 3 WZV; Arcares, 2003, Modernisering AWBZ) niet in zorgminuten worden uitgedrukt. Daar waar de EBISgegevens worden benut voor het bepalen van de noodzakelijke formatie wordt het risico gelopen dat onvoldoende zorgverleners beschikbaar zijn om de door de bewoners gewenste diversiteit aan zorgtaken te verrichten. Vooral als op de behoefte aan begeleiding wordt ingegaan, komt de formatie in de knel. Uit onderzoek blijkt namelijk dat het in overleg treden met bewoners, hen aansporen of overtuigen keuzes te maken en andere begeleidende werkzaamheden meer tijd in beslag nemen dan bijvoorbeeld het overnemen van de lichamelijke verzorging van een bewoner die daar zelf niet meer toe in staat is (Kardol e.a., 1986; 1987).

\subsection{Beschouwing}

Het verzorgingshuis heeft zich in een halve eeuw tijd ontwikkeld van bejaardenoord, waar het wonen van ouderen centraal staat, naar een voorziening die enkel op basis van een indicatie voor verzorging toegankelijk is. In het begin van de jaren zestig van de vorige 
eeuw worden ouderen gestimuleerd om te verhuizen naar een bejaardenoord, zodat zij woonruimten vrijmaken voor jongere generaties. Vanaf de ontwikkeling van bejaardenoord tot verzorgingshuis is hier een kentering in gekomen. Met de Wet op de bejaardenoorden krijgt de overheid een grotere financiële bemoeienis met en verantwoordelijkheid voor de zorg en het wonen van ouderen in verzorgingshuizen. Vanaf 1980 verandert het overheidsbeleid. Het besef dat de vergrijzing van de samenleving grote gevolgen heeft voor de kosten van de voorzieningensector en de economische malaise waarin Nederland zich bevindt, leiden tot een restrictief voorzieningenbeleid. Ouderen worden gestimuleerd zo lang mogelijk thuis te blijven en zo min mogelijk afhankelijk te zijn van intramurale ouderenzorg, c.q. van plaatsing en verblijf in duur geachte verzorgings- of verpleeghuizen. Het ouderenbeleid van de overheid dat is gericht op het terugdringen van intramurale verzorgingscapaciteit houdt geen twee decennia stand. De dubbele vergrijzing in Nederland heeft tot gevolg dat ondanks tal van extramurale-, flankerende en woon-zorg voorzieningen de noodzaak tot uitbreiding van intramurale instellingen groeit. De wachtlijsten voor het verzorgingshuis worden groter en de wachttijd wordt gelimiteerd, waardoor capaciteitsnormen worden bijgesteld en uiteindelijk losgelaten. De aanhoudende druk op de wachtlijsten, de diversiteit van voorzieningen en de functionele indicatiestelling hebben tot gevolg dat de zorgzwaarte van ouderen die in het verzorgingshuis geplaatst worden oploopt. Fysieke beperkingen blijken niet de enige reden te zijn waarom ouderen voor plaatsing in het verzorgingshuis kiezen. Als deze beperkingen gepaard gaan met het ontbreken van een sociaal netwerk, met gevoelens van eenzaamheid of depressie vestigt de oudere de hoop op het verzorgingshuis. De oudere die in het verzorgingshuis geplaatst wordt, wordt in de WBO en de AWBZ door de overheid gemaand tot zelfstandigheid en het voeren van regie over het eigen leven. Het verzorgingshuis krijgt van overheidswege de opdracht de zelfstandigheid te waarborgen en er voor zorg te dragen dat de bewoner zijn eigen leven kan voorzetten. In de afgelopen drie decennia hebben onderzoeken aangetoond dat het institutionele karakter van het verzorgingshuis het realiseren van die opdracht bemoeilijkt.

In 2001, het jaar waarin verzorgingshuiszorg voor het eerst onder de AWBZ valt, stelt deze wet dat verblijf in een verzorgingshuis onlosmakelijk samenhangt met de ernst van zelfzorgtekorten en met de mate waarin de cliënt in staat is regie over het eigen leven te voeren. In deze omschrijving gaat voor het eerst de verwachting schuil dat het verzorgingshuis in toenemende mate bewoond zal worden door ouderen die niet of niet meer geheel in staat zijn de regie over hun leven te voeren. Maar de (gemoderniseerde) AWBZ stelt tevens dat het verzorgingshuis moet uitgaan van de zelfbeschikking van de bewoner; dat optimaal moet worden tegemoetgekomen aan zelfredzaamheid en individuele wensen en dat de autonomie gerespecteerd en beschermd moet worden. Het verzorgingshuis 
heeft nog een weg te gaan om hier aan tegemoet te komen. Ze draagt, zoals eerder gesteld, kenmerken van een institutie in zich die de eigen verantwoordelijkheid en keuzemogelijkheden van de bewoner beperken. Er moet voor worden gewaakt dat de aandacht voor de fysieke zelfredzaamheid van de bewoners niet tot gevolg heeft dat hun zelfstandigheid geweld wordt aangedaan. De zorgverlener wordt immers geconfronteerd met een toenemende behoefte aan zorg en zorgzwaarte van de bewoner enerzijds en anderzijds wordt andacht gevraagd voor een meer op de individuele bewoner gerichte werkwijze. Het beperkt aantal zorgminuten dat de zorgverlener ter beschikking staat, de deskundigheid binnen het team van zorgverleners en de discontinuïteit in de zorgrelatie als gevolg van het beperkte dienstverband van het merendeel van de verzorgenden maken deze opgave niet eenvoudig. De afgelopen jaren zijn evenwel tal van maatregelen genomen om de positie van de zorgvrager te versterken en om verzorgingshuizen er toe aan te zetten werk te maken van een zorg die op de zelfstandigheid van de bewoner is gericht. 
In dit hoofdstuk worden initiatieven beschreven die de laatste decennia zijn genomen om het zorgsysteem vraaggestuurd te maken, het zorgaanbod vraaggericht te laten zijn, een verantwoorde kwaliteit te leveren, de rechtspositie van de zorgvrager te versterken en de zorg voor zelfstandigheid te bewaken en bevorderen. Ofschoon in het vorige hoofdstuk een beeld is geschetst van een verzorgingshuis dat veel institutionele kenmerken bevat, zijn door de overheid, patiëntenorganisaties en de beroepsgroep voor verzorging en verpleging allerlei initiatieven genomen om het zorgaanbod af te stemmen op de zorgvrager en om de positie van de zorgvrager te versterken, zoals:

- de ombuiging van aanbodgestuurde naar vraaggestuurde zorg

- de aandacht voor de kwaliteit van zorg in instellingen

- de aandacht voor de rechtspositie van de patiënt of bewoner

Intrigerend is de vraag, die in dit hoofdstuk wordt opgeworpen en besproken, wat de gevolgen zijn van de diverse initiatieven voor de positie van de zorgvrager. Nagegaan wordt of de verwachtingen die ouderen hebben van het verblijf in het verzorgingshuis alsmede hun beleving van dit verblijf er door beïnvloed zijn. Het hoofdstuk wordt afgesloten met een verwijzing naar de opdracht die vanaf 2001 expliciet aan verzorgingshuizen is gegeven om de autonomie en de persoonlijke levenssfeer van de zorgvrager te respecteren en te beschermen c.q. om zorg voor zelfstandigheid te betrachten.

\subsection{Van aanbodgestuurde naar vraaggestuurde zorg}

Om de positie van de verzekerde in de AWBZ te versterken is volgens de werkgroep Marktwerking, Deregulering en Wetgevingskwaliteit (MDW, 2000) vraagsturing noodzakelijk. Dat houdt in dat de verzekerde zelf moet kunnen kiezen hoe de zorg wordt ingevuld. Kiest de verzekerde ervoor om zelf de zorg in te kopen, dan is er sprake van een persoonsgebonden budget (pgb) (Ruimte voor zorg, 2000). Het persoonsgebonden budget stelt de gebruiker in staat de zorg in de woon- en leefomgeving naar eigen idee vorm te geven (Tweede Kamer, 1995b):

De budgethouder (cliënt) kan een keuze maken tussen soorten voorzieningen en zorgaanbieders en met die laatste naar eigen behoefte en voorkeur afspraken maken over onderwerpen als de aard van de hulp en het tijdstip van levering.

Het persoonsgebonden budget is ontstaan als reactie op de kritiek van de Gehandicaptenraad dat verschillende regelingen en voorzieningen voor gehandicapten 
onoverzichtelijk en moeilijk bereikbaar zijn. Alle regelingen op het gebied van het verstrekken van voorzieningen zouden geïntegreerd moeten worden en via één loket geregeld moeten worden. Het 'cliëntgebonden budget', later persoonsgebonden budget genoemd, geeft de cliënt een instrument in handen om de noodzakelijke voorzieningen te verkrijgen en heeft een emancipatorisch karakter (NP/CF 2000):

Met een persoonsgebonden budget ben je opdrachtgever, in plaats van ontvanger van een gunst; je kunt je eigen dienstverlener kiezen. De beslissingsbevoegdheid over de besteding van de met zorg gemoeide gelden bevordert de zelfstandigheid en onafhankelijkheid van de zorgvrager.

Vanaf 1995 worden persoonsgebonden budgetten toegekend. Verzekerden komen voor een zorgbudget in aanmerking door middel van een indicatiestelling (NZI, 1995). Om de hoogte van het budget parallel te laten lopen met de mate van zorgbehoevendheid is in de regeling voor het persoonsgebonden budget 'verpleging en verzorging' de mogelijkheid opengehouden een budget toe te kennen dat een stuk uitgaat boven de gemiddelde dagverpleegprijs van een instelling. Deze mogelijkheid is opmerkelijk, omdat binnen de intramurale ouderenzorg geen gedifferentieerde tarieven gehanteerd worden, ondanks grote verschillen in zorgzwaarte. Het persoonsgebonden budget leidt volgens de NP/CF (2000) niet per definitie tot vraaggerichte zorg. Dit als gevolg van beperkte mogelijkheden om een geschikt aanbod op de markt te vinden en vanwege de niet altijd aanwezige vaardigheden bij de budgethouder om een op eigen maat ingericht aanbod samen te stellen.

Het Sociaal Cultureel Planbureau (1998) becijfert het gebruik van een persoonsgebonden budget voor verpleging en verzorging: eind 1998 maken 7.394 mensen gebruik van het persoonsgebonden budget, terwijl er bijna 4.000 wachtenden zijn. De gemiddelde leeftijd van een pgb-gebruiker is 58 jaar; $41 \%$ is ouder dan 65 jaar. Het merendeel van de pgbgebruikers is vrouw; de motorische beperkingen overheersen en er is overwegend behoefte aan huishoudelijke hulp. Laagopgeleiden en alleenstaanden hebben minder vaak een voorkeur voor pgb dan hoogopgeleiden en mensen die hun huishouden delen (SCP, 1998). De behoefte aan een persoonsgebonden budget in de sector Verzorging en Verpleging stijgt in een paar jaar sterk. In september 2001 worden ruim 23.000 budgethouders geregistreerd, terwijl op de wachtlijst niet meer dan 15 mensen staan (VWS, Voortgangsrapportage PGB, 2001). Het pgb wordt in Nederland tot op dit moment overwegend benut voor de inzet van formele, professionele zorg. In Duitsland daarentegen heeft de introductie van Pflegeversicherung, die kenmerken van persoonsgebonden budgettering in zich heeft, laten zien dat tweederde van alle zelfstandig wonende ouderen ervoor heeft gekozen middelen in te zetten voor informele zorg. Tien procent koos alleen professionele zorg (Arcares, 2000). Het verzorgingshuis wordt in haar aanbod aan intramurale zorg in zeer beperkte mate gestuurd door een eigen, vrij besteedbaar budget van de zorgvrager. Het persoonsgebonden 
budget wordt ook niet toegekend in geval de oudere in aanmerking komt voor permanent verblijf in een verzorgingshuis. Vanaf 2002 kunnen bewoners het zorgaanbod in verzorgingshuizen financieel sturen door de maatregel dat bewoners de waskosten en de kosten voor broodmaaltijden (die onderdeel uitmaken van het verzorgingstarief) zelf kunnen innen. Bewoners bepalen of zij de was en broodmaaltijden zelf regelen of door het verzorgingshuis laten regelen. Van het totale verzorgingstarief maken deze kosten een marginaal deel uit, maar de vraag is of bewoners van verzorgingshuizen behoefte hebben aan een grotere invloed. Het SCP (1998) veronderstelt dat hoogbejaarden er tegen op zien zelf hulp te moeten regelen en dat de belangstelling voor het $\mathrm{pgb}$ minder wordt naarmate de ernst van de beperkingen toeneemt en naarmate de leeftijd toeneemt.

Om, onder meer met behulp van het persoonsgebonden budget, daadwerkelijk tot vraagsturing te komen, moet volgens de onderzoekscommissie Gezondheidszorg in Tel 2001 (GiT, 2000) het huidig zorgstelsel, dat gebaseerd is op aanbodregulering en op centrale prijsvorming van verstrekkingen, worden losgelaten:

In de huidige aanbodsturing heeft de zorgvrager niet of nauwelijks keuzemogelijkheden. De zorgverzekeraars fungeren voor een goed deel als 'doorgeefluik' voor het beschikbare budget. Zorgverzekeraars onderhandelen in het algemeen niet exclusief voor hun eigen verzekerden, maar voor alle verzekerden in de regio waarin zij marktleider zijn. De vraagkant van de zorg is op deze wijze niet in staat invloed uit te oefenen op de vormgeving van het zorgaanbod.

De algemene doelstelling van de overheid ten aanzien van het stelsel van gezondheidszorg is het bevorderen van een kwalitatief hoogwaardige gezondheidszorg. Daarnaast stelt de overheid zich ten doel de betaalbaarheid van de gezondheidszorg te bewaken, de financiële toegankelijkheid te creëren, de fysieke toegankelijkheid te bewaken, solidariteit te betrachten en uit te gaan van het recht op een gelijke behandeling.

De financiële toegankelijkheid wordt gewaarborgd door het vaststellen van een macrobudget, het Budgettair Kader Zorg (BKZ) en de invulling daarvan middels een volksverzekering voor de onverzekerbare risico's (AWBZ). Tevens door een verplichte ziekenfondsverzekering (ZFW) voor dat deel van de bevolking dat een inkomen beneden de loongrens heeft. De Wet op de Toegang tot de Zorgverzekeringen (WTZ) regelt dat particuliere zorgverzekeraars acceptatieplicht hebben van bepaalde groepen mensen (met name ouderen) met een relatief hoog risico. De fysieke toegankelijkheid, als doelstelling van overheidsbeleid, wordt bewaakt door een plannings- en spreidingsbeleid voor grote delen van het zorgaanbod (WZV). De doelstelling solidariteit wordt geregeld in het verzekeringsstelsel; door de koppeling tussen de wettelijke aanspraken die een verzekerde heeft en de verstrekkingen die een zorgaanbieder mag leveren, is verzekerd dat iedereen 
met gelijke problemen recht heeft op een gelijke behandeling. In een vraaggestuurd zorgstelsel is volgens de onderzoekscommissie Gezondheidszorg in Tel (2000) een macrobudget niet meer te handhaven, omdat de vraag de omvang van de benodigde zorg bepaalt. In die vraag zullen steeds meer de individuele preferenties van de verzekerden tot uiting komen. Toch zal de overheid vanuit macro-economische overwegingen (inkomensdruk, premiedruk ed.) een rem willen zetten op de omvang van de collectieve financiering van de gezondheidszorg. Omwille van de betaalbaarheid van de zorg zal toch een Budgettair Kader Zorg gesteld moeten worden, dat gebaseerd moet zijn op reële ramingen over de groei van de volume en prijsontwikkeling in de zorg.

De toegankelijkheid van de zorg, die door de acceptatieplicht en zorgplicht gewaarborgd zijn, gaat ten koste van de betaalbaarheid. De solidariteit komt onder druk te staan, omdat een ruime differentiatie ontstaat in het aanbod aan aanvullende verzekeringen en in het aanbod aan privaat te financieren zorg. De financiële verantwoordelijkheid van burgers voor de gezondheidszorg zal de komende jaren toenemen. Zij zullen te maken krijgen met hogere eigen betalingen bij het gebruik van zorg (VWS, 2003). Naarmate een individuele zorgvrager ruimer verzekerd is dan wel over meer eigen financiële middelen beschikt, zal zijn keuze van zorgpakketten ruimer kunnen zijn, waardoor een gelijke behandeling in het gedrang kan komen. Dit kan worden ondervangen door de aanspraken het karakter te geven van 'minimaal te leveren verstrekkingen' (GiT, 2000).

\subsection{Kwaliteit van zorg}

De aandacht voor kwaliteit van zorg die de zorgsector met name de laatste tien jaar aan de dag legt, is een gevolg van een terugtredende overheid. De overheid beperkt zich tot het opstellen van kaders en legt de verantwoordelijkheid voor een kwalitatief goede zorg bij de zorgaanbieders. In de nota Kwaliteit van Zorg (Tweede Kamer, vergaderjaar 1990-1991, 22 113 , nr. 1 en 2) verantwoordt de overheid haar beleid en nodigt zij zorgaanbieders uit tot de ontwikkeling van kwaliteitssystemen. Tijdens 'Leidschendamconferenties' over kwaliteit van zorg is overeengekomen dat de zorgaanbieders kwaliteitssystemen invoeren om de kwaliteit van zorg te waarborgen en te kunnen toetsen en dat terzake het kwaliteitsbeleid een duidelijke rol moet worden weggelegd voor de cliënten (Brancherapport, 2000).

In de Kwaliteitswet zorginstellingen (Kwaliteitswet, Staatsblad 1996, 80), die per 1 april 1996 in werking is getreden, worden een aantal algemene eisen gesteld waarbinnen instellingen hun eigen kwaliteitsbeleid kunnen vormgeven (Van Wijmen, 1995, 1996). Centraal in de wet staat het begrip 'verantwoorde zorg', wat wordt omschreven als 'een 
doeltreffende, doelmatige en op de reële behoefte van de patiënt/cliënt afgestemde zorg, waarbij sprake is van voldoende afstemming en samenwerking tussen zorgaanbieders'. In de tweede plaats stelt de wet verschillende voorwaarden aan de organisatie van de zorgverlening. Instellingen moeten voldoende en capabel personeel in dienst nemen. Daarnaast verplicht de wet zorginstellingen een systematisch kwaliteitsbeleid te voeren: zorgaanbieders moeten kwaliteitssystemen invoeren om de kwaliteit van de zorg te waarborgen. Aan de hand van externe toetsing, bijvoorbeeld door certificatie, kan het kwaliteitsbeleid van een zorginstelling vervolgens getoetst worden. Van de kwaliteit van zorg die de instelling heeft verleend en van het gevoerde kwaliteitsbeleid dient de instelling jaarlijks verantwoording af te leggen an de regionale inspectie en aan het regionale patiënten/consumenten platform (rp/cp).

De LOC, de Landelijke Organisatie Cliëntenraden (2003), laat zich uit over wat zij vanuit cliëntenperspectief verantwoorde zorg vindt. Zij spreekt hiervan als het zorgplan door overleg tussen zorgaanbieder en cliënt tot stand is gekomen en als dit zorgplan voldoet aan de volgende voorwaarden:

De wensen van de cliënt, zijn dagelijks leven en dagelijkse leefpatronen zijn uitgangspunten bij het opstellen van het zorgplan. Het zorgplan voldoet aan nader genoemde eisen; het wordt minimaal tweemaal per jaar geëvalueerd en bijgesteld en er wordt niets overeengekomen dat in strijd is met deze eisen.

In haar document 'Verantwoorde Zorg' geeft het LOC (2003) een opsomming van eisen die aan de zorgaanbieder gesteld worden op het gebied van de opname en introductie van de bewoner, het verblijf en het wonen, de verpleging en verzorging, de voeding, de (para)medische behandeling, de dagbesteding, de contacten met familie en de bejegening en privacy van de bewoner.

Het NIVEL (2000) onderzocht hoever instellingen gevorderd zijn met de ontwikkeling van kwaliteitssystemen. De conclusie luidt dat weinig verzorgingshuizen in het bezit zijn van een certificaat of keurmerk, dat wordt afgegeven wanneer het kwaliteitssysteem zodanig is ontwikkeld dat het de kritische blik van een externe toetsingscommissie heeft kunnen doorstaan. Het ISO-certificaat is slechts door $1 \%$ van de instellingen behaald; het MIK-Vcertificaat door geen enkel verzorgingshuis; het HKZ-certificaat door $1 \%$ van de verzorgingshuizen en het WoonZorg kwaliteitslabel is door $4 \%$ behaald. Wel spant bijna $75 \%$ van de verzorgingshuizen zich in voor het behalen van een certificaat of keurmerk. Om voor het certificaat in aanmerking te kunnen komen, moet de instelling haar kwaliteitssysteem in strategische, organisatorische en operationele activiteiten uitwerken. Verder moet de zorgvisie helder zijn, de aard en inhoud van de samenwerking met andere zorgaanbieders moet aan de orde komen, de functies van het verzorgingshuis moeten zijn 
omschreven, de organisatiestructuur moet zijn uitgewerkt, alsmede de functies, taken en deskundigheden van de medewerkers; de procedures en protocollen moeten ontwikkeld zijn; de betrokkenheid van de cliëntenraad moet inzichtelijk zijn en de tevredenheid van de bewoners moet zijn gemeten.

Ondanks het geringe aantal verzorgingshuizen dat een keurmerk heeft behaald en het groot aantal instellingen dat nog doende is een kwaliteitssysteem te implementeren, is brancheorganisatie Arcares van mening dat tussen 1995 en 2000 vooruitgang is geboekt op het gebied van kwaliteitsbeleid (Arcares, 2000):

Met name de hoeveelheid instellingen met een kwaliteitsjaarverslag is sterk toegenomen, evenals de hoeveelheid instellingen met een kwaliteitsbeleid op schrift. Er is een duidelijke toename te zien van het aantal instellingen dat protocollen en kwaliteitshandboeken heeft opgesteld. Het aantal instellingen met een cliëntenraad en met tevredenheidsonderzoek onder gebruikers en medewerkers is sterk toegenomen. Cliënten zijn op individueel niveau, via de cliëntenraad en via cliëntenorganisaties betrokken bij het beleid van de instelling: $86 \%$ van de verzorgingshuizen betrekt individuele cliënten bij het opstellen van het zorgplan; $95 \%$ van de verzorgingshuizen heeft periodiek overleg met de cliëntenraad; in $76 \%$ van de instellingen worden de aanbevelingen van de cliëntenraad vertaald in (nieuw) beleid; in $34 \%$ van de verzorgingshuizen vindt periodiek overleg plaats met cliëntenorganisaties. De aanbevelingen van de cliēntenorganisaties worden slechts door $14 \%$ van de huizen vertaald in (nieuw) beleid.

De rol die de cliëntenraden in verzorgingshuizen vervullen, en die Arcares als een consequentie van het kwaliteitsbeleid ziet, is een opdracht waartoe het verzorgingshuis zich gesteld weet door de Wet medezeggenschap cliënten zorginstellingen die per 1 juni 1996 in werking is getreden. Deze wet heeft tot doel de medezeggenschap van cliënten te regelen met betrekking tot het beleid in zorginstellingen. Daarnaast zijn 'spelregels voor cliëntenraad en zorgaanbieder' ontwikkeld waarin ondermeer de werkwijze en bevoegdheden van de cliëntenraad in verzorgingshuizen zijn omschreven (Modelreglement voor de cliëntenraad, deel $1 \mathrm{t} / \mathrm{m} \mathrm{4}$, WZF, LOBB 1996). De cliëntenraad behartigt de algemene belangen van de patiënten of bewoners van de instelling en praat mee over aangelegenheden die haar aangaan.

De cliëntenraad kan advies uitbrengen over alle kwesties waarbij het bewonersbelang in het geding is, zoals wijzigingen van de doelstellingen van de instelling, of wijzigingen in de organisatie. De instelling moet voor bepaalde besluiten een zwaarwegend advies vragen aan de cliëntenraad, zoals besluiten over voeding, veiligheid, kwaliteitsbeleid en klachtenregelingen (Staatsblad, 1996).

De totstandkoming van de Wet op de beroepen in de individuele gezondheidszorg (Wet 
BIG, Stb. 1993, 665) (Individuele gezondheidszorg wordt omschreven als zorg op niveau, gericht op de individuele hulpvrager en op diens gezondheid) draagt eveneens bij aan het bevorderen van de kwaliteit van de beroepsuitoefening. De BIG beschermt bewoners in verzorgingshuizen tegen ondeskundig en onzorgvuldig handelen door beroepsbeoefenaren.

De Wet regelt welke geneeskundige handelingen door welke beroepsbeoefenaar verricht mogen worden. Bepaalde handelingen, de zogenoemde 'voorbehouden handelingen' mogen slechts door een beperkte groep beroepsbeoefenaren worden verricht, omdat zij een aanmerkelijk gezondheidsrisico voor de patiënt met zich meebrengen als zij door niet deskundigen worden verricht. In de care-setting van het verzorgingshuis gaat het slechts om een beperkt aantal, overwegend verpleegtechnische handelingen.

Op 1 december 1997 is de Wet BIG in werking getreden op de onderdelen opleidingseisen, deskundigheidsgebied en registratie. Het bij algemene maatregel van bestuur (amvb) vastgestelde Besluit opleidingseisen verpleegkundige is op dat tijdstip van kracht. (Besluit van 15 juni 1995, Stb. 1995, 339). Krachtens artikel 34 wet BIG zijn via een ambv het deskundigheidsgebied en de MBO-opleiding voor verzorgenden geregeld. Voor de verzorgingshuizen is dit van belang, omdat een groot deel van de medewerkenden deze functie bekleedt. De Wet BIG bevat regels met betrekking tot het tuchtrecht en geeft twee tuchtnormen. De eerste heeft betrekking op zorgvuldigheid bij het verlenen van zorg jegens de bewoner en zijn naaste betrekkingen; de tweede norm heeft betrekking op alle gedragingen die strijdig zijn met het belang van een goede uitoefening van de individuele gezondheidszorg.

\subsection{De positie van de zorgvrager}

Het perspectief van de overheid op professionele zorg is volgens de Wetenschappelijke Raad voor het Regeringsbeleid (WRR, 2001) tussen 1974 en 1999 veranderd vanuit de constatering dat mensen in de professionele hulpverlening vaak onnodig afhankelijk worden gemaakt. Zij moeten volgens de WRR meer eigen verantwoordelijkheid gaan dragen en een zelfstandige rol krijgen bij het definiëren, oplossen en voorkomen van problemen.

"De zelfbewuste patiënt kan en moet meebeperken door mee te beslissen over effectievere, andersgerichte zorg", stelt Van Wijmen (1984). Het bevorderen van de zelfstandigheid en de eigen verantwoordelijkheid van de patiënt door zorginstellingen is volgens hem geen vrijblijvende zaak en hoeft door de patiënt niet als gunst te worden beschouwd. Van Wijmen verwijst naar de Grondwet, naar adviezen van de Centrale Raad voor de Volksgezondheid, naar nota's van het Kabinet, waar deze adviezen nader in worden 
uitgewerkt, en naar bestaande en zich ontwikkelende wetgeving over de positie van de patiënt:

Aan de rechten van mensen in de gezondheidszorg ligt een grondwettelijke basis. Het betreft enerzijds individuele grondrechten, vervat in de artikelen 10 en 11 van de Grondwet, met name de bescherming van de persoonlijke levenssfeer en van de onaantastbaarheid in lichamelijk en geestelijk opzicht van het menselijk lichaam. Anderzijds gaat het om het zgn. sociale grondrecht, het recht op goede gezondheidszorg, zoals vervat in artikel 22, lid 1 Grondwet.

De Centrale (later Nationale) Raad voor de Volksgezondheid heeft in de periode 1980-1982 een vijftal deeladviezen uitgebracht, die zijn voorbereid door de Commissie Rechten van de Patiënt. Ze betreffen: de juridische relatie tussen patiënt en arts, het recht van de patiënt op informatie en het toestemmingsvereiste; de bescherming van de privacy van de patiënt; medische experimenten met mensen; bemiddeling bij klachten van patiënten en kernbepalingen voor de regeling van de relatie tussen patiënt en arts. De overheid geeft verdere uitwerking aan de rechten van de patiënt; in een modelovereenkomst gaat de privaatrechtelijke verhouding patiënt-hulpverlener geregeld worden; wettelijke regelingen zijn in bewerking, zoals voor de psychiatrische patiënten (Bopz) en de erkenningsvoorwaarden aan zorginstellingen bevatten op dit terrein bepalingen (Van Wijmen, 1984).

In onder meer de nota's 'Bouwstenen van een ouderenbeleid' (TK, 1981/1982); 'Volksgezondheid bij beperkte middelen' (TK, 1983/1984b) en de Nota Zorg voor Ouderen (TK, 1985/1986) worden de bevordering van de zelfstandigheid en zelfredzaamheid van de patiënt centraal gesteld. Zorg die nodeloos afhankelijk maakt, moet volgens de nota's worden vervangen door zorg die de eigen activiteiten alsmede het benutten van eigen mogelijkheden stimuleert. Gezondheidsvoorlichting, -opvoeding, preventie, informatie en begeleiding vanuit de eerste lijn dienen volgens Van Wijmen een centrale rol te vervullen voor de bevordering van die zelfstandigheid en eigen verantwoordelijkheid. Juist in situaties waar de afhankelijkheid van patiënten groter wordt, bijvoorbeeld in geval van gespecialiseerde hulp, vindt hij actieve inbreng van de patiënt van belang. Deze inbreng kan gestalte krijgen in rechten van patiënten, met name door het toestemmingsvereiste, het beginsel dat een behandeling slechts plaatsvindt met toestemming van de betrokkene en door 'informed consent', het recht op informatie. Op basis van informatie en overleg dient de patiënt te kunnen beslissen inzake diagnose en therapie (Van Wijmen, 1984).

\section{Wet Persoonsregistraties}

De deeladviezen, waar Van Wijmen aan refereert, hebben vanaf het eind van de jaren 
tachtig geresulteerd in wet- en regelgeving die de rechtspositie van de zorgvrager beschermt en versterkt. Zo treedt in 1989 de Wet Persoonsregistraties (WPR, Stb. 1988, 665) in werking. De WPR geeft voorschriften ter bescherming van de privacy van degene wiens persoonsgegevens zijn opgenomen in een persoonsregistratie, zoals een zorgdossier in het vezorgingshuis. De 'houder' van de persoonsregistratie, in dit geval het verzorgingshuis, moet alleen die persoonsgegevens registreren en benutten die voor een goede zorg noodzakelijk zijn. Er worden eisen gesteld aan de opslag van persoonsgegevens, de beveiliging en de verstrekking van gegevens aan derden en de houder is verplicht om een beschrijving te maken van door hem gehouden registraties. Alleen onder bepaalde voorwaarden is het geoorloofd gevoelige gegevens van een persoon in een persoonsregistratie op te nemen. Indien het verzorgingshuis persoonsregistraties voert, moet een privacyreglement worden gemaakt en dit moet worden aangemeld bij het toezichthoudend orgaan van de WPR.

\section{Wet bijzondere opnemingen in psychiatrische ziekenhuizen (Bopz)}

In 1994 treedt de Wet bijzondere opnemingen in psychiatrische ziekenhuizen (Bopz) in werking. De wet bestaat uit een regeling die zich in hoofdzaak op twee terreinen begeeft: de procedures voor onvrijwillige opnemingen en de voorschriften binnen de instelling die van toepassing zijn wanneer een patiënt eenmaal onvrijwillig is opgenomen. De Wet Bopz regelt de externe rechtspositie van de patiënt. Het gaat daarbij om procedures met betrekking tot de opname van de patiënt, verlof en ontslag. De wet regelt ook de interne rechtspositie, die regels omvat over het opstellen van een behandelplan en huisregels, het toepassen van middelen en maatregelen en van vrijheidsbeperkende maatregelen tijdens het verblijf in het verzorgingshuis. Bij de opneming moet de patiënt worden medegedeeld wie voor zijn behandeling verantwoordelijk is en moet hem informatie over de gang van zaken in de instelling worden gegeven. Aan het begin van het verblijf moet in overeenstemming met de patiënt het behandelingsplan worden opgesteld. De Wet Bopz legt vast op welke wijze de patiënt een klacht kan indienen en stelt de verplichting om gegevens vast te leggen en aan te leveren bij de regionale inspectie voor de Gezondheidszorg (Stb. 1992, 671; Wet Bopz evaluatierapport, 1996). Sinds 1 december 1999 is de reikwijdte van de Bopz verbreed tot verzorgingshuizen met het oog op de toenemende groep ouderen met psychogeriatrische problemen die duurzaam in het verzorgingshuis verblijft. Door deze zogenoemde reikwijdteverbreding kunnen afdelingen van verzorgingshuizen als Bopz-instelling worden aangemerkt (Arcares 2001). Bij een aanmerking is voor het verzorgingshuis ook de Wet op het Mentorschap ten behoeve van Meerderjarigen van belang, die in 1995 in werking is getreden. Deze wet is van toepassing op somatische en psychogeriatrische bewoners die niet 
in staat zijn, wilsonbekwaam zijn, om hun belangen van persoonlijke aard te behartigen en in wiens plaats een mentor optreedt.

\section{Wet op de geneeskundige behandelingsovereenkomst}

De Wet op de geneeskundige behandelingsovereenkomst (Wgbo), die in 1995 in werking treedt, heeft eveneens tot doel de positie van de patiënt te versterken. De Wgbo legt de rechten en plichten van patiënt en arts vast die voortvloeien uit de overeenkomst tot een geneeskundige behandeling (Stb. 1994, 837). De Wgbo regelt de fundamentele rechten van de patiënt te weten: recht op informatie, toestemmingsvereiste, inzagerecht en bescherming van de persoonlijke levenssfeer. Voor het verrichten van onderzoek of behandeling is het 'informed consent' van de patiënt vereist. Dit betekent dat de toestemming van de patiënt moet zijn gebaseerd op voldoende door de hulpverlener verstrekte informatie over het onderzoek of de behandeling. De toestemming moet vrijwillig zijn verleend door een daartoe bekwame patiënt. Informed consent geeft volgens het Ministerie van Justitie uiting aan het beginsel van autonomie en is als zodanig van fundamentele betekenis voor de positie van de patiënt (Handreiking voor de beoordeling van wilsbekwaamheid, Ministerie van Justitie, 1994).

Tot de relatie tussen huisarts en bewoner in een verzorgingshuis worden ook de verpleging en verzorging gerekend die in het kader van de behandelingsovereenkomst plaatsvinden. Dit maakt de Wgbo van betekenis voor verzorgingshuizen.Voor het verzorgingshuis worden de rechten van de bewoner in het kader van de Wgbo als volgt concreet gemaakt:

\section{Recht op informatie}

Om een zorgplan voor een bewoner in het verzorgingshuis te kunnen vaststellen is overleg met de bewoner noodzakelijk. Van zijn arts, verplegende of verzorgende krijgt de bewoner informatie over de verzorgings- en behandelingsmogelijkheden en over de gevolgen van een bepaalde behandeling. Ook tijdens de uitvoering van een zorgplan krijgt een bewoner op de door hem gewenste wijze informatie. De bewoner geeft zelf ook informatie aan de zorgverleners die van belang is voor zijn verzorging of behandeling en hij geeft aan wanneer hij veranderingen in de zorg wenst.

\section{Toestemmingsvereiste}

Het uiteindelijke zorgplan heeft de instemming van de bewoner nodig. Met het vaststellen van het zorgplan geeft de bewoner zijn toestemming voor alle activiteiten die daarin beschreven staan. Met toestemming van de bewoner kan het zorgplan gewijzigd worden. Ook tussentijds kan een bewoner de afspraken laten wijzigen. 


\section{Plicht van een goed hulpverlener}

In bepaalde situaties, waarin de bewoner kan komen te verkeren, is het verzorgingshuis verplicht direct te handelen. Met behulp van gedragsregels en protocollen zorgt het verzorgingshuis er voor dat sprake kan zijn van een adequate invulling van deze norm.

\section{Bijhouden zorgdossier en Inzagerecht}

Het verzorgingshuis moet een dossier bijhouden met betrekking tot de behandeling, waaronder verpleging en verzorging van de bewoner. De handelingen die ten behoeve van de gezondheid van de bewoner zijn verricht, moeten worden geregistreerd. Het verzorgingshuis maakt zelf de keuze welke gegevens noodzakelijk zijn voor een goede zorgverlening. De bewoner heeft het recht de gegevens over zijn persoon in te zien. Inzage kan plaatsvinden samen met iemand van het verzorgingshuis, die uitleg kan geven over de inhoud van het zorgdossier.

\section{Bescherming van de persoonlijke levenssfeer: het recht op privacy}

Het recht op privacy kent veel aspecten, waaronder: een bewoner wordt niet onnodig gestoord; een bewoner kan rustig en afgezonderd bezoek ontvangen; een bewoner krijgt een respectvolle bejegening; behandeling en verzorging vinden niet in een voor ieder toegankelijke ruimte plaats en de bewoner kan zich desgewenst terugtrekken.

In de setting van het verzorgingshuis heeft de behandelingsovereenkomst tussen de bewoner van het verzorgingshuis en de huisarts, voor zover er al sprake van is, in veel gevallen geen directe invloed op de verzorging van de bewoner en op het zorgplan. Omdat niet precies valt af te bakenen welke verpleging en verzorging plaats vindt in het kader van de Wgbo en welke niet wordt aanbevolen om bij alle verpleging en verzorging de Wgbo als leidraad te nemen, omdat deze regels voor het merendeel algemeen zijn erkend en op grond daarvan ook van toepassing zijn op situaties waarop de Wgbo formeel niet direct betrekking heeft (Bolscher, 1995). Dit betekent dat in een overeenkomst die het verzorgingshuis afsluit met de bewoner analoog aan de geneeskundige behandelovereenkomst de hiervoor genoemde rechten en plichten van de bewoner en zorgaanbieder zijn opgenomen.

De Woonzorg Federatie (WZF), de voormalige koepelorganisatie van verzorgingshuizen, heeft in deze geest gehandeld en is voor verzorgingshuizen de rechten en plichten van de bewoners en van de instelling gaan vastleggen in een 'verzorgingsovereenkomst'. In een dergelijke overeenkomst is opgenomen welke zorg wordt aangeboden en wat de rol van de zorgvrager is bij het bepalen van het zorgaanbod en bij het formuleren van het zorgplan. De verzorgingsovereenkomst bevat onder meer bepalingen over de wijze waarop met het 
appartement van de bewoner wordt omgegaan, bepalingen over de privacy en gegevensbeheer van bewoners en over de persoonlijke levenssfeer (WZF, LOBB, 1997) :

De zorgaanbieder schept zodanige voorwaarden dat de keuzemogelijkheden voor de cliënt ten aanzien van zijn eigen leefsituatie zo ruim zijn als redelijkerwijs mogelijk is; de zorgaanbieder respecteert en beschermt de autonomie en de persoonlijke levenssfeer van de cliēnt.

Het zorgplan heeft in dit kader een belangrijke functie, wanneer hierin de rechten en plichten zijn geconcretiseerd en afspraken zijn opgenomen die de bewoner en verzorgende zijn overeengekomen over de zorg die wordt verleend.

In de vernieuwde en gemoderniseerde AWBZ geeft de centrale overheid een verdere uitwerking aan een vraaggestuurd zorgconcept en aan de centrale positie van de zorgvrager. Zij stelt onder meer dat de hulp die door de zorgaanbieder wordt verleend tegemoet moet komen aan wat de cliënt wenst en verwacht, dat in de eerste plaats moet worden uitgegaan van de zelfbeschikking van de zorgvrager en dat het zorgsysteem zich moet richten op individuele diversiteit (NP/CF, 2000; Prismant, 2000; Arcares, 2003). In aansluiting daarop stelt de Brancheorganisatie van zorgaanbieders van Verzorging en Verpleging dat cliëntgerichtheid en onderhandelingsbereidheid dominante waarden zullen worden in het professionele handelen en zij formuleert de volgende hoofdambitie (Prismant, 2000; Arcares, 2003):

Uiterlijk in 2004 zijn de voorwaarden gerealiseerd om vanuit het integrale zorgaanbod binnen de branche verpleging en verzorging als zorgaanbieders aan alle cliënten individuele zorgarrangementen te bieden die optimaal tegemoet komen aan hun zorgbehoefte, wensen en leefstijl en die doelmatig en doeltreffend zijn ingericht, ongeacht de plaats waar zorg geleverd wordt dan wel de organisatie die zorg realiseert. Cliënten hebben, voor zover mogelijk, zelf de regie en financiële middelen in handen en arrangeren samen met de zorgaanbieders het individuele zorgaanbod.

Om binnen de intramurale ouderenzorg c.q. in verzorgingshuizen tot concretisering te komen van vraaggerichte zorg hebben Zorgverzekeraars Nederland, de Kontaktcommissie Publiekrechtelijke Ziektekostenregelingen voor ambtenaren (KPZ) en de Brancheorganisatie Verpleging en Verzorging, een zogenoemde Uitkomst van Overleg (UvO) tot stand gebracht, waarin regels zijn gesteld voor een op de vrager gerichte, kwalitatief verantwoorde zorgverlening, waaraan zorgaanbieders zich hebben te houden. Een van de belangrijkste regels, waartoe het verzorgingshuis zich verplicht in de overeenkomst over productieafspraken die jaarlijks met het zorgkantoor worden aangegaan, is nagenoeg overgenomen uit de hierboven genoemde bijdragen in de verzorgingsovereenkomst van de WZF en de LOBB: 
Het verzorgingshuis draagt zorg voor een klantgerichte aanpak binnen de organisatie. Het verzorgingshuis schept zodanige voorwaarden dat de keuzemogelijkheden voor de cliënt ten aanzien van zijn eigen leefsituatie zo ruim als redelijkerwijs mogelijk zijn. Het verzorgingshuis respecteert en beschermt de autonomie en de persoonlijke levenssfeer van de cliēnt (Uv0, 2001).

De omslag van een aanbodgericht naar een vraaggericht zorgaanbod, de ontwikkeling van kwaliteitssystemen en de versterking van de positie van de zorgvrager, zoals hierboven beschreven, moeten een positieve invloed hebben op de verwachtingen die ouderen hebben van een verblijf in het verzorgingshuis en op hun beleving van het verblijf. Er moet immers worden uitgegaan van de zelfbeschikking van de zorgvrager; de zorgvrager moet zo ruim mogelijke keuzemogelijkheden hebben en diens autonomie en persoonlijke levenssfeer moeten gerespecteerd en beschermd worden.

\subsection{Verwachting en beleving van het verblijf van bewoners in verzorgingshuizen}

\subsection{Verwachting van het verblijf}

Eenderde van de 50-plussers ziet sterk op tegen opname in een verpleeg-of verzorgingshuis. Ze vrezen vooral dat verzorgend personeel te weinig tijd voor hen heeft. Ruim de helft van deze ouderen denkt dat in verzorgings- en verpleeghuizen 'anderen beslissen over mijn leven en dood'. $86 \%$ vreest hun zelfstandigheid en persoonlijke levensstijl te verliezen; bijna $80 \%$ zegt zich zorgen te maken over het gebrek aan privacy en $50 \%$ geeft aan dat er gebrek aan ruimte is voor eigen meubels en persoonlijke bezittingen.

"Ik ben iemand met een onafhankelijk karakter en kan me moeilijk aanpassen aan andere gewoonten. Ik wil vrij zijn, laat opstaan, laat warm eten en laat naar bed gaan", is een reactie van één van de 900 ondervraagden (Trouwonderzoek Zorg voor ouderen, Trouw juni 1999).

Het beeld wat uit dit onderzoek naar voren komt, contrasteert in hoge mate met de verwachtingen die ouderen zouden mogen hebben op grond van voornoemde ontwikkelingen op het gebied van kwaliteit van zorg en de (rechts)positie van de zorgvrager. Opvallend is dat juist op het gebied van zelfstandigheid, persoonlijke levensstijl, keuzemogelijkheden en privacy van bewoners, kortom op die gebieden die inzet van verandering en verbetering zijn, de verwachtingen laag gespannen zijn.

Het negatieve beeld uit dit onderzoek doet volgens het Sociaal Cultureel Planbureau (1999) mogelijk niet geheel recht aan de feitelijke situatie in verzorgingshuizen waar $70 \%$ van alle ouderen die in een intramurale ouderenzorg instelling wonen, verblijft. Zo wordt in het onderzoek geen onderscheid gemaakt tussen verzorgings - en verpleeghuizen, terwijl op het gebied van privacy, eigen meubels en persoonlijke bezittingen de mogelijkheden in het 
verzorgingshuis wezenlijk anders zijn dan in het verpleeghuis. In het verzorgingshuis heeft iedere bewoner een eigen kamer of appartement, terwijl een bewoner van het verpleeghuis zijn woon- en leefruimte deelt met één of meer medebewoners. Eenbeds-kamers maken in het verpleeghuis iets meer dan $10 \%$ van het totale aanbod an woonruimte uit. Met name zes-beds-kamers met $28.4 \%$ en vijfbeds-kamers met $33.9 \%$ vormen het grootste aanbod (JOZ, 1999). De verpleeghuizen die na 1990 zijn gebouwd, zijn uitgegaan van de norm $50 \%$ eenpersoonskamers en $50 \%$ tweepersoonskamers (SCP, 2001). Een tweede kanttekening bij het onderzoek is dat de groep van ondervraagden van het onderzoek heterogeen is samengesteld. Iemand van 51 jaar, die geen hinder heeft van chronische beperkingen, niet alleenstaand is en op velerlei terreinen maatschappelijk actief is, heeft zich wellicht niet of minder georiënteerd op de intramurale ouderenzorg dan een 85 - jarige alleenstaande, die verzorgingsbehoevend is.

Het Sociaal en Cultureel Planbureau (SCP, 1997) onderscheidt twee soorten onderzoek, specifiek gericht op het verzorgingshuis, om na te gaan op basis van welke verwachtingen ouderen voor het verzorgingshuis kiezen:

1. kwalitatief onderzoek warbij aan ouderen zelf wordt gevraagd wat zij van het verzorgingshuis verwachten en welke factoren of motieven een rol hebben gespeeld bij de aanvraag voor plaatsing in een verzorgingshuis;

2. kwantitatief onderzoek dat met behulp van statistische technieken verbanden zoekt tussen een aantal onafhankelijke variabelen, zoals beperkingen, leeftijd, samenstelling van de gezinssituatie en woningkenmerken en de afhankelijke variabelen, waaronder de aanmelding, indicatie of urgentiebepaling voor de opname in een verzorgingshuis.

De tweede groep van onderzoeken zijn volgens het SCP meestal gebaseerd op de vergelijking tussen twee groepen ouderen, bijvoorbeeld ouderen die een aanvraag voor een verzorgingshuisopname hebben ingediend en ouderen die dat niet hebben gedaan.

Uit kwalitatieve analyses van literatuuronderzoek naar de verwachtingen van ouderen die op de wachtlijst voor een verzorgingshuis staan, blijkt volgens het SCP dat de helft van de ondervraagden aangeeft daar minder eenzaam te zullen zijn. (Deze bevinding komt niet overeen met de opvatting van De Keyzer en Hertogh (1999), zoals ook in 3.2.1. is aangegeven, die stellen dat de mogelijkheden van het verzorgingshuis om op gevoelens van eenzaamheid in te gaan niet moeten worden overschat). Als voordelen van een opname noemen ouderen de permanente aanwezigheid van hulp en de volledige verzorging. Ook noemen zij veiligheid, afwezigheid van trappen, aanwezigheid van een ontmoetingsruimte, gelegenheid tot aanspraak en een goede maaltijdvoorziening. Nadelen die volgens het SCP 
door ouderen worden genoemd betreffen vooral het verlies van zelfstandigheid en privacy, alsmede de noodzaak om zich an te passen.Voor circa $80 \%$ van de ouderen is de gezondheid de belangrijkste reden om een plaats in het verzorgingshuis aan te vragen. Een deel van deze groep ondervindt ernstige fysieke, psychische of sociale problemen. Plaatsing is niet uitstelbaar. De angst speelt dat als de gezondheid nog verslechtert opname in een verpleeghuis geboden is. Er is ook een groep ouderen op de wachtlijst die zich uit voorzorg heeft opgegeven. De gezondheid is nog redelijk, maar de mensen zijn bang dat in de toekomst hun beperkingen verergeren of de beschikbare hulp vermindert. Een aantal mensen meldt zich uit voorzorg aan, soms op instigatie van de familie of de huisarts. Er is een groep ouderen die positief geïndiceerd is voor het verzorgingshuis, maar toch niet bereid is om naar het verzorgingshuis te gaan zolang de gezondheid niet verslechtert en thuis nog hulp aanwezig is. Daarnaast zijn er ouderen die in aanmerking zouden komen voor positieve indicatie, maar zich niet aanmelden, omdat zij baas in eigen huis willen blijven, huisdieren niet kwijt kunnen, niet uit de buurt weg willen of niet tegen de drukte in het verzorgingshuis kunnen (SCP, 1997).

Uit de kwantitatieve analyses van het SCP naar de factoren die van invloed zijn op de aanmelding voor een verzorgingshuis blijkt dat alleenstaande mannen gemiddeld twee jaar jonger zijn bij aanmelding dan vrouwen (resp. 81 en 83 jaar); door de aanwezigheid van informele hulp of het wonen in een serviceflat wordt de aanvraag voor een verzorgingshuis twee jaar later ingediend, maar wanneer zij zich aanmelden hebben zij beduidend meer problemen bij de algemene dagelijkse levensverrichtingen (ADL) dan andere aanmelders. Gevoelens van eenzaamheid en de omvang van informele hulp spelen een rol; naarmate mensen eenzamer zijn en minder informele hulp ontvangen, dienen zij eerder een aanvraag in. Ouderen met een partner zijn minder sterk op het verzorgingshuis georiënteerd. Ouderen met veel beperkingen en professionele thuiszorg zijn daarentegen sterk op een verzorgingshuis georiënteerd. Professionele hulp thuis wordt blijkbaar als tussenoplossing gezien en niet als substituut voor het verzorgingshuis.

Het SCP (1997) vroeg aan bewoners die reeds in verzorgingshuizen verblijven waarom zij naar het verzorgingshuis zijn gegaan. De belangrijkste reden is dat zij veel verzorging nodig hadden. Daarnaast werd het huishouden voor de meeste bewoners te zwaar. Bij ongeveer vier op de tien ouderen heeft de huisarts aangedrongen op de opname; veertig procent geeft an dat men bang was dat er niemand in de buurt zou zijn bij gezondheidsproblemen; twintig procent zegt dat de thuiszorg de verzorging niet meer aankon; de geschiktheid van de woning heeft bij dertig procent een bepaalde rol gespeeld bij het doen van de aanvraag (SCP, 1997). Onderzoek uit 1996 naar ouderen die zijn geplaatst in verzorgingshuizen laat onder meer zien dat zestig procent van de geplaatsten ernstige c.q. chronische beperkingen 
heeft. Ook de woonsituatie van ouderen, met name het type woning en de mate waarin de woning is aangepast aan de beperkingen die men ondervindt, is van belang voor een eventuele verhuizing naar het verzorgingshuis. Het SCP constateerde verder dat mensen die in het verzorgingshuis zijn opgenomen meer beperkingen hebben, vaker alleenstaand zijn, vaak tot de 80-plussers behoren en vaker alleen een lagere opleiding hebben gevolgd dan mensen die niet intramuraal verblijven (SCP, 1997).

\subsubsection{Beleving van het verblijf}

Over de vraag wat bewoners van verzorgingshuizen van de geboden zorg vinden, is volgens Arcares op landelijk niveau weinig onderzoeksmateriaal beschikbaar (Arcares, 2000). Literatuuronderzoek bracht een tweetal onderzoeken aan het licht:

- een onderzoek uit 1996 van de onderzoekscommissie Gezondheidszorg in Tel (GiT), waarin is nagegaan wat onder kwalitatief goede zorg in verzorgingshuizen verstaan wordt;

- een onderzoek van de Landelijke Organisatie Bewonerscommissie Bejaardenoorden (LOBB, 1998), waarin aan bewoners gevraagd is wat kwaliteit van zorg voor hun inhoudt.

De onderzoekscommissie Gezondheidszorg in Tel 4 (GiT, 1996) heeft met behulp van de methode van concept mapping aan gebruikers en zorgverleners van verzorgingshuiszorg gevraagd wat kwalitatief goede zorg inhoudt. Door de gebruikers wordt veel belang gehecht aan materiële privacy. In verzorgingshuizen beschikken bewoners over een eigen kamer, maar de kamers voldoen naar hun mening niet altijd aan het gewenste wooncomfort. De zorg moet voor de geïnterviewden zijn afgestemd op de persoonlijke behoeften. Vragen van cliënten moeten, binnen de grenzen van de mogelijkheden, gehonoreerd worden. De autonomie van de bewoner die afhankelijk is, en met name diens zelfstandigheid in het maken van keuzes, moet gerespecteerd worden. Een waardige, vriendelijke bejegening krijgt een hoge prioriteit; de manier van communiceren tussen zorgvragers en zorgverleners verdient veel aandacht en goed overleg over het individueel zorgplan wordt van belang gevonden.

Of deze opvattingen van de bewoners over de zorg en het woon-leefklimaat overeenkomen met hun ervaring, komt uit de resultaten niet naar voren. De geïnterviewde zorgverleners en zorgaanbieders spreken zich hierover wel uit door te stellen dat geen sprake is van een optimale, op de bewoner afgestemde zorg. Onvoldoende medewerkers en een toenemende zorgzwaarte veroorzaken volgens zorgverleners en het management van instellingen een hoge werkdruk. Dit gaat ten koste van de bejegening van en tijd en aandacht voor de bewoners, hetgeen voor het personeel een nadelig effect heeft op de motivatie. Door 
organisatorische maatregelen, met name de instelling van eerst - verantwoordelijke verzorgenden (evv-ers) wordt een betere interactie tussen zorgvrager en zorgverlener en een hogere arbeidssatisfactie nagestreefd. Deze omschakeling naar een meer cliëntgericht georganiseerde inrichting van de zorg verloopt geleidelijk en moeizaam concludeert de onderzoekscommissie (GiT, 1996). Een hoge werkdruk als gevolg van een toegenomen zorgzwarte veroorzaakt volgens de in de concept mapping geïnterviewde medewerkers een discrepantie tussen de benodigde ondersteuning van bewoners in verzorgingshuizen en de feitelijke ondersteuning.

Volgens Van Loveren (1995) ontstaat deze discrepantie door een eenzijdige gerichtheid van medewerkers in verzorgingshuizen op de lichamelijke hulpbehoevendheid van bewoners en hun ontkenning of miskenning van de zelfstandigheid, verantwoordelijkheid en competenties van de bewoner. Impliciet beweert zij dat verzorgenden meer ADLactiviteiten overnemen dan nodig is en dat op dit gebied tijd kan worden bespaard. Becker (2003) geeft dit vanuit eigen bevindingen in zijn woonzorg-instellingen voor ouderen expliciet aan en hij stelt daarbij dat beter te weinig dan teveel van deze zorg kan worden gegeven.

De Landelijke Organisatie Bewonerscommissie Bejaardenoorden (LOBB, 1998) peilde, onder meer door middel van open interviews, de mening van een (niet nader genoemd, door heel Nederland verspreid) aantal verzorgingshuisbewoners over kwaliteit van zorg. Aan de bewoners werd onder meer gevraagd een beeld te schetsen van het ideale verzorgingshuis, aan te geven wat kwaliteit van zorg is en wat in het verzorgingshuis essentieel is en wat minder belangrijk is.

Keuzevrijheid voor bewoners en het voortzetten van de persoonlijke levensstijl blijken zeer belangrijk gevonden te worden: bewoners willen geen beperkingen van bewegingsvrijheid; men moet zelf kunnen bepalen hoe laat men naar bed gaat en opstaat; de menulijst moet ruime keuzemogelijkheden bevatten en de bewoner geeft aan hoe laat hij wil eten; de bewoner moet invloed kunnen uitoefenen op het tijdstip waarop huishoudelijke medewerkers langskomen om schoon te maken; er moet een ruim aanbod zijn van diverse, recreatieve activiteiten. De appartementen moeten naar eigen smaak ingericht kunnen worden en het houden van huisdieren die geen overlast voor anderen bezorgen moet mogelijk zijn. Ofschoon bewoners zelf hun dagindeling willen bepalen, geven zij aan dat het sociale leven ook verankerd moet kunnen zijn in vaste momenten. Gedoeld wordt op de mogelijkheden om op bepaalde tijdstippen met andere bewoners koffie en thee te kunnen drinken en gezamenlijk activiteiten te ondernemen.

Informatie is eveneens een belangrijk punt: het verzorgingshuis moet voldoende informatie geven, bijvoorbeeld over de rol van de cliëntenraad, over huisregels, over de 
klachtenprocedure, over de voorzieningen van het huis en over de veiligheid in huis. Het zorgplan moet worden doorgesproken en uit de verzorgingsovereenkomst moet duidelijk blijken welke zorg en diensten wel en niet verwacht kunnen worden.

Ook aan de houding en vaardigheid van het personeel tillen bewoners zwaar: zij willen niet als patiënt worden gezien en verwachten dat het personeel aandacht heeft voor hun gevoelens van afhankelijkheid en machteloosheid; het personeel moet afspraken nakomen; nieuw personeel moet zich voorstellen; het personeel moet zich niet al te afstandelijk opstellen, een luisterend oor hebben, openstaan voor vragen, respect tonen voor de levensstijl van de bewoner en 'hart voor de bewoner hebben'; het personeel moet steun geven aan familie van ernstig zieke en pas overleden bewoners en bij voorkeur levenservaring hebben.

De woonsfeer van het verzorgingshuis draagt ook bij aan de kwaliteit van het verblijf: de algemene ruimten moeten goed schoongemaakt en netjes onderhouden zijn en sfeervol en gezellig zijn ingericht; er moeten kleinschalige, of kleinschalig ogende ruimten zijn; klachten of storingen in het appartement moeten door de technische dienst snel worden opgelost.

De bovengenoemde opvattingen van verzorgingshuisbewoners over hoe het verzorgingshuis er zou moeten uitzien, sluit aan bij de opdracht die de Brancheorganisatie voor zorgaanbieders van Verzorging en Verpleging aan haar leden stelt (zie 4.3).

In de onderzoeken van het LOBB en van de onderzoekscommissie Gezondheidszorg in Tel is de door bewoners wenselijk geachte situatie niet vergeleken met de door hen beleefde situatie. De resultaten van de beide onderzoeken komen overeen: het hebben van keuzevrijheid en het ontmoeten van medewerkers in verzorgingshuizen die de bewoner respectvol bejegenen, in staat stellen tot en ondersteunen bij een waardig leven en met wie in overleg wordt getreden voor het opstellen en bespreken van het zorgplan, zijn belangrijke verwachtingen van bewoners. De vraag of aan die verwachtingen tegemoet wordt gekomen, is zijdelings beantwoord. In onderzoek in verpleeghuizen van De Veer en Kerkstra (1998) is dit wel aan de orde gekomen. Zij stelden bewoners de vraag wat zij belangrijk vinden aan het verblijf en welke ervaringen zij hebben ten aanzien van de onderwerpen die zij belangrijk vinden. "Voldoende gerespecteerd worden', 'vriendelijk personeel' en 'gevoel van veiligheid' werden het belangrijkst gevonden. De discrepantie met de ervaring van bewoners bij deze punten was gering. Wat eveneens van groot belang wordt geacht, maar waarbij de discrepantie het grootst is, zijn de onderwerpen: 'zelf tijdstip kunnen bepalen van het naar toilet gaan of verschoond kunnen worden', 'verzorgenden doen snel wat bewoner vraagt', 'zelf tijdstip van slapen kunnen bepalen' en 'ruimte voor eigen bezoek'. 
Wat opvalt is dat in onderzoeken naar de verwachting en beleving van het verblijf in het verzorgingshuis het thema 'dood' niet belicht wordt. Omdat $78 \%$ van alle ouderen die in het verzorgingshuis verblijven daar overlijdt en twintig procent van alle 65 -jarigen eenzelfde lot wacht (Huijsman, 1990; Steverink, 1996), is dit opmerkelijk. Het gebrek aan aandacht voor dit thema komt volgens Michels (1975) voort uit het gegeven dat de dood in het verzorgingshuis een normale, verwachte en zelfs gewenste gast is. Matse (1977) is het daar niet mee eens. Hij plaatst kanttekeningen bij de opvatting dat de dood van een bejaarde in een verzorgingshuis een minder ingrijpend gebeuren zou zijn. De bewoners in een verzorgingshuis zitten naar zijn mening in een levensfase waarin ze in aanzienlijk grotere mate met de dood geconfronteerd worden dan in vorige levensperioden. Dit zou als een drukkende factor in het leven ervaren moeten worden. Dat dit niet het geval is en dat ouderen die naar het verzorgingshuis gaan of er reeds verblijven nauwelijks gewag maken van de beleving van sterven of van het naderend levenseinde is volgens Matse het gevolg van de aard van het verzorgingshuis. Het verzorgingshuis is een samenleving sub specie mortis; de dood is er onopvallend aanwezig. Degenen die niet geconfronteerd willen worden met de dood hebben veel speelruimte om de confrontatie te ontlopen of te minimaliseren.

\subsection{Beschouwing}

Indien bewoners van verzorgingshuizen gemeenschappelijke kenmerken bezitten, hun zorgbehoeften en verwachtingen sterke gelijkenis vertonen, hun eigenheid nauwelijks een rol speelt en zij de regie over hun leven overdragen, is een institutionele werkwijze van het verzorgingshuis te plaatsen. Voor wat betreft de lichamelijke zorgbehoefte van ouderen in het verzorgingshuis kan worden geconstateerd dat steeds meer bewoners eenzelfde type hulp nodig hebben bij de algemeen dagelijkse levensverrichtingen. De grote wachtlijsten werken in de hand dat de zorgzwaarte van 'nieuwe' bewoners hoog is en de lichamelijke zelfredzaamheid beperkt is. Maar wettelijke bepalingen ten aanzien van de positie van de zorgvrager, contractuele verplichtingen met de zorgfinancier en een vraaggerichte visie op zorg van de zorgaanbieder moeten juist waarborgen dat de eigenheid en zelfstandigheid van de individuele bewoner tot hun recht kunnen komen, en dat een op de individuele zorgvrager gericht aanbod aan zorg wordt geleverd in plaats van een eenheidsproduct. De overheid heeft door middel van wetgeving, waaronder erkenningsvoorwaarden, de Wet BIG en de Kwaliteitswet, de zorgaanbieder kaders aangereikt om verantwoorde, vraaggerichte zorg te bieden. Daarnaast geeft zij de zorgvrager mogelijkheden in handen om verantwoorde zorg te bedingen. De vraag is of de zorgaanbieder de bepalingen naleeft en de 
mogelijkheden benut. Privacy, respect, een vriendelijke bejegening, voldoende informatie, keuzevrijheid, een aanbod aan activiteiten en een prettige woonsfeer worden door ouderen van belang geacht in het verzorgingshuis. Maar de oudere die in het verzorgingshuis komt is er niet zeker van dat die aandacht ook gegeven wordt, alle wettelijke maatregelen ten spijt. Onderzoek wijst uit dat ouderen verwachten niet zelfstandig te kunnen leven in het verzorgingshuis, dat geen ruimte gegeven wordt aan een eigen leefstijl en dat zij genoodzaakt zullen zijn zich aan te passen. Tussen deze verwachtingen van ouderen die nog niet in een verzorgingshuis zijn geplaatst en de beleving van het verblijf van ouderen die in het verzorgingshuis wonen, kan een discrepantie bestaan. Over de zorg voor zelfstandigheid in het verzorgingshuis zijn niet veel gegevens bekend. De indruk bestaat dat de verzorgenden waarmee bewoners een zorgrelatie onderhouden sterk gericht zijn op hun behoefte aan ondersteuning bij de lichamelijke verzorging. Niet denkbeeldig is dat zorg voor zelfstandigheid uitblijft, omdat de opdracht voor het verzorgingshuis tot het respecteren en beschermen van de autonomie en de persoonlijke levenssfeer van de cliënt niet eenduidig wordt geïnterpreteerd. In het volgend hoofdstuk staat de vraag centraal hoe deze opdracht kan worden begrepen. 


\section{Hoofdstuk 5 Zorg voor zelfstandigheid: een begripsbepaling}

\subsection{Zelfredzaamheid en zelfstandigheid}

Voor het verzorgingshuis worden ouderen geïndiceerd die niet voldoende zelfredzaam zijn; ze zijn fysiek niet meer in staat om zelf zorg te dragen voor al hun algemeen dagelijkse levensverrichtingen (ADL) en huishoudelijke dagelijkse levensverrichtingen (HDL).

Aan de beslissing van een oudere om in een verzorgingshuis te gaan wonen, gaat het een en ander vooraf. Door fysieke beperkingen, die chronisch van aard zijn, ondervinden ouderen ongemakken in hun woning. Drempels en trappen worden obstakels. Allerlei materiële aanpassingen in de eigen woning worden nodig om daar te kunnen blijven wonen. De zorg voor de warme maaltijd wordt een probleem, niet alleen vanwege de moeite die gepaard gaat met de bereiding, maar ook omdat ouderen steeds minder in staat zijn zelf boodschappen te doen. Naast fysieke beperkingen ontwikkelen ouderen een gevoel van onveiligheid en eenzaamheid en de behoefte aan een andere sociale en materiële omgeving neemt toe. Om in de eigen woning te kunnen blijven wonen, heeft de oudere hulpvaardige, bereidwillige anderen nodig en is hij aangewezen op regelingen en voorzieningen.

Familieleden en kennissen, voor zover aanwezig, vrijwilligers en professionele zorgverleners worden ingeschakeld om de oudere thuis te ondersteunen. Met financiële steun van de lokale overheid kan de oudere zijn woning laten aanpassen en heeft hij de mogelijkheid van bepaalde vervoersvoorzieningen gebruik te maken. Hij kan door gebruik te maken van 'tafeltje-dek-je' dagelijks een warme maaltijd thuis bezorgd krijgen en zich laten aansluiten op een systeem van sociale alarmering, zodat hij direct iemand kan bereiken als hij acuut om hulp verlegen zit. Toegeven aan de hulp van anderen betekent voor de oudere dat hij rekening moet houden met de mogelijkheden en beperkingen van degenen die hem vrijwillig en /of professioneel ondersteunen. Wellicht moet hij zijn levensritme aanpassen en concessies doen aan de intensiteit wararmee hij activiteiten beoefent.

In de beleving van de oudere kan het scala aan voorzieningen en mogelijkheden tot ondersteuning uiteindelijk niet voldoende zijn. De oudere ervaart dat hij een te groot appèl gaat doen op de woonomgeving en op de mensen die hem ondersteunen in zijn zelfredzaamheid. Vaak in samenspraak met familieleden en de huisarts wordt de beslissing genomen om niet meer in het eigen huis te blijven wonen en zich te laten indiceren voor het verzorgingshuis. Wanneer de oudere voor meer functies wordt geïndiceerd en de kosten 
voor professionele thuiszorg die van het verblijf in het verzorgingshuis overstijgen, wordt de mogelijkheid tot verhuizing naar het verzorgingshuis geboden. De oudere verwacht dat hem in het verzorgingshuis het comfort en de affectie worden geboden waarom hij verlegen zit en waardoor hij zich mens kan voelen (Steverink, 1996).

In het verzorgingshuis komt de oudere in een zorgomgeving waar niet of nauwelijks behandeld wordt. Het verzorgingshuis is immers geen cure-instelling, waar het wegnemen of opheffen van lichamelijke problematiek centraal staan, maar een care-setting. Bij care gaat het volgens de Nederlandse Patiënten/Consumenten Federatie om de voortzetting van een menselijke bestaanswijze, van het dagelijks leven dat iemand leidt (NP/CF, 2000). Het verzorgingshuis heeft vanuit die omschrijving een tweeledige taak: het dient zich bezig te houden met de vraag wat de menselijke bestaanswijze van de bewoner inhoudt en hoe die kan worden gewaarborgd; het heeft tevens tot taak de bewoner in staat te stellen het leven dat hij tot aan de opname in het verzorgingshuis heeft geleid in het verzorgingshuis voort te zetten. De individuele bewoner kan blijkbaar verwachten dat het verzorgingshuis zijn eigenheid eerbiedigt en zijn dagelijks leven voort laat gaan. De initiatieven van het verzorginghuis om die verwachtingen in te lossen, kunnen zeer verschillend van aard zijn. Het kan betekenen dat het verzorginghuis zich inspant om de bewoner niet te hinderen, hem zijn gang te laten gaan en zich niet of zo min mogelijk te bemoeien met de wijze waarop de bewoner zijn leven in het verzorgingshuis wil leiden; het kan betekenen dat het verzorgingshuis zich maximaal geroepen voelt de grenzen van haar verplichtingen aan te geven, de bewoner te informeren over het aanbod aan zorg en diensten en de wederzijdse rechten en plichten vast te leggen in een verzorgingsovereenkomst, een huisreglement of in andere contracten; het kan ook betekenen dat het verzorgingshuis een gevarieerd aanbod aan activiteiten aanbiedt en inspanningen verricht waarmee wordt ingegaan op een appèl dat de individuele bewoner doet op het verzorgingshuis en waarmee hem de mogelijkheid wordt verschaft zich te ontplooien en invulling te geven aan het leven.

De vraag is in hoeverre een diversiteit aan initiatieven tegemoet komt aan de eigenheid en verwachtingen van de bewoner die in het verzorgingshuis komt en daar verblijft. Misschien wil de bewoner het leven dat hij tot aan opname in het verzorgingshuis heeft geleid niet voortzetten, wil hij de spaarzame contacten die hij thuis had verruilen voor een contactrijk bestaan en wil hij, om die reden, de beperkte lichamelijke energie die hij heeft zo min mogelijk aanwenden voor zijn lichamelijke verzorging en voor huishoudelijk werk. Ook is het mogelijk dat de oudere niet geïnteresseerd is in zijn rechten en plichten, zich in zijn nieuwe situatie helemaal niet bewust bezighoudt met het maken van keuzes voor zijn zelfontplooiing en zich enkel richt op zijn gevoelens bij het vertrek uit het eigen huis en het komen wonen in een verzorgingshuis. Wellicht hoopt de oudere dat hij mensen ontmoet die zich wel met hem bemoeien, die hem helpen zijn afhankelijkheid en kwetsbaarheid een 
plaats in zijn leven te geven. Misschien brengt zijn eigenheid met zich mee dat hij het liefst gewoon afwacht wat de dag hem brengt.

Aan het verzorgingshuis worden schijnbaar geen restricties opgelegd om een veelheid van initiatieven te nemen en inspanningen te verrichten om de bestaanswijze of eigenheid van de individuele bewoner te respecteren en om hem zijn leven op de door hem gewenste wijze voort te laten zetten. Integendeel, de overheid verplicht de zorgaanbieder hiermee ernst te maken. In het vorige hoofdstuk is beschreven dat de zorgfinancier en de zorgaanbieder jaarlijks een schriftelijke overeenkomst aangaan, waarin laatstgenoemde toezegt om de bewoner voor zijn eigen leefsituatie ruime keuzemogelijkheden aan te bieden en om de autonomie en de persoonlijke levenssfeer van de bewoner te respecteren en te beschermen (UvO verzorgingshuizen, 2001). Definities van de abstracte begrippen 'autonomie' en 'persoonlijke levenssfeer', een omschrijving van de taken 'respecteren' en 'beschermen' en geformuleerde eisen waaraan het verzorgingshuis concreet moet voldoen, worden in de overeenkomst niet gegeven.

In dit hoofdstuk is door bestudering van literatuur, die voornamelijk op de gezondheidsethiek en het gezondheidsrecht betrekking heeft, de vraag behandeld hoe zorg voor zelfstandigheid kan worden gedefinieerd. Volgens Van Delden, Hertogh en Manschot (1999) leeft de ethiek op dezelfde filosofische wortels als het recht:

Beide gaan terug op de Verlichtingstraditie en de theorie van het sociaal contract, waarin het menselijk samenleven wordt voorgesteld als een verdrag tussen autonome subjecten, aangegaan op grond van weloverwogen eigenbelang, en beide funderen de regels voor aanvaardbaar gedrag in dergelijke verdragsrelaties tot anderen.

In de gezondheidsethiek wordt in plaats van het begrip 'zelfstandigheid' het begrip 'autonomie' gebezigd en in het gezondheidsrecht neemt het begrip 'zelfbeschikking' de plaats in van het begrip 'zelfstandigheid'. De inzet van de discipline gezondheidsrecht voor de bescherming van het zelfbeschikkingsrecht van de patiënt verschilt volgens Van Delden (1999) nauwelijks van het morele pleidooi voor het respecteren van de autonomie van de patiënt. Hieruit mag niet geconcludeerd worden dat beide disciplines tot een eenduidige definitie komen van wat onder het beschermen en respecteren van de autonomie of van de zelfbeschikking moet worden verstaan. In paragraaf 5.2 wordt duidelijk gemaakt dat binnen de gezondheidsethiek verschillende autonomie-concepten bestaan. Daarnaast wordt gesteld dat inmenging in het leven van de zorgvrager en het overnemen van beslissingen van de zorgvrager door de zorgverlener in de gezondheidsethiek kenmerken zijn van de zorgrelatie en uitdrukking geven aan het elkaar nabij en op elkaar betrokken zijn, terwijl in het gezondheidsrecht de zorgverlener zich niet zonder instemming van de zorgvrager in diens 
leven mengt of beslissingen overneemt. Paragraaf 5.3 gaat op de gezondheidsrechtelijke benadering van zelfbeschikking in. In paragraaf 5.4 wordt een beschouwing op hoofdstuk 5 gegeven.

De begrippen autonomie en persoonlijke levenssfeer worden in de literatuur niet duidelijk onderscheiden. Van Asperen (1993) stelt dat het synonieme begrippen zijn. Hij spreekt van autonomie als een niet-inmenging in de persoonlijke levenssfeer, en van respect voor de persoonlijke levenssfeer door het aanspreken van mensen als volwassen en mondige personen. Kenmerken die ook door anderen als essentieel worden gezien voor het respecteren van autonomie (Pool, 1995). De betekenis die Van Wijmen (1984) geeft aan het begrip 'persoonlijke levenssfeer' leunt aan tegen een bepaald concept van autonomie. Hij wijst op het recht op bescherming van de persoonlijke levenssfeer, dat in artikel 10, lid 1 van de Grondwet geregeld is. Naast andere grondrechten symboliseert dit grondrecht de eigenheid van de mens, die in de gezondheidszorg uitwerking heeft gekregen in de op het zelfbeschikkingsrecht gebaseerde rechten van patiënten. Het recht op bescherming van de persoonlijke levenssfeer vraagt van de zorgverlener om geheimhouding van vertrouwelijkheden en het slechts met toestemming van de betrokkene doorgeven van vertrouwelijke gegevens. Daarnaast dient de zorgverlener voorzieningen te treffen voor ruimtelijke privacy (Van Wijmen, 1984).

Vanwege de kennelijke verwevenheid van de begrippen 'persoonlijke levenssfeer' en 'autonomie' zal in dit hoofdstuk verder alleen laatstgenoemd begrip worden uitgediept.

\subsection{Zorg voor autonomie: een gezondheidsethische omschrijving}

De literatuur associeert autonomie met de begrippen 'vrijheid', 'identiteit' en '(on)afhankelijkheid' en laat zien dat er verschillende gezondheidsethische autonomieconcepten bestaan. Twee autonomieconcepten worden behandeld: een autonomieconcept dat uitgaat van negatieve vrijheid en een autonomieconcept dat positieve vrijheid vooropstelt. Het autonomieconcept van positieve vrijheid is vervolgens onderscheiden in een rationele benadering waarin reflectie een centraal kenmerk is en een benadering waarbij het accent ligt op de vraag of datgene wat iemand doet voor de persoon betekenisvol is en past in zijn levensplan (Widdershoven, 2000).

Het naast elkaar bestaan van meerdere autonomieconcepten werkt in de hand dat het zorgveld op uiteenlopende wijze kan omgaan met de opdracht om de autonomie van de bewoners te respecteren en te beschermen. Het roept de vraag op vanuit welk autonomieconcept recht gedaan kan worden aan de opdracht van het verzorgingshuis de 
eigenheid of zelfstandigheid van de zorgafhankelijke bewoner te eerbiedigen en hem in die eigenheid invulling te laten geven aan zijn leven in het verzorgingshuis. Het vraagstuk van inmenging van de zorgverlener in het leven van de zorgvrager is daarbij aan de orde.

Het begrip autonomie is uit de Griekse taal afkomstig en betekent letterlijk 'eigen (autos) wetgever' (nomos) zijn. Lange tijd is de gezondheidszorg gekenmerkt door het wetgeverschap van de medische macht. Minder dan een halve eeuw geleden bepaalden de medici de wetten van de gezondheidszorg vanuit de overtuiging dat het behoud van het leven boven elke wens van de patiënt gesteld is en dat de medici weten wat het beste is voor de patiënt (het bestwil-principe). De paternalistische, patriarchale medische macht maakte mensen tot object van zorg en liet weinig ruimte voor zeggenschap over het eigen leven (Manschot, 1992; Pool, 1995; Van Thiel e.a., 1997; Widdershoven, 1995, 2000).

Het gegeven in de gezondheidszorg dat mensen tot leek worden verklaard en beslissingen uit hun handen worden genomen op belangrijke punten van hun eigen bestaan werd vooral op het eind van de jaren zestig ter discussie gesteld. Een toenemende kritiek uit de samenleving op de autoriteit van het medisch model maakte de weg vrij voor een andere opvatting over de rol van de patiënt (Stüssgen, 1997). Het gaf ruimte aan het gedachtegoed van Kant waarin de mens gezien wordt als een vrij wezen, dat het eigen handelen bepaalt onafhankelijk van de wetmatigheden of beperkingen van het eigen lichaam, dat niet als object beschouwd moet worden maar als subject voor wie vrijheid en autonomie belangrijke waarden vertegenwoordigen (Widdershoven, 2000; Ter Meulen, 1994).

Om vrijheid en autonomie ook in de gezondheidszorg tot uiting te laten komen, is het van belang dat het de zorgvrager niet ontbreekt aan, wat Manschot (1992) omschrijft, twee onderling nauw samenhangende houdingen: een defensieve en een affirmatieve:

De defensieve houding is de wil gevrijwaard te blijven van ongewenste inmenging van medici en andere verzorgers in het eigen leven. De affirmatieve houding verwijst naar het vermogen en de taak om zelf te beslissen en het eigen leven vorm te geven, ook als dit door ziekte, een handicap of andere belemmeringen wordt getroffen.

De defensieve en affirmatieve houding verwijzen respectievelijk naar de vrijheidsconcepties 'negatieve vrijheid' en 'positieve vrijheid' die in 1958 door Isaiah Berlin geformuleerd zijn en die richting geven aan het denken over autonomie en vrijheid in de gezondheidszorg.

\subsubsection{Autonomie en vrijheid}

Volgens Berlin (1996) is positieve vrijheid het vermogen zelfstandig richting te geven aan het eigen leven. Positieve vrijheid duidt op het verlangen van de mens verantwoordelijk te 
zijn voor zijn daden, zelf te kunnen kiezen en de overtuiging te hebben dat de gemaakte keuzes bijdragen aan het actief vormgeven aan het eigen leven (Widdershoven, 2000). Positieve vrijheid omvat zowel een aspect van zelfbepaling als van zelfverwerkelijking. Van zelfbepaling is sprake als iemands handelen berust op eigen keuzes, die een uitdrukking zijn van zijn identiteit. Zelfverwerkelijking houdt in dat iemand zijn capaciteiten, talenten en vermogens ten volle kan ontplooien. Negatieve vrijheid heeft betrekking op de vrije handelingsruimte waarin iemand datgene kan doen wat in zijn vermogen ligt. Negatieve vrijheid vormt een voorwaarde voor positieve vrijheid: men kan alleen keuzes maken als er ook wat te kiezen valt en indien men niet door anderen gedwongen of gehinderd wordt (Stüssgen, 1997).

Negatieve vrijheid en positieve vrijheid onderscheiden zich terzake het vraagstuk van interventie of inmenging door de zorgverlener in het leven van de zorgvrager (Metaal, 1992): het individu moet vrij zijn van inmenging door anderen, respectievelijk interventie door anderen is mogelijk onder voorwaarde dat de inmenging gericht is op fundamentele waarden van de zorgvrager en vanuit de overtuiging dat de zorgvrager zonder inmenging onzorgvuldige keuzes maakt. Maar positieve vrijheid manifesteert zich niet enkel op basis van gereflecteerde, beredeneerde keuzes die fundamentele waarden representeren. De persoon maakt zijn identiteit ook kenbaar in de sociale en materiële wereld. In de 'everyday ethics', in de gewone dagelijkse omgang en verzorging geeft hij zin en betekenis aan het leven (Ter Meulen, 1994).

In het verzorgingshuis wonen overwegend mensen die niet voldoende zelfredzaam zijn en afhankelijk zijn van de zorg van anderen. De zorgverlener dient hun autonomie te respecteren en te beschermen. In deze paragraaf worden de autonomieconcepten negatieve vrijheid en positieve vrijheid nader toegelicht. Daarbij wordt nagegaan welke plaats het concept geeft aan afhankelijkheid van mensen en op welke wijze het respecteren en beschermen van autonomie in het concept gestalte kan krijgen.

\subsubsection{Autonomie als negatieve vrijheid}

De opvatting dat mensen vrij moeten zijn van inmenging van anderen is enige eeuwen geleden tot ontwikkeling gekomen in het liberale gedachtegoed van Mill en Locke. Autonomie krijgt daarin de betekenis van zelfbeschikking: mensen moeten beslissingen kunnen nemen zonder inmenging van derden; zij moeten zelf vorm kunnen geven aan het leven zonder te treden in de vrijheid van anderen en vrij van dwang van de omgeving; zij zijn vrij in het maken van keuzes en het volgen van eigen preferenties (Manschot, 1992; Ter Meulen, 1994; Van Thiel e.a., 1997; Widdershoven, 2000). In de gezondheidsethiek wordt 
autonomie als zelfbeschikking de principebenadering van autonomie genoemd en geassocieerd met negatieve vrijheid. De invulling van vrijheid moet in dit autonomieconcept worden overgelaten aan het individu zelf; anderen moeten zich niet inmengen in de persoonlijke levenssfeer; dwang en druk van buitenaf zijn afwezig; de persoon moet met rust gelaten worden en er moeten zo weinig mogelijk restricties worden opgelegd. Autonomie wordt in deze benadering geconceptualiseerd als zelfvoorzienendheid, vrijheid van ongemak (Sevenhuijsen, 1996) en als een onaantastbare fysieke en psychische integriteit (Boutellier, 1997).

\section{Negatieve vrijheid en afhankelijkheid}

In de liberalistische visie op autonomie wordt afhankelijkheid uitgelegd als een onvolkomenheid die moet worden opgeheven en gecorrigeerd; de autonomie is aangetast en moet worden hersteld. Afhankelijkheid en autonomie sluiten elkaar in deze visie uit. De autonome persoon is immers competent, tot kritische reflectie in staat en beschikt over zelfcontrole en onafhankelijkheid. Hij maakt rationele afwegingen, komt tot eigen keuzen of handelingen op basis van eigen redenen en reflectie; emoties spelen daarbij geen overwegende rol; volgzaamheid is uitgesloten en doelgerichtheid is van belang (Metaal, 1992). De relatie tussen de zorgvrager en zorgverlener is in dit autonomieconcept hiërarchisch en asymmetrisch van aard. De zorgvrager spreekt de zorgverlener aan op diens competentie om zijn stoornis of ongemak op te heffen. Omdat de zorgvrager de gevolgen van een besluit moet dragen, dient hij, en niet de zorgverlener, degene te zijn die besluiten neemt (Pool, 1995). De oudere zorgvrager die een beroep doet op de zorgverlener in het verzorgingshuis dient op basis van dit autonomieconcept tegemoet getreden te worden als een onafhankelijk om informatie vragend persoon die keuzes maakt ten aanzien van zijn gezondheid en bij wie geen (medische) interventies plaatshebben zonder dat hij daartoe toestemming verleent. Als tegenhanger van het bestwil-principe van de medische macht is het hier de zorgvrager zelf die weet wat het beste voor hem is. Dit liberaal autonomieconcept heeft volgens Ter Meulen (1994) ook in de zorg voor ouderen belangrijke verworvenheden opgeleverd:

Zo zijn het recht op informatie, het principe van de vrije toestemming en het waarborgen van de privacy belangrijke en niet meer weg te denken ethische beginselen in de gezondheidszorg, ook in de zorg voor chronisch zieke ouderen.

\section{Negatieve vrijheid, afhankelijkheid en het respecteren en beschermen van de autonomie}

Manschot (1994) en Widdershoven (1998; 2000) stellen dat de gezondheidszorg het principe van niet-bevoogding en niet-inmenging, c.q. van negatieve vrijheid, heeft 
uitgewerkt tot 'respect voor de autonomie van de zorgvrager'. In het kader van de principebenadering van 'respect voor autonomie', (Manschot, 1992, 1997; Ter Meulen, 1994; Widdershoven, 1995, 1998, 2000) dient het verzorgingshuis de bewoners als onafhankelijke, vrije mensen te beschouwen die geen inmenging in hun persoonlijke leven wensen en voor wie derhalve aandacht voor niet-inmenging, voor de passieve kant van respect voor autonomie (NVVZ,1996) op zijn plaats is. Voor het verzorgingshuis zal dat betekenen dat aan het recht op zelfbeschikking van de bewoner de hoogste prioriteit gegeven moet worden. Uitgangspunt hierbij is dat de bewoners van het verzorgingshuis mentaal in staat zijn om besluiten te nemen, mogelijkheden te beoordelen en toestemming te verlenen terzake eventuele behandelingsvoorstellen. De bewoner wil ook, op de door hem gewenste wijze, betrokken worden bij de totstandkoming, evaluatie en bijstelling van het zorgplan en geïnformeerd worden over onderwerpen die de dagelijkse gang in het verzorgingshuis betreffen (LOBB, 1998). De consequentie hiervan is dat van het verzorgingshuis een opstelling wordt verwacht waarbij het handelen wordt geleid door de rechten en plichten van zorgverlener en zorgvrager. Het respecteren van de autonomie krijgt in dit concept gestalte door informed consent. De zorgverlener informeert de bewoner over de mogelijkheden van het huis, over de wijze waarop hij kan worden ondersteund bij zijn beperkingen en zijn afhankelijkheid van zorg en hij laat de beslissingen over aan de zorgvrager. Volgens Van Thiel e.a. (1997) is in dit concept van autonomie sprake van een 'handen-af benadering'.

Indien de opdracht voor het verzorgingshuis slechts zou luiden dat de autonomie van de zorgvrager gerespecteerd moet worden is de 'handen-af benadering' te begrijpen. 'Respecteren' betekent volgens Van Dale 'de ander geen geweld aandoen', 'onbeschadigd, in zijn waarde laten'. Maar de opdracht gaat verder: de autonomie van de bewoner moet 'beschermd' worden; de zorgverlener moet de zorgvrager beschutten, zijn leven bevorderen en hem voorthelpen. Een 'handen-af benadering' schiet daarbij te kort. Beschermen van autonomie vraagt geen terughoudende opstelling. De opdracht impliceert ook dat de bewoner van het verzorgingshuis niet alleen naar het verzorgingshuis komt om 'zijn recht te halen'. Hij kan vanuit een autonomieconcept dat autonomie en onafhankelijkheid gelijkstelt om gerichte inmenging vragen, opdat de gevolgen van zijn lichamelijke beperkingen worden verzacht. De mogelijkheid om de beperkingen weg te laten nemen en de psychische en fysieke integriteit terug te krijgen, zodat hij weer autonoom kan zijn, is, gezien het chronisch karakter van zijn beperkingen en de beperkingen van het verzorgingshuis, geen optie. De verzorginghuisbewoner vraagt daar ook niet om. Hij vraagt er om zichzelf te mogen zijn. 


\section{Kritische kanttekeningen}

De tweeledige opdracht om de autonomie van ouderen in verzorgingshuizen te respecteren en te beschermen is in dit concept van negatieve vrijheid problematisch. In de liberale ideologie wordt afhankelijkheid beschouwd als een verlies van autonomie, hetgeen betekent dat de vraag en beslissing van de zorgvrager om inmenging door anderen van een tekortschietende autonomie getuigt, evenals de aanwezigheid van lichamelijke beperkingen die het de oudere onmogelijk maken 'volwaardig' aan het leven deel te nemen. Toch wordt de besluitvorming voor zijn leven in het verzorgingshuis bij de zorgvrager gelegd.

Ondanks de verworvenheden die in de gezondheidszorg aan het recht op zelfbeschikking kleven, is dit autonomieconcept niet toereikend in de setting van het verzorgingshuis, alleen al vanwege de opdracht aan het verzorgingshuis en de verwachting van de bewoner om bij te dragen aan de zorg voor de bewoner, om hem voort te helpen. Voor het beschermen van de autonomie, voor de vraag hoe de bewoner gesteund kan worden en geholpen kan worden betekenis te geven aan de situatie waarin hij verkeert, is in dit autonomieconcept geen ruimte.

"In de chronische zorg, zoals in verzorgingshuizen, waar sprake is van blijvende afhankelijkheid, waar mensen kwetsbaar zijn, de eindigheid van het leven ervaren en op anderen zijn aangewezen, biedt autonomie in de betekenis van zelfbeschikking, vrijheid en onafhankelijkheid geen perspectief', stelt Manschot (1992) en Widdershoven (2000) zegt hierover het volgende:

Het model van individuele probleemoplossing is niet eenvoudig toepasbaar in situaties waar het niet gaat om keuzes tussen concrete behandelalternatieven, maar om het zoeken naar gezamenlijke uitwegen onder condities van langdurige zorg. Het interpreteren van een hulpverleningsrelatie in termen van rechten en plichten schiet tekort wanneer het voor de patiënt resulteert in een right to rot.

Het vrijheidsideaal wordt dan zo radicaal uitgelegd dat individuen 'met rust gelaten worden', zelfs als hun feitelijke toestand directe interventies noodzakelijk maakt (Ter Meulen, 1994). Er ontstaat dan een dunne grens tussen het verdedigen van autonomie en mensen aan hun lot overlaten (Van Houten en Van Lieshout, 1994). Ook Sevenhuijsen (1996) keert zich tegen een autonomieconcept waarin wordt uitgegaan van zelfbeschikking en vrijheid (van ongemak) als een strikt individuele aangelegenheid. Zij stelt dat autonomie volgens een dergelijke opvatting lijnrecht staat tegenover zorg, die immers afhankelijkheid benadrukt.

In het autonomieconcept van zelfbeschikking is het verschaffen van keuzevrijheid aan bewoners van verzorgingshuizen een belangrijk andachtspunt (LOBB, 1998), maar de implicaties hiervan zijn moeilijk te omlijnen. Individuele keuzevrijheid kan een 
onbegrensde diversiteit aan keuzes tot gevolg hebben. De bewoner kan kiezen voor selfmanagement, voor het regelen van zijn eigen zaken (Van Wijmen, 1997). Gezien de fysieke beperkingen die de bewoner ondervindt, kan de consequentie van een dergelijke keuze zijn dat de zorgverleners in hoge mate ad hoc zorg moeten leveren. Individuele keuzevrijheid betekent ook dat het verzorgingshuis zich dient te manifesteren vanuit het individuele perspectief op gezondheidszorg met als opdracht de individuele preferenties van de bewoners te bevredigen (Kiezen en Delen, 1991) en met het gevolg dat er geen grenzen bestaan aan de vraag naar zorg (Denken over Zorg, 1997). Vanuit zijn sociale plicht (Leenen, 1992) en zijn plicht 'een goede patiënt' te zijn (Van Wijmen, 1997), kan het zijn dat de bewoner zich bescheiden opstelt in het maken van keuzes, of zich laat leiden door de mogelijkheden die het verzorgingshuis aandraagt.

Toch schiet, volgens Ter Meulen en Widdershoven, dit autonomieconcept tekort in de zorg voor hulpbehoevende ouderen. Widdershoven stelt dat het ideaal van een bewuste, geïnformeerde keuze nooit te realiseren is en ook niet nastrevenswaardig is. Het 'informed consent doctrine' reduceert volgens hem het keuzeproces tot een mathematische procedure waarin de relatie tussen de zorgvrager en de zorgverlener uit het oog verloren wordt en waarbij wordt voorbijgegaan aan het gegeven dat het handelen niet geleid wordt door bewuste keuzes en beredeneerde conclusies. Het respecteren en beschermen van autonomie kan volgens hem niet enkel worden uitgelegd als informed consent (Widdershoven,1995; 1998; 2000). In de zorg voor ouderen, waarin het recht op zelfbeschikking gerespecteerd moet worden, maar waarin de bewoner van het verzorgingshuis ook vraagt om hem voort te helpen op een wijze die hem past, wordt een autonomieconcept gevraagd waarin de zorgvrager en zorgverlener zich naar elkaar richten, dat keuzevrijheid vanuit de levensgeschiedenis betekenis geeft en dat inmenging niet uitsluit. Een concept van autonomie als positieve vrijheid biedt die mogelijkheid.

\subsubsection{Autonomie als positieve vrijheid door kritische reflectie}

In het autonomieconcept van positieve vrijheid, ook wel persoonlijke autonomie genoemd, krijgen zowel zelfbeschikking als keuzevrijheid een belangrijke plaats. Het individu wordt aangesproken als verantwoordelijk en zelfkiezend, zelfbeschikkend en zelfbepalend wezen. Autonome beslissingen van een persoon zijn in dit concept beslissingen die in overeenstemming zijn met fundamentele waarden van de persoon en die zich ook kunnen en moeten ontwikkelen (Pool, 1995; Stüssgen, 1997; Van Thiel et al., 1997; Widdershoven, 2000). Naast negatieve vrijheid of 'freedom from' moet de samenleving de persoon in staat stellen tot positieve vrijheid, tot 'freedom to': 
Een samenleving die persoonlijke autonomie wil bevorderen moet meer doen dan haar burgers met rust laten. $\mathbf{Z i j}$ dient haar instituties zodanig te laten functioneren dat personen gestimuleerd worden hun autonomie te ontwikkelen. Dit kan om een actief ingrijpen vragen om de autonomie van personen te stimuleren of te herstellen (Metaal, 1992).

Een samenlevingsverband als het verzorgingshuis geeft haar bewoners in dit autonomieconcept de kans om hun autonomie te ontwikkelen door keuzevrijheid voor te staan, door de bewoners uit te nodigen gereflecteerde keuzes te maken; zorgvuldig overwogen keuzes die van fundamenteel belang zijn voor de bewoners en die bijdragen tot het actief vormgeven aan het eigen leven (Pool, 1995; Widdershoven, 2000).

\section{Positieve vrijheid en afhankelijkheid}

In dit autonomieconcept wordt afhankelijkheid niet beschouwd als verlies van autonomie. Het vermogen tot autonomie wordt niet aangetast door beperkingen waarmee de bewoner van het verzorgingshuis wordt geconfronteerd. De meeste bewoners van het verzorgingshuis hebben voor hun opname een leven geleid waarin zij nog in staat waren voor zichzelf te zorgen. In het verzorgingshuis ligt dat anders. Vijfennegentig procent van de bewoners in het verzorgingshuis ondervindt chronische, lichte tot ernstige lichamelijke beperkingen (SCP, 2001). Deze beperkingen hebben, volgens Pool (1995), geleid tot een discontinuîteit in de levensloop en nopen tot een bijstelling van de levensloop. Hij interviewde 29 chronisch zieken thuis en 29 wijkverpleegkundigen/wijkziekenverzorgenden over de relatie autonomie, afhankelijkheid en langdurige zorgverlening. In zijn dissertatie over dit onderwerp stelt hij dat ziekte en lichamelijke verstoring invloed hebben op het autonoom functioneren. Daarbij kan het zijn dat door de ziekte en de lichamelijke verstoring de ervaring van autonomie zich juist kan ontwikkelen. Pool maakt een onderscheid tussen autonomie en competentie: Autonomie heeft vooral te maken met het hebben van redenen voor keuzes en competentie met het uitvoeren van taken. De competente persoon is in staat tot het uitvoeren van een taak (waaronder Pool ook het nemen van een beslissing schaart), terwijl de autonome persoon in staat is tot reflectie en zelfregulering:

lemand kan autonoom zijn maar toch incompetent om een bepaalde taak uit te voeren. Of iemand kan competent zijn om een bepaalde handeling uit te voeren maar incompetent tot het uitvoeren van een andere handeling. lemand kan competent zijn om te beslissen maar niet competent in het nemen van een bepaalde beslissing" (Pool, 1995).

De beperkingen en zorgafhankelijkheid van de bewoner hebben consequenties voor de beleving van het eigen zelf (Ter Meulen, 1994); ze doen inbreuk op de vertrouwdheid met de wereld en met het eigen leven. De bewoner probeert een nieuwe weg te vinden door na 
te gaan wat hem aanspreekt in de nieuwe situatie, op welke wijze hij verzoend raakt met de situatie en welke keuzes hem voldoening schenken.

\section{Positieve vrijheid, afhankelijkheid en respecteren en beschermen van de autonomie}

In een autonomieconcept dat positieve vrijheid tot uitgangspunt neemt, respecteert de zorgverlener de situatie waarin de bewoner verkeert. Hij beschermt diens autonomie door hem de ondersteuning te geven die hij vraagt bij het maken van keuzes en het nemen van besluiten en, zo nodig, door in te grijpen. Ingegrepen mag worden als de keuze van de persoon niet past in zijn levensplan, als de keuze geen fundamentele waarde belichaamt waarmee hij zich identificeert, als de keuze niet door kritische reflectie tot stand is gekomen (Widdershoven, 2000) en zijn gezondheid in de weg staat (Tronto, 1997). De zorgverlener wordt in dit concept van persoonlijke autonomie uitgenodigd om concrete antwoorden te geven op concrete, doordachte vragen van de zorgvrager. Een volgtijdelijkheid van vraag en antwoord markeert de relatie.

\section{Kritische kanttekeningen}

De zorgverlener verschaft zich in dit concept van autonomie de mogelijkheid de keuzes te beoordelen. De vraag is evenwel hoe de andacht en belangstelling voor de bewoner is geweest en of ze de zorgverlener voldoende bekend hebben gemaakt met de eigenheid van de bewoner, met de betekenis van het zorgafhankelijk zijn en met de dingen en mensen die voor de bewoner betekenisvol zijn. De vraag is hoe zeker de zorgverlener er van is dat keuzes, besluiten en afwegingen van de bewoner voor hem geen dieperliggende preferentie en geen fundamentele waarde vertegenwoordigen en niet gehonoreerd hoeven te worden. Wellicht stelt de zorgverlener op basis van rationele afwegingen grenzen aan de vraag naar zorg en aan de kwaliteit van keuzes van de bewoner. Niet denkbeeldig is dat de afweging gemaakt wordt op basis van dieperliggende preferenties van het verzorgingshuis, waaronder de identiteit van het verzorgingshuis, en staan deze preferenties het respecteren en beschermen van fundamentele waarden van de bewoner in de weg.

De preferentie waartegen de keus van de bewoner wordt afgezet, kan een algemene maatschappelijke norm zijn, of een institutionele opvatting over het doel van verzorgingshuiszorg. 'Bewerkstelligen dat bewoners het leven dat zij hebben geleid kunnen voorzetten', de missie die de NP/CF het verzorgingshuis meegeeft, kan worden uitgelegd als een gemeenschappelijke behoefte van bewoners en kan voorbijgaan aan de situatie waarin de individuele bewoner verkeert. Wanneer geen acht wordt geslagen op de eigenheid van de bewoner en op de betekenis van de nieuwe levensfase die de oudere door zijn afhankelijkheid doormaakt, en het verzorgingshuis gefixeerd is op de fysieke 
mogelijkheden van de oudere voordat de beperkingen optraden en die hem nog resten, wordt de zorgverlener uitgenodigd tot objectiverende, protocollaire verzorging, waar standaard verzorgingsplannen een instrument zijn, gericht op het herstellen en bewaken van continuilteit in de levensloop van de bewoner. Beschermen van de autonomie wordt dan uitgelegd als 'het stimuleren van zelfzorg'. De bewoner, die nog gedeeltelijk in staat is voor zichzelf te zorgen, wordt dan op die competentie of vaardigheid aangesproken en wordt geactiveerd om zelf te doen waartoe hij fysiek nog bekwaam is.

De rechtvaardiging voor deze eenzijdige en paternalistische invulling van care kan het verzorgingshuis vinden in een overtuiging dat het stimuleren van fysieke competenties het proces van lichamelijke achteruitgang vertraagt en geen verdere afbreuk doet aan het gevoel van eigenwaarde, maar dit juist herstelt of versterkt. De discontinuïteit in de levensloop, waarvan Pool gewag maakt, zou langs die weg beperkt kunnen blijven en de levensloop zou slechts gering hoeven worden bijgesteld. De verzorgingshuisbewoner blijft gemiddeld bijna vier jaar in het verzorgingshuis en in die periode kunnen 'enige bijstellingen' plaatsvinden. Problematisch is het voor de bewoners van verzorgingshuizen die ernstige beperkingen hebben en die zichzelf niet meer lichamelijk kunnen verzorgen of andere lichamelijke inspanningen kunnen verrichten, kortom voor die bewoners voor wie de levensloop drastisch moet worden bijgesteld. Voor hen zou, wanneer de definitie van care van de $\mathrm{NP} / \mathrm{CF}$ conform het beschrevene wordt uitgelegd, het verzorgingshuis geen taak hebben. Het verplesghuis dat in het kader van het vraagstuk van autonomie expliciet aangeeft gericht te zijn op het terugdringen, stabiliseren of opheffen van de zorgbehoefte (Ter Meulen, 1994) heeft evenmin plaats voor deze ouderen.

'Beschermen van autonomie' de betekenis geven van het stimuleren van de zelfzorg naar professionele standaarden, die over het hoofd van de individuele bewoner zijn opgesteld, sluit persoonlijke autonomie uit en sluit aan bij een oplossingsgerichte benadering in de gezondheidszorg. Het draagı bij aan een verdere verzelfstandiging van de zorg (Gelauff en Manschot, 1997; Manschot, 1997; Van Houten en Van Lieshout, 1994) en miskent de waarde van afhankelijkheid en zorg in het leven. Het draagt er ook toe bij dat de betrokkenheid van de zorgverlener op de zorgvrager institutioneel wordt in plaats van intentioneel, dat de bewoner niet gezien wordt als 'concrete other', een concreet individu met een eigen geschiedenis, identiteit, emoties, specifieke behoeften, talenten en vermogens, maar als 'generalized other' als iemand met dezelfde identiteit en behoeften als alle andere bewoners (Verkerk, 1994). 


\subsubsection{Autonomie als positieve vrijheid door voorbewuste betekenisgeving}

In de fenomenologische benadering van 'autonomie als positieve vrijheid door voorbewuste betekenisgeving' is het uitgangspunt dat mensen betekenis geven aan een situatie. Niet op basis van kritische reflectie die tot het expliciteren van fundamentele waarden en betekenisgeving leidt, maar vanuit het zelfconcept dat de ontwikkelingsgeschiedenis van de persoon representeert. Keuzen hoeven niet overdacht te zijn, maar moeten ingepast kunnen worden in het leven van de persoon en het de persoon mogelijk maken zijn eigen identiteit vorm te geven (Widdershoven, 2000). Autonoom handelen betekent in de praktijk dat het handelen gemotiveerd is, dat het voortvloeit uit en consistent is met de eigen identiteit (Ter Meulen, 1994).

\section{Positieve vrijheid door voorbewuste betekenisgeving en afhankelijkheid}

Ouderen, die voor het verzorgingshuis worden geïndiceerd vanwege lichamelijke beperkingen, doen een beroep op inmenging en ondersteuning. Ook ouderen die geen lichamelijke beperkingen ondervinden en naar het verzorgingshuis gaan, kiezen voor een bestaan waarin inmenging van anderen wordt geprefereerd. Uit eerder aangehaald onderzoek blijkt dat veertig procent van de ouderen die zich aanmelden voor het verzorgingshuis zich om andere redenen dan zorgafhankelijkheid hebben aangemeld. Hoofdredenen van aanmelding zijn verminderde sociale contacten en gevoelens van onveiligheid c.q behoefte an affectie en comfort. De zekerheid dat er hulp aanwezig is, brengt mensen tot verhuizing naar het verzorgingshuis. De wijze waarop en de intensiteit waarmee de bewoner zich in het verzorgingshuis manifesteert, zijn behoefte an informatie, zijn drang om zich te laten gelden door standpunten in te nemen en keuzes te maken, zijn behoefte aan contact met de zorgverlener en zijn vraag om een deskundige reactie en om interventie door de zorgverlener wisselt en verandert bij de bewoner in de loop van het verblijf in het verzorgingshuis.

\section{Positieve vrijheid door voorbewuste betekenisgeving, afhankelijkheid en het respecteren en beschermen van autonomie}

Het respecteren en beschermen van de autonomie van de bewoner in het verzorgingshuis houdt in dat de bewoner wiens levensloop een andere wending heeft gekregen, geholpen wordt zin te geven aan het leven door identificatiemogelijkheden te bieden die betekenisvol zijn, door zijn keuzes in te passen in de eigenheid van zijn leven en door aandacht te schenken aan die zaken die voor hem werkelijk belangrijk zijn. In dit concept sluit afhankelijkheid van bewoners autonomie niet uit, maar is het een voorwaarde. Het verzorgingshuis dient zich aan als gemeenschap waarin mensen elkaar steun verlenen, er 
een wederzijdse betrokkenheid is, ervaringen worden uitgewisseld en rekening gehouden wordt met de behoefte aan individualiteit of autonomie (Bussemaker, 2002). De autonomie kan niet gerespecteerd en beschermd worden zonder betrokkenheid tussen bewoner en zorgvrager en zonder aandacht voor de ervaringen van de bewoner. Autonomie krijgt gestalte in de zorgrelatie. De zorgverlener stelt zich de vraag of datgene wat de bewoner doet betekenisvol is en past in zijn levensplan. De relatie tussen de bewoner en de zorgverlener maakt mogelijk dat de zorgverlener oog en oor krijgt voor de waarden waar de bewoner afhankelijk van is en dat hij de ruimte krijgt keuzes van de bewoner te beïnvloeden, niet vanuit preferenties van het verzorgingshuis, maar vanuit de betekenis ervan voor de bewoner (Widdershoven 1995, 2000). Het respecteren en beschermen van autonomie richt zich in de dagelijkse zorg niet zozeer op ernstige levensvraagstukken, maar op 'everyday ethics', op keuzemogelijkheden die in de zorg in het verzorgingshuis voortdurend aan de orde zijn, variërend van eigen keuzes wat betreft de eet- en slaaptijden tot de inrichting van de kamer en het dragen van bepaalde kleding. Er moet een sociale sfeer zijn waarin de bewoner zich kan herkennen en waarin hij zijn individualiteit kan ontplooien (Ter Meulen, 1994):

Juist in het licht van zijn chronische ziekte heeft de hulpbehoevende oudere behoefte aan steun bij het terugvinden en aanpassen van zijn identiteit. Juist dan moet zij of hij zich kunnen herkennen in de keuzes die zij of hij maakt en moeten er mogelijkheden worden geboden om deze keuzes inderdaad te maken. Juist dan is het belangrijk om in relatie met hulpverleners en anderen de eigen identiteit terug te winnen of te vernieuwen.

De zorgverlener kan die sociale sfeer creëren. Beschermen van de autonomie kan in dit concept betekenen dat de zorgverlener voor de bewoner keuzes maakt en beslissingen neemt die naar zijn mening de individualiteit van de bewoner vergroten, terwijl de bewoner op dat moment drang en dwang ervaart en de keuzes en beslissingen van de zorgverlener anders waardeert. De vrouwelijke bewoner met lichamelijke beperkingen die zo min mogelijk hulp van de zorgverlener aanvaardt, die een groot deel van de ochtend tijd neemt om zich te verzorgen, op te maken en an te kleden, maar die zich enorm verheugt op een sociale activiteit in het huis die vroeg in de ochtend gepland is, en waarvan de zorgverlener weet dat ze daar nog dagenlang van zal genieten, komt in de problemen. Als zij zich niet laat verzorgen zal ze een deel van de sociale activiteit missen. De zorgverlener oefent drang uit om de bewoner te helpen bij het wassen en aankleden en tegen heug en meug laat de bewoner dat gebeuren. Op het eind van de ochtend geeft de bewoner aan het fijn te vinden dat ze bij de sociale activiteit is geweest.

Om een juiste inschatting te kunnen maken van wat nevengeschikte en dieperliggende preferenties van de bewoner zijn, aan welke keuzemogelijkheden de bewoner waarde 
toekent, welke aspecten in de zorgrelatie hem aanspreken en wanneer de zorgverlener dwang en drang kan toepassen, diept Widdershoven (2000) het fenomenologisch concept positieve vrijheid uit. In de narratieve (door Van Thiel et al. (1997) het biografisch perspectief genoemd), hermeneutische en discoursethische benadering komen volgens hem de intersubjectiviteit van zorgvrager en zorgverlener, de symmetrie van de zorgrelatie en de betekenis van samenspraak naar voren (Widdershoven, 2000).

Door de narratieve benadering kan de zorgverlener het handelen van de bewoner duiden en een belangrijke plek geven. Respect voor autonomie veronderstelt een dusdanige betrokkenheid van de zorgverlener op de bewoner dat hij kan luisteren naar de ervaringen en reacties van de bewoner, handelingen en activiteiten van de bewoner in het verhaal van die bewoner kan plaatsen, verschillende verhalen van de bewoner naast elkaar laat bestaan, ze allen respecteert als relevante levensuitingen en waardeert dat ze worden verteld en uitgesproken. In de hermeneutische en discoursethische benadering komt het deliberatieve aspect naar voren.Van de zorgverlener wordt gevraagd in dialoog te gaan met de bewoner over zingevingsvraagstukken, over ethische kwesties te beraadslagen en gezamenlijk na te gaan of de omstandigheden waarin de bewoner zich bevindt en perspectieven die hij ziet om een verdere oriëntatie op, of heroriëntatie van waarden vraagt. Het gaat om het gezamenlijk, in onderling overleg, vinden van oplossingen voor concrete problemen, gebruik makend van ervaringen uit het verleden.

Door te investeren in de zorgrelatie ontstaat onderlinge betrokkenheid die de bewoner en zorgverlener uitnodigen onderwerpen aan de orde te stellen die de bewoner bewegen. In een visie waarin niet het individu maar de interactie tussen individuen als gewone morele subjecten op de voorgrond staat, wordt zorg 'iets wat iemand nodig heeft' en staat de afhankelijkheid van de bewoner niet langer op de voorgrond. In dit concept van autonomie verminderen lichamelijke ongemakken de waarde van het subject niet. Sevenhuysen (1996) stelt dat het verlenen van zorg aan een zorgbehoevende een erkenning is van de autonomie (het subject-zijn) van de ander en de hulpverlener bevestigt in de eigen autonomie. Autonomie is hier verbonden met het nemen van verantwoordelijkheid en het afleggen van verantwoording door zowel de zorgvrager als de zorgverlener.

\section{Een zorgende houding}

Wat betekenen het nemen van verantwoordelijkheid en het afleggen van verantwoording voor de zorgverlener? Welke houding past hem in een relatie waarin afhankelijkheid gezien wordt als een bevestiging van autonomie en niet als verlies of beperking van autonomie, waarin de bewoner een appèl doet op de zorgverlener om hem voort te helpen op een wijze waarin hij zich herkent, die hem eigen is?

Respect hebben voor de autonomie van iemand en tegelijk een zorgende houding hebben, ziet Pool als een probleem. Met een 'zorgende houding' doelt Pool op een instrumentele 
opvatting over zorgverlening, waarin het functioneren bij de ADL (activiteiten van het dagelijks leven) en bij de HDL (huishoudelijke activiteiten van het dagelijks leven) alle aandacht krijgen en waarin de zorgvrager wordt gereduceerd tot een beperking of handicap (Pool, 1995).

De vraag is of een zorgende houding een dialoog en deliberatie tussen de bewoner en de zorgverlener in de weg staat. Een zorgende houding is een antwoord van een discipline die op die kwaliteit wordt aangesproken. Een antwoord op een concrete vraag die aan de indicatie voor het verzorgingshuis voorafging. De ruimte die de bewoner geeft en de zorgverlener neemt tot lichamelijke intersubjectiviteit schept juist een basis voor dialoog en deliberatie over het leven van alledag en de zin die er aan wordt toegekend. Gepaste aandacht daarbij voor de hulpmiddelen of instrumenten die de zorgverlener nodig heeft om ondersteuning te bieden bij de ADL en HDL en voor de competentie waarmee dit moet gebeuren, kan een ongedwongen en vertrouwelijke sfeer creëren die uitnodigt tot gesprek, en die drang of overtuiging van de bewoner mogelijk maken wanneer de situatie daar om vraagt.

"Van belang is dat de zorgende houding een antwoord is op de vraag van de bewoner", stelt Widdershoven (2000). Hij haalt Moody aan die een zorgrelatie voorstaat die is gebaseerd op 'negotiated consent'; een relatie waarin de zorgverlener de betrokkene probeert te motiveren tot deelname aan een proces van gezamenlijke exploratie van mogelijke handelswijzen. Door zo nodig de belangen van de bewoner te verdedigen, door stimulering, overreding, het overnemen van beslissingen van de bewoner en door aandacht aan de relaties van de ouderen helpt de zorgverlener de bewoner bij het omgaan met levensvragen (Widdershoven, 2000).

Voor Tronto (1993) gaat het bij zorg om een wederzijdse betrokkenheid, een erkenning dat het zonder die ander niet kan. Haar zorgconcept neemt de behoefte van de zorgvrager als uitgangspunt van zorg, maakt concreet aan welke voorwaarden de zorgrelatie moet voldoen en welke 'deugden' de zorgverlener moet bezitten om op de behoeften van de zorgvrager in te gaan. Samen met Berenice Fisher onderscheidt zij vier fasen in het proces van zorg: 'De eerste fase is het zich zorgen maken om iemand of iets (caring about); de tweede fase is het zorg op zich nemen (caring for), de zorgverlener neemt de zorg op zich; de derde fase betreft de daadwerkelijke uitvoering van de zorg: het verlenen van zorg (care-giving); de vierde fase is het ontvangen van zorg (care-receiving)'. Aan het zich zorgen maken verbindt Tronto de deugd 'aandacht voor de behoefte van de ander'(attentiveness). Wanneer een behoefte eenmaal is onderkend, ontstaat het probleem wie aan die behoefte moet voldoen en hoe daaraan voldaan zal worden. De tweede deugd is 'de bereidheid verantwoordelijkheid 
te nemen voor het verbeteren van de toestand van degene die zorg behoeft' (responsibility). De derde deugd is 'competente, deskundige zorgverlening' (competence) en de vierde deugd is 'responsiviteit' (responsiveness): degene die zorg ontvangt, moet ontvankelijk zijn voor die zorg, waardoor de zorgverlener weet of hij op de behoefte van de zorgvrager is ingegaan (Sevenhuysen, 1996; Tronto, 1993, 1998; Van Houten, 1999; Widdershoven, 2000).

In de vierde fase van zorg die Tronto onderscheidt, komt de legitimatie van de houding en de handelingen van de zorgverlener aan de orde. Of de vraag om aandacht voor de behoefte van de bewoner daadwerkelijk gesteld is, de zorgverlener terecht een verantwoordelijkheid gevoeld heeft, de zorgbehoefte juist heeft geïnterpreteerd en het goede antwoord heeft gegeven, kan worden opgemaakt uit de ontvankelijkheid van de bewoner.

Het zorgconcept van Tronto wordt bekritiseerd, omdat er in doorklinkt dat het verminderen van afhankelijkheid door haar als 'goed antwoord' wordt gezien. De aandachtige betrokkenheid (fase 1) van de zorgverlener is gericht op noden en behoeften van de zorgvrager, die volgens Sevenhuysen (1996) niet uit de lucht komen vallen. Het verhaal van de zorgvrager met zijn eigen betekenisgeving komt bij Tronto pas in de vierde fase van het zorgproces in beeld, hetgeen de zorgrelatie een 'trial and error' karakter kan geven.

Ook Manschot (1994) bekritiseert het zorgconcept van Tronto. Terwijl de zorgverlener naar zijn mening tot doel heeft de zorgvrager te helpen zijn afhankelijkheid en kwetsbaarheid te integreren en als uitdrukking van autonomie te zien, is het doel van zorg voor Tronto het afhankelijk zijn te beëindigen. Daarmee brengt Tronto de zorgvrager in de positie van zorgbehoevende, van iemand die iets mist. Dit roept op tot een asymmetrische zorgrelatie, waar het respecteren en beschermen van autonomie niet gekenmerkt worden door dialoog en deliberatie en een minimale distantie tussen zorgvrager en zorgverlener, maar waar de wederzijdse betrokkenheid door zorgdoelen wordt bepaald. 'Het verbeteren van de toestand van degene die zorg behoeft', wat Tronto noemt als tweede deugd, kan niet zonder het vermogen daartoe en de intentie daarvoor van de bewoner van het verzorgingshuis worden nagestreefd. Het risico bestaat dan dat de concrete other uit het oog verloren raakt en de generalized other in beeld komt (Verkerk, 1994).

\subsection{Zorg voor zelfbeschikking: een gezondheidsrechtelijke benadering}

Uit de wijze waarop in de gezondheidsethische benadering van autonomie wordt ingegaan op het recht op zelfbeschikking zou kunnen worden geconcludeerd dat het gezondheidsrecht vooral focust op autonomie als negatieve vrijheid. In een dergelijk autonomieconcept wordt 
van de zorgverlener een handen-af-benadering gevraagd; de bewoner moet met rust worden gelaten; afhankelijkheid betekent verlies van zelfbeschikking en de hulp- of zorgverlening dient er op gericht te zijn de afhankelijkheid op te heffen. In een gezondheidsrechtelijke benadering, die in deze paragraaf wordt behandeld, wordt deze conclusie niet gedeeld. Het opheffen van afhankelijkheid wordt niet nagestreefd; de zorgvrager hoeft niet met rust gelaten te worden, hij en de zorgverlener gaan de dialoog aan; de zorgrelatie wordt gekenmerkt door wederkerigheid en kan tot gevolg hebben dat de zorgverlener de ruimte krijgt de zorgvrager te stimuleren en drang uit te oefenen.

Voor wat betreft eerstgenoemd punt stelt Van Wijmen (2003) het volgende:

Door de rechten van de patiënt uit te schrijven en vast te leggen wordt de afhankelijkheid die de patiënt voelt t.o.v. de hulpverlener als het ware gecompenseerd; hij heeft rechten om op te staan, rechten die afdwingbaar zijn.

Als de afdwingbaarheid van rechten het fundament zou zijn van de zorgrelatie bevestigt het gezondheidsrecht de kwalificatie die de gezondheidsethiek haar heeft opgelegd. Afhankelijkheid blijft dan 'een situatie die er niet zou mogen zijn' of 'een tekortkoming die om compensatie vraagt'. Het risico bestaat dat de zorgvrager zich opstelt als een partij die belangen terzake zijn gezondheid te verdedigen heeft en dat de zorgverlener zich verantwoord van zijn taak wil kwijten vanwege het feit dat hij zich rekenschap geeft van de rechten van de zorgvrager. Om een dergelijke afstandelijke, door rechten gestuurde zorgrelatie te voorkomen, stelt het gezondheidsrecht dat de zorgvrager niet enkel beschouwd moet worden als rechtssubject (Van Wijmen, 1992). Het recht op zelfbeschikking vraagt er om dat de afhankelijke zorgvrager en de zorgverlener in een situatie worden geplaatst, waarin de dialoog het uitgangspunt is. Het voorkomt dat de zorgverlener een vrijblijvendheid zou kunnen ervaren om de zorgvrager wel of niet te betrekken in overwegingen over de zorgverlening; het doet een appèl op de zorgvrager zijn verantwoordelijkheid te nemen en de dialoog aan te gaan en het attendeert de zorgverlener op goed zorgverlenerschap.

De dialoog mag voor de zorgvrager vervolgens niet tot doel hebben rechten veilig te stellen en voor de zorgverlener mag hij niet de legitimatie zijn om beslissingen van de zorgvrager over te nemen. Van Wijmen (2003) stelt over dit laatste punt het voIgende:

Wanneer de zorgverlener de belangen van de zorgvrager gaat behartigen, hem gaat stimuleren of overreden, of beslissingen van hem gaat overnemen, stuit dit vanuit gezondheidsrechtelijk oogpunt op principiële vragen voor zover het om beslissingen over en zonder de patiënt gaat.

Om inmenging in het leven van de zorgvrager te rechtvaardigen, is de wederkerigheid van de zorgrelatie een conditio sine qua non (Raad voor de Volksgezondheid en Zorg, 2003). 
Bedoeld wordt dat de zorgvrager en zorgverlener de verantwoordelijkheid en morele plicht op zich nemen om in de zorgrelatie de ander tot zijn recht te laten komen en een volwaardige partner te laten zijn. De zorgverlener moet verantwoorde zorg leveren: hij moet ingaan op de (reële) behoefte van de zorgvrager of keuzemogelijkheden bieden waardoor behoeften kunnen worden opgeroepen en keuzes kunnen worden gemaakt; hij moet de zorgvrager benaderen met de vraag wat diens behoefte is en om dit te weten te komen treedt hij zo nodig in contact met de relaties van de zorgvrager; de handelingen en beslissingen die de zorgverlener voornemens is te verrichten, respectievelijk te nemen, moet hij vooraf communiceren met de zorgvrager; als hij de verantwoordelijkheid op zich neemt voor de handelingen of beslissingen ten behoeve van de zorgvrager dient de zorgverlener dat bekwaam en deskundig te doen en als hij de handelingen of beslissingen heeft uitgevoerd, dient hij bij de zorgvrager na te gaan of hij antwoord heeft gegeven op de behoefte van de zorgvrager. De zorgvrager, op zijn beurt, moet geen passieve rol vervullen. Hij heeft de morele plicht een goede zorgvrager en zo nodig een goede klager te zijn (Van Wijmen, 1996; 2003). Dit houdt onder meer in dat hij de zorgverlener informeert, dat hij zijn behoeften kenbaar maakt, dat hij keuzes maakt, meebeslist en meewerkt en dat hij zich geroepen voelt aan te geven of de verleende zorg aan zijn behoefte heeft voldaan. De wederkerigheid van de zorgrelatie plaatst het recht op zelfbeschikking op de achtergrond en de zorg voor zelfbeschikking op de voorgrond.

In het verzorgingshuis, waar zorgvragende ouderen hun woon- en leefsituatie hebben en de zorgrelatie een duurzaam karakter heeft, mag van de zorgverlener gevraagd worden dat hij een zorgrelatie opbouwt. Hij probeert de zorgvrager zo nabij te zijn dat hij een goede inschatting van zijn behoefte kan maken en dat hij weet welke bejegening of zorg door de zorgvrager gewenst wordt. Als deze nabijheid verworven is door goed zorgverlenerschap, door geregelde informatie-uitwisseling of gespreksvoering tussen de zorgvrager en de zorgverlener, waarbij informed consent een evidentie is (Van Wijmen, 1992 en 2003; RVZ, 2003; Stüssgen, 1997; Pool, 1995), kortom als geïnvesteerd is in wederkerigheid van de zorgrelatie, krijgt het vraagstuk van inmenging een ander karakter.

Beperkingen en sociale gebeurtenissen waarmee de oudere in het verzorgingshuis geconfronteerd wordt, kunnen zijn dagelijkse leven zodanig verstoren dat hij zelf niet meer in staat is bepaalde handelingen te verrichten, keuzes te maken of beslissingen te nemen. Het kan ook zijn, zoals Pool (1995) het uitdrukt, dat de bewoner competent is bepaalde beslissingen te nemen en niet competent is andere beslissingen te nemen. Mogelijk ook maakt de bewoner bewust geen keuze of laat hij beslissingen na, omdat hij denkt de zorgverleners tot last te zijn of omdat hij het even gewoon niet weet. Indien het respecteren of beschermen van het recht op zelfbeschikking tot gevolg zou moeten hebben dat de 
zorgzame zorgverlener geen keuze of beslissing voor de zorgvrager mag maken, wordt de zorgvrager de mogelijkheid ontnomen om met behulp van ondersteuning zijn dagelijks leven te blijven leiden; het biedt de zorgverlener niet de mogelijkheid de informatie te benutten die de zorgvrager hem heeft toevertrouwd, juist met het oog op het kunnen continueren van het dagelijks leven.

De overtuiging die de zorgverlener heeft dat de keuze die hij voor de bewoner wil maken aan een belangrijke behoefte van de zorgvrager voldoet en past in diens levensplan, terwijl de zorgvrager dit naar zijn mening niet beaamt of overziet, betekent dat hij zijn keuze of beslissing niet zonder de bewoner neemt. Hij kan zijn voornemen ook communiceren met de betekenisvolle omgeving (Van Wijmen, 2003) van de zorgvrager. Hij kan haar vragen zijn keus te ondersteunen of door de omgeving te laten overnemen, maar de vraag is of de zorgvrager nog relaties onderhoudt, hoe betekenisvol zijn omgeving is en of hij er van gediend is buitenspel te staan (Van Delden, 1999). De zorgverlener kan de omgeving van informatie voorzien, voor zover het alledaagse leven van de zorgvrager en de ervaring van een duurzame zorgrelatie zijn over te dragen. Het contact van de zorgvrager met zijn omgeving en haar vermogen om in te voelen wat het beste is voor de zorgvrager kunnen van een mindere kwaliteit zijn dan die van de zorgverlener. Wellicht beslist de omgeving over de zorgvrager en maakt zij keuzes die geen antwoord zijn op de behoefte van de bewoner en waardoor de zorgverlener vindt dat het goed zorgverlenerschap in het gedrang is gekomen. De zorgverlener kan de mening zijn toegedaan dat hij zelf de keus voor de bewoner moet maken als hij vanuit zijn relatie met de zorgvrager de overtuiging heeft dat de zorgvrager dezelfde beslissing genomen zou hebben als hij daartoe in staat was. Alvorens een keus te maken kan hij samen met andere zorgverleners, die eveneens een zorgrelatie met de zorgvrager onderhouden, tot afweging van keuzes komen.

In paragraaf 5.2.1.3 is het voorbeeld gegeven van de keus die de zorgverlener voor de vrouwelijke bewoner maakt om haar te helpen met de lichamelijke verzorging, zodat ze bij een sociale activiteit kan zijn. Er was overreding en aandrang voor nodig; de bewoner zou die keus niet zelf hebben gemaakt, maar ze was achteraf blij met de houding van de zorgverlener. De zorgrelatie tussen bewoners en verzorgenden in het verzorgingshuis draait om de everyday ethics. Het recht op zelfbeschikking stelt de zorgvrager in staat zowel impliciet als expliciet ruimte te geven aan de hem nabije verzorgenden om keuzes voor hem te maken, of beslissingen voor hem te nemen die passen in zijn leven. Het past de verzorgende zorgvuldig om te gaan met die ruimte, keer op keer de responsiviteit in acht te nemen en de verantwoordelijkheid van de bewoner niet uit het oog te verliezen. 


\subsection{Beschouwing}

Geconcludeerd kan worden dat in de gezondheidsethiek concepten van autonomie bestaan waarin aan vrijheid, afhankelijkheid en het respecteren en beschermen van autonomie verschillende betekenissen worden toegekend. In het autonomieconcept van negatieve vrijheid staat zelfbeschikking centraal; afhankelijkheid wordt gezien als afwezigheid van autonomie, wat hersteld moet worden. De zorgverlener kan de autonomie van de bewoner respecteren door hem te informeren over de wederzijdse rechten en plichten en hem keuzevrijheid te verschaffen. Voor het beschermen van autonomie, in de betekenis van het voorthelpen van de bewoner, is in dit concept nauwelijks plaats, omdat non-interventie het uitgangspunt is. De consequentie van keuzevrijheid die aan het recht op zelfbeschikking kleeft, heeft in het verzorgingshuis grenzen. De commissie Keuzen in de zorg (1991) kent het verzorgingshuis de ruimte toe om noodzakelijke zorg te verlenen en associeert dit voornamelijk met 'hulp bij de algemeen dagelijkse levensverrichtingen' (ADL), sinds de gemoderniseerde AWBZ de functie 'persoonlijke verzorging' genoemd. Het budget voor verzorgingshuizen is daar op afgestemd. Zorg voor zelfstandigheid houdt in de gezondheidsethische benaderingen meer in dan uitgaan van het recht op zelfbeschikking. Een autonomieconcept van positieve vrijheid biedt die mogelijkheid.

Positieve vrijheid wordt onderscheiden in een tweetal concepten:

1. een concept dat naast zelfbeschikking de keuzevrijheid van de bewoner centraal stelt en waarin het maken van keuzes wordt gerespecteerd, beredeneerd is en als betekenisvol wordt gezien als de keuzes fundamentele waarden vertegenwoordigen; als het gaat om gereflecteerde keuzes, om keuzes die door zorgvuldige afweging tot stand komen. In dit autonomieconcept is plaats voor afhankelijkheid. Afhankelijkheid tast het vermogen tot autonomie niet aan, maar heeft invloed op de competenties van de zorgvrager. Inmenging of beschermen van autonomie vindt zijn legitimatie in de opvatting dat voor de zorgvrager een bewuste keuze gemaakt wordt, die een identificatie met fundamentele waarden van de zorgvrager weerspiegelt. In deze gezondheidsethische benadering, waar bewuste keuzes op basis van reflecties en dieperliggende preferenties het fundament van autonomie vormen, zijn autonomie en afhankelijkheid rationeel verbonden en is betrokkenheid van de zorgverlener een voorwaarde om op een door de bewoner gewenste wijze te kunnen interveniëren.

2. een concept van positieve vrijheid dat naast zelfbeschikking en keuzevrijheid uitgaat van voorbewuste betekenisgeving. Autonomie krijgt hier gestalte en betekenis in prereflexieve processen van identificatie, in de dagelijkse wereld in 
sociale processen en door materiële mogelijkheden. Deze benadering gaat uit van keuzes die gemotiveerd zijn. Afhankelijkheid en autonomie zijn onlosmakelijk, intersubjectief en materieel verbonden. Er is sprake van een sterke mate van het op elkaar betrokken zijn van zorgvrager en zorgverlener.

Het autonomieconcept van positieve vrijheid omvat zowel de mogelijkheid tot nietinmenging als tot inmenging. Het respecteren en beschermen van autonomie zou in het verzorgingshuis in dit concept gestalte kunnen krijgen. Maar de mogelijkheid tot inmenging stelt hoge eisen aan de zorgverlener. Hij dient te investeren in de zorgrelatie om de juiste beslissingen te kunnen nemen als hij tot inmenging overgaat. Hij moet zich er van vergewissen dat dieperliggende of tweede orde preferenties van de bewoner, die hij in het eerstgenoemd concept van positieve vrijheid tot maatstaf van zijn keuze maakt, ook daadwerkelijk de preferenties van de bewoner zijn. Ze moeten betekenisvol zijn en op de concrete other zijn gericht. De zorgverlener moet er voor waken dat instellingspreferenties niet tot norm van het handelen worden gemaakt.

In het tweede concept van positieve vrijheid krijgt de investering van de zorgverlener in de zorgrelatie gestalte door onderling overleg, dialoog en deliberatie tussen hem en de bewoner. De zorgverlener is geïnteresseerd in het levensverhaal van de bewoner en respecteert diens autonomie door een sfeer te creëren waarin de bewoner zich herkent en zichzelf kan zijn. De zorgverlener is attentief en zijn activiteiten passen in het levensplan van de bewoner. Doordat de zorgverlener de bewoner nabij is en op hem betrokken is, kan het beschermen van de autonomie het karakter aannemen van belangenbehartiging, van stimulering, overreding en zelfs van het overnemen van beslissingen, maar het motief van de inmenging is het recht doen aan de eigenheid en specifieke of dagelijkse behoeften van de bewoner, als concrete other.

In de gezondheidsrechtelijke visie op zelfbeschikking die in dit hoofdstuk is uitgewerkt, wordt de grens die het autonomieconcept van negatieve vrijheid trekt terzake de mogelijkheid tot interventie, gepasseerd. De zelfredzaamheid van bewoners van verzorgingshuizen is vaak van dien aard dat een beroep moet worden gedaan op hulp door de zorgverleners, maar deze vorm van afhankelijkheid betekent niet per definitie dat de bewoner het recht op zelfbeschikking verliest. Dit is wel het geval als de verzorgende zich geen goede zorgverlener toont en de zorgvrager geen goede zorgvrager is, oftewel als de rechten en plichten die men heeft niet in acht worden genomen. Op dat moment kan de fysieke afhankelijkheid van de bewoner tot gevolg hebben dat de zorgverlener eigenstandig beslissingen neemt, bijvoorbeeld over de wijze waarop hij de bewoner ondersteunt en het moment waarop dat gebeurt. Evenals in een gezondheidsethisch concept van autonomie als 
positieve vrijheid wordt in een gezondheidsrechtelijke visie op zelfbeschikking het investeren in de zorgrelatie van belang gevonden. Onderling overleg, dialoog en deliberatie vormen de basis van waaruit de zorgverlening tot stand komt en de zorgverlener handelingen van de zorgvrager ondersteunt of beslissingen mee helpt nemen. De wederkerigheid van de zorgrelatie verstevigt die basis. Wanneer deze basis wegvalt, wordt in een gezondheidsrechtelijke benadering inmenging in het leven van de zorgvrager geproblematiseerd en geconditioneerd. In het tweede gezondheidsethische concept van positieve vrijheid blijft inmenging gelegitimeerd vanuit de basis die eerder is gelegd en waarop de zorgrelatie gefundeerd is. Maar ook dan zal het vraagstuk van legitimatie continu de aandacht vragen. 


\section{Hoofdstuk 6 Zorg voor zelfstandigheid: een praktische invulling}

\subsection{Inleiding}

In het vorige hoofdstuk is de vraag behandeld wat onder zorg voor zelfstandigheid kan worden verstaan en welke betekenis er in deze studie aan gegeven wordt. Aangesloten wordt bij een gezondheidsethische opvatting over zorg voor zelfstandigheid waarin wordt gesteld dat de zorgverlener geïnteresseerd is in het levensverhaal van de bewoner en activiteiten verricht die passen in het levensplan en het dagelijkse leven van de bewoner. De zorgrelatie die wordt onderhouden, kenmerkt zich door dialoog en deliberatie maar biedt de zorgverlener zo nodig ook de ruimte om de bewoner te overtuigen of beslissingen van hem over te nemen. Tevens wordt aangesloten bij een gezondheidsrechtelijke opvatting over zorg voor zelfstandigheid waarin de verantwoordelijkheid en rechten en plichten van de bewoner en de zorgverlener in de zorgrelatie benadrukt worden en waarin wordt gesteld dat beslissingen die door de zorgverlener ten behoeve van de bewoner worden genomen niet over diens hoofd heen genomen mogen worden.

In dit hoofdstuk wordt de vraag beantwoord op welke wijze praktisch invulling kan worden gegeven, of gegeven wordt, aan zorg voor zelfstandigheid in de hierboven genoemde betekenissen. In paragraaf 6.2 worden een tweetal zorgbenaderingen beschreven waarin de zorgrelatie en het levensverhaal of levensplan van de bewoner een centrale plaats innemen, te weten: belevingsgerichte zorg en levensfasegeoriënteerde zorg. Met belevingsgerichte zorg is de afgelopen tien jaren ervaring opgedaan in de zorg voor ouderen; levensfasegeoriënteerde zorg als zorgbenadering is van meer recente datum en biedt een theoretisch en conceptueel kader dat nog in de dagelijkse praktijk van de ouderenzorg beproefd moet worden.

In vorige hoofdstukken is beschreven dat in onze samenleving aan ouderen geen plichten worden opgelegd en dat ze geen rol van betekenis meer spelen, zeker niet als ze zorgbehoevend zijn en in een verzorgingshuis worden opgenomen. Het verzorgingshuis heeft niet het imago van woonsituatie waar bewoners ruimte voor eigen leven hebben; het heeft evenmin een traditie opgebouwd van medezeggenschap van bewoners of van het benadrukken van hun eigen verantwoordelijkheid, ondanks wetgeving die daar op appelleert. Tegen een dergelijke achtergrond kan betwijfeld worden of bewoners zich bewust zijn van hun rechten; of zij voldoende zelfbewust zijn om verantwoordelijkheid te nemen en om de dialoog aan te gaan. Het risico bestaat dat bewoners zich afhankelijk opstellen, zich schikken naar de regels en gewoonten van het verzorgingshuis en zich niet 
geroepen voelen hun behoeften en wensen te communiceren. De zorgverleners op hun beurt kunnen van mening zijn dat hun zorgaanbod tegemoet komt aan de behoeften van bewoners zonder dat zij hierover met bewoners in gesprek gaan. Om in de individuele zorgrelaties een sfeer van samenspraak, nabijheid en wederkerigheid te kunnen creëren, van waaruit activiteiten worden verricht die passen in het levensplan van de bewoner en van waaruit de bewoner inmenging door de zorgverlener toestaat, is in het verzorgingshuis een cultuur van medezeggenschap en gezamenlijke verantwoordelijkheid nodig. Om die reden wordt in paragraaf 6.3. ingegaan op responsieve evaluatie. Responsieve evaluatie is een visie op evaluatie die volgens Abma en Widdershoven (2001) goed aansluit bij belevingsgerichte en narratieve (biografische) stromingen in de zorgsector. Responsieve evaluatie kan een democratische en emancipatorische invloed hebben op het leven en werken in het verzorgingshuis. Degenen die in de dagelijkse leven een zorgrelatie onderhouden, krijgen de mogelijkheid en verantwoordelijkheid de kwaliteit van die relatie ter discussie te stellen en op een hoger plan te brengen.

In paragraaf 6.4 wordt een beschouwing op dit hoofdstuk gegeven.

\subsection{Belevingsgerichte zorg en levensfasegeoriënteerde zorg: persoonsgerichte zorgbenaderingen}

'Zicht op en gevoel voor preferenties van de bewoner is een onmisbaar onderdeel van professionele kwaliteit' stelt Arcares (2002) in: "Balans: aandacht voor levensverhalen en levensbalans in de ouderenzorg". Zij pleit er voor om naast de fysieke verpleging en verzorging meer aandacht te laten ontstaan voor belevingsgerichte zorg, voor een gevoel van welbevinden en kwaliteit van leven, en om eigenheid en autonomie van zorgafhankelijke mensen op een actieve manier te respecteren. 'Belevingsgerichte zorg' en 'levensfasegeoriënteerde zorg' bieden volgens Arcares daartoe de mogelijkheid.

Belevingsgerichte zorg (Verdult, 1993) en levensfasegeoriënteerde zorg (Arcares, 2001) kunnen worden aangeduid als persoonsgerichte zorgbenaderingen. Een persoonsgerichte zorgbenadering wordt hier onderscheiden van een bewonersgerichte zorgbenadering:

* in een bewonersgerichte zorgbenadering, waaronder teamverpleging (Mercx, 1979), groepsverpleging (Boekholdt, 1981) en integrerende verpleegkunde (Koene, et al., 1982; Heeremans et al., 1994), wordt voornamelijk ingegaan op de werkwijze van de zorgverlener en de organisatie van de directe zorgverlening. Zo noemt Berkhout (2000) in haar studie naar 'resident-oriented care in nursing homes' een viertal karakteristieken van bewonersgerichte zorg: de bewonertoewijzing; het gebruik van het verpleegproces (anamnese, 
verpleegkundige diagnose, verpleegdoelen ed.); de taken van de zorgverleners, alsmede hun communicatie, waaronder het intra- en interdisciplinair overleg. Bodt (1995) spreekt dan ook niet van bewonersgerichte zorg, maar van een 'werkorganisatiemodel' voor verpleegafdelingen.

in een persoonsgerichte zorgbenadering staan de persoon van de zorgvrager, diens persoonlijke behoeften, verwachtingen, beperkingen en mogelijkheden en diens beleving van de zorg centraal. Bij persoonsgerichte zorg wordt vertrokken vanuit de biografie van degene die op zorg is aangewezen. De aandacht gaat niet uit naar zorgafhankelijkheid, maar naar de vraag welke plaats zorg in het leven van de zorgvrager inneemt. Een persoonsgerichte zorgbenadering gaat uit van dialogische relaties en geeft geen ruimte aan standaardisering van zorgactiviteiten (Van Houten, 1999). Het levensverhaal of de biografie van de zorgvrager vormt de basis voor de zorgondersteuning en niet de eventuele behandelbehoeften en de daarop gebaseerde verpleegdoelen.

\subsubsection{Belevingsgerichte zorg}

Belevingsgerichte zorg is een benaderingswijze van zorg die een decennium oud is. In Nederland wordt ze voornamelijk toegepast bij de zorg voor demente ouderen op verpleegafdelingen van intramurale instellingen (Verdult, 1993; Dröes et al. 1999, 2001; Van der Kooij, 2003). Ook op afdelingen voor groepsverzorging in verzorgingshuizen, waar ouderen naar toe gaan die in de beginfase van een dementeringsproces zitten, is belevingsgerichte zorg geïntroduceerd (Van Heusden et al., 1999; Schrijnemaekers, 2002). Belevingsgerichte zorg is ontstaan als reactie op het besef, dat in de jaren tachtig van de vorige eeuw groeide, dat dementerende ouderen in verpleeghuizen bejegend worden als mensen zonder eigen identiteit, individualiteit en autonomie, die geen beslissingen meer kunnen nemen en keuzes kunnen maken (Van der Kooij, 2003). Tegen deze achtergrond definieert Dröes (1998b) belevingsgerichte zorg als volgt:

Belevingsgerichte zorg is zorg, gericht op het verbeteren van het emotionele en sociale functioneren, en uiteindelijk de kwaliteit van leven van mensen met dementie door hen te begeleiden in het omgaan met cognitieve, emotionele en sociale gevolgen van de ziekte en door aan te sluiten bij de individuele, functionele mogelijkheden en de subjectieve beleving van de persoon.

In deze definitie schuilt de opvatting dat mensen die dementeren niet alleen worden geconfronteerd met cognitieve gevolgen van hun ziekte, zoals geheugenstoornissen, maar eveneens met emotionele en sociale gevolgen, waarbij onder meer angstig gedrag en achterdocht kunnen worden waargenomen. (Dröes et al., 2001). Door de zorg 
belevingsgericht te laten zijn wordt de individualiteit en eigenheid van ouderen met dementie beschermd. Volgens Van der Kooij (2003) is dit mogelijk door de zorgdoelen van de zorgverleners te vertalen in omgangsstrategieën voor vier fasen van ik-beleving tijdens het dementeringsproces: het bedreigde, verdwaalde, verborgen en verzonken ik.

Wanneer de bewoner zich, in een eerste fase van het dementeringsproces, onzeker voelt en zijn geheugenproblemen probeert te verbergen, is het zaak dat de zorgverlener veiligheid en structuur of houvast aanbiedt. Als het onderscheid tussen verleden, heden en toekomst vervaagt en mensen verdwalen in hun innerlijke werkelijkheid hebben zij behoefte aan contact en nabijheid en aan een zorgverlener die het gesprek vasthoudt. Wanneer de bewoner in zichzelf verzonken lijkt en niet meer open lijkt te zijn voor contact, wanneer het ik verborgen is, leeft hij op als de zorgverlener contact maakt door aanraken, vrolijkheid, muziek en beweging. Maar ook als er geen wederkerigheid meer is en de bewoner verzonken is in zijn ik, kan hij genieten van passief samenzijn en van zintuiglijke prikkeling,

Bij belevingsgerichte zorg worden in het contact met de dementerende oudere communicatietechnieken toegepast uit de Validation benadering. Validation heeft tot doel de leefwereld van de dementerende te waarderen en er betekenis aan te verlenen in plaats van hem te confronteren met zijn beperkingen en onvermogens. Daarnaast worden communicatiestrategieën gebruikt uit de reminiscentie- en realiteitsoriënterende benadering met de intentie dementerenden aan te spreken op hun nog aanwezige vermogens en die te stabiliseren. Er wordt ook lichamelijk contact gemaakt, zoals bij zintuigstimulatie, omdat bij dementie het lichamelijk ervaren blijft bestaan of zelfs sterker wordt (Van der Kooij, 2003). Bij belevingsgerichte zorg wordt gesproken van goede zorg als de zorgrelatie centraal wordt gesteld en niet de autonomie van de bewoner, de mate van zelfzorg of 'gezond' functioneren. De zorgrelatie moet de bewoner een gevoel van geborgenheid en waardigheid geven. 'Relationele zorg' heeft veel verschijningsvormen: ze kan betekenen dat de bewoner wordt gestimuleerd voor zichzelf te zorgen; de zorgverlener kan ook de zorg overnemen en in zijn plaats beslissingen nemen. Emotioneel is de zorgverlener de bewoner nabij en de zorgverlener moet er zich van bewust zijn dat hij zijn eigen emoties meeneemt in de zorgrelatie. Om relationele zorg te kunnen geven, moet de zorgverlener zich verdiepen in de belevingswereld van de bewoner. Kenmerkend is dat de dementerende bewoner probeert zich op allerlei wijzen aan te passen aan zijn afnemende vermogens, bijvoorbeeld door zijn wereld kleiner te maken en te structureren, door dwangmatig vast te houden aan gewoonten, door zich terug te trekken of door emotioneel te reageren. De zorgverlener probeert zich in te leven en zich af te vragen op welke gevoelens het gedrag van de bewoner is gebaseerd.

In de persoonsgerichte, belevingsgerichte zorg worden door verzorgenden en andere zorgverleners inspanningen verricht om de eigenheid en individualiteit van de 
dementerende bewoner niet verloren te laten gaan en levend te houden. Van der Kooy (2003) heeft hiertoe 'belevingsgerichte methodische instrumenten', oftewel formulieren voor de registratie van zorg, ontwikkeld. De levensgeschiedenis en de karakteristiek van de bewoner worden geregistreerd om aanknopingspunten te hebben voor contacten die verschillende doelen dienen. Gestreefd wordt het emotioneel en sociaal functioneren te verbeteren; de bewoner moet begeleid worden bij de cognitieve, emotionele en sociale gevolgen van zijn ziekte en de zorg moet ansluiten bij de (afnemende) individuele, functionele mogelijkheden en bij de subjectieve beleving van de persoon. Deze diversiteit aan informatie en doelen worden vermeld op de formulieren 'observatie', 'levensgeschiedenis', 'karakteristiek' en 'zorgkaart'. Daarenboven wordt een zorg- en behandelplan ingevuld. Hiervoor hanteert Van der Kooij een apart formulier. Zorg- en behandelactiviteiten zijn niet integraal op de zorgkaart of op de andere formulieren aangegeven. De probleemformuleringen op deze zorg- en behandelplannen moeten volgens Van der Kooij onder meer 'objectief en toetsbaar, zonder interpretaties' zijn. Hier manifesteert zich een inconsistentie in de methodiek van Van der Kooij. Zij geeft aan afstand te willen doen van probleemgestuurd, doelgericht werken en van een verpleegkundige diagnostiek, zoals door verpleegkundige theoretici Henderson (1987), Orem (1992) en Gordon (1995) ontwikkeld zijn, en van 'methodisch systematisch handelen', zoals die in het Nederlands taalgebied door Van den Brink-Tjebbes (1989) is uitgewerkt. Van der Kooij (2003) stelt, in navolging van Van den Brink-Tjebbes, dat elke verpleegsituatie in zichzelf betekenis heeft. Maar door het hanteren van registratieformulieren die een onderscheiden functie hebben, zoals het zorgplan, het zorgen behandelplan en het actieplan, waarmee ook doelgericht en probleemgestuurd gewerkt moet worden, schuilt het risico dat het primaat van de zorgrelatie in het gedrang komt en dat 'gestandaardiseerde zorg' wordt gegeven. In de omschrijving die Van der Kooij geeft van het actieplan als "het geheel van activiteiten die per probleem worden afgesproken om het doel te halen dat is geformuleerd bij dat probleem" wordt nadrukkelijk gerefereerd aan een probleemgestuurd begrippenkader.

Van de zorgverleners wordt bij belevingsgerichte zorg een hoge mate van deskundigheid geëist. Zij moeten beschikken over de eigenschappen 'attentiveness', 'responsibility', 'competence' en 'responsiveness', die Tronto van belang acht in de zorgrelatie (zie hoofdstuk 5.2.1.3). Naarmate het dementeringsproces voortschrijdt, de afhankelijkheid van de bewoner toeneemt, de zichtbare wederkerigheid afneemt en de ontvankelijkheid voor de zorg steeds moeilijker te beoordelen valt, neemt de zorgverlener een steeds grotere verantwoordelijkheid voor de beslissingen en keuzes die voor de kwaliteit van het leven van de bewoner gemaakt worden. Of belevingsgerichte zorg betekent dat daadwerkelijk wordt 
ingegaan op de eigenheid en individualiteit van de bewoner en antwoord wordt gegeven op diens behoeften is een vraag die op basis van onderzoek is beantwoord. In een klinisch experimenteel onderzoek in zestien psychogeriatrische verpleeghuisafdelingen is nagegaan of belevingsgerichte zorg voor demente ouderen meerwaarde biedt ten opzichte van gangbare zorg (Dröes et al., 1999). Gedurende zeven maanden kregen acht afdelingen belevingsgerichte zorg en de overige ontvingen gangbare zorg. Door middel van cursussen, begeleiding op de werkplek, de invoering van de hierboven genoemde zorgformulieren en het opzetten van belevingsgerichte groepen kreeg de belevingsgerichte zorg gestalte op de experimentele verpleegafdelingen. Aan het eind van het experiment werd nagegaan of een toename van enkele specifiek zorgkundige vaardigheden kon worden geconstateerd. Geconcludeerd werd dat de kennis over bewoners en de empathische houding en omgangstechnieken verbeterd waren en dat men op de experimentele afdelingen belevingsgerichter was gaan werken. De tendens werd bespeurd dat bewoners die belevingsgerichte zorg ontvingen meer open stonden voor sociaal contact dan bewoners van de controle afdelingen.

Op basis van onderzoek naar de effectiviteit van belevingsgerichte zorg concluderen Schrijnemaekers (2002) en Van der Kooij (2003) evenwel dat nog onvoldoende bewijs is geleverd voor de effectiviteit van deze benadering en dat aanvullend onderzoek nodig is. Schrijnemaekers verrichtte haar onderzoek op afdelingen groepsverzorging in zestien verzorgingshuizen: in acht interventiehuizen werden medewerkers geschoold en werd belevingsgerichte zorg geïmplementeerd; in acht controlehuizen werd de standaardzorg gecontinueerd. Nagegaan werd of gedragsproblemen van bewoners sterker afnamen en de arbeidstevredenheid van het verzorgend personeel meer toenam op de experimentele afdelingen dan op de controleafdelingen. Schrijnemaekers komt tot de algemene bevinding dat dit niet het geval is:

De gevonden verschillen tussen de twee groepen zijn statistisch niet significant en klinisch niet relevant, de verschillen zijn 'borderline'.

Zij bedoelt te zeggen dat het proces van invoering interessant was, maar dat de inspanningen niet het gewenst effect sorteerden.

Terwijl belevingsgerichte zorg voornamelijk is ontwikkeld ten behoeve van zorg voor ouderen met dementeringsverschijnselen of een afnemend geheugen, en de levensgeschiedenis van de bewoner op basis van informatieverzameling en - interpretatie door de zorgverlener wordt geregistreerd, neemt in de levensfasegeoriënteerde zorg de directe herinnering of reproductie van levensgebeurtenissen door de oudere zelf een belangrijke plaats in. In de volgende paragraaf wordt nader op deze benadering ingegaan en wordt bezien welke betekenis ze heeft voor de zorg voor zelfstandigheid in het 
verzorgingshuis waar ouderen leven die mentaal in staat zijn in dialoog met zorgverleners hun preferenties te communiceren.

\subsubsection{Levensfasegeoriënteerde zorg}

In zijn "biografische verkenningen" gaat Wais (1995) in op de historische oorsprong en functie van de biografie of het levensverhaal. Hij vertelt hoe de beschrijving van het leven van Boeddha en van boeddhistische heiligen tot doel heeft een ideaal-type te geven van het menselijk leven. De individuele 'normale' levensloop wordt beschouwd als een afwijking van de ideale ontwikkeling. Het Oude Testament geeft een ander licht op het levensverhaal. Het vertelt de biografie van het Jodendom, het volk van God. Afzonderlijke levens staan in dienst van de totale ontwikkeling van het volk; het individuele leven is niet interessant, de mens wordt 'van buitenaf' geleid. Het Nieuwe Testament doorbreekt het groepsbewustzijn en gaat in op individuele lotgevallen van mensen die het eigen leven 'van binnenuit' oppakken, vanuit een ik-beleving en gericht op het geloof. Wais spreekt van een keerpunt in de geschiedenis van de mensheid, van waaruit de individuele levensloop mogelijk wordt. Maar nog tot in de tweede helft van de vorige eeuw ging de individuele mens op in een net van tevoren vastgelegde patronen en rolverwachtingen. Pas in de laatste decennia ontstaat het bewustzijn dat ieder mens zijn eigen en unieke lot heeft, dat hij in vrijheid tot anderen kan vinden. Het 'lot' waarvan Wais spreekt, moet volgens hem niet beschouwd worden als een voorbestemde situatie die de mens niet zou hoeven uitdagen actief vorm te geven aan het leven. Integendeel, de biografie ontwikkelt zich, uitdagingen moeten worden opgezocht en opgepakt. De biografie laat steeds opnieuw de innerlijke samenhang van de gebeurtenissen zien en de individualiteit, het 'ik', het 'zelf' komt er in naar voren.'Het verhaal zijn wij zelf' stelt Weijs (1998). De eigen 'persoon' klinkt er in door ('persoon' komt van het Latijnse 'persona', oorspronkelijk datgene waar iets doorheen klinkt: per sonare betekent door-klinken). Wais (1995) maakt onderscheid tussen het 'dagelijks ik' en het 'hogere ik'. Het dagelijks ik maakt de balans op van het leven, kijkt terug en kent zichzelf vanuit het verleden. De biografische ontwikkeling komt er niet door tot uiting. Daarvoor is nodig dat mensen zich op weg begeven, nieuwe uitdagingen aangaan, open staan voor iets nieuws, voor andere opvattingen of gedrag vertonen waarmee in het verleden geen ervaring is opgedaan, kortom hun 'hogere ik' laten spreken.

Aandacht voor de biografie past in een tijdperk van persoonsgerichte benaderingen die de laatste decennia ook in de zorgsector hun intrede hebben gedaan (Breed et al., 1998) en die op (het respecteren en beschermen van) de individualiteit of zelfstandigheid van de zorgvrager appelleren. In de levensfase ouderdom neemt het levensverhaal een belangrijke 
plaats in. In het perspectief van het levenseinde werpt de vraag naar de zin van het leven zich op en ontstaat de behoefte het eigen levensverhaal in beeld te krijgen (Franssen, 1995; 1998) of aan zelfbeschouwing over de eigen levensloop (Munnichs, 1990). Deze behoefte manifesteert zich volgens Wais (1995) vooral in samenhang met beproevingen, een crisis, breuk, verlies van iemand of een ziekte. Verhuizing van de eigen woning naar het verzorgingshuis wakkert deze behoefte aan en vraagt niet alleen om reflectie op het verleden, maar ook om het zetten van nieuwe stappen.

Het levensverhaal heeft een toehoorder nodig, een welwillende, betrokken en geduldige luisteraar, waarmee de dialoog kan worden aangegaan en die kan helpen om nieuwe stappen te zetten (Weijs, 1998; Leenhouwers, 1998). Maar volgens Deckers (et al., 1998) is in de zorgverlening voor ouderen tot nu toe nauwelijks plaats voor het levensverhaal van de oudere. Het methodisch en doelgericht aanbieden van een pakket zorgverrichtingen met bovenal aandacht in het zorgplan en in de dagelijkse zorg voor de handelingen die de oudere zelf moet kunnen uitvoeren, staan een persoonsgerichte zorg in de weg. In een dergelijke zorgstructuur kunnen mensen hun verhaal niet kwijt, er is geen geduldige luisteraar. De huidige zorgstructuur is nog teveel gebaseerd op een natuurwetenschappelijk paradigma. Van Heeswijk (1995) illustreert dit aan de hand van een gevalsbeschrijving. Een 118-jarige Franse vrouw die in een verzorgingshuis in Arles woonde, werd onderworpen aan onder meer een batterij neuropsychologische tests om haar mentale toestand te meten. Een CT-scan toont een duidelijke atrofie van het hersenweefsel maar 'haar algemene prestatie was feitelijk veel beter dan voorspeld had kunnen worden uit de mate van geobserveerde hersenschors-degeneratie...'. Het 'geheim van hoogbejaardheid' werd op reductionistische wijze onderzocht, zonder verwijzing naar haar levensverhaal, naar haar manier van leven, haar gewoonten en de dingen waar de vrouw betekenis aan gaf.

De levensfasegeoriënteerde zorg moet afrekenen met een reductionistische, aspectologische benadering. Ze wordt door Arcares omschreven als 'een specifieke vorm van belevingsgerichte zorg, waarbij een juiste ruimte, zorg en aandacht voor beleving van de laatste levensfase en voor een goede persoonlijke afronding van het leven als belangrijkste preferenties worden gezien'. Het belang van een dergelijke zorg wordt als volgt verwoord (Arcares, 2001):

Ieder mens heeft een uniek verhaal te vertellen en door hen daartoe uit te nodigen en naar hen te luisteren worden ouderen bevestigd in hun identiteit en eigenwaarde, en ondersteund in het afronden van het leven. Want door het levensverhaal te vertellen, ontstaat het gevoel dat het leven geleefd is, komen de kernen weer boven die het leven zin en betekenis hebben gegeven, en wordt het tevens mogelijk om de eindigheid daarvan te accepteren. 
Levensfasegeoriënteerde zorg is gericht op doorleefde betrokkenheid (Widdershoven, 2000) op introspectie (Munnichs, 1990) of reflectie op het verleden, en op het heden en de toekomst. Een persoonlijke afronding van het leven, het accepteren van de eindigheid van het leven en het gericht zijn op de toekomst vragen aandacht voor een verdere biografische ontwikkeling en een voort-durende interactie tussen zorgvrager en zorgverlener. Het levensverhaal van de zorgvrager houdt immers niet op bij zijn intrede in het verzorgingshuis; zijn zelfstandigheid en regie over het leven krijgen verder vorm in het sociale verband van het verzorgingshuis waar anderen er wezenlijk toe doen (Van Houten, 1999).

Levensfasegeoriënteerde zorg is niet op zoek naar de autobiografie, naar de innerlijke dialoog van de zorgvrager. Een autobiografie handelt over een geschreven of vertelde levensbeschrijving weergegeven door de persoon in kwestie zelf. De schrijver of verteller stelt zichzelf centraal en vraagt van de luisteraar erkenning en instemming (Munnichs, 1990; Van Knippenberg, 1998), maar het is de vraag of de zorgrelatie er door gevormd wordt. De biografie is een levensbeschrijving die in het verzorgingshuis door de zorgverlener wordt geregistreerd en de interactie tussen de zorgvrager en zorgverlener neemt een voorname plaats in. Vanwege deze interactie en omdat het beschrevene ook bedoeld is om er andere zorgverleners van in kennis te stellen en er mee om te laten gaan, is de biografie gevoelig voor interpretaties door de zorgverlener. De biografie stelt de zorgverlener voor een moeilijke taak. Hij moet waarborgen dat de zorgvrager 'zelfstandigheid' beleeft. De zorgvrager moet het gevoel hebben dat zijn 'zelf' 'blijft staan', overeind blijft, ondanks de ervaring van discontinuïteit als gevolg van plaatsing in het verzorgingshuis. Maar dit veronderstelt dat duidelijk is wat dit 'zelf' behelst. Wais (1995) stelt dat dit geen uitgemaakte zaak is:

Is het niet eerder zo dat je biografie pas in beweging komt op het moment dat je met gebeurtenissen wordt geconfronteerd die je uit je gewoonten, zekerheden en denkpatronen lostrekken?

Gewoonten, zekerheden en denkpatronen zijn voor ieder mens uniek en representeren een deel van dit zelf, het deel dat Wais aanduidt met 'het dagelijks ik'. Ze hebben continuïteit aan het leven gegeven en worden door de zorgverlener in beeld gebracht met vragen naar onder meer de sociale verbanden, opleiding, werkervaring, levensritme en persoonlijke hygiëne van de zorgvrager. Beweging of ontwikkeling van de biografie, van 'het hogere ik', betekent dat de zorgvrager er in slaagt de discontinuitteit in zijn leven een zodanige plaats te geven, dat zijn beleving van 'zelf-standigheid' er niet onder lijdt, maar verder door gevormd wordt. De attentiviteit, die van de zorgverlener gevraagd wordt, dient hiertoe het karakter te hebben van een ontmoeting (Wais, 1995), waarbij de zorgverlener er bij de zorgvrager niet 
zonder meer op kan aandringen zijn fysieke mogelijkheden te benutten of hem tot 'zelfverzorging' te stimuleren. Volgens Becker (2003) doet de zorgverlener er evenmin goed aan alles uit handen te nemen. Er moet in de ontmoeting van zorgvrager en zorgverlener geen sprake zijn van doelgerichtheid, maar juist van het niet vooringenomen zijn en van luisteren met oprechte belangstelling. Door doelgerichtheid en probleemgefocused denken bestaat het risico dat ervaringen die bepalend zijn geweest voor de identiteit van de zorgvrager uit het zicht verdwijnen en dat alleen nog de behoefte aan zorg wordt opgemerkt (Kardol, 1982). Door de zorgvrager te ondersteunen bij het geven van een plaats aan 'discontinuitteit', en hem te beschouwen als iemand die bezig is verder vorm te geven aan zijn leven, krijgt de zorgrelatie het karakter van respect en gelijkwaardigheid. Door rekening te houden met de rechten, plichten en verantwoordelijkheden van de zorgvrager en de zorgverlener wordt de zorgrelatie ook gekenmerkt door wederkerigheid.

De zorgverlener moet op zoek gaan naar het 'anders zijn', naar de vraag wat deze zorgvrager zo bijzonder maakt. Deze vraag moet bij elke nieuwe ontmoeting gesteld worden, in de eerste plaats omdat het 'kennen' van de zorgvrager tot vooringenomen handelen zou kunnen leiden en van de veronderstelling uitgaat dat het levensverhaal af en consistent is (Widdershoven, 2000), en in de tweede plaats omdat de wederkerigheid verloren zou kunnen gaan. De zorgverlener moet zich volgens Kunneman (1996) steeds inleven in de unieke complexiteit van de situatie waarin de zorgvrager zich bevindt en zich verstaan met de manier waarop de zorgvrager zich uitdrukt. Dit vraagt om een open, vragende houding van de zorgverlener waarmee hij de zorgvrager tegemoet treedt. Gezamenlijk, in dialoog (Becker, 2003), moet worden nagegaan welke keuzes en mogelijkheden het verzorgingshuis biedt en op welke wijze kan worden omgegaan met beperkingen die worden ondervonden en met behoeften aan zorg. Dit kan gebeuren door een (her)oriëntatie op waarden van de zorgvrager, maar ook door deel te nemen aan het alledaagse leven in het verzorgingshuis.

Voor wat betreft de oriëntatie op waarden komt Hijmans (1994) op basis van empirisch onderzoek naar hedendaagse zingevingssystemen tot de bevindingen dat sprake is van 'pluralisering van het zingevingsaanbod' en van 'privatisering van zingevingsprocessen'. Op de vraag waar het leven volgens mensen om draait, geven sommige van de door haar geïnterviewden aan dat reflexiviteit van belang is, terwijl het voor anderen gaat om concrete waarden en betekenissen, waaronder het zich binden aan instituties, referentiegroepen of aan individuele mensen. Weer anderen hebben één of meerdere levensdoelen, maar ook passiviteit en onverschilligheid tegenover zingeving en gebrek aan reflexiviteit komen voor. 
Een zorgrelatie waarin de zorgverlener competenties toont als het niet vooringenomen en het belangstellend zijn, het hebben van een open, vragende houding en het in dialoog kunnen treden met de zorgvrager, waarin de zorgverlener de zorgvrager ondersteuning biedt bij het accepteren of integreren van discontinuitteit en hem de ruimte en mogelijkheid biedt vorm te geven aan zijn leven, waarborgt de zorg voor zelfstandigheid. Responsiviteit is hier gelijk aan 'informed consent': de zorgvrager ondertekent dat deel uit het zorgdossier waarin informatie uit zijn levensverhaal is opgenomen en afspraken zijn vermeld die zijn 'zelf' overeind houden. Hij eist daarmee zijn recht niet op, maar doet recht aan de ontmoeting en dialoog met de zorgverlener.

Arcares (2001) stelt voor al bij aanvang van de zorgrelatie, tijdens het huisbezoek aan de toekomstige bewoner, een eerste beeld te verkrijgen van de levensloop of het levensverhaal van de bewoner, van levensgewoonten, van verlieservaringen en van belangrijke contacten. Deze gegevens moeten een plaats krijgen in het zorgdossier. In de bewonersbespreking komen zaken aan de orde die betrekking hebben op het levensverhaal van de oudere. Ook disciplines, zoals de activiteitenbegeleiding en de geestelijk verzorger, brengen in dit overleg ervaringen in die ze mogelijk hebben opgedaan met de oudere.

Het verzorgingshuis heeft geen historie opgebouwd met een wijze van werken waarin aan het levensverhaal een leidende rol wordt toebedeeld en waarin een methodiek van doel- en probleemgericht werken is vervangen door een methodiek van zorgend 'handelen' waar een bewoner zich in herkent. In hoofdstuk 9 wordt een vorm van rapportage beschreven die ruimte biedt aan het levensverhaal en die is geïntroduceerd op een drietal afdelingen van verzorgingshuizen.

\subsection{Responsieve evaluatie: het opkomen voor zorg voor zelfstandigheid}

Door een belevingsgerichte en levensfasegeoriënteerde zorgbenadering verwacht de zorgverlener op individueel niveau responsiviteit of ontvankelijkheid te krijgen voor de zorg die hij aanbiedt. Ontvankelijkheid betekent dat hij op de zelfstandigheid van de zorgvrager is ingegaan. Behalve de zorgverlener, die in zijn één-op-één-contact responsiviteit nastreeft, heeft ook de zorgaanbieder de verantwoordelijkheid een zorgaanbod te organiseren dat aansluit bij de levensverhalen en verwachtingen, behoeften en wensen van de bewoners. Waar de zorgverlener probeert de beperkte groep bewoners die hem zijn toegewezen individueel van dienst te zijn, heeft de zorgaanbieder tot taak de organisatie zo in te richten dat aan de zorg voor zelfstandigheid van alle bewoners recht kan worden gedaan. De regels en gewoonten van het verzorgingshuis waarmee bewoners 
kennismaken, de mate waarin en de wijze waarop zij geïnformeerd worden en de omgangsvormen, deskundigheden en werkwijzen van personeelsleden hebben tot doel in algemene zin en op individueel niveau aan te sluiten op de vragen, wensen en behoeften van bewoners. Of de zorginstelling dat doel bereikt is een vraag die bij de bewoners moet worden neergelegd, wanneer de organisatie pretendeert persoonsgericht te zijn. Bewoners verblijven permanent in het verzorgingshuis en de invloed van de beleidskeuzen van de instelling wordt dan ook het sterkst door hen ervaren. Ook de opvatting van de zorgverleners is van belang, niet alleen omdat zij door hun nauwe contacten met bewoners een inschatting kunnen maken van de beleving van bewoners, maar ook omdat hun werkwijze wordt beïnvloed door de omstandigheden waarbinnen zij moeten werken.

In hoofdstuk 4.2. is aangegeven dat de Wet medezeggenschap cliënten zorginstellingen (Wmcz) medezeggenschap van cliënten regelt met betrekking tot het beleid van zorginstellingen. In beginsel kunnen in vergaderingen van de cliëntenraad met de directie veel onderwerpen aan de orde gesteld worden en opvattingen worden uitgewisseld. Voor bepaalde besluiten moet de directie of bestuur een zwaarwegend advies vragen aan de cliëntenraad. Statuten regelen de samenstelling, werkwijze en min of meer de agenda van de cliëntenraad. De bijeenkomst van de cliëntenraad heeft daarmee een formele basis. Doorgaans staan punten op de agenda over voeding, veiligheid of de kwaliteit van de accommodatie. In veel gevallen stelt de cliëntenraad zich reactief op. In de regel wordt niet gesproken over de betekenis die het instellingsbeleid heeft voor de individuele situatie van het lid van de cliëntenraad of voor individuele bewoners. Of en hoe de cliëntenraad communiceert met de medebewoners en of zij bekend is met wat onder bewoners leeft, is een vraagstuk apart. Als de cliëntenraad het enige orgaan is waarmee door de directie over instellingsbeleid wordt gesproken, is de invloed hierop van het merendeel van de bewoners beperkt. $\mathrm{Bij}$ bewoners kan het gevoel ontstaan dat kritiek niet gepast is, dat aanpassing aan vigerende regels en gewoonten geboden is en dat negatieve ervaringen over de organisatie en over het aanbod van zorg geen weerklank vinden. Vanuit een dergelijke beleving kunnen vraagtekens worden geplaatst bij de responsiviteit van bewoners op het instellingsbeleid.

De zorgaanbieder kan de ontvankelijkheid van bewoners voor dit beleid toetsen door hun opvattingen te inventariseren over onder meer de kwaliteit van het zorgaanbod, de houding van het personeel, de regels van het huis. Door met geprecodeerde vragenlijsten te werken, kan inzicht worden verkregen in de mate van consensus van bewoners over de effecten van het instellingsbeleid. Of het bekend zijn met algemene opvattingen van bewoners tot gevolg heeft dat de zorgaanbieder het instellingsbeleid zodanig wijzigt dat iedereen er ontvankelijk voor is, valt te betwijfelen. Wellicht hebben bewoners de vragenlijst ingevuld, maar zetten ze vraagtekens bij de evaluatiecriteria of hebben ze de vragenlijst niet of niet volledig 
ingevuld, omdat ze niet kwijt konden wat hun eigenlijk beroert. Misschien trekt de zorgaanbieder de conclusie dat het met de kwaliteit van het instellingsbeleid wel meevalt als 'gemiddeld genomen' de tevredenheid onder bewoners hoog is.

Om zorg voor zelfstandigheid te bewerkstelligen is meer nodig. Bewoners, maar ook zorgverleners, moeten een directe mogelijkheid hebben opmerkingen te plaatsen bij de zorg die geboden wordt en zij moeten invloed kunnen uitoefenen op een gewenste verandering van het aanbod. Door bewoners en verzorgenden participant te laten zijn in de kwalitatieve evaluatie van de zorg en hen de ruimte te geven een gewenst veranderingsproces op gang te brengen, wordt verondersteld dat de kans groot is dat de beoogde veranderingen ook plaatsvinden. Responsieve evaluatie is volgens Abma (1997) ontwikkeld als een vorm van beleidsevaluatie, waarbij belanghebbenden de mogelijkheid hebben rechtstreeks en actief invloed te hebben op het beleid van een organisatie.

Responsieve evaluatie krijgt in deze studie een plaats, omdat ze een emancipatorische doelstelling heeft. De vermeende afhankelijke houding van bewoners enerzijds en het routinematig, institutioneel handelen dat het verzorgingshuis wordt toegedacht anderzijds, oftewel de betekenis van de dagelijkse praktijk (Widdershoven, 1995), kunnen door responsieve evaluatie aan de orde worden gesteld en zo nodig worden doorbroken. Door bewoners en verzorgenden actief te betrekken bij de evaluatie van de dagelijkse zorg en bij de discussie over gewenste veranderingen wordt een positief klimaat geschapen voor het bevorderen van zorg voor zelfstandigheid in de zorgrelatie tussen de individuele bewoner en de verzorgende.

\subsubsection{Responsieve evaluatie: herkomst, uitgangspunten, methode en toepassingen}

Responsieve evaluatie is evaluatie-onderzoek, waarbij mensen die betrokken zijn bij een onderwerp zich gezamenlijk een oordeel vormen over dat onderwerp.

In deze studie vormen groepen betrokkenen zich een oordeel over de resultaten van vraaggesprekken met bewoners en van een enquête onder het verzorgend personeel (zie hoofdstuk 9). Aan het oordeel van de betrokkenen wordt een belangrijke betekenis toegekend; er kan bijvoorbeeld gedragenheid voor een verandering mee worden gecreëerd, of de gewenste richting van de verandering kan er mee worden aangegeven. De interactie tussen betrokkenen en de mogelijkheid tot participatie in de oordeelsvorming kunnen op zichzelf al veranderingen bewerkstelligen bij individuele deelnemers aan de responsieve evaluatie. 


\section{Herkomst}

Greene en Abma (2001) beschrijven hoe Stake in 1973 de basis legde voor responsieve evaluatie als vorm van evaluatie-onderzoek:

Evaluation was reframed from the application of sophisticated analytic techniques that address distant policymakers' questions of program benefits and effectiviness 'on the average' to an engagement with on-site practioners about the quality and meaning of their practice.

\section{Uitgangspunten en methode}

Responsieve evaluatie pleit voor een verandering van beleidsevaluatie. In plaats van een top-down evaluatie, waarin de beleidsmaker nagaat of de doelen en intenties zijn bereikt, wordt een bottom-up evaluatie voorgestaan: de evaluatiecriteria moeten betrekking hebben op onderwerpen die voor de belanghebbenden van belang zijn en die ook door hen gekozen worden. Responsieve evaluatie is door Guba en Lincoln wetenschappelijk ontwikkeld en de basisassumpties die zij hanteren, worden door Abma en Widdershoven $(2001,2002)$ als volgt omschreven:

- de werkelijkheid is meervoudig, voor velerlei uitleg vatbaar en laat zich niet herleiden tot oorzaak - en gevolg relaties;

- $\quad$ om 'de meervoudige werkelijkheid' op het spoor te komen en de werkelijkheid van individuen te beïnvloeden, is bereidheid tot interactie met betrokkenen nodig en moeten mensen de ruimte krijgen hun beleving in te brengen;

- $\quad$ opvattingen, inzichten en belevingen van mensen (waaronder die van de evaluator) zijn divers; ze kunnen niet onder een algemene noemer worden samengevat, omdat ze de individuele werkelijkheid te kort zouden kunnen doen en omdat ze situationeel bepaald en aan verandering onderhevig zijn.

Waarheid en validiteit, belangrijke begrippen in de wetenschapsbeoefening, worden door Guba en Lincoln vervangen door geloofwaardigheid, fairness en authenticiteit, en door het hermeneutisch - dialectische proces:

Van geloofwaardigheid is sprake als respondenten zich herkennen in de interpretaties van de onderzoeker of evaluator. Fairness wordt betracht door alle belangstellenden in staat te stellen hun stem te laten horen; authenticiteit wordt bereikt als het persoonlijk inzicht van de respondent toeneemt, als het denken verschuift en de mogelijkheid om actie te ondernemen toeneemt. Het hermeneutisch - dialectische proces treedt op door actieve inbreng van zoveel mogelijk betrokkenen en door onderlinge deliberatie.

Deze inbreng en deliberatie hebben het karakter van oordeelsvorming over onderwerpen die de deelnemers raken of waarmee ze geconfronteerd worden. De evaluator inventariseert deze onderwerpen, bij responsieve evaluatie claims (verwachtingen), concerns (zorgen) en 
issues (discussiepunten) genoemd. De procedure voor het inhoudelijk verloop van de evaluatie wordt aangeduid met 'emergent design', waarmee bedoeld wordt dat het ontwerp of design c.q. de verwachtingen, zorgen en discussiepunten die worden besproken, niet vooraf wordt vastgesteld en het verloop van de evaluatie bepaalt, maar dat de evaluatie bepaald wordt door hetgeen in de loop van de evaluatie naar voren komt (Abma en Widdershoven, 2002). De evaluator moet er op letten dat zowel degenen die een belangrijke positie bekleden als degenen die zich 'slachtoffer' voelen en niet op de voorgrond treden voldoende ruimte voor inbreng krijgen. Er worden derhalve niet alleen punten op de agenda geplaatst waar de deelnemers uiteenlopende ervaringen over kunnen inbrengen, ook de bijdrage van mensen met uiteenlopende achtergronden dient evenwichtig te zijn en de evaluator is gespitst op interactie tussen de betrokkenen. Hij draagt zorg voor wat genoemd wordt 'het ontstaan van 'hermeneutisch -dialectische cirkels': degenen die aan de evaluatie deelnemen, krijgen inzicht in hetgeen aan de orde komt door ervaringen en opvattingen die worden ingebracht en die worden geïnterpreteerd, door te luisteren, elkaar te bevragen en door te vragen. Zij zijn niet bang om deel te nemen, tonen betrokkenheid, staan open voor anderen en respecteren elkaar. Het is niet nodig consensus te bereiken. Belangrijker nog is het waarderen van verschillende opvattingen. Deze waardering kan zover gaan dat de eigen opvatting plaats maakt voor die van een ander. Het verloop van de dialoog kan de onderzoeker aanzetten tot voorstellen voor verandering die aansluiten op de gemeenschappelijke behoeften van de betrokkenen (Abma, 1996; Widdershoven, 2001; Schrijnemaekers et al., 2002).

Om elke belanghebbende maximaal te betrekken bij de evaluatie stellen Guba en Lincoln voor de groepen voor responsieve evaluatie homogeen samen te stellen om vervolgens langs directe of indirecte weg aan alle betrokkenen de verschillende inzichten kenbaar te maken. De evaluator stelt zich naar hun mening voornamelijk op als interpretator, educator en facilitator van het proces: hij geeft betekenis aan ervaringen die worden ingebracht; creëert begrip door ervaringen uit te leggen en de dialoog op gang te brengen; hij waardeert de verschillen, maar stimuleert ook het zoeken naar overeenstemming en raakvlakken tussen de verschillende ervaringen; in zijn evaluatierapport vat de evaluator de dialoog niet op hoofdpunten samen, maar benoemt de verschillen die naar voren zijn gekomen.

\section{Toepassingen}

Fortuin (1994) beschrijft hoe een responsieve onderzoeksaanpak, ontleend aan Guba en Lincoln, in Rotterdam gehanteerd is om bureaucratische schotten te doorbreken, de betrokkenheid van de burger bij beleid te vergroten, vernieuwingsgerichtheid en enthousiasme te mobiliseren, ofwel om tot 'sociale vernieuwing' te komen. De stedelijke vernieuwing die de stad aan het eind van de jaren tachtig doorvoerde, ging teveel aan de 
burgers voorbij en sociale vernieuwing had tot doel deze omissie van het stadsbestuur te corrigeren. De winst van de sociale vernieuwing werd vooral behaald in de rechtstreekse bijdrage van mensen aan ontwikkelingen die hen aangaan en in de confrontatie en combinatie van verschillende gezichtspunten van burgers en overheid, waardoor het beeld van de afzonderlijke partijen verruimd werd.

Abma en Ritterbeeks (1996) verwijzen naar een project arbeidsrehabilitatie voor expsychiatrische patiënten. Met behulp van responsieve evaluatie werd de vraag aan de orde gesteld op welke wijze belanghebbenden betekenis geven aan de functie arbeidsrehabilitatie van deze patiënten. Een resultaat van de sessies was dat therapeuten zich niet langer als experts zagen, dat patiënten niet langer benaderd werden als dociele en passieve subjecten en dat patiënten zich gingen opstellen als kritische consumenten. Abma (2001) beschrijft hoe door middel van responsieve evaluatie een blessurepreventieprogramma voor balletstudenten tot stand is gekomen en Abma en Widdershoven (2001) verwijzen naar de ontwikkeling van palliatieve units in verpleeghuizen en van Supported Employement programma's voor geestelijk gehandicapten door gebruikmaking van responsieve evaluatie.

Er is geen literatuur bekend waaruit blijkt dat de methode van responsieve evaluatie wordt toegepast in het verzorgingshuis. In het verzorgingshuis is nog gangbaar dat het bestuur of de directie top-down een meerjaren strategisch beleidsplan opstelt, dat (indirect) gecommuniceerd wordt met belanghebbenden en waarmee hoofden van diensten aan de slag gaan om er jaar-werkplannen uit af te leiden. Het meerjaren strategisch beleidsplan behandelt onderwerpen zoals de visie op zorg, de kwaliteit van het zorgaanbod, de organisatie van zorg en de kosten van zorg. Met name de onderwerpen als visie op zorg, kwaliteit van zorg en organisatie van zorg raken de bewoners en het personeel meer dan wie ook en zij ervaren aan den lijve of het instellingsbeleid en de keuzes die daarbij gemaakt zijn, aansluiten bij hetgeen in het rechtstreekse contact tussen bewoner en zorgverlener verwacht en gewenst wordt. Als dat niet het geval is en voorbij wordt gegaan aan de ervaringen van bewoners en zorgverleners loopt de zorgaanbieder het risico dat, zoals Abma (1997) het uitdrukt 'de beleefde werkelijkheid wordt vervangen door een 'betere' constructie die niet de hunne is'.

In hoofdstuk 9 wordt beschreven hoe groepen bewoners en verzorgenden met behulp van responsieve evaluatie nader zijn ingegaan op de resultaten van het onderzoek van deze studie naar de zorg voor zelfstandigheid op verzorgingsafdelingen en de mogelijkheden tot verbetering van die zorg hebben besproken. 


\subsection{Beschouwing}

Persoonsgerichte zorgbenaderingen als belevingsgerichte zorg en levensfasegeoriënteerde zorg proberen invulling te geven aan zorg voor zelfstandigheid. Belevingsgerichte zorg legt daarbij het accent op de ervaring van identiteit en eigenheid door de demente bewoner. De zorgverlener verdiept zich in de achtergrond van de bewoner en investeert in de relatie om voor hem de juiste keuzes en beslissingen te kunnen maken. In het verloop van het dementeringsproces van de bewoner is sprake van een toenemende inmenging door de zorgverlener in het leven van de bewoner en de expliciete vraag om inmenging of de goedkeuring daartoe wordt op een gegeven moment door de bewoner niet meer gesteld of gegeven. De zorgverlener bedient zich van registratieformulieren waarop hij het functioneren van de bewoner beschrijft en waarop de vereiste zorg wordt gepland. Opvallend in de beschrijving van belevingsgerichte zorg is dat gesteld wordt dat probleemgericht en doelgericht handelen niet het uitgangspunt van zorg mogen zijn, terwijl een aantal rapportageformulieren die in deze persoonsgerichte benadering gehanteerd worden de doelgerichtheid juist oproepen. Daarbij gaat het om het hanteren van een behandelplan en zorgplan, waarvan niet helder is welke functie zij vervullen. Of de zorgverlener slaagt in de missie om belevingsgericht te werken, is niet met zekerheid te zeggen. Naarmate het dementeringsproces vordert, is de zorgverlener meer en meer aangewezen op eigen interpretaties en op signalen van de bewoner om de attentiviteit en responsiviteit te bepalen. Onderzoeken naar de effecten van belevingsgerichte zorg tonen niet onomstotelijk aan dat beter op de behoeften en verwachtingen of de persoon van de zorgvrager wordt ingegaan dan bij niet-belevingsgerichte zorg.

Bij levensfasegeoriënteerde zorg speelt de kwaliteit van de zorgrelatie eveneens een prominente rol. Niet in de eerste plaats om verantwoord keuzes en beslissingen van de zorgvrager over te kunnen nemen, maar om de bewoner te helpen bij zijn levensverhaal, bij het zich herinneren van gebeurtenissen die betekenis hebben gegeven aan zijn leven en die van waarde kunnen zijn voor de acceptatie en waardering van de situatie waarin de bewoner zich bevindt. Dit hoeft niet te betekenen dat de waarde van het leven beleefd wordt door reflectie op vroegere ervaringen en gebeurtenissen. Een doordenking van het leven is een preferentie die andere preferenties niet in de weg hoeft te staan of die er door verdrongen wordt. De 'everyday ethics' moeten niet uit het oog worden verloren. Het dagelijks leven in het verzorgingshuis kan in zichzelf uitnodigend genoeg zijn om er zingeving aan te ontlenen en de bewoner uit te laten kijken naar de dag van morgen; zijn biografie of levensverhaal wordt er verder door gevormd. In de levensfasegeoriënteerde zorg ontmoeten bewoner en zorgverlener elkaar en ze gaan een dialoog aan. Op basis van respect, niet vooringenomen 
zijn en wederkerigheid helpt de zorgverlener de bewoner zijn afhankelijkheid en kwetsbaarheid te integreren en als uitdrukking van zelfstandigheid te zien. De zorgverlener ondersteunt de bewoner bij het overeind laten van zijn 'zelf'; hij respecteert de rechten van de bewoner en komt zijn plichten na. De ontmoeting met de bewoner vormt de zorgverlener in zijn eigen ontwikkeling. In deze benadering bedient de zorgverlener zich van een registratiesysteem dat gegevens vastlegt die van belang zijn voor de zorg voor zelfstandigheid. Probleem- en doelgerichtheid en standaard verzorgingsplannen zijn daarbij niet aan de orde. Een behandelplan, zo al aanwezig, heeft de functie van het cureren van een (tijdelijk) ongemak en reduceert de bewoner niet tot 'zorgafhankelijke'; het krijgt de plaats die het nodig heeft in de zorg voor zelfstandigheid.

Onderzoek naar de effecten van levensfasegeoriënteerde zorg op de zorg voor zelfstandigheid zijn in deze studie niet opgemerkt.

In het verzorgingshuis wonen overwegend wilsbekwame bewoners. Cure-vraagstukken, waarvoor de zorgverlener zich een rol van expert zou kunnen aanmeten, zijn nauwelijks aan de orde. In de zorgvisie wordt persoonsgerichtheid nagestreefd en dient het levensverhaal van de bewoner door te klinken in de zorgrelatie. Wederkerigheid of symmetrie van de relatie staan hoog in het vaandel van het verzorgingshuis en beslissingen terzake de zorg worden voornamelijk op decentraal niveau genomen. Tegen die achtergrond past in het verzorgingshuis een vorm van actieve participatie van bewoners en zorgverleners bij het beleid inzake zorg voor zelfstandigheid. Waar de bewoner en zorgverlener op individueel niveau zorgdragen voor de zelfstandigheid van de bewoner biedt responsieve evaluatie de mogelijkheid om op afdelings- of instellingsniveau in interactie en samenspraak met bewoners en zorgverleners de verwachtingen van en de mogelijkheden en condities voor een persoonsgericht zorg te evalueren. Aan de orde komt dan het issue of het verzorgingshuis een woon-, leef- en zorgomgeving creëert waarin bewoners hun gang kunnen gaan en verantwoordelijkheid kunnen nemen; of hun eigenheid tot recht kan komen en wensen, keuzes en behoeften van bewoners worden onderkend, geplaatst en beantwoord, kortom waarin zorg voor zelfstandigheid wordt beleefd. Door bewoners en verzorgenden actief te betrekken bij bevindingen van onderzoek naar de vraag of zorg voor zelfstandigheid voldoende is gewaarborgd, wordt de acceptatie van de bevindingen verhoogd en een gewenste implementatie van verbeteringen vergemakkelijkt, omdat zij zich persoonlijk betrokken voelen (Abma en Widdershoven, 2001). 


\section{Hoofdstuk 7 Zorg voor zelfstandigheid: probleemstelling en methode van onderzoek}

\section{$7.1 \quad$ Inleiding}

In het begin van deze studie is de sociale positie van ouderen in de Nederlandse samenleving aan de orde gesteld. In de literatuur die over dit thema is geraadpleegd, klinkt door dat van mensen van 65 jaar en ouder niet verwacht wordt dat maatschappelijke verantwoordelijkheid gedragen wordt. De plicht tot maatschappelijke verantwoordelijkheid is althans niet geïnstitutionaliseerd. Het beeld dat fysieke vermogens van ouder wordende mensen afnemen, wordt aan het einde van de negentiende eeuw gevestigd en beïnvloedt het denken over de productiviteit van ouderen in het arbeidsproces tot ver in de twintigste eeuw. Ouderdom wordt, zeker in geval ouderen gebruik maken van gezondheidsvoorzieningen, geassocieerd met afhankelijkheid. Wanneer zelfstandigheid synoniem is aan zelfredzaamheid en wordt gedefinieerd als het vermogen om met name in fysieke zin voor zichzelf te kunnen zorgen, heeft fysieke afhankelijkheid tot gevolg dat de zelfstandigheid verloren gaat. Ouderen die gebruik maken van zorgvoorzieningen zijn vanuit een dergelijke optiek overgeleverd aan degenen die voor hen zorgen en lijken de verantwoordelijkheid voor hun leven in de handen van professionele zorgverleners gelegd te hebben, zeker wanneer zij permanent in een instelling verblijven. De functie van het verzorgingshuis, dat ouderen plaatst die een bepaalde mate van fysieke hulp behoeven, is onder de loep genomen. Met raadpleging van literatuur is de vraag beantwoord in hoeverre het verzorgingshuis de taak of plicht heeft de zelfstandigheid van ouderen te bewaken of te bevorderen. Wetgeving heeft de rechtspositie van de bewoner van het verzorgingshuis versterkt en van overheidswege is een op de vraag van de individuele bewoner gerichte zorg gestimuleerd. De vraag is of dit daadwerkelijk betekent dat het verzorgingshuis de letter van de wet hanteert en dat de bewoner zijn verantwoordelijkheid neemt en een appèl doet op dit recht. Het imago van het verzorgingshuis is dat bewoners zich afhankelijk voelen en geleefd worden, ondanks de plicht van het verzorgingshuis de zelfstandigheid van de bewoner te respecteren en te beschermen en vraaggericht te werken.

Met behulp van literatuur uit de gezondheidsethiek en uit het gezondheidsrecht is ingegaan op de betekenis die aan zorg voor zelfstandigheid wordt toegekend. In de gezondheidsethiek wordt in plaats van 'zelfstandigheid' het begrip 'autonomie' gebezigd en bij gezondheidsrecht wordt met name over 'zelfbeschikking' gesproken. Gesteld wordt dat zelfstandigheid niet bepaald wordt door de mate van zelfredzaamheid of zelfverzorging en afhankelijkheid en zelfstandigheid sluiten elkaar niet uit. Als de zorgrelatie is gebaseerd op 
gelijkwaardigheid en wederkerigheid, waarin ook de zorgvrager zijn verantwoordelijkheid neemt, als de zorgverlener zich richt op het levensverhaal van de bewoner en als vanuit overleg tussen bewoner en zorgverlener zorgafspraken worden geformuleerd waar de persoon van de bewoner in doorklinkt, kan gesproken worden van zorg voor zelfstandigheid.

In dit deel van de studie komen bewoners en verzorgenden aan het woord. Gevraagd is naar hun opvatting over en beleving van zorg voor zelfstandigheid, naar de manier waarop zelfstandigheid kan worden bevorderd en of door interventies een toename van zorg voor zelfstandigheid geconstateerd wordt. Aan wie dat is gevraagd, op welke wijze dat is gebeurd, welke instrumenten zijn ingezet en hoe deze gehanteerd zijn, kortom hoe het onderzoek is verlopen, wordt in dit hoofdstuk aan de orde gesteld. In hoofdstuk 7.2 wordt de probleemstelling van het onderzoek beschreven; hoofdstuk 7.3 schetst de methodologische context van het onderzoek, met name het onderzoeksontwerp; in hoofdstuk 7.4 wordt het onderzoeksproces beschreven: de stappen die gezet zijn om de probleemstelling te beantwoorden worden vermeld; ingegaan wordt op de onderzoekslocatie en de respondenten en op de onderzoeksopzet en -uitvoering. In hoofdstuk 7.5 wordt een beschouwing op dit hoofdstuk gegeven.

\subsection{Probleemstelling}

Wat wordt door bewoners en verzorgenden van verzorgingshuizen onder zorg voor zelfstandigheid verstaan en beantwoordt de dagelijkse praktijk daar naar hun mening aan; hoe kan zorg voor zelfstandigheid worden bevorderd en hebben interventies hiertoe tot gevolg dat de zorg voor zelfstandigheid toeneemt?

De probleemstelling richt zich op opvattingen van bewoners en verzorgenden die in het verzorgingshuis in nauw contact staan met elkaar, die een zorgrelatie vormen. Aan hen wordt gevraagd aan te geven wat 'zorg voor zelfstandigheid' betekent in het verzorgingshuis. Vervolgens wordt gevraagd of ze de theoretische notie van zorg van zelfstandigheid ook terugzien in de praktijk van alledag. Vanuit de gedeelde opvattingen dat zorg voor zelfstandigheid verbetering behoeft, wordt de vraag gesteld wat kan worden ondernomen om tot meer zorg voor zelfstandigheid te komen. Er worden interventies gepleegd om de zorg voor zelfstandigheid te bevorderen en na de interventies worden bewoners en verzorgenden opnieuw ondervraagd over de zorg voor zelfstandigheid. Nagegaan wordt of de meningen van de respondentgroepen vòor de interventies 
overeenkomen of verschillen met de reacties na de interventies c.q. of van het bevorderen van zorg voor zelfstandigheid sprake is.

\subsection{Methodologische context}

Uit de probleemstelling moet volgens Swanborn (1990) blijken welke vorm van onderzoek nodig is. In dit onderzoek zijn opvattingen geïnventariseerd over wat zorg voor zelfstandigheid inhoudt. Het onderzoek kan om die reden getypeerd worden als descriptief onderzoek. In het onderzoek naar zorg voor zelfstandigheid zijn ook exploratieve stappen gezet en is aan 'grounded theory research' gedaan (Baker, 1999):

because of this circular process of deriving theoretical ideas inductively from data and than returning to the data to verify those ideas, the theories are considered to be grounded in the data.

De beantwoording van de vraag of er veranderingen in de zorg voor zelfstandigheid kunnen optreden, duidt ook op een vergelijkende (quasi)experimentele studie. Er zijn derhalve meerdere vormen van onderzoek nodig geweest voor de behandeling van de probleemstelling.

De opvattingen van een kleine groep respondenten over wat zorg voor zelfstandigheid is, zijn in deze studie gebundeld, in categorieën ondergebracht en nader gespecificeerd. Vervolgens zijn ze onder rubrieken in een vragenlijst vervat en hebben grotere groepen respondenten de gelegenheid gekregen hun opvattingen over de dagelijkse zorg voor zelfstandigheid aan te geven en zo nodig toe te lichten. Deze informatie is het vertrekpunt van dit onderzoek: de status quo is beschreven en beoordeeld op wenselijkheid en of deze voldoet aan de verwachtingen en normen die op basis van de literatuur en regelgeving uit de voorgaande hoofdstukken kunnen worden afgeleid. Hiermee is de eerste meting van opvattingen afgesloten en is inzicht ontstaan in wat in de dagelijkse praktijk van het verzorgingshuis onder zorg voor zelfstandigheid wordt verstaan.

Op grond van de resultaten en conclusies van de eerste meting is een interventieprogramma ontwikkeld met het doel de beoogde veranderingen aan te brengen. De totale onderzoeksgroep is in tweeën gesplitst: een experimentele en een controle groep.

Daarmee heeft deze studie ook het karakter van een toetsend onderzoek gekregen. Bij toetsend onderzoek wordt aan de hand van uit theorie afgeleide hypothesen een vraagstelling geformuleerd die empirisch wordt getoetst. Er worden hoge eisen gesteld aan reproduceerbaarheid, interne en externe validiteit en betrouwbaarheid van het gebruikte instrumentarium (Malhotra, 1999). Er moet volgens Baker (1999) sprake zijn van een hoge 
mate van 'reliability', dat door haar wordt gedefinieerd als 'the degree to witch a measurement procedure produces similar outcomes when it is repeated'.

Voor de beantwoording van het laatste deel van de probleemstelling, aangaande het bevorderen van de zorg voor zelfstandigheid, moet vanwege de genoemde eisen voor het uitvoeren van een toetsend onderzoek sprake zijn van een theoretisch kader (werking van mechanismen die zelfstandigheid bevorderen dan wel belemmeren); er moeten hypothesen uit afgeleid kunnen worden (gerichte interventies zullen de zorg voor zelfstandigheid bevorderen) en het gewenste eindniveau moet worden gespecificeerd, namelijk de mate van zorg voor zelfstandigheid van bewoners en het verschil hierin tussen de periode voor en na de interventies. Wanneer een interventie bij een gedeelte van de bewoners in het zorgcentrum wel wordt uitgevoerd en bij een ander gedeelte niet zal moeten kunnen worden nagegaan worden of de interventie het gewenste effect geeft en of veranderingen niet door andere (non specifieke) factoren zijn opgetreden. Een toetsend onderzoek maakt gebruik van een experimenteel design (Baker, 1999), zoals bijvoorbeeld het 'Pretest posttest controle groep design'. Schematisch:

\begin{tabular}{|l|l|l|l|}
\hline Groep & Meting & Interventie & meting \\
\hline Experimentele groep & ja & $\mathrm{Ja}$ & $\mathrm{Ja}$ \\
\hline Controle groep (TAU-conditie) & ja & Nee & $\mathrm{Ja}$ \\
\hline
\end{tabular}

Tabel: Pretest posttest controle groep design

Bij de experimentele groep wordt het interventieprogramma uitgevoerd en de controle groep krijgt de gebruikelijke 'behandeling' (TAU- conditie). De experimentele groep bestaat uit 3 verzorgingsafdelingen en de controlegroep uit vier. Per afdeling bestaat derhalve steeds dezelfde conditie om onderlinge beïnvloeding te vermijden.

Het doel van het interventieprogramma is het bevorderen van de zorg voor zelfstandigheid. Dit programma is in twee achtereenvolgende fases doorlopen:

1. de fase responsieve evaluaties: de resultaten van de inventarisatie van opvattingen uit de eerste meting zijn besproken met groepen respondenten. De respondenten konden aangeven of en in welke mate ze zich herkenden in de resultaten en of ze de opvattingen wilden nuanceren. De gesprekken scherpten de inzichten aan over wat zorg voor zelfstandigheid inhoudt en benadrukten het belang van een actieve participatie van de meest belanghebbenden over het thema zorg voor zelfstandigheid. Het deelnemen aan de gespreksgroepen was voor bewoners al een uiting van zorg voor zelfstandigheid en door de bewoners en verzorgenden zo veel 
mogelijk bij de evaluatie te betrekken is de kans op het realiseren van gewenste verbeteringen groter;

2. de fase interviews over individuele zorgafspraken: per bewoner is een document opgesteld waarin zijn levensverhaal naar voren komt en waarin afspraken zijn vervat over de activiteiten die worden verricht om de zorg voor zelfstandigheid te waarborgen. Deze afspraken zijn in het zorgdossier opgeslagen en bij de bewonersbesprekingen doorgenomen en geëvalueerd.

Het onderzoek van deze studie vond plaats in de praktijk van verzorgingshuizen. Praktijkonderzoek kent beperkingen in de mate waarin mogelijke 'confounders' kunnen worden gecontroleerd of gemanipuleerd. De basiselementen van een toetsend onderzoek waren niettemin aanwezig: er was een eerste meetmoment of voormeting waarop alle respondenten zijn bevraagd naar hun opvatting over zorg voor zelfstandigheid; het interventieprogramma heeft de omstandigheden van een deel van de respondenten beïnvloed; in gespreksgroepen is nagegaan hoe de opvattingen van de experimentele groep zich verhouden tot de algemene opvattingen bij de eerste meting en zijn voorstellen voor verbetering van zorg voor zelfstandigheid aangedragen; in interviews is op individueel niveau besproken welke invulling aan de zorg voor zelfstandigheid van de bewoner gegeven kan worden. Vervolgens heeft een tweede meting plaatsgevonden en is nagegaan of de opvattingen over zorg voor zelfstandigheid veranderd zijn. De vraag of verschillen in de opvattingen tussen de eerste en tweede meting (uitsluitend) zijn toe te schrijven aan het interventieprogramma kan evenwel niet duidelijk beantwoord worden. Sommige mogelijke beïnvloedende factoren kunnen gecontroleerd worden, zoals of de zorgzwaarte van de bewoners is toegenomen en of hun gevoel van afhankelijkheid daardoor veranderd is, maar de invloed van bijvoorbeeld personeelswijzigingen, mutaties van bewoners of van verandering van aansturing van de verzorgingsafdelingen zijn niet gemeten, terwijl ze de verkregen data van de tweede meting en de interpretaties ervan wel kunnen beïnvloeden. Het feit dat verzorgenden van controleafdelingen op de hoogte waren van de implementatie van een interventieprogramma op de experimentele afdelingen kan ook van betekenis zijn geweest voor hun reacties. Daarom is de wetenschappelijke eis van reproduceerbaarheid niet te verwezenlijken. Door het werken met een controlegroep wordt wel geprobeerd om de non-specifieke factoren van beide condities tegen elkaar te laten wegvallen, maar dit is niet te controleren en conclusies dienen met enige terughoudendheid getrokken te worden. Ook de externe validiteit is moeilijk aan te geven waardoor generalisatie van de resultaten niet zonder meer is uit te voeren.

Naast de gehanteerde begrippen 'descriptief- ', 'exploratief- ' en 'toetsend onderzoek' is in deze paragraaf de aanduiding 'praktijkonderzoek' gebruikt en zijn ook de begrippen 
kwalitatief en kwantitatief onderzoek op het in deze studie gebezigde onderzoeksontwerp van toepassing. In de volgende paragraaf wordt dit ontwerp nader toegelicht.

\subsection{Het onderzoeksontwerp: $k$ wantitatief en kwalitatief onderzoek}

\section{Kwantitatief onderzoek}

Wester $(2000,1995)$ merkt op dat kwantitatief onderzoek niet geassocieerd moet worden met cijfers en kwalitatief onderzoek niet met woorden. Het onderscheid wordt bepaald door het meetniveau dat kan worden gehanteerd. Kwantitatief onderzoek is het toewijzen van kwantitatieve waarden aan kwaliteiten. De wijze waarop opvattingen over de zorg voor zelfstandigheid in deze studie zijn beschreven en geëxploreerd, kan worden aangeduid als een combinatie van kwalitatief en kwantitatief onderzoek. Meningsvorming over wat onder zorg voor zelfstandigheid wordt verstaan en het toevoegen van een eigen opvatting, wanneer de gegeven antwoordcategorieën in een vragenlijst niet van toepassing zijn, zijn voorbeelden van kwalitatief onderzoek, terwijl het registreren van het aantal respondenten dat zich herkent in een antwoordcategorie als kwantitatief onderzoek bestempeld wordt.

\section{Kwalitatief onderzoek}

Kwalitatief onderzoek onderscheidt zich in de literatuur van kwantitatief onderzoek door de betrokkenheid van de onderzoeker bij het onderzoeksobject, door een open onderzoeksprocedure die gericht is op het directe contact met de werkelijkheid en door het strategisch combineren van verschillende methoden om meer facetten van de werkelijkheid te belichten en op elkaar te betrekken (Maso en Smaling, 1990; Wester, 1995). Malhotra definieert kwalitatief onderzoek als volgt (1999):

Qualitative research is unstructured, exploratory research methodology bases on small samples that provides insights and understanding of the problem setting.

Denzin en Lincoln (1994) leggen in hun definitie van kwalitatief onderzoek niet zozeer de nadruk op het effect ervan maar meer op de methode van onderzoek:

Qualitative research is multimethod in focus, involving an interpretative, naturalistic approach to its subject matter.

Maso en Smaling (1990) stellen dat kwalitatief onderzoek zich in eerste instantie baseert op de wereld zoals de onderzochte subjecten die definiëren, beleven of constitueren. Deze studie voldoet aan die eis van kwalitatief onderzoek, omdat opvattingen of meningen van respondenten over het dagelijks wonen, leven of werken in het verzorgingshuis worden geïnventariseerd. Opvattingen zijn persoonsgebonden en volgens Smaling (1990) is het deze uniciteit en variaties in opvattingen, in plaats van de frequentieverdelingen of 
statistische variantie, die kenmerkend zijn voor kwalitatief onderzoek. De onderzoeker heeft, in zijn hoedanigheid van algemeen directeur van de verzorgingshuizen waar het onderzoek plaatsvond, een grote betrokkenheid bij het onderzoeksobject c.q. bij de opvattingen van bewoners en zorgverleners. Hierin schuilt het risico dat onvoldoende afstand wordt genomen van het onderzoeksobject c.q. van de opvattingen van bewoners en zorgverleners. De keerzijde is dat situaties en reacties goed invoelbaar zijn. Triangulatie biedt volgens Smaling (1990) de mogelijkheid om de betrokkenheid bij het onderzoeksobject niet tot gevolg te laten hebben dat de variatie in de werkelijkheid onvoldoende wordt blootgelegd. In deze studie is gebruik gemaakt van verschillende vormen van triangulatie:

1. van datatriangulatie, waarbij verschillende gegevensbronnen worden gecombineerd. Door in de vragenlijst, die in vraaggesprekken met bewoners is besproken, en in de enquête die aan verzorgenden is overhandigd het vraagstuk 'zorg voor zelfstandigheid' te splitsen in het thema 'informatievoorziening', het thema 'keuzevrijheid' en het thema 'houding van het personeel' is geprobeerd te voorkomen dat onderzoeksresultaten bij de verschillende thema's zonder empirische evidentie worden gegeneraliseerd. Daarnaast zijn de vragenlijsten zo opgesteld dat gesloten vragen, half open vragen, open vragen en statements gecombineerd worden;

2. van methodentriangulatie, waarbij meerdere onderzoeksmethoden worden gebruikt. Met behulp van de methode van concept mapping is het vraagstuk 'zorg voor zelfstandigheid' bediscussieerd, geconceptualiseerd en nader geconcretiseerd (Swanborn, 1999); in vraaggesprekken is aan de hand van semi-gestructureerde en open vragen aan bewoners de mogelijkheid geboden hun opvattingen over de thema's te nuanceren;

3. van onderzoekerstriangulatie, waarbij meerdere onderzoekers zich op het onderzoeksobject richten. De schrijver van dit proefschrift heeft zelf geen gegevens verzameld in het rechtstreeks contact met respondenten. De concept mapping is door een ervaren onderzoeker afgenomen; de vraaggesprekken met bewoners en de groepsgesprekken met bewoners en zorgverleners zijn door getrainde interviewers gevoerd.

Triangulatie heeft nog een andere betekenis. Door verschillende vormen van triangulatie (multiple triangulatie) toe te passen kan volgens Maso en Smaling (1990) betrouwbaarheid en validiteit worden verkregen. Dat betekent dat de kans gering is dat de onderzoeksresultaten door toevalsfouten, respectievelijk door toevalsfouten en systematische fouten, de werkelijkheid vertekenen en dat de conclusies staande gehouden 
kunnen worden (interne validiteit). Pool (1995) voegt daar aan toe dat door triangulatie ook de generaliseerbaarheid, externe validiteit of overdraagbaarheid van de resultaten naar vergelijkbare situaties wordt verhoogd; een replica van het onderzoek zal dezelfde onderzoeksresultaten moeten opleveren. Van der Kamp (2000) plaatst vraagtekens bij de betekenis die aan triangulatie gegeven wordt en stelt dat er bij de diverse vormen van triangulatie geen duidelijke procedures of criteria zijn om te bepalen of uit verschillenden bronnen verkregen gegevens of perspectieven elkaar daadwerkelijk ondersteunen. Swanborn (1990) plaatst kanttekeningen bij het uitgangspunt dat het onderzoek repliceerbaar moet zijn, dat andere onderzoekers bij herhaling van het onderzoek tot dezelfde onderzoeksresultaten zullen moeten komen. Niet alleen geven de omstandigheden waarin het onderzoeksobject zich bevindt daar niet de mogelijkheid toe, ook de situatie van de respondenten wijzigt en bij elk onderzoek brengt de onderzoeker zichzelf mee. In de setting van het verzorgingshuis verandert de mate van zorg die een bewoner nodig heeft gedurende zijn verblijf en ook zijn opvattingen over zorg voor zelfstandigheid kunnen veranderen. Uit deze, wat Swanborn (1990) noemt, 'principiële dynamiek van de werkelijkheid' mag niet de conclusie worden getrokken dat onderzoeksresultaten beïnvloed mogen worden door bias van de onderzoeker en van toevallige omstandigheden. Van belang is dat de onderzoeker duidelijk aangeeft welke onderzoeksstappen zijn gezet en dat procedures geëxpliciteerd worden. In paragraaf 7.4 .3 zijn de onderzoekstappen van deze studie beschreven.

Met verwijzing naar Guba en Lincoln acht Swanborn het van belang dat sprake is van 'credibility', dat de onderzoeksconclusies waar zijn voor de respondenten en de onderzochte situatie. Triangulatie, het gebruik van audio-visuele middelen en member checks, oftewel het voortdurend aan de respondenten voorleggen van conclusies, zullen volgens Swanborn de credibility verhogen. Om de geloofwaardigheid van de beschrijving van opvattingen te verhogen is bij de verslaggeving van de onderzoeksresultaten van deze studie herhaaldelijk gebruik gemaakt van citaten van uitspraken van respondenten; de resultaten van de gesprekken bij de concept mapping zijn uitgeschreven en vastgelegd; de vragenlijsten voor de onderzoeksronden zijn in proefinterviews getoetst en bij aanvang van de eerste ronde responsieve evaluatie is, als een vorm van member check, aan de deelnemers gevraagd te reageren op de resultaten van de eerste onderzoeksronde. 


\subsubsection{Inleiding}

Bestudering van literatuur over wetenschappelijk onderzoek naar de opvatting van bewoners en verzorgenden in Nederlandse verzorgingshuizen over wat zorg voor zelfstandigheid inhoudt, hoe zorg voor zelfstandigheid beleefd wordt en hoe deze zorg kan worden verbeterd, laat zien dat geen materiaal beschikbaar is dat op de voor deze studie geformuleerde probleemstelling is gericht. Wel zijn er onderzoeken die direct of indirect één of meer deelvragen behandelen of die zich op dezelfde respondenten richten. In de hoofdstukken 3 en 4 van deze studie is verwezen naar onderzoek van Van Loveren (1995) over psychosociale problematiek van ouderen in verzorgingshuizen en naar onderzoek van het Sociaal Cultureel Planbureau (1997) over verwachtingen die ouderen hebben van een eventuele opname in een voorziening voor ouderenzorg. Andere onderzoekers richten zich meer op de motieven die ten grondslag liggen aan de keuze voor plaatsing in een zorginstelling voor ouderen (Steverink, 1996; Wielink et al., 1995; Te Wierik en Frederiks, 1990). De landelijke organisatie Bewonerscommissie Bejaardenoorden (1998) onderzocht wat verzorgingshuisbewoners goede zorg vinden, zonder te vragen of die zorg ook geleverd wordt en De Veer en Kerkstra (1998) lieten bewoners van verpleeghuizen vertellen wat zij van belang vinden in de zorg en of de zorg goed gevonden wordt. In verpleeghuizen is onderzoek gedaan naar aan-zelfstandigheid-gerelateerde onderwerpen: Dijkstra (1998) ontwikkelde een instrument om zorgafhankelijkheid te meten bij verstandelijk gehandicapten en verpleeghuisbewoners; Proot (2000) onderzocht de autonomie van CVApatiënten in verpleeghuizen en Schrijnemaekers (2002) en Van der Kooij (2003) gingen na of belevingsgerichte zorg bij dementerende ouderen in verzorgingshuizen respectievelijk verpleeghuizen tot een vermindering van gedragsproblemen bij ouderen en een verhoging van de arbeidstevredenheid bij het verzorgend personeel leiden. Bijsterveld (2001) onderzocht de wensen en behoeften van ouderen die thuiszorg genieten en Becker (2003) ging na wat gelukbevorderende zorg inhoudt voor de medewerkers van zijn instelling en voor de ouderen die gebruik maken van zijn woonzorgvoorzieningen. De onderzoekscommissie Gezondheidszorg in Tel (GiT, 1996) ondervroeg bewoners en verzorgenden van verzorgingshuizen over wat kwalitatief goede zorg inhoudt. Dit gebeurde aan de hand van de methode van concept mapping. Uit het onderzoek kwam naar voren dat met name een op de behoefte van de bewoner afgestemde zorg van belang wordt gevonden, dat voldoende en bekwaam personeel gewenst wordt, dat bewoners respectvol bejegend willen worden, dat de kwaliteit van de woonvoorziening belangrijk is en dat bewoners invloed willen uitoefenen. De vraag in hoeverre de praktijk van alledag beantwoordt aan 
deze verwachtingen en wensen is niet onderzocht. Deze studie borduurt voort op de onderzoeksmethode en resultaten van de onderzoekscommissie GiT.

\subsubsection{Onderzoekslocatie en respondenten}

Het onderzoek vond plaats op zeven verzorgingsafdelingen van drie verzorgingshuizen en de bewoners en de teams van verzorgenden van die afdelingen vormden de groepen respondenten. Alleen die bewoners die mentaal in staat waren deel te nemen aan het onderzoek zijn benaderd. Dit betekent dat bewoners met (beginnende) dementie niet aan het onderzoek hebben deelgenomen. Of bewoners fysiek in staat zijn om deel te nemen, is een afweging die zij zelf hebben gemaakt.

\section{Onderzoekslocatie}

De drie verzorgingshuizen waar het onderzoek is verricht vallen onder één stichting. Ze zijn gesitueerd in Noord-Brabant, in de nabijheid van een stedelijk gebied. In twee van de drie huizen verblijven zowel ouderen die verpleging behoeven als ouderen die geïndiceerd zijn voor verzorging. Het derde verzorgingshuis biedt enkel verblijf aan verzorgingsbehoevende ouderen. In één verzorgingshuis verblijven naast 84 bewoners van verzorgingsappartementen, verdeeld over drie afdelingen, ook 44 verpleeghuisbewoners verdeeld over twee afdelingen. Van de 84 verzorgingshuisbewoners nemen er om mentale redenen ongeveer 18 deel aan een project individuele meerzorg en 12 in een project aanvullende zorg in groepsverband. In een ander verzorgingshuis worden 90 bewoners verzorgd op drie verzorgingsafdelingen en 15 verpleegd op één afdeling. Ook dit huis heeft aanvullende zorg voor een groep van 12 bewoners en voor ongeveer 10 bewoners een andere vorm van meerzorg; in het derde verzorgingshuis dat bij het onderzoek is betrokken, worden 20 bewoners verzorgd.

\section{Samenstelling van de respondentgroep bewoners}

Van de 150 bewoners die benaderd zijn om aan het onderzoek deel te nemen, deden er van de drie verzorgingshuizen bij de eerste meting 106 mee: 85 vrouwen en 21 mannen, een respons van ruim 70 procent. 7 bewoners gaven aan geen belangstelling te hebben voor deelname en 37 bewoners voelden zich om uiteenlopende redenen fysiek of mentaal niet in staat om mee te doen. De gemiddelde leeftijd van de respondentgroep was 85,2 jaar. Ten tijde van het interview verbleven deze bewoners gemiddeld 3,5 jaar in het verzorgingshuis. 87 bewoners zijn alleenstaand, 70 daarvan zijn weduwe of weduwnaar, 15 bewoners zijn niet gehuwd en 2 bewoners zijn gehuwd geweest en gescheiden. 19 bewoners zijn nog gehuwd. Bijna zestig bewoners hebben enkel lager (beroeps)onderwijs genoten; iets meer 
dan eenderde heeft een middelbare (beroeps) opleiding gevolgd en tien bewoners een hogere (beroeps) opleiding. 77 bewoners hebben een jaarinkomen van minder dan 23.000 euro; 24 bewoners hebben een inkomen tussen 23.000 en 34.000 euro en vijf bewoners hebben een inkomen van meer dan 34.000 euro. De zorgzwaarte van de bewoners, uitgedrukt in het gemiddeld aantal zorgminuten dat per dag aan een bewoner wordt besteed, was bij de eerste onderzoeksronde op de verzorgingsafdelingen ongeveer gelijk. De gemiddelde verblijfsduur was bij de voormeting ruim 4,5 jaar, bij de nameting ongeveer 3 jaar.

Tabel 7.1: gegevens van de respondentgroep bewoners $(\mathrm{n}=106)$

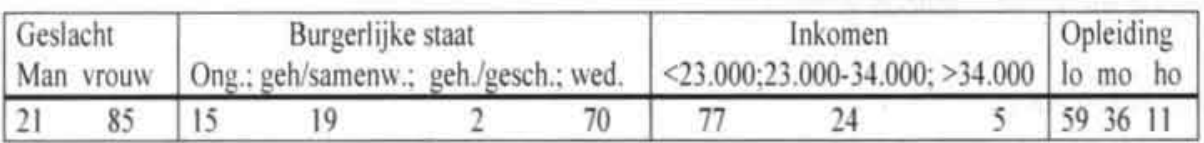

De gemiddelde leeftijd van de bewoners uit de onderzoeksgroep komt redelijk overeen met de gemiddelde leeftijd van verzorgingshuisbewoners, die 84 jaar is en waarbij $55 \%$ ouder is dan 85 jaar. In Ruimte voor zorg (2000) en in het Brancherapport (Arcares, 2000) wordt daarenboven gesteld dat tachtig procent van de verzorgingshuisbewoner vrouw is en dat eenzelfde percentage alleenstaand is. Huijsman (1994) merkt op dat zelfs negentig procent van ouderen die gebruik maken van intramurale instellingen alleenstaand is. Voor wat betreft de opleiding van ouderen stelt het Sociaal Cultureel Planbureau (2001) dat in het jaar 2000 vijftig procent van alle 75-plussers alleen lager onderwijs heeft gevolgd. Met het stijgen van de leeftijd loopt dit percentage verder op. Het merendeel van de hoogbejaarden moet volgens het SCP met een relatief beschouwd laag inkomen zien rond te komen; van de groep 80-plussers vult bijna $28 \%$ van de ouderen het AOW aan met bezit uit (verkoop van ) eigen woning.

De onderzoeksgroep vormt een goede afspiegeling van deze referentiegegevens. Tachtig procent is vrouw, $82 \%$ is alleenstaand en de gemiddelde verblijfsduur is 3,5 jaar, bij een gemiddelde leeftijd van even boven de 85 jaar. In de onderzoeksgroep heeft $56 \%$ alleen lager onderwijs gevolgd en zit $73 \%$ in de laagste inkomenscategorie.

Aan de tweede meting nemen 85 bewoners deel. 21 minder dan in de eerste ronde als gevolg van overplaatsing naar verpleegafdelingen, door overlijden of vanwege gezondheidsredenen. Van de 85 bewoners verblijven er 50 op de vier controleafdelingen, veertig vrouwen en tien mannen. Hun gemiddelde leeftijd is bijna 88 jaar; de jongste is 74 en de oudste 98 . De overige 35 respondenten, 26 vrouwen en 9 mannen, verblijven op de drie experimentele verzorgingsafdelingen. Hun gemiddelde leeftijd is ongeveer 86 jaar; de 
jongste is 77 en de oudste 97 . De zorgzwaarte is in de tweede ronde hoger dan in de eerste ronde.

\section{Samenstelling van de respondentgroep verzorgend personeel}

De personele samenstelling van de verzorgingshuizen is ongeveer gelijk; naast verzorgenden, zijn helpenden en huishoudelijke medewerkenden werkzaam en de afdelingen worden direct aangestuurd door verpleegkundigen of ziekenverzorgenden. Alleen de functionarissen die gekwalificeerd zijn om verzorgende werkzaamheden te verrichten, te weten verpleegkundigen, verzorgenden en helpenden, hebben aan het onderzoek deelgenomen. Vaste nachtdiensten van de afdelingen hebben niet meegedaan, omdat zij maar een beperkt contact met de bewoners onderhouden. Van de 59 personeelsleden die benaderd zijn voor het onderzoek hebben er aan de eerste meting van het onderzoek 50 meegedaan, een respons van bijna $85 \%$. Van één verzorgingshuis namen 22 medewerkenden deel, van het tweede 19 en van het derde, kleine verzorgingshuis $9.70 \%$ van hen heeft de opleiding van verzorgende gevolgd. Ziekteverzuim en zwangerschapsverlof waren de belangrijkste redenen van non-respons. $62 \%$ van de respondenten heeft meer dan tien jaar ervaring; $44 \%$ werkte tussen de 29 en 36 uur en $33 \%$ had een dienstverband tussen 17 en 28 uur. De arbeidsomvang van de respondenten en hun opleidingsachtergrond komen overeen met landelijke cijfers hieromtrent (zie ook hoofdstuk 3.2.2). De gemiddelde leeftijd en het aantal jaren werkervaring ligt iets boven het gemiddelde.

Tabel 7,2:Gegevens van de respondentgroep verzorgend personeel $(n=50$ : vrouw $=49$; $\operatorname{man}=1$ )

\begin{tabular}{|c|c|c|c|l|c|c|c|c|c|c|c|}
\hline \multicolumn{4}{|l|}{ Leeftijdscategorie (\%) } & \multicolumn{4}{l|}{ Functie } & \multicolumn{4}{|c|}{ Aantal jaren ervaring (\%) } \\
\hline $20-29$ & $30-39$ & $40-49$ & $50-53$ & Verz. & Verpl/Tl & Help. & $0-1$ & $1-3$ & $3-5$ & $5-10$ & $>10$ \\
\hline 22 & 26 & 33 & 19 & 34 & 10 & 6 & 7 & 9 & 9 & 13 & 62 \\
\hline
\end{tabular}

Landelijk beschouwd werkt $75 \%$ in een deeltijdfunctie, hetgeen niet veel afwijkt van het dienstverband van de respondenten. Op verzorgingsafdelingen van verzorgingshuizen in Nederland zijn weinig mannen werkzaam. Een aantal mannen is werkzaam in ondersteunende diensten als de voedingsdienst, de technische dienst en de administratieve dienst, waardoor de verhouding vrouwen - mannen op 85-15 komt (Jaarboek ouderenzorg, 1997). De leeftijd van de respondenten ligt iets boven het landelijk gemiddelde, waar $55 \%$ jonger is dan 35 jaar. Ook uit het aantal jaren ervaring in de zorgsector van de respondenten is op te maken dat de leeftijd van de respondenten van de verzorgingsafdelingen in de drie verzorgingshuizen wat boven het landelijk gemiddelde ligt. Twaalf procent van de respondenten van de teams heeft een opleidingsachtergrond als 'helpende'; twintig procent 
heeft een verpleegkundige achtergrond of is werkzaam als teamleider. Landelijk heeft ongeveer tien procent een verpleegkundige achtergrond. Omdat slechts de helft van de teamleiders een verpleegkundige achtergrond heeft, loopt het percentage verpleegkundigen uit de onderzoeksgroep in de pas met het landelijk percentage.

Aan de tweede meting nemen 44 verzorgend teamleden deel: 24 van de controleafdelingen, waarvan 22 vrouwen en 2 mannen en 20 van de experimentele afdelingen, 19 vrouwen en 1 man. De omvang van het dienstverband is op de controleafdelingen 28.7 uur, op de experimentele afdelingen 22.7 uur. De afname van het aantal respondenten is veroorzaakt door beëindiging van het dienstverband of door zwangerschapsverlof.

\subsubsection{Onderzoeksopzet en-uitvoering}

In deze paragraaf worden de onderzoeksstappen nader toegelicht. De periode van voormeting (stap $1 \mathrm{t} / \mathrm{m} 5$ ) startte eind 2000 en eindigde in juni 2002; de interventieperiode liep in fases: van september tot en met december 2002 (stap 6), en van januari 2003 tot juni 2003 (stap 7); van juni tot en met september 2003 vond de fase van nameting plaats (stap 8 $\mathrm{t} / \mathrm{m} 11)$.

Tabel 7.3: Onderzoeksfasen en -stappen

\begin{tabular}{|lll|}
\hline \multicolumn{1}{|c|}{$\begin{array}{c}\text { Onderzoeksfase 1 } \\
\text { voormeting }\end{array}$} & \multicolumn{1}{c|}{$\begin{array}{c}\text { Onderzoeksfase 2 } \\
\text { interventieprogramma }\end{array}$} & \multicolumn{1}{c|}{$\begin{array}{c}\text { Onderzoeksfase 3 } \\
\text { nameting }\end{array}$} \\
1.concept mapping & 6.responsieve evaluatie & 8.construeren van vragenlijsten \\
2.construeren vragenlijsten & 7.individuele zorgafspraken & 9.proefinterviews \\
3.proefinterviews & & 10.interview bewoners en \\
4.interview bewoners en & & enquête onder verzorgenden \\
enquête onder verzorgenden & & 11.verzamelen en analyseren van \\
5.verzamelen en analyseren van & & onderzoeksgegevens \\
onderzoeksgegevens & & \\
\hline
\end{tabular}

Onderzoeksfase 1: de voormeting

\section{Concept mapping}

In de genoemde literatuur treffen we geen vragenlijsten of instrumenten aan waarmee op de probleemstelling kon worden ingegaan. Dit betekent dat deze zelf geconstrueerd dienden te worden. Er is voor gekozen om de opvattingen van bewoners en verzorgenden over zorg voor zelfstandigheid, die in de concept mapping geventileerd werden, de inhoudelijke basis te laten zijn van de vragenlijst. 
Concept mapping is een groepsinterview waarin op gestructureerde wijze items worden gegenereerd die de belangrijkste opvattingen van de deelnemers over het onderwerp representeren (Swanborn, 1999; Novak, 1990). In deze studie zijn drie groepen samengesteld: 11 bewoners van de drie onderzochte verzorgingshuizen en 12 van de 100 ouderen die op de wachtlijst voor het verzorgingshuis stonden, vormden elk een groep. De derde groep werd gevormd door 9 verzorgenden; drie van elk verzorgingshuis. Elke sessie vond in een verzorgingshuis plaats en heeft ongeveer drie uur in beslag genomen. Tussen december 2000 en februari 2001 zijn 3 bijeenkomsten belegd: één voor bewoners die binnen het zorgcentrum wonen, één voor personen die op de wachtlijst staan en één voor de groep verzorgenden. De bewoners die deelnamen, maakten allen deel uit van de cliëntenraden van de drie verzorgingshuizen. De onderzoeker had hun gevraagd om deel te nemen, omdat uit hoofde van hun lidmaatschap van de cliëntenraad verondersteld mocht worden dat zij wisten welke opvattingen er onder bewoners leefden. De verzorgenden die deelnamen, hebben zichzelf aangemeld nadat de leidinggevenden van de verzorgingsafdelingen de belangstelling gepeild had. Ofschoon bewoners en verzorgenden het meest direct betrokken zijn bij het onderwerp is ook een groep ouderen benaderd die op de wachtlijst voor de verzorgingsafdelingen stonden. De opnameconsulenten van de verzorgingshuizen die de wachtlijstbegeleiding voor hun rekening nemen, hebben contact gezocht met de eerste twintig mensen die bovenaan de wachtlijst stonden en waarvan, gezien het jaarlijks verloop in de huizen, verwacht werd dat zij binnen een jaar geplaatst zouden worden. Er bleek veel belangstelling te bestaan voor deelname.

Aan de deelnemers is gevraagd wat 'zelfstandigheid' voor hen betekent als je dit begrip in verband brengt met het dagelijks leven van bewoners in verzorgingshuizen. Dit is gebeurd met behulp van de megaplanmethode. Hierbij is aan de deelnemers allereerst gevraagd hun eigen ideeën en gedachten over zelfstandigheid, en hoe het verzorgingshuis die kan bewaken of bevorderen, op papier te zetten door van belang zijnde items of begrippen te noteren. Vervolgens zijn alle genoteerde items verzameld en de totale verzameling is aan de deelnemers voorgelegd met de vraag deze te ordenen naar inhoud (welke horen bij elkaar) en vervolgens naar belangrijkheid. Op deze wijze zijn de volgende clusters of kernbegrippen gevormd die volgens de deelnemers van belang zijn in het kader van zorg voor zelfstandigheid:

- informatieverstrekking. Gesteld werd dat bewoners moeten weten wat ze kunnen verwachten van het verzorgingshuis en het verzorgingshuis moet op de hoogte zijn van de verwachtingen, wensen en behoeften van de bewoner. Het goed in beeld hebben van wat een bewoner kan en wil en de schommelingen daarin werd door alle groepen als hoogste prioriteit gezien;

- keuzevrijheid kreeg de op één na hoogste prioriteit: bewoners moeten de 
mogelijkheid hebben keuzes te maken en zoveel mogelijk het eigen leven te leiden in het verzorgingshuis;

- bejegening door en aandacht van de verzorgenden. De deelnemers vinden dat bewoners zich gerespecteerd moeten voelen en moeten merken dat op hun behoeften kan worden ingegaan. Daarvoor is nodig dat er voldoende personeel is en dat het personeel deskundig is;

- woon- en leefomgeving: bewoners moeten privacy ervaren en zich veilig voelen. De woon- en leefomgeving moet op orde zijn en er moeten geen mankementen zijn die niet worden opgemerkt of niet tijdig worden gerepareerd.

\section{Het construeren van vragenlijsten}

Op basis van de kernbegrippen is een vragenlijst geconstrueerd, waarbij onder elk cluster vragen zijn geformuleerd die de kernbegrippen verfijnen en die ook in de concept mapping aan de orde zijn gekomen. Daarnaast zijn vragen opgenomen waarmee de behoefte aan zorg kan worden aangegeven en een rubriek met persoonsgegevens.

De vragenlijst is in twee versies opgesteld; een versie voor bewoners en één voor verzorgenden (zie bijlage 1 en 2). Bij de vragen bij de kernbegrippen is op de vragenlijst voor de bewoners gevraagd aan te geven welke uitspraak of statement doorgaans het meest van toepassing is, terwijl aan verzorgenden is gevraagd zich te verplaatsen in de bewoner en aan te geven wat de opvatting van de bewoners hieromtrent zal zijn. De open vragen geven de bewoners en verzorgenden de gelegenheid nadere informatie te verschaffen over hun woon- en leefomgeving of werksituatie in het verzorgingshuis.

\section{Proefinterviews}

Alvorens de vragenlijsten zijn uitgezet, hebben proefinterviews plaatsgevonden. De vragenlijsten werden afgenomen door interviewers die hiertoe twee instructie bijeenkomsten hebben gekregen van een extern begeleider om er voor te zorgen dat de interviews zo uniform mogelijk zouden verlopen. Alle interviewers hadden ervaring met de verzorging van bewoners in verzorgingshuizen. Na de eerste instructie hebben de interviewers één of twee proefinterviews afgenomen en de ervaringen in de tweede instructiebijeenkomst besproken. Dit leidde tot een bijstelling van de vragenlijst, toevoegingen van enkele vragen en verduidelijking van sommige antwoordcategorieën. Vervolgens is een selectie gemaakt van welke bewoners an het interview of vraaggesprek zouden kunnen deelnemen. Bewoners die door hun geestelijke toestand niet in staat werden geacht om de vragen te beantwoorden, zijn uitgezonderd van deelname. Hiertoe behoren in 
ieder geval de bewoners die aanvullende zorg kregen en die op de verpleegafdelingen verbleven.

\section{Interview van bewoners en enquête onder het verzorgend personeel}

Alle interviews of vraaggesprekken zijn afgenomen in de periode september - december 2001. Hiervoor zijn ruim 150 bewoners benaderd met een schriftelijke uitleg over het onderzoek in de vorm van informed consent. De bewoners die bereid waren om deel te nemen tekenden dit informed consent. In totaal is bij 106 bewoners een interview afgenomen, een respons van 70 procent. De redenen voor niet deelname waren: de bewoner is niet bereid om deel te nemen; hij voelt zich niet in staat om aan het interview deel te nemen in verband met lichamelijke of psychische problemen of hij verblijft tijdelijk elders, bijvoorbeeld in het ziekenhuis. Interviewers hebben de vragenlijst besproken in een face-toface interview met de bewoner. Om die reden wordt gesproken van 'interview' of 'vraaggesprek'. Tijdens de afname van de interviews zijn regelmatig bijeenkomsten gehouden om de voortgang te bewaken en er op toe te zien dat alle interviews op een uniforme wijze verliepen.

Aan de verzorgenden van de drie verzorgingshuizen werd een vergelijkbare vragenlijst voorgelegd waarop zij schriftelijk konden aangeven of de zorg voor zelfstandigheid gewaarborgd is. Deze vragenlijsten zijn in de periode januari-februari 2002 verspreid. In totaal hebben 50 medewerkers de lijst ingevuld geretourneerd; een respons van 85 procent. Redenen van niet-deelname waren hier: ziekteverzuim, zwangerschapverlof, vakantie en in een enkel geval werkdruk.

\section{Het verzamelen en analyseren van onderzoeksgegevens}

In 2001 zijn in een periode van ongeveer twaalf weken de interviews of vraaggesprekken gevoerd en de schriftelijke vragenlijsten ingevuld. Nagegaan is hoeveel bewoners en verzorgenden dezelfde antwoordcategorieën hebben ingevuld en de overeenkomsten en verschillen zijn in percentages weergegeven. In de tekst van hoofdstuk 8 zijn sommige reacties van bewoners en verzorgenden bij half open vragen of bij open vragen, die beweringen bevestigen, nuanceren of tegenspreken, als citaten opgenomen. Vanuit de constatering dat de zorg voor zelfstandigheid verbetering behoeft, zowel wat betreft de informatievoorziening, de keuzevrijheid en de bejegening of houding van de verzorgenden, werd een interventieprogramma opgesteld en ingebracht. 
De groep bewoners en verzorgenden zijn in elk verzorgingshuis gesplitst in experimentele groepen, die aan het interventieprogramma deelnemen, en controlegroepen die daar niet aan deelnemen. Voor de experimentele groep werd een programma opgesteld voor interventies om de zorg voor zelfstandigheid te bevorderen:

- er werden responsieve evaluaties belegd waarin een onafhankelijke evaluator nader op de resultaten van de voormeting inging. Beoogd werd de deelnemers kennis te laten nemen van de resultaten van de voormeting en hen hier op te laten reageren waardoor de resultaten uit de vragenlijsten konden worden genuanceerd of bevestigd of waardoor de variëteit van opvattingen werd benadrukt. Daarnaast is nagegaan of overeenstemming kon worden bereikt over voorstellen voor verbetering van de zorg voor zelfstandigheid;

- uit de responsieve evaluaties kwam het voorstel om de verzorgenden schriftelijke afspraken te laten maken over de door bewoners gewenste zorg, om het zorgregistratiesysteem aan te passen en persoonsgericht te maken. Vervolgens werd het registratiesysteem aangepast, verzorgenden werden ermee vertrouwd gemaakt en in een face-to-face interview van een verzorgende met een bewoner is geprobeerd tot individuele zorgafspraken te komen.

Bij de onderzoeksstappen 6 en 7 wordt nader op het interventieprogramma ingegaan.

\section{Responsieve evaluatie: de deelnemers, de planning en de issues}

\section{De deelnemers}

Aan de twee ronden responsieve evaluaties hebben meerdere groepen deelgenomen: van één verzorgingsafdeling van elk van de drie verzorginghuizen heeft één groep bewoners geparticipeerd en één groep verzorgenden. Van de drie verzorgingshuizen namen in de eerste ronde in totaal 20 bewoners en 20 verzorgenden deel en in de tweede ronde 15 respectievelijk 18. Bewoners die niet aan de tweede ronde deelnamen, waren niet langer geînteresseerd in deelname of vonden het te inspannend. Twee verzorgenden die de tweede ronde niet deelnamen, waren verhinderd omdat zij dienst hadden. Daarnaast hebben de drie leidinggevende hoofden van de 3 deelnemende afdelingen gezamenlijk een groep gevormd. In totaal hebben derhalve 7 groepen deelgenomen. Van de bewoners van de experimentele afdelingen nam ongeveer dertig procent en van de verzorgenden gemiddeld vijfennegentig procent deel. Overeenkomstig de opvatting van Guba en Lincoln (Abma en Widdershoven, 2002) terzake de praktische organisatie van de responsieve evaluatie zijn de groepen 
homogeen samengesteld. Er is om meerdere redenen niet gekozen voor het samenstellen van groepen waarin zowel bewoners als verzorgenden en leidinggevenden zaten:

1. van de bewoners heeft $17 \%$ tijdens de vraaggesprekken van de eerste onderzoeksronde vermeld zich niet vrij te voelen om kritisch te zijn ten opzichte van de verzorgenden, vanwege mogelijke gevolgen van een kritische houding. Vermenging van groepen zouden gevoelens van onveiligheid kunnen versterken;

2. de kans dat verzorgenden minder vrij spreken als hun leidinggevende er bij zit, is aanwezig;

3. bij het samenstellen van heterogene groepen wordt de groep gemiddeld 15 deelnemers groot. Bij een dergelijke groepsgrootte is de kans aanwezig op nonparticipatie van individuele deelnemers en is het risico aanwezig dat betrokkenen als verschillende partijen in plaats van als gezamenlijk belanghebbenden het gesprek ingaan;

4. naarmate blijkt dat groepen uit dezelfde (deel)populatie eenzelfde resultaat opleveren, staat volgens Swanborn (1999) de onderzoeker sterker in de conclusie dat de resultaten betrouwbaar zijn.

De selectie van de participanten aan responsieve evaluatie is per groep verschillend geweest. Bij de samenstelling van de bewonersgroepen is geprobeerd het criterium van 'maximale variatie' te hanteren (Abma en Widdershoven, 2002). Het verzorgend personeel en de leidinggevende van de deelnemende verzorgingsafdeling stelden een groep van maximaal acht bewoners samen die naar hun mening binnen hun verzorgingsafdeling de diversiteit van opvattingen over de verschillende onderwerpen uit de vraaggesprekken uitdroegen. Anders gesteld: binnen de homogene groepen is zoveel mogelijk heterogeniteit in opvattingen nagestreefd. Alle bewoners die vervolgens zijn benaderd om deel te nemen, hebben die bereidheid getoond. Waar die bereidheid uit voortkwam, is niet geheel duidelijk. Wellicht hadden bewoners het gevoel niet te kunnen weigeren. Uit het verloop van de eerste ronde responsieve evaluatie bleek dat het doel ervan niet voor iedere bewoner even duidelijk was. Omdat op elke verzorgingsafdeling tussen de twintig en dertig bewoners verblijven, heeft het merendeel van de bewoners van de bij de responsieve evaluatie betrokken verzorgingsafdelingen niet deelgenomen. Vanwege mutaties op de verzorgingsafdelingen betekent dit overigens niet dat alle niet-deelnemende bewoners aan de eerste meting hebben meegedaan.

Op de experimentele verzorgingafdelingen werken acht tot tien verzorgenden. Elk teamlid is uitgenodigd voor deelname aan responsieve evaluatie. Aan de eerste ronde responsieve hebben uiteindelijk in totaal 22 verzorgenden van de drie teams deelgenomen. Alleen vaste nachtdiensten en een enkele avonddienst namen vanwege het tijdstip van de evaluatie niet 
deel. Bij de verzorgenden en leidinggevenden was de bereidheid om deel te nemen groot, omdat het als een volgende stap gezien werd in de ontwikkeling van een meer op de zelfstandigheid van de bewoner afgestemde zorg. Menig verzorgend teamlid nam op haar vrije dag deel. De rol van evaluator is niet door de onderzoeker vervuld, maar door iemand van buiten de organisatie die ervaring heeft in het begeleiden van groepen die in zorginstellingen wonen en werken. Als de onderzoeker de rol van evaluator op zich zou nemen, is de kans aanwezig op sociaal wenselijke en gereserveerde reacties van de deelnemers, gezien de positie die de onderzoeker in de organisatie bekleedt.

\section{De planning en procedure}

In de periode september 2002 tot januari 2003 zijn twee ronden responsieve evaluatie gehouden. In de periode september/oktober 2002 vond de eerste ronde plaats. De deelnemende groepen zijn door de evaluator bekendgemaakt met de resultaten van de vraaggesprekken met de bewoners en van de enquête onder het verzorgend personeel. Het doel hiervan is niet alleen de overdracht van informatie waar betrokkenen benieuwd naar zijn, maar ook een verantwoording en legitimatie voor de voorgestelde gespreksonderwerpen. Deze doelstelling moet duidelijk zijn voor de deelnemers, omdat anders vertekening van de resultaten kan ontstaan (Maso en Smaling, 1999). De diversiteit aan opvattingen die uit de onderzoeksresultaten naar voren is gekomen, zowel binnen de groepen bewoners en verzorgenden als tussen deze groepen, is door de evaluator ingebracht om daarover in de groepen te delibereren. Ook zijn de uitkomsten van de responsieve evaluaties van andere groepen door de evaluator ter sprake gebracht.

In de periode november/december 2002 is de tweede ronde responsieve evaluatie gehouden. De evaluator is met de deelnemers nagegaan of interpretaties, die in het verslag van de eerste gespreksronde zijn opgenomen, juist zijn en of voldoende recht is gedaan aan hetgeen iedere betrokkene heeft ingebracht. Vervolgens is elke deelnemende groep geconfronteerd met de eigen inzichten, zoals ze blijkens het verslag in de eigen groep hebben postgevat, en met de beraadslagingen en meningen van andere groepen.

Door de groepen kennis te laten nemen van resultaten van dialoog in andere groepen kunnen volgens Widdershoven (Abma et al., 2001) de eigen inzichten worden aangescherpt. Met name omwille van eventuele gevoelens van machtsongelijkheid tussen de verschillende groepen, die een open, vrije meningsuiting in de weg zouden kunnen staan, is er voor gekozen om dit langs indirecte weg te doen. Het nadeel hiervan is dat de uitnodiging tot het kennisnemen van andere uitkomsten van responsieve evaluatie en tot het bijstellen van eigen opvattingen minder pregnant gevoeld worden. Daarnaast is de mogelijkheid niet aanwezig om standpunten verder te nuanceren en door een directe dialoog tot consensus of (meer) onderling begrip te komen. Ook is de evaluator de enige schakel die 
uitkomsten van overleg van andere groepen verbindt met claims, concerns en issues van de groep waar hij voorstaat. De kans op een te sturende rol is daarbij aanwezig.

\section{De issues}

De groepen die aan de responsieve evaluaties deelnamen, zijn door de evaluator op de hoogte gebracht van de resultaten van de interviews of vraaggesprekken en de enquêtes. De evaluator heeft voorgesteld de onderwerpen 'informatie', 'regie in het verzorgingshuis' en 'houding van het personeel' te selecteren voor de responsieve evaluaties. Over deze onderwerpen bestonden uiteenlopende verwachtingen, opvattingen en ervaringen, zowel binnen als tussen de verschillende groepen respondenten. Aan de deelnemende bewoners en verzorgenden is de keuze voor deze onderwerpen toegelicht en gevraagd of zij ermee aan de slag wilden gaan. Alle groepen hebben daar mee ingestemd. De keuze voor de onderwerpen is daarmee voorafgegaan aan de eerste ronde responsieve evaluatie. Dit lijkt op gespannen voet te staan met de opmerkingen van Guba en Lincoln (Abma en Widdershoven, 2002) dat claims, concerns en issues van betrokkenen (CCl,s) niet vooraf kenbaar zijn en gaandeweg het onderzoek worden verkend en dat rekening moet worden gehouden met 'emergent design', met een 'ontwerp' dat zich geleidelijk ontwikkelt in samenspraak met belanghebbenden. Voor wat betreft de betrokkenheid van bewoners bij de CCl's is de verkenning aan het evaluatieonderzoek voorafgegaan. Zij heeft plaatsgevonden in de uitwisseling van individuele reacties van bewoners met een interviewer of in de weergave van opvattingen van het verzorgend personeel op een vragenformulier. In de responsieve evaluatie heeft elke deelnemende bewoner en verzorgende de ruimte gekregen zijn reactie verder toe te lichten en het onderwerp nader te verkennen.

Het uitdrukken van belevingen en inschattingen in percentages, wat in hoofdstuk 8 is gedaan, lijkt eveneens voorbij te gaan aan de voorkeur van Guba en Lincoln aan kwalitatieve methoden als het gaat om inzicht krijgen in geleefde ervaringen. Gesteld kan worden dat de percentages representeren hoeveel consensus of verschil van opvatting er in het algemeen bestaat tussen verschillende groepen respondenten. De responsieve evaluaties voegen kwalitatieve dimensies toe en laten de cijfers 'tot leven komen'. Daarnaast wordt gedragenheid gecreëerd voor verandering, omdat voorstellen worden ingebracht door de meest betrokkenen.

In hoofdstuk 9 wordt op het verloop van de responsieve evaluaties ingegaan. 


\section{Individuele zorgafspraken: de deelnemers, de planning en procedure en de issues}

\section{De deelnemers}

Door 11 eerstverantwoordelijke verzorgenden (evv-ers) van de drie experimentele afdelingen zijn 35 bewoners geïnterviewd met het doel in overleg zorgafspraken te formuleren die recht doen aan de zorg voor zelfstandigheid van de individuele bewoner.

\section{De planning en procedure}

In de periode december 2002 tot maart 2003 zijn de 3 experimentele verzorgingsafdelingen intensief getraind in het werken met het Overzicht Zorgafspraken. Aansluitend heeft tot en met juni 2003 het merendeel van de face-to-face interviews met de bewoners plaatsgevonden. Een paar interviews zijn pas in de maand augustus gevoerd vanwege de combinatie van ziekenhuisopnames van bewoners en vakantie van de interviewer.

Met behulp van semi-gestructureerde interviews hebben verzorgenden bewoners geïnterviewd over hun verblijf in het verzorgingshuis. Aan de hand van een aantal items en rubrieken is de verzorgende in samenspraak met de bewoner nagegaan welke karakteristieken uit het leven van de bewoner van belang zijn om te registreren, welke keuzes de bewoner zou willen maken, welke mogelijkheden hij zou willen benutten, welke zorgbehoeften hij heeft en of er behoefte bestaat aan hulp door andere hulpverleners. Aan de bewoner is niet gevraagd om op voor-gestructureerde antwoorden te reageren. De reacties of het verhaal van de bewoner werden in het interview geïnterpreteerd door de verzorgende. De noodzaak tot interpretatie was ook gelegen in het karakter van het interview; het was meer een gesprek dan een vraag en antwoord sessie (Baker, 1999). Het risico van deze werkwijze is dat de interviewer tot verkeerde beoordelingen of interpretaties komt (Swanborn, 1990). Om die kans te verkleinen, is de afspraak gemaakt dat het verslag dat de verzorgende maakt (het Overzicht Zorgafspraken) aan de bewoner ter goedkeuring wordt voorgelegd en aan collega verzorgenden ter inzage wordt gegeven. Van de interviewer is geen afstandelijke houding ten opzichte van de bewoner gevraagd. Hij moet zich juist kunnen verplaatsen in de bewoner; er moet sprake kunnen zijn van role-taking (Maso, 1990) om aan te voelen wat de respondent bedoelt.

Om de teams verzorgend personeel, met name de eerst verantwoordelijke verzorgenden, voor te bereiden op het voeren van interviews over individuele zorgafspraken zijn ze door een extern begeleider getraind. Eerstverantwoordelijke verzorgenden hebben in de onderzochte verzorgingshuizen een dienstverband van minimaal 20 uur per week en zij krijgen doorgaans 5 tot 8 bewoners toegewezen voor wie zij de zorg coördineren en aan wie zij ook zorg verlenen. Er is voor gekozen om alleen eerstverantwoordelijke verzorgenden 
(evv-ers) te trainen, omdat zij een vooruitgeschoven verantwoordelijkheid hebben in de registratie van de zorg en omdat zij, in tegenstelling tot 'helpenden', geacht worden vaardig te zijn in het rapporteren. Niet in de laatste plaats is van belang dat evv-ers doorgaans meer een vertrouwensband hebben opgebouwd met de bewoners dan andere verzorgend teamleden, waardoor verwacht wordt dat de bereidheid van de bewoner om geïnterviewd te worden over zijn leven in het verzorgingshuis groot zal zijn. De training vond plaats in afzonderlijke groepen van 5 tot 6 verzorgenden per verzorgingshuis en duurde één dagdeel. In de trainingen is geoefend met casus van bewoners van de eigen afdeling, die door elke deelnemer gekend worden. De verzorgenden zijn bekendgemaakt met de opzet, indeling en achtergrond van het Overzicht Zorgafspraken. In de vorm van een rollenspel, dat op de band is opgenomen, is getraind in het interviewen van een bewoner ten behoeve van het kunnen maken van individuele zorgafspraken en in de houding die de verzorgende daarbij kan aannemen; op basis van een rollenspel is bovendien door de deelnemers gezamenlijk een overzicht van individuele zorgafspraken ingevuld.

$\mathrm{Na}$ de training zijn de verzorgenden aan de slag gegaan met het houden van interviews bij 'hun' bewoners en met het invullen van het Overzicht Zorgafspraken. Via een 'helpdesk' is dit proces door de trainer begeleid en zijn de verzorgenden bijgestaan en geadviseerd. Ook heeft onderlinge coaching plaatsgevonden. Met de leidinggevenden is afgesproken dat de gereedgekomen Overzichten Zorgafspraken zoveel mogelijk in de bewonersbesprekingen van mei en juni 2003 zouden worden toegelicht door de evv-er, waarbij eventuele aanvullingen konden worden opgenomen. Tevens is afgesproken dat, nadat de bewoner heeft ingestemd met hetgeen over hem is opgeschreven en toestemming heeft gegeven om de individuele zorgafspraken uit te voeren, door de experimentele verzorgingsafdeling geprobeerd wordt dienovereenkomstig te handelen.

\section{De issues t.b.v individuele zorgafspraken}

De individuele zorgafspraken die de verzorgende in haar rol van interviewer overeenkomt met de bewoner worden geregistreerd in wat is genoemd 'het Overzicht Zorgafspraken' (zie bijlage 3). In verpleegkundige literatuur over het schriftelijk rapporteren of registreren van de zorg komt deze aanduiding niet voor en wordt over het algemeen over 'het zorgplan' gesproken.

De betekenis die aan het formulier 'zorgplan' wordt toegekend (Kardol, 1985) heeft er toe geleid dat in dit onderzoek voor de registratie van individuele zorgafspraken is gekozen voor het formulier met de aanduiding 'Overzicht Zorgafspraken'. In de benaming 'zorgafspraken' komt het dialogisch karakter van de zorgrelatie naar voren. Het geeft tevens aan dat een zorgactiviteit of interventie niet wordt geregistreerd en verricht zonder medeweten of toestemming van de bewoner. 'Overzicht' duidt op het registratieformulier 
waarop de zorgafspraken zijn vermeld en waarop de bewoner door het plaatsen van een handtekening de zorgafspraken onderschrijft.

Het registratieformulier Overzicht Zorgafspraken is aan de hand van een aantal uitgangspunten opgesteld:

* Het bevat items waar gegevens van de bewoner bij kunnen worden geplaatst. De items die in de responsieve evaluaties door bewoners naar voren zijn gebracht, zijn in het Overzicht Zorgafspraken opgenomen. Het gaat om de items: persoonlijke verzorging; beweging; voeding; daginvulling en levensritme; psychisch functioneren; sociaal functioneren; functioneren in de woon-leefomgeving en levensbeschouwelijk functioneren. In verpleegkundige literatuur komen deze items in andere bewoordingen naar voren: als aspecten van het menselijk functioneren (Van den Brink-Tjebbes, 1987), of als zelfzorgactiviteiten (Orem, 1995). Dijkstra (1998) noemt in zijn Care Dependency Scale een vijftiental items, waarbij hij 'persoonlijke verzorging' onderverdeelt in: incontinentie, aan- en uitkleden, lichaamstemperatuur, hygiëne en vermijden van gevaar. 'Beweging' splitst hij in: lichaamshouding en mobiliteit en het item 'sociaal functioneren' onderscheidt hij in communicatie en contact met anderen. Voor het overige komen de items overeen, zij het dat Dijkstra andere termen gebruikt.

* Het bevat rubrieken waarmee bij elk item 'karakteristieken' uit het levensverhaal en 'keuzes', 'zorgbehoeften' en 'interventie- , of behandelbehoeften' van de bewoner kunnen worden geregistreerd.

In de gegevens die de verzorgende registreert onder de rubriek 'karakteristieken' klinkt de persoon van de bewoner, zijn 'zelf' door en kunnen keuzes, zorgbehoeften en interventie en behandelbehoeften in een context geplaatst worden. Ter illustratie: de beschrijving van de vrouwelijke bewoner, onder het item sociaal functioneren, dat ze in een groot boerengezin is opgegroeid waar altijd veel mensen over de vloer kwamen en iedereen welkom was, kan de keuze en eventuele zorgbehoefte van mevrouw plaatsen dat ze graag naar de koffie-uurtjes gaat en aan festiviteiten van het huis wil deelnemen; de bewoner wiens echtgenote is overleden en er trots op is dat er een mooie, eervolle dienst is gehouden met muziek die zijn vrouw zelf had uitgekozen, heeft de gewoonte regelmatig 's avonds naar het bandje met deze muziek te luisteren. De karakteristiek typeert de bewoner en met zijn keuzes en ondersteuningsbehoeften, die hij meer of minder expliciet aangeeft, geeft hij aan hoe hij zich in de setting van het verzorgingshuis staande wil houden en wil ontwikkelen.

Onder de rubriek 'ondersteuningsbehoefte' wordt verstaan de behoefte van de bewoner om hem te helpen bij activiteiten, bijvoorbeeld bij het opmaken van het bed en het 
schoonhouden van zijn appartement (woon-leefomgeving), of bij een activiteit van het verzorgingshuis (daginvulling/levensritme). De verwachtingen die de bewoner heeft van de verzorgenden terzake ondersteuning bij zijn keuzes en behoeften zijn divers en kunnen als volgt worden onderscheiden:

1 de bewoner wil ruimte hebben zijn eigen gang te gaan;

2 de bewoner wil dat de verzorgende fysiek in de buurt is; hem aandacht geeft en kijkt of hij tot een bepaalde activiteit of beslissing in staat is;

3 de bewoner wil worden aangespoord of worden geadviseerd een bepaalde activiteit te verrichten, een keuze te maken of een beslissing te nemen;

4 de bewoner wil worden geholpen bij de uitvoering van de activiteit, bij het maken van keuzes of het nemen van beslissingen, bijvoorbeeld door aanwijzingen te krijgen of te worden overtuigd;

5 de bewoner wil dat de verzorgende de activiteit van hem overneemt, dat voor hem gekozen of beslist wordt.

Orem (1995) en Van den Brink-Tjebbes (1987) beschrijven vijf basisvarianten van zorg, respectievelijk zes verpleegkundige gedragscategorieën, waarmee antwoord kan worden gegeven op de diverse verwachtingen van de bewoner. Dijkstra (1998) hanteert een vijfpunts schaal om de mate van zorgafhankelijkheid an te duiden: van 'volledig zorgafhankelijk' (1) tot 'vrij zelfstandig' (5).

Een 'interventiebehoefte/behandelbehoefte' van de bewoner is de behoefte om een andere hulpverlenende discipline dan de verzorging in te schakelen of om een bepaalde behandeling of therapie te ondergaan. De behoefte aan contact met de pastor of een predikant, aan een mediator vanwege een familieconflict, aan een consult van de oogarts, aan een regelmatig bezoek van een pedicure, aan het laten spuiten van insuline of het laten aanbrengen van een door de huisarts voorgeschreven huidcrême, zijn voorbeelden hiervan.

Op basis van een gesprek tussen de bewoner en de verzorgende vult laatstgenoemde het Overzicht Zorgafspraken in. Welke items en rubrieken worden ingevuld hangt af van de bewoner, van de ontwikkeling van zijn persoon gedurende het verblijf in het verzorgingshuis. Het hangt ook samen met de vertrouwelijkheid van de informatie die door de bewoner wordt gegeven. De bewoner kan in de open, onvooringenomen sfeer van het gesprek met de verzorgende fragmenten uit zijn levensverhaal vertellen die hij niet geregistreerd wil hebben (Commissie Vorming en Toerusting, 1996). De bewoner moet zich er wel van bewust zijn dat hij verzorgenden gegevens moet verschaffen om als persoon tegemoet getreden te kunnen worden en om geholpen te worden keuzes te kunnen maken. Een Overzicht Zorgafspraken is geen statisch document, dat eenmalig vastlegt wie de 
bewoner is en welke ondersteuning hij wenst. De mogelijkheden van de verzorgenden om op de behoeften in te gaan, kunnen eveneens variëren. Het kan zijn dat de bewoner een beroep doet op verzorgende activiteiten die door organisatorische belemmeringen nog niet of in onvoldoende mate kunnen worden verricht. Om het overleg hierover open te houden, kan op het Overzicht Zorgafspraken worden vermeld op welke behoeften nog niet kan worden ingegaan of welke belemmeringen moeten worden opgeheven. Van het zorgmanagement wordt gevraagd de belemmeringen aan te pakken. Daarmee wordt de verantwoordelijkheid voor de directe zorg voor zelfstandigheid verbreed naar het management. De medeverantwoordelijkheid van anderen in de organisatie ten behoeve van de kwaliteit van zorg op de verzorgingsafdeling en de visie dat zorg voor zelfstandigheid door meerdere geledingen moet worden gedragen, wordt hiermee onderstreept. Op het Overzicht Zorgafspraken wordt tevens vermeld of de bewoner mantelzorgers of vrijwilligers heeft en bij welke activiteiten die worden ingeschakeld. Van de bewoner wordt, onder de kop 'ondertekening zorgafspraken', gevraagd een handtekening te plaatsen voor toestemming voor de uitvoering van de zorgafspraken. Tevens wordt gevraagd of de bewoner over een exemplaar van het Overzicht Zorgafspraken wenst te beschikken. Hiermee voldoet het Overzicht Zorgafspraken aan de voorwaarden die de Landelijke Organisatie Cliëntenraden stelt aan dit document (LOC, 2003). Het recht van de bewoner op informatie, het vereiste om de bewoner toestemming te laten geven op de uitvoering van zorgafspraken, de plicht van de verzorging tot het bijhouden van het zorgdossier en het Inzagerecht van de bewoner (Wgbo, 1995) worden door deze vorm van zorgregistratie gewaarborgd. In hoofdstuk 9 wordt de implementatie van het Overzicht Zorgafspraken beschreven.

\section{Onderzoeksfase 3: de nameting}

In de maanden juli tot en met oktober 2003 heeft de nameting plaatsgevonden. Met bewoners van zowel de controleafdelingen als de experimentele afdelingen zijn opnieuw vraaggesprekken gevoerd aan de hand van een vragenlijst en aan de verzorgenden die de eerste enquête hebben ingevuld, is gevraagd om ook een tweede enquête in te vullen. De stappen die in onderzoeksfase drie zijn gezet worden achtereenvolgens onder de punten 8 tot en met 11 toegelicht.

\section{Het construeren van vragenlijsten.}

In de vragenlijsten die voor de tweede meting worden gebruikt, worden veel vragen herhaald die ook voor de eerste meting gesteld zijn. Omdat dezelfde groepen bewoners en 
verzorgenden zijn benaderd en er geen nieuwe respondenten zijn bijgekomen, zijn ook vragen weggelaten, zoals de vraag naar de verwachting die bewoners van het verzorgingshuis hadden toen ze daar naar toe gingen. Een dergelijke vraag hoeft niet opnieuw herhaald te worden. Verder zijn dezelfde clusters of rubrieken aangehouden. Bij elke rubriek zijn vragen toegevoegd. Gevraagd is of bewoners veranderingen hebben bemerkt in de wijze van informatievoorziening, in de invloed op het programma en de regels of gewoonten van het huis en in de houding van de medewerkers. Met behulp van open vragen hebben de respondenten de gelegenheid gekregen de door hun geconstateerde veranderingen toe te lichten. Ook is gevraagd naar veranderingen in de omstandigheden van de respondenten, bijvoorbeeld naar de mate van zorgbehoevendheid van bewoners.

\section{Proefinterviews.}

Alvorens de vragenlijsten zijn uitgezet, zijn ook aan de nameting proefinterviews vooraf gegaan. De vraaggesprekken met bewoners zijn door dezelfde interviewers gevoerd als bij de voormeting, waarbij de interviewers zoveel mogelijk met dezelfde bewoners gesproken hebben als tijdens de eerste ronde vraaggesprekken. De extern begeleider heeft de vragenlijst toegelicht aan de interviewers en ze kort geïnstrueerd. Drie bewoners hebben aan een proefinterview deelgenomen en de interviewers hebben zelf de vragenlijst voor de verzorgenden als proefenquête ingevuld. De proef met de vragenlijst heeft slechts enkele tekstuele wijzigingen tot gevolg gehad.

\section{Interview van bewoners en enquête onder het verzorgend personeel.}

Alle interviews zijn afgenomen in de periode juli tot en met oktober 2003. Er namen 85 bewoners deel, 21 minder dan bij de eerste meting als gevolg van overlijden of een slechte gezondheid. Van de 85 bewoners verbleven er 50 op de controleafdelingen en 35 op de experimentele afdelingen. Aan de enquête onder het personeel namen 44 verzorgenden deel; 24 van de controleafdelingen en 20 van de experimentele afdelingen. Dit zijn er zes minder dan bij de eerste meting, als gevolg van beëindigingen van het dienstverband, ziekte of zwangerschapsverlof. De extern begeleider is ook in de periode van het afnemen van interviews beschikbaar geweest voor de benodigde ondersteuning aan de interviewers.

\section{Het verzamelen en analyseren van onderzoeksgegevens}

De resultaten van de nameting, de tweede meting, zijn uitgeschreven voor de controleafdelingen en de experimentele afdelingen, waarbij de respondentgroepen bewoners 
en verzorgenden zijn onderscheiden. Opnieuw is nagegaan hoeveel bewoners en verzorgenden dezelfde antwoordcategorieën hebben ingevuld en de overeenkomsten en verschillen zijn in percentages weergegeven. De 'resultaten 2001' zijn vergeleken met de 'resultaten 2003' van de controlegroep bewoners en van de experimentele groep bewoners. De 'resultaten 2003' van de controlegroep bewoners en van de experimentele groep zijn eveneens met elkaar vergeleken en deze exercitie is herhaald voor de groepen verzorgenden.

De vraag is gesteld of er verschillen kunnen worden geconstateerd tussen de resultaten van de eerste meting en van de tweede meting en welke verschillen het meest in het oog springen. Met name is gekeken naar de mate waarin het aantal bewoners en verzorgenden van experimentele afdelingen, dat aangeeft dat de informatievoorziening beter is geworden, dat de keuzevrijheid of invloed is toegenomen en dat de houding van verzorgenden is verbeterd, afwijkt van de opvattingen van de bewoners en verzorgenden van de controlegroepen. In hoofdstuk 10 worden de resultaten gepresenteerd.

\subsubsection{De gegevensverwerking}

Op diverse manieren zijn gegevens vastgelegd:

1 de schriftelijke reacties van de deelnemers aan de concept mapping zijn op verzamellijsten geplaatst;

2 door getrainde en ervaren interviews zijn de bewoners twee maal met een voorgecodeerde vragenlijst benaderd en in een gesprek van gemiddeld $1-1,5$ uur zijn de vragen beantwoord en op de lijst ingevuld. Deze lijsten zijn met behulp van SPSS-DATA ENTRY in een computer ingevoerd, zowel de geprecodeerde antwoorden als de antwoorden op de open vragen;

3 met behulp van coderingen van vragenlijsten zijn omwille van de vergelijking van twee metingen verbindingen gemaakt tussen individuele respondenten en vragenlijsten;

4 een aantal opmerkingen van respondenten bij half open en open vragen, die beweringen bevestigen, nuanceren of tegenspreken, zijn als citaten in deze studie opgenomen;

5 aan de verzorgenden die aan de enquête deelnamen, is een vragenlijst toegestuurd met het verzoek deze in te vullen. De lijsten zijn op dezelfde manier verwerkt als de lijsten van de interviews;

6. alle gesprekken van de responsieve evaluaties zijn met behulp van een bandrecorder opgenomen en zowel tijdens de gesprekken als aan de hand van deze banden zijn verslagen van de bijeenkomsten gemaakt. De essentiële onderdelen 
van deze verslagen zijn verwerkt bij de beschrijving van het onderzoeksproces alsmede bij de resultaten;

7 het registratieformulier 'Overzicht Zorgafspraken', waarop de resultaten van de interviews van verzorgenden met de bewoners staan vermeld, is in het zorgdossier van de bewoners opgenomen.

De kwantitatieve gegevens zijn met behulp van SPSS verwerkt. De gebruikte analyses zijn: frequentieverdelingen ter controle van de juiste invoer van de gegevens en om overzichten te maken van de descriptieve variabelen. Voor het maken van statistische vergelijkingen tussen en binnen de respondentgroepen is gebruik gemaakt van t-toetsen.

\subsection{Beschouwing}

De zorg voor zelfstandigheid in verzorgingshuizen is op verschillende manieren onderzocht. De vraag wat ze volgens bewoners en verzorgenden inhoudt, is op basis van kwalitatieve onderzoeksmethoden onderzocht; voor de beantwoording van de vraag in welke mate kenmerken van zorg voor zelfstandigheid voorkomen, is kwantitatief onderzoek verricht. De vraag hoe zorg voor zelfstandigheid kan worden bevorderd, is op basis van een quasi experimenteel onderzoeksdesign behandeld, waarbij moet worden aangetekend dat in de experimentele en controlesituatie op verzorgingsafdelingen veel factoren en variabelen niet controleerbaar of meetbaar zijn. Het interventieprogramma heeft tot doel de zorg voor zelfstandigheid in de dagelijkse praktijk van zorg te verbeteren en de introductie ervan kan om die reden worden aangemerkt als onderdeel van 'praktijkgericht' onderzoek. Dit type onderzoek dient zich volgens Smaling (1996) te kenmerken door de 'benuttingswaarde' voor de betrokkenen. Het taalgebruik moet herkenbaar zijn voor de betrokkenen en de gegevens, die bijvoorbeeld in het Overzicht Zorgafspraken zijn geregistreerd, moeten aansluiten bij de leefwereld van de bewoners. Als meerdere betrokkenen zich voelen uitgenodigd om een bijdrage te leveren aan zorg voor zelfstandigheid, waarvoor deze studie opteert, heeft het interventieprogramma ook 'participatieve waarde'; indien het interventieprogramma tot gevolg heeft dat de zorg voor zelfstandigheid wordt bevorderd, hetgeen in hoofdstuk 10 aan de orde wordt gesteld, heeft het ook 'implementatiewaarde'. Deze waarden staan volgens Smaling op gespannen voet met de methodologische kwaliteit die gevraagd wordt bij experimenteel en toetsend onderzoek. Dat onderzoeksconclusies waar zijn en waarde hebben voor de onderzochte respondenten, oftewel dat sprake is van credibility, betekent niet dat ze generaliseerbaar zijn naar andere verzorgingshuizen. Door diverse data, methoden en onderzoeksvormen te combineren en multiple triangulatie te 
bewerkstelligen, is geprobeerd de betrouwbaarheid en interne en externe validiteit van het onderzoek te vergroten. 


\section{Hoofdstuk 8 Zorg voor zelfstandigheid: "Ik wou dat ik wat mankeerde!"}

In dit hoofdstuk worden de resultaten beschreven van de eerste ronde interviews met bewoners en enquête onder het verzorgend personeel. In paragraaf 8.1. wordt aangegeven wat uit de interviews of vraaggesprekken met de bewoners naar voren is gekomen terzake de volgende onderwerpen:

- de motieven om naar het verzorgingshuis te gaan

- de verwachtingen van het verzorgingshuis

- de kwaliteit van het leven in het verzorgingshuis

- de zorgvragen en de beoordeling van het zorgaanbod

- de informatievoorziening in en van het verzorgingshuis

- de houding van verzorgenden

- keuzevrijheid in het verzorgingshuis

In paragraaf 8.2 wordt weergegeven wat de meningen van het verzorgend personeel zijn terzake deze onderwerpen en in paragraaf 8.3 worden de opvattingen van de twee groepen respondenten met elkaar vergeleken. In paragraaf 8.4 worden de resultaten van dit hoofdstuk nader beschouwd.

\subsection{Resultaten van interviews met bewoners}

\subsubsection{Motieven voor verhuizing naar het verzorgingshuis}

De ouderen die voor verhuizing naar het verzorgingshuis kozen, deden dat in $48 \%$ van de gevallen op eigen initiatief, terwijl $52 \%$ van de onderzoeksgroep aangaf op initiatief van anderen, met name van de huisarts, kinderen of de partner naar het verzorgingshuis te zijn gegaan. Deze cijfers corresponderen met gegevens uit onderzoek van het SCP (1997) waaruit blijkt dat bij ongeveer vier op de tien ouderen die naar het verzorgingshuis gaan de huisarts heeft aangedrongen op opname. Aan de ouderen is gevraagd op grond van welke motieven zij voor opname in het verzorgingshuis gekozen hebben. Omdat meerdere motieven een rol kunnen spelen, zijn in onderstaand overzicht de genoemde motieven in absolute aantallen weergegeven. 
Tabel 8.1: Motieven van bewoners voor verhuizing naar het verzorgingshuis

\begin{tabular}{|lc|}
\hline Motief voor verhuizing & Aantal malen genoemd (abs.) \\
& \\
onvoldoende zelfredzaam & 56 \\
onvoldoende professionele hulp & 44 \\
onvoldoende informele hulp & 40 \\
woning ongeschikt & 18 \\
onveilig gevoel & 15 \\
eenzaamheid / behoefte aan contact & 11 \\
indicatie partner & 10 \\
overige & 4 \\
\hline
\end{tabular}

Problemen met de zelfredzaamheid en onvoldoende professionele- en informele hulp zijn de meest genoemde motieven. Het ongeschikt zijn van de woning wordt weliswaar als een op zichzelf staand motief genoemd, maar alleen door de ouderen die problemen ondervinden met hun zelfredzaamheid. Met 'onveilig gevoel' wordt niet gedoeld op angst voor inbraken of bedreigingen, maar op de angst dat niemand in de buurt is als plotseling fysieke problemen ontstaan. Iets meer dan tien procent van de ondervraagden geeft 'eenzaamheid' en 'behoefte aan contact' op als motieven voor verhuizing. Maar ook een groep van ondervraagden die 'onvoldoende informele hulp' noemt als motief voor verhuizing, mist contacten met naasten, relaties of leeftijdgenoten. Informele hulp of mantelzorg wordt door het Sociaal en Cultureel Planbureau (2003) gedefinieerd als 'de hulp bij het dagelijks functioneren, die vrijwillig en onbetaald wordt verleend aan personen uit het sociale netwerk die - door welke oorzaak dan ook - vrij ernstige, fysieke, verstandelijke of psychische beperkingen hebben'. Eerder in deze studie is aangegeven dat informele hulpverleners meer sociale- en huishoudelijke ondersteuning geven dan bijspringen bij de ADL. Meer dan acht van de tien respondenten is alleenstaand en van de 91 ouderen die gehuwd zijn (geweest) heeft driekwart kinderen. Ongeveer twintig ouderen hebben nauwelijks of geen contact met hun kinderen, hun sociaal netwerk is beperkt. Anderen beschikken wel over een sociaal netwerk, maar de zorgbehoefte werd zo hoog en/of de informele hulpverlener voelde zich zo zwaar belast, dat opname van de oudere in het verzorgingshuis als onvermijdelijk werd gezien.

\subsubsection{Verwachtingen van het verzorgingshuis}

Uit de antwoorden op de vraag naar motieven voor opname in het verzorgingshuis blijkt dat ouderen alleen beperkingen noemen die zij ondervinden bij het leven en wonen in hun eigen 
huis. Aan de ouderen van de onderzoeksgroep is bovendien de vraag gesteld met welke verwachtingen zij naar het verzorgingshuis zijn gegaan. Onderstaande tabel laat de reacties zien. Ook bij deze vraag zijn meerdere antwoorden mogelijk geweest.

Tabel 8.2: Verwachtingen van bewoners van verhuizing naar het verzorgingshuis

\begin{tabular}{|lc|}
\hline verwachtingen van het verzorgingshuis & aantal keren genoemd (abs.) \\
hulp bij de huishouding & 72 \\
een gevoel van veiligheid & 65 \\
woning die naar eigen smaak kan worden ingericht & 64 \\
zelfstandig kunnen wonen & 59 \\
een gevoel van rust & 56 \\
hulp bij de verzorging & 53 \\
contacten met medebewoner & 51 \\
aanwezigheid van attente medewerkers & 48 \\
een aanbod aan activiteiten & 36 \\
iets kunnen ondernemen & 31 \\
geen verwachtingen & 10 \\
\hline
\end{tabular}

Hulp bij de huishouding is de meest genoemde verwachting. Ouderen die in het verzorginghuis komen, gaan er van uit dat het personeel die hulp biedt. Het verzorgingshuis wordt door tweederde van de onderzoeksgroep geassocieerd met veiligheid. De angst dat thuis niemand anwezig is als de situatie nijpend is, wordt naar verwachting van deze ouderen door het wonen in een verzorgingshuis weggenomen. lets meer dan de helft van de ondervraagde ouderen geeft aan dat hierdoor ook een gevoel van rust zal ontstaan. Meer dan de helft van de ouderen die de stap naar het verzorgingshuis zetten, gaan er van uit dat ze zelfstandig kunnen wonen en dat ze hun woning naar eigen smaak kunnen inrichten. Slechts de helft van de ouderen verwacht hulp bij hun verzorging. Het is opmerkelijk dat deze verwachting niet door meer ouderen is uitgesproken, omdat lichamelijke hulpbehoevendheid voor het Indicatieorgaan een zwaarwegende factor is voor indicering voor verblijf in het verzorgingshuis. Het resultaat komt wel overeen met het in de vorige tabel getoonde gegeven dat niet meer dan 56 van de 106 ouderen van de onderzoeksgroep vanwege onvoldoende zelfredzaamheid voor plaatsing in het verzorgingshuis kiezen. Bijna de helft van de onderzoeksgroep verwacht contacten met medebewoners te kunnen leggen en attente medewerkers in de buurt te hebben. Ongeveer eenderde verwacht actief te kunnen zijn door de activiteiten die worden aangeboden of door zelf iets te ondernemen. 


\subsubsection{Informatievoorziening}

Aan de onderzoeksgroep zijn vragen gesteld over de wijze waarop zij na de indicatiestelling, voorafgaande aan de plaatsing, over het verzorgingshuis van hun keuze geïnformeerd is.

In onderstaand overzicht is aangegeven welke informatie volgens de onderzoeksgroep is verschaft.

Tabel 8.3: Informatievoorziening door het verzorgingshuis, voorafgaande aan plaatsing

\begin{tabular}{lc}
\hline Verstrekte Informatie & aantal keren genoemd (abs.) \\
informatiepakket over verzorgingshuis & 42 \\
mondelinge voorlichting & 75 \\
kennismakingsbezoek & 80 \\
'zittende' bewoners gesproken & 41 \\
overige & 23
\end{tabular}

Naast het kennismakingsbezoek, dat driekwart van de ouderen brengt aan het verzorgingshuis van hun keuze, wordt in een bezoek vanuit het verzorgingshuis bij de oudere thuis informatie overgedragen c.q. voorlichting gegeven. Onder de categorie 'overige' vallen de volgende reacties:

Ik woonde daarvoor in een aanleunwoning en kwam regelmatig in het verzorgingshuis.

Een familielid werkt in het verzorgingshuis.

Ik heb even op een logeerafdeling van het verzorgingshuis gewoond.

De meningen van de onderzoeksgroep over de mate waarin ze voor hun verhuizing door het verzorgingshuis geïnformeerd is, lopen sterk uiteen:

Figuur 8.1: Informatie door het verzorgingshuis

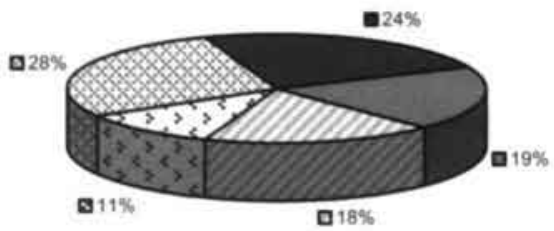


Ofschoon bewoners aangeven langs verschillende wegen informatie over het verzorgingshuis te verkrijgen, blijkt 57 procent niet goed ('een beetje', 'tamelijk slecht' en 'helemaal niet') geïnformeerd naar het verzorgingshuis te zijn gegaan. Eén van de respondenten verwoordt het als volgt:

Toen ik hier zes jaar geleden kwam wonen, heb ik met pijn in mijn hart afstand gedaan van mijn piano. Ik heb tot aan mijn pensioen les gegeven op het conservatorium en sindsdien heb ik iedere dag gespeeld. Ze wisten dat hier niet en ik heb dat zo maar gelaten. Ik sta er ook alleen voor. Ik ging er van uit dat ik hier niet met zo'n gevaarte kon ankomen. Toen ik onlangs hoorde dat die piano gemakkelijk geplaatst had kunnen worden, ging er heel wat door mij heen. Nu willen mijn vingers niet meer zo...

Voor sommige bewoners kwam het bericht dat zij geplaatst konden worden zo snel dat zij niet de tijd hadden zich goed voor te bereiden. Anderen voelden zich om gezondheidsredenen niet in staat informatie tot zich te nemen en lieten dat aan hun kinderen of familieleden over.

Behalve algemene vragen aan bewoners over de wijze waarop en de mate waarin zij geïnformeerd zijn, is gevraagd naar hun beoordeling van de verstrekte informatie tijdens het verblijf en hun betrokkenheid bij de volgende onderwerpen:

1. de verzorgingsovereenkomst en het zorgdossier

2. het reanimeerbeleid en euthanasiebeleid

3. de cliëntenraad en de menucommissie

\section{ad.I De verzorgingsovereenkomst en het zorgdossier}

In de verzorgings- of zorgverleningsovereenkomst zijn de rechten en plichten opgenomen van het verzorgingshuis en haar bewoners, bijvoorbeeld ten aanzien van het gebruik en inrichting van het woonappartement; ten aanzien van privacy, het houden van huisdieren en het gebruik van de voorzieningen in het huis. Het zorgdossier is een document voor elke bewoner afzonderlijk. Het bevat onder meer het zorgplan of de zorgafspraken, waarin de activiteiten zijn genoemd die de verzorging voornemens is te verrichten op basis van de keuzes, zorgbehoeften, wensen, verwachtingen en vragen van de bewoner.

De onderzoeksgroep geeft aan onvoldoende geïnformeerd te zijn over de verzorgingsovereenkomst: $10.5 \%$ van de bewoners zegt een verzorgingsovereenkomst te hebben getekend; $22 \%$ zegt dat niet te hebben gedaan en $67.5 \%$ weet zich niet te herinneren dat te hebben gedaan. Minder dan de helft van de ondervraagde bewoners $(45.5 \%)$ weet dat van hen een zorgdossier wordt bijgehouden. $62.5 \%$ zegt niet betrokken te worden bij het opstellen van het zorgdossier; $85 \%$ zegt niet regelmatig geïnformeerd te worden over het zorgdossier. Er is nauwelijks beeld van de informatie die in een zorgdossier is opgeslagen. Bijna geen enkele bewoner leest zijn zorgdossier door; $83 \%$ weet niet dat het dossier kan 
worden ingezien en $87.5 \%$ antwoordt met 'nee' op de vraag of toestemming is gegeven voor wat in het dossier c.q. in het zorgplan is opgetekend. Enige bewoners die weten dat het verzorgend personeel een zorgdossier bijhoudt of gegevens over hen registreert, reageren als volgt:

Ik weet dat er een blaadje op de kast hangt, maar ik heb nooit gekeken wat er op staat.

In het begin moest ik iets over mijn leven schrijven.

I $k$ heb een formulier ingevuld over mijn levensloop.

Toen ik ziek was werd alles opgeschreven.

Ze zullen wel een lijst hebben over de medicijnen die ik nodig heb, over het regelen van mijn begrafenis en zo.

Ik weet niet wat er in staat.

\section{ad.2 Reanimeerbeleid en euthanasiebeleid}

Het beleid van een verzorgingshuis terzake reanimeren en euthanasie dient transparant te zijn, omdat dit, meer dan bij andere onderwerpen, de keuze van de oudere voor een bepaald verzorgingshuis kan bepalen. Het verzorgingshuis kan hieromtrent opvattingen hebben die indruisen tegen persoonlijke opvattingen van een oudere.

Van de ondervraagde ouderen bleek $60 \%$ niet geïnformeerd te zijn over het reanimeerbeleid; $71 \%$ is niet op de hoogte van het euthanasiebeleid van het verzorgingshuis waar men verblijft; $48 \%$ geeft aan wel geïnformeerd te willen worden over zowel het reanimeerbeleid als het euthanasiebeleid. Van de bewoners die aangeven niet geïnformeerd te willen worden, zegt het merendeel zelf het moment te kiezen om hierover in gesprek te gaan en zelf te willen bepalen wat in de gegeven situatie het beste is. In deze reactie schuilt de verwachting dat niet het beleid van het huis, maar de individuele situatie bepalend is voor de keuze die gemaakt wordt.

Een van de bewoners drukt tijdens het vraaggesprek zijn beleving hierover als volgt uit:

$\mathrm{U}$ bent de eerste die mij hierover iets vraagt. Nee, ik heb van het verzorgingshuis nooit iets gelezen over reanimeren. Een paar maanden geleden vroeg één van de verzorgsters mij of ik een niet - reanimeren pas zou willen nemen. Er zijn hier mensen van de NVVE (Nederlandse Vereniging voor Vrijwillige Euthanasie) in huis geweest, maar ik heb geen behoefte aan een pas. Laat ze maar opschrijven dat ik gereanimeerd wil worden als er iets met me gebeurt. En tegen de tijd dat ik er anders over ga denken, laat ik het wel weten.

Een bewoner die wel was geïnformeerd merkte het volgende op:

Ja, ik herinner me dat nog heel goed. Ik was net in huis of het hoofd van de afdeling kwam aanzetten met informatie over het euthanasiebeleid van het huis. Mijn dochter die bij mij op bezoek was en ik keken elkaar aan en we vroegen ons af waar ik terecht was gekomen. Ik lees het nog wel door, had ik tegen het afdelingshoofd gezegd. 
Weer een andere bewoner was ontstemd over de wijze en het moment waarop de onderwerpen te berde werden gebracht en over de inhoud van het formulier dat hij geacht werd in te vullen. Een verzorgende had de bewoner een modelformulier 'volmacht' van de NVVE gegeven en gevraagd of hij dat zou willen doorlezen en invullen. Op dit formulier kan de bewoner aangeven welke personen zijn belangen behartigen wanneer hij niet meer in staat is zijn wensen op medisch gebied aan te geven. Deze personen moeten er in zijn plaats voor zorgen dat zijn behandelverbod wordt nageleefd en dat zij zijn euthanasieverklaring zo nodig ondersteunen. De bewoner merkte het volgende op:

Ik was net een paar dagen daarvoor uit het ziekenhuis gekomen. Ik had een zware ingreep achter de rug en praatte mezelf moed in dat het weer goed zou komen. Toen kwam de zuster met dat formulier binnen. Als ik naar de vraagstellingen kijk word je naar een bepaalde denkwijze geleid. Maar ik wil nog iets van het leven proberen te maken en als ik het aan mijn hart krijg, hoop ik dat iedereen hier weet dat ik gereanimeerd wil worden. Weten ze dat hier eigenlijk wel?

\section{ad. 3 Cliëntenraad en menucommissie}

Aan de onderzoeksgroep is gevraagd of zij bekend is met de anwezigheid en het functioneren van de cliëntenraad en van de menucommissie. $83 \%$ van de bewoners zegt op de hoogte te zijn van de aanwezigheid van een cliëntenraad. Wat een cliëntenraad doet, wat in de verslagen staat en wat op een ledenvergadering besproken wordt, is bij de meerderheid van de geïnterviewden niet bekend. Toch is $44 \%$ tevreden over het functioneren van de cliëntenraad; $38 \%$ is noch tevreden, noch ontevreden; $10 \%$ is ontevreden en $8 \%$ heeft geen mening. Van het bestaan van een menucommissie heeft $43 \%$ wel en $57 \%$ geen weet. De indruk leeft dat de menucommissie zich met de kwaliteit van de voeding bezighoudt (volgens $68.5 \%$ ) en/of voorstellen doet over de menukeuze (44\%), maar zeker is men daar niet van, omdat meer dan $80 \%$ aangeeft dat de menucommissie niet laat weten waar ze mee bezig is.

\subsubsection{Kwaliteit van leven in het verzorgingshuis}

Ouderen hebben verschillende motieven om zich voor het verzorgingshuis te laten indiceren en zij stappen met verschillende verwachtingen het verzorgingshuis binnen. In deze paragraaf wordt de vraag beantwoord of het leven en wonen in het verzorgingshuis ook aan deze verwachtingen voldoet. Allereerst wordt een algemene indruk gegeven van de wijze waarop ouderen tegen de kwaliteit van hun leven in het verzorgingshuis aankijken. Vervolgens worden concrete voorbeelden gegeven van zaken die het leven in het verzorgingshuis meer of minder aantrekkelijk maken. De vraag wordt behandeld in welke mate bewoners zich in het verzorgingshuis afhankelijk of onafhankelijk voelen van het 
verzorgend personeel, welke zorgvragen zij hebben en in hoeverre het zorgaanbod in hun beleving is afgestemd op hun zorgbehoeften.

Figuur 8.2: Kwaliteit van leven in het verzorgingshuis

\section{Positieve aspecten}

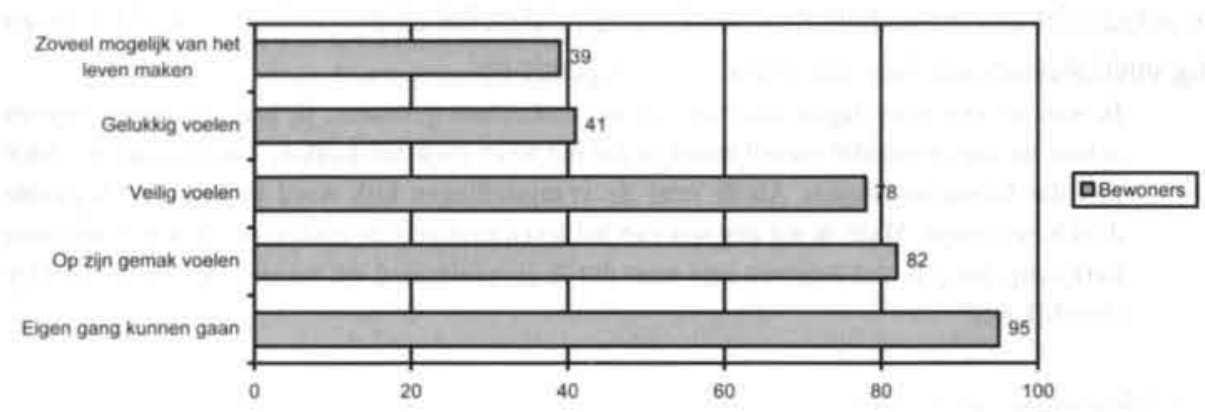

Negatieve aspecten

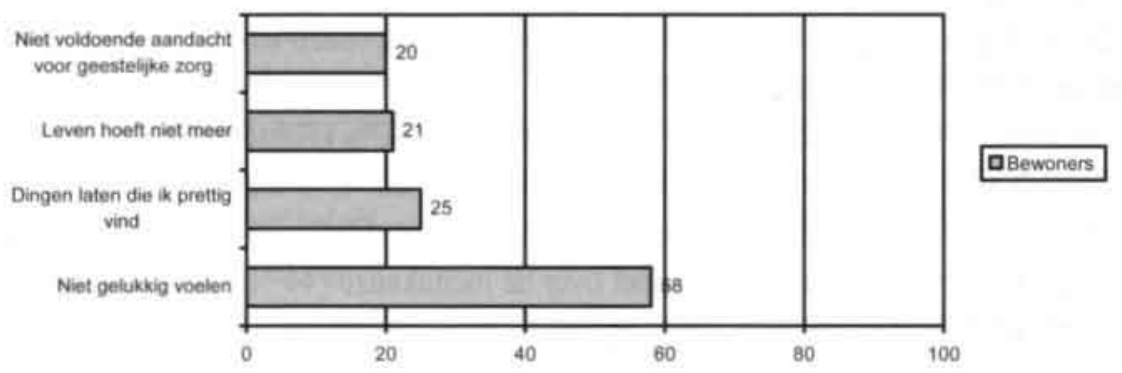

Uit bovenstaande figuren, waarbij de cijfers staan voor percentages, valt op te maken dat ongeveer veertig procent van de bewoners zegt zich gelukkig te voelen in het verzorgingshuis. De overigen voelen zich niet gelukkig en ruim eenderde daarvan geeft aan dat het leven voor hen niet meer hoeft, dat het spoedig zou mogen aflopen. De bewoners spreken verder uit dat ze zich veilig en op hun gemak voelen en ze hebben het gevoel de eigen gang te kunnen gaan. Daarbij merkten meer dan vier van elke tien bewoners op dat zij door het wonen in het verzorgingshuis anders tegen het leven zijn gaan aankijken: sommigen zeggen zich prima te voelen, blij te zijn aanspraak te hebben, het fijn te vinden dat er altijd iemand in de buurt is en steeds weer uit te zien naar de activiteiten die worden georganiseerd; anderen vragen zich af waar zij nog voor leven, zeggen het leven te hebben 
gehad en het niet erg te vinden als 'ze' hem of haar komen halen. Bijna veertig procent van de respondenten wil ondanks de behoefte aan verzorging nog zoveel mogelijk van het leven maken. Anderen zeggen slecht om te kunnen gaan met de aanwezige gebreken; twintig procent vindt dat er niet voldoende aandacht is voor geestelijke zorg; ruim eenderde vindt het vervelend als anderen zien dat hulp aan hen geboden wordt; een kwart van de ondervraagden betreurt het dat zij dingen moet laten die zij prettig vindt en eenvijfde deel drukt het anders uit door te stellen dat zij niet toekomt aan dingen die prettig zijn.

\subsubsection{Zorgvragen en beoordeling van het zorgaanbod}

Aan de bewoners is de vraag voorgelegd of zij bij bepaalde activiteiten ondersteuning wensen en, als dat het geval is, of zij tevreden zijn over de verleende hulp. Hieronder zijn de reacties vermeld (in percentages).

Tabel 8.4: Zorgvragen en beoordeling van het zorgaanbod

\begin{tabular}{|l|r|r|r|c|}
\hline \multirow{2}{*}{ Activiteit } & \multicolumn{2}{|c|}{ Ondersteuning } & \multicolumn{2}{c|}{ Tevreden } \\
& Ja & Nee & Ja \\
\hline lichamelijke verzorging & 41 & 59 & 98 & 2 \\
\hline Voeding & 2 & 98 & 100 & - \\
\hline toiletgang (buiten ADL) & 8 & 92 & 83 & 17 \\
\hline mobiliteit (overdag) & 21 & 79 & 75 & 25 \\
\hline schoonhouden appartement & 97 & 3 & 66 & 34 \\
\hline Verwerken situatie & 22 & 78 & 76 & 24 \\
\hline
\end{tabular}

De ondervraagden die hulp nodig hebben bij de lichamelijke verzorging zijn overwegend tevreden over de verleende hulp, althans wanneer die verstrekt wordt op tijden dat de verzorging 'de ronde doet'. Wanneer ouderen buiten deze tijden hulp nodig hebben bij de toiletgang of bij hun mobiliteit is $17 \%$, respectievelijk $25 \%$ niet tevreden. Bijna iedereen geeft aan hulp nodig te hebben bij het schoonhouden van het appartement, maar over de hulp die wordt geboden is meer dan éénderde van de bewoners niet, of niet geheel tevreden. Mentale steun bij het verwerken van de situatie waarin men verkeert, wordt volgens een kwart van de respondenten niet naar tevredenheid verleend.

Het vragen om ondersteuning en hulp bij de huishouding en verzorging gaat niet gepaard met een gevoel van afhankelijkheid of van verlies van zelfstandigheid. Aan de respondenten is gevraagd op een schaal van 1 tot 10 aan te geven in welke mate zij zich afhankelijk of onafhankelijk voelen ( 1 is volledig afhankelijk, 10 is volledig onafhankelijk). 
Tabel 8.5; Gevoel t.a.v. mate van afhankelijkheid

\begin{tabular}{|cccccccccc|}
\hline \multicolumn{2}{|c|}{ volledig afhankelijk } & & & & & & \multicolumn{2}{c|}{ volledig onafhankelijk } \\
1 & 2 & 3 & 4 & 5 & 6 & 7 & 8 & 9 & 10 \\
7 & 2 & 5 & 2 & 11 & 11 & 11 & 20 & 10 & 21 (perc.) \\
\hline
\end{tabular}

$27 \%$ vult een antwoordcategorie in van $1 \mathrm{t} / \mathrm{m} 5$ in en $73 \%$ vult $6 \mathrm{t} / \mathrm{m} 10$ in. Hulp vragen bij de toiletgang, bij de mobiliteit en bij mentale vragen wordt als moeilijk ervaren, omdat een groot appèl gedaan wordt op de directe beschikbaarheid van de verzorging of op hun tijd. Bijna 73\% voelt zich vrij om kritiek te uiten op de kwaliteit van zorg, 17\% zegt niet snel openlijk kritiek te geven, vanwege mogelijke negatieve gevolgen.

\subsubsection{Houding van de verzorgenden}

Een aantal houdingsaspecten van de verzorgende medewerkers wordt overwegend positief beoordeeld: het merendeel van hen betuttelt niet en bejegent de bewoners met respect $(87 \%)$; de bewoners worden attent benaderd ( $84 \%)$; de verzorgenden zijn vakkundig $(82 \%)$ en de woning van de bewoners wordt niet onaangekondigd betreden (75\%); $73 \%$ antwoordt dat rekening wordt gehouden met hun wensen en behoeften, hoewel sommige bewoners deze opvatting nuanceren:

$\mathrm{Ik}$ vind het fijn als verzorgende $\mathrm{A}$. me komt verzorgen. Ik moet geholpen worden met aankleden en ze vraagt altijd aan me welke jurk ik wil aandoen. Dat lijkt misschien gewoon, maar er zijn er ook die een jurk uit de kast pakken en verder niets vragen.

Van alle geïnterviewde bewoners zegt $72 \%$ dat de medewerkers doen wat ze beloven, dat een medewerker beschikbaar is als hij nodig is en dat mankementen aan de woning snel worden opgelost; $70 \%$ zegt dat er rekening mee wordt gehouden als men het met een bepaalde medewerker moeilijk kan vinden. Over bepaalde houdingsaspecten zijn de opvattingen meer verdeeld of ze worden minder positief beoordeeld: $67 \%$ van de geïnterviewden geeft aan voldoende tijd te krijgen om te eten of andere zaken in het eigen tempo te doen; $62 \%$ ervaart dat de medewerkers zich om hen bekommeren en $61 \%$ ervaart steun van de medewerkers; slechts $56 \%$ geeft aan dat de medewerkers doorgaans voldoende tijd hebben; $90 \%$ antwoordt dat de medewerkers vinden dat bewoners zelf datgene moeten doen waartoe zij fysiek in staat zijn. $54 \%$ vermeldt daarbij dat de medewerkers niet uitgaan van wat de bewoner wil doen, maar enkel van wat hij kan doen. Een van de respondenten zegt over dit laatste:

Ik leef toe naar het koffie-uurtje in de zaal, 's morgens om tien uur. Maar het is iedere keer weer een race tegen de klok. Het kost me ook zoveel moeite om mezelf te verzorgen, maar sommige zusters zeggen steeds weer dat ik zolang mogelijk mezelf moet blijven verzorgen. 
Gelukkig zijn er ook een paar die af en toe een handje toesteken. Dat zijn dan van die ochtenden dat ik het meest geniet van de contacten in de zaal. Op andere momenten zou ik wel eens willen dat ik meer mankeer, zodat ze me steeds komen helpen.

Ongeveer eenderde van de bewoners merkt op dat de medewerkers er geen rekening mee houden dat de ene dag meer hulp nodig is dan de andere dag. Bijna de helft zegt dat de medewerkers niet merken welke aanpassingen zij in de woning nodig hebben; $33 \%$ stelt dat de medewerkers verzuimen te vragen of zij hulp moeten geven en ongevraagd helpen en $69 \%$ zegt dat niet wordt gevraagd of de geboden zorg naar wens is; met $24 \%$ wordt niet overlegd over het tijdstip waarop hulp geboden kan worden; $25 \%$ zegt daarentegen dat veel overleg met hen wordt gepleegd.

\subsubsection{Keuzevrijheid bij regels en gewoonten van het verzorgingshuis}

Aan de onderzoeksgroep zijn vragen gesteld over de dagindeling, de huisregels en het activiteitenprogramma. Nagegaan is door wie deze 'regels en gewoonten' zijn bepaald en wat er van wordt gevonden. Heeft de bewoner de vrijheid tot keuzes, vindt overleg plaats tussen de zorgaanbieder en de bewoner, of bepaalt het verzorgingshuis hoe de dag wordt ingedeeld, welke regels gesteld worden en welke activiteiten worden aangeboden?

$51 \%$ van de geïnterviewden vindt de dagindeling van het huis goed; voor $71 \%$ biedt ze voldoende ruimte om hun eigen gang te gaan en ze sluit voor $90 \%$ van de respondenten ook aan bij hun eigen dagritme en daginvulling. $88 \%$ is van mening dat de dagindeling niet aan individuele wensen wordt aangepast, maar de wens om de dagindeling te veranderen is bij $83 \%$ ook niet aanwezig. Bijna $10 \%$ geeft aan de dagindeling zo aan te willen passen dat ook 's avonds een warme maaltijd genuttigd kan worden. $15 \%$ weet niet dat er huisregels zijn. Bij degenen die dat wel weten lopen de meningen over de huisregels uiteen. Opgemerkt wordt dat het nodig is dat er regels zijn, want "dit schept duidelijkheid"; $8 \%$ vindt dat er geen huisregels moeten worden opgesteld; $35 \%$ vindt dat de huisregels samen met de bewoners moeten worden opgesteld; $61 \%$ vindt van niet. Slechts een enkeling is de mening toegedaan dat huisregels door de bewoners (of cliëntenraad) moeten worden opgesteld. $90 \%$ van de respondenten vindt het goed dat de instelling een activiteitenprogramma voor de bewoners opstelt. $23 \%$ is van mening dat in dit programma individuele wensen moeten worden opgenomen; $30 \%$ vindt dat het programma in samenspraak met de bewoners moet worden opgesteld. Een enkeling (1\%) vindt dat de bewoners het programma moeten opstellen en een minderheid $(4 \%)$ vindt dat helemaal geen programma moet worden opgesteld. 
De diversiteit aan opvattingen over keuzevrijheid komt tot uiting in de volgende tegengestelde reacties:

Ik heb hier het gevoel alsof ik een huis gehuurd heb en ik weet niet dat er regels zijn.

Ik word regelmatig gestoord tijdens mijn rustuurtje en ik voel me gedwongen om me aan de regels te houden, maar ik slaap liever ook eens uit.

\subsubsection{De resultaten nader beschouwd}

De motieven van ouderen uit de onderzoeksgroep om voor verhuizing naar het verzorgingshuis te kiezen, sluiten aan bij wat hierover in de literatuur bekend is (Sweere et al., 1990). Problemen met de gezondheid, waardoor de zelfredzaamheid afneemt, is volgens het SCP (1997) voor ouderen de belangrijkste reden om een plaats in het verzorgingshuis aan te vragen. Daarbij moet een onderscheid worden gemaakt tussen de groep van ouderen die is opgenomen omdat de zelfredzaamheid verminderde en de angst aanwezig was dat als de beperkingen verergerden er te weinig hulp beschikbaar zou zijn, en de groep van ouderen die ervoer dat thuis te weinig hulp aanwezig was voor ondersteuning bij hun beperkingen. Zo blijkt uit onderzoek van het SCP (1997) naar de factoren die van invloed zijn geweest op de aanmelding voor een verzorgingshuis, dat veertig procent van de ondervraagde bewoners aangeeft bang te zijn dat er niemand in de buurt zou zijn bij gezondheidsproblemen; twintig procent zegt dat de thuiszorg het niet meer aankon. De geschiktheid van de woning heeft bij dertig procent een rol gespeeld bij het doen van de aanvraag voor verhuizing. Volgens Steverink (1996) is niet alleen de afnemende zelfredzaamheid de reden tot indicering, maar is het de combinatie van fysieke hulpbehoevendheid (comfort) en het gemis van mensen in hun sociale omgeving die hen tot steun willen zijn (affectie), waarom ouderen voor plaatsing in het verzorgingshuis kiezen. De in de tabel genoemde motieven 'onvoldoende zelfredzaam', 'onvoldoende informele hulp' en 'eenzaamheid en behoefte aan contact' onderschrijven haar opvatting (zie ook hoofdstuk 3.4).

De informele hulp die wordt gegeven heeft niet zozeer betrekking op het geven van lichamelijke verzorging of verpleging, maar op het aanwezig zijn, de organisatie van de huishouding en het geven van emotionele ondersteuning aan de oudere (SCP, 2003). Wanneer deze hulp ontbreekt of niet voldoende is, neemt de behoefte aan andere contacten toe. De behoefte aan contact komt niet enkel voort uit eenzaamheid. Het kan betrekking hebben op de preferenties van ouderen. In hoofdstuk 2 is al opgemerkt dat ouderen met een beperkt sociaal netwerk de voorkeur geven aan een homogeen woonmilieu. Ouderen prefereren een woonomgeving waarin mensen van ongeveer dezelfde leeftijd wonen (Braam, 1981; GGD Groningen, 1994). 
In hoofdstuk 4.4.1 is een onderzoek uit 1999 aangehaald waaruit blijkt dat ouderen met een negatief beeld naar het verzorgingshuis zouden gaan, als zij daarvoor geplaatst zouden worden. De hier gepresenteerde onderzoekgegevens weerspreken dit. De vaak genoemde verwachtingen dat de woning naar eigen smaak kan worden ingericht en dat de oudere zelfstandig kan wonen, laat een ander beeld zien dan het onderzoek uit 1999 aangeeft. Eerder is al opgemerkt dat in dat onderzoek geen onderscheid is gemaakt tussen het wonen in het verzorgingshuis en in het verpleeghuis. Het verzorgingshuis biedt van oudsher ouderen een eigen woonruimte, terwijl het verpleeghuis kamers voor meer personen aanbiedt en (nog) weinig éénpersoonsappartementen heeft. Een tweede kanttekening bij het onderzoek uit 1999 is dat de 50-plussers die aan het onderzoek hebben deelgenomen niet in de fysieke en sociale omstandigheid verkeren dat zij daadwerkelijk een keus moeten maken. Wat opvalt is dat slechts de helft van de in deze studie geïnterviewde ouderen hulp bij de verzorging verwacht. Dit duidt er op dat lichamelijke hulpbehoevendheid niet de belangrijkste drijfveer voor opname in het verzorgingshuis is. Door tien procent van de onderzoeksgroep wordt 'eenzaamheid' of 'gebrek aan contacten' genoemd als motief voor opname, terwijl bijna de helft van de onderzoeksgroep verwacht contacten met medebewoners te kunnen leggen en attente medewerkers in de buurt te hebben. Ook het SCP (1997) merkt op dat de permanente aanwezigheid van hulp en de gelegenheid tot aanspraak belangrijke verwachtingen zijn.

Ongeveer éénderde van de onderzoeksgroep verwacht actief te kunnen zijn door activiteiten die worden aangeboden of door zelf iets te ondernemen. Deze behoefte aan een actieve invulling van het verblijf in het verzorgingshuis wordt in de literatuur nauwelijks belicht, maar is wel van belang in het kader van de zorg voor zelfstandigheid van de oudere die in het verzorgingshuis woont. Waar eerder in deze studie stereotype beelden worden gegeven van een instelling voor ouderenzorg, waar ouderen hun zelfstandigheid en persoonlijke levensstijl verliezen, wordt -in het verlengde van die opvatting- de oudere die naar het verzorgingshuis gaat doorgaans enkel geassocieerd met zorgbehoevendheid. Ambities om een actief leven te leiden, lijken niet te worden onderkend. Het SCP (1997) stelt dat ouderen een negatieve verwachting hebben ten aanzien van het tot uitdrukking kunnen brengen van competenties. Een deel van de bewoners die in deze studie aan het woord komt, deelt die verwachting kennelijk niet.

Externe, negatieve beeldvorming nodigt het verzorgingshuis uit ouderen informatie te verschaffen die, zo mogelijk, een ander licht werpt op wat het verzorginghuis kan bieden. Het belang van het verstrekken van goede informatie door het verzorgingshuis, niet alleen aan ouderen die op de drempel tot toetreding staan maar ook aan ouderen die er verblijven, komt naar voren in het onderzoek van de Landelijke Organisatie Bewonerscommissie 
Bejaardenoorden (zie paragraaf 4.4.2). Hierin is aan bewoners van verzorgingshuizen gevraagd naar hun mening over kwaliteit van zorg. Geconcludeerd wordt dat informatie een belangrijk punt is: het verzorgingshuis moet voldoende informatie geven over onder meer de huisregels, de verzorgingsovereenkomst, het zorgplan en de cliëntenraad.

Los van de verwachtingen die ouderen hebben van het leven in het verzorgingshuis en het gewicht dat bewoners die er verblijven aan een goede informatie toekennen, is het verzorgingshuis in het kader van de Wet op de geneeskundige behandelingsovereenkomst (Wgbo) formeel gehouden aan het verschaffen van informatie. Met name voor het opstellen van de verzorgingsovereenkomst of zorgverlenings-overeenkomst, het zorgplan en het zorgdossier, is, analoog aan de Wgbo, overleg met de bewoner noodzakelijk (Arcares, 2003, modernisering AWBZ). Het zorgplan dat is opgesteld heeft de instemming van de bewoner nodig. Om het zorgplan ten uitvoer te kunnen brengen is het 'informed consent' van de bewoner vereist. Op basis van voldoende informatie over de zorgactiviteiten die de verzorging voornemens is te verrichten, kan de bewoner zijn toestemming verlenen om de activiteiten uit te laten voeren. Het zorgdossier moet worden bijgehouden en de bewoner heeft het recht de gegevens over zijn persoon in te zien.

De onderzoeksresultaten laten zien dat naar de mening van veel ouderen die in het verzorgingshuis verblijven aan het recht op informatie, het toestemmingsvereiste en het inzagerecht onvoldoende aandacht wordt besteed. De meeste bewoners zeggen geen tot nauwelijks weet te hebben van de inhoud van het zorgplan; het wordt niet in samenspraak met de bewoner opgesteld en om toestemming voor het uitvoeren van de voorgenomen activiteiten wordt niet gevraagd. Over het beleid inzake reanimeren en euthanasie wordt onvoldoende gecommuniceerd. De bewoners willen op het goede moment en op de juiste wijze op de hoogte worden gebracht van dit beleid, waarbij men zich het recht voorbehoudt zelf keuzes te maken.

In paragraaf 4.2 is de rol van de cliëntenraad omschreven. Zij behartigt de belangen van de bewoners en praat mee over aangelegenheden die haar aangaan. Over besluiten aangaande voeding, veiligheid, kwaliteitsbeleid en klachtenregelingen moet de instelling een zwaarwegend advies vragen an de cliëntenraad. Hoewel het merendeel van de ondervraagde bewoners aangeeft te weten dat er een cliëntenraad is, is niet goed bekend welke rol zij vervult en waar zij toe bevoegd is. Ook de taak van de menucommissie, die in tegenstelling tot de cliëntenraad niet wordt geïnstalleerd op basis van een wettelijke regeling, maar waaraan door de instelling ook medezeggenschap wordt toegekend, is voor het merendeel van de bewoners niet duidelijk. 
Het leven in het verzorgingshuis is niet voor iedere bewoner waard geleefd te worden. Als het leven niet meer hoeft of als de bewoner zich niet gelukkig voelt, hoeft dat niet aan het wonen in het verzorgingshuis te liggen. Veel bewoners vinden het verzorgingshuis een comfortabele woonplek en zij vinden er de rust en veiligheid waar zij om verlegen zaten. De bewoner wordt over het algemeen naar tevredenheid ondersteund bij de lichamelijke verzorging en het appartement wordt naar verwachting schoongehouden, met dien verstande dat ruim eenderde van de bewoners niet erg tevreden is over de kwaliteit waarmee dat gebeurt. Veel van de ondervraagde ouderen hebben een groot deel van hun leven veel tijd besteed aan de zorg voor de huishouding. De wijze waarop het verzorgingshuis deze activiteit overneemt wordt kritischer beoordeeld dan welke andere activiteit ook.

De bewoner kan zelfstandig wonen, maar door gebrek aan informatie en aan samenspraak kan de bewoner die nieuw binnenkomt in de veronderstelling leven dat de woning niet naar eigen smaak kan worden ingericht. De privacy die wordt geboden, de contacten met medebewoners die kunnen worden gelegd, worden als 'plezierig aspecten' van het wonen in het verzorgingshuis getypeerd. Het gemis aan contacten en aandacht en, voor een aantal ouderen, de wijze van bejegening worden als 'negatieve aspecten' genoemd. De confrontatie met hun gebreken maakt dat veel ouderen zich niet gelukkig voelen. Ouderen ervaren dat zij dingen moeten laten die zij prettig vinden of niet toekomen aan dingen die prettig voor hen zijn en zin aan het leven geven. De beleving van een groot deel van de bewoners, dat de verzorging gericht is op het stimuleren van hun zelfredzaamheid in plaats van op hun zelfstandigheid is veelbetekenend; bewoners vinden dat zij van verzorgenden zelf moeten doen waartoe zij doorgaans fysiek in staat zijn. Meer dan de helft geeft expliciet aan dat verzorgenden niet uitgaan van wat de bewoner wil doen en bijna eenderde van de ondervraagden merkt op dat er geen rekening mee wordt gehouden dat de bewoner de ene dag meer hulp nodig heeft dan de andere dag.

De onderzoekscommissie Gezondheidszorg in Tel 4 (1996) laat gebruikers en zorgverleners van verzorgingshuiszorg aan het woord en gesteld wordt dat de zelfstandigheid van de bewoner in het maken van keuzes gerespecteerd moet worden. Goed overleg over het individueel zorgplan wordt hieromtrent van belang gevonden. Uit de constatering, in dit onderzoek, dat eenderde van de respondenten stelt dat de medewerkers verzuimen te vragen of zij hulp moeten geven en de bewoner ongevraagd helpen, en dat ruim tweederde zegt dat verzuimd wordt te vragen of de geboden zorg naar tevredenheid is, kan worden geconcludeerd dat de zorg blijkbaar onvoldoende is afgestemd op persoonlijke behoeften van de bewoner en op overleg of samenspraak. Tegen die achtergrond is het opmerkelijk dat veel ouderen zich lijken te schikken in de gewoonten en regels van het verzorgingshuis en dat hun keuzevrijheid zich op deze gebieden nauwelijks manifesteert. Gewoonten vormen 
volgens Bernlef, in zijn literair essay: "De macht der gewoonte, literatuur en het afwijkende brein" (2001), de persoonlijkheid, het 'ik' van de mens. Uit de reacties van de respondenten kan niet worden geconcludeerd dat het verzorgingshuis met een veelheid aan gewoonten rekening houdt. Toch kan het merendeel van de bewoners zich vinden in de dagindeling of het dagritme van het huis. De bewoners constateren tegelijkertijd dat in de dagindeling van het huis niet an individuele keuzes of wensen wordt tegemoetgekomen, maar animo om dit te veranderen is er bij velen niet. De huisregels worden door éénderde van de bewoners als een keurslijf ervaren en bij hen bestaat de behoefte om daar in overleg met het verzorgingshuis verandering in aan te brengen. De rest van de respondenten kan zich wel vinden in de keuzes die het verzorgingshuis voor de bewoners gemaakt heeft. Dit geldt ook voor het activiteitenprogramma in het verzorgingshuis. Het huis stelt dit op en de meeste bewoners hebben daar geen probleem mee. Zij hebben de vrijheid om wel of niet aan dit programma deel te nemen, maar de sociale controle van medebewoners en de mening van het verzorgend personeel beïnvloeden niet zelden deze keuze. Daarentegen vindt dertig procent dat het activiteitenprogramma moet worden gemaakt op basis van overleg met bewoners; eenvierde deel van alle respondenten is van mening dat het programma niet aansluit bij individuele keuzes.

\subsection{Resultaten van het enquête-onderzoek onder het verzorgend personeel}

De keuze is gemaakt om verzorgenden geen inschatting te laten maken van de motieven van ouderen om in het verzorgingshuis geplaatst te worden. Omdat de afweging om een verzorgingshuisindicatie aan te vragen doorgaans geruime tijd voor plaatsing gemaakt wordt, is het voor de zorgrelatie veel belangrijker dat verzorgenden een goede inschatting kunnen maken van de verwachtingen die bewoners hebben van het verzorgingshuis.

\subsubsection{Verwachtingen van het verzorgingshuis}

Aan de respondenten is gevraagd in te schatten met welke verwachtingen de ouderen van hun verzorgingsafdeling naar het verzorgingshuis zijn gekomen. De reacties zijn in onderstaande figuur in percentages weergegeven. Het merendeel van de respondenten geeft aan dat ouderen verwachten dat het verzorgingshuis hen een gevoel van veiligheid biedt alsmede hulp bij de verzorging. De verwachting van ouderen dat hulp wordt gegeven bij de huishouding en dat zij contacten met medebewoners kunnen maken, wordt door iets meer dan eenderde van de respondenten aangegeven. Slechts een beperkt aantal respondenten 
denkt dat bewoners verwachtingen hebben terzake het zelfstandig kunnen wonen en de woning naar eigen smaak te kunnen inrichten.

Figuur 8.3: Verwachtingen van het verzorgingshuis

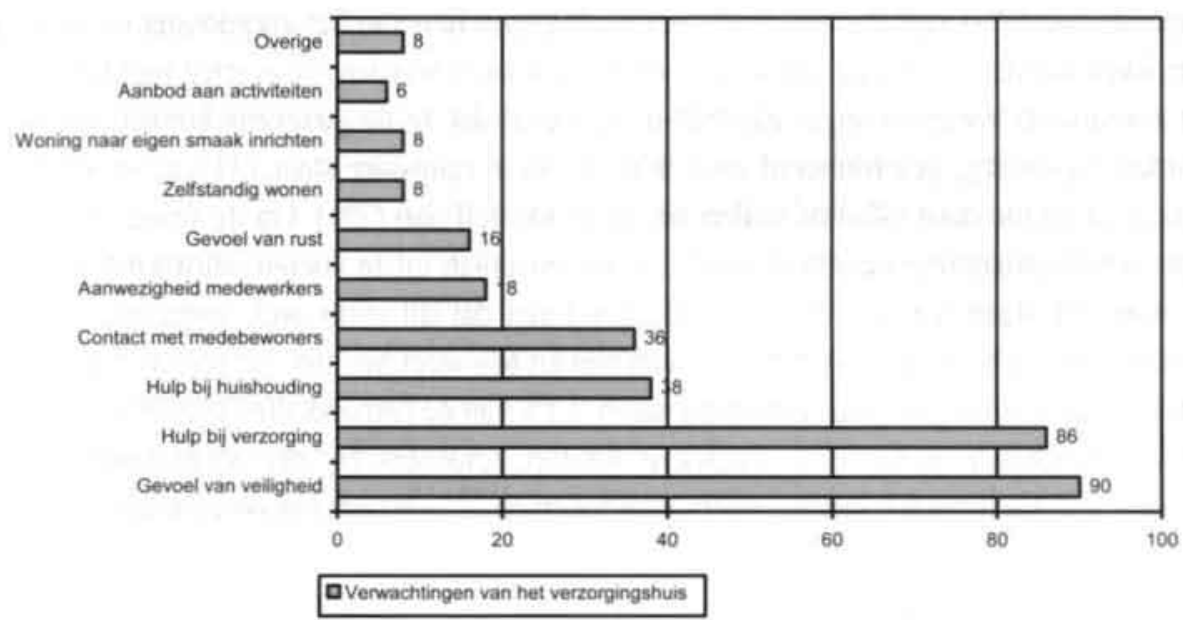

\subsubsection{Informatievoorziening}

Aan het verzorgend personeel dat aan de enquête deelnam zijn de volgende vragen gesteld:

1. zijn bewoners geïnformeerd over algemene regels of rechten en plichten in het verzorgingshuis, zoals die onder meer in een verzorgingsovereenkomst zijn weergegeven;

2. zijn bewoners bekend met het zorgdossier en zorgplan, wat is hun betrokkenheid daarbij en hoe appreciëren zij die betrokkenheid;

3. zijn bewoners bekend met het reanimeer- en euthanasiebeleid van het verzorgingshuis en met (het functioneren van) de cliëntenraad.

De verzorgingsovereenkomst en het zorgdossier

$64 \%$ van de respondenten is van mening dat de bewoners goed $(14 \%)$ tot voldoende $(50 \%)$ op de hoogte zijn van de regels van het verzorgingshuis m.b.t. het inrichten van het appartement, het al dan niet toestaan van huisdieren ed.; $26 \%$ geeft aan dat de bewoners onvoldoende op de hoogte zijn; $10 \%$ geeft aan het niet te weten. $51 \%$ van de respondenten geeft aan dat de bewoners een verzorgingsovereenkomst hebben getekend en langs die weg op de hoogte zijn van hun rechten en plichten; 8\% zegt dat bewoners geen verzorgingsovereenkomst hebben getekend en $41 \%$ weet het niet. $96 \%$ van de respondenten 
veronderstelt dat de bewoners weten dat een zorgdossier van hen wordt bijgehouden; $4 \%$ zegt dat de bewoners dat niet weten. $64 \%$ meent dat bewoners goed tot voldoende op de hoogte zijn van de inhoud van het zorgdossier; $24 \%$ is van mening dat bewoners onvoldoende of niet op de hoogte zijn en $12 \%$ weet het niet. Een klein percentage respondenten $(6 \%)$ zegt dat bewoners niet bij het opstellen van het zorgdossier of zorgplan betrokken worden: $94 \%$ zegt dat ze er wel bij betrokken worden; in overleg met hen wordt het zorgdossier/zorgplan opgesteld ( $82 \%)$; ze weten dat ze de gegevens kunnen inzien en worden regelmatig geïnformeerd over wat in het zorgdossier staat $(31 \%)$; ze lezen het dossier af en toe door (4\%) of vullen het af en toe zelf aan (2\%). Op de vraag of aan de bewoners toestemming gevraagd wordt om het zorgplan uit te voeren, antwoordt $60 \%$ dat dit over het algemeen wel gebeurt; $18 \%$ geeft aan dat dit soms wel, soms niet gebeurt; volgens $16 \%$ gebeurt dit over het algemeen niet en $6 \%$ weet het niet, hetgeen in ieder geval betekent dat zij zelf geen toestemming vragen. $12 \%$ van de respondenten is zeer tevreden en $42 \%$ is redelijk tevreden over de wijze waarop bewoners bij het zorgdossier worden betrokken; $24 \%$ is noch tevreden, noch ontevreden en $22 \%$ is tamelijk ontevreden.

\section{Reanimeerbeleid en euthanasiebeleid}

$68 \%$ van de respondenten is van mening dat de bewoners goed tot voldoende op de hoogte zijn van het reanimeerbeleid; $26 \%$ denkt dat ze onvoldoende op de hoogte zijn en $6 \%$ weet het niet. Voor wat betreft het euthanasiebeleid wordt door $30 \%$ van de respondenten geantwoord dat de bewoners voldoende op de hoogte zijn, terwijl $50 \%$ aangeeft dat zij onvoldoende of niet op de hoogte zijn; $20 \%$ weet niet of de bewoners op de hoogte zijn. Verzorgenden $(96 \%)$ achten adequate informatie over reanimeerbeleid en euthanasiebeleid van belang. $78 \%$ daarvan is die mening toegedaan, maar merkt op dat de wens van de bewoner moet worden gerespecteerd, terwijl $18 \%$ angeeft dat die informatie moet worden verschaft opdat de bewoners weten waar zij in dit verzorgingshuis aan toe zijn.

Voor wat betreft het euthanasiebeleid vindt $70 \%$ dat de wens van de bewoner moet worden gerespecteerd en dat zij om die reden geïnformeerd moeten worden; $20 \%$ vindt informatievertrekking van belang opdat de bewoners weten waar zij aan toe zijn; $8 \%$ vindt informatie over het euthanasiebeleid pas van belang, als de situatie daar om vraagt. De informatie mag daarbij niet de functie hebben van voorschrift, maar slechts van alternatieve mogelijkheid.

\section{Functioneren van de Cliëntenraad}

$64 \%$ van de respondenten veronderstelt dat de bewoners bekend zijn met de functie van de cliëntenraad; $14 \%$ denkt dit niet en $22 \%$ weet het niet. $24 \%$ is van mening dat de cliëntenraad er in slaagt de belangen van de bewoners te behartigen; $54 \%$ vindt dat meer 
moet worden opgekomen voor de belangen van de bewoners; $7 \%$ is de mening toegedaan dat het verzorgingshuis te weinig luistert naar de cliëntenraad en $15 \%$ heeft geen mening over het functioneren van de cliëntenraad.

\subsubsection{Kwaliteit van leven in het verzorgingshuis}

Volgens $70 \%$ van de respondenten ervaren bewoners de veiligheid waaraan zij behoeften hebben. $18 \%$ van de respondenten heeft de indruk dat bewoners zich gelukkig voelen met hun situatie, $26 \%$ geeft aan dat de bewoners zich niet gelukkig voelen en $56 \%$ meent dat deze gevoelens wisselend zijn. $39 \%$ is van mening dat bewoners hun leven de moeite waard vinden en $59 \%$ antwoordt hierbij 'soms wel en soms niet'. $56 \%$ heeft de indruk dat bewoners al met al een plezierig leven hebben in het verzorgingshuis waar de respondent werkt. $50 \%$ zegt dat bewoners ondanks hun zorgbehoeften nog zoveel mogelijk van het leven willen maken; het afhankelijk zijn betekent volgens $39 \%$ van de respondenten niet dat men zich ook afhankelijk voelt. $48 \%$ zegt dat bewoners in het verzorgingshuis hun eigen gang willen gaan en $36 \%$ geeft aan dat bewoners doorgaans toekomen aan dingen die zij prettig vinden. Eveneens $36 \%$ stelt daarentegen dat bewoners dingen moeten laten die zij prettig vinden. $57 \%$ van de respondenten heeft de indruk dat bewoners zoveel mogelijk zelf doen wat ze zelf kunnen; $15 \%$ is van mening dat bewoners vaak te weinig om hulp vragen. $60 \%$ wil het verzorgingshuis waar men werkzaam is aanprijzen aan thuiswonende zorgbehoevende ouderen, $20 \%$ prijst het niet aan; $38 \%$ van de verzorgenden zou er later ook zelf willen wonen.

\subsubsection{Zorgvragen en beoordeling van het zorgaanbod}

Aan de respondenten is gevraagd aan te geven voor welke hulpvragen en behoeften bewoners doorgaans veel of voldoende aandacht vragen. Uit de percentages in onderstaande figuur valt op te maken dat met name de ADL-aktiviteiten (verzorging, toiletgang en eten en drinken) hoog scoren. Maar ook veel respondenten geven aan dat bewoners aandacht vragen voor levensvraagstukken, als het omgaan met afhankelijkheid, het verwerken van de situatie en het invulling geven aan het leven. 
Figuur 8.4: Hulpvragen en behoeften

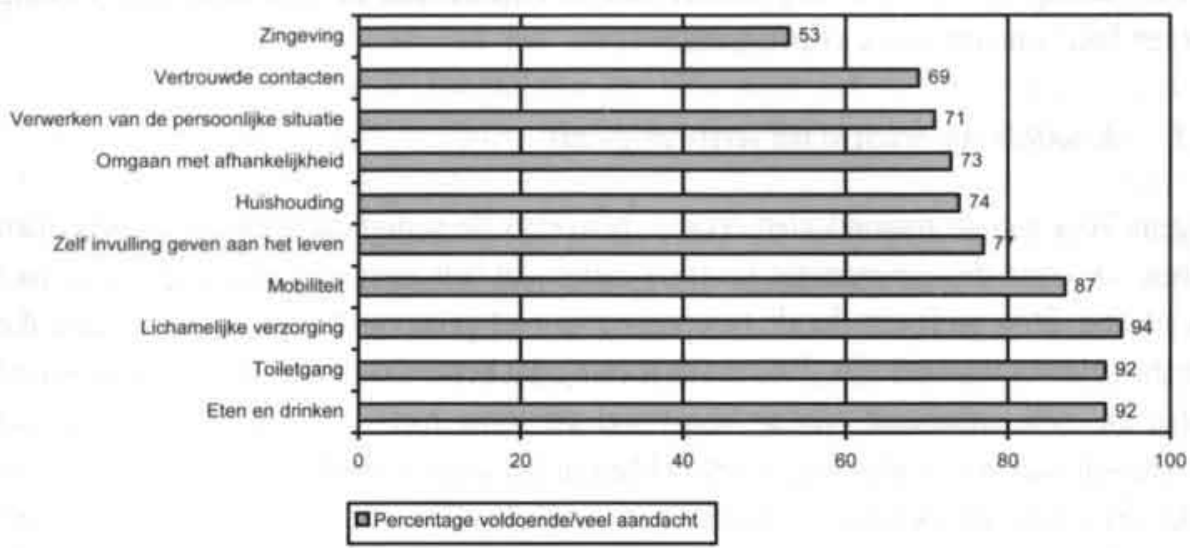

\subsubsection{Houding van de verzorgenden}

Aan het verzorgend personeel is tevens gevraagd uitspraken te doen over de houding waarmee zij de bewoners tegemoet treden. Zij merken op dat hun opvatting niet gevoed is door uitspraken van bewoners. Volgens de respondenten zijn bewoners onvoldoende kritisch op het handelen en de houding van het verzorgend personeel. $54 \%$ van de ondervraagden geeft aan dat bewoners moeten worden uitgenodigd om kritisch te zijn en $30 \%$ vindt dat zij ook zonder uitnodiging kritisch moeten durven zijn.

De respondenten beoordelen de houding van het verzorgend personeel jegens de bewoners op veel aspecten positief (de percentages geven an in welke mate een houdingsaspect 'altijd' en 'meestal' voorkomt): men vindt zich zorgzaam ( $89 \%)$; de belangen van bewoners worden behartigd $(88 \%)$; de bewoners worden met respect benaderd $(87 \%)$; an de bewoners wordt steun geboden $(87 \%)$; ze worden attent benaderd $(82 \%)$ en niet betutteld $(81 \%)$; wat beloofd wordt, wordt ook nagekomen $(81 \%)$; als er mankementen of gebreken zijn in het appartement van de bewoner worden die snel opgelost (79\%); men bekommert zich om de bewoners, nodigt de bewoner uit zijn wensen kenbaar te maken en gaat iedere dag opnieuw na hoe het met de bewoner gesteld is ( $77 \%)$; er wordt rekening gehouden met de wensen en behoeften van bewoners (73\%). Over bepaalde houdingsaspecten zijn de meningen meer verdeeld: $69 \%$ geeft aan dat de bewoner gestimuleerd wordt activiteiten te ontplooien en eenzelfde percentage zegt soms besluiten voor bewoner te nemen voor zijn bestwil. Toch heeft $88 \%$ de indruk dat bewoners er behoefte aan hebben dat met hen wordt 
overlegd en $65 \%$ is van mening dat overleg plaatsvindt over het tijdstip waarop hulp gegeven wordt; $65 \%$ laat de bewoner met rust; $62 \%$ reikt de bewoner mogelijkheden aan waar hij uit kan kiezen en eveneens $62 \%$ stelt dat wordt nagegaan of de bewoner aanpassingen nodig heeft in zijn appartement. Bij het geven van hulp wordt volgens ruim de helft van de respondenten uitgegaan van het tempo van de bewoners $(55 \%)$; de bewoner wordt af en toe voor zijn bestwil overtuigd mee te werken (54\%); $51 \%$ geeft aan dat tijd genomen wordt voor de bewoner, alsmede direct beschikbaar te zijn voor bewoners. Eén van de verzorgenden laat zich hierover als volgt uit:

Positief is dat bij de bewoner bekend is dat je beperkt tijd hebt. Je grens is dan min of meer bepaald, je bent dan beschermd en als je stopt met je werk bij de bewoner accepteert hij dat.

De overige respondenten zeggen dat tijdgebrek hen voor moeilijke keuzes plaatst. Sommigen drukken dit als volgt uit:

Mevrouw vraagt regelmatig of $i k$ sinaasappels wil uitpersen. Tot nu toe heb ik wat om het antwoord heen kunnen draaien. Ik vind dat ik het voor die mevrouw zou moeten doen, maar ik zie al gebeuren dat veel meer bewoners mij die vraag gaan stellen...

Het ergste is dat ik die deur voorbij moet lopen, terwijl ik weet dat mevrouw snakt naar een gesprek.

Wat ik graag anders zou willen zien is wat meer persoonlijke aandacht, niet alleen tijdens verzorging of eten. Het is gewoon te druk.

$50 \%$ vindt dat bewoners ongevraagd geholpen worden; $49 \%$ geeft aan dat vaak aan bewoners gevraagd wordt of zij tevreden zijn over de verleende zorg. Door $47 \%$ wordt ingeschat dat er rekening mee gehouden wordt als een bewoner liever niet door een collega geholpen wil worden. Wat een bewoner zelf kan doen, laat men de bewoner zelf ook doen $(85 \%)$, er wordt slechts door $28 \%$ gevonden dat wordt uitgegaan van wat de bewoner wil doen in plaats van wat hij kan doen.

\subsubsection{Keuzevrijheid bij regels en gewoonten van het verzorgingshuis}

De meeste verzorgenden ( $86 \%$ ) zijn van mening dat bewoners medezeggenschap moeten hebben over de regels van het verzorgingshuis; $8 \%$ vindt dat de invloed van bewoners beperkt moet zijn en dat het verzorgingshuis de regels moet bepalen en $6 \%$ vindt dat alleen de bewoners moeten beslissen over de regels van het verzorgingshuis.

Volgens $16 \%$ van de respondenten is het goed dat het verzorgingshuis de dagindeling van bewoners bepaalt; $20 \%$ is van mening dat het verzorgingshuis de dagindeling meer aan de wensen van bewoners moet aanpassen, terwijl $44 \%$ vindt dat de dagindeling in samenspraak met de bewoners moet worden opgesteld; $20 \%$ meent dat het verzorgingshuis geen 
dagindeling voor bewoners moet maken. Verzorgenden geven het volgende aan:

Je zou de bewoner meer keuzes moeten laten, bijvoorbeeld wanneer hij in bad wil en hoe laat hij naar bed wil gaan. Onze bewoners zouden zelf moeten kunnen bepalen wanneer ze eten, wat ze eten en waar ze eten. Volgens mij wordt met autonomie van de bewoners in ons verzorgingshuis bedoeld dat zij zo optimaal mogelijk zelfstandig hun leven kunnen leven zoals zij dat graag willen en gewend zijn. Ons verzorgingshuis doet het aardig maar zeker niet voldoende naar mijn mening.

$30 \%$ vindt het goed dat de instelling een activiteitenprogramma voor bewoners opstelt; $66 \%$ heeft de opvatting dat een dergelijk programma samen met de bewoners moet worden opgesteld en $2 \%$ vindt dat er geen programma moet worden opgesteld. Eveneens $2 \%$ heeft hieromtrent geen mening.

De diversiteit van opvattingen van het verzorgend personeel over keuzevrijheid voor de bewoners terzake huisregels, de dagindeling en het activiteitenprogramma wordt door onderstaande uitspraken nogmaals geïllustreerd.:

I $k$ vind dat bewoners zich wel te houden hebben aan de regels van het huis, anders wordt het heel chaotisch.

Van de keuze van bewoners uitgaan gebeurt onvoldoende. Veel werknemers zijn niet op de hoogte van wat de bewoner voor keuze wil maken.

Bewoners maken wel een keus, maar door de dagindeling die het verzorgingshuis maakt, wordt weinig op deze keus ingegaan.

Dat gebeurt nog te weinig. Laat de bewoner meer de keuze hoe hij zijn dag indeelt en geef hem meer inspraak in regels, activiteiten ed.

De organisatie is niet erg ingesteld op bewoners die buiten de gebaande paden gaan. Dit is zichtbaar bij de organisatie van grote activiteiten, er wordt dan verwacht dat je meedoet want buiten de activiteit kun je geen kopje koffie meer krijgen.

\subsubsection{De resultaten nader beschouwd}

Wat opvalt is dat de verwachting van comfort c.q. van veiligheid en hulp bij de lichamelijke verzorging door een hoog percentage respondenten genoemd wordt, terwijl de verwachting van affectie c.q. van contacten met medebewoners en aanwezigheid van attente medewerkers, veel lager word ingeschat. Geconcludeerd kan worden dat de verwachtingen waarmee bewoners het verzorgingshuis binnenkomen volgens de verzorgenden meer receptief dan actief van aard zijn en voornamelijk betrekking hebben op fysieke aspecten. De medewerkers geven aan dat bewoners een omgeving verwachting die door het personeel of de omstandigheden gecreëerd wordt en niet zozeer een omgeving die zij zelf creëren. Slechts een beperkt aantal verzorgenden schat dan ook in dat bewoners verwachtingen hebben ten aanzien van het 'zelfstandig kunnen wonen', 'een woning die naar eigen smaak 
kunnen inrichten' en 'een aanbod aan activiteiten'.

Kijken we naar opvattingen over de veronderstelde hulpvragen en behoeften van bewoners dan zien we een veel gevarieerder beeld. De behoeften aan fysieke ondersteuning wordt genuanceerd weergegeven; de behoefte an zelfstandigheid scoort hoog en volgens de verzorgenden vragen veel bewoners aandacht voor behoeften op mentaal en sociaal gebied. Ook de behoefte aan ondersteuning bij vragen op het gebied van zingeving wordt nogal eens gesignaleerd. Dit betekent niet dat de respondenten vinden dat zij die ondersteuning moeten bieden. Zo vindt iets minder dan de helft van de respondenten dat bewoners behoefte hebben aan geestelijke zorg en aan vertrouwde contacten, zonder er een signaal voor ondersteuning in te zien. Hulp bij administratieve zaken wordt zeker niet gezien als een taak voor de verzorging of voor het verzorgingshuis.

Een op de vier respondenten vindt dat bewoners niet goed geïnformeerd zijn over de regels van het huis en de rechten en plichten van de bewoner en het verzorgingshuis. Ofschoon verzorgenden menen dat praktisch elke bewoner weet dat er een zorgdossier van hem is, betekent dat nog niet dat zijn inbreng daarin optimaal is. Minder dan de helft van de verzorgenden is tevreden over die inbreng.

Uit de reacties van het verzorgend personeel terzake de onderwerpen reanimeerbeleid en euthanasiebeleid valt op te maken dat over het algemeen geen instellingsbeleid wordt voorgestaan dat aan de bewoner wordt opgelegd. Principiële keuzes van de instelling dienen ondergeschikt te zijn aan de uiteindelijke keus of beslissing van de bewoner. Een minderheid stelt dat de keus van de bewoner ondergeschikt gemaakt moet worden aan die van het verzorgingshuis. De meerderheid vindt dat voor levensbeschouwelijke standpunten van het verzorgingshuis, die richting geven aan de behandeling van vraagstukken op het gebied van euthanasie en reanimeren, geen plaats is.

De cliëntenraad mag van de respondenten meer aan de weg timmeren. Ze moet zich meer laten gelden en de communicatie naar de overige bewoners moet worden verbeterd. Een directe betrokkenheid van bewoners bij het bepalen van de dagindeling, de huisregels en het activiteitenprogramma vindt bijna tweederde van het personeel van belang.

Het aantal bewoners dat zich thuis voelt in het verzorgingshuis en dat het leven neemt zoals het komt, schommelt volgens het personeel zo rond de vijftig procent. Met afhankelijkheid van het personeel, bijvoorbeeld bij de lichamelijke verzorging, gaat volgens bijna veertig procent van de respondenten voor de bewoner ook een algemeen gevoel van afhankelijkheid gepaard.

De meeste respondenten vinden dat zij zorgzaam zijn, de belangen van de bewoners behartigen, de bewoners met respect bejegenen en attent reageren. Tegen die achtergrond 
kunnen de reacties van de respondenten begrepen worden dat bewoners gestimuleerd worden activiteiten te ontplooien, dat zij voor de bewoner beslissen, of dat zij de bewoner 'voor zijn bestwil' overtuigen. Of voor het uitleggen van deze keuzes ook voldoende tijd genomen wordt en of ook in de ogen van de bewoner de juiste beslissingen worden (over) genomen of handelingen worden verricht, valt te betwijfelen. De helft van de respondenten geeft namelijk aan dat bij het zorg verlenen niet voldoende tijd genomen wordt, dat bewoners ongevraagd worden ondersteund en dat niet wordt nagegaan of de verleende zorg naar wens is. lets meer dan een kwart van het aantal respondenten geeft aan dat in de beoordeling van de benodigde ondersteuning wordt uitgegaan van wat de bewoner wil. De meerderheid gaat uit van wat de bewoner kan in plaats van wat hij wil.

De opvattingen dat te weinig tijd wordt genomen voor de bewoners, dat zij ongevraagd worden ondersteund en niet wordt nagegaan wat zij van de zorg vinden, contrasteren met de opvattingen van driekwart van de respondenten dat de bewoner wordt uitgenodigd zijn wensen kenbaar te maken en dat dagelijks wordt nagegaan hoe het met de bewoner gesteld is. Ze spreken ook tegen dat rekening wordt gehouden met de wensen en behoeften van bewoners.

In hoeverre de opvattingen van de bewoners en die van het verzorgend personeel corresponderen of met elkaar in tegenspraak zijn, is in het volgend deel van dit hoofdstuk aan de orde gesteld. De resultaten van de vraaggesprekken met bewoners en van de enquête bij het verzorgend personeel zijn met elkaar vergeleken.

\subsection{Vergelijking van de resultaten van de interviews met bewoners met de resultaten van de enqûete onder het verzorgend personeel}

In deze paragraaf worden resultaten van de metingen bij de bewoners en het verzorgend personeel naast elkaar geplaatst. Nagegaan wordt of de verwachtingen waarmee bewoners naar het verzorgingshuis zijn gekomen, overeenkomen met opvattingen die het verzorgend personeel daar over heeft. Op eenzelfde wijze worden de opvattingen van de bewoners en het verzorgend personeel met elkaar vergeleken op de gebieden 'informatievoorziening'; 'kwaliteit van leven in het verzorgingshuis'; 'zorgvragen en beoordeling van het zorgaanbod'; 'houding van de verzorgenden' en 'keuzevrijheid bij regels en gewoonten'.

\subsubsection{Verwachtingen}

Onderstaand overzicht toont de verwachtingen die zijn genoemd en de percentages die uitdrukken hoeveel respondenten die verwachting hebben genoemd. 
Figuur 8.5: Verwachtingen van het verzorgingshuis volgens de twee respondentgroepen

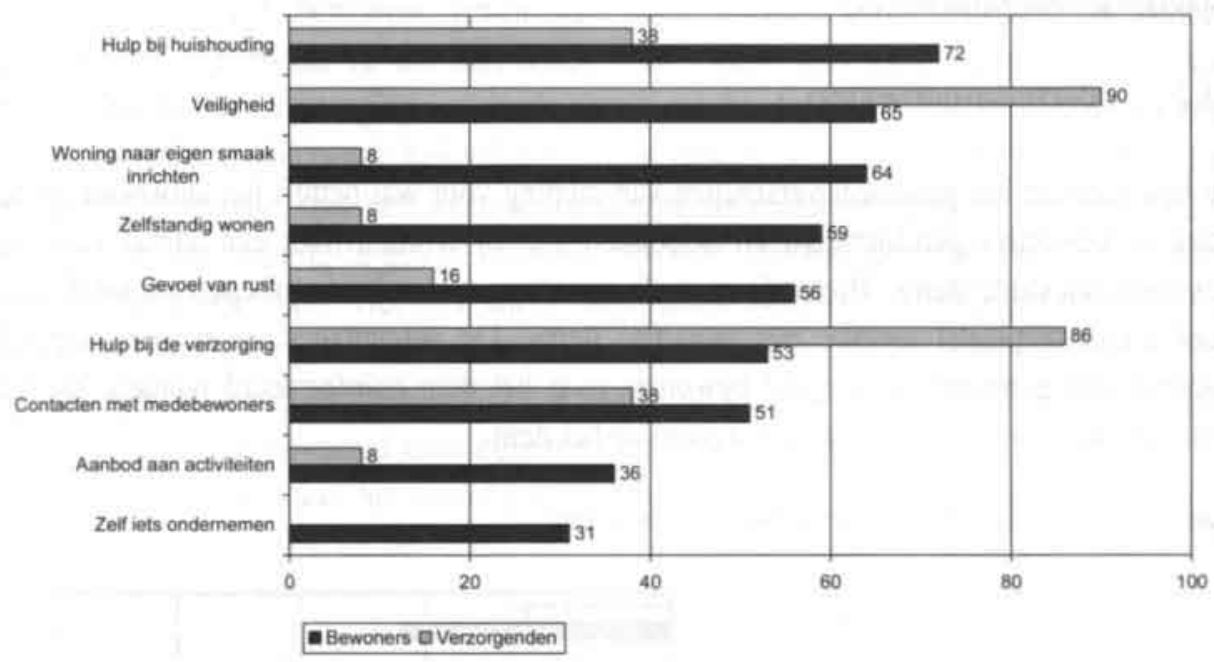

\section{Conclusies}

De verwachtingen die bewoners hebben van plaatsing in het verzorgingshuis lopen allerminst parallel met de inschatting die het verzorgend/verplegend personeel maakt van deze verwachtingen. Het belang dat bewoners toekennen aan de aanwezigheid van hulp bij de huishouding wordt door het verzorgend team blijkbaar onderschat. Eenmaal geplaatst geeft het merendeel van de bewoners aan daadwerkelijk hulp te willen ontvangen bij het schoonmaken van hun appartement, terwijl het verzorgend team van mening is dat $38 \%$ procent van de bewoners om deze hulp verlegen zit. Deze onderschatting, respectievelijk verkeerde inschatting, heeft mogelijk tot gevolg dat eenderde van de bewoners niet tevreden is over de hulp bij de huishouding. Bij de verwachting 'hulp bij de verzorging' zien we het omgekeerde beeld: het verzorgend personeel heeft de indruk dat het merendeel van de bewoners voornamelijk voor deze hulp en voor de veiligheid naar het verzorgingshuis gaan, terwijl voor bewoners de mogelijke contacten met medebewoners zeker zo belangrijk zijn. Eenderde van de ondervraagde bewoners die naar het verzorgingshuis gaat verwacht 'een aanbod aan activiteiten' en wil 'zelf iets ondernemen'. In hoofdstuk 2.7 zijn de ouderen die voor plaatsing in een verzorgingshuis in aanmerking komen, getypeerd als mensen die een teruggetrokken bestaan leiden, die met beperkte financiën moeten zien rond te komen en die afhankelijk zijn van anderen. Het verzorgend personeel heeft wellicht dit beeld voor ogen en dicht de bewoners nauwelijks ondernemingslust toe. Bewoners die redelijk in staat zijn voor zichzelf te zorgen kunnen hun eigen gang gaan, maar voor anderen kunnen het tijdstip 
en het tempo van verzorging, alsmede de aard en mate van ondersteuning van belang zijn voor het kunnen ondernemen van activiteiten. De vraag is of de preferenties door de verzorging onderkend worden.

\subsubsection{Informatievoorziening}

De bewoners en het personeel verschillen van mening voor wat betreft het antwoord op de vraag of bewoners geïnformeerd en betrokken zijn of worden over een aantal voor de bewoners relevante items. Hieronder zijn de opvattingen van beide groepen respondenten naast elkaar geplaatst terzake een twaalftal items. De percentages geven aan hoeveel respondenten genoemd hebben dat bewoners over het item geïnformeerd worden, bij het item betrokken worden, of positief reageren op het item.

Figuur 8.6: Informatievoorziening ten behoeve van bewoners

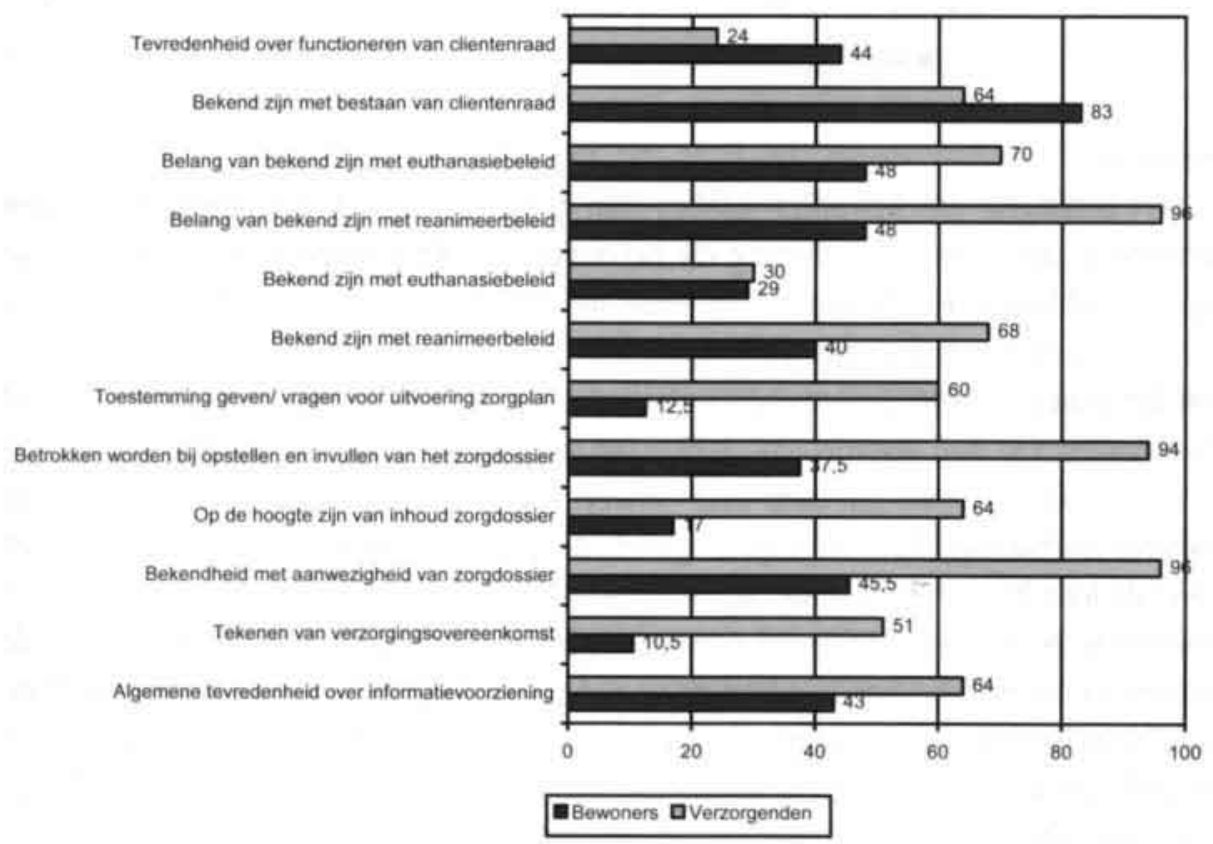

\section{Conclusies}

Het verzorgend personeel heeft een veel positiever beeld dan de bewoners over de mate waarin de bewoners geïnformeerd zijn over het verzorgingshuis in het algemeen en over de verzorgingsovereenkomst, het zorgdossier, het zorgplan en het beleid inzake reanimeren en 
euthanasie in het bijzonder. Alleen over het bestaan en functioneren van de cliëntenraad geven bewoners aan beter geïnformeerd te zijn dan door de verzorgenden wordt verondersteld. Veel bewoners geven aan geen verzorgingsovereenkomst te hebben getekend, of zeggen dat ze dat niet weten. Een groter percentage verzorgenden is van mening dat wel een verzorgingsovereenkomst is getekend. Duidelijk is dat het zorgdossier en het zorgplan onvoldoende bekend zijn bij de bewoners. Veel bewoners zeggen niet te weten wat er in staat, niet betrokken te worden bij de invulling ervan en niet gevraagd te worden om toestemming te geven voor het uitvoeren van het zorgplan. De verzorgenden denken daar anders over. Het merendeel vindt dat de bewoners wel bekend zijn met het zorgdossier en dat ze betrokken worden bij het opstellen en invullen ervan. Ook geven zij aan dat de bewoners op de hoogte zijn van de inhoud van het zorgdossier. Over de vraag of toestemming wordt gevraagd voor de uitvoering van het zorgplan lopen de meningen ver uiteen: zestig procent van het verzorgend personeel antwoordt bevestigend tegenover nog geen dertien procent van de bewoners. Het verzorgend personeel schat de bekendheid van bewoners met het reanimeerbeleid hoger in dan de bewoners. Het bekend zijn met het euthanasiebeleid wordt daarentegen door beide groepen laag gewaardeerd. De verzorgenden vinden, meer nog dan de bewoners, dat het bekend zijn met het reanimeer - en euthanasiebeleid van het verzorgingshuis van belang is voor de bewoners maar wil de beslissingsruimte voor de bewoner terzake deze onderwerpen zo groot mogelijk laten zijn. De bewoners zijn meer bekend met het bestaan van de cliëntenraad dan de verzorgenden denken; bewoners zijn matig tevreden over het functioneren van de cliëntenraad maar meer tevreden dan de teams van verzorgenden veronderstellen.

\subsubsection{Kwaliteit van leven in het verzorgingshuis}

In onderstaand overzicht zijn reacties van bewoners en van verzorgend teamleden op items terzake 'kwaliteit van leven' naast elkaar geplaatst. Aan de verzorgende teams is gevraagd in te schatten hoe de bewoners op de vragen reageren. Alleen bij de antwoordcategorieën die zijn aangekruist, zijn percentages gegeven. Dit betekent dat wanneer $80 \%$ antwoordcategorie 'ja' invult en niemand antwoordcategorie 'nee', niet geconcludeerd mag worden dat $20 \%$ onder de antwoordcategorie 'nee' geschaard kan worden. 
Figuur 8,7: Kwaliteit van leven in het verzorgingshuis

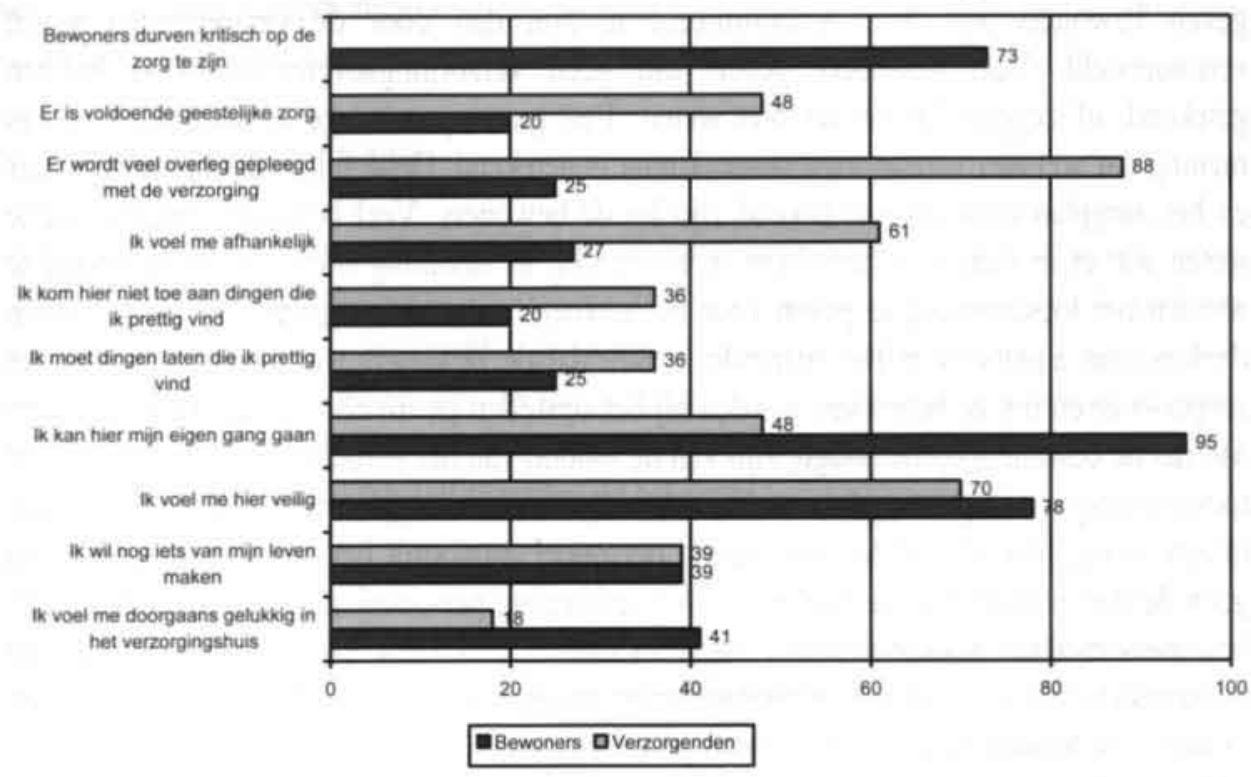

\section{Conclusies}

Verzorgenden maken geen goede inschatting van de reacties van bewoners op de vraag of ze zich doorgaans gelukkig voelen in het verzorgingshuis. De verwachting waarmee veel bewoners naar het verzorgingshuis zijn gekomen, namelijk dat er een veilig gevoel gecreëerd wordt, wordt voor meer dan drievierde deel van de bewoners ook ingelost en het verzorgend personeel maakt daar een juiste inschatting van. Het merendeel van de bewoners heeft het gevoel de eigen gang te kunnen gaan. Minder dan de helft van het verzorgend personeel heeft de indruk dat de bewoner zijn eigen gang kan gaan en ongeveer zestig procent denkt dat bewoners zich afhankelijk voelen. Eerder is al opgemerkt dat het verzorgend personeel fysieke afhankelijkheid bij de lichamelijke verzorging, waar eveneens ongeveer zestig procent van de bewoners mee te maken heeft, associeert met een gevoel van afhankelijkheid, terwijl dit voor de bewoners anders ligt. Vooral die bewoners die een regelmatig appèl doen op de verzorging buiten 'de verzorgingstijden' om, omdat ze problemen hebben met hun mobiliteit of continentie, voelen zich bezwaard omdat ze een extra beroep doen op de tijd van de verzorging. Chronische beperkingen die bewoners ondervinden, kunnen tot gevolg hebben dat bewoners dingen moeten laten die zij prettig vinden. Vijfentwintig procent van de bewoners moet prettige dingen laten en een hoger percentage verzorgenden meent dat er nog meer bewoners zijn die dit ervaren. Meer dan eenderde deel van de verzorgenden is van mening dat de bewoners wel toekomen aan dingen die zij prettig vinden; twintig procent van de bewoners geeft aan daar juist niet aan 
toe te komen. Voor de verzorging is het van belang in overleg met de bewoner na te gaan of de oorzaken waarom bewoners prettige dingen moeten laten of er niet aan toekomen door het verzorgingshuis kunnen worden weggenomen. In de ogen van het verzorgend personeel is er een cultuur van overleg waarin deze kwesties besproken kunnen worden, maar slechts één op de vier bewoners ervaart dat er ruimte is voor overleg. Zeventien procent van de bewoners geeft expliciet aan geen kritiek te durven uiten. Meer dan tachtig procent van de verzorgenden geeft aan zich open te stellen voor kritiek van bewoners; iets meer dan de helft van de verzorging merkt hierbij op dat de bewoners moeten worden uitgenodigd kritisch te zijn en bijna eenderde deel van de respondenten vindt dat bewoners ook zonder uitnodiging kritisch moeten zijn.

\subsubsection{Zorgvragen en beoordeling van het zorgaanbod}

Bijna alle verzorgenden geven aan dat de behoefte van bewoners aan lichamelijke verzorging vaak tot regelmatig wordt geuit en $60 \%$ van de bewoners vindt zichzelf behoevend op het gebied van lichamelijke verzorging. Hulp bij de toiletgang en bij het zich verplaatsen worden volgens $92 \%$ van de verzorgenden regelmatig gegeven, maar in veel gevallen valt deze hulp samen met hulp bij de lichamelijke verzorging. Bewoners waarbij dit niet volledig samenvalt, en die buiten de ronden om hulp nodig hebben bij de toiletgang $(8 \%)$ of bij de mobiliteit ( $21 \%$ ) worden door de verzorgenden niet onderscheiden, terwijl het juist deze groepen zijn die aangeven niet tevreden te zijn over de steun bij de toiletgang ( $16 \%$ ) of bij de mobiliteit ( $25 \%$ ). $16 \%$ van de bewoners zou graag, "buiten de zorgtijden om' onder begeleiding een wandeling willen maken. Evenzo geeft $71 \%$ van de verzorgenden aan dat de bewoners van hun afdeling behoefte hebben aan hulp bij de verwerking van de situatie waarin zij verkeren, maar tekent een beduidend lager percentage bewoners $(22 \%)$ an dat zij die hulp nodig hebben. Van de bewoners die hiervoor hulp krijgen is $24 \%$ niet tevreden. Eerder is al opgemerkt dat de behoefte aan hulp bij het schoonhouden van het appartement door het personeel wordt onderschat. $34 \%$ van de bewoners is niet (geheel) tevreden over de verleende hulp. Volgens $69 \%$ van de verzorgenden hebben bewoners behoefte aan vertrouwde contacten. De bewoners daarentegen vragen veeleer aandacht van het personeel voor een praatje. Bijna één op de drie bewoners zou willen dat daar meer tijd voor wordt uitgetrokken.

\subsubsection{Houding van de verzorgenden}

De houding van het verzorgend personeel is een belangrijke factor bij de zorg voor zelfstandigheid. In de paragrafen 8.1.6 en 8.2.5 is aangegeven hoeveel respondenten van 
mening zijn dat de genoemde houdingsaspecten doorgaans voorkomen. In deze paragraaf worden de opvattingen van de respondentgroepen naast elkaar geplaatst waarbij de houdingsaspecten zijn gegroepeerd (naar de indeling van Tronto) in de volgende categorieën:

1. attentiviteit, oftewel de juiste aandacht voor de behoefte van de bewoner

2. responsibiliteit, oftewel bereidheid verantwoordelijkheid te nemen

3. competentie, oftewel deskundigheid

4. responsiviteit, oftewel antwoord geven op de behoefte, wens of vraag van de bewoner of aan diens verwachtingen voldoen.

Figuur 8.8 Attentiviteit

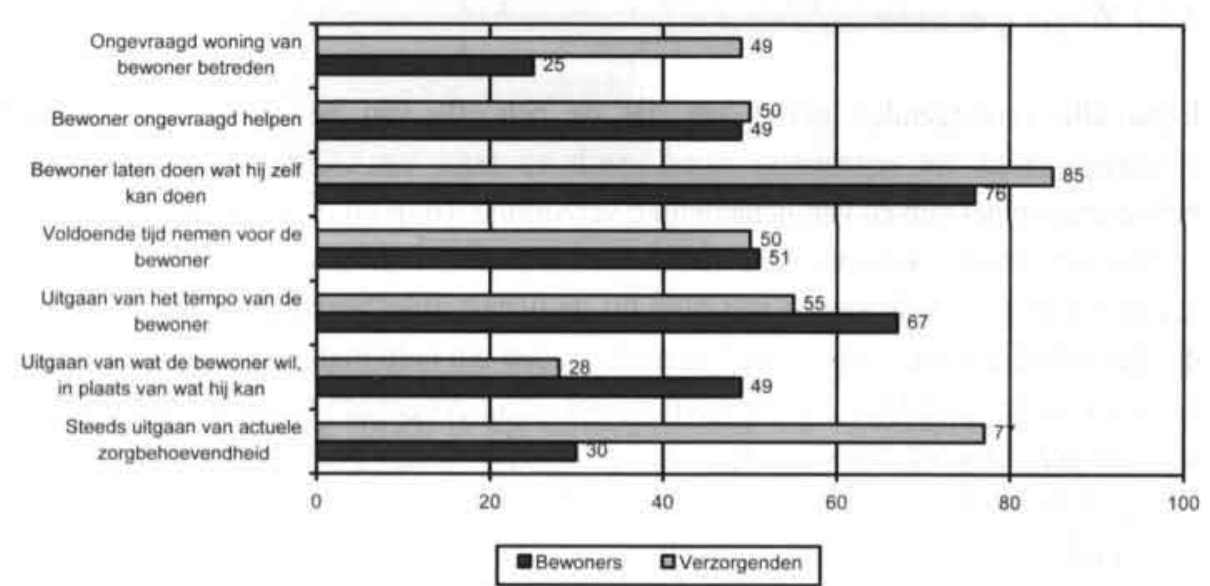

De attentiviteit van de verzorgenden laat op een aantal punten te wensen over: de helft van de verzorgenden is van mening dat ongevraagd de woning van de bewoners wordt betreden, dat bewoners ongevraagd worden geholpen en dat niet voldoende tijd voor de bewoners wordt genomen. Nagenoeg eenzelfde percentage bewoners deelt de mening dat zij ongevraagd wordt geholpen en dat niet voldoende tijd wordt genomen. Eenvierde deel van de bewoners vindt dat verzorgenden ongevraagd hun woning betreden. Het merendeel van beide respondentgroepen heeft de opvatting dat verzorgenden bewoners zelf laten doen wat ze zelf kunnen doen. Dat uit die opvattingen niet geconcludeerd mag worden dat de respondenten vinden dat op dit punt attentief gedrag getoond wordt, blijkt uit het gegeven dat slechts $28 \%$ van de verzorgenden en $49 \%$ van de bewoners aangeven dat uitgegaan wordt van wat de bewoner wil in plaats van wat hij kan. Ook vindt men dat de bewoner niet altijd het tempo van de zorgverlening bepaalt. De fysieke mogelijkheden of zelfredzaamheid van de bewoner lijken te bepalen of verzorgenden ondersteuning geven. 
Ruim driekwart van de verzorgenden heeft de indruk dat de actuele behoefte aan zorg gesignaleerd wordt en uitgangspunt van zorg is; slechts eenderde van de bewoners is dezelfde mening toegedaan.

Figuur 8.9: Responsibiliteit

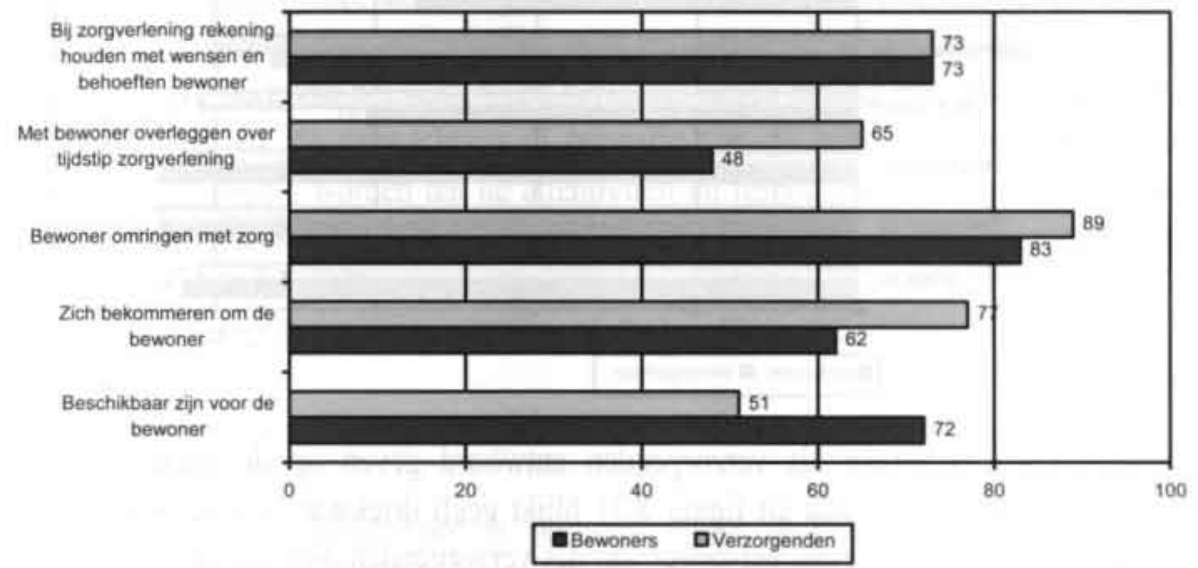

Een groot deel van beide respondentgroepen vindt dat de verzorgenden bereid zijn om de zorg voor de bewoner op zich te nemen. Tijdens de zorgverlening wordt naar de mening van driekwart van de respondenten rekening gehouden met de wensen en behoeften van de bewoner; de bewoner wordt omringd met zorg en het merendeel van de verzorgenden vindt dat ze zich bekommert om de bewoners en overlegt over het tijdstip van zorgverlening. Minder tevreden zijn verzorgenden over hun beschikbaarheid voor de bewoners; ongeveer de helft geeft aan beschikbaar te zijn, terwijl een groter deel van de bewoners van mening is dat verzorgenden beschikbaar zijn. Minder enthousiast zijn de bewoners over het overleg met verzorgenden over het tijdstip van zorgverlening; nog geen vijftig procent vindt dat hierover overleg gevoerd wordt.

De meningen over de competentie of deskundigheid van het verzorgend personeel lopen weinig uiteen tussen de twee groepen respondenten. De meeste respondenten hebben de opvatting dat de verzorgenden deskundig zijn: ze worden respectvol, attent en vakkundig gevonden; ze betuttelen niet, komen beloftes na en mankementen of gebreken in de woning worden verholpen. Nogal wat bewoners vinden dat mankementen of gewenste aanpassingen niet altijd worden opgemerkt en dat niet de gewenste steun wordt gegeven. In onderstaande figuur is een en ander in beeld gebracht. 


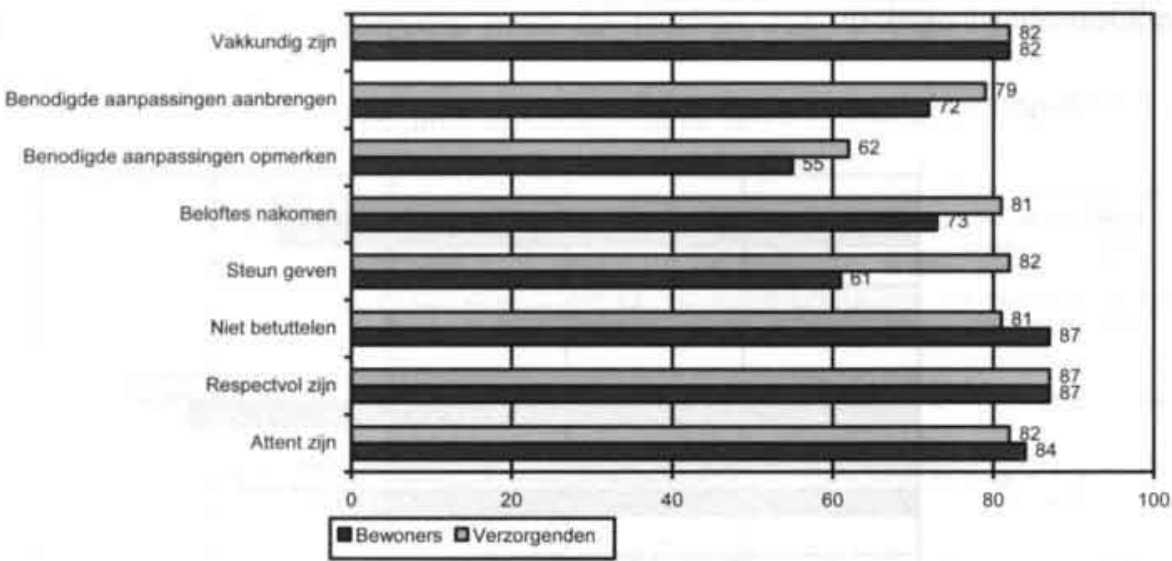

Van responsiviteit is sprake als verzorgenden antwoord geven op de vraag, wens of behoefte van de bewoner. Zoals uit figuur 8.11 blijkt geeft driekwart van de bewoners en bijna de helft van het verzorgend personeel aan dat verzorgenden niet vragen of nagaan of de verleende zorg aan de verwachtingen of behoeften van de bewoner heeft voldaan.

Figuur 8.11: Responsiviteit

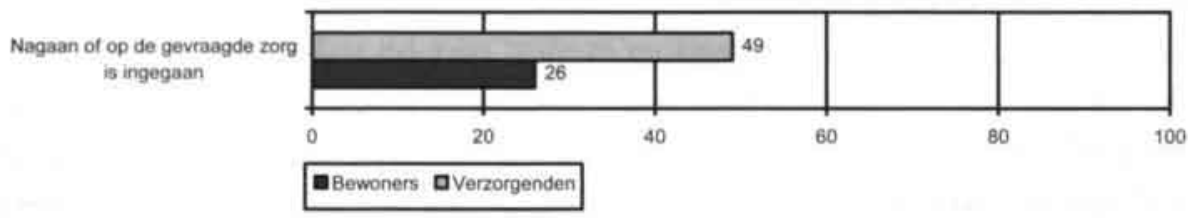

\section{Conclusies}

Geconcludeerd kan worden dat de mening bestaat dat verzorgenden de bewoner correct en respectvol bejegenen en dat de bewoner kan vertrouwen op de afspraken die de verzorgenden maken. Hoewel het verzorgend personeel vindt dat zij onvoldoende tijd ter beschikking heeft voor de bewoner, kan uit de opvatting van de bewoners worden afgeleid dat zij er in veel gevallen in slaagt dit gevoel niet over te dragen aan de bewoner. De individuele hulpvraag, verwachting of behoefte van de bewoner zijn volgens de respondentgroepen lang niet altijd vertrekpunt van het handelen: in vijftig procent van alle contacten tussen bewoner en verzorgende wordt ongevraagd zorg verleend en is vooraf niet gecommuniceerd over het tijdstip van zorgverlening; de tijd die voor de zorgverlening 
genomen wordt, wordt slechts door de helft van de respondenten als voldoende beschouwd en het tempo van de zorgverlening wordt volgens 4 van de 10 bewoners niet zelf bepaald; bij de zorgverlening wordt voornamelijk uitgegaan van wat de bewoner kan, niet van wat hij wil; het personeel baseert, volgens zeven van de tien bewoners, de dagelijkse zorgverlening niet op de hier-en-nu-situatie, oftewel op de actuele zorgbehoevendheid. Twee van de tien personeelsleden zijn het met die kritische noot van de bewoners eens; de zorgverlening wordt niet geẻvalueerd met de bewoner. Ongeveer driekwart van de bewoners en de helft van het verzorgend personeel geven aan dat niet wordt nagegaan of de verleende zorg aan de verwachting of behoefte van de bewoner heeft voldaan. In het algemeen kan gesteld worden dat de attentiviteit en responsiviteit, oftewel de aanvang en beëindiging van een concrete zorgsituatie, niet voldoen aan verwachtingen die hieraan gesteld mogen worden. Een grote groep respondenten constateert wel dat verzorgenden verantwoordelijkheid nemen voor de zorg en deskundig zorg verlenen.

\subsubsection{Ketzevrijheid bij regels en gewoonten}

Aan de twee respondentgroepen is gevraagd welke invloed bewoners zouden moeten hebben bij de bepaling van de huisregels, de dagindeling en het activiteitenaanbod. De opvatting dat de bewoners beslissen welke huisregels er moeten zijn, hoe de dagindeling er uit moet zien en welke activiteiten moeten worden aangeboden, alsmede de opvatting dat het verzorgingshuis op deze gebieden niets gemeenschappelijks moet regelen, is hier getypeerd als een 'vraaggerichte benadering'; de opvatting dat programma's op deze gebieden door samenspraak en medezeggenschap van individuele of groepen bewoners moeten worden opgesteld, is de 'overleggerichte benadering' genoemd; de opvatting dat het verzorgingshuis in dezen alle verantwoordelijkheid op zich moet nemen, is de 'aanbodgerichte benadering' genoemd.

\section{Invloed op de huisregels}

Het verzorgend personeel verwacht een grotere betrokkenheid van de bewoners bij de bepaling van huisregels dan de bewoners zelf: $86 \%$ van de verzorgenden is van mening dat de bewoners medezeggenschap moeten hebben en $6 \%$ wil alleen de bewoners laten beslissen over de regels; $8 \%$ vindt dat de invloed van bewoners beperkt moet zijn. $35 \%$ van de bewoners is voor samenspraak over de regels; voor $60 \%$ van de bewoners hoeft dat niet; $8 \%$ daarvan vindt dat er geen huisregels zouden moeten zijn. $50 \%$ van het personeel vindt dat de cliëntenraad meer moet doen aan de behartiging van belangen van bewoners, onder meer terzake de huisregels.

Deze reacties zijn in onderstaand diagram samengevat. 
Figuur 8.12: Invloed op de huisregels

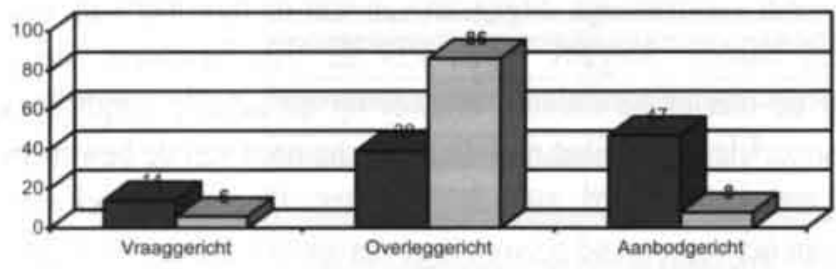

Bewoners

口Verzorgenden

\section{Invloed op de dagindeling}

Het merendeel van de bewoners heeft niet de behoefte verandering aan te brengen in de dagindeling; $10 \%$ is wel vóór aanpassing. Met name de warme maaltijden zouden 's avonds genuttigd moeten kunnen worden. Een groter deel van het personeel vindt dat de bewoners meer bemoeienis moeten hebben met de dagindeling. $20 \%$ is van mening dat de dagindeling meer bij individuele wensen van bewoners moet aansluiten en $44 \%$ vindt dat de keuze voor de dagindeling in het verzorgingshuis het resultaat moet zijn van overleg met bewoners. $20 \%$ van het personeel vindt dat voor bewoners geen dagindeling gemaakt zou moeten worden en $16 \%$ is juist van mening dat bewoners geen invloed moeten hebben op de dagindeling.

In figuur 8.13 zijn de opvattingen weergegeven.

Figuur 8.13: Invloed op de dagindeling

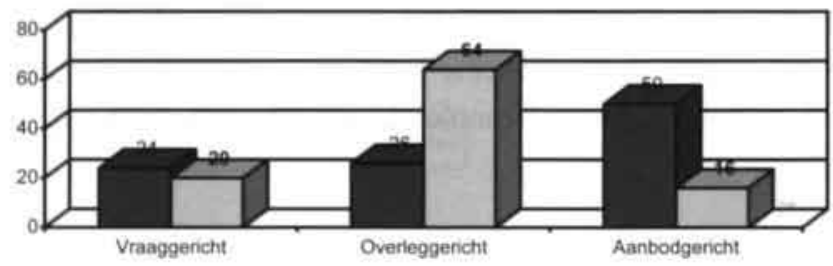

Bewoners

DVerzorgenden

\section{Invloed op het activiteitenprogramma}

Ongeveer eenderde van het personeel is het er mee eens dat het verzorgingshuis een activiteitenprogramma voor de bewoners opstelt; tweederde vindt dat dit in samenspraak met de bewoners moet gebeuren. De reacties van de bewoners laten het omgekeerde beeld zien: eenderde is vóór samenspraak, iets minder dan tweederde is voorstander van een hoofdrol voor het verzorgingshuis; $5 \%$ vindt het niet nodig dat een programma wordt opgesteld. 


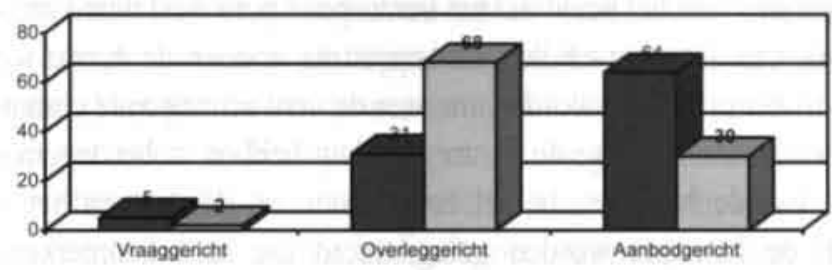

\section{Conclusies}

Het is opmerkelijk dat het verzorgend personeel vindt dat moet worden aangestuurd op overleg met de bewoners over de huisregels en de dagindeling en, in iets mindere mate, het activiteitenprogramma. Opmerkelijk, omdat de houding die naar de mening van de verzorgenden in het directe contact met de bewoners geëtaleerd wordt, niet als overleggericht of vraaggericht getypeerd kan worden. Tweederde deel van de bewoners kan zich redelijk vinden in een leidende rol van het verzorgingshuis. Grofweg gesteld heerst de opvatting dat ongeveer eenderde van de bewoners wil meepraten over de huisregels, de dagindeling en het activiteitenaanbod. Dit meepraten hoeft overigens niet te betekenen dat er behoefte bestaat om wijzigingen aan te brengen. In paragraaf 8.1.7 is reeds gesteld dat voor het overgrote deel van de bewoners de huidige gewoonten en regels gehandhaafd mogen blijven. Met de wens van een aantal bewoners om mee te praten en om aanpassingen te bewerkstelligen, moet niet lichtvaardig worden omgesprongen. In de bereidheid om medeverantwoordelijkheid te dragen kan zingeving schuil gaan; mensen kunnen zich aangesproken voelen op hun competenties en mogelijkheden in plaats van op hun beperkingen en het geeft bewoners de mogelijkheid hun ambitie om iets te ondernemen waar te maken.

\subsection{De resultaten nader beschouwd}

In hoofdstuk 8 zijn de opvattingen van bewoners en verzorgenden weergegeven over onderwerpen die betrekking hebben op zorg voor zelfstandigheid in verzorgingshuizen. Of de opvattingen volledig overeenkomen met de werkelijkheid van alledag is de vraag. In deze studie is niet met behulp van bijvoorbeeld participerende observatie nagegaan of de meningen die worden uitgesproken ook bevestigd worden in de dagelijkse praktijk. Er is voor gekozen om de werkelijkheid zoals die door de respondentgroepen wordt beleefd te inventariseren en hun beeld van de werkelijkheid tot hèt beeld van de werkelijkheid te verheffen. 
De verwachtingen waarmee bewoners naar het verzorgingshuis zeggen te komen, lopen op diverse gebieden niet parallel met het beeld dat het verzorgend personeel daar van heeft. Als de praktijk beantwoordt aan deze verschillen van opvatting zouden de eerste weken van kennismaking en verblijf benut moeten worden om over de verwachtingen te communiceren en om samen te bepalen welke bijdrage de verzorging kan hebben in het tegemoetkomen aan de verwachtingen van de bewoner. In het zorgdossier, en daarbinnen het zorgplan, kunnen gegevens van de bewoner worden geregistreerd die hem kenmerken, die de verzorging kan benutten om tegemoet te kunnen komen aan de behoeften, vragen en verwachtingen van de bewoner en die waarborgen dat gewoonten van de bewoner gerespecteerd en zo nodig beschermd worden. Maar de onderzoeksresultaten wijzen uit dat gevonden wordt dat de informatievoorziening allesbehalve optimaal is. Hoewel het verzorgend personeel van mening is dat de bewoners veel meer betrokken worden bij het zorgplan dan de bewoners zelf beweren, vindt meer dan de helft van de verzorgenden dat de informatie an en rapportage over de bewoner verbetering behoeft. Wettelijke bepalingen als informed consent, het toestemmingsvereiste en het inzagerecht lijken niet of niet afdoende geïntroduceerd.

Adequate rapportage en registratie zijn van belang, maar hebben slechts instrumentele betekenis. Ze dienen om een goed beeld te krijgen van de bewoner en om zijn zorg voor zelfstandigheid te waarborgen. Ze moeten er voor zorgen dat het verzorgend team niet tot verkeerde beoordelingen komt over de kwaliteit van leven, zoals dat door de bewoner wordt beleefd. De cijfers laten zien dat wordt ingeschat dat die verkeerde beoordelingen veelvuldig worden gemaakt en niet worden gecorrigeerd in de directe contacten tussen het verzorgend personeel en de bewoner.

De opvatting heerst dat op een nette, vriendelijke en ook deskundige manier handelingen worden verricht bij en beslissingen worden genomen over de bewoners. Maar ook dat in veel gevallen bewoners zorg ontvangen zonder dat aan hen de vraag gesteld wordt of ze die zorg ook wensen. Veel respondenten zijn van mening dat niet om toestemming wordt gevraagd om te mogen handelen en dat niet wordt gevraagd of de handelingen die zijn verricht, en de zorg die is verleend, naar de wens, behoefte of verwachting van de bewoner hebben plaatsgevonden. Het schort met andere woorden aan overleg, dialoog en deliberatie; aan attentief en responsief gedrag van verzorgenden. Sommige bewoners lijken het best te vinden, blij wellicht dat er iemand in het appartement is, dat er aanspraak is en dat in het verzorgingshuis aan primaire levensbehoeften wordt voldaan. Wellicht ook vinden bewoners dat het leven in het verzorgingshuis niet van een mindere kwaliteit is dan de situatie waarin zij de laatste jaren voor hun verhuizing naar het verzorgingshuis verkeerd hebben. De beschikbaarheid van de hulp, de continuïteit ervan en de garantie van 
onmiddellijke hulp in gevallen van crisis bepalen volgens Wolffensperger e.a. (1991) blijkbaar in hoofdzaak de tevredenheid van ouderen. De tevredenheid van bewoners met hun invloed op de huisregels, de dagindeling en het activiteitenprogramma is redelijk maar niet optimaal. Vier van de tien bewoners vinden dat zij een meer of minder nadrukkelijke rol moeten vervullen bij het opstellen van huisregels, een derde vindt dat dit ook moet gebeuren bij het opstellen van een activiteitenprogramma en iets meer dan twintig procent van de bewoners vindt dat zij ook invloed moet hebben op het bepalen van de dagindeling. lets meer dan één op de vijf bewoners geeft aan 'niets meer van het leven te willen maken'. Het verzorgend personeel schat in dat deze opvatting voor zes van de tien bewoners opgeld doet. De vraag is hoe deze opvattingen begrepen moeten worden. Den Dulk (1998) citeert de klacht van Prediker: "Ik heb er geen zin meer in, het leven smaakt mij niet meer", en interpreteert ze als een uiting van gelatenheid, van opstandigheid, vertwijfeling of strijdlust. De bewoner kan vinden dat het leven mooi is geweest en rijp is afgebroken te worden, of hij kan vinden dat het leven hem alleen nog maar ellende brengt en dat hij hoopt dat er gauw een eind aan komt. Ook het verzorgend personeel heeft hier zijn gedachten bij. Zonder het levensverhaal te kennen van de bewoner die deze opvatting kenbaar maakt, kan de intentie volgens Den Dulk niet begrepen worden (1998).

De vraag is welke betekenis gegeven dient te worden aan de in dit hoofdstuk gepresenteerde resultaten. Moeten de respondenten die aangeven niet gelukkig te zijn met de dagindeling, de huisregels en het activiteitenprogramma accepteren dat zij de minderheid vormen, geen invloed kunnen uitoefenen en met de situatie leren leven? Moet de constatering dat zeventig tot tachtig procent van de bewoners zich kan vinden in keuzes die het verzorgingshuis maakt tot tevredenheid stemmen, of moeten de bewoners die zich conformeren aan de gewoonten en regels van het verzorgingshuis tot inzicht worden gebracht dat zij zich teveel laten welgevallen? Moeten de opvattingen van bewoners en verzorgenden dat de zorgregistratie zich voor een groter of kleiner deel buiten het gezichtsveld van de bewoners onttrekt, worden gerelativeerd door te stellen dat in verzorgingshuizen overwegend gerapporteerd wordt over alledaagse zaken, die buiten het 'werkingsgebied' van de Wgbo vallen? Moet bij de conclusie dat de houdingsaspecten attentiviteit en responsiviteit van verzorgenden verbeterd moeten worden de tegenwerping worden gemaakt dat toch sprake is van een hoge mate van tevredenheid, zodat niet dringend aan de houding gewerkt hoeft te worden?

De opvattingen van de verschillende respondenten maken duidelijk dat de zorg voor zelfstandigheid bevorderd moet worden. Als het aan attentiviteit schort, bestaat het risico van standaardverzorging, waar de 'concrete other' onvoldoende in beeld is en de eigenheid 
of zelfstandigheid van de bewoner niet doorklinkt in de zorgrelatie. Als het aan responsiviteit ontbreekt, wordt de bewoner niet in staat gesteld verantwoordelijkheid te dragen voor de keuzes en beslissingen die voor de zorgverlening gemaakt worden en mist de zorgverlener de legitimatie van zijn handelen. Elke zorgrelatie waarin deze tekortkomingen worden gesignaleerd, is er één te veel.

Het volgend hoofdstuk beschrijft het verloop van de interventies die zijn gepleegd om zorg voor zelfstandigheid te bevorderen. 


\section{Hoofdstuk 9 Responsieve evaluatie en een persoonsgerichte zorgregistratie voor een dialogische zorgrelatie}

\section{$9.1 \quad$ Inleiding}

De resultaten in het vorige hoofdstuk laten zien dat de verwachtingen waarmee bewoners naar het verzorgingshuis zeggen te komen anders zijn dan het beeld wat het verzorgend personeel daar van heeft. Dit verschil in verwachtingen wordt gedurende de eerste weken van het verblijf naar de mening van betrokkenen niet overbrugd, hetgeen te wijten is aan een beperkte uitwisseling van informatie tussen verzorgingshuis en bewoner. Ook in het zorgplan, dat een belangrijk middel zou moeten zijn voor het waarborgen van beleving van zelfstandigheid (Arcares, 2003; LOC, 2003), worden niet die gegevens opgenomen die nodig zijn om deze functie waar te maken. De bewoners vinden dat zij niet op de hoogte zijn van de inhoud van het zorgplan en dat zij niet worden betrokken bij het opstellen en invullen ervan. Er wordt in hun beleving niet gevraagd naar hun levensgeschiedenis en er vindt geen overleg of dialoog plaats over de verwachtingen en vragen van de bewoner en de mogelijkheden en beperkingen van het verzorgingshuis. De bewoner komt hiertegen niet in het geweer. Het bestaan van een zorgplan is, anders dan de Wgbo zou doen vermoeden, voor veel bewoners onbekend. Voor zover het wel bekend is, wil een aantal van hen niet lastig zijn, anderen durven niet kritisch te zijn en het merendeel van de bewoners maakt geen punt, althans niet in directe zin, van het ontbreken van inzicht in de functie en status van het zorgplan. De mening van bewoners dat de verzorging zich meer richt op hun fysieke mogelijkheden en te weinig op hun vraag hoe zij met deze mogelijkheden wensen om te gaan, slaat terug op een gebrek aan communicatie en op een verzuim om afspraken hierover vast te leggen. Daarmee worden vraagtekens geplaatst bij de kwaliteit van aandacht voor de behoeften van de bewoner, voor de attentiveness (Tronto, 1997). Een verkeerde inschatting van deze behoefte achtervolgt de zorgverlener gedurende het zorgproces en kan er toe leiden dat de responsiviteit of ontvankelijkheid van de bewoner voor de verleende zorg niet gegarandeerd is. Dit risico is aanwezig, omdat het merendeel van de bewoners en de helft van het personeel aangeven dat niet wordt gevraagd of de zorg naar wens of verwachting is. Uitspraken van bewoners dat zorgverleners in hun houding niet uitgaan van wat bewoners willen, maar vooral van wat zij kunnen, zijn hier het gevolg van.

In dit hoofdstuk wordt het verloop beschreven van een tweetal interventies die de zorg voor zelfstandigheid moeten bevorderen: responsieve evaluatie en persoonsgerichte 
zorgregistratie. De wijze waarop de interventies 'responsieve evaluatie' en 'persoonsgerichte zorgregistratie' zijn geïntroduceerd, oftewel de stappen die zijn gezet en de gehanteerde methoden, de interventieperiode, de interventielocaties, de betrokkenen en de gekozen issues, respectievelijk de gekozen registratievorm, zijn in hoofdstuk 7 al aan de orde gesteld.

De basisprincipes van responsieve evaluatie zijn in hoofdstuk 6 uitgelegd. Aangegeven is dat deze vorm van evaluatie tot doel heeft die mensen bij het beleid te betrekken die het meest betrokken of belanghebbend zijn. Responsieve evaluatie gaat uit van een bottum-up benadering vanuit de verwachting dat gewenste veranderingen van beleid het best gerealiseerd kunnen worden als deze verandering gedragen wordt door de meest belanghebbenden, als het hun beleid is. In deze studie zijn bewoners en verzorgenden het meest betrokken bij het bewerkstelligen van een zorg waarin de zelfstandigheid van de bewoner tot zijn recht kan komen en om die reden zijn zij uitgenodigd om deel te nemen aan responsieve evaluaties. In hoofdstuk 9.2 wordt hier op ingegaan.

In hoofdstuk 6 is eveneens aan de orde gesteld dat verzorgingshuizen in Nederland geen zorgregistratiesysteem beschikbaar hebben dat persoonsgericht genoemd kan worden. De registratievorm die in een aantal verpleeghuizen gekozen wordt voor belevingsgerichte zorg van ouderen met dementeringsverschijnselen wordt niet geheel van toepassing geacht voor persoonsgerichte zorg in verzorgingshuizen. Om die reden is een registratieformulier ontwikkeld dat beter op deze zorg aansluit. In hoofdstuk 9.3 wordt het proces van de introductie van deze persoonsgerichte zorgregistratie toegelicht.

\subsection{Responsieve evaluaties}

Hoofdstuk 9.2 laat zien hoe door middel van responsieve evaluaties bewoners en teams van verzorgenden betrokken zijn geworden bij de in hoofdstuk 8 gepresenteerde resultaten van de interviews met de bewoners en van de enquête onder het verzorgend personeel. Door interactie en dialoog hebben zij hun verwachtingen, ervaringen en belevingen naar voren kunnen brengen, hun zienswijze over het wonen en leven in het verzorgingshuis kunnen aangeven of bijstellen (Widdershoven, 2001; Abma en Widdershoven, 2002) en zijn voorstellen gedaan om de zorg voor zelfstandigheid te bevorderen. In 9.2 .1 en 9.2 .2 wordt op het verloop van de eerste respectievelijk de tweede ronde responsieve evaluaties ingegaan en in 9.2.3 wordt hier op teruggeblikt. 


\subsubsection{Verloop van de eerste ronde responsieve evaluatie}

De gesprekken verlopen in een goede sfeer. De houding van de aanwezigen is geïnteresseerd, open en opbouwend. Leidinggevenden en verzorgenden schromen niet om kritiek te uiten en zijn goed in staat om uitspraken te onderbouwen met voorbeelden. Verschillende bewoners vinden het moeilijk om kritische op- en aanmerkingen te maken. Ze ervaren het uiten van kritiek al snel als klagen en dat willen ze liever niet. Een van de bewoners geeft aan het eind van de eerste bijeenkomst zelfs aan dat één keer klagen wel genoeg is en dat hij daarom liever niet bij de volgende gespreksronde wil zijn. Sommige bewoners geven aan dat ze niet lastig willen zijn en dat zij kunnen begrijpen dat de verzorgenden het druk hebben. In één van de drie huizen lijken bewoners zich sociaal wenselijk op te stellen tijdens de evaluatie. Er wordt door hen geen onvertogen woord gezegd over het wonen en leven in het verzorgingshuis. Maar er zijn ook bewoners die de ruimte nemen om opmerkingen te maken over de houding en werkwijze van de verzorgenden.

Van alle gesprekken worden verslagen gemaakt, die ter goedkeuring aan de deelnemers zijn voorgelegd. Twee deelnemers (één personeelslid en één bewoner) hebben een paar kleine aanmerkingen op het verslag van de eerste ronde responsieve evaluatie. Deze worden verwerkt alvorens de verslagen te verstrekken aan de andere groepen. Het beperkt aantal wijzigingen op het verslag is het gevolg van de keuze van de evaluator om tijdens de responsieve evaluaties regelmatig mondeling samen te vatten wat besproken is en aan de betrokkenen te vragen of het een juiste weergave is. De issues die aan de orde worden gesteld zijn: 'informatievoorziening', 'regie in het verzorgingshuis' en houding van het verzorgend personeel'. In hoofdstuk 7 is aangegeven dat deze issues de kernbegrippen uit de vragenlijsten zijn en dat deze kernbegrippen het resultaat zijn van de gehanteerde methode van concept mapping.

\section{Informatievoorziening}

Verzorgenden en leidinggevenden zijn unaniem van mening dat bewoners onvoldoende geïnformeerd zijn bij binnenkomst in het verzorgingshuis en dat de verzorging onvoldoende op de hoogte is van de achtergronden en levensgeschiedenissen van bewoners. Het personeel mist een goede overdracht met de opnamecommissie. Op het RIO-formulier (indicatiestelling) staat vaak weinig informatie vermeld en de informatie die wordt overgedragen heeft alleen betrekking op zorgbehoeften en beperkingen van de bewoner. Een enkele keer geven een paar regels tekst iets aan van de contacten die de bewoner onderhoudt met de kinderen. Om zich een goed beeld te kunnen vormen van de toekomstige bewoner wordt gesteld dat de evv-ers (eerstverantwoordelijke verzorgenden) de taak 
hebben ontbrekende informatie aan te vullen. Het is de bedoeling dat dit al gebeurt bij een huisbezoek voorafgaand aan plaatsing van de bewoner. Binnen één van de drie huizen is echter niet duidelijk wie evv-er is van een bepaalde bewoner, waardoor een huisbezoek achterwege is gebleven. Binnen een ander huis is vanwege personeelsgebrek vaak geen tijd voor een huisbezoek. Dit maakt dat het tijdig verstrekken van informatie aan, of het verkrijgen van informatie over de bewoner als veel te beperkt wordt ervaren. Op de verzorgingsafdeling waar evv-ers voldoende tijd hebben om op huisbezoek te gaan of snel na binnenkomst van de bewoner een gesprek kunnen hebben, wordt het informatiegebrek als minder nijpend ervaren. Leidinggevenden vullen hierbij aan dat er weinig geprotocolleerd of gestandaardiseerd is voor het verstrekken van informatie. Het is nog teveel afhankelijk van de ervaring en houding van de evv-er welke informatie van belang gevonden wordt. Hierin wordt verandering gewenst.

Een deel van de bewoners geeft aan geen last te hebben gehad van een tekort aan informatie bij binnenkomst in het verzorgingshuis. Zij kregen geleidelijk aan van alles te horen en dat is voor hen voldoende. Een ander deel van de bewoners ervoer wel degelijk een gebrek aan informatie. Helderheid betreffende de financiën (wat moet ik betalen om in een verzorgingshuis te kunnen wonen) is hierbij een belangrijk kritiekpunt. Een ander punt van kritiek betreft de aard van de informatie die wordt verschaft. Bewoners hebben regelmatig behoefte aan andere informatie dan die welke wordt gegeven door de opnameconsulent of het verzorgend personeel. Eén van de bewoners merkt het volgende op:

De teamleider kwam binnen en bestookte me met informatie over euthanasiebeleid, terwijl ik verlegen zat om informatie over de was- en voedingskosten.

Als oplossing voor het gebrek aan informatie geven leidinggevenden en verzorgenden aan dat er betere afspraken gemaakt kunnen worden over huisbezoeken van EVV-ers en over de overdracht met de opnamecommissie. Ook de overdracht naar andere collega's kan verbeterd worden. Dit geldt zowel voor mondelinge als voor schriftelijke rapportage. Alhoewel er met 'zorgactiviteiten' wordt gewerkt, staan deze niet altijd geregistreerd en worden ze niet geactualiseerd. Het lezen van zorgdossiers door verzorgenden wordt niet consequent gedaan. Voor het verzamelen van informatie over de bewoner hebben verzorgenden en leidinggevenden behoefte aan een ander systeem, waar iedereen zich van bedient.

Een aantal bewoners is van mening dat iedere bewoner anders is en dat het goed zou zijn om per bewoner te inventariseren aan welke informatie hij behoefte heeft en welke informatie hij kwijt wil. Volgens deze bewoners is het belangrijk deze informatie te rapporteren en ze te laten gebruiken door de verzorgenden. 
Eén van de bewoners vindt dat het geven en vragen van informatie op gepaste wijze moet gebeuren:

Je kunt de bewoners wel met allerlei informatie bestoken als ze hier binnenkomen, Maar het is veel belangrijker dat er eerst geluisterd wordt. Voor elke bewoner betekent de binnenkomst in het verzorgingshuis iets anders en iedereen heeft zijn eigen vragen, behoeften en gevoelstoestand. Het is ook niet altijd prettig als er veel aan je gevraagd wordt, want je kunt herinnerd worden aan een positie die je niet meer hebt en niet meer krijgt. Je mag er toch van uit gaan dat de verzorging daar rekening mee houdt.

\section{Regie in het verzorgingshuis}

De reacties van leidinggevenden, verzorgenden en bewoners op de opvatting dat het verzorgingshuis de regels en de dagindeling van de bewoners bepaalt, zijn wisselend. De leidinggevenden van twee huizen geven aan dat hun werkwijzen en programma onvoldoende zijn aangepast aan de behoeften en wensen van bewoners. Zo verstrekt bijvoorbeeld de keuken alleen warme maaltijden op het middaguur. Als een bewoner zijn warme maaltijd 's avonds wil nuttigen, is dat niet mogelijk. Het verzorgend personeel vult aan dat het 'loopbriefje' (lijstje met zorgactiviteiten die dagelijks bij een bewoner worden verricht) en vaste koffiepauzes voornamelijk richting geven aan het werk. Het werk wordt gedaan op basis van het loopbriefje en dient klaar te zijn voor de vast geplande koffiepauze. Als bewoners buiten dit loopbriefje of tijdens een koffiepauze geholpen willen worden, gebeurt dit maar sporadisch. Een aantal verzorgenden komt tijdens het gesprek over dit onderwerp tot het besef dat het eigenlijk niet goed is om het werk zo te laten bepalen door koffiepauzes en loopbriefjes. Ze geven aan te willen kijken of het mogelijk is meer flexibel te werken. Tijdgebrek en personeelstekort worden door verzorgenden en leidinggevenden van de twee huizen aangegeven als redenen waarom het huis de regels en dagindeling bepaalt en onvoldoende overleg gepleegd wordt met de bewoner over zijn wensen en verwachtingen.

De leidinggevende en het verzorgend personeel van een ander verzorgingshuis vinden dat hun werkwijze anders is en meer uitgaat van wat de bewoners willen. Ze geven voorbeelden van de wijze waarop de bewoner de regels en de dagindeling van het verzorgingshuis mee bepaalt. Het loopbriefje wordt hier meer als middel ingezet en niet als doel. Verzorgenden en de leidinggevende van dit huis hebben het gevoel regelmatig in gesprek te zijn met bewoners over hun wensen en verwachtingen. Wel geven deze personeelsleden aan dat het van belang is dat een aantal zaken in het huis vaststaan, omdat anders het werk niet goed georganiseerd kan worden.

De reacties van de bewoners van de huizen zijn eveneens wisselend. Een deel vindt dat er voldoende oog is voor de wensen en verwachtingen van bewoners en dat zij invloed kan 
uitoefenen op de dagindeling en regels van het huis. Volgens deze bewoners is het daarbij van belang dat zij het personeel aanspreken als zaken niet naar wens verlopen. Een enkele bewoner geeft schoorvoetend aan niet gewend te zijn voor zichzelf op te komen. Ze durft veel dingen niet te vragen aan het personeel. Sommige bewoners herkennen en beamen dit. Andere bewoners zoeken naar een goede mix tussen het zich aanpassen en het voor zichzelf opkomen:

Ik wil me best aanpassen, dat is ook nodig, maar soms zou het fijn zijn, vooral tijdens de lange avonden, als er iemand eens een praatje komt maken, zomaar even langs komt.

Een paar bewoners merken op dat je ook steun kunt zoeken en vinden bij de medebewoners, bijvoorbeeld in het restaurant als een medebewoner een kopje koffie voor je inschenkt, dat je elkaar kunt helpen en van dienst kunt zijn. Eén van de bewoners vindt dat dit te weinig gebeurt:

Ik mis de saamhorigheid onder de bewoners hier. Soms wil ik er wat van zeggen als één van de bewoners weer eens op alles en iedereen zit te mopperen. Maar ze zullen van 'zo'n oude Trien van 91 jaar' wel niks aannemen. Het ergste is dat ik me er pas op betrapte dat ik nog mee zat te mopperen ook. Dat hoort niet bij mij, zo ken ik mezelf niet.

Eén van de bewoners zegt dat een medebewoner haar heeft gevraagd een onderwerp in te brengen. De medebewoner heeft vernomen dat een verzorgende van haar afdeling door de teamleidster wordt overgeplaatst, terwijl zij met die verzorgende een heel goed contact onderhoudt. De medebewoner wil niet dat dit gebeurt en vraagt of zij hier invloed op uit kan oefenen. Na enige discussie komen de bewoners gezamenlijk tot de conclusie dat een dergelijke beslissing niet aan hen is en dat de keuze van de teamleidster gerespecteerd moet worden. Wel kan er volgens de bewoners aan de teamleidster om een toelichting gevraagd worden.

Volgens de afdelingshoofden is de bepalende rol van het verzorgingshuis te verminderen door een betere dossiervoering, waarin meer ruimte wordt gemaakt voor wensen en verwachtingen van bewoners. De acties die daarop volgen, dienen dan wel regelmatig geëvalueerd te worden met de bewoner, op basis van goede rapportage. Een aantal verzorgende personeelsleden onderschrijft dit. Een voorwaarde om flexibeler om te kunnen gaan met de dagindeling en regels is naar de mening van de verzorgenden een goede aansturing door het afdelingshoofd. Het verzorgend personeel van één van de huizen, dat hun leidinggevende ervaart als onvoldoende sturend, voelt zich genoodzaakt een strak schema aan te houden om het werk gedaan te krijgen. Hierdoor voelen ze zich tekortschieten in het ingaan op de wensen en verwachtingen van bewoners. 


\section{Houding van het verzorgend personeel}

Leidinggevenden, verzorgenden en bewoners onderschrijven de opvatting dat het personeel voornamelijk uitgaat van wat een bewoner kan en niet van wat een bewoner wil.

Het verzorgend personeel geeft aan zich soms 'gebruikt' te voelen als ze ingaan op een verzoek van een bewoner om dingen te doen die hij in principe zelf kan. Een deel van het personeel zegt het niet gemakkelijk te vinden om 'extra' dingen te doen voor individuele bewoners, zoals het persen van sinaasappelen of een stukje gaan wandelen, omdat ze bang zijn dat andere bewoners dan ook om een gunst gaan vragen, terwijl ze daar geen tijd voor hebben. Ook laten sommige personeelsleden na extra dingen te doen, omdat ze bang zijn hierover te worden aangesproken door een collega. Het zoeken naar een goed evenwicht tussen wat een bewoner wil en kan en wat wel en niet voor een bewoner gedaan zou moeten worden, wordt als moeilijk ervaren. Sommige personeelsleden geven aan behoefte te hebben aan meer ruimte voor overleg en voor uitwisseling van ervaringen met bewoners. In hun beleving lopen ze nu door tijdgebrek de bewoner voorbij. Eén van de verzorgenden verwoordt dit als volgt:

Iedere keer als ik meneer $\mathbf{X}$ op de gang tegen kom, schaam ik me. Sinds zijn vrouw hier een paar maanden geleden overleden is, hebben we bijna geen contact met hem gezocht, terwijl hij met zijn ziel onder de arm loopt.

De bewoners ervaren dat de verzorgenden voornamelijk uitgaan van 'het minimale', van het 'hoognodige'. Tijd en aandacht voor extra zaken is er volgens hen te weinig. Daarbij doet één van de bewoners de volgende ontboezeming:

Ik wou dat ik iets mankeerde.

De bewoner drukt met deze uitspraak haar gevoel uit dat er vooral aandacht is voor bewoners die hulp nodig hebben bij de lichamelijke verzorging. In het vraaggesprek met de interviewer heeft zij dit geluid ook al laten horen. Een andere bewoner vraagt zich af wie eigenlijk bepaalt wat een bewoner wel of niet kan en wil. Het kan naar zijn mening niet zo zijn dat de verzorging dat uitmaakt. Bewoners vinden dat de bewonersbespreking een goed moment is om door te spreken wat mogelijk en haalbaar is in de zorg. Maar belangrijker vinden zij het gevoel dat verzorgenden betrokkenheid tonen, dat zij goed aanvoelen of de juiste zorg wordt gegeven en of de bewoner tevreden is met hetgeen de verzorging biedt. Eén van de bewoners formuleert dit als volgt:

Een keer, ik vergeet het nooit, toen ik een paar maanden in huis was, sprak de teamleidster mij aan en vroeg 'mevrouw doen wij genoeg voor u'. Ik werd hier zo door verrast. 
Bewoners constateren dat er te grote verschillen zijn in de houding van de verzorgenden. $\mathrm{Ze}$ begrijpen dat elk teamlid zijn eigenaardigheden heeft, maar sommigen nodigen niet uit om vragen aan te stellen.

Soms denk ik, ik wacht tot morgen dan heeft verzorgende $\mathrm{X}$ weer dienst en aan haar kan ik wel vragen of zij mijn staande klok opwindt.

Een andere bewoner reageert direct op deze uitspraak.

Een keer per week wordt mijn klok opgedraaid. Aan de verzorgende die op dat moment in mijn appartement is, geef ik de sleutel van de klok in haar hand en er is nog niemand geweest die dat niet voor mij wil doen.

Voor een andere bewoner zijn deze verschillende belevingen van medebewoners aanleiding te zeggen dat de bewoner in het contact met de verzorging ook zichzelf meebrengt.

Om de houding van het personeel meer af te kunnen stemmen op de wensen en verwachtingen van bewoners dragen verzorgenden aan dat meer ruimte voor discussie en uitwisseling van ervaringen over de bewoners van belang zijn. Volgens de afdelingshoofden is een goede rapportage van belang voor de houding van het personeel. Rapportage over de wijze waarop een personeelslid op een behoefte van een bewoner is ingegaan, kan volgens hen door een andere verzorgende gebruikt worden in haar contact met de bewoner.

\subsubsection{Verloop van de tweede ronde responsieve evaluatie}

De gesprekken in de tweede ronde verlopen in een goede sfeer. Wat opvalt is dat de animo bij sommige bewoners om deel te nemen aan de tweede gespreksronde kleiner is dan bij de eerste ronde. Een paar bewoners laten weten niet deel te willen nemen aan het tweede gesprek. Als reden hiervoor geven zij aan dat ze nu wel genoeg geklaagd hebben, dat ze geen interesse meer hebben of dat ze het erg vermoeiend vinden. De houding van de bewoners die wel deelnemen, is wederom geïnteresseerd, open en opbouwend. Dit laatste geldt ook voor het verzorgend personeel. Twee verzorgenden kunnen de tweede ronde niet meedoen, omdat zij dienst hebben. Van alle gesprekken worden verslagen gemaakt die ter goedkeuring aan de deelnemers zijn voorgelegd en zo nodig zijn gecorrigeerd.

Bij aanvang van de tweede gespreksronde worden de deelnemers geïnformeerd over het verloop van de gesprekken van de eerste ronde. Hierbij wordt ingegaan op zowel het resultaat van de gesprekken van de gezamenlijke groepen, als op de belangrijkste resultaten van de evaluaties in elk verzorgingshuis afzonderlijk. Ook gedurende het verloop van de tweede ronde responsieve evaluatie zijn door de evaluator uitkomsten van gesprekken in de verschillende groepen ingebracht. 
In de groepen is in de tweede ronde ook de vraag voorgelegd hoe het mogelijk is om tot een persoonsgerichte informatie en rapportage te komen.

Terugkoppeling van het verloop van de gesprekken uit de eerste ronde responsieve evaluatie

De evaluator heeft in alle gesprekken aangegeven dat de resultaten van de eerste gespreksronde met bewoners, verzorgenden en leidinggevenden in grote lijnen overeenkomen. Iedereen vindt dat veranderingen moeten worden doorgevoerd. Met name de informatievoorziening, de dossiervoering en rapportages over de zorg worden over het algemeen als onvoldoende ervaren. Zorgactiviteiten worden niet altijd vastgelegd, er wordt te weinig over gerapporteerd en de rapportages laten niets van de levensgeschiedenis van de bewoner zien. Verzorgenden hebben de neiging de regie over het leven van de bewoner over te nemen. Zij geven aan weinig overleg te voeren over regels, gewoonten en activiteiten in huis met de bewoners. Ook over de gewenste zorg en de tevredenheid van de bewoner over de geleverde zorg wordt weinig gesproken. De houding van de verzorgenden is niet gericht op wat een bewoner wil of wenst en wat diens beweegredenen daarbij zijn. De vraag of de zorg die gegeven is naar wens is, wordt niet gesteld. Veel meer staat de vraag naar wat de bewoner kan centraal. Het verzorgend personeel heeft weinig tijd voor bewoners die geen of weinig fysieke ondersteuning nodig hebben.

De evaluator schetst bij aanvang van de tweede ronde responsieve evaluaties, naast het hiervoor beschreven algemeen beeld, een aantal in het oog springende uitkomsten van de afzonderlijke bijeenkomsten. De meeste groepen bewoners en verzorgenden van de experimentele verzorgingsafdelingen kiezen er voor om in de tweede ronde één issue uit te diepen waarover verschillende opvattingen bestaan tussen bewoners en verzorgenden. Met de leidinggevenden van de verschillende afdelingen worden twee issues geëvalueerd.

\section{Issue: regie in het verzorgingshuis}

Met bewoners en verzorgenden is in de eerste ronde responsieve evaluatie gesproken over het verschil in beleving tussen deze groepen over het onderwerp 'regie in het verzorgingshuis'. Veel bewoners zijn van mening dat het huis veel voor hen bepaalt, dat ze weinig zeggenschap hebben. Verzorgenden van één van de verzorgingshuizen vinden daarentegen juist dat de bewoners veel zelf kunnen bepalen, vooral in vergelijking tot de andere huizen. De evaluator gebruikt dit voorbeeld om dit issue in de tweede ronde verder uit te diepen.

De bewoners reageren bevestigend op het door de evaluator geconstateerde verschil in opvatting en illustreren dit met voorbeelden. Eén van de bewoners haalt het volgende aan:

's Morgens kiezen mijn vrouw en ik er graag voor om samen in ons appartement koffie te 
drinken, maar er wordt door het personeel regelmatig op aangedrongen om naar de koffiekamer te gaan om samen met medebewoners wat te gaan drinken. Wij voelen ons daar ongemakkelijk bij.

Eén van de verzorgenden vindt dat vooral bij de lichamelijke verzorging van bewoners de kwestie van regie aan de orde is:

Wij dringen er bij bewoners op aan dat zij zich iedere dag goed verzorgen en schoon ondergoed aan doen, terwijl veel bewoners daar hun leven lang anders mee zijn omgegaan, en zich misschien maar één keer per week douchen. Dan voel je wel dat wij hun iets proberen op te dringen.

Andere verzorgenden brengen naar voren dat bewoners veel strakker vastzitten aan bijvoorbeeld een dagindeling van het huis dan het personeel:

's Morgens om half elf zit de koffiekamer al vol met bewoners. Als je dan nog ergens bezig bent en je bent wat later in de koffiekamer merk je al dat bewoners dat niet op prijs stellen. Het tijdstip voor de koffie is heilig en zij verwachten dat wij op tijd zijn om koffie in te schenken.

De verzorgenden van het betreffende verzorgingshuis onderkennen het verschil in beleving en gaan hierover met elkaar in gesprek. Ze concluderen dat binnen hun huis nog veel gebeurt volgens de regels van het huis, maar ook volgens eigen inzichten. Naar een werkwijze die meer tegemoet komt aan de wensen van de bewoner wordt onvoldoende gezocht. Eén van de verzorgenden nuanceert de algemene opvatting dat teveel voor bewoners geregeld wordt door aan te geven dat lang niet elke bewoner last heeft van het feit dat het huis de regels bepaalt. Er zijn volgens de verzorgende ook bewoners die de regels op prijs stellen.

\section{Issue: tevredenheid over de geboden zorg}

In één van de andere verzorgingshuizen blijkt in de eerste gespreksronde een opmerkelijk verschil te bestaan tussen de opvattingen van de bewoners en het verzorgend personeel over de tevredenheid over de geboden zorg. Bewoners geven aan tevreden te zijn en spreken geen onvertogen woord over de zorg. Een van de bewoners merkte, met instemming van andere bewoners, het volgende op:

We hebben het hier goed naar ons zin. We krijgen drie keer per dag een maaltijd, het is hier veilig en als je iets mankeert is er hulp bij de hand. Meer hebben we niet te willen, wel dan? We hebben vroeger vaak slechtere tijden gekend.

De verzorgenden daarentegen geven aan heel ontevreden te zijn over de door hen geboden zorg. Ze vinden zich bijna allemaal tekortschieten. Met bewoners en personeel is in de 
tweede gespreksronde gesproken over de mogelijke oorzaak van dit verschil in beleving. De bewoners lijken in het tweede ronde responsieve evaluatie gestimuleerd te worden door de kritische opmerkingen die het personeel over zichzelf heeft gemaakt. Spontaan wordt alsnog ingegaan op onderwerpen van de eerste gespreksronde. Er volgen een aantal voorbeelden van zaken die niet goed gaan in het verzorgingshuis. Met name worden opmerkingen gemaakt over de kwaliteit van de contacten met de verzorgenden:

Kwam er maar eens iemand een kopje koffie drinken, een kaartje leggen of zo maar even buurten. Maar ja, dat is misschien teveel gevraagd.

Sinds ik in de rolstoel zit, kom ik niet veel meer buiten. Nu in de wintermaanden is dat niet zo erg, maar over een paar maanden hoop ik toch dat er iemand is die me even mee naar buiten neemt.

Ik heb een euthanasieverklaring en vertelde dat aan één van de verzorgenden. Praat daar maar niet over, zei de verzorgende toen, want daar willen ze hier in huis niets van weten. Over reanimeren wel, dat kan wel opgeschreven worden in het rapport.

Ik zou ook graag tussen de middag in het restaurant eten, maar er is maar plaats voor 30 mensen. Ik hoop dat er een plaatsje vrij komt.

Je ziet steeds meer verzorgenden die allemaal maar een halve week of nog minder werken. Er zijn er niet veel meer die een hele week werken. Vandaag zie je die en morgen weer een ander.

We hebben toch e.v.v.-ers (eerstverantwoordelijke verzorgenden). Daar mogen we toch van verwachten dat ze zich wat vaker laten zien.

Een andere bewoner is het met laatstgenoemde opmerking oneens en vindt dat de e.v.v.-er er is als je haar nodig hebt. Eén van de medebewoners geeft aan niet eerder te hebben geweten dat een gespreksgenoot graag kaart. Kaarten is ook zijn hobby en zijn aanbod om binnenkort langs te komen wordt aanvaard.

De verzorgenden noemen een aantal redenen voor het verschil in beleving. Zij geven aan dat ze proberen niet te klagen over het gebrek aan tijd waar de bewoners bij zijn, terwijl ze best in de gaten hebben dat ze dingen laten liggen. Ook wordt geopperd dat wellicht alleen bewoners aan de eerste gespreksronde hebben deelgenomen die tevreden zijn over het wonen in het huis. De tegenwerping wordt gemaakt dat ook als mondig bekend staande bewoners hebben geparticipeerd. Verder wordt aangegeven dat het huishoudelijk werk op deze verzorgingsafdeling goed geregeld is en dat er daardoor wellicht tevredenheid is, omdat aan het goed schoonhouden van de appartementen door bewoners veel gewicht wordt toegekend. Eén van de verzorgenden betwijfelt of de bewoners wel zo tevreden zijn als ze in de eerste ronde hebben doen voorkomen. $\mathrm{Zij}$ is van mening dat de bewoners niet gewend zijn aan een gespreksgroep deel te nemen en kritisch te zijn in een groep. Voor de bewoners 
in de gespreksgroep is het volgens haar spannend en om die reden benadrukken zij vooral de positieve dingen in het verzorgingshuis.

\section{Issue: houding van het verzorgend personeel}

Eén van de verzorgenden geeft bij aanvang van de tweede ronde aan dat, als reactie op een door haar aangedragen onderwerp in de eerste gespreksronde, inmiddels een aanpassing heeft plaatsgevonden in de werkwijze van het team. Zij miste een moment van overdracht binnen de dagdienst, waardoor personeelsleden die dezelfde dienst hebben niet altijd van elkaar weten wat de ander heeft gedaan. Naar aanleiding van het eerste gesprek heeft het betreffende team hierover met elkaar gesproken en besloten een extra moment van overdracht in te voeren. Er wordt op nog een ander onderwerp teruggekomen. In één van de verzorgingshuizen blijkt in de eerste gespreksronde dat bewoners ten aanzien van het onderwerp 'houding van het personeel' aangeven dat het van de verzorgende afhangt of er wel of niet iets extra's gedaan wordt voor een bewoner. Verzorgenden onderkennen dit verschil niet echt, maar sommigen lieten in de eerste gespreksronde wel weten het moeilijk te vinden om bepaalde dingen voor bewoners te doen. Dit omdat ze de extra zorg de volgende keer wellicht niet aan de bewoner kunnen bieden in verband met tijdgebrek, of omdat andere bewoners deze extra zorg dan wellicht ook willen. In de tweede ronde responsieve evaluatie is dit onderwerp door de groep verzorgenden nader uitgediept.

Verzorgenden vinden dat 'de parttime factor' (een aspect dat in de bewonersgroep van één van de verzorgingshuizen aan de orde werd gesteld) van invloed is op het al dan niet geven van extra aandacht. Verzorgenden met een klein dienstverband worden op de drukste momenten van de dag ingezet. Dit zijn momenten dat er weinig tijd is voor extra dingen. Deze personen werken vrijwel nooit op momenten dat het rustiger is op de afdeling en kunnen om die reden weinig extra's doen voor bewoners. Dit kan bij bewoners de beleving oproepen dat deze verzorgenden nooit iets extra's willen doen. Eén van de verzorgenden vindt het doen van extra dingen geen punt van discussie.

Wat is extra? Als een bewoner mij iets vraagt, bijvoorbeeld of ik iets meebreng van de drogist uit het dorp, doe ik dat als ik daar de gelegenheid voor heb. Ik doe dat graag en ik vind dat daar geen probleem van gemaakt moet worden.

De verzorgenden concluderen met de bewoners dat er verschillen zijn in ieders aanpak en ieders mogelijkheden om iets extra's te bieden. De verzorgenden ervaren deze verschillen echter niet als groot en geven aan een verschillende houding hierin te waarderen.

De bewoners zijn van mening dat er grenzen zijn aan de verschillen. Zij vinden dat van iedere verzorgende mag worden gevraagd dat zij zich correct opstelt, de privacy van de 
bewoner in acht neemt en bekend is met wensen van de bewoner, bijvoorbeeld ten aanzien van het schoonmaken van het appartement.

In de tweede ronde responsieve evaluatie gaan de bewoners van één van de verzorgingshuizen nader in op de behoefte aan contact en gesprekken met verzorgenden en met medebewoners. Hun ervaring is dat vrijwilligers en de activiteitenbegeleiding graag bereid zijn om mee te gaan wandelen of een praatje te maken. Verder wordt opgemerkt dat het van belang is als sommige zaken goed zijn gerapporteerd:

Ik vind wel dat de verzorging moet weten dat ik regelmatig naar 'de Dienst' ga. Nu kan ik het nog alleen, maar straks misschien niet meer.

Issues: evenwicht tussen vraag en aanbod en voorbereiding van de responsieve evaluaties Met de leidinggevenden van de drie experimentele verzorgingsafdelingen is in de tweede ronde gesproken over een tweetal onderwerpen die zijn opgevallen tijdens de eerste gespreksronde. Zij geven aan dat verzorgenden van hun afdelingen moeite hebben met het vinden van een evenwicht in wat ze willen, kunnen en moeten bieden aan de bewoners. Veel verzorgenden laten zich in hun handelen leiden door zowel reacties van bewoners als van collega's. Volgens de leidinggevenden is een goede communicatie van groot belang. Als een bewoner buiten de gebruikelijke zorg iets extra's wil en een personeelslid heeft hiervoor geen tijd, dan is het belangrijk hierover overleg te plegen met deze bewoner en samen een moment af te spreken waarin de gevraagde zorg wel geboden kan worden. Personeelsleden zijn echter terughoudend in het maken van dergelijke afspraken, omdat de zorgzwaarte erg hoog is en niemand op meer werk zit te wachten.

Het tweede onderwerp betreft de motivatie van de bewoners om aan de gespreksrondes deel te nemen. Ten tijde van het eerste onderzoek zijn de bewoners volgens de leidinggevenden heel enthousiast om geïnterviewd te worden. Ze willen graag hun mening geven over allerlei zaken. Vóór het ingaan van de eerste gespreksrondes (september/oktober 2002) gaven bewoners volgens de leidinggevenden aan dat ze laat geïnformeerd zijn over de resultaten van het onderzoek en dat ze een aantal vragen in het interview te privé vonden. Het deelnemen aan groepsgesprekken is naar de mening van de leidinggevenden voor veel bewoners niet gemakkelijk; niet alle bewoners kunnen goed naar elkaar luisteren. Sommige bewoners willen heel graag hun verhaal doen en houden misschien te weinig rekening met anderen. De leidinggevenden vinden de groepssamenstelling niet altijd gelukkig. Er is geselecteerd op 'maximale variatie', maar dit heeft tot gevolg dat bewoners bij elkaar komen te zitten die het niet altijd goed met elkaar kunnen vinden. De relatie tussen het eerste deel van het onderzoek en de gespreksrondes is misschien wel goed uitgelegd aan de 
bewoners, maar de ene bewoner moet meer voorbereid worden dan de ander. Hiermee is volgens hen niet altijd rekening gehouden.

\section{Issue: persoonsgerichte informatie en registratie}

De onderzoeksresultaten uit de eerste ronde responsieve evaluatie wijzen volgens de evaluator uit dat bewoners en de verzorgingshuizen tot een betere uitwisseling van informatie moeten komen. Naast betere en tijdige informatie over het verzorgingshuis wordt van belang geacht dat verzorgenden de bewoners goed leren kennen en bekend raken met hun levensgeschiedenis, hun wensen, verwachtingen en behoeften. Aan bewoners en personeel is in de tweede gespreksronde de volgende vraag gesteld: 'Over welke onderwerpen moeten verzorgenden geïnformeerd zijn om de zorg af te kunnen stemmen op de individuele bewoner?'

Deze vraag blijkt niet voor alle bewoners gemakkelijk te beantwoorden. Een aantal bewoners heeft het leven reeds zodanig afgestemd op het ritme van het verzorgingshuis, dat het moeilijk voor hen is om los te komen van de gangbare regels en structuren in het huis. Een aantal bewoners geeft zelfs aan het vanzelfsprekend te vinden dat bewoners zich aanpassen aan hoe het er in het huis aan toe gaat. Andere bewoners geven de volgende onderwerpen aan waarover een betere informatie-uitwisseling moet plaatsvinden: privacy, eten en drinken, deelname aan activiteiten, persoonlijke verzorging, wensen t.a.v. de huishouding en contacten met anderen. Eén van de bewoners vraagt zich overigens af of je wel over al de genoemde onderwerpen informatie moet inwinnen wanneer een bewoner pas kort in huis is:

Je moet je eigen behoeften vaak nog leren kennen, als je hier komt wonen. Het duurt even voordat je precies weet wat je wilt.

De verzorgenden en leidinggevenden blijken over het algemeen duidelijke ideeën te hebben over de onderwerpen waarover informatie verzameld moet worden. Genoemd worden: informatie over persoonlijke verzorging, medicatie, het privé-leven (wel of niet getrouwd, wel of geen kinderen), contacten met familie en artsen/therapeuten, mantelzorg, inrichting appartement, voeding, huishouding, hobby's/activiteiten, gewoonten, levensbeschouwing en privacy.

De evaluator stelt aan het slot van de tweede ronde responsieve evaluaties dat gewerkt wordt aan de opzet van een vorm van persoonsgerichte rapportage, waarin items worden meegenomen die door de bewoners en verzorgenden zijn ingebracht. Deze rapportage zal worden opgesteld op basis van een gesprek tussen verzorgende en bewoner. De bewoner zal zich moeten kunnen blijven herkennen in deze rapportage. Zijn wensen, behoeften, keuzes en verwachtingen moeten worden gerapporteerd en met de verzorgende zal worden 
besproken of en op welke wijze de verzorging er mee om kan gaan. Omdat is gebleken dat nieuwe bewoners niet goed geïnformeerd worden over het verzorgingshuis geeft de evaluator aan dat ook zal worden gewerkt aan het verschaffen van betere algemene informatie.

\subsection{Persoonsgerichte zorgregistratie}

Als onderdeel van het onderzoek naar de beleving van zelfstandigheid door bewoners van verzorgingshuizen heeft, in het kader van de interventiefase, op drie verzorgingsafdelingen (één van elk verzorgingshuis) de invoering plaatsgevonden van een persoonsgerichte registratie van zorg, het 'Overzicht Zorgafspraken' genoemd. Door de zorgregistratie persoonsgericht te laten zijn en tot richtsnoer van de zorgverlening te maken, wordt geprobeerd de zorg voor zelfstandigheid te bevorderen.

Een opvatting van alle betrokkenen, die in de responsieve evaluaties wordt onderstreept, is dat de registratie van de zorg moet veranderen. De betrokkenheid van de bewoner bij deze registratie moet worden verhoogd en het zorgplan moet persoonsgericht worden. In plaats van 'verpleegproblemen' en 'verpleegdoelen' moet het zorgplan items bevatten, die het levensverhaal van de bewoner present stellen en waaronder de diversiteit van behoeften, keuzes en verwachtingen van de bewoner gerangschikt kunnen worden. In de responsieve evaluaties hebben bewoners, leidinggevenden en verzorgenden items aangedragen waarover naar hun mening gerapporteerd moet worden. In samenspraak en nauw overleg met de teams van verzorgenden van de experimentele afdelingen is gedurende een half jaar gewerkt aan een persoonsgerichte wijze van rapporteren.

In paragraaf 9.3.1 van dit hoofdstuk wordt ingegaan op de vraag waarom een persoonsgerichte registratie van zorg van belang is. In het verzorgingshuis, waar ouderen voor de rest van hun leven verblijven, moet in het algemeen beschouwd de registratie van zorg betrekking hebben op hun levensverhaal en niet, zoals bijvoorbeeld in een curatieve short-stay-situatie, op het ziekteverloop van de patiënt, op verpleegproblemen of verpleegdoelen.

Het Overzicht Zorgafspraken is een concrete uitwerking van een persoonsgerichte registratie. In hoofdstuk 7 is beschreven uit welke items het Overzicht Zorgafspraken is opgebouwd. In 9.3.2 wordt het verloop van de introductie van de persoonsgerichte registratie beschreven. Deze introductie is begeleid door een extern begeleider die trainingen heeft belegd met de teams van de drie experimentele verzorgingsafdelingen. Van deze trainingen en van andere bijeenkomsten tijdens de introductie van de nieuwe 
registratie zijn door de begeleider gespreksverslagen gemaakt, die in hoofdstuk 9.3 .2 benut zijn om het verloop van de introductie weer te geven. In 9.3.3 wordt teruggeblikt op de interventie 'persoonsgerichte zorgregistratie'.

\subsubsection{Overzicht Zorgafspraken: blauwdruk of persoonsgericht document?}

De Modernisering AWBZ (Arcares, 2003) schrijft voor dat het verzorgingshuis een zorgverleningsovereenkomst en een zorgplan opstelt:

In de zorgverleningsovereenkomst wordt de inhoud en samenstelling van het zorgarrangement vastgelegd en de wijze waarop de zorg geleverd wordt. In het zorgplan wordt dat uitgewerkt, rekening houdend met de wensen en voorkeuren van de cliënt, het criterium van goed hulpverlenerschap en de feitelijke mogelijkheden van de aanbieder.

Arcares geeft aan dat zij samen met de Landelijke Organisatie Cliëntenraden een handreiking gaat ontwikkelen voor het opstellen van een zorgverleningsovereenkomst. Daarbij geeft zij aan dat het indicatiebesluit (met name de functie(s) waarvoor de zorgvrager geïndiceerd is) de basis vormt bij het bepalen van de inhoud en samenstelling van het zorgarrangement. De zorgverleningsovereenkomst zal in algemene termen de mogelijkheden en grenzen van de zorg benoemen, alsmede de kwaliteitseisen en procedures die als goed zorgverlener in acht moeten worden genomen (NVBV/NVVZ, 1994), terwijl het zorgplan de wensen en voorkeuren van de bewoner beschrijft binnen de gestelde grenzen. Dit laatste betekent dat de functies die worden verricht in het zorgplan terug moeten komen, zodat het verzorgingshuis kan verantwoorden dat het verzorgingshuis het zorgarrangement biedt waarvoor de bewoner geïndiceerd is.

Anno 2003 betekent verhuizing naar het verzorgingshuis dat de zorgvrager overwegend door het indicatieorgaan wordt geïndiceerd voor de functie 'verblijf', hetgeen inhoudt dat ondersteuning nodig kan zijn bij persoonlijke verzorging en huishoudelijke verzorging en/of dat verpleging en ondersteunende begeleiding gewenst is. In alle gevallen is de indicatie gesteld op basis van geconstateerde tekortkomingen of beperkingen van de geïndiceerde, met name terzake diens zelfredzaamheid. Een 'beperking' is synoniem aan 'de moeite die men heeft met het uitvoeren van dagelijkse bezigheden'(Commissie Kwalificatiestructuur, 1996).

De bewoner krijgt in zijn appartement in het verzorgingshuis voornamelijk te maken met verzorgenden. Verzorgenden worden volgens de Commissie Kwalificatiestructuur (1996) geacht hulp te bieden op die plaatsen en die momenten waar in de primaire leefomgeving van de zorgvrager aanvulling nodig is. Het uitgangspunt van de zorgverlening door verzorgenden is volgens deze commissie de handhaving en stimulering van de 
zelfredzaamheid van de zorgvrager'. Verzorgenden worden in staat geacht in de zorgverlening rekening te houden met het belang van een zo groot mogelijke zelfredzaamheid (of zelfverzorging). Aan de hand van 'standaarden' dienen zij systematisch gegevens te verzamelen over de zelfredzaamheid van de bewoner, een anamnesegesprek te voeren aan de hand van een gestructureerde vragenlijst en aan de hand van standaardlijsten een zorgplan op te stellen en daarbij zorgdoelen te formuleren. Op basis van deze zorgdoelen worden volgens de Commissie Kwalificatiestructuur activiteiten en interventies gepleegd. Een 'activiteit' wordt gedefinieerd als een 'werkzaamheid, niet noodzakelijk voortvloeiend uit een (verpleegkundige, medische) diagnose'. Voor het begrip 'interventie' worden twee omschrijvingen gegeven: 'een handeling uitgevoerd in interdisciplinair verband gericht op de opheffing of vermindering van de beperkingen van een cliënt of op de reductie van de sociale nadelen van de beperkingen of handicaps' (ICIDH/NRV, 1994) en 'een handeling die een cliënt van zijn huidige toestand naar de beoogde toestand moet brengen'. Onder interventie in laatstgenoemde betekenis vallen zowel (ver)zorgende handelingen voortkomende uit verpleegkundige diagnoses, als verzorgende verrichtingen van dagelijks essentiële activiteiten die de cliënt niet zelf kan verrichten. In deze omschrijving van interventie, waar Gordon (1995) wordt geciteerd en die door de Commissie Kwalificatiestructuur is overgenomen (1996), wordt het onderscheid opgeheven tussen 'een verzorgende activiteit' en 'een verzorgende interventie'. Handhaving en stimulering van de zelfredzaamheid van de bewoner van het verzorgingshuis, als uitgangspunt van de zorgverlening, houdt daarmee in het plegen van interventies bij de bewoner gericht op het uitvoeren van diens dagelijkse bezigheden .

Dit uitgangspunt verklaart waarom aan verzorgenden wordt geleerd probleem- en doelgericht te handelen. Ouderen worden vanwege problemen of beperkingen geplaatst in het verzorgingshuis en ze verwachten dat die problemen worden opgelost of aangepakt. Het is vanuit zo'n gezichtspunt de taak van verzorgenden om op deze problemen in te gaan. De problemen spitsten zich volgens de indicatieformulieren toe op 'de uitvoering' van dagelijkse bezigheden, op fysieke, materiële beperkingen. Van verzorgenden wordt verwacht dat hun interventies daar op georiënteerd zijn. De vraag of zij daar gevolg aan geven, is in hoofdstuk 8 beantwoord. In de beleving van bewoners richten verzorgenden zich niet op wat zij willen, maar op wat zij kunnen. De beleving van bewoners is dat verzorgenden niet in gesprek gaan over hun verwachtingen, wensen, keuzes en mogelijkheden, dat verzorgenden met andere woorden niet attentief zijn. Uit de formulieren van het indicatieorgaan kan door verzorgenden onvoldoende informatie worden geput om te weten welke ondersteuning de bewoner nog meer nodig heeft.

Omdat verzorgenden hebben geleerd dat bij een bepaalde categorie fysieke beperkingen 
standaard-interventies horen, is ook de vraag van responsiviteit of ontvankelijkheid voor de interventie geen onderwerp van dialoog, maar een vermeend gevolg van de interventie. Met het ontbreken van communicatie tussen bewoner en verzorgende over de aanvang en de evaluatie van het verzorgend handelen, wordt voorbijgegaan aan de eisen die de Wet op de geneeskundige behandelingsovereenkomst (Wgbo, 1995) hieromtrent stelt.

In zorgplannen en zorgregistratiesystemen, die op basis van probleem- en doelgericht denken en handelen zijn opgesteld, is sprake van een methodische gerichtheid, niet van een persoonsgerichte zorgregistratie. Met een methodische gerichtheid ontstaat de kans dat de individuele bewoner uit het gezichtsveld verdwijnt (Kardol, 1985). In hoofdstuk 6 is gesteld dat een zorgregistratie persoonsgericht is als de persoon van de zorgvrager c.q. de bewoner van het verzorgingshuis, er in doorklinkt. De verzorgende zal op zoek gaan naar het levensverhaal van de bewoner: naar zijn gewoonten, zekerheden en denkpatronen, maar ook naar de betekenis die de bewoner verleent aan zijn verblijf in het verzorgingshuis en aan de wijze waarop hij zich wil manifesteren. Omdat levensgeschiedenis en ervaring van het verleden, de beleving van het heden en de houding ten opzichte van de toekomst voor iedere bewoner anders zijn, kan een persoonsgerichte registratie geen blauwdruk zijn. In een persoonsgerichte zorgregistratie moet de verzorgende op zoek gaan naar de vraag wat deze bewoner zo bijzonder maakt, wat het 'zelf' is dat deze bewoner staande wil houden. De verzorgende vormt zich niet vooringenomen en belangstellend een beeld van de zelfstandigheid van de bewoner en niet op basis van indicatieformulieren. Zij vraagt zich niet alleen en niet zozeer af welke beperkingen iemand ondervindt bij de dagelijkse bezigheden, maar meer hoe hij die beperkingen weet te integreren, of hoe hij er mee om wil gaan. De verzorgende luistert, staat open voor hetgeen de bewoner inbrengt, gaat de dialoog aan en beschrijft, interpreteert en registreert die gegevens van de bewoner die door de bewoner en de verzorgende in de zorgverlening van belang worden geacht voor het waarborgen van de beleving van zelfstandigheid. De gegevens die de verzorgende registreert dienen, met toestemming van de bewoner, als richtlijn voor het handelen van de verzorgenden en niet als doel (Kardol, 1985). De ontvankelijkheid voor de zorg is de maatstaf om de zorgafspraak uit te voeren en om hem niet bij te stellen.

\subsubsection{Invoering van persoonsgerichte zorgregistratie}

De invoering van een persoonsgerichte zorgregistratie vond plaats op drie verzorgingsafdelingen van drie verzorgingshuizen. $\mathrm{Ze}$ is begeleid door een trainer van buiten de organisatie die e.v.v.-ers trainde in het interviewen van bewoners over zorgafspraken en in het registreren van die afspraken. Er is voor gekozen om niet elk 
verzorgend teamlid interviews te laten afnemen en niet elke bewoner van de afdeling te interviewen. Alleen de e.v.v.-ers, die al een vooruitgeschoven taak en verantwoordelijkheid hebben met betrekking tot de zorgregistratie en om die reden kritisch beoordelaar van een nieuwe registratie kunnen zijn, zijn begeleid. De overige teamleden zijn wel geïnformeerd, maar worden in een later stadium, buiten deze studie om, voorbereid en geïnstrueerd.

Omdat met het interviewen van bewoners en het uitwerken van zorgafspraken veel tijd is gemoeid die binnen de reguliere werktijd moet worden gevonden, is besloten dat elke e.v.V.-er van maximaal vier bewoners een Overzicht Zorgafspraken opstelt.

Om de teams verzorgenden van de drie experimentele verzorgingsafdelingen voor te bereiden op het houden van interviews hebben trainingen plaatsgevonden. De rubrieken die in het Overzicht Zorgafspraken staan genoemd, zijn door de begeleider uitgelegd; de handleiding is doorgenomen en met behulp van een rollenspel, waarin een verzorgende een 'bewoner' interviewt, is geoefend met de gewenste wijze van interviewen en het invullen van het Overzicht Zorgafspraken.

Ook in de periode dat de verzorgenden bezig zijn geweest met het interviewen van bewoners over zorgafspraken is de extern deskundige beschikbaar of bereikbaar geweest voor ondersteuning. Van die mogelijkheid is op verschillende manieren gebruik gemaakt. In één van de verzorgingsafdelingen is er voor gekozen om een aantal bijeenkomsten te plannen met de externe begeleider waar zoveel mogelijk verzorgenden bij aanwezig zijn. Tijdens deze bijeenkomsten zijn vragen gesteld en ingevulde overzichten doorgenomen. Een andere experimentele verzorgingsafdeling koos voor een traject van individuele begeleiding in combinatie met een evaluatie in een teamvergadering. Verzorgenden van het derde verzorgingshuis hebben, naast een evaluatiegesprek van de leidinggevende met de begeleider, voornamelijk gebruik gemaakt van telefonisch contact met de begeleider voor het doornemen van vragen over het Overzicht Zorgafspraken. In dit huis vervulde de leidinggevende ook een begeleidende rol.

Deze paragraaf behandelt het verloop van en de bevindingen bij de invoering van het Overzicht Zorgafspraken op de experimentele afdelingen van de drie verzorgingshuizen.

Verloop van de invoering op één van de experimentele verzorgingsafdelingen

Alle verzorgenden die de taak van eerstverantwoordelijke verzorgende (evv-er) op zich nemen, vervullen een actieve rol bij de invoering. Zij kiezen voor een indeling van bewoners waarmee gesprekken worden gevoerd over het Overzicht Zorgafspraken die aansluit bij het evv-schap.

Bij het oefenen met het invullen van het Overzicht Zorgafspraken, dat aan de gesprekken met de bewoners vooraf is gegaan, geven de verzorgenden aan vooral moeite te hebben met 
het beschrijven van karakteristieken van een bewoner en met het verschil tussen ondersteuningsbehoefte enerzijds en interventiebehoefte/behandelbehoefte anderzijds. Er ontstaat een discussie over het 'breder kijken' naar bewoners dan naar verzorgingsaspecten rondom beperkingen. Tevens wordt gesproken over welke informatie onder welke rubriek geplaatst moet worden. Verder blijkt de lengte van het Overzicht Zorgafspraken de verzorgenden enigszins af te schrikken. Ook vraagt men zich af hoe het Overzicht zich verhoudt tot de anamnese en de profielschets die er nu in de zorgdossiers van bewoners zitten en waarmee zij zijn opgeleid. Uit een vergelijking van deze informatie met het Overzicht Zorgafspraken blijkt dat het laatste op veel meer gebieden informatie genereert dan het zorgplan. Een deel van de aanwezige personeelsleden ziet in dat het verzamelen van gegevens over de geschiedenis van de bewoner belangrijk is om de bewoner beter te leren kennen. Enkele andere personeelsleden ontkennen dit niet, maar blijven zich afvragen of de inhoud van het huidige dossier niet voldoende is of alleen wat kan worden bijgesteld.

Er ontstaat wederom een discussie, ditmaal over de meerwaarde van het invoeren van het Overzicht Zorgafspraken. Gesteld wordt dat uit de onderzoeken en eerdere gesprekken (responsieve evaluaties) is gebleken dat de huidige registratie van zorg moet worden aangepast en dat meer op de individuele bewoner moet worden ingegaan.

\section{Verloop van de invoering op een tweede, experimentele verzorgingsafdeling}

Tijdens het doornemen van het Overzicht Zorgafspraken, als voorbereiding op de gesprekken met de bewoners, worden door de verzorgenden een aantal kritische opmerkingen gemaakt. Zo wordt, voor wat betreft de bijdrage van mantelzorgers aan de zorg, gesteld dat dit onderwerp in aanwezigheid van familieleden zou moeten worden besproken. Door een e.v.v.-er wordt opgemerkt dat één van de bewoners van haar afdeling aangeeft dat zijn zoon veel voor hem doet, terwijl zijn zoon juist van mening is dat hij veel minder kan bieden dan zijn vader wil. Er wordt geconcludeerd dat bewoners niet altijd goed kunnen inschatten wat familie aan mantelzorg wil en kan bieden. Overleg met bewoner en familie hierover wordt belangrijk gevonden.

De toevoeging van het onderwerp 'organisatorische belemmeringen' aan het Overzicht Zorgafspraken wordt door de verzorgenden als positief ervaren, omdat belemmeringen gemeld dienen te worden aan de leidinggevenden. De verzorgenden zijn het erover eens dat hierdoor bij het management meer inzicht komt in zaken die bewoners wel willen maar die momenteel niet te realiseren zijn (bijvoorbeeld twee maal per week in bad in plaats van eenmaal). Over het formulier met persoonsgegevens (een registratieformulier dat in het dossier van de bewoner aan het Overzicht Zorgafspraken voorafgaat) wordt opgemerkt dat naam en adres van de apotheek worden gemist en ook of er wel of geen sprake is van de wens tot reanimeren. Verzorgenden willen dit laatste punt in de registratie snel kunnen 
terugvinden. Tijdens het oefenen met het Overzicht Zorgafspraken worden vragen gesteld die voornamelijk betrekking hebben op de plaats waar bepaalde gegevens van de bewoner opgeschreven moeten worden.

De verzorgenden geven aan dat echtparen het naar hun inschatting wenselijk vinden om afzonderlijke gesprekken te voeren. Sommige verzorgenden vinden dat het Overzicht Zorgafspraken te weinig ruimte biedt om alle informatie op te schrijven. Ook is er onvoldoende ruimte om bijvoorbeeld de naam, adres of telefoonnummer van de kapper, pedicure of van een taxibedrijf een plek te geven.

Het rollenspel, waarin een verzorgende de rol van bewoner speelt en een andere verzorgende met haar in gesprek gaat om tot een Overzicht Zorgafspraken te komen, levert bevindingen op waarover de verzorgenden met elkaar discussiëren. Zo blijkt het stellen van open vragen minder vanzelfsprekend te zijn bij verzorgenden dan vooraf gedacht. Vragen aan de bewoner, zoals waar hij graag bij geholpen zou willen worden of wat hij er van vindt om alleen te zijn, maken meer los dan de vraag of het bed moet worden opgemaakt en of hulp bij de huishouding gewenst is. Ook het omgaan met de beschikbare tijd voor het gesprek blijkt voor verzorgenden lastig te zijn als de bewoner een uitgebreid verhaal gaat vertellen. De verzorgenden merken tijdens de rollenspelen hoe gewend ze zijn te vragen naar aspecten rondom de persoonlijke verzorging en hoe weinig ze gewoon zijn om in te gaan op thema's met betrekking tot het psychisch-, sociaal- en levensbeschouwelijk functioneren.

De verdeling van de verzorgenden over de bewoners waarmee een Overzicht Zorgafspraken wordt ingevuld (elke e.v.v.-er stelt van maximaal vier bewoners zorgafspraken op), verloopt op deze verzorgingsafdelingen zonder restricties of voorkeuren.

Op het eind van de training ontstaat spontaan de idee om een protocol op te stellen over de begeleiding van een bewoner bij binnenkomst in het verzorgingshuis. Voorgesteld wordt vast te leggen wanneer het thuisbezoek bij deze oudere plaats kan vinden en wie zorgdraagt voor dit bezoek, voor de introductie van de bewoner in het verzorgingshuis en voor het gesprek over het Overzicht Zorgafspraken.

\section{Verloop van de invoering op de derde experimentele verzorgingsafdeling}

Op deze verzorgingsafdeling blijkt het niet mogelijk om alle e.v.v.-ers tegelijkertijd te laten deelnemen aan de training. Gekozen wordt voor twee trainingsmomenten met kleinere groepen. Alle aanwezigen hebben e.v.v.-taken maar zijn hiervoor niet allemaal opgeleid. In verband met een tekort aan verzorgenden met e.v.v.-taken zijn in dit huis recentelijk drie clusters gevormd waar meerdere verzorgenden eerstverantwoordelijke zijn voor eenzelfde 
groep bewoners. Nog niet elke verzorgende is voldoende toegerust voor het e.v.v.-schap en tijdens de training blijkt dat het voeren van gesprekken en het invullen van de overzichten voor één van de verzorgenden te hoog gegrepen is. Er wordt afgesproken dat het betreffende personeelslid niet zelfstandig gesprekken hoeft te voeren en overzichten in te vullen maar dit samen met een meer ervaren verzorgende te doen, mits de bewoner geen bezwaar heeft tegen twee gesprekspartners.

De sfeer binnen de training is goed, al worden wel kanttekeningen geplaatst bij het invullen van het Overzicht Zorgafspraken. Enige verzorgenden zien weliswaar het belang in van een gesprek en van een beter beeld van de bewoner en van diens keuzes en behoeften, maar hebben toch het gevoel dat het in het gesprek met de bewoner vooral gaat om het invullen van de zorgafspraken. Het risico bestaat dat het middel tot doel wordt verheven. Over de opzet en indeling van het Overzicht Zorgafspraken worden ook door deze verzorgingsafdeling vragen gesteld. Niet altijd duidelijk is onder welk item gegevens moeten worden ondergebracht en soms worden dezelfde gegevens onder meer dan één item geplaatst. Ook de rubriek 'karakteristiek' is niet voor iedereen duidelijk.

In overleg wordt besloten om gezamenlijk een overzicht in te vullen door één van de bewoners te bespreken. Dit levert een interessante uitwisseling op waarin informatie aan de orde komt van de desbetreffende bewoner die bij een deel van de verzorgenden niet bekend is. Deze ervaring versterkt het gevoel dat rapportage van zorgafspraken kan bijdragen aan een beter beeld van de bewoner en van zijn keuzen en behoeften, maar ook aan een betere afstemming van de zorgverlening.

\section{Bevindingen bij de interviews van bewoners over zorgafspraken}

Verzorgenden ervaren het over het algemeen als positief om een gesprek te kunnen voeren met de bewoners over het leven en de leefwijze van de bewoner en om van daaruit zorgafspraken te maken. Het motiveert de verzorgenden en ze geven aan dat ook de bewoners het plezierig vinden dat tijd voor hen genomen wordt en dat naar hen geluisterd wordt. Personeelstekort en daarmee gepaard gaande hoge werkdruk maken het volgens het verzorgend personeel moeilijk om tot inhoudelijke verdieping en samenspraak te komen met bewoners.

Het blijkt voor verzorgenden niet vanzelfsprekend om te inventariseren en te beschrijven wat karakteristiek is voor een bewoner. Veelal verwarren ze dit onderdeel met de ondersteuningsbehoefte van de bewoner, waarbij het gaat om wat de bewoner aan zorg nodig heeft. Wie de bewoner is, welke episoden uit zijn levensgeschiedenis van belang zijn om vermeld te worden en wat zijn ervaringen, keuzes en verwachtingen zijn, worden minder vanzelfsprekend geregistreerd. Het stellen van open vragen, die de bewoner uitnodigen over deze onderwerpen te vertellen, maakt snel plaats voor gesloten vragen over 
de aard en mate van zorg die gewenst wordt. Hierdoor ontstaat de kans dat in het Overzicht Zorgafspraken gegevens worden geregistreerd die de verzorgenden van belang vinden, terwijl gegevens die de eigenheid van de bewoner present stellen onvoldoende naar voren komen. Gezien de snelle veranderingen die zich voor kunnen doen in de gezondheid van de bewoners kan naar de mening van de verzorgenden een ingevuld en getekend Overzicht Zorgafspraken van het een op het andere moment verouderd zijn en om aanpassing vragen. Dit betekent dat een persoonsgerichte zorgregistratie een groot beslag legt op hun werktijd. Enige verzorgenden merken op dat bij het bespreken van de zorgafspraken onderwerpen aan de orde zijn gesteld die door bewoners als een inbreuk op hun privacy ervaren werden en waar ze niet op in wilden gaan. Deze reactie geeft aan dat een open, luisterende en niet vooringenomen houding van de verzorgende niet altijd gemakkelijk is en dat de kans aanwezig is dat niet het levensverhaal van de bewoner maar 'het instrument' Overzicht Zorgafspraken het gesprek dicteert. Enkele andere bewoners hebben volgens verzorgenden laten weten dat niet alles wat zij vertellen schriftelijk mag worden vastgelegd.

Het Overzicht Zorgafspraken zou reeds bij binnenkomst van een bewoner in het verzorgingshuis moeten worden ingevuld. Volgens de verzorgenden geven twee bewoners expliciet aan dat hun verhaal er bij binnenkomst veel anders uitzag dan nu ze een tijdje in het verzorgingshuis verblijven. Omdat de bewoner in het verzorgingshuis een ontwikkeling doormaakt, zal het Overzicht Zorgafspraken ook meermalen moeten worden bijgesteld.

Verder geven verzorgenden aan dat vergeetachtigheid van sommige bewoners het invullen van het Overzicht Zorgafspraken bemoeilijkt. Zij ondertekenen weliswaar het overzicht, terwijl ze zich lang niet alles meer herinneren van wat ze verteld hebben.

\subsection{Beschouwing}

In de twee ronden responsieve evaluaties is de betekenis van het wonen en werken in het verzorgingshuis aan de orde gesteld. Voor het merendeel van de deelnemende bewoners gebeurde dat in de niet vertrouwde situatie van een groepsgesprek. Ofschoon eerder en vaker de bedoeling van de responsieve evaluatie is uitgelegd en ze ook gezien is als een vervolg op de vraaggesprekken, ontkwamen bewoners er niet aan de bijeenkomst in te gaan met de idee dat zij zouden worden uitgenodigd kritiek te spuien over het wonen en leven in het verzorgingshuis. Dit leidde in een van de bewonersgroepen aanvankelijk tot een terughoudende opstelling en pas in de tweede ronde ontstond discussie en kwamen genuanceerde reacties los. De groepen verzorgenden benutten de bijeenkomsten om hun werkwijze en houding ten opzichte van de bewoners te evalueren en om in te gaan op de resultaten van onderzoek, met name op de opvattingen van bewoners. Zij beschouwden het 
als een vorm van onderling overleg, waar zij in de praktijk van alledag te weinig aan toe komen en waarin aanzetten gegeven konden worden voor veranderingen.

Het issue 'informatievoorziening' bleek alle betrokkenen te raken. Breed werd onderkend dat het elkaar informeren op twee gebieden fout gaat: het verzorgingshuis verschaft de bewoner niet die informatie die hij nodig heeft vóór opname en gedurende de beginperiode van diens verblijf; de bewoner, op zijn beurt, kan niet die informatie kwijt die hij van belang acht om overeind te kunnen blijven, zelfstandigheid te beleven in de nieuwe situatie waarin hij belandt. Over de noodzaak om hierin verandering te brengen, onder meer door een persoonsgerichte rapportage met aandacht voor onder meer de levensgeschiedenis, is algemene consensus. Wel waarschuwt één van de bewoners ervoor dat het verschaffen van informatie geen opgelegde zaak moet zijn. Door goed te luisteren kan de verzorgende het best inschatten wat op welk moment van belang is, is de boodschap van deze bewoner.

Interessant is de constatering dat 'de regierol' in het verzorgingshuis verschillend beleefd wordt. Bewoners vinden dat de dagindeling van het verzorgingshuis, en met name het ochtendprogramma, gedicteerd wordt door de pauzetijden van de verzorgenden. Voor de eerste koffiepauze moeten de bewoners verzorgd zijn en wensen van bewoners die buiten het ritme van de verzorging geuit worden, zijn moeilijk in te willigen. Dit is een mogelijke verklaring van de ontevredenheid van bewoners, die uit de vraaggesprekken naar voren komt, over de hulp die verleend wordt op het gebied van toiletgang en mobiliteit buiten de 'rondetijden' van de verzorging om (zie 8.1.5). De dagindeling lijkt niet aan te sluiten bij preferenties van bewoners, maar eerder bij een persoonlijke preferentie van verzorgenden of bij een impliciete instellingsnorm. Een groep verzorgenden deelt die mening niet. Zij stelt dat het de bewoners zijn die de regie bepalen door tijdig naar de koffie te willen. Het werkschema van de verzorgenden moet daar op worden aangepast. Deze groep verzorgenden wordt gesterkt in haar opvatting door de uitspraak van bewoners in een andere gespreksgroep dat de dagindeling helemaal aansluit bij hun levensritme en dat verandering van de gang van zaken in het verzorgingshuis niet nodig is. De vraag is of deze bewoners de dagindeling van het verzorgingshuis zijn gaan idealiseren en er naar zijn gaan leven.

Er is overeenstemming bij de groepen verzorgenden over de noodzaak tot overleg met individuele bewoners om na te gaan of de keuzes die op de afdeling gemaakt worden, aansluiten bij de wensen en verwachtingen van bewoners. Zij onderkennen dat hun houding niet uitnodigend is voor de bewoners. Vragen naar verwachtingen van bewoners en of op hun behoeften is ingegaan, worden vaak vermeden, omdat een gesprek hierover tijd kost die 
volgens de verzorgenden niet beschikbaar is. Bewoners beamen dat verzorgenden het druk hebben en dat er weinig tijd is, maar dit neemt hun verwachtingen van een betere zorgrelatie niet weg. Wat bijvoorbeeld moeilijk geaccepteerd wordt, is de nadruk die verzorgenden in hun contact met bewoners leggen op hun fysieke mogelijkheden. Het stimuleren van de zelfverzorging wordt belangrijker gevonden dan het uitgaan van keuzes en beslissingen die de bewoner ten aanzien van zijn lichamelijke verzorging wil nemen. Bewoners die geen hulp nodig hebben bij de lichamelijke verzorging lopen vaak contacten met de verzorgenden mis. Over andere behoeften en verwachtingen wordt nauwelijks gecommuniceerd. Door de introductie van een persoonsgerichte rapportage, maar ook door de uitwisseling van opvattingen in de responsieve evaluaties, verwachten zowel bewoners als verzorgenden dat daar verandering in komt. Er worden wel kanttekeningen bij geplaatst. De beschikbare tijd blijtt schaars en veel verzorgenden werken in een half-time dienstverband waardoor continuitteit in de zorgrelatie moeilijk te realiseren is. Als de dagindeling bepaald wordt door piektijden in de verzorging en de formatie van verzorgenden vooral op die tijden wordt ingezet, is een verdieping van de zorgrelatie moeilijk waar te maken.

De responsieve evaluaties hebben verzorgenden geïnspireerd kritisch te kijken naar hun werkwijze. Op één verzorgingafdeling is naar aanleiding van de eerste ronde responsieve evaluatie de werkwijze bijgesteld om een betere overdracht van informatie over bewoners te laten plaatsvinden. Ook voor veel bewoners zijn de responsieve evaluaties motiverend geweest. Een aantal heeft zich gerespecteerd gevoeld om te mogen deelnemen. Bewoners weten te waarderen dat verzorgenden zich inspannen om de zorg op een hoger plan te brengen. Ze hebben ook de gelegenheid te baat genomen om hun gedachten en gevoelens te uiten en ze hebben medebewoners beter leren kennen. Eén van de bewoners drukte haar beleving van de responsieve evaluaties als volgt uit:

I $k$ woon hier al negen jaar, maar in deze gesprekken merk ik voor het eerst een gevoel van saamhorigheid onder de bewoners.

Verzorgingshuizen hebben de plicht een zorgplan op te stellen. In dat zorgplan moeten de wensen en voorkeuren van bewoners terzake de zorg worden weergegeven. In de zorgplannen die in de verzorgingshuizen gehanteerd worden, komen deze eisen niet naar voren. Op basis van gesignaleerde problemen en behoeften van de bewoner op het gebied van de uitvoering van dagelijkse bezigheden, met name zelfredzaamheid bij ADLactiviteiten, heeft het zorgplan het karakter van een opsomming van voornamelijk verzorgende taken die verricht moeten worden. Door het gebruik van 'zorgkaarten', wordt in menig verzorgingshuis het zorgplan efficiënt ingedikt en ontstaat een soort van 
zorgrecept dat voor veel bewoners geschikt wordt geacht. Het risico dat dit zorgplan niet gebaseerd is op wensen en voorkeuren en op het eigene van het leven van een individuele bewoner is aanwezig. Hoofdstuk 8 laat in dit verband zien dat slechts dertig procent van de ondervraagde bewoners vindt dat dagelijks wordt nagegaan hoe het met hen gesteld is, maar ook dat schommelingen in de behoefte aan zorg niet worden opgemerkt of gecommuniceerd.

De persoonsgerichte zorgregistratie die is geïntroduceerd in de vorm van het Overzicht Zorgafspraken moet de tekortkomingen van het zorgplan opheffen. A priori gebeurt dit op het gebied van de communicatie en de naleving van de voorschriften van de Wgbo. Zorgafspraken zijn het resultaat van een dialoog tussen de bewoner en de verzorgende. In deze ontmoeting komen gegevens van de bewoner ter sprake die in het Overzicht Zorgafspraken moeten worden opgenomen. Het gaat hierbij niet alleen om gegevens over concrete behoeften, maar ook om keuzes en karakteristieken waardoor bewoners zich van elkaar onderscheiden.

De training van verzorgenden in het werken met het Overzicht Zorgafspraken, maar ook de reacties van verzorgenden over de interviews van bewoners, laten zien dat verzorgenden niet gemakkelijk loskomen van een registratiemethodiek waarin zij tijdens hun opleiding zijn geschoold en waartoe zij zijn gekwalificeerd. Vragen en reacties zijn er over de technische invulling van het Overzicht Zorgafspraken. Zo is er soms onduidelijkheid over welke informatie onder welke rubriek gerangschikt moet worden. Moeite hebben verzorgenden met het stellen van (half) open vragen om de bewoner in de gelegenheid te stellen episoden uit zijn levensverhaal te vertellen. De beantwoording van die vraag vergt niet alleen veel tijd, die volgens de verzorgenden onvoldoende beschikbaar is, maar genereert ook informatie waaraan niet direct een handelingsperspectief gekoppeld kan worden. Toch overheerst het gevoel dat de bewoners door deze informatie beter en breder in beeld zijn gekomen en dat het motiverend is om op deze wijze met de bewoner te communiceren. Het levert ook het inzicht op dat de ontwikkeling van bewoners tijdens het verblijf in het verzorgingshuis doorgaat en dat zijn leven verandert. Het Overzicht Zorgafspraken zal deze ontwikkeling moeten volgen en op gezette tijden moeten worden bijgesteld. Verzorgenden constateren deze consequentie en merken op dat hiervoor kostbare tijd wordt gevraagd. Of door de introductie van het Overzicht Zorgafspraken de zorg voor zelfstandigheid is bevorderd, wordt in hoofdstuk 10 aan de orde gesteld. 


\section{Hoofdstuk 10 Zorg voor zelfstandigheid in verzorgingshuizen: resultaten na interventies}

Dit hoofdstuk beschrijft de opvattingen van bewoners en verzorgenden, die zij in 2003 geventileerd hebben, over de zorg voor zelfstandigheid bij bewoners van de verzorgingshuizen die aan dit onderzoek hebben deelgenomen. In 2001 zijn vraaggesprekken met bewoners gevoerd en zijn verzorgende medewerkers geënquêteerd. Beide groepen respondenten vinden dat op het gebied van informatievoorziening, de regievoering over het leven in het verzorgingshuis en de houding van het verzorgend personeel veranderingen wenselijk zijn (zie hoofdstuk 8). Zo zullen de bewoners een actieve bijdrage moeten kunnen leveren aan de zorgafspraken, zullen de bewoners invloed moeten kunnen hebben op de regels en gewoonten van het verzorgingshuis en zullen verzorgenden in de zorgrelatie een hogere attentiviteit en responsiviteit aan de dag moeten leggen.

Door de interventie 'responsieve evaluatie', waaraan afzonderlijke groepen verzorgenden en bewoners van drie experimentele verzorgingsafdelingen deelnamen, is nader op deze onderwerpen ingegaan (zie hoofdstuk 9). Een van de conclusies uit de responsieve evaluatie is dat een persoonsgerichte registratie van zorg een hulpmiddel kan zijn om gewenste veranderingen te bewerkstelligen. In samenspraak met verzorgenden van de experimentele afdelingen is een dergelijke registratie opgezet. Door de experimentele groep bewoners te interviewen, hebben verzorgenden informatie over de bewoner geïnventariseerd op het gebied van zijn levensgeschiedenis, zijn wensen, behoeften en keuzes. De gegevens van de bewoner zijn vervolgens op het registratieformulier 'Overzicht Zorgafspraken' vermeld. $\mathrm{Na}$ de responsieve evaluaties en de interviews over de zorgafspraken zijn in 2003 de vraaggesprekken met alle bewoners en de enquête bij alle verzorgende medewerkers, die ook aan het begin van het onderzoek gehouden werden, herhaald.

Dit hoofdstuk beschrijft de resultaten van die tweede meting. In de paragrafen 10.1 tot en met 10.4 zijn de opvattingen van de bewoners en verzorgenden van de 3 experimentele afdelingen vergeleken met die van de bewoners en verzorgenden van de vier controleafdelingen. De uitkomsten zijn gelegd naast de resultaten van de eerste meting in 2001. Daaraan voorafgaand wordt in paragraaf 10.1 eerst nader ingegaan op oordelen van alle respondentgroepen verzorgenden over het woon-leefklimaat en de werkomstandigheden in het verzorgingshuis en van alle respondentgroepen bewoners over de zorgbehoefte. In paragraaf 10.5 wordt een beschouwing op dit hoofdstuk gegeven. 


\subsection{Opvattingen van verzorgenden over afdelingsomstandigheden}

Woon-leefklimaat, werkomstandigheden en zorgzwaarte

Aan de verzorgenden van zowel de controlegroep als de experimentele groep is bij de tweede meting de vraag gesteld of het woon-leefklimaat van bewoners en de werkomstandigheden van de verzorgenden zijn veranderd ten opzichte van de periode waarop de eerste meting plaatsvond. In onderstaande tabel is hun reactie in percentages aangeven $(1=$ verbeterd; 2 = gelijk gebleven; 3 = verslechterd $)$.

Tabel 10.1: Opvattingen van verzorgenden over afdelingsomstandigheden

\begin{tabular}{|l|c|c|c|c|c|c|}
\hline \multirow{2}{*}{} & \multicolumn{3}{|c|}{ Woon-leefklimaat } & \multicolumn{3}{c|}{ Werkomstandigheden } \\
\cline { 2 - 7 } & $\mathbf{1}$ & $\mathbf{2}$ & $\mathbf{3}$ & $\mathbf{1}$ & $\mathbf{2}$ & $\mathbf{3}$ \\
\hline Controlegroep verzorgenden & 48 & 43 & 9 & 39 & 22 & 39 \\
\hline Experimentele groep verzorgenden & 26 & 63 & 11 & 22 & 39 & 39 \\
\hline
\end{tabular}

Aan de verzorgenden is gevraagd toe te lichten waarom veranderingen naar hun mening zijn opgetreden. De controlegroep verzorgenden vindt het woon-leefklimaat verbeterd doordat er koffiehoekjes zijn ontstaan waar kleine groepjes bewoners zich kunnen terugtrekken, doordat sommige deuren zijn verbreed voor rolstoelgebruikers, doordat er meer rekening met de bewoner wordt gehouden en de bewoners een vast aanspreekpunt hebben. Als voorbeelden van verslechtering noemt zij dat het saai is in het verzorgingshuis voor de bewoner, dat er weinig te beleven valt en dat door de toegenomen zorgzwaarte niet die persoonlijke aandacht kan worden gegeven die bewoners verdienen. Volgens de controlegroep zijn er ook verbeteringen in de werkomstandigheden opgetreden: er wordt meer in teamverband gewerkt en beter samengewerkt; de aankleding van de afdeling is verbeterd en er is airco geplaatst. 12 van de 19 opmerkingen $(=39 \%)$ die verzorgenden maken over een verslechtering van de werkomstandigheden hebben betrekking op de werkdruk op de verzorgingsafdeling. De zorgzwaarte is volgens hen flink toegenomen en er is niet meer personeel gekomen. Het gevolg hiervan is dat er te weinig tijd beschikbaar is voor de individuele bewoner en de verzorgende voelt zich hiervoor verantwoordelijk.

Van de experimentele groep verzorgenden vindt $26 \%$ het woon-leefklimaat verbeterd, onder meer doordat openbare ruimtes gezelliger zijn aangekleed, het project aanvullende zorg is ingevoerd voor een groep ouderen met een beginnende dementie, door de goede sfeer in huis en door de aandacht voor persoonsgerichte zorg die tot meer respect voor de bewoners leidt. Het woon-leefklimaat is volgens $11 \%$ verslechterd door de hoge zorgzwaarte en een tekort aan gekwalificeerd personeel en door de mindere aandacht die 
an bewoners kan worden gegeven, onder meer voor wat betreft het schoonmaken van de appartementen. De verslechtering van de werkomstandigheden, wat door $39 \%$ van de experimentele groep verzorgenden wordt gevonden, wordt overwegend toegeschreven aan de hogere zorgzwaarte en de toegenomen werkdruk die hier het gevolg van is. Daarnaast wordt opgemerkt dat de persoonsgerichte zorgregistratie veel tijd vraagt, terwijl het resultaat nog niet echt zichtbaar is. De introductie van persoonsgerichte zorg wordt door de verzorgenden ook als voorbeeld genoemd van een verbetering van de werkomstandigheden, omdat ze heeft geleid tot gerichte bewonersbesprekingen en een structurering van de rapportage. De aanstelling van een nieuw clusterhoofd heeft volgens de verzorgenden ook motiverend gewerkt.

\subsection{Toename van de behoefte aan zorg: opvattingen en feiten}

De behoefte van bewoners aan zorg is in de loop van het onderzoek toegenomen, zowel in de beleving van bewoners als van verzorgenden. Gezien de gemiddelde verblijfsduur van bewoners in verzorgingshuizen (zie hoofdstuk 3 ) mag deze toename ook worden verwacht in een tijdsbestek van twee jaar. Zoals uit onderstaande tabel blijkt is er echter een groot verschil in de beoordeling van bewoners en verzorgenden. Een groot deel van de verzorgenden is van mening dat de behoefte aan zorg is gestegen, terwijl het merendeel van de bewoners vindt dat de behoefte aan zorg niet veranderd is.

Figuur 10.1: Opvattingen over de behoefte aan zorg

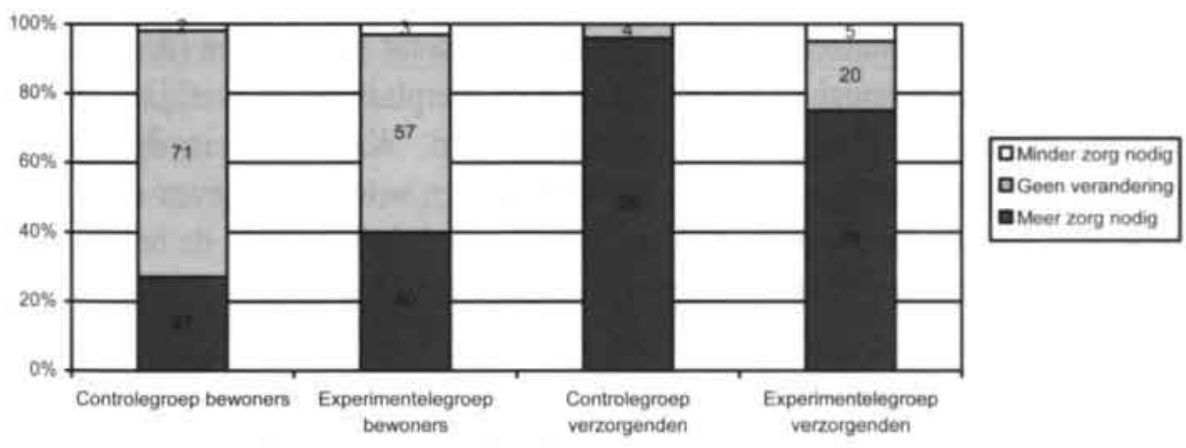

Van de controlegroep bewoners geeft $27 \%$ aan dat meer ondersteuning nodig is, met name op het gebied van mobiliteit en lichamelijke verzorging, $71 \%$ zegt geen verandering te zien en $2 \%$ zegt dat de behoefte an ondersteuning minder is. Van de controlegroep verzorgenden is $96 \%$ van mening dat de bewoners op lichamelijk, psychisch en sociaal 
gebied zorgbehoevender zijn geworden, terwijl $4 \%$ zegt geen toename op te merken. Van de experimentele groep bewoners vindt $40 \%$ dat meer zorgondersteuning nodig is, zowel op lichamelijk gebied als op psychisch gebied, met name bij het zich herinneren van zaken; $57 \%$ vindt dat de persoonlijke situatie ongewijzigd is en $3 \%$ geeft aan minder zorg nodig te hebben. $75 \%$ van de experimentele groep verzorgenden heeft de opvatting dat bewoners op verschillende gebieden om meer zorg vragen, $20 \%$ vindt dat geen verschil is opgetreden en $5 \%$ geeft aan dat minder zorg nodig is.

Een vergelijking van de opvatting van de respondenten met de EBIS-scores, die het gemiddeld aantal zorgminuten aangeven dat aan voornamelijk persoonlijke verzorging voor bewoners op een verzorgingsafdeling wordt gegeven (zie ook hoofdstuk 3.4), laat zien dat de zorgzwaarte bij de eerste interviewronde lager ligt dan bij de tweede meting.

Tabel 10.2: Ontwikkeling van het gemiddeld aantal zorgminuten per bewoner per dag

Locatie

verzorgingshuis 1 verzorgingshuis 2 verzorgingshuis 3 gem. aantal zorgmin. 2001

97

106

122 gem. aantal zorgmin. 2003

118

115

94

In twee van de drie verzorgingshuizen steeg het gemiddeld aantal zorgminuten per bewoner per dag aanzienlijk: in één verzorgingshuis daalde het. Het landelijk gemiddelde bedraagt medio 2003 ruim 100 minuten, met een spreiding van 58 tot 141 minuten (Arcares, 2004). De daling in één verzorginghuis is veroorzaakt door overplaatsing en overlijden van enige bewoners waaraan veel zorgminuten werden besteed. Wat opvalt is dat de sterke verandering van zorgbehoefte, die door de verzorgenden wordt aangegeven en die wordt ondersteund door de EBIS-scores, niet als zodanig wordt beleefd door de bewoners. Het merendeel van hen is van mening dat de zorgbehoefte niet is gewijzigd.

\section{Gevoel van afhankelijkheid van bewoners}

Aan de bewoners van de controle- en experimentele afdelingen (2003-c resp. 2003-e) is ook bij de tweede meting gevraagd op een schaal van 1 tot 10 aan te geven in welke mate zij zich afhankelijk of onafhankelijk voelen ( 1 is volledig afhankelijk, 10 is volledig onafhankelijk). De resultaten zijn in percentages aangegeven onder die van de meting in 2001 . 
Tabel 10.3: Gevoel van afhankelijkheid van bewoners

\begin{tabular}{|lcccccccccc|}
\hline & \multicolumn{1}{c|}{ Volledig afhankelijk } & \multicolumn{8}{c|}{ Volledig onafhankelijk } \\
2001 & 1 & 2 & 3 & 4 & 5 & 6 & 7 & 8 & 9 & 10 \\
$2003-\mathrm{c}$ & 2 & 2 & 5 & 2 & 11 & 11 & 11 & 20 & 10 & 21 \\
$2003-\mathrm{e}$ & 3 & 4 & 2 & & 14 & 4 & 10 & 16 & 24 & 24 \\
\hline
\end{tabular}

Geconcludeerd kan worden dat het gevoel van afhankelijkheid niet is toegenomen, ondanks de eerdere uitspraken van een deel van de bewoners dat de behoefte aan zorg is toegenomen. Dat de behoefte aan ondersteuning niet betekent dat bewoners zich afhankelijk voelen, kan worden afgeleid uit de volgende reacties van bewoners:

Ik doe heel veel zelf, maar ben veel slechter dan ik wil toegeven.

Het is een veilig gevoel dat iemand in de buurt is als je hulp nodig hebt.

Ik voel me niet echt afhankelijk, maar heb wel huishoudelijke hulp en lichte zorg nodig.

Wat hulp hoort er bij.

ledere morgen word ik gedoucht. Ik vind dat plezierig.

Bij de hulp die ik krijg, geef ik zelf aan wat ik wil. Ik moet daar de verzorging soms van overtuigen.

Kwaliteit van leven van bewoners in het verzorgingshuis

Bij de eerste interviewronde is aan bewoners gevraagd aan te geven welke uitspraken zij voor hun situatie van toepassing achten. Bij de tweede ronde is die vraag opnieuw voorgelegd. Hieronder is in percentages aangegeven hoeveel bewoners zich in uitspraken herkennen.

Tabel 10.4 Kwaliteit van leven van bewoners in het verzorgingshuis

\begin{tabular}{|llll|}
\hline \multicolumn{1}{|c}{ Meting } & & \multicolumn{2}{c|}{2003} \\
Item & 2001 & Contr.groep & Exp.groep \\
Ik kan mijn eigen gang gaan & & 94 & 96 \\
Ik voel me op mijn gemak in het verzorgingshuis & 82 & 92 & 85 \\
Ik voel me hier veilig & 78 & 73 & 81 \\
Ik ben gelukkig met mijn situatie & 41 & 44 & 44 \\
Ik wil nog zoveel mogelijk van het leven maken & 39 & 38 & 33 \\
Ik moet dingen laten die ik prettig vind & 25 & 18 & 25 \\
Ik kom niet toe aan dingen die ik prettig vind & 20 & 35 & 18 \\
lk heb het leven geleefd, het hoeft niet meer & 20 & 17 & 14 \\
\hline
\end{tabular}

Het beeld van de kwaliteit van leven van bewoners is niet veel veranderd. Het gevoel dat men zijn eigen gang kan gaan, dat men op zijn gemak is en dat het verzorgingshuis 
veiligheid waarborgt, blijft overheersen. En aantal bewoners voegt uitspraken toe:

Ik wil graag naar het hiernamaals, maar ben tevreden met mijn huidig leven.

Ik denk veel aan vroegere tijden, toen ik me beter voelde.

Ik maak me soms zorgen dat ik minder mobiel word.

Men laat mij hier in mijn waarde.

Ik voel me nu prettiger en heb het beter dan ooit in mijn leven.

Ik voel me op mijn gemak, maar laat me in mijn waarde.

Ik neem de dingen zoals ze komen.

Aan de bewoners is bij de tweede meting de open vraag gesteld wat zij plezierig vinden in het verzorgingshuis en wat naar hun mening anders moet. Van de 34 opmerkingen over de plezierige facetten in het verzorgingshuis worden onder meer genoemd het contact met medebewoners $(8 x)$, het contact met het personeel $(5 x)$, de activiteitenbegeleiding $(5 x)$, de sfeer $(3 \mathrm{x})$ en vrijheid in huis $(3 \mathrm{x})$, de lichamelijke verzorging $(3 \mathrm{x})$ en de directe omgeving van het verzorgingshuis (3x). Van de 45 reacties op de vraag wat anders moet, wordt 24 keer vermeld dat het verzorgend personeel meer aandacht aan bewoners zou moeten schenken. Een aantal bewoners geeft daarbij aan dat de verzorging het te druk heeft om dat te doen. Verder zou beter moeten worden schoongemaakt $(5 \mathrm{x})$, de voeding kan soms beter $(3 \mathrm{x})$, de afdelingen kunnen sfeervoller worden ingericht $(2 \mathrm{x})$ en er zou minder verschil in houding moeten zijn tussen verzorgenden $(2 \mathrm{x})$. Verder wordt onder meer gesteld dat nieuwe bewoners beter begeleid zouden moeten worden, dat er meer contacten tussen de bewoners zouden moeten zijn en dat er met carnaval teveel lawaai in huis is.

\section{Vrij voelen om aan de vraaggesprekken deel te nemen}

Bij de eerste interviewronde geeft $73 \%$ van de bewoners aan zich vrij te voelen om op de vragen van de interviewer te antwoorden en om kritiek te geven. $17 \%$ spreekt uit geen kritiek te durven geven. Bij de tweede ronde geeft $88 \%$ van bewoners van de controleafdelingen en $91 \%$ van de bewoners van experimentele afdelingen aan zich vrij te voelen om te reageren; $12 \%$ respectievelijk $9 \%$ makt een voorbehoud. De hogere score uit de tweede ronde kan mogelijk worden verklaard door de bekendheid met de vragen, het vertrouwd zijn met een vraaggesprek en met de interviewer en de ervaring dat persoonlijke reacties conform de afspraak anoniem blijven. Daarbij moet in acht worden genomen dat het aantal respondenten lager is dan bij de eerste ronde. 


\subsection{Informatievoorziening}

In de eerste ronde vraaggesprekken met bewoners is nagegaan wat zij vinden van de informatie die zij krijgen over onderwerpen die van invloed kunnen zijn op het leven in het verzorgingshuis, en of zij bij bepaalde onderwerpen betrokken worden. Ook de mening van verzorgenden is gepeild. In de tweede ronde vraaggesprekken heeft dezelfde inventarisatie plaatsgevonden. Daarnaast is aan bewoners en verzorgenden gevraagd of zij vinden dat de invloed die bewoners kunnen hebben op de informatievoorziening in het verzorgingshuis ten opzichte van de eerste meting vermeerderd, gelijk gebleven of verminderd is. In deze paragraaf wordt allereerst op de opvattingen over de eventuele verandering van invloed ingegaan en vervolgens zijn de meningen van de verschillende groepen respondenten over de informatievoorziening en hun betrokkenheid daarbij (in perc.) weergegeven.

Tabel 10.5 Algemene indruk van de mogelijkheid tot uitoefenen van invloed op de informatievoorziening $(1=$ meer invloed gekregen; 2 = evenveel invloed; 3 = minder invloed)

\begin{tabular}{|l|c|c|c|c|c|c|c|c|c|c|c|c|}
\hline \multirow{2}{*}{ Item } & \multicolumn{4}{|c|}{ 2003 Controlegroep } & \multicolumn{4}{c|}{ 2003 Experimentele groep } \\
\cline { 2 - 12 } & 1 & \multicolumn{3}{|c|}{ Bewoners } & \multicolumn{3}{|c|}{ Verzorgenden } & \multicolumn{3}{|c|}{ Bewoners } & \multicolumn{3}{|c|}{ Verzorgenden } \\
\cline { 2 - 12 } & 1 & 2 & 1 & 2 & 3 & 1 & 2 & 3 & 1 & 2 & 3 \\
\hline $\begin{array}{l}\text { Algemene indruk van } \\
\text { de invloed op } \\
\text { informatievoorziening }\end{array}$ & 13 & 87 & - & 67 & 33 & - & 26 & 74 & - & 26 & 74 & - \\
\hline
\end{tabular}

Opvallend is dat $67 \%$ van de controlegroep verzorgenden van mening is dat bewoners van hun afdeling meer invloed hebben gekregen, terwijl niet meer dan $13 \%$ van de controlegroep bewoners die mening deelt. De opvattingen van de experimentele groep bewoners en verzorgenden sluiten volledig op elkaar aan.

\section{Vergelijking van experimentele groepen bewoners}

Nagegaan is of de experimentele groep bewoners die aan de interventies responsieve evaluatie en zorgafspraken $(\mathrm{RE}+\mathrm{ZA})$ heeft deelgenomen een andere indruk heeft van de mogelijkheid die men heeft om invloed uit te oefenen op de informatievoorziening dan de groep bewoners die alleen aan de interventie zorgafspraken (ZA) heeft deelgenomen. Onderstaand overzicht toont de verschillen: 
Tabel 10.6 Vergelijking van experimentele groepen bewoners

\begin{tabular}{|l|c|c|c|c|c|c|}
\hline \multirow{2}{*}{ Item } & \multicolumn{6}{|c|}{ 2003 experimentele groep bewoners } \\
\cline { 2 - 7 } & \multicolumn{3}{|c|}{ Interventie ZA } & \multicolumn{3}{c|}{ Interventie RE + ZA } \\
\cline { 2 - 7 } & $\mathbf{1}$ & $\mathbf{2}$ & $\mathbf{3}$ & $\mathbf{1}$ & $\mathbf{2}$ & $\mathbf{3}$ \\
\hline $\begin{array}{l}\text { Opvatting over de mogelijkheid om } \\
\text { invloed uit te oefenen op de } \\
\text { informatievoorziening }\end{array}$ & 21 & 79 & - & 31 & 69 & - \\
\hline
\end{tabular}

In de experimentele groep met twee interventies zijn meer bewoners van mening dat invloed op de informatievoorziening kan worden uitgeoefend dan in de groep met alleen de interventie zorgafspraken. De verschillen zijn evenwel niet groot.

In onderstaande figuur zijn de opvattingen van bewonersgroepen naast elkaar geplaatst. De percentages achter elk staafdiagram geven aan hoeveel respondenten van de volledige bewonersgroep in 2001, van de bewoners controlegroep 2003 en van de bewoners experimentele groep 2003 positief hebben geantwoord op het genoemde item. Ter illustratie: $56 \%$ van de bewonersgroep experimenteel is in 2003 van mening dat zij op de hoogte is van de inhoud van het zorgdossier, terwijl in 2001 niet meer dan $17 \%$ van alle ondervraagde bewoners aangaf op de hoogte te zijn.

Figuur 10.2: Opvattingen van bewoners: vergelijking van drie respondentgroepen

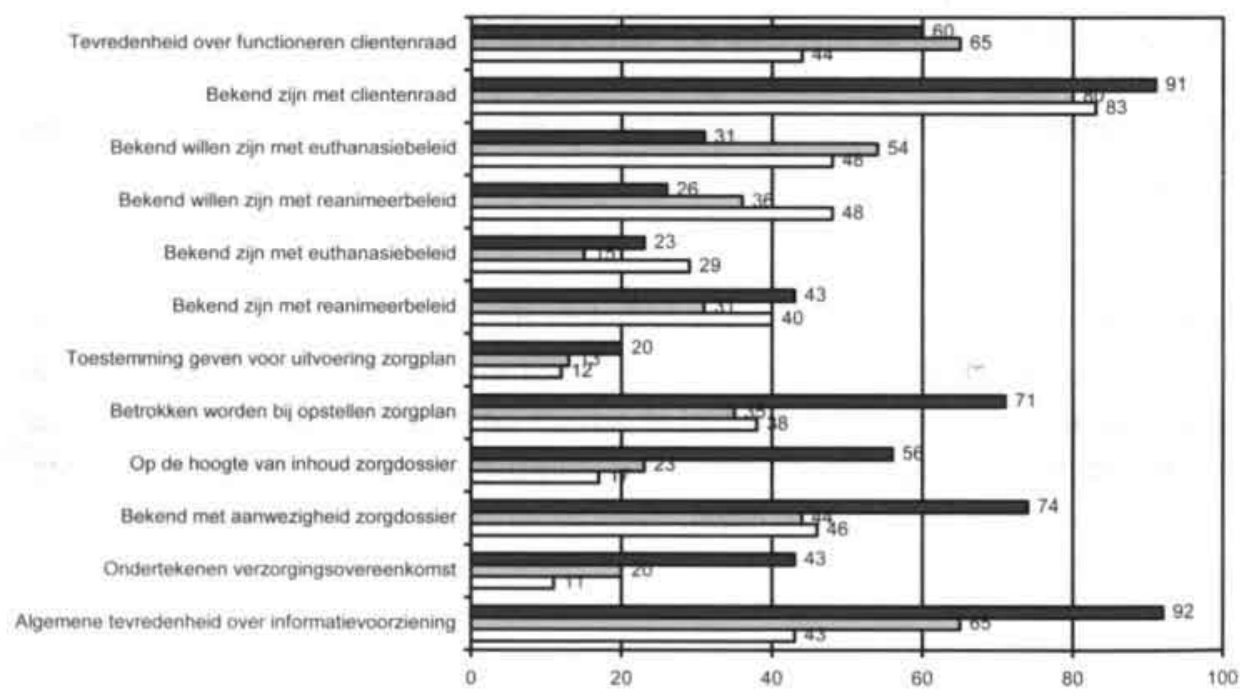

DBewoners 2001 DBewoners controlegroep 2003 Bewoners experimentele groep 2003 
Geconcludeerd kan worden dat veel bewoners tevreden zijn over de informatievoorziening. Dit geldt met name voor de bewoners van de experimentele afdelingen. De aandacht die door de interventies bij de experimentele bewonersgroepen naar het zorgdossier is uitgegaan, vertaalt zich in de percentages bij de items 'bekend met de aanwezigheid van een zorgdossier', 'op de hoogte van de inhoud van het zorgdossier' en 'betrokken bij de inhoud van het zorgdossier'. Meer dan tweemaal zoveel bewoners van de experimentele afdelingen dan die van de controleafdelingen geven aan dat zij de verzorgingsovereenkomst hebben ondertekend, dat ze op de hoogte zijn van de inhoud van het zorgdossier en betrokken zijn geweest bij het opstellen van het zorgplan. $74 \%$ van de experimentele afdelingen zegt bekend te zijn met de aanwezigheid van het zorgdossier tegen $44 \%$ van de controlegroep. Ook geven meer bewoners van experimentele afdelingen dan van controleafdelingen aan dat zij toestemming geven voor de uitvoering van het zorgplan. Toch is het percentage van $20 \%$ van de bewoners van de experimentele afdelingen, dat zegt toestemming te geven, laag in verhouding tot het percentage van $71 \%$ van de bewoners dat aangeeft betrokken te zijn geweest bij het opstellen van het zorgplan. De verschillen tussen de experimentele en controlegroep bij de meting 2003 zijn getoetst met een t-test. Hieruit blijkt dat verschillen in de informatievoorziening, met name ten aanzien van de betrokkenheid bij het dossier, significant zijn $(t=2,92 ; p=.005)$. In de tweede onderzoeksronde hebben meer bewoners hun tevredenheid uitgesproken over het functioneren van de cliëntenraad dan in de eerste ronde. Belangstelling voor het euthanasiebeleid en reanimeerbeleid van het verzorgingshuis is bij het merendeel van de bewoners niet aanwezig.

\section{Vergelijking van experimentele groepen bewoners}

In onderstaande figuur is in percentages angegeven hoeveel bewoners van de experimentele groep responsieve evaluaties en zorgafspraken $(\mathrm{RE}+\mathrm{ZA})$ positief hebben geantwoord op de items betreffende informatievoorziening en hoeveel bewoners van de groep zorgafspraken (ZA) dat hebben gedaan.

De meningen van beide groepen lopen niet ver uiteen, zeker niet voor wat betreft de informatie over het zorgdossier. De groep RE $+\mathrm{ZA}$ is beter bekend met de cliëntenraad, wil meer op de hoogte zijn van het beleid terzake reanimeren, wil meer betrokken worden bij het zorgplan en is iets minder tevreden over de informatievoorziening in het verzorgingshuis dan de groep $\mathrm{ZA}$; de $\mathrm{RE}+\mathrm{ZA}$-groep stelt zich wat kritischer en actiever op over de informatie van het verzorgingshuis dan de andere experimentele bewonersgroep. 
Figuur 10.3: Opvattingen van bewoners

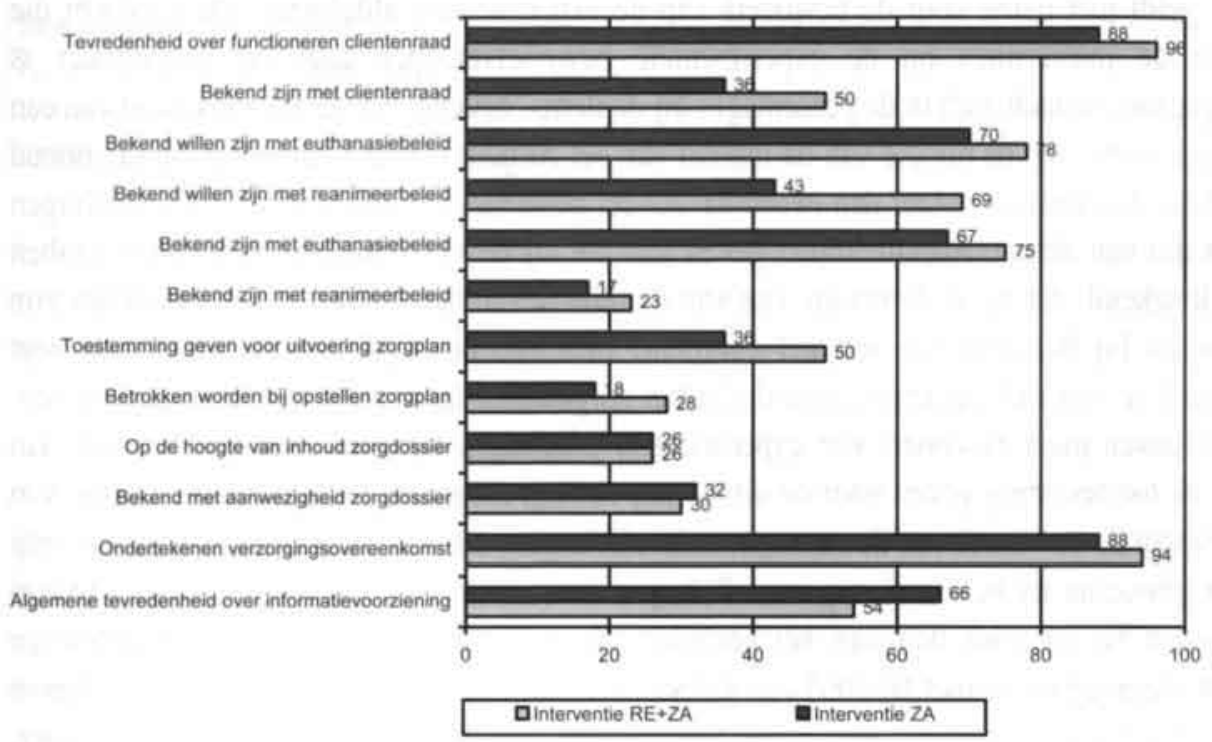

Figuur 10.4: Opvattingen van verzorgenden

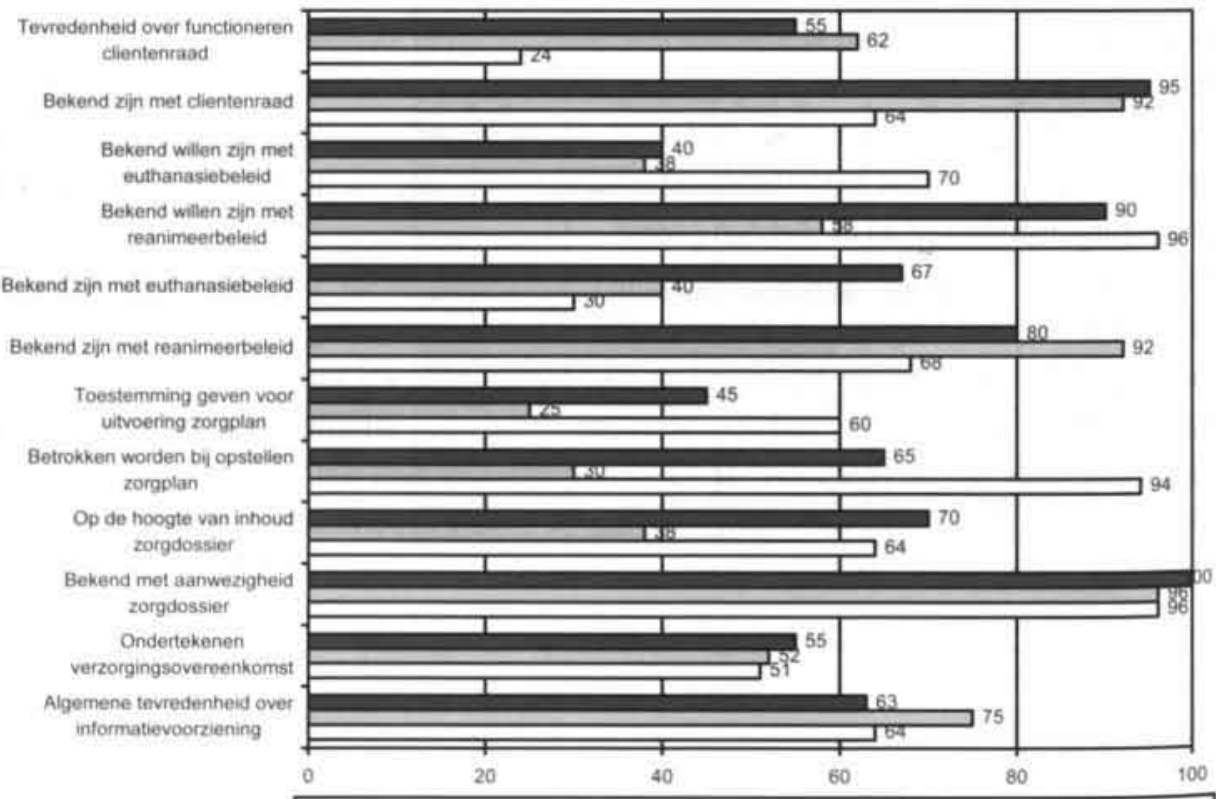

QVerzorgenden 2001 QVerzorgenden controlegroep 2003 QVerzorgenden experimentele groep 2003 
In figuur 10.4 zijn op eenzelfde wijze als in figuur 10.3 de opvattingen die verzorgenden van de controleafdelingen en de experimentele afdelingen in 2003 hebben, geplaatst naast de opvattingen van alle ondervraagde verzorgenden in 2001.

De verzorgenden van de experimentele afdelingen hebben voor wat betreft de algemene tevredenheid van bewoners over de informatievoorziening nagenoeg dezelfde opvatting als bij de eerste meting, terwijl iets meer verzorgenden van de controleafdelingen van mening zijn dat bewoners de informatievoorziening voldoende tot goed zijn gaan vinden. Het percentage verzorgenden dat van mening is dat bewoners een verzorgingsovereenkomst hebben getekend, is ongeveer gelijk gebleven. De verzorgingsovereenkomst wordt getekend bij binnenkomst in het verzorgingshuis en omdat de samenstelling van de onderzoeksgroep van bewoners niet gewijzigd is, is dit te verklaren. Toch is het aantal bewoners uit de experimentele groep dat in 2001 niet en bij de tweede meting in 2003 wel aangeeft een verzorgingsovereenkomst te hebben getekend sterk gestegen. Omdat bij de eerste meting een grote groep bewoners heeft aangegeven niet zeker te weten of een dergelijke overeenkomst is ingevuld, kunnen de discussie over de informatievoorziening en over de verzorgingsovereenkomst en het zorgdossier tijdens de responsieve evaluaties er toe geleid hebben dat bewoners beter in staat zijn aan te geven of ze de verzorgingsovereenkomst wel of niet hebben ingevuld.

Opvallend is dat de inschatting die het verzorgend personeel van de controleafdelingen maakt van de bekendheid van hun bewoners met de inhoud van het zorgdossier en hun betrokkenheid bij het zorgplan veel lager is dan bij de eerste enquêteronde. De wetenschap dat de experimentele afdelingen aan de slag zijn met een interventie op het gebied van betrokkenheid van bewoners bij het zorgplan kan hun opvatting hebben beïnvloed. $45 \%$ van de verzorgenden van de experimentele afdelingen vermeldt dat bewoners toestemming verlenen voor de uitvoering van het zorgplan. Dit percentage is ruim tweemaal zo hoog als dat van de bewoners van hun afdelingen. Of de mening van de verzorgenden gebaseerd is op ondertekening van het Overzicht Zorgafspraken door de bewoner, op hun mondelinge toestemming of op een impliciete toestemming van de bewoner is niet duidelijk. Wel is duidelijk dat praktisch alle verzorgenden van controleafdelingen ook bij de tweede meting de indruk hebben dat de bewoners van hun afdelingen weten dat er een zorgdossier van hen wordt bijgehouden, terwijl dit door minder dan de helft van de bewoners bevestigd wordt. In zijn algemeenheid kan worden gesteld dat bewoners minder bekend en betrokken zeggen te zijn bij registraties over de zorg dan door de verzorgenden wordt ingeschat. Voor wat betreft het al dan niet bekend (willen) zijn met het reanimeerbeleid en/of euthanasiebeleid van de verzorgingshuizen is het beeld niet veel veranderd. Voor ongeveer eenderde deel van de bewoners leeft deze onderwerpen, terwijl verzorgenden de indruk blijven houden dat het 
merendeel van de bewoners zich met deze onderwerpen bezighoudt. Uit reacties van een aantal bewoners blijkt dat de wens om bijvoorbeeld een niet-reanimeren pas te hebben of een euthanasieverklaring af te leggen pas geuit wordt als de lichamelijke gesteldheid minder wordt.

De verzorgenden hebben bij de tweede meting een andere inschatting van de bekendheid van bewoners met (het functioneren van) de cliëntenraad dan bij de eerste meting; meer verzorgenden geven aan dat de bewoners op de hoogte zijn van de cliëntenraad, hetgeen overeenkomt met de mening van de verschillende groepen bewoners.

Het merendeel van de geënquêteerde verzorgenden uit de experimentele groep vervult de rol van e.v.v.-er. Nagenoeg alle verzorgend teamleden hebben deelgenomen aan de responsieve evaluaties en de e.v.v.-ers hebben bewoners geïnterviewd voor de zorgafspraken. Omdat slechts een beperkte groep verzorgenden geen interviews heeft afgenomen, is geen nadere uitsplitsing gemaakt van de experimentele groepen verzorgenden die bij één of twee interventies betrokken zijn.

\subsection{Regievoering in het verzorgingshuis}

Onder de kop 'keuzevrijheid bij regels en gewoonten' is in hoofdstuk 8 beschreven welke opvattingen bij bewoners en verzorgenden heersen terzake de invloed die bewoners willen uitoefenen op de dagindeling, de huisregels en het activiteitenprogramma in het verzorgingshuis. De reacties zijn getypeerd als 'vraaggericht' als de respondenten van mening zijn dat het verzorgingshuis de bewoners wil laten beslissen en niets gemeenschappelijks aanbiedt c.q. als de bewoner zelf kan beslissen; als 'overleggericht' als de dagindeling, de huisregels en het activiteitenprogramma op basis van medezeggenschap en samenspraak tot stand komen en als 'aanbodgericht' als gevonden wordt dat het verzorgingshuis bepaalt wat op deze gebieden gebeurt.

In deze paragraaf wordt aangegeven wat bij de tweede meting de meningen zijn van de verschillenden groepen respondenten en hoe die zich verhouden tot de in 2001 geuite opvattingen. Allereerst is nagegaan wat bewoners en verzorgenden van de controle- en experimentele afdelingen in het algemeen vinden van de invloed van bewoners op regels en gewoonten in het verzorgingshuis. Hieronder zijn in percentages de reacties weergegeven. 
Tabel 10.6 Regievoering in het verzorgingshuis.(Antwoordcategorie 1 staat voor 'veel/voldoende invloed"; antwoordcategorie 2 voor 'weinig/ geen invloed' en categorie 3 staat voor 'anders, namelijk..')

\begin{tabular}{|l|c|c|c|c|c|c|c|c|c|c|c|c|}
\hline \multirow{2}{*}{ Item } & \multicolumn{4}{|c|}{ 2003 controle } & \multicolumn{3}{c|}{ 2003 experimenteel } \\
\cline { 2 - 13 } & \multicolumn{4}{|c|}{ Bewoners } & \multicolumn{2}{|c|}{ Verzorgenden } & \multicolumn{3}{c|}{ Bewoners } & \multicolumn{3}{c|}{ Verzorgenden } \\
\cline { 2 - 12 } & $\mathbf{1}$ & $\mathbf{2}$ & $\mathbf{3}$ & $\mathbf{1}$ & $\mathbf{2}$ & $\mathbf{3}$ & $\mathbf{1}$ & $\mathbf{2}$ & $\mathbf{3}$ & $\mathbf{1}$ & $\mathbf{2}$ & $\mathbf{3}$ \\
\hline $\begin{array}{l}\text { Indruk van invloed op } \\
\text { regels en gewoonten } \\
\text { in het verzorgingshuis }\end{array}$ & 29 & 40 & 31 & $\mathbf{7 8}$ & $\mathbf{2 2}$ & $\mathbf{-}$ & $\mathbf{6 3}$ & $\mathbf{1 2}$ & $\mathbf{2 5}$ & $\mathbf{6 3}$ & 37 & - \\
\hline
\end{tabular}

De opvatting van de verzorgenden van de controleafdelingen strookt niet met die van de bewoners van de controleafdelingen. Waar minder dan een op de drie bewoners van mening is dat de invloed (meer dan) voldoende is, schatten meer dan drie van de vier verzorgenden in dat bewoners vinden dat ze voldoende invloed hebben. Het merendeel van de bewoners dat de antwoordcategorie 'anders' heeft genoemd, geeft aan geen oordeel te hebben. Sommigen willen zich er niet mee bemoeien, anderen zeggen genoeg aan zichzelf te hebben. Een tweetal illustraties:

Ik bemoei me nergens mee.

I hoef geen invloed te hebben. I $k$ vind het wel prettig als alles geregeld is.

Er is een significant verschil tussen het aantal bewoners van de experimentele groep en van de controlegroep bewoners dat van mening is dat de invloed op de regels en gewoonten van het huis is toegenomen $(t=5,35 ; \mathrm{p}<.001)$. Ook in vergelijking met de situatie tijdens de meting in 2001 is volgens de experimentele groep bewoners hun invloed groter geworden $(t=3,08 ; p=.003)$. Meer dan zes van de tien bewoners van de experimentele afdelingen vinden dat ze (meer dan) voldoende invloed hebben en de verzorgenden van die afdeling hebben dat ook ingeschat. De gedachte van de verzorgenden van de experimentele afdelingen dat bijna vier van de tien bewoners weinig of geen invloed menen te hebben, komt niet overeen met de mening van de bewoners. Ook hier geeft een aantal bewoners aan alles wel goed te vinden, of geen behoefte te hebben aan invloed. Twee bewoners merken het volgende op:

Als er iets te bespreken mocht zijn, ga ik naar de directeur.

Met redelijke op-en aanmerkingen kan men invloed hebben.

Vergelijking van experimentele groepen bewoners

Nagegaan is of de experimentele groep bewoners die aan de interventies responsieve evaluatie en zorgafspraken $(\mathrm{RE}+\mathrm{ZA})$ heeft deelgenomen een andere indruk heeft van de invloed die men kan uitoefenen op de regels en gewoonten van het huis dan de groep bewoners die alleen aan de interventie zorgafspraken (ZA) heeft deelgenomen. Onderstaand schema toont de verschillen: 
Tabel 10.7: Vergelijking van experimentele groepen bewoner. (Antwoordcategorie 1 staat voor 'veel/voldoende invloed'; antwoordcategorie 2 voor 'weinig/ geen invloed' en categorie 3 staat voor 'anders, namelijk..').

\begin{tabular}{|l|c|c|c|c|c|c|}
\hline \multirow{2}{*}{ Item } & \multicolumn{6}{|c|}{ 2003 experimentele groep bewoners } \\
\cline { 2 - 7 } & \multicolumn{4}{|c|}{ Interventie ZA } & \multicolumn{3}{|c|}{ Interventie RE + ZA } \\
\cline { 2 - 7 } & $\mathbf{1}$ & $\mathbf{2}$ & $\mathbf{3}$ & $\mathbf{1}$ & $\mathbf{2}$ & $\mathbf{3}$ \\
\hline $\begin{array}{l}\text { Indruk van invloed op regels } \\
\text { en gewoonten in het } \\
\text { verzorgingshuis }\end{array}$ & 49 & 24 & 27 & 77 & - & 23 \\
\hline
\end{tabular}

Wat opvalt is dat beduidend meer respondenten die aan twee interventies hebben deelgenomen van mening zijn dat invloed kan worden uitgeoefend op de regels en gewoonten van het verzorgingshuis dan de respondenten die alleen aan de interventie 'zorgafspraken' hebben deelgenomen. Daarnaast heeft geen enkele respondent van de groep $R E+Z A$ aangegeven geen of weinig invloed te hebben, tegen $24 \%$ van de experimentele groep ZA.

\section{Invloed uitoefenen op dagindeling, huisregels en het activiteitenprogramma}

In onderstaande diagrammen is in percentages aangegeven hoeveel bewoners en verzorgenden van mening zijn dat de dagindeling, de huisregels en het activiteitenprogramma door het verzorgingshuis, door middel van onderling overleg of door de bewoners zelf moeten worden bepaald.

Figuur 10.5: Dagindeling: opvattingen van bewoners

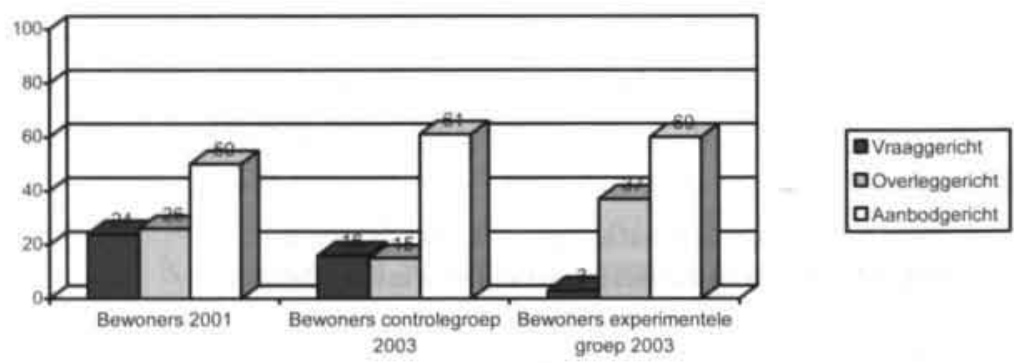

In de figuur zijn de opvattingen van de respondenten in percentages weergegeven. Het totaal van de percentages bij 'bewoners controlegroep 2003' is $92 \%$, hetgeen betekent dat een groep van $8 \%$ de antwoordcategorie 'anders, namelijk..' heeft ingevuld. Zo hebben enige bewoners aangegeven dat de enige wijziging die zij op de dagindeling willen 
aanbrengen het tijdstip betreft waarop de warme maaltijd wordt geserveerd. Een illustratie:

Het middageten is te vroeg, verder doe ik precies wat ik wil.

De controlegroep laat een afnemende belangstelling van bewoners zien voor een dagindeling die aansluit bij de individuele bewoner of die op basis van overleg wordt opgesteld; het verzorgingshuis mag van zes van de tien bewoners de dagindeling bepalen. De bewoners van de experimentele groep vragen evenmin om een vraaggerichte dagindeling. Ook hier mag van zes van de tien bewoners het verzorgingshuis de dagindeling maken. Het percentage bewoners dat van mening is dat een dagindeling op basis van overleg tot stand moet komen, is bij de experimentele groep met $37 \%$ meer dan tweemaal zo hoog als bij de controlegroep, waar $15 \%$ voor overleg kiest.

Figuur 10.6: Dagindeling: inschatting van de mening van bewoners door verzorgenden:

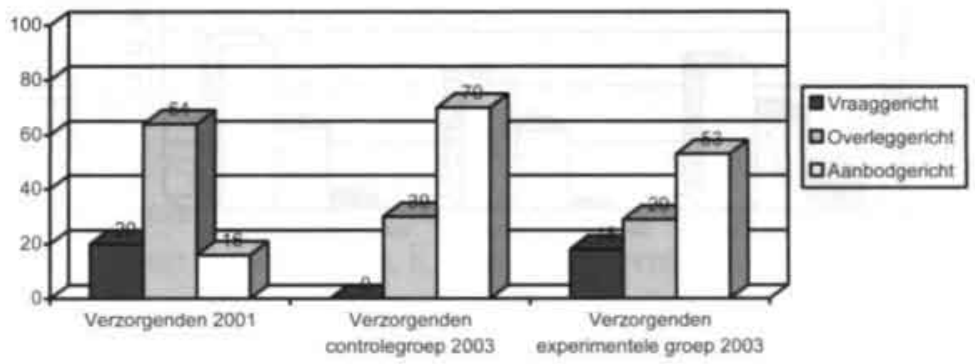

De tweede meting laat een geheel ander resultaat zien dan de eerste meting. Waar verzorgenden bij de eerste meting van mening zijn dat de dagindeling in hoofdzaak in overleg met bewoners moet worden opgesteld, zien we bij de tweede meting dat het merendeel van de controlegroep $(70 \%)$ de opvatting huldigt dat de dagindeling aanbodgericht moet zijn, terwijl $30 \%$ voor overleg kiest. Van de experimentele groep vindt $53 \%$ dat het verzorgingshuis de keuzes moet maken; $18 \%$ vindt dat de dagindeling vraaggericht tot stand moet komen en $29 \%$ kiest voor 'overleggericht'.

Vergelijking van de verschillende respondentgroepen laat zien dat de inschatting die verzorgenden bij de tweede meting maken van de opvattingen van de bewoners van hun afdelingen redelijk overeenkomen met de mening van bewoners voor wat betreft de behoefte aan een vraaggerichte dagindeling. Bij de controlegroepen geeft $61 \%$ van de bewoners en $70 \%$ van de verzorgenden de voorkeur 'aanbodgericht' aan, bij de experimentele groepen is dit $60 \%$ respectievelijk $53 \%$. De behoefte van bewoners aan een 
dagindeling die op basis van overleg tot stand is gekomen, wordt door $30 \%$ van de verzorgenden van de controleafdelingen genoemd, terwijl $15 \%$ van de bewoners van die afdelingen voor die keuze opteert. Bij de experimentele groepen maakt een hoger percentage bewoners die keus $(37 \%)$ dan verzorgenden $(29 \%)$. De behoefte an een vraaggerichte dagindeling wordt binnen de controlegroepen en experimentele groepen anders ingeschat. Terwijl 16\% van de bewoners van controlegroepen individuele keuzes zou willen maken, wordt die voorkeur door de verzorgenden van die afdelingen niet onderkend. Dit beeld is ook terug te zien bij de experimentele afdelingen: $3 \%$ van de verzorgenden is van mening dat bewoners voor een vraaggerichte dagindeling kiezen en $18 \%$ van de bewoners spreekt zich uit voor vraaggerichtheid.

Figuur 10.7: Huisregels: opvattingen van bewoners:

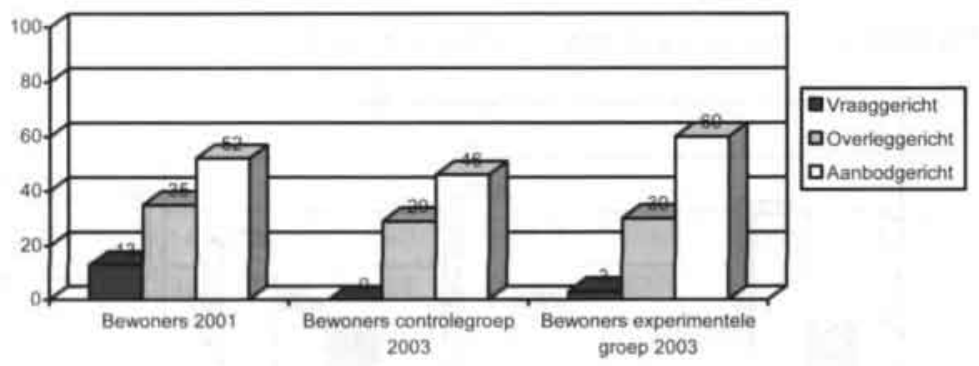

Van de bewoners van de controlegroep heeft $25 \%$ de antwoordcategorie 'anders' ingevuld; van de experimentele groep $9 \%$. De toelichting die bewoners uit de controlegroep bij deze reactie geven, is divers. Enige illustraties:

Hebben we hier huisregels? Daar heb ik nooit iets van gemerkt.

Volgens mij zijn de huisregels voor het personeel, niet dan?

De regels van de bewoners zijn moeilijk te doorbreken, het wordt niet op prijs gesteld om bij elkaar op de koffie te gaan.

Kan de buitendeur's avonds niet vroeger gesloten worden?

Van de controlegroep bewoners is $29 \%$ van mening dat de bewoner en het verzorgingshuis over huisregels moeten overleggen en $46 \%$ vindt dat het verzorgingshuis de huisregels moet bepalen. Deze opvatting wijkt niet veel af van die uit de eerste meting met dien verstande dat de bewoners $(13 \%)$ die in 2001 van mening zijn dat de bewoner over huisregels moet beslissen bij de tweede meting een andere opvatting hebben. Bij de experimentele groep bewoners is een lichte verschuiving te constateren: de vraaggerichtheid neemt af van $13 \%$ naar $3 \%$; het willen overleggen over de huisregels gaat van $35 \%$ naar $30 \%$ en de aanbodgerichtheid neemt toe van $52 \%$ naar $59 \%$. 
Figuur 10.8: Huisregels: inschatting van de mening van bewoners door verzorgenden:

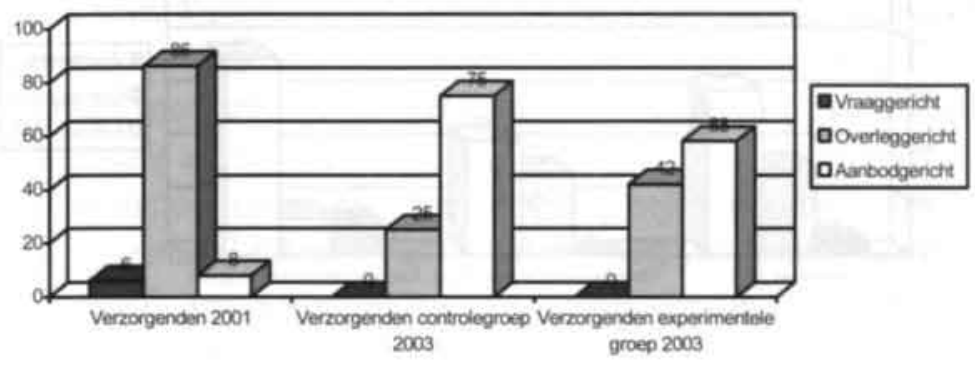

De inschatting van de verzorgenden is bij de tweede meting drastisch gewijzigd ten opzichte van de eerste meting. De gedachte dat bewoners over huisregels willen overleggen, die in de eerste meting door $86 \%$ was uitgesproken, heeft plaatsgemaakt voor de inschatting van $75 \%$ van de verzorgenden van de controlegroep en $58 \%$ van de experimentele groep dat het verzorgingshuis van de bewoners de huisregels mag bepalen. $25 \%$ van de controlegroep en $42 \%$ van de experimentele groep menen dat hun bewoners willen overleggen over de huisregels. De controlegroep en de experimentele groep verzorgenden verschillen derhalve, zowel op het gebied van de inschatting van het overleggericht als van het aanbodgericht omgaan met huisregels. Kleiner zijn de verschillen tussen de bewoners en verzorgenden van de controlegroep en van de experimentele groep. $0 \%$ van de controlegroep verzorgenden en bewoners kiest voor 'vraaggericht'; $25 \%$ respectievelijk $29 \%$ kiest voor 'overleggericht' en $75 \%$ van de verzorgenden en $46 \%$ van de bewoners geven de antwoordcategorie 'aanbodgericht' aan. Van de experimentele groep bewoners spreekt $3 \%$ zich uit voor vraaggerichtheid, tegenover $0 \%$ van de verzorgenden, $30 \%$ van de bewoners is voor overleggericht omgaan met huisregels, terwijl verzorgenden inschatten dat $42 \%$ die keuze maakt. De percentages bij de keuze voor 'aanbodgericht' lopen nauwelijks uiteen ( $60 \%$ bewoners en $58 \%$ verzorgenden).

Een vergelijking van de uitkomsten van meting één en twee (zie figuur 10.9) laat zien dat bij de controlegroep bewoners de voorkeur voor een door het verzorgingshuis opgesteld activiteitenprogramma is afgenomen van $62 \%$ (eerste meting) naar $43 \%$. De wens tot vraaggerichtheid gaat van $5 \%$ naar $0 \%$ en de opvatting dat overleg de voorkeur heeft, blijft nagenoeg constant (van 33\% naar 31\%). 
Figuur 10.9: Activiteitenprogramma: opvattingen van bewoners:

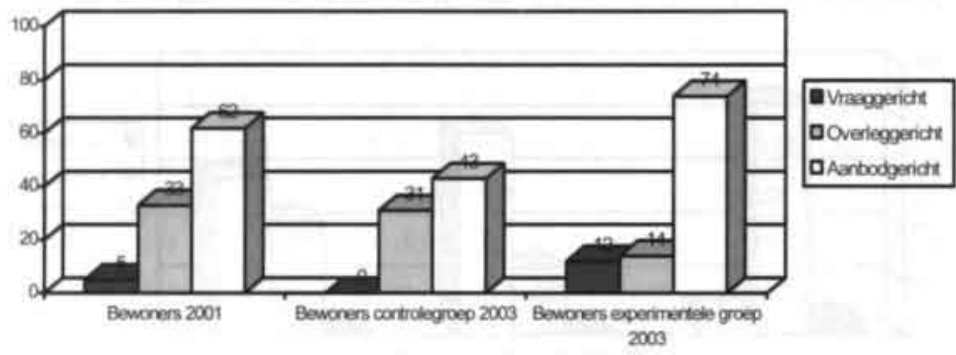

$26 \%$ van de bewonersgroep op de controleafdelingen heeft de antwoordcategorie 'anders' ingevuld. De volgende reacties zijn hier bij opgetekend:

I $k$ ben te oud om me met activiteiten bezig te houden en ik ben er ook niet het type voor.

Aan degenen die niet mee willen doen, moeten ze geen activiteiten opdringen.

Bij veel 'clubjes' is het moeilijk om aansluiting te vinden.

I $\mathrm{k}$ hou niet $z 0$ van groepsactiviteiten en vind de dwang om deel te nemen vervelend.

De 'meisjes' weten wel wat een leuk programma voor ons is.

Bij de experimentele groep neemt het percentage bewoners dat voor vraaggerichte activiteiten kiest toe van $5 \%$ naar $12 \%$; de behoefte aan overleg over het activiteitenprogramma neemt af van $31 \%$ naar $14 \%$ en de opvatting dat het verzorgingshuis zorg moet dragen voor het programma wordt bij de tweede meting gedeeld door $74 \%$ en bij de eerste meting door $62 \%$ van de bewoners.

Figuur 10.10: Activiteitenprogramma: inschatting van de mening van bewoners door verzorgenden:

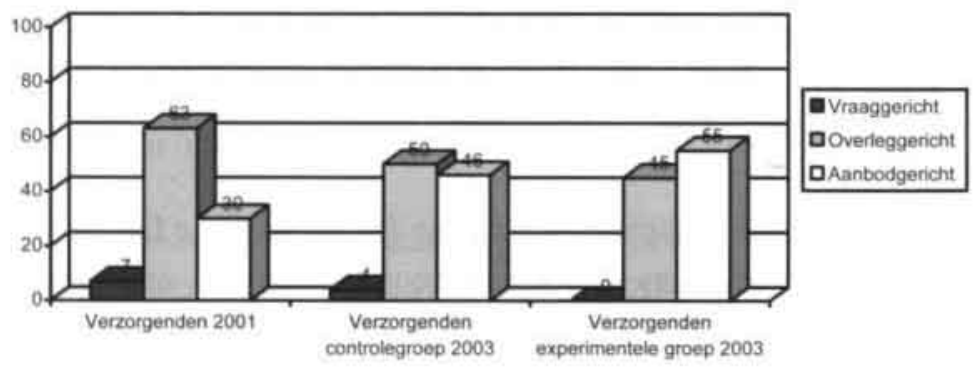

De verzorgenden maken bij de tweede meting een andere inschatting van de keuze van bewoners om zelf het activiteitenprogramma te bepalen, dit in overleg met de verzorging te doen of dit geheel aan het verzorgingshuis over te laten, dan bij de eerste meting: de 
verzorgenden van de controlegroep verwachten dat $50 \%$ van de bewoners overleg wil over het programma, tegenover $63 \%$ van alle verzorgenden bij de eerste meting en $46 \%$ geeft aan dat bewoners zullen kiezen voor een aanbod van het verzorgingshuis, tegenover $30 \%$ bij de eerste meting; de verzorgenden van de experimentele afdelingen denken dat het merendeel van de bewoners voor aanbodgerichtheid kiezen $(55 \%)$ en in iets mindere mate voor overleg over het programma aan activiteiten.

De inschatting van de verzorgenden van de beide groepen afdelingen wijkt bij de tweede meting in zijn algemeenheid minder af van de opvatting van de bewoners dan bij de eerste meting. De behoefte van bewoners van controleafdelingen aan overleg is minder groot dan de verzorgenden van deze afdelingen veronderstellen ( $31 \%$ versus $50 \%$ ) en de inschatting van de behoefte aan aanbodgerichte programmering komt met $46 \%$ tegenover $43 \%$ bewoners sterk overeen. Op de experimentele afdelingen heeft $45 \%$ van de verzorgenden de verwachting dat bewoners overleg willen over het activiteitenprogramma, terwijl maar $14 \%$ van de bewoners invloed op het programma wil uitoefenen. De opvatting dat het verzorgingshuis het activiteitenprogramma moet samenstellen heerst bij $74 \%$ van de bewoners; $55 \%$ van de verzorgenden heeft die inschatting gemaakt.

\section{Vergelijking van experimentele groepen bewoners}

In onderstaand schema is in percentages aangegeven hoeveel bewoners van de experimentele groep die aan de interventies responsieve evaluatie/zorgafspraken (RE+ZA) hebben deelgenomen, en hoeveel van de experimentele groep waarmee zorgafspraken (ZA) zijn gemaakt, van mening zijn dat de dagindeling, de huisregels en het activiteitenprogramma door het verzorgingshuis, door onderling overleg of door de bewoners zelf moeten worden bepaald.

Tabel 10.8 Vergelijking van experimentele groepen bewoners

\begin{tabular}{|l|l|c|c|c|c|c|c|}
\hline & Item & \multicolumn{2}{|c|}{ Dagindeling } & \multicolumn{2}{c|}{ Huisregels } & \multicolumn{2}{c|}{ Activiteitenprogramma } \\
\cline { 2 - 8 } & Interventie & RE+ZA & ZA & RE+ZA & ZA & RE+ZA & ZA \\
\hline $\begin{array}{l}\text { Bepaald } \\
\text { door: }\end{array}$ & & & & & & & \\
\hline Aanbieder & & 54 & 62 & 51 & 67 & 70 & 78 \\
\hline Overleg & & 40 & 34 & 36 & 24 & 18 & 10 \\
\hline Vrager & & 6 & 4 & 5 & 1 & 12 & 12 \\
\hline
\end{tabular}

De verschillen in percentages zijn gering. De tendens is waarneembaar dat meer bewoners met de interventies RE + ZA voor overleg kiezen dan de groep met enkel de interventie zorgafspraken en dat een iets groter percentage van laatstgenoemde groep kiest voor een aanbod of regie door het verzorgingshuis. 


\subsection{Houding van de verzorgenden}

Bij de eerste ronde interviews of vraaggesprekken is aan bewoners gevraagd welke houdingsaspecten van verzorgenden naar hun mening doorgaans voorkomen of herkend worden. Ook aan verzorgenden is gevraagd aan welke houdingsaspecten zij doorgaans aandacht besteden.

De opvattingen van bewoners zijn geplaatst naast die van de verzorgenden en de overeenkomsten en verschillen in beoordeling zijn geanalyseerd. Geconcludeerd wordt dat verzorgenden volgens veel bewoners ongevraagd hulp verlenen, dat over het tijdstip van zorgverlening in veel gevallen niet gecommuniceerd wordt, dat de tijd die voor de zorg wordt uitgetrokken voor een aantal bewoners onvoldoende is en dat het recht van bewoners op zelfbeschikking door verzorgenden ondergeschikt wordt gemaakt aan de fysieke mogelijkheid tot zelfverzorging. Dat de behoefte aan zorg varieert, wordt volgens menig bewoner niet opgemerkt en de vraag of de zorg die wordt verleend overeenkomt met de zorg die wordt gewenst is volgens veel bewoners geen onderwerp van gesprek. Daartegenover staat de opvatting dat bewoners met respect worden benaderd, dat verzorgenden attent zijn, niet betuttelen en beloftes nakomen. Ook in de tweede ronde interviews en enquêtes zijn de opvattingen van bewoners respectievelijk verzorgenden geïnventariseerd en in deze paragraaf worden ze in tabellen weergegeven, uitgedrukt in percentages waarmee de houdingsaspecten doorgaans voorkomen. Daarbij worden de resultaten van de controle en experimentele bewonersgroepen onder elkaar geplaatst en afgezet tegenover de resultaten van de bewoners uit de eerste ronde. Ditzelfde gebeurt met de resultaten van de groepen verzorgenden, waarna de verschillende gegevens met elkaar worden vergeleken.

De houdingsaspecten zijn in vier clusters onderscheiden, gerelateerd aan de vier fases van het proces van zorg, zoals door Tronto (1993) onderscheiden (zie paragraaf 5.2.1.3).

\section{Cluster 1: aandacht voor de behoeften van de bewoner}

Aandacht voor de behoeften van de bewoner, oftewel attentiviteit, is volgens Tronto een deugd die van belang is om een juiste inschatting te maken van de behoefte aan zorg. In onderstaande tabel zijn houdingsaspecten weergegeven die attentiviteit representeren of die er aan voorbijgaan. Allereerst wordt ingegaan op de opvatting van bewoners en vervolgens op die van verzorgenden. 


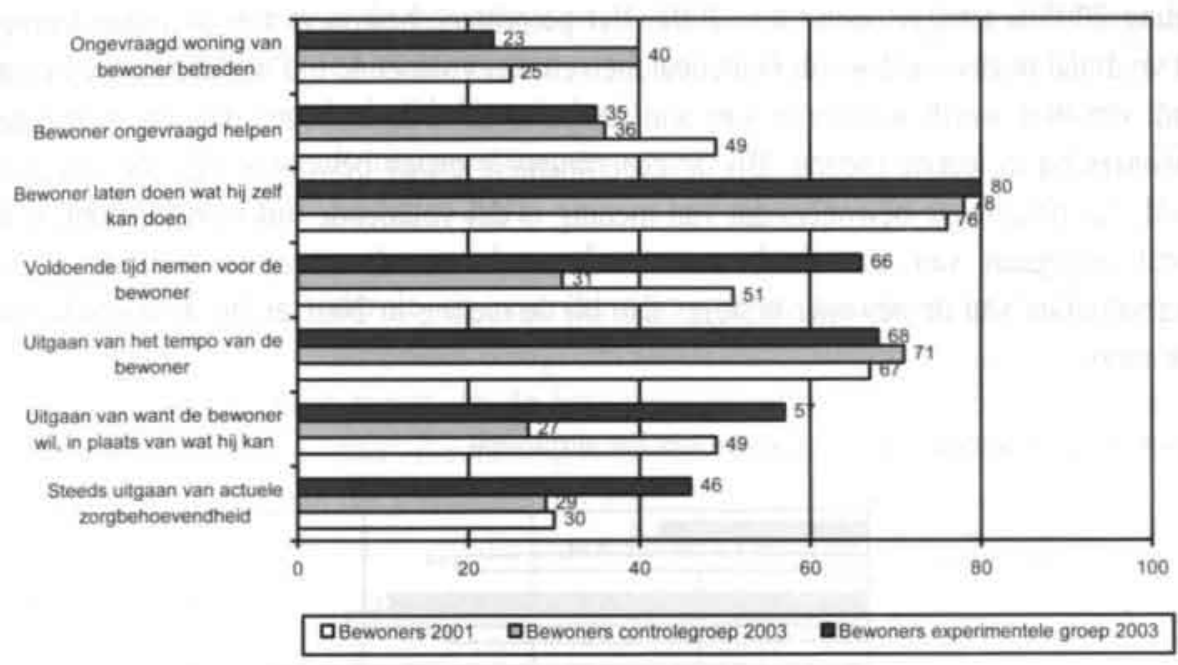

Vier van de tien bewoners van de controlegroep geven aan dat hun woning ongevraagd wordt betreden en bij bijna een kwart van de bewoners van de experimentele groep bewoners is dat eveneens het geval. Meer dan eenderde van beide groepen bewoners wordt ongevraagd geholpen, weliswaar een afname van $13 \%$ tot $14 \%$ ten opzichte van de eerste meting, maar nog altijd een grote groep bewoners die niet zelf de keuze bepaalt waarop verzorgenden hun persoonlijke leefwereld binnentreden. De meeste bewoners krijgen de ruimte zelf te doen wat zij kunnen doen. Minder dan eenderde van de controlegroep vindt dat verzorgenden voldoende tijd nemen en van de experimentele groep bewoners is tweederde die mening toegedaan. Ongeveer $70 \%$ van de bewoners van beide groepen 'mag' van verzorgenden zelf het tempo van de zorg bepalen. Omdat met name bij de controlegroep bewoners veel minder wordt uitgegaan van wat een bewoner wil, maar vooral van wat hij kan, mag er van worden uitgegaan dat verzorgenden de zorg overnemen als zij vinden dat bewoners veel tijd voor de eigen verzorging nodig hebben. De experimentele groep bewoners heeft meer 'beslissingsruimte', maar toch geven nog vier van de tien bewoners aan dat aan hun wil wordt voorbijgegaan. De behoefte van bewoners aan zorg kan variëren. Veel bewoners voelen zich de ene dag wat beter dan de andere dag. De verzorging heeft onvoldoende oog voor deze schommelingen. Slechts $29 \%$ van de controlegroep en $46 \%$ van de experimentele groep zijn van mening dat verzorgenden uitgaan van de actuele behoeften. De overigen vinden dat doorgaans wordt uitgegaan van een constante behoefte aan zorg. 
Een vergelijking van de opvattingen van de beide bewonersgroepen met de eerste meting laat zien dat het aantal bewoners dat vindt dat verzorgenden ongevraagd helpen, bij de meting 2003 is teruggelopen t.o.v. 2001. Het percentage bewoners van de controlegroep, dat vindt dat ongevraagd wordt binnengelopen en niet voldoende tijd wordt genomen en dat vindt dat niet wordt uitgegaan van wat de bewoner wil, is hoger dan het percentage bewoners bij de eerste meting. Bij de experimentele groep bewoners zien we een ander beeld: het percentage bewoners dat van mening is dat voldoende tijd wordt genomen, dat wordt uitgegaan van wat de bewoner wil en dat wordt uitgegaan van de actuele zorgbehoeften van de bewoner is hoger dan bij de meting in 2001 en bij de controlegroep bewoners.

Figuur 10.12: Opvattingen van verzorgenden over hun attentiviteit

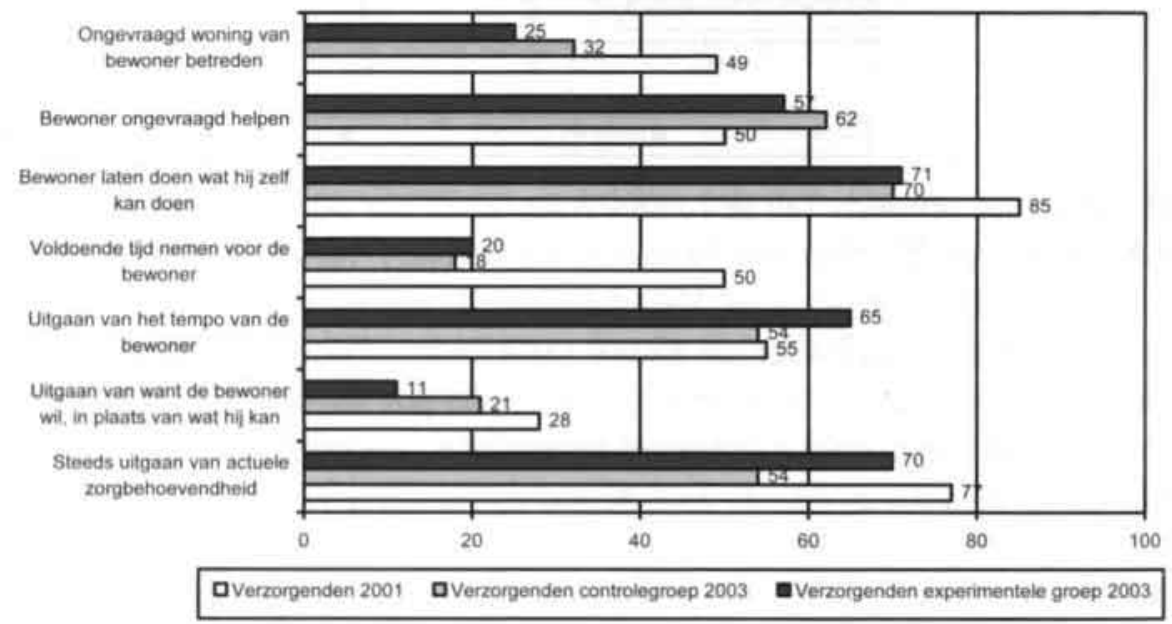

Een kwart tot eenderde van de verzorgenden zegt de woning van de bewoner ongevraagd te betreden en $57 \%$ van de experimentele groep en $62 \%$ van de controlegroep geven aan de bewoner ongevraagd te helpen. Ongeveer zeven van de tien verzorgenden vinden dat men de bewoner zelf laat doen wat hij zelf kan doen. Niet meer dan $11 \%$ van de verzorgenden van de experimentele groep en $21 \%$ van de controlegroep zijn van mening dat wordt uitgegaan van wat de bewoner wil in plaats van wat hij kan. Het merendeel van beide groepen verzorgenden vindt niet dat voldoende tijd voor de bewoner genomen wordt en $65 \%$ van de experimentele groep en $54 \%$ van de controlegroep hebben de opvatting dat bij ondersteuning in de zorg wordt uitgegaan van het tempo van de bewoner. $54 \%$ van de controlegroep en $70 \%$ van de experimentele groep zeggen dat de actuele zorgbehoevendheid van bewoners uitgangspunt van de zorg is. Ten opzichte van de eerste 
meting is het aantal verzorgenden dat aangeeft de woning ongevraagd te betreden gedaald. Terwijl in 2001 de helft van de verzorgenden van mening is dat voldoende tijd voor de bewoner genomen wordt, is dit percentage twee jaar later gedaald tot $20 \%$. Het merendeel van de experimentele groep verzorgenden vindt dat in 2003 minder dan in 2001 wordt uitgegaan van wat de bewoner wil. Van de controlegroep verzorgenden is iets meer dan de helft van mening dat wordt uitgegaan van de actuele zorgbehoevendheid, tegenover $77 \%$ van de totale groep verzorgenden in 2001.

Een vergelijking van de controle- en experimentele groepen bewoners met de controle- en experimentele groepen verzorgenden brengt een aantal discrepanties aan het licht: ongeveer $60 \%$ van de verzorgenden meent dat de bewoners ongevraagd geholpen worden, terwijl ongeveer $35 \%$ van de bewoners die mening is toegedaan; het percentage verzorgenden van de controlegroep dat vindt dat voldoende tijd wordt genomen voor de bewoner is met $18 \%$ veel lager dan de $31 \%$ bewoners van die groep. Bij de experimentele groep verzorgenden is dit beeld nog sterker: $20 \%$ van de verzorgenden geeft aan dat voldoende tijd voor de bewoner wordt genomen tegenover $66 \%$ van de bewoners. $57 \%$ van de bewoners van de experimentele groep meent dat de verzorging uitgaat van wat de bewoner wil, in plaats van wat hij kan, maar slechts $11 \%$ van de verzorgenden van de experimentele groep deelt die mening. Voor wat betreft het houdingsaspect 'steeds uitgaan van de actuele zorgbehoevendheid' zien we een omgekeerd beeld: $29 \%$ van de controlegroep bewoners en $46 \%$ van de experimentele groep bewoners vinden dat die houding doorgaans getoond wordt, terwijl $54 \%$ respectievelijk $70 \%$ van de verzorgenden die mening hebben.

\section{Cluster 2: Bereidheid verantwoordelijkheid te nemen}

Oog hebben voor de mogelijkheden, beperkingen, wensen, keuzes en behoeften van de bewoner, oftewel attentief zijn, vraagt om andere houdingsaspecten dan het op zich nemen van de zorg door de verzorgende. Als de verzorgende bereid is verantwoordelijkheid op zich te nemen en de bewoner dit accepteert, kunnen in een overleg tussen en in de ontmoeting van bewoner en verzorgende afspraken worden gemaakt over de zorg.

In onderstaande figur is weergegeven in welke mate houdingsaspecten, die de bereidheid om verantwoordelijkheid te nemen representeren, naar de mening van bewoners en verzorgenden doorgaans voorkomen. 
Figuur 10.13: Opvattingen van bewonersgroepen over de bereidheid van verzorgenden om verantwoordelijkheid voor de zorg te nemen

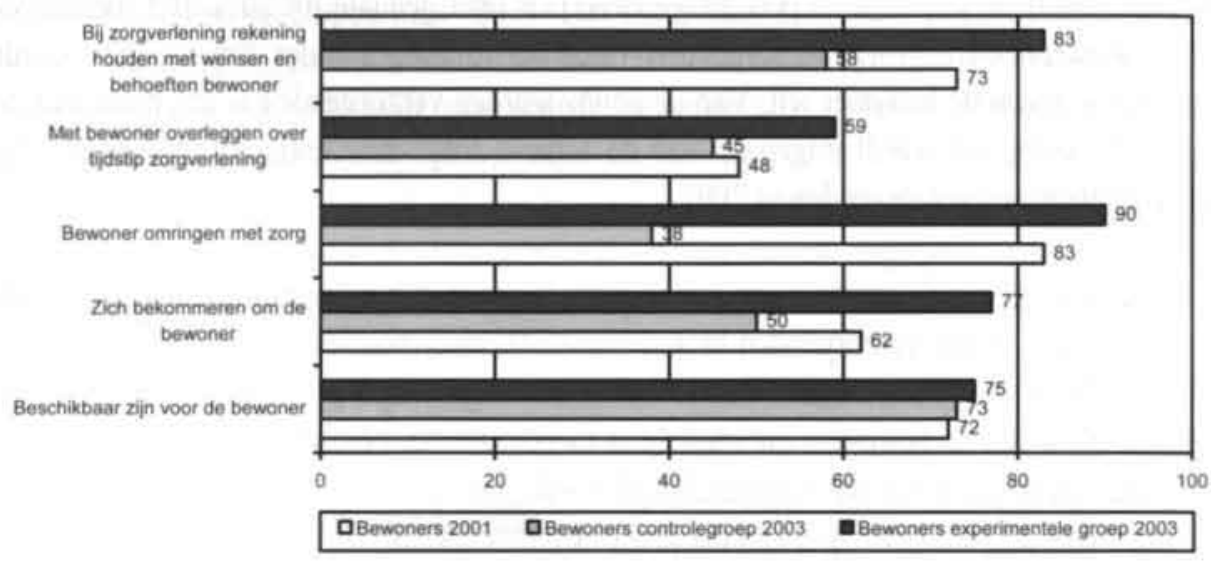

Driekwart van beide groepen bewoners vindt dat verzorgenden beschikbaar zijn als men hen nodig heeft. Verder zijn de verschillen tussen de experimentele groep en de controlegroep groot: $83 \%$ van de bewoners van de experimentele groep vindt dat rekening wordt gehouden met hun wensen en behoeften tegenover $58 \%$ van de controlegroep; $90 \%$ van de experimentele groep en $38 \%$ van de controlegroep zeggen omringd te worden met zorg; $77 \%$ van de experimentele groep is van mening dat verzorgenden zich om bewoners bekommeren en $50 \%$ van de controlegroep deelt die mening. Bij het houdingsaspect 'met bewoner overleggen over het tijdstip van de zorgverlening' zijn de verschillen kleiner: $59 \%$ van de experimentele groep en $45 \%$ van de controlegroep geven an dat dit doorgaans gebeurt. Ten opzichte van de meting in 2001 is volgens de controlegroep in 2003 het op zich nemen van zorg door verzorgenden afgenomen en volgens de experimentele groep bewoners is dit toegenomen. Alleen voor wat betreft het beschikbaar zijn voor bewoners is de situatie hetzelfde gebleven.

Zoals figuur 10.14 toont, komen de opvattingen van de controlegroep en van de experimentele groep sterk overeen. Ze geven weer dat verzorgenden van mening zijn dat de bereidheid verantwoordelijkheid te nemen is toegenomen ten opzichte van 2001, met uitzondering van het houdingsaspect 'bewoner omringen met zorg'. Het merendeel van beide groepen verzorgenden vindt dat rekening wordt gehouden met de wensen en behoeften van bewoners, namelijk $95 \%$ van de experimentele groep en $87 \%$ van de controlegroep, een stijging met $22 \%$ respectievelijk $14 \%$ ten opzichte van de meting 2001 . $76 \%$ van de experimentele groep en $71 \%$ van de controlegroep geven aan dat overlegd 
wordt over het tijdstip van de zorgverlening; meer dan $90 \%$ van beide groepen respondenten heeft de opvatting dat verzorgenden zich bekommeren om bewoners. $64 \%$ van de experimentele groep en $71 \%$ van de controlegroep zegt ook beschikbaar te zijn voor de bewoners.

Figuur 10.14: Opvattingen van verzorgenden over hun bereidheid verantwoordelijkheid voor de zorg te nemen

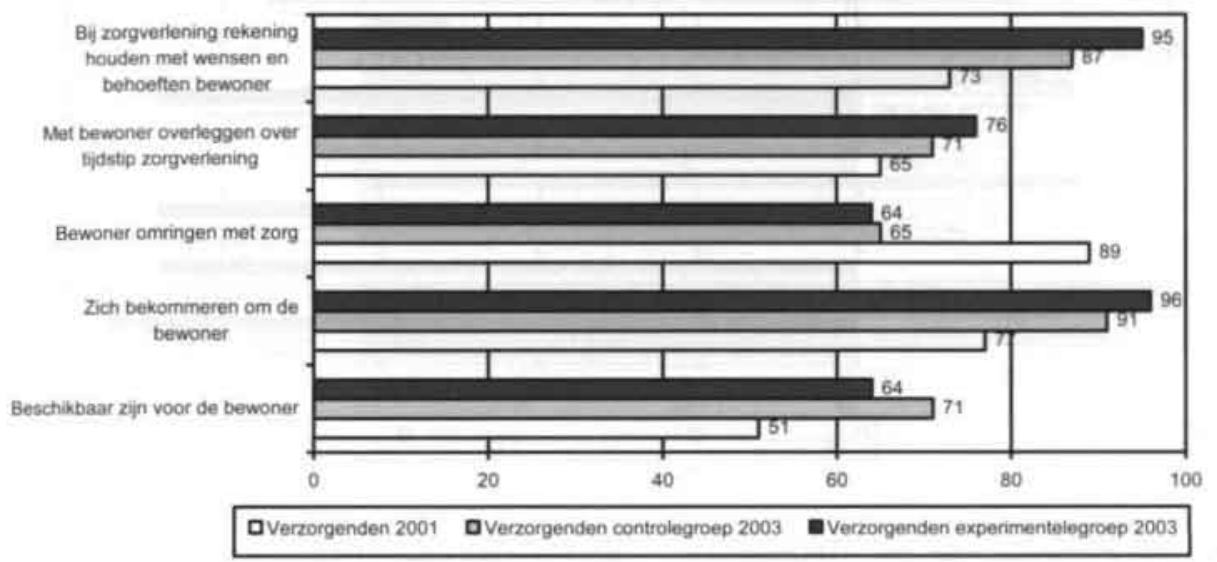

Een vergelijking van de controle- en experimentele groepen bewoners met die van verzorgenden maakt duidelijk dat de opvatting van de controlegroep bewoners en verzorgenden alleen overeenkomt bij het houdingsaspect 'beschikbaar zijn'. Van de andere vier houdingsaspecten vinden veel minder bewoners dat die doorgaans voorkomen dan de verzorgenden. De verschillen zijn minimaal $26 \%$ bij het houdingsaspect 'met de bewoner overleggen over het tijdstip van de zorgverlening' en maximaal $29 \%$ bij het rekening houden met wensen en behoeften van bewoners. Bij de experimentele groepen geeft $90 \%$ van de bewonersgroep aan dat zij omringd wordt met zorg, tegenover $64 \%$ van de verzorgenden; het aspect 'zich bekommeren om de bewoner' komt volgens $77 \%$ van de experimentele bewonersgroep en $96 \%$ van de experimentele groep verzorgenden doorgaans voor. Bij het 'overleggen over het tijdstip van de zorg' zien we dat een hoger percentage verzorgenden aangeeft dit te doen $(76 \%)$ dan volgens de bewoners het geval is $(59 \%)$.

\section{Cluster 3: Competente en deskundige zorgverlening}

Voor het verlenen van zorg moet de verzorgende competent zijn en ze moet er blijk van geven die houdingsaspecten aan de dag te leggen die in de zorgrelatie gevraagd worden. Zo moet onder meer de kwaliteit van de woonruimte bewaakt worden, op signalen terzake zorgbehoevendheid moet attent gereageerd worden en de verzorgende moet de bewoner als 
gelijkwaardige tegemoet treden. In de onderstaande figuren worden de opvattingen van bewoners en verzorgenden terzake de zorgverlening weergegeven.

Figuur 10.15: Opvattingen van bewonersgroepen over de competentie van verzorgenden

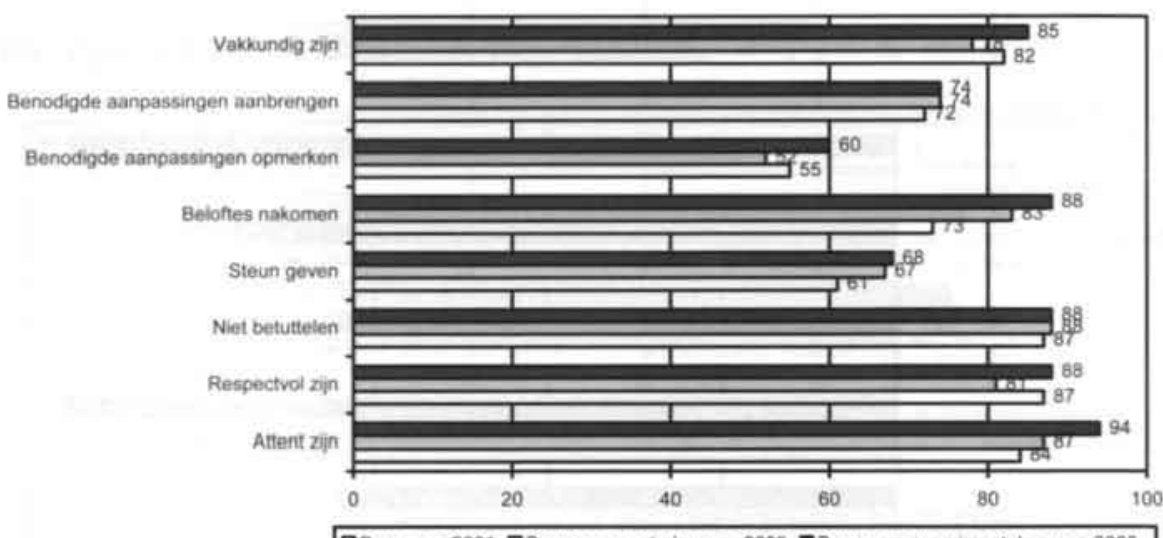

DBewoners 2001 DBewoners controlegroep 2003 Dewoners experimentele groep 2003

De opvattingen van de verschillende bewonersgroepen lopen weinig uiteen en corresponderen in hoge mate met de opvattingen van de bewoners in 2001. De bewoners vinden dat de verzorgenden attent zijn, dat zij niet door hen betutteld worden, maar respectvol worden bejegend. Verzorgenden zijn volgens de bewoners vakkundig en komen beloftes na. Ongeveer vier van de tien bewoners zijn van mening dat de kwaliteit van de woonomgeving meer bewaakt mag worden en als aanpassingen nodig zijn, bijvoorbeeld voor de veiligheid van de doucheruimte of de noodzaak van een verhoogd toilet, worden ze volgens $74 \%$ van de bewonersgroepen ook aangebracht. Bijna $70 \%$ van de bewonersgroepen vindt dat verzorgenden steun geven.

De meningen van de verzorgenden terzaken hun competentie lopen meer uiteen dan die van de bewoners, zoals uit figuur 10.16 blijkt. Verzorgenden vinden dat attent wordt gewerkt, dat zij zich respectvol opstellen, dat aan de bewoners steun wordt gegeven, dat vakkundig gewerkt wordt en dat benodigde aanpassingen worden opgemerkt. Van de controlegroep verzorgenden is maar $41 \%$ van mening dat niet betutteld wordt, tegenover $75 \%$ van de experimentele groep. Verzorgenden van de experimentele groep zijn weliswaar van mening dat benodigde aanpassingen worden opgemerkt $(84 \%)$, maar het aanbrengen van de aanpassingen wordt niet ter hand genomen. Slechts $11 \%$ geeft aan dat dit wel gebeurt, tegenover $73 \%$ van de controleafdelingen. 
Dat benodigde aanpassingen niet tijdig worden aangebracht heeft volgens verzorgenden van doen met de wisseling van de wacht bij de technische dienst en de onervarenheid van de nieuwkomer.

Figur 10.16: Opvattingen van verzorgenden over hun competentie

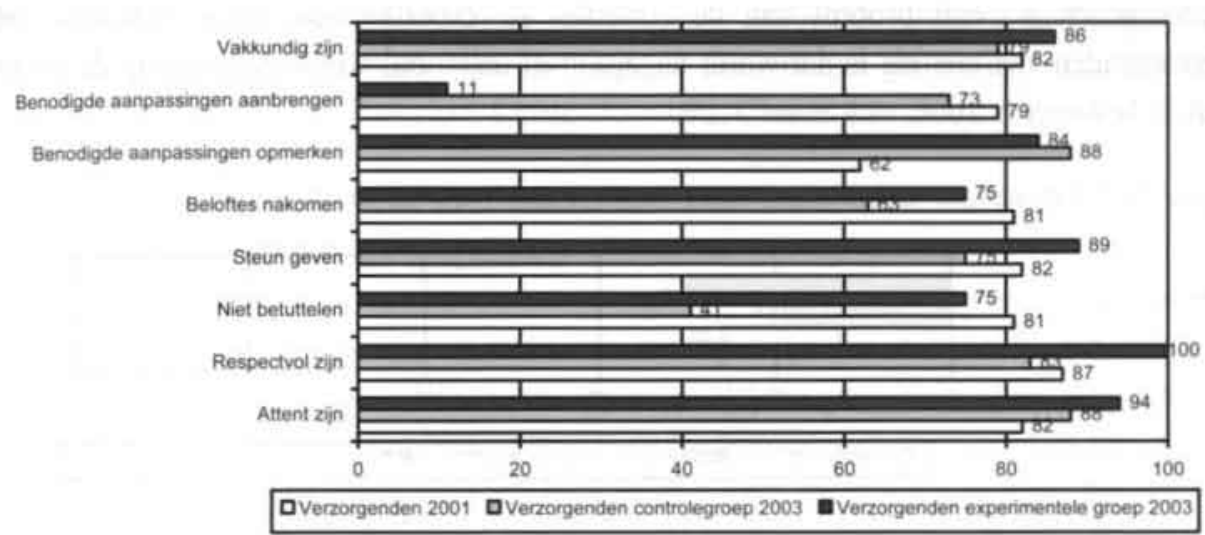

Uit bovenstaande vergelijking van de controle- en experimentele groepen bewoners met die van verzorgenden valt op te maken dat de opvattingen van de controlegroep bewoners en de controlegroepen verzorgenden op een drietal houdingsaspecten duidelijk verschillen: $52 \%$ van de bewoners vindt dat verzorgenden benodigde aanpassingen opmerken, terwijl 88 $\%$ van de verzorgenden die mening deelt; $83 \%$ van de bewoners spreekt uit dat verzorgenden beloftes nakomen en $63 \%$ van de controlegroep verzorgenden deelt die opvatting; $88 \%$ van de bewoners is van mening dat verzorgenden niet betuttelen, terwijl $41 \%$ van de verzorgenden dezelfde mening heeft. De experimentele groep bewoners heeft ten aanzien van twee houdingsaspecten een andere mening dan de experimentele groep verzorgenden: $74 \%$ van de bewoners vindt dat benodigde aanpassingen ook worden aangebracht, terwijl die mening slechts door $11 \%$ van de verzorgenden gedeeld wordt; $60 \%$ van de bewoners geeft aan dat verzorgenden opmerkzaam zijn voor wat betreft de behoefte aan aanpassingen in hun woning, terwijl $84 \%$ van de verzorgenden zichzelf op dit punt opmerkzaam vindt.

\section{Cluster 4: Antwoord geven op de vraag van de bewoner}

In hoofdstuk 5 is gesteld dat van degene die de zorg ontvangt verwacht mag worden dat hij ontvankelijk is voor de zorg. Ontvankelijkheid of responsiviteit betekent dat bij de bewoner wordt nagegaan of op zijn verwachtingen en behoeften is ingegaan. Bij de eerste meting in 
2001 is geconstateerd dat responsiviteit niet vanzelfsprekend is. Geconstateerd is dat niet meer dan $26 \%$ van de bewoners aangeeft dat verzorgenden vragen of de zorg die is verleend aan de verwachting of behoefte van de bewoner voldoet. $49 \%$ van de verzorgenden is in 2001 van mening dat de responsiviteit bewaakt wordt. De overige verzorgenden onderkennen de opvatting van het merendeel van de bewoners. In onderstaande tabellen is weergegeven hoeveel procent van de controle- en experimentele groep bewoners en verzorgenden van mening is dat wordt nagegaan of antwoord wordt gegeven op de vraag van de bewoner.

Figuur 10.17: Opvattingen van bewonersgroepen over de responsiviteit van verzorgenden

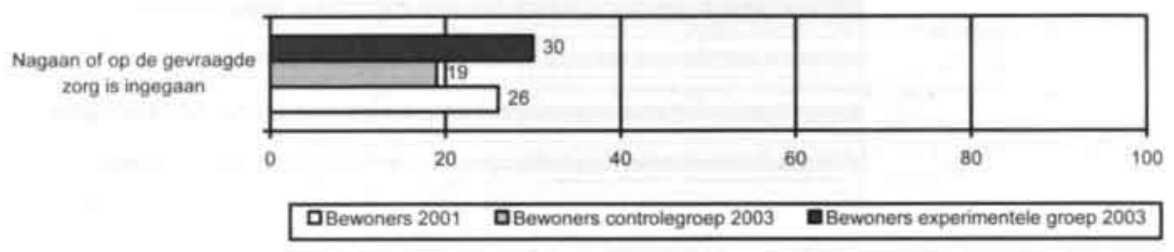

Slechts 19\% van de controlegroep bewoners en $30 \%$ van de experimentele groep bewoners vinden dat verzorgenden nagaan of de ontvanger van de zorg tevreden is over de verleende zorg cq of de zorg aan zijn verwachtingen voldoet. Deze percentages komen redelijk overeen met die van de meting van 2001 , hetgeen betekent dat op dit punt niet veel veranderd is.

Figuur 10.18: Opvatting van verzorgenden over hun responsiviteit

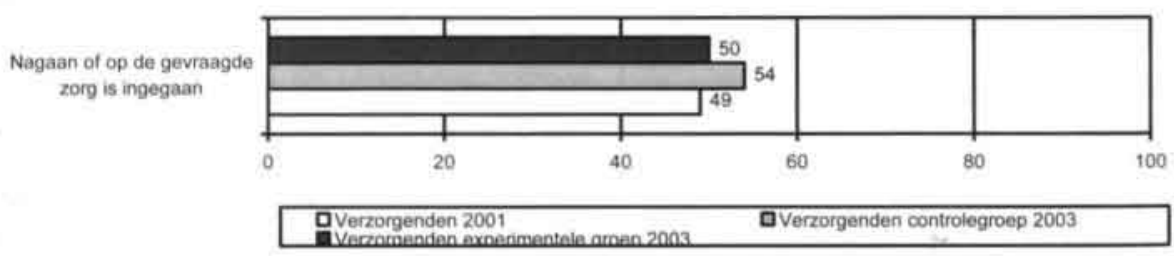

De opvattingen van de controlegroep en van de experimentele groep verzorgenden lopen nauwelijks uiteen. Evenals bij de meting 2001 is ongeveer $50 \%$ van mening dat aandacht voor responsiviteit een houdingsaspect is dat doorgaans de aandacht van verzorgenden krijgt. De opvatting van de controlegroep verzorgenden wijkt met $54 \%$ sterk af van die van de controlegroep bewoners, waar $19 \%$ meent responsiviteit waar te nemen. Ook de opvatting van experimentele groep verzorgenden $(50 \%)$ sluit niet aan bij die van de experimentele groep bewoners $(30 \%)$. 


\section{Vergelijking van experimentele groepen bewoners}

Nagegaan is of verschillen zijn waar te nemen in de resultaten van de twee experimentele groepen. De vraag is gesteld of bewoners die aan twee interventies hebben meegedaan $(\mathrm{RE}+\mathrm{ZA})$ tot andere beoordelingen komen over de houding van de verzorgenden dan bewoners die aan één interventie (ZA) hebben deelgenomen.

Met behulp van de t-toets $(\alpha=.05)$ is voor de vier genoemde clusters nagegaan of er significante verschillen bestaan. Bij geen van de clusters kon dit worden geconstateerd (Cluster 1:t=.780; Cluster 2:t=.737; Cluster 3:t=.092; Cluster 4:t=.560).

\subsection{De resultaten nader beschouwd}

Tussen de eerste meting in 2001 en de tweede meting in 2003 is de behoefte aan zorg van menig bewoner toegenomen. EBIS-scores wijzen uit dat het gemiddeld aantal zorgminuten dat dagelijks aan een bewoner besteed wordt in die periode met ongeveer tien minuten is gestegen. Het verzorgend personeel houdt de EBIS-scores bij en het is te begrijpen dat het merendeel van de verzorgenden van mening is dat de zorgzwaarte van bewoners van hun afdelingen is gestegen. Maar opmerkelijk genoeg is niet meer dan eenderde deel van de ondervraagde bewoners het daar mee eens. De meeste bewoners vinden dat hun behoefte aan zorg niet veranderd is. Voor de bewoners die aangeven dat hun behoefte an zorg gestegen is, overheerst net als bij de overige bewoners het gevoel dat de afhankelijkheid niet versterkt is. Eerder in deze studie is naar voren gebracht dat ouderen verwachten dat zij in het verzorgingshuis hulp bij de zorg krijgen, maar dat zij andere zaken belangrijker vinden. Tegen die achtergrond is het te begrijpen dat een toegenomen ondersteuning bij de verzorging door hen minder bewust beleefd wordt dan door de verzorgenden die juist overwegend gericht zijn op het verlenen van zorg. Veel bewoners vinden dat ze hun eigen gang kunnen gaan en voelen zich in het verzorgingshuis veilig en op hun gemak. Er bestaat wel zorg over de gezondheid, beperkingen worden ervaren en voor ongeveer eenvijfde deel van de bewoners is dit aanleiding om te zeggen dat het leven geleefd is en niet meer hoeft. Ongeveer veertig procent van de bewoners geeft aan nog zoveel mogelijk van het leven te willen maken of merkt op zich gelukkig te voelen met de situatie waarin zij verkeert. Het contact met medebewoners, met medewerkers en de activiteiten in het verzorgingshuis dragen bij aan dit gevoel. Daarentegen maken bewoners opmerkingen over het gebrek aan aandacht van het verzorgend personeel en vinden zij dat onvoldoende op de behoefte aan contact wordt ingegaan. Door de verzorgenden wordt dit gevoel onderkend en onderstreept. De toegenomen behoefte aan zorg heeft naar hun mening tot een hoge werkdruk geleid, waardoor persoonlijke aandacht voor bewoners in de klem is gekomen. Op de 
experimentele afdelingen heeft die werkdruk niet geleid tot vermindering van de kwaliteit van de informatievoorziening, van het bekend zijn van bewoners met het zorgdossier of van hun betrokkenheid bij het opstellen van het zorgplan (op de experimentele afdelingen het Overzicht Zorgafspraken genoemd). Integendeel. Het merendeel van de bewoners dat aan de responsieve evaluaties heeft deelgenomen en heeft meegewerkt aan de persoonsgerichte zorgregistratie vindt dat de informatievoorziening is verbeterd ten opzichte van de periode waarin de eerste meting plaatsvond. Het aantal bewoners van de experimentele groep dat vindt dat zij meer betrokken wordt bij het zorgplan verschilt significant van het aantal bewoners van de controlegroepen die die mening is toegedaan. Veel van de bewoners van de experimentele groep geven aan dat zij bekend zijn met hun zorgdossier en betrokken worden bij het zorgplan. Verzorgenden van deze afdelingen beamen dat. De meeste bewoners en in iets mindere mate verzorgenden van de controleafdelingen geven daarentegen aan dat de bewoners van deze afdelingen niet betrokken worden bij het zorgdossier en het zorgplan. Geconcludeerd kan worden dat de meeste bewoners en verzorgenden van de experimentele afdelingen van mening zijn dat met het recht op informatie rekening wordt gehouden, dat het toestemmingsvereiste meer in acht wordt genomen en dat ruim de helft van de bewoners aangeeft gebruik te maken van het inzagerecht. De experimentele groep bewoners die aan twee interventies heeft deelgenomen stelt zich iets kritischer op over de informatievoorziening en vraagt om meer informatie van het verzorgingshuis dan de experimentele groep die alleen aan het opstellen van de zorgafspraken heeft deelgenomen. De verschillen zijn evenwel gering. De verschillen in opvatting tussen de respondentgroepen van de controleafdelingen en de respondentgroepen van de experimentele afdelingen over de informatievoorziening met betrekking tot het zorgplan of de zorgafspraken zijn te verklaren. Op de controleafdelingen is de situatie niet gewijzigd; op de experimentele afdelingen hebben alle verzorgenden en een deel van de bewoners in de responsieve evaluaties gediscussieerd over de kwaliteit van de informatievoorziening en aangedrongen op een grotere betrokkenheid hierbij van bewoners. De gesprekken over de zorgafspraken zijn hier het gevolg van geweest. De experimentele afdelingen en met name de verzorgenden hebben het bevorderen van de informatievoorziening derhalve heel bewust meegemaakt. Ook veel bewoners van experimentele afdelingen vinden dat ze betrokken worden bij de zorgafspraken, maar het voeren van gesprekken met verzorgenden over hun leven lijkt voor hen van meer betekenis dan het geattendeerd worden op of het gebruik maken van het recht op informatievoorziening.

Meer dan tweemaal zoveel bewoners van de experimentele afdelingen dan van de controleafdelingen hebben de indruk dat zij invloed kunnen uitoefenen op de regels en 
gewoonten van het verzorgingshuis. Met name de groep die aan twee interventies heeft deelgenomen, is die mening toegedaan. Toch heeft een minderheid van deze bewoners behoefte aan een dagindeling die afwijkt van die van het verzorgingshuis; de huisregels wil men niet naast zich neerleggen en aan een individueel of een op basis van overleg tot stand gekomen activiteitenprogramma is weinig behoefte. Over de dagindeling en de huisregels willen ongeveer vier op de tien bewoners van de experimentele groep overleg voeren tegenover vijftien procent van de controlegroep, maar het merendeel van de bewoners zegt zich te kunnen vinden in de keuzes van het huis. Opvallend is dat de meeste verzorgenden in 2001 aangeven dat de dagindeling en huisregels vooral in overleg met de bewoner moeten worden opgesteld, terwijl ze bij de tweede meting voornamelijk vinden dat de zorgaanbieder de keuzes op dit gebied moet bepalen. Niet duidelijk is waar deze verandering van opvatting door is ingegeven. Mogelijk zijn verzorgenden bekend met de opvatting van de bewoners en delen ze hun mening, maar evenzeer is mogelijk dat verzorgenden opzien tegen een op de keuze van de bewoner afgestemde dagindeling of huisreglement, vanuit de inschatting dat een dergelijke verandering extra tijd vraagt en werkdrukverhogend is. De experimentele bewonersgroepen verschillen niet sterk van opvatting over de vraag of de gewoonten, regels en het dagprogramma in het verzorgingshuis door de zorgaanbieder moeten worden bepaald, door overleg tot stand moeten komen of aan de bewoners moeten worden overgelaten. De tendens is waarneembaar dat meer bewoners met de interventies responsieve evaluatie en zorgafspraken $(\mathrm{RE}+\mathrm{ZA})$ voor overleg kiezen dan de groep met enkel de interventie zorgafspraken $(\mathrm{ZA})$ en dat een iets groter percentage van laatstgenoemde groep kiest voor een aanbod of regie door het verzorgingshuis. In zijn onderzoek naar wensen en behoeften van ouderen die in hun eigen huis formele hulp krijgen, concludeert Bijsterveld (2001) dat ouderen veel waarde hechten aan vaste tijden waarop ondersteuning geboden wordt of waarop activiteiten plaatsvinden. De vaste tijden geven volgens hem een gevoel van controle over het eigen leven. Wellicht is dit de verklaring voor de keuze van het merendeel van de ouderen om zich aan te passen aan de regels en het programma van het verzorgingshuis.

In de responsieve evaluaties komt naar voren dat sommige verzorgenden gesprekken met bewoners vermijden, omdat ze tijd in beslag nemen die volgens hen niet beschikbaar is (zie hoofdstuk 9). Dat tijd als een probleem wordt gezien, blijkt uit de beoordeling van houdingsaspecten van verzorgenden. Van de controleafdelingen vindt maar eenvijfde deel van de verzorgenden en ongeveer drie van elke tien bewoners dat verzorgenden voldoende tijd voor hen nemen. De verzorgenden van de experimentele afdelingen delen de opvatting van hun collega's. Wellicht dat zij door de gesprekken over de zorgafspraken tot het inzicht 
zijn gekomen dat zij de bewoners doorgaans tekort doen. Tweederde deel van de bewoners is wel van mening dat voldoende tijd genomen wordt. Mogelijk dat hun opvatting wordt beïnvloed door de hoeveelheid tijd die is uitgetrokken voor de persoonlijke gesprekken over het Overzicht Zorgafspraken. Over de start en evaluatie van de zorg, oftewel de attentiviteit van verzorgenden en hun aandacht voor responsiviteit, zijn met name de bewoners van de controleafdelingen niet positief. Ook een groot deel van de verzorgenden vindt dat gezorgd en verzorgd wordt zonder zich voldoende rekenschap te geven van de verwachtingen, wensen en keuzes van bewoners en zonder na te gaan of de verleende zorg aan de verwachtingen van de bewoner voldoet. Weliswaar geven meer verzorgenden van experimentele afdelingen dan van controleafdelingen aan uit te gaan van wat de bewoner wil, maar de verschillen zijn niet groot. Eenderde deel van de bewoners van de experimentele groep geeft aan dat zij ongevraagd wordt geholpen en dat niet voldoende tijd wordt genomen. Het merendeel van alle verzorgenden onderschrijft de opvatting dat te weinig tijd wordt uitgetrokken. Toch zijn meer bewoners van de experimentele groep dan van de controlegroep van mening dat de attentiviteit is toegenomen. Meer dan de helft stelt dat niet wordt uitgegaan van de actuele behoefte aan zorg, hetgeen tot gevolg kan hebben dat de bewoner wordt aangesproken op veronderstelde vermogens in plaats van op zijn feitelijke vermogens. De verzorgende zal dan uitgaan van wat de bewoner kan, in plaats van wat hij wil. Meer dan veertig procent van de bewoners van de experimentele groepen is van mening dat dit ook gebeurt. Over de bereidheid om zorg te verlenen en de houding die getoond wordt tijdens de zorgverlening wordt positiever gedacht. De bereidheid tot overleg over het tijdstip van de zorg wordt vooral door bewoners van controleafdelingen evenwel als minder groot gezien. Bijna alle bewoners van experimentele afdelingen hebben het gevoel dat zij omringd worden met zorg, terwijl dit gevoel bij het merendeel van de bewoners van de controleafdelingen niet aanwezig is. Over de deskundigheid of competentie van het verzorgend personeel oordeelt het merendeel van de bewoners positief, terwijl de verzorgenden kritischer op zichzelf zijn. De interventies hebben er niet toe geleid dat de responsiviteit is toegenomen. Weliswaar is het aantal bewoners van experimentele afdelingen, dat aangeeft dat de verleende zorg wordt geëvalueerd met de bewoners, hoger dan het aantal bewoners van de controleafdelingen ( 30 versus 19 procent), maar ten opzichte van 2001 kan geen toename worden geconstateerd.

Samengevat kan worden gesteld dat de interventies tot een hogere betrokkenheid van bewoners bij de informatievoorziening rondom de zorg hebben geleid. De behoefte van de experimentele groepen aan overleg over de dagindeling is toegenomen ten opzichte van de eerste peiling en groter dan die van de controlegroep bewoners. Het merendeel van de experimentele groep bewoners heeft de indruk invloed te hebben op de regels en gewoonten 
in het verzorgingshuis, terwijl een minderheid van de controlegroep die opvatting deelt. Ook de attentiviteit, oftewel de gevoeligheid en aandacht van verzorgenden voor de behoeften en verwachtingen van de bewoners is volgens de experimentele groep bewoners toegenomen. De verzorgenden van de experimentele afdelingen zijn eveneens van mening dat de informatievoorziening naar bewoners verbeterd is. Zij constateren met de bewoners van hun afdelingen dat een vraaggericht aanbod van activiteiten en van huisregels bij de behoefte van bewoners aansluit. De verzorgenden van de experimentele afdelingen onderkennen dat de attentiviteit is toegenomen, maar het gevolg hiervan is dat zij kritischer zijn geworden op hun handelen en vinden dat onvoldoende tijd beschikbaar is voor het contact met de bewoner. 
Hoofdstuk 11 Beschouwing, conclusies en aanbevelingen

\subsection{Inleiding}

De vraag van de bewoner, in de inzet van het inleidend hoofdstuk, waar zij zich aan te houden heeft, alsmede regelmatig opduikende persberichten over de afhankelijkheid van bewoners in verzorgingshuizen riepen bij mij de vraag op hoe het is gesteld met de zorg voor zelfstandigheid in verzorgingshuizen in het algemeen en in die waar ik werkzaam ben in het bijzonder. Het exploreren van die vraag heeft geen vrijblijvend karakter. De overheid lijkt de zorg voor zelfstandigheid van ouderen in zorginstellingen ernstig te nemen. In het document UvO (uitkomst van overleg) dient de zorgaanbieder ieder jaar te ondertekenen dat hij zich zal houden aan de opdracht om de autonomie van de bewoner te beschermen en te respecteren en om hem voldoende keuzevrijheid te geven. Als eindverantwoordelijke voor de dagelijkse gang van zaken in zorgcentra voor ouderen besloot ik werk te gaan maken van die opdracht, maar al snel werd duidelijk dat dit pionierswerk zou gaan worden, een zoektocht met bewoners en verzorgenden. Er was immers geen blauwdruk beschikbaar, geen nadere omschrijving van wat zorg voor zelfstandigheid inhoudt, geen explicatie van de opdracht om de autonomie te respecteren en te beschermen en geen overzicht van keuzes waarbinnen bewoners vrij kunnen kiezen. Niet geheel toevallig overigens, want de overheid beperkt zich tot het stellen van kaders terzake de kwaliteit van zorg en tot het maken van wetten voor de rechtspositie van de bewoner. Ze laat de invulling hiervan aan de zorgaanbieders en de zorgvragers over. Deze uitnodiging is in deze studie opgepakt en er is een antwoord gezocht op de vraag wat zorg voor zelfstandigheid inhoudt, of er in de dagelijkse praktijk van het verzorgingshuis aandacht aan wordt geschonken, hoe ze kan worden bevorderd en of inspanningen om ze bevorderen vruchten afwerpen. Met behulp van literatuuronderzoek en onderzoek in verzorgingshuizen zijn de vragen beantwoord. In paragraaf 11.2 wordt een terugblik gegeven op de literatuurbevindingen en in 11.3 worden de belangrijkste onderzoeksbevindingen beschreven en van commentaar voorzien. In paragraaf 11.4 worden de beperkingen van deze studie weergegeven en tot slot worden in paragraaf 11.5 aanbevelingen gedaan voor het bevorderen van de zorg voor zelfstandigheid.

\subsection{Literaturbevindingen}

Zorg voor zelfstandigheid: betekenis en rolverwachting

In deze studie is nagegaan wat in de literatuur onder zorg voor zelfstandigheid wordt 
verstaan. Er wordt aansluiting gevonden bij een gezondheidsrechtelijke en gezondheidsethische omschrijving. In een gezondheidsrechtelijke benadering wordt de zelfbeschikking van de bewoner geaccentueerd: rechten en plichten moeten in acht worden genomen; de verzorgende mengt zich niet ongevraagd in het leven van de bewoner, verricht geen handelingen bij de bewoner en neemt geen beslissingen voor de bewoner zonder diens instemming of goedkeuring. Dialoog tussen de bewoner en verzorgende en een zorgrelatie die is gebaseerd op wederkerigheid zijn noodzakelijk om de behoeften, keuzes en beslissingen van de bewoner uitgangspunt van zorg te kunnen laten zijn. In een gezondheidsethische benadering wordt zorg voor zelfstandigheid uitgelegd als het respecteren en beschermen van de autonomie van de bewoner. Het feit dat de bewoner in het verzorgingshuis is komen wonen, betekent dat hij vraagt om inmenging van verzorgenden in zijn leven. De verzorgende wordt geacht dit respectvol te doen en geïnteresseerd te zijn in het levensverhaal van de bewoner, in de keuzes die hij wil maken en in de behoeften aan ondersteuning, zodat de verzorgende de gewenste inmenging daar op af kan stemmen. Dialoog en deliberatie zijn belangrijk voor een op de persoon van de bewoner gerichte zorg; zonder nabijheid en betrokkenheid van de verzorgende op de bewoner mag een verzorgende zich niet ongevraagd mengen in het leven van de bewoner. Inmenging is gelegitimeerd als de verzorgende er blijk van geeft de volgende deugden te bezitten (Tronto, 1993): oog te hebben voor de bewoner en zijn behoeften, bereid is verantwoordelijkheid te nemen, competent is en bewaakt dat de zorg die wordt gegeven, aansluit bij de zorg die wordt gevraagd.

\section{Rolvervulling door de bewoner, de verzorgende en het verzorgingshuis}

Uit de literatuur komt naar voren dat zorg voor zelfstandigheid een direct appèl is op degenen die een zorgrelatie vormen, namelijk de bewoner van het verzorgingshuis en de verzorgende van de verzorgingsafdeling. Eveneens door bestudering van literatuur is nagegaan wat de verwachtingen zijn ten aanzien van de rolvervulling door de bewoner, de verzorgende en het verzorgingshuis op het gebied van de zorg voor zelfstandigheid. Dit heeft tot de volgende bevindingen geleid:

\section{De bewoner}

Zorg voor zelfstandigheid kan niet worden bewerkstelligd zonder de inbreng of verantwoordelijkheid van de bewoner. Als de bewoner er prijs op stelt zichzelf te kunnen zijn, zijn eigenheid te bewaren, zijn voorkeuren gehonoreerd te zien en een affectieve omgeving te hebben, dient hij de dialoog aan te gaan, zo nodig voor zijn rechten op te komen en verzorgenden om hem heen te hebben die hem aanspreken. Er bestaan evenwel gerede twijfels of de bewoner die rol zal vervullen. In hoofdstuk 2 van deze studie wordt 
stilgestaan bij de positie die ouderen in de Nederlandse samenleving innemen. Duidelijk wordt dat in de laatste jaren die aan de plaatsing in het verzorgingshuis voorafgaan menig oudere niet in de omstandigheid verkeert door dialoog of overleg zijn leven te bepalen. In de jaren na de pensionering wordt zijn sociale positie er niet beter op en boeten zijn 'zelfbewust zijn' en zelfrespect aan kracht in. Op het moment dat een oudere zijn intrek neemt in een verzorgingshuis biedt wetgeving hem rechten, maar hij weet zich hier geen raad mee, niet in de laatste plaats omdat hij jarenlang in een maatschappelijk zwakke positie heeft verkeerd. Het recht op zelfbeschikking, medezeggenschap of rechten die aan de Wgbo ontleend kunnen worden, zijn de bewoner vreemd. De overgang van een roleless-role, die het merendeel van de ouderen jarenlang heeft ondervonden, naar die van regisseur van zorg of gesprekspartner over de zorg is abrupt en groot. Het merendeel van de ouderen stelt zich niet vragend op, neemt geen initiatief om behoeften, wensen of verwachtingen ter sprake te brengen. De geringe animo van ouderen voor het benutten van het persoonsgebonden budget wordt als illustratie gegeven. Hieruit mag niet de conclusie worden getrokken dat ouderen geen opvatting hebben over hoe zorg voor zelfstandigheid er uit zou moeten zien. In onderzoeken van de Landelijke Organisatie Bewonerscommissie Bejaardenoorden (1998) van het Sociaal Cultureel Planbureau (1997) en van de Commissie Gezondheidszorg in Tel (1996) krijgen ouderen het woord en zij pleiten voor een betere informatievoorziening, keuzevrijheid, aandacht van de verzorgenden en een schoon en sfeervol appartement. Dit betekent dat zorg voor zelfstandigheid wel degelijk een issue voor hen is, maar dat het aan moed ontbreekt om er een punt van te maken.

\section{De verzorgende}

Er worden ook vraagtekens geplaatst bij de rol die verzorgenden vervullen in het kader van zorg voor zelfstandigheid. Verzorgenden associëren zelfstandigheid voornamelijk met zelfredzaamheid. Zorg voor zelfstandigheid betekent dan dat het uitgangspunt wordt gehanteerd dat de bewoners die activiteiten zelf verrichten waartoe zij fysiek in staat zijn. Deze associatie is te begrijpen. De indicatiestelling voor het verzorgingshuis is voornamelijk gericht op de beperkingen en de mogelijkheden van de bewoner voor wat betreft persoonlijke en huishoudelijke verzorging. Daarbij krijgen verzorgenden in hun opleiding geleerd dat de kern van hun beroep draait om het bieden van ondersteuning bij met name de persoonlijke verzorging en om het stimuleren van de zelfzorg. De vaardigheden die zij krijgen aangeleerd, zijn daar op afgestemd. De techniek van de verzorging eist daarbij de meeste aandacht op. De deskundigheid of het deskundigheidsniveau van de verzorgende wordt niet bepaald door de mate waarin de verzorgende er in slaagt de aangeleerde techniek te matchen met de behoefte van de individuele zorgvrager, maar door het mogen gebruiken van meer of minder complexe 
hulpmiddelen. De consequentie hiervan is dat de verzorgende de individuele bewoner niet nodig heeft om hem te verzorgen. Bedoeld wordt dat het risico op standaardverzorging groot is en dat de verzorgende op basis van de beperkingen en lichamelijke behoeften van de bewoners van de verzorgingsafdelingen, maar eigenlijk al op basis van de indicatieformulieren, weet welke zorg geboden is. Voor dialoog, overleg en wederkerigheid, het bieden van keuzemogelijkheden aan de bewoner en het zoeken naar aansluiting bij de leefpatronen van de bewoner is dan geen plaats.

\section{Het verzorgingshuis en haar omgeving}

Als de historische ontwikkeling van het verzorgingshuis in ogenschouw wordt genomen, lijkt het evident dat deze instelling voor ouderen de opdracht tot zorg voor zelfstandigheid stevig heeft omarmd. In de periode tussen 1963 en 2003 benadrukt de overheid, in haar beleidsnota's over de functie en taak van het verzorgingshuis, in allerlei bewoordingen dat zorg moet worden gedragen voor een goed woonmilieu, voor de regierol van de bewoner, voor een aansluiting van de zorg op de dagelijkse leefpatronen van de bewoners, voor goede informatie en voor voldoende keuzemogelijkheden. Daarnaast worden met name in de jaren negentig van de vorige eeuw wetten gemaakt die de rechtspositie van de bewoner veilig stellen en versterken. Maar de zorg voor zelfstandigheid is er niet door verbeterd.

Spauwen-Micka (1975) en Van Loveren (1995) tonen aan dat het verzorgingshuis er in de loop van haar bestaan niet in is geslaagd een op de individuele bewoner gerichte zorg te bewerkstelligen, omdat het sterk institutionele trekken heeft die een ontplooiing van individuele bewoners in de weg staat. In plaats van zorg voor zelfstandigheid lijkt zorg voor afhankelijkheid de missie voor het verzorgingshuis. Zo is Becker (2003) van mening dat verzorgenden eerder teveel zorg overnemen dan te weinig. Mensen die ondervraagd zijn over hun idee van het wonen en leven in het verzorgingshuis (Trouwonderzoek, 1999; SCP, 1997) bevestigen het beeld dat de zelfstandigheid verloren gaat.

Dat het verzorgingshuis door de overheid wordt opgeroepen zorg voor zelfstandigheid te betrachten, maar blijkbaar de ruimte heeft om hier niet aan tegemoet te komen, is het gevolg van een niet samenhangend beleid van verschillende partijen of organen, waarvan het verzorgingshuis afhankelijk is of waaraan het verantwoording moet afleggen. Zo 'toetst' het zorgkantoor, als medeondertekenaar van de UvO, het nakomen hiervan langs de weg van productieafspraken. In het voorjaars- en najaarsoverleg tussen zorgaanbieder en zorgkantoor worden de productiecijfers besproken, maar het onderwerp 'zorg voor zelfstandigheid' prijkt niet op de agenda. Ook in de indicering van ouderen voor verblijf in het verzorgingshuis, die door het RIO plaatsvindt, wordt met geen woord gerept over de mogelijkheden die de geïndiceerde heeft om zijn verantwoordelijkheden te kunnen nemen, 
over de aandacht die door het verzorgingshuis moet worden geschonken aan de behoefte van de bewoner aan affectie, aan het zichzelf mogen zijn of aan respect en bescherming van autonomie. Schijnbaar wordt verondersteld dat deze aandacht vanzelfsprekend wordt gegeven en wordt voornamelijk aangegeven welke zorgklasse de bewoner heeft c.q. hoeveel minuten aan zorg de geïndiceerde vraagt voor met name persoonlijke en huishoudelijke verzorging. De inspectie van de Gezondheidszorg gaat na of het verzorgingshuis zich materieel heeft toegerust om bewoners inspraak te geven en om verantwoorde zorg te leveren, maar of en op welke wijze dit ook daadwerkelijk gebeurt, komt in het inspectiebezoek nauwelijks aan de orde. In het overleg met de cliëntenraden worden agendapunten besproken die op het algemeen cliëntenbelang betrekking hebben. De mate van individualisering van het zorgaanbod is nauwelijks een issue.

\subsection{Onderzoeksbevindingen}

De literatuurstudie schetst een beeld van een maatschappelijke bejegening van ouderen die hen niet uitnodigt tot het nemen van verantwoordelijkheid; van een verzorgende beroepsgroep die niet is voorbereid op een persoonsgerichte zorg en van een instelling voor ouderen die wetten, regelgeving en een ethisch besef aan zich voorbij kan laten gaan. In deze studie is aan een selecte groep bewoners en verzorgenden van drie verzorgingshuizen gevraagd wat zorg voor zelfstandigheid zou moeten inhouden. De items die door hun worden genoemd, sluiten aan bij de betekenis die geraadpleegde literatuur er aan geeft: informatievoorziening; keuzevrijheid of regievoering over regels en gewoonten van het verzorgingshuis, en een op de individuele bewoner gerichte houding worden van belang geacht. Vervolgens zijn op een tweetal meetmomenten grotere groepen bewoners en verzorgenden van drie verzorgingshuizen ondervraagd om na te gaan of en in welke mate aan deze punten aandacht wordt besteed in het dagelijkse leven in het verzorgingshuis. Op basis van de opvattingen van bewoners en verzorgenden worden een aantal conclusies getrokken:

\section{Conclusies na de eerste meting}

- verzorgenden hebben geen goed beeld van de verwachtingen waarmee bewoners naar het verzorgingshuis komen. Zo wordt in het geheel niet onderkend dat een deel (eenderde van de ondervraagden) van de bewoners verwacht nog iets te kunnen ondernemen;

- bewoners vinden het maken en onderhouden van contacten zeker zo belangrijk als het krijgen van hulp bij de lichamelijke verzorging, terwijl de verzorgende 
medewerkers de indruk hebben dat bewoners vooral zitten te wachten op hulp bij de lichamelijke verzorging; de behoefte van bewoners om hulp te krijgen bij het schoonhouden van hun appartement is daarentegen veel groter dan de verzorgenden denken;

- bewoners zijn van mening dat de informatievoorziening niet goed is. Zij worden niet betrokken bij hun zorgplan en zorgdossier, maar zij vragen daar ook niet naar en malen er niet om; verzorgenden vinden ook dat de informatievoorziening kan worden verbeterd, maar hebben het idee dat de betrokkenheid van bewoners bij het zorgplan wel meevalt;

- de dagindeling, de huisregels en het activiteitenprogramma mogen van het merendeel van de bewoners 'aanbodgericht' bepaald worden; een deel vindt dat deze programma's op basis van overleg tot stand moeten komen en een zeer beperkte groep is voor een 'vraaggerichte' benadering, voor een programma dat door de bewoners bepaald wordt; de verzorgenden schatten daarentegen in dat bewoners willen overleggen over de regels en gewoonten en dat een aantal het graag zelf wil bepalen;

- verzorgenden hebben de idee dat bewoners zich afhankelijk voelen als hun zelfredzaamheid beperkt is, terwijl bewoners zelfredzaamheid en afhankelijkheid niet aan elkaar verbinden;

- twee op elke tien bewoners geven, om diverse redenen, aan dat het leven niet meer hoeft en dat het afgelopen zou mogen zijn. De verzorgenden hebben de indruk dat die gedachte bij zes van de tien bewoners leeft;

- verzorgenden zijn niet attentief en hebben geen oog voor responsiviteit; daarentegen zijn ze wel responsibel en competent. Het gemis aan attentiviteit openbaart zich doordat veel bewoners ongevraagd worden geholpen, te weinig tijd krijgen om zichzelf te helpen of het tempo van de zorg niet geheel zelf mogen bepalen. Schommelingen in de zorgbehoefte worden vaak niet opgemerkt. Er wordt met andere woorden gezorgd zonder dat gevraagd wordt welke zorg en ondersteuning gewenst wordt. Het responsibel zijn houdt in dat verzorgenden bereid zijn zorg op zich te nemen; het competent zijn betekent dat er deskundig en vakkundig gewerkt wordt. Dat de responsiviteit niet voldoende wordt gevonden, betekent dat verzorgenden niet vragen of de zorg die is verleend, is afgestemd op de zorg die de bewoner verwachtte of wenste.

In een gezondheidsethische benadering van zorg voor zelfstandigheid, die uitgaat van autonomie als positieve vrijheid door voorbewuste betekenisgeving, stelt Widdershoven (2000) dat een zorgende houding een antwoord moet zijn op de vraag van de bewoner. Door 
zich te verdiepen in het levensverhaal van de bewoner en met hem in contact te treden, probeert de verzorgende de vraag op het spoor te komen. Als de verzorgende geen attentiviteit aan de dag legt, hetgeen geconcludeerd wordt, mist de zorgrelatie een basis om de bewoner te helpen, te stimuleren of te overreden, laat staan dat beslissingen overgenomen zouden mogen worden. De bewoner constateert het gemis aan attentiviteit, maar komt hiertegen niet in het geweer. Hij mist de moed voor zichzelf op te komen, stelt zich niet zelfbewust op en/of het ontbreekt hem aan kennis van zijn rechten. Verzorgenden onderkennen de beperkingen in de zorgrelatie, zij het in mindere mate dan de bewoners, maar voeren zorgzwaarte en tijdgebrek aan als excuses. Het gevoel overheerst dat het negeren van een mogelijke vraag minder tijd kost dan het stilstaan bij een vraag. De verwachtingen van de bewoner worden dan niet gecommuniceerd en er wordt aan voorbij gelopen. Dit betekent niet dat er helemaal geen aandacht is voor de bewoner. Zoals eerder aangegeven constateerde Becker (2003) dat verzorgenden soms teveel zorg uit handen nemen van de bewoner. Ook in deze studie zien we dat verzorgenden activiteiten van de bewoner overnemen wanneer het tempo van de bewoner niet strookt met de tijd die de verzorgende beschikbaar meent te hebben voor de ondersteuning. De verzorgende activiteit wordt dan niet meer verricht op basis van de behoefte of voorkeur van de bewoner als 'concrete other' (Verkerk, 1994), maar op basis van een veronderstelde instellingsnorm dat het werk binnen een bepaalde tijd gedaan moet zijn. Ook de wederkerigheid van de zorgrelatie, goed zorgverlenerschap en goed zorgvragerschap (Van Wijmen, 2003) zijn ver te zoeken als de basis van de zorgrelatie niet door informatie, dialoog en een gevoel van verantwoordelijkheid gelegd wordt.

Meer verzorgenden dan bewoners zijn voor een vraaggerichte en overleggerichte besluitvorming terzake de dagindeling, de huisregels en het activiteitenprogramma, terwijl bewoners overwegend voor een aanbodgerichte benadering kiezen. De reactie van de verzorgenden is opmerkelijk, omdat in de directe zorgrelatie met de bewoner minder ruimte voor samenspraak aanwezig lijkt (zie conclusies t.a.v. de houding van verzorgenden). De ruimte die bewoners op deze gebieden an het verzorgingshuis wil laten, betekent voor hen niet dat hun eigen dagelijks leefritme wordt gestuurd. De bevinding uit het onderzoek van de LOBB (1998) dat bewoners het sociale leven in het verzorgingshuis graag verankerd willen zien in vaste momenten sluit hier op aan. Ook Bijsterveld (2001) toont aan dat ouderen die (thuis)zorg ontvangen veel waarde hechten aan vaste tijden waarop ondersteuning geboden wordt of waarop activiteiten plaatsvinden. De vaste tijden geven volgens hem een gevoel van controle over het eigen leven en worden dus niet ervaren als het uit handen geven van de regie.

Het belang dat de bewoner toekent aan sociale contacten met leeftijdgenoten of met de 
verzorgenden wordt niet voldoende onderkend. De verwachting van bewoners om contacten te kunnen maken, strookt met de bevinding van Steverink (1996) dat de behoefte aan affectie een belangrijke drijfveer is om naar het verzorgingshuis te verhuizen.

Dat de behoefte van bewoners actief te zijn en iets te kunnen ondernemen niet wordt opgemerkt door verzorgenden is volgens Van Loveren (1995) kenmerkend voor een institutionele omgeving, waar de medewerkers niet gericht zijn op individuele competenties, maar op beperkingen van bewoners. De bewoner verwacht dat hij de mogelijkheid krijgt zijn aspiraties waar te maken. Als hij daarvoor een beroep moet doen op verzorgenden en dat nalaat, omdat hij het moeilijk vindt om vragen te stellen en voor zichzelf op te komen, is de kans groot dat zijn ondernemingslust niet wordt opgemerkt en verloren gaat.

\section{Conclusies na de tweede meting}

$\mathrm{Na}$ de eerste meting zijn de respondentgroepen van bewoners en verzorgenden in tweeën gesplitst: een controlegroep van bewoners en één van verzorgenden en een experimentele groep van bewoners en één van verzorgenden. De experimentele groepen hebben twee interventies gehad: de interventie 'responsieve evaluatie' en de interventie 'zorgafspraken'. In beide interventies staat het voeren van overleg door degenen die het meest betrokken zijn bij zorg voor zelfstandigheid centraal. De deelnemers aan de responsieve evaluatie hebben kennisgenomen van bovengenoemde onderzoeksresultaten; ze hebben er over gediscussieerd, van persoonlijke illustraties voorzien en er zijn suggesties gedaan om zorg voor zelfstandigheid te verbeteren. Zo is gesteld dat de rapportage en de registratie over de zorg moet wijzigen en plaats moet maken voor informatie over de individuele bewoner en over de keuzes die hij wil maken en de behoeften die hij heeft. Er is een Overzicht Zorgafspraken opgesteld dat is benut voor de tweede interventie. Op basis van een dialoog tussen de bewoner en de verzorgende zijn zorgafspraken geformuleerd die aan genoemde voornemens invulling kunnen geven. Een deel van de bewoners van de experimentele afdelingen heeft aan beide interventies deelgenomen $(R E+Z A)$, een deel alleen aan het gesprek over de zorgafspraken (ZA).

$\mathrm{Na}$ de interventieperiode zijn de verschillende respondentgroepen ondervraagd over dezelfde onderwerpen als bij de eerste meting. Een groot deel van de ondervraagde verzorgenden van de experimentele afdelingen en van de controleafdelingen geven aan dat de behoefte aan zorg cq de benodigde ondersteuning bij lichamelijke verzorging sterk is gestegen. Ook een aantal bewoners van de verschillende respondentgroepen is die mening toegedaan, maar het merendeel vindt dat de behoefte aan deze zorg niet veranderd is. Een registratie die wordt bijgehouden (EBIS-scores) van het aantal zorgminuten dat dagelijks 
aan de bewoners wordt besteed, onderstreept de mening van de verzorgenden. Maar het maakt opnieuw duidelijk dat verzorgenden veel meer gericht zijn op de lichamelijke behoefte aan zorg dan de bewoners zelf. Vergelijking van uitkomsten tussen de eerste en tweede meting en tussen de verschillende respondentgroepen van controleafdelingen en experimentele afdelingen levert de volgende conclusies op:

- de respondentgroepen van de experimentele afdelingen vinden voor het merendeel dat beter met informatie rondom de inhoud van het zorgplan en de rechten van de bewoner wordt omgegaan dan bij de eerste meting; er is een significant verschil met de bewoners van controleafdelingen die geen verbetering constateren; de groep verzorgenden van deze afdelingen vindt dat de informatievoorziening op deze punten eerder verslechterd is, getuige het beperkt antal respondenten dat bevestigend reageert op vragen of bewoners betrokken worden bij deze informatie;

- bij de experimentele groep bewoners is een groep van veertig procent nog onvoldoende op de hoogte van de inhoud van het zorgdossier en het dubbele aantal bewoners zegt dat niet om schriftelijke toestemming is gevraagd voor de uitvoering van het zorgplan;

- significant meer bewoners van experimentele afdelingen vinden dat zij meer invloed kunnen uitoefenen op de regels en gewoonten van het verzorgingshuis dan bij de eerste meting, maar het merendeel merkt op aan te willen sluiten bij de keuzes die het verzorgingshuis maakt; significant minder bewoners van controleafdelingen zijn van mening dat de mogelijkheden om invloed uit te oefenen vergroot zijn en ook zij kiezen op dit punt overwegend voor de regie door het verzorgingshuis; verzorgenden van zowel controleafdelingen als experimentele afdelingen zijn bij de tweede meting opgeschoven van een overleggerichte regie naar een aanbodgerichte regie voor de regels en gewoonten; voorstanders voor een vraaggerichte regie zijn bij alle respondentgroepen beperkt in aantal;

- de attentiviteit is volgens bewoners van de experimentele afdelingen verbeterd t.o.v. de eerste meting. Minder bewoners worden ongevraagd geholpen; er wordt meer tijd genomen voor de zorg; bewoners kunnen meer zelf het tempo bepalen en er wordt meer uitgegaan van wat de bewoner wil in plaats van wat hij kan; volgens veel bewoners en verzorgenden van de controleafdelingen is de attentiviteit terzake deze punten verder verminderd. Bij de experimentele groep verzorgenden is een kentering in de houding waarneembaar. De verzorgenden zijn van mening dat de woning van de bewoner minder ongevraagd betreden wordt en dat wat meer wordt uitgegaan van het tempo van de bewoner, maar de indruk heerst dat minder tijd wordt genomen en minder dan voorheen wordt uitgegaan van wat de bewoner wil en meer van wat hij kan. Verondersteld wordt dat deze verzorgenden kritischer 
op zichzelf zijn geworden, omdat zij meer oog hebben gekregen voor de individuele behoeften van bewoners, terwijl de bewoners van hun afdelingen vinden dat ze meer tot hun recht zijn gekomen, omdat zij meer persoonlijke aandacht hebben gekregen. Al met al vindt nog ongeveer dertig tot veertig procent van de bewoners dat de attentiviteit verbeterd kan worden;

- de responsibiliteit, oftewel de bereidheid van verzorgenden om de zorg op zich te nemen, is volgens de experimentele groepen bewoners toegenomen, terwijl de controlegroep bewoners van mening is dat die is afgenomen. De beschikbaarheid van verzorgenden is volgens beide respondentgroepen onverminderd aanwezig. Er wordt volgens de experimentele groep bewoners meer dan voorheen rekening gehouden met wensen en behoeften, er vindt meer overleg plaats over het tijdstip van zorgverlening en de zorgzaamheid is toegenomen. Op deze punten is de responsibiliteit volgens de controlegroep bewoners juist afgenomen. De opvattingen van de verschillende respondentgroepen van verzorgenden sluiten meer op elkaar aan: zowel de experimentele groep verzorgenden als de controlegroep vinden dat de responsibiliteit licht is toegenomen. Opmerkelijk is dat dit door de experimentele groep bewoners wel en door de controlegroep bewoners niet wordt onderkend;

- de competentie van verzorgenden is volgens de verschillende respondentgroepen van bewoners onverminderd hoog; de experimentele groep verzorgenden deelt die mening, terwijl de controlegroep verzorgenden die zich bij die mening aansluit kleiner is;

- de responsiviteit is volgens de experimentele groepen bewoners wat gestegen en volgens de controlegroep bewoners is hij licht gedaald. Zeventig respectievelijk tachtig procent van de bewoners stelt dat niet wordt nagegaan of de gegeven zorg naar wens is. Ongeveer de helft van alle ondervraagde verzorgenden is het hier mee eens.

De algemene conclusie kan worden getrokken dat de interventies bij bewoners het gevoel hebben opgeroepen dat verzorgenden meer attentief zijn geworden. Zij hebben eveneens de indruk meer invloed te kunnen uitoefenen op regels en gewoonten in het verzorgingshuis. Dit geldt vooral voor bewoners die aan zowel de interventie responsieve evaluatie als Overzicht Zorgafspraken hebben deelgenomen. De betrokkenheid bij met name het zorgplan is ook sterk toegenomen, maar hierbij is geen duidelijk verschil waarneembaar in reacties van bewoners die aan één of twee interventies hebben meegedaan. Er is een tendens bespeurd dat bewoners die aan zowel de Responsieve Evaluatie als de Zorgafspraken hebben deelgenomen meer voor overleg over de dagindeling kiezen dan bewoners met 
alleen de interventie ZA, die meer voor een aanbodgerichte benadering kiezen.

Het kundig en vaardig of competent zijn, is volgens Bijsterveld (2001) voor ouderen belangrijker dan het respectvol bejegenen, maar voor de NP/CF (2000) komt laatstgenoemd houdingsaspect op de eerste plaats. Dit verschil in prioritering kan mogelijk worden toegeschreven aan de plaats waar de zorg wordt verleend. Bijsterveld verrichte zijn onderzoek in de thuiszorg waar verzorgenden kortdurend contact onderhouden met de zorgvragers en het scala van verzorgende werkzaamheden meer specialistisch is, terwijl voor de NP/CF de intramurale sector, waar overwegend care activiteiten worden verricht, als referentiekader diende. Emotionele betrokkenheid en het ervaren van steun worden door veel bewoners belangrijker geacht dan een 'verzorgingstechnische' relatie. De vaak geuite wens dat er meer tijd moet zijn voor een praatje illustreert het belang wat zij daar aan toekennen. Deze bevinding komt overeen met de resultaten van een benchmarking verpleeg- en verzorgingshuizen van Arcares (2004), waarbij minder dan twaalf procent van de verzorgende medewerkers aangeeft dat bewoners voldoende affectie ontvangen. Bewoners en verzorgenden van experimentele verzorgingsafdelingen hebben in het kader van de interventies aandacht en tijd besteed aan zowel indirect als direct overleg met elkaar. De bewoners 'waarderen' dit door aan te geven dat de attentiviteit is verhoogd, terwijl de bewoners van de controleafdelingen vinden dat de attentiviteit is afgenomen.

Verzorgenden blijven tekortschieten voor wat betreft het evalueren van de zorg. Er wordt volgens de meeste bewoners niet nagegaan of met de verleende zorg op de vraag, behoefte, wens of verwachting van de bewoner is ingegaan. De helft van de verzorgenden beaamt dit. De consequentie van deze houding kan zijn dat de ontwikkeling van de bewoner tijdens zijn verblijf op de verzorgingsafdeling onvoldoende gevolgd wordt en dat de attentiviteit, waar verzorgenden van de experimentele afdelingen in hebben geïnvesteerd, weer afneemt. Indien de behoefte aan zorg op de verzorgingsafdelingen verder toeneemt, hetgeen in de lijn der verwachting ligt, de attentiviteit weer afneemt en de responsiviteit achterwege blijft, lopen bewoners het risico dat verzorgenden beslissingen overnemen, niet vanuit betrokkenheid, nabijheid of wederkerigheid maar vanuit standaard verzorgingsplannen, gericht op de 'generalized other'. Als de bewoners ook bij een verdere toename van de behoefte aan zorg het gevoel blijven houden dat ze niet afhankelijk zijn, zou verwacht mogen worden dat zij dit risico afwenden door een zelfbewuste houding en dat zij voor hun recht op zorg voor zelfstandigheid opkomen. De twijfel of dit zal gebeuren, is voorlopig niet weggenomen. 


\subsection{Beperkingen van de studie}

In deze studie is gebruikt gemaakt van gezondheidsethische, gezondheidsrechtelijke, gerontologische en verplegingswetenschappelijke literatuur. Een mix van wetenschappelijke opvattingen gaat ten koste van de diepgang die sommige onderwerpen, die in deze studie zijn aangesneden, verdienen. Het empirisch onderzoek heeft betrekking op de situatie in drie verzorgingshuizen, hetgeen geen representatieve steekproef is uit de populatie verzorgingshuizen. Resultaten van onderzoek, waar in deze studie naar is verwezen, over de situatie in andere verzorgingshuizen doen vermoeden dat de geventileerde opvattingen ook op andere plaatsen herkenbaar zijn. De uitkomsten van het recent verschenen onderzoek (Cliënten\&Raad/LOC, 2004) onderschrijven een aantal conclusies uit deze studie: ruim 10.000 bewoners van 276 zorginstellingen in Nederland gaven hun mening over de zorg en dienstverlening in verzorgingshuizen en verpleeghuizen. Bewoners van verzorgingshuizen stelden dat de informatie en inspraak voor verbetering vatbaar zijn. In één op de drie verzorgingshuizen wordt overleg gevoerd over het zorgplan en aan de bejegening en autonomie wordt veel belang toegekend. In hoofdstuk 7 is de generaliseerbaarheid of externe validiteit reeds aan de orde gesteld. De uitkomsten van de metingen, van de interviews met bewoners en de enquêtes onder het verzorgend personeel, geven de meningen weer van respondenten in bepaalde verzorgingshuizen, zoals ze op die momenten beleefd zijn. Maar opvattingen kunnen veranderen en de houdbaarheid van conclusies die op opvattingen zijn gebaseerd, komt daarmee in het geding. De opvattingen over de veranderingen in de zorg voor zelfstandigheid zijn gepolst nadat interventies hebben plaatsgevonden. Of ze ook volledig aan de interventies kunnen worden toegeschreven, is een vraag die vanwege de methodologische context van dit onderzoek moeilijk te beantwoorden is. Het verband tussen het nadrukkelijk betrekken van bewoners bij zorgafspraken en hun mening dat zij een rol zijn gaan vervullen bij de zorgregistratie lijkt gemakkelijk gelegd te kunnen worden. Toch hebben niet alle bewoners die relatie gelegd en de verklaringen hiervoor zijn niet eenduidig: bewoners laten doorschemeren dat de gesprekken die zij hebben gevoerd veel belangrijker zijn dan hetgeen daarvan wordt opgetekend; verzorgenden hebben de indruk dat het geheugen van de bewoners hen hier en daar beperkt om de betekenis van het gesprek over de zorgafspraken goed te reproduceren. Het risico op vertekening is derhalve aanwezig. Dit geldt evenzeer voor uitspraken over de effecten van de responsieve evaluaties en de zorgafspraken op de informatievoorziening en op de houding van verzorgenden. Ook hier is niet een één-op-één relatie te leggen, terwijl wel duidelijk verschillen worden opgetekend. Het effect dat alleen al uitgaat van het nemen van tijd en het schenken van aandacht aan de bewoner moet vanwege de sterke hang naar affectie niet worden onderschat. Daarnaast moet worden opgemerkt dat de termijn tussen de 
interventies en de tweede meting relatief kort is. Deze beperking is onder ogen gezien, maar de korte gemiddelde verblijfsduur van bewoners maakt dat de onderzoeker niet veel tijd beschikbaar heeft om de ontwikkeling van de bewoner in het verzorgingshuis te kunnen volgen.

\subsection{Aanbevelingen}

Zorg voor zelfstandigheid kan worden bevorderd als de bewoner, de verzorgende en het verzorgingshuis initiatieven en verantwoordelijkheid daartoe nemen. De bewoner zal weet moeten hebben van zijn rechten, zich zelfbewuster moeten opstellen en een dialoog of overleg met de verzorging moeten opzoeken; de deskundigheid van de verzorgende op het gebied van A.D.L.-activiteiten zal niet op zichzelf moeten staan, maar de zorg voor zelfstandigheid moeten dienen. De competenties zullen ook moeten worden uitgebreid: het 'overleggericht werken'; een verdieping in de rechtspositie van de bewoner; het voeren van een dialoog met de bewoner over diens levensverhaal, over de gevolgen daarvan voor de keuzes en behoeften van de bewoner en over de mogelijkheden en beperkingen van het verzorgingshuis, alsmede het kunnen hanteren van een levensfase-georiënteerd systeem van zorgregistratie zullen aandacht moeten krijgen. Een bredere blik op de persoon van de zorgvrager zal ook de attentiviteit verhogen. In het recentelijk verschenen Kwalificatieprofiel van de Eerst Verantwoordelijke Verzorgende (SOV\&V, 2003) wordt dit streven ondersteund, doordat expliciet aandacht wordt gevraagd voor een persoonsgerichte zorg. Het verzorgingshuis zal moeten investeren in persoonsgerichte informatievoorziening, in de houding van medewerkers en in het ontwikkelen van vormen van dialoog, deliberatie en overleg met bewoners. Uit deze studie blijkt dat de interventie responsieve evaluatie het gevoel creëert dat mensen hun verhaal kwijt kunnen, dat er aandacht aan hen geschonken wordt, dat hun individuele opvatting telt en dat het partijen bindt. Het samenlevingsverband van het verzorgingshuis brengt mensen bijeen die behoefte hebben aan het uitwisselen van opvattingen over de 'everyday ethics', of aan reflexie op bepaalde thema's. Responsieve evaluatie, maar ook een moreel beraad over deze vraagstukken zullen moeten worden ingebed in de gewoonten en programma's van het verzorgingshuis. Een (vaak impliciete) instellingsnorm om bewoners dagelijks te verzorgen, zal plaats moeten maken voor een zorgafspraak tussen de bewoner en de verzorgende over de gewenste en mogelijke frequentie van ondersteuning; elke gewoonte van het huis, die het leefritme van de bewoner beïnvloedt, zal moeten worden beoordeeld op de betekenis ervan voor de individuele bewoner. De levensfasegeoriënteerde zorg en zorgregistratie zullen verder ontwikkeld moeten worden. Gezien de ervaringen met het Overzicht Zorgafspraken zal extra aandacht 
gegeven moeten worden aan de registratie van de responsiviteit en aan de handzaamheid van het systeem.

De opleiding voor verzorgenden zal, zoals hierboven al aangegeven, meer 'veldspecifiek' moeten worden. Ook moet worden overwogen of de personele samenstelling niet moet wijzigen, waarbij meer personeelsleden worden aangetrokken met een gerontologische beroepsopleiding, die geleerd hebben aandacht te besteden aan het levensverhaal van bewoners, aan levensfasegeoriënteerde vraagstukken, aan het leiden van responsieve evaluaties of moreel beraad en aan het voeren van één-op-één gesprekken. De interventies die in deze studie zijn gebruikt, kunnen als voorbeeld dienen om die weg in te slaan of te vervolgen.

Naast voornoemde aanbevelingen, die op de empirische bevindingen in deze studie betrekking hebben, is het voor de verdere ontwikkeling van zorg voor zelfstandigheid van belang dat helder is of de rol die het verzorgingshuis dient te vervullen, gecontinueerd kan worden of aanpassing behoeft.

Arcares (2004), de brancheorganisatie verpleging en verzorging, legt in een recentelijk schrijven vast dat aandacht van deze zorginstelling voor de kwaliteit van leven, voor leefomstandigheden, participatie en mentaal welbevinden van de individuele bewoner, hoge prioriteit verdienen. De brancheorganisatie refereert hierbij aan de Kwaliteitswet Zorginstellingen die van zorgaanbieders vraagt verantwoorde zorg te bieden. De hierboven genoemde aanbevelingen sluiten naadloos aan bij dit denken. De Regionale Indicatieorganen (RIO's), die tot nu toe overwegend belangstelling hebben voor de beperkingen van de aanvrager, komen daarentegen nog verder van de individuele aanvrager af te staan met hun voornemen te gaan werken met een systeem van protocollaire indicatiestelling, waarbij de behoeften van de zorgvrager worden ondergebracht in zorgcategorieën. Maar zolang het verzorgingshuis gehouden is een op de individuele bewoner gerichte zorg te verlenen, zal de indicatiestelling dit tot uiting moeten brengen, zal de tarifering voor de zorg daar op moeten worden aangepast en zullen sancties moeten worden geheven als niet aan de opdracht wordt voldaan.

Of de overheid het verzorgingshuis de ruimte biedt zich verder te ontwikkelen, is zeer de vraag. VWS constateert in haar Houdbaarheidsbrief (15-9-2003) dat de AWBZ te weinig appelleert op de eigen verantwoordelijkheid van cliënten, te royaal is en daardoor onhoudbaar is voor de toekomst. Het financieringsvraagstuk is leidend in deze conclusie, omdat het AWBZ-pakket te duur is en moet worden ingekrompen. In de landelijke media verscheen recentelijk het bericht dat de staatssecretaris van VWS 70.000 van de ongeveer 110.000 intramurale verzorgingsplaatsen wil opheffen. Een verhoging van de drempel tot 
toetreding, omzetting van verzorgingshuiscapaciteit in voornamelijk woonzorgvoorzieningen, en in mindere mate in verpleeghuiscapaciteit, moeten dit mogelijk maken.

Kempen (2003) merkt op dat de overheid ouderen en chronisch zieken onafhankelijk wenst te laten zijn van voorzieningen, zonder dat er op dit punt visie en beleid ontwikkeld wordt. Visie en beleid moeten van de lagere overheden komen. Zij krijgen door de in voorbereiding zijnde Wet Maatschappelijke Ondersteuning de taak beleid te voeren dat gericht is op wat wordt genoemd 'het herstellen van de zelfredzaamheid van de burgers'. Niet duidelijk is wat de gevolgen hiervan zullen zijn voor de taken en functies van het verzorgingshuis.

Bij het doel van de overheid om herstel van zelfstandigheid na te streven, kunnen vraagtekens worden geplaatst. Zelfstandigheid wordt door de overheid geassocieerd met zelfredzaamheid, met de fysieke vermogens van mensen. Zeker voor ouderen en chronisch zieken is herstel van de zelfredzaamheid uitgesloten en zij zullen derhalve buiten het werkingsgebied van de Wet Maatschappelijke Ondersteuning vallen. Dit kan niet de bedoeling zijn. Analoog aan de betekenis die in deze studie aan zelfstandigheid wordt gegeven, en waarbij begrippen als rechten, plichten, verantwoordelijkheid, wederkerigheid, betrokkenheid, nabijheid en participatie van belang zijn, zal de Wet Maatschappelijke Ondersteuning 'zelfstandigheid' moeten definiëren. De eerste ambitie zal moeten zijn er voor te waken dat de zelfstandigheid van mensen verloren gaat. Mensen in onze samenleving zijn twintig tot dertig jaar lang oud en aan de levensfase ouderdom moet een participatieplicht, een sociale dienstplicht gekoppeld worden. De inzichten, kennis en vaardigheden van ouderen moeten ten dienste worden gemaakt van de andere generaties om te voorkomen dat de samenleving uiteenvalt in 'plichtsbetrachters' en 'rechtsbeschermden'; om te voorkomen dat het gebruik van zorgvoorzieningen emotioneel gezien als een gunst beschouwd wordt en om te bewerkstelligen dat bewoners van verzorgingshuizen, ondanks hun behoefte aan zorg, als zelfbewuste burgers overeind blijven. 


\section{Summary}

This study answers the question whether homes for the elderly provide independency. Nowadays residents, care clients, are strongly admonished to personally direct their need for care. Homes for the elderly are expected to work in a demand-oriented manner, to attune their care to the needs, expectations and choices of the residents, in short to provide demand-oriented care.

Providing independency in residential homes implies that the resident develops activities, makes choices and takes decisions that match his personality, and that maintain and enhance his self-respect. Making for independency also means that the carer provides the resident with breathing space, with support, that he or she respects the resident's individuality and provides the means to lead an independent life. The literature has outlined the parties concerned: the elderly resident applying for care in a home, the home itself, and its carers, who are in a relationship of care with the residents.

Chapter 2 shows that it is not a matter of course that elderly people, especially those in need of care, take their own responsibility. In the period before entering a residential home, which they do at an average age of more than eighty, they have unlearned to be socially responsible. Our society, strongly guided by economic principles as it is, has gradually precluded their social commitment. Rather, departicipation is expected, a withdrawal from society and a preparation of their approaching death. The limited number of elderly people who do not wish to comply with this role, and who do not wish to stop their personal development are not given enough room in a residential home. This concusion is drawn in chapter 3. It describes the way residential homes have developed. Though the main task of a residential home has always been promoting its residents' self-determination, everyday practice reveals a different picture. A residential home shows strong institutional traits, and on the other hand has the growing attention for the coping ability of its residents resulted in a generalised approach and in standardised methods and treatment. The individual resident loses his grip of the situation and is unable to direct his own care. Training colleges for carers are unable to reverse this process. Care for the elderly entails specific characteristics that are not reflected in the qualifications of the training college graduates. Goal-oriented and problem-solving skills, which form the core business of a therapeutic setting, a cure setting, are also the model of a care setting, concerned with the continuation of life.

Chapter 4 describes the actions undertaken by the government in the middle of the $90 \mathrm{~s}$ of the $20^{\text {th }}$ century to stimulate independency. A personal care budget has enabled people who do not live in institutions but who are in need of care to organize the necessary care 
themselves; the law regulating the quality of residential homes requires those who provide care to do so in a responsible manner, to hire qualified staff in sufficient numbers, and to establish quality standards. The law regulating medical treatment has laid down the rights of the individual resident, including safeguards of his or her personal privacy. The law regulating the participation of those living in residential homes ( the "Wet Medezeggenschap Cliënten Zorginstellingen") has given them a say in management. In the late $90 \mathrm{~s}$ it appeared that the majority of the people with a personal care budget were below 60 years of age. In the year 2000 many residential homes were reported to be developing quality standards, but only a limited number of homes had become certified. Apparently the improved legal situation has not resulted in significant changes for the residents. Moreover, society does not have a high opinion of life in a residential home. Especially low are the expectations in the field of independency, personal lifestyle and the possibilities of choice. On the other hand, catering, personal safety and physical care score much higher. It seems that residential homes associate independency with coping ability. Chapter 5 outlines the meaning of the notion "making for independency" within the context of this study. Characteristic are both the dialogic property of making for independency and the intensity of the relationship of care, which is tinged by reciprocity and responsibility. This relationship of care is characterized by mutual information transfer, by the carer being interested in the resident's life story, in his needs, choices and questions, and in general by competent care, supplemented by a general interest in how the care provided is experienced by the resident receiving it. Different residents have different needs, ask different questions and make different choices. Their life stories are different and that is why making for independency is not served by generalising the residents' needs and standardising both care and treatment.

Chapter 6 discusses emotion-oriented care and lifephase-oriented care. These two approaches of care are capable of implementing independency. Emotion-oriented care has been developed during the care for demented elderly people. Research into the effects of emotion-oriented care has not proven conclusively that the needs of the person demanding care are met better in this way than with non-emotion-oriented care. The connection between emotion-oriented care and its methodical implementation can be queried, especially when looking at the function of certain medical record forms. Lifephase-oriented care is an approach that may provide independency: there is room for the resident's biography; resident and carer together attempt to formulate the resident's expectations, needs and wishes, and investigate the possibilities of the residential home to comply with them. Lifephase-oriented care has not been developed instrumentally, nor have results been published about the implementation of lifephase-oriented care or of its effects on the 
provision of independency.

As stated before, elderly people tend to reconcile themseives with their allotted roles; they fail to express their expectations and needs, and carers have learned to act in standard situations instead of in personal situations. Independency can only be achieved through communication and interaction between resident and carer. Since residential homes have not built up a tradition in this respect, methods and approaches have been looked for that stimulate the people involved to express their own views and listen to the views of others; this is to take place in such a setting that they are confronted with the experiences of others and are stimulated to find solutions for questions and problems. The responsive evaluation method offers those possibilities.

Responsive evaluation gets the dialogue between people going, it sheds light on subtle differences in opinion of those involved, it makes clear who is responsible for what situation and it attempts to create a solid basis for realising desired improvements. Responsive evaluation has been practised in different fields, also in the care sector, though not yet in the care for the elderly.

In chapter 7 the subject of the present study is provided with a methodological context. A limited group of residents and carers were asked how they would define "making for independency". Respondents indicated those aspects that are closely linked to the provision of independency: sharing information, freedom of choice with respect to rules and habits, such as the houserules, timetable and programme of activities, and the attitude of the carers. Subsequently through interviews and questionnaires a larger group of elderly people was asked what they thought of the way independency was given shape in three residential homes.

The research plan comprises three phases: in phase one the opinions of the respondents (residents and carers) are asked about the aforementioned subjects. In phase two an intervention programme is introduced, i.e. responsive evaluation and an individually tailored care report, referred to as a "list of care agreements". Residents and carers of three experimental care units take part in the interventions. The other four care units involved in the investigation serve as control groups.

In phase three of the investigation all respondent groups are again asked the questions of phase one in order to find out if and in how far the views of the respondents of the control units differ from those of the experimental units.

Chapter 8 describes the outcome of the interviews of the residents and the questionnaire among the carers in phase one. It appears that carers insufficiently recognize the expectations residents have of their stay in a residential home. Carers assume that residents expect to be assisted in their physical care, whereas residents long for social contacts. There is little communication about these expectations, and the care file, which should really be 
used to collect information and agreements, is not used as a means of communication. The majority of residents indicate that they are unaware of the existence, let alone of the contents of the care file. This means that the principle of informed consent is ignored: residents are entitled to be informed, to have access to their care file, and to be asked permisssion when receiving care. It is significant that a large majority of carers is of the opinion that residents should be consulted about house rules, timetables and programmes of activities, wheras no more than a third of the residents share this opinion: the majority of residents think that that is the responsibility of the home. Opinions also vary with respect to the carers' attitude: both residents and carers are of the opinion that the residents' needs and demands are ignored by the carers. The number of residents that thinks that there is a general lack of attentiveness is larger than the number of carers that holds the same opinion. There is no significant difference of opinion about the carers' willingness to provide care, although half of the residents would like to be consulted about the time care is supplied. Both carers and residents think that carers are competent, attentive and respectful. Yet carers fail to check if the sort of care supplied matches the sort of care desired by the residents. In other words, there is a lack of responsiveness.

Chapter 9 describes the interventions themselves. Each group of respondents of the experimental care units has been informed about the results of the interviews and questionnaire in two responsive evaluation sessions. The participants have applied them to their own situation and they have added several qualifications and refinements. Information supply, control management within the residential home and carers' attitudes have received extra attention. Carers have faced up to the fact that the realization of independency shows deficiencies. Information about residents is inadequate if individually tailored attention is aimed for. Part of this inadequacy is attributed to the information available on indication forms, part of it is due to the lack of time on the part of carers to make house calls before elderly people are admitted to residential homes. It is an interesting observation that carers have the feeling that the time in which the work has to be done is more or less dictated by the habits of groups of residents, whereas the same residents are convinced that the care they receive is determined by the internal rhythm of the residential home. Many residents emphasize that they can find themselves in the habits of the home, as long as these do not interfere with their own needs and habits. A number of carers give a startling account of how residents' preferences are ignored: carers do not want to run the risk of establishing precedents, because time is in short supply. Similarly, care is not properly evaluated if there is the risk that the care provided has been insufficient. In spite of the seriousness of this situation the groups of respondents were very positive about the openness with which these topics were raised, and about the carers' commitment. The groups of residents had to 
get used to responsive evaluation. They are not used to group meetings and to being allowed to discuss how it is to live and work in a residential home. However, the remark by one of the residents that the talks had resulted in a greater feeling of togetherness is indicative of the atmosphere of these talks. The responsive evaluations have also created the support for the second intervention. Many subscribe to the notion that the registration of residents' characteristics and needs must be readjusted.

Carers have been trained to work with individually tailored care registration, resulting in a care file containing the residents' life story, choices and needs. Starting points are an active role on the part of the residents, and respect for the residents' rights on the part of the carers. Carers find it difficult to let go of problem-oriented registration and to switch to a person-oriented one, as it is more time-consuming, but it is clear that the latter form of registration does more justice to the residents.

Chapter 10 describes the results of the second round of interviews and of the second questionnaire. The results of the first and second round have been compared, and also the differences between the experimental units and the control units in the second round have been analysed. Carers report a heavier care burden in the second round, whereas residents hardly realise that their need for care has increased. Carers of the control units report that the heavier care burden has had a detrimental effect on the attention given to the residents, and the latter confirm this, though in a less outspoken way. On the other hand, residents of the experimental units report an increase in personal attention. This can be deduced from an increase in the number of residents that report being involved in or participating in the supply of information for the care agreements. Similarly, more residents report increased care for their person and their needs, and also a greater influence on the rules and habits of the residential home. Still there is little room for an evaluation of the care provided, the responsiveness obtained, also after the interventions.

Chapter 11 looks back on the previous chapters. Conclusions are drawn and recommendations are made. Since this study has made an inventory of the views of a nonrepresentative number of residents of homes for the elderly a short comment has been added how far the results can be generalised. Since the views have been obtained in the daily practice of residential homes, the "fundamental dynamics of reality" cannot be ignored. A serious attempt has been made to prevent a distortion of the research results by applying a multiple triangulation approach. 


\section{Samenvatting}

In deze studie wordt de vraag beantwoord of in verzorgingshuizen sprake is van zorg voor zelfstandigheid. In het tijdsbeeld waarin we leven wordt een sterk appèl gedaan op de zorgvrager, op de cliënt van zorg, om de regie over de zorg in handen te nemen. Van verzorgingshuizen wordt verwacht dat zij hun aanbod aan zorg afstemmen op de vraag, de behoeften, verwachtingen en keuzes van de bewoner; zij dienen vraaggericht te werken.

Zorg voor zelfstandigheid in verzorgingshuizen impliceert dat de bewoner activiteiten onderneemt, keuzes maakt en beslissingen neemt die bij hem passen, waardoor hij zichzelf kan zijn en die zijn zelfrespect en eigenwaarde overeind laten en verder ontwikkelen. Zorg voor zelfstandigheid houdt tevens in dat de zorgverlener de bewoner de benodigde ruimte geeft, hem ondersteunt, zijn eigenheid respecteert en in staat stelt om zelfstandig te zijn. Door literatuurstudie is een beeld verkregen van de partijen die verantwoordelijk zijn voor zorg voor zelfstandigheid: van de oudere die een beroep doet op zorg in een verzorgingshuis, van het verzorgingshuis dat ouderen een verblijf verschaft en van de verzorgende medewerkers die een zorgrelatie onderhouden met de bewoners.

Hoofdstuk 2 laat zien dat het nemen van verantwoordelijkheid door ouderen, en met name door zorgbehoevende ouderen, geen vanzelfsprekende zaak is. Op het moment dat de ouderen met een gemiddelde leeftijd van meer dan tachtig jaar het verzorgingshuis binnentreden, hebben zij een periode achter zich waarin het dragen van maatschappelijke verantwoordelijkheid not done is. Ouderen hoeven zich in onze, door de economie geregeerde, samenleving niet meer maatschappelijk te engageren; veeleer wordt een ontparticipatie, een terugtrekken uit de samenleving en een voorbereiding op het levenseinde verwacht. De beperkte groep van ouderen die zich niet neerlegt bij een dergelijke rol en die zich verder wil ontwikkelen, krijgt in het verzorgingshuis daartoe niet de benodigde ruimte. Deze conclusie wordt in hoofdstuk 3 getrokken. De ontwikkeling van het verzorgingshuis wordt er in beschreven. Ofschoon het verzorgingshuis altijd tot taak heeft gehad haar wilsbekwame bewoners de regie over hun leven te laten houden, tonen onderzoeken aan dat de praktijk van alledag er anders uit ziet. Het verzorginghuis komt niet los van institutionele kenmerken en de toenemende aandacht voor de zelfredzaamheid van de bewoners werkt juist een generalisering van bewoners en standaardisering van werkwijzen en bejegening in de hand. De individuele bewoner raakt eerder uit beeld dan dat hij regisseur van zorg wordt. De opleiding van verzorgenden brengt geen ommekeer in dit proces. Het eigene van de ouderenzorg komt niet terug in de eindtermen van de opleiding van verzorgenden. Het doelgericht en probleemoplossend denken en handelen, die tot de kerntaken van een cure-setting behoren, staan ook model voor een werkveld waarin het om 
Hoofdstuk 4 beschrijft hoe de overheid vooral in het midden van de jaren negentig van de vorige eeuw de zorg voor zelfstandigheid van impulsen heeft voorzien. Door het persoonsgebonden budget worden zorgvragers, die niet in een intramurale instelling verblijven, in staat gesteld zelf de benodigde zorg te organiseren; door de Kwaliteitswet zorginstellingen wordt van zorgaanbieders gevraagd verantwoorde zorg te bieden, voldoende en capabel personeel aan te nemen en kwaliteitssystemen in te voeren; door de Wet op de geneeskundige behandelingsovereenkomst worden de rechten van de bewoner, onder meer op het gebied van informatie en de bescherming van de persoonlijke levenssfeer, vastgelegd; de Wet Medezeggenschap Cliënten Zorginstellingen regelt de medezeggenschap van cliënten met betrekking tot het beleid in zorginstellingen. Eind jaren negentig van de vorige eeuw wordt geconstateerd dat het merendeel van de gebruikers van het persoonsgebonden budget jonger is dan 60 jaar; in het jaar 2000 wordt geregistreerd dat veel verzorgingshuizen aan de opbouw van kwaliteitssystemen werken, maar dat slechts een beperkt aantal huizen gecertificeerd is. Naast deze feiten, waaruit kan worden afgeleid dat de verbetering van de (rechts)positie van de bewoner niet onmiddellijk leidt tot veranderingen, wijst onderzoek uit dat de maatschappij geen positief beeld heeft van het leven in het verzorgingshuis. Juist op het gebied van zelfstandigheid, persoonlijke levensstijl en keuzemogelijkheden zijn de verwachtingen laag gespannen. Daarentegen bestaat de indruk dat op het gebied van de fysieke veiligheid, maaltijdvoorziening en de lichamelijke verzorging aan de verwachtingen van ouderen wordt tegemoetgekomen. Zorg voor zelfstandigheid wordt door het verzorgingshuis schijnbaar geassocieerd met zorg voor zelfredzaamheid. In hoofdstuk 5 wordt de betekenis omschreven die in het kader van deze studie aan 'zorg voor zelfstandigheid' wordt toegekend. Kenmerkend in deze omschrijving zijn het dialogisch karakter van zorg voor zelfstandigheid en de intensiteit van de zorgrelatie waarin wederkerigheid en verantwoordelijkheid doorschijnen. De zorgrelatie wordt opgebouwd door wederzijdse informatie-overdracht, door interesse van de verzorgende in het levensverhaal van de bewoner, door aandacht voor de behoeften, keuzes en vragen van de bewoner, door een competente zorgverlening en door belangstelling voor de beleving van de verleende zorg. Behoeften, keuzes en vragen van bewoners verschillen en ook een levensverhaal is persoonlijk. Zorg voor zelfstandigheid sluit om die reden niet aan bij een generalisering van behoeften van bewoners en een standaardisering van zorg en bejegening.

In hoofdstuk 6 wordt ingegaan op belevingsgerichte zorg en levensfasegeoriënteerde zorg. Het zijn zorgbenaderingen waarmee zorg voor zelfstandigheid in de praktijk gebracht kan 
worden. Belevingsgerichte zorg is tot ontwikkeling gebracht in de zorg voor demente ouderen. Onderzoek naar de effecten van belevingsgerichte zorg toont niet onomstotelijk aan dat beter op de behoeften of op de persoon van de zorgvrager wordt ingegaan dan bij niet-belevingsgerichte zorg. Vraagtekens worden gezet bij de samenhang tussen de visie 'belevingsgerichte zorg' en de methodische uitwerking, met name bij de functie van bepaalde rapportageformulieren. Levensfasegeoriënteerde zorg is een benadering waarmee zorg voor zelfstandigheid bewerkstelligd zou kunnen worden: het levensverhaal van de bewoner krijgt aandacht; de bewoner en de verzorgende gaan in samenspraak op zoek naar de verwachtingen, behoeften en wensen van de bewoner en naar de mogelijkheden van het verzorgingshuis om daar op in te gaan. Levensfasegeoriënteerde zorg is niet instrumenteel uitgewerkt; evenmin is onderzoek bekend naar de implementatie van levensfasegeoriënteerde zorg of naar de effecten ervan op zorg voor zelfstandigheid.

Eerder is geconstateerd dat ouderen zich neerleggen bij de rol die hen wordt toebedeeld, dat ze niet het gesprek aangaan om verwachtingen en behoeften te uiten en dat verzorgenden geleerd hebben te handelen in standaardsituaties en niet in persoonlijke situaties. Omdat zorg voor zelfstandigheid om samenspraak en interactie tussen de bewoner en de verzorgende vraagt en het verzorgingshuis op dit gebied geen traditie heeft opgebouwd, is gezocht naar methoden of benaderingen waarin betrokkenen worden uitgenodigd hun eigen opvatting kenbaar te maken en kennis te nemen van de mening van anderen, waarin ze geconfronteerd worden met andere belevingen en gestimuleerd worden tot het aanreiken van oplossingen voor problemen of vraagstukken. De methode responsieve evaluatie biedt die mogelijkheden. Bij responsieve evaluatie wordt de dialoog tussen mensen op gang gebracht, krijgen nuanceverschillen in opvattingen van betrokkenen de aandacht, wordt de verantwoordelijkheid van betrokkenen voor het omgaan met hun situatie gestipuleerd en wordt geprobeerd een draagvlak te creëren voor het realiseren van veranderingen of gewenste verbeteringen. Responsieve evaluatie is in verschillende werkvelden beproefd en ook in de zorgsector is deze methode toegepast, zij het nog niet in de ouderenzorg.

In hoofdstuk 7 wordt de probleemstelling van het onderzoek van deze studie van een methodologische context voorzien. Gesteld wordt dat aan een beperkte groep bewoners en verzorgenden is gevraagd wat zorg voor zelfstandigheid naar hun mening inhoudt. Informatievoorziening, keuzevrijheid bij regels en gewoonten, zoals de huisregels, de dagindeling en het activiteitenprogramma, en de houding van verzorgenden zijn volgens deze respondenten aspecten die nauw verband houden met zorg voor zelfstandigheid Vervolgens is in drie verzorgingshuizen, op basis van interviews respectievelijk enquêtes, nagegaan wat grotere groepen ouderen die er wonen en verzorgenden die er werken vinden van de wijze waarop met zorg voor zelfstandigheid wordt omgegaan. Het onderzoeksontwerp omvat een drietal fasen: in de eerste fase worden de meningen van de 
respondentgroepen c.q. de bewoners en verzorgenden gepeild terzake de genoemde onderwerpen; in de tweede fase wordt een interventieprogramma geïntroduceerd, te weten responsieve evaluatie en een persoonsgerichte zorgrapportage, 'overzicht zorgafspraken' genoemd. Bewoners en verzorgenden van een drietal experimentele verzorgingsafdelingen nemen aan de interventies deel; de overige vier verzorgingsafdelingen die bij het onderzoek zijn betrokken fungeren als controlegroepen.

In de derde fase van het onderzoek worden alle respondentgroepen net als bij de eerste fase ondervraagd over hun opvatting naar het voorkomen van zorg voor zelfstandigheid. Daarbij wordt nagegaan of en in welke mate de opvattingen van respondenten van de controlegroepen verschillen van die van de respondenten van de experimentele groepen.

Hoofdstuk 8 beschrijft de resultaten van de interviews van bewoners en de enquête onder verzorgenden in de eerste fase. De verwachtingen die bewoners hebben van het verblijf in het verzorginghuis blijken door de verzorgenden niet goed te worden onderkend. Verzorgenden hebben de indruk dat bewoners vooral verwachten dat zij hulp krijgen bij de lichamelijke verzorging, terwijl bewoners uitzien naar sociale contacten. Over de verwachtingen wordt weinig gecommuniceerd en het zorgplan of zorgdossier, dat benut zou moeten worden om informatie te verzamelen en afspraken te maken, wordt niet als communicatiemiddel gebruikt. Het merendeel van de bewoners geeft zelfs aan geen weet te hebben van het bestaan en de inhoud van het zorgdossier. Dit betekent dat voorbij wordt gegaan aan informed consent, het recht op informatie, aan het recht op inzage in het dossier en aan het vereiste om toestemming van de bewoner te krijgen voor het verlenen van zorg. Opvallend is dat het overgrote deel van het verzorgend personeel van mening is dat met bewoners moet worden overlegd over de huisregels, de dagindeling van het huis en het activiteitenprogramma, terwijl niet meer dan eenderde deel van de bewoners die mening deelt. Voor de meerderheid van de bewoners mag het verzorgingshuis deze regels en gewoonten handhaven. Over de houding van de verzorgenden lopen de meningen eveneens uiteen, met dien verstande dat zowel bewoners als verzorgenden vinden dat verzorgenden niet uitgaan van de behoeften en vragen van bewoners. Er wordt te weinig uitgegaan van de situatie van de bewoner. Het aantal bewoners dat vindt dat het aan attentiviteit ontbreekt, is evenwel groter dan het aantal verzorgenden dat die mening is toegedaan. Over de bereidheid van verzorgenden om de zorg op zich te nemen zijn de meningen niet veel verdeeld. Die bereidheid is er, alhoewel de helft van de bewoners zou willen zien dat overleg plaatsvindt over het tijdstip van de verzorging. Zowel bewoners als verzorgenden vinden dat de verzorgenden vakkundig, attent en respectvol zijn. Daarentegen verzuimen verzorgenden na te gaan of de zorg die zij verlenen, aansluit bij de zorg die door de bewoner gevraagd wordt. 
In hoofdstuk 9 wordt op het verloop van de interventies ingegaan. Elke afzonderlijke respondentgroep van de experimentele verzorgingsafdelingen heeft in een tweetal sessies responsieve evaluatie kennis genomen van de resultaten van de interviews en enquête; de deelnemers hebben ze op hun eigen situatie geprojecteerd en van nuances voorzien. De onderwerpen informatievoorziening, regie in het verzorgingshuis en houding van verzorgenden zijn uitgediept. Verzorgenden hebben onderkend dat er hiaten zijn in de zorg voor zelfstandigheid. Zo is de informatie over de bewoner niet voldoende om tot persoonsgerichte zorg te komen. Voor een deel wordt dit toegeschreven aan de informatie op de indicatieformulieren, voor een deel ook aan het gebrek aan tijd van verzorgenden om bijvoorbeeld een huisbezoek te doen voordat de oudere naar het verzorgingshuis komt. Interessant is de constatering dat verzorgenden de indruk hebben dat de tijd waarbinnen werkzaamheden moeten worden verricht min of meer gedicteerd wordt door gewoonten van groepen bewoners, terwijl bewoners het gevoel hebben dat de zorg sterk wordt bepaald door het ritme van het verzorgingshuis. Menig bewoner onderstreept dat hij zich kan vinden in de gewoonten van het huis, zolang daarmee de eigen gewoonten of behoeften niet worden doorbroken. Confronterend is het relaas van een aantal verzorgenden dat preferenties van bewoners worden genegeerd. Het risico van een 'precedentwerking' wordt niet gelopen, omdat het aan tijd ontbreekt. Als de kans bestaat dat de verleende zorg niet naar wens is geweest, wordt vanwege hetzelfde motief de zorg niet geëvalueerd. Ondanks de ernst van deze situatie hebben de respondentgroepen positief gereageerd op de openheid waarmee de onderwerpen ter sprake zijn gebracht en op de bewogenheid van de verzorgenden. De groepen bewoners hebben moeten wennen aan de responsieve evaluatie. Zij zijn niet vertrouwd met groepsgesprekken en met het ter discussie mogen stellen van het wonen en werken in het verzorgingshuis, maar de reactie van een van de bewoners dat de gesprekken een gevoel van saamhorigheid hebben teweeggebracht, tekent de sfeer van de gesprekken. De responsieve evaluaties hebben ook de gedragenheid voor de tweede interventie gecreëerd. De mening dat de registratie over kenmerken en behoeften van de bewoner moet worden aangepast, werd door velen onderkend. Verzorgenden zijn getraind in het werken met een persoonsgerichte zorgregistratie (het overzicht zorgafspraken), waarin het levensverhaal, keuzes en behoeften van de bewoner zijn opgenomen. Uitgegaan wordt van een actieve rol van de bewoner in de informatieoverdracht en van het respecteren van de rechten van de bewoner door de verzorgende. Het verloop van de interventie 'overzicht zorgafspraken' wijst uit dat verzorgenden moeilijk los kunnen komen van een probleemgerichte registratie en dat een persoonsgerichte registratie meer tijd vraagt, maar de ervaring dat de bewoner veel breder in beeld komt, overheerst. 
In hoofdstuk 10 worden de resultaten beschreven van de tweede ronde interviews en enquête. Nagegaan is of de eerste en tweede onderzoeksronde andere resultaten opleveren en of uit de tweede ronde verschillen of overeenkomsten naar voren komen tussen de controlegroepen en experimentele groepen. Gesteld wordt dat de verzorgenden een forse toename in zorgzwaarte registreren ten opzichte van de eerste onderzoeksronde, terwijl de bewoners veel minder de indruk hebben dat hun behoefte aan zorg is toegenomen. Verzorgenden van de controleafdelingen geven aan dat de toegenomen zorgzwaarte ten koste is gegaan van de persoonlijke aandacht voor bewoners en de bewoners van deze afdeling bevestigen deze mening, zij het wat minder in het oog springend. Bewoners van experimentele afdelingen vinden daarentegen dat de persoonlijke aandacht juist is toegenomen. Dit kan worden afgeleid uit een stijging van het aantal bewoners dat aangeeft dat zij betrokken worden bij of deeinemen aan de informatievoorziening voor de zorgafspraken. Ook geven meer bewoners aan dat de aandacht voor hun persoon en voor hun behoeften is toegenomen en dat zij invloed kunnen uitoefenen op de regels en gewoonten van het verzorgingshuis. Voor de evaluatie van de zorgverlening, oftewel de responsiviteit, is ook na de interventies nog weinig aandacht.

Hoofdstuk 11 geeft een beschouwing op de vorige hoofdstukken. Conclusies worden getrokken en aanbevelingen worden gedaan. Omdat het in deze studie gaat om het inventariseren van opvattingen van een niet representatief aantal bewoners van verzorgingshuizen wordt een kanttekening geplaatst bij de generaliseerbaarheid van de resultaten. Omdat de opvattingen zijn geïnventariseerd in de dagelijkse praktijk van het verzorgingshuis kan aan 'de principiële dynamiek van de werkelijkheid' niet worden voorbijgegaan. Door multiple triangulatie is geprobeerd vertekening van onderzoeksresultaten zoveel mogelijk te voorkomen. 


\section{Dankwoord}

"Laat hem maar, hij is er niet helemaal bij". Deze vriendelijke verwensing viel mij ten deel als ik weer eens uren achtereen was opgegaan in mijn proefschrift, die inspanning even onderbrak om met de gezinsgenoten aan tafel te gaan, maar me niet echt als een aanwezige tafelgenoot gedroeg.

De afgelopen jaren heeft het thema zorg voor zelfstandigheid van en voor ouderen in verzorgingshuizen mijn leven in de greep gehad. Mijn aanvankelijk vaag omlijnde gedachte wat dit onderwerp inhoudt, is ontwikkeld tot de beschrijving van een kader van waaruit het kan worden begrepen en in praktijk kan worden gebracht. Gesprekken met mijn promotor professor Frans van Wijmen hebben me hierbij op weg geholpen. Hij pleitte ervoor het onderwerp niet alleen theoretisch te benaderen, maar het onder de aandacht te brengen van betrokkenen, met name van bewoners en zorgverleners. Zijn creatieve geest lepelde in onze gesprekken over de aanpak en voortgang van dit proces een veelheid van methoden op van waaruit in deze studie keuzes zijn gemaakt. Ik dank Frans voor zijn begeleiding en bovenal voor zijn attente en stimulerende houding. Zijn telefoontjes over de voortgang van de studie en opbeurende opmerkingen over de kwaliteit van mijn pennestreken hebben mijn motivatie om de studie tot een goed einde te brengen versterkt. Medepromotor professor Guy Widdershoven heeft mij, vaak vanuit een socratische attitude, kennis laten maken met zorgethische benaderingswijzen die mijn object van studie sterk aanbelangen, maar die mij bij aanvang van mijn proefschrift min of meer vreemd waren. Zijn inbreng heeft mij de beleving gebracht dat promoveren het intensief betreden van nieuwe wegen is. Ook methodoloog en co-promotor dr. No Sijben heeft gedurende mijn studie op stimulerende wijze aan mijn zijde gestaan, niet alleen voor technische adviezen over de constructie van vragenlijsten of voor het trainen van interviewers, maar vooral vanuit zijn intrinsieke betrokkenheid bij het onderwerp.

Veel bewoners en verzorgenden hebben bijgedragen aan deze studie door vraaggesprekken te voeren, aan groepsgesprekken deel te nemen of vragenformulieren in te vullen. Ik ben hen dank verschuldigd voor hun bereidheid, openheid en betrokkenheid. De interviewers Olga Boef, Bertie Fransen, Annemarie van Hoof, Kim van Hoof, Tonnie van de Heyden, Gerrie Hulsbosch en Linda van Nes hebben in hun vraaggesprekken uit de eerste hand opgetekend welke betekenis bewoners geven aan zorg voor zelfstandigheid. Resie Bessems heeft haar rol als evaluator van responsieve evaluaties met zoveel enthousiasme en deskundigheid vervuld dat de deelnemers aan deze bijeenkomsten zitten te wachten op een vervolg. Karin Bos, locatiemanager van een collega-instelling, ben ik erkentelijk vanwege haar kritisch commentaar op en suggesties voor de Overzichten Zorgafspraken. Dochter Maartje dank ik voor haar adviezen bij de grafische weergaven van resultaten. Echtgenote 
Bea was een permanente steun en stimulator. Zij heeft allerlei hand- en spandiensten verricht bij het typewerk, de lay-out van het proefschrift en de voorbereiding van de promotie.

De leescommissie, voorzitter professor dr. C. Spreeuwenberg en de leden dr. T.A. Abma; professor dr. J.J.M. van Delden, mr. dr. J.C.J. Dute en professor dr. J.M.G.A. Schols, dank ik voor hun bereidheid dit proefschrift te beoordelen en voor hun kritisch commentaar. Paranimf filosofe Anne Bruijn bedankt voor jouw reactie op stukken, voor het luisterend oor en voor de verslaglegging van responsieve evaluaties. Paranimf geneeskundige Hugo Masselink stond mij nu eens niet terzijde als mede-auteur voor artikelen over de zorg, maar trad mij tegemoet als ervaringsdeskundige, als manager van verzorgingsafdelingen waarin het proces van zorg voor zelfstandigheid gestalte moet krijgen. 


\section{Curriculum vitae}

Na de middelbare school volgde Tinie Kardol de opleiding tot verpleegkundige in het Sint Lambertusziekenhuis in Helmond. Aansluitend behaalde hij de aantekeningen Pedagogiek MO-A en MO-B. Hij praktiseerde de onderwijsbevoegdheid, die hiermee werd verkregen, in een vormingsinstituut voor werkende en studerende jongeren in Oss. In 1981 trad hij in dienst van het Ministerie van Volksgezondheid van waaruit hij zich gedurende een viertal jaren bezig hield met de ontwikkeling van de kwaliteit van zorg in Nederlandse verpleeghuizen, met name ten aanzien van vraagstukken als de relatie vraag en aanbod van zorg, de organisatie van de verpleegafdelingen, de zorgregistratie en de personeelsallocatie. In 1984 sloot hij de doctoraalstudie Andragogische Wetenschappen cum laude af an de Rijksuniversiteit te Utrecht. Hij volgde een uitgebreid bijvak organisatiekunde bij de vakgroep Bedrijfskunde van de Universiteit Twente en van 1984 tot 1987 verrichtte hij, in samenwerking met medewerkers van deze vakgroep en adviesbureau Hoeksma, Homans en Menting, onderzoek naar kwaliteit van zorg en tijdnormstelling in verpleeghuizen. Hij combineerde dit met een functie als stafdocent aan de Hogeschool voor Gezondheidszorg in Breda. In 1988 stapte hij over naar de lokale overheid. Als directeur bewonerszaken bij de gemeente Uden hield hij zich bezig met de aansturing van onder meer beleidsafdelingen op het gebied van onderwijs, zorg en welzijn. In het najaar van 1994 werd hij door Bestuur en Management Consultants in Leusden voor enige maanden uitgezonden naar Curaçao om de eilandelijke overheid te adviseren over de structuur en kwaliteit van de ouderenzorg in dit koninkrijksdeel. De afgelopen zes jaar is hij als algemeen directeur van zorginstellingen voor ouderen weer terug in de praktijk van de zorg. 


\section{LITERATUURLIJST}

Aakster C.W. (Red.) Oud: Beeld van ouderen en ouderenzorg. Wolters Noordhoff, Groningen, 1987.

Abma T.A. en P.Rittersbeeks. Al doende zoeken we de weg. Eindverslag van een responsieve evaluatie van het project arbeidsexploratie en -rehabilitatie in psychiatrisch centrum Welterhof, Heerlen, 1996.

Abma T.A. en G.Widdershoven. Responsieve evaluatie en haar betekenis voor de verplegingswetenschap. Maastricht, 2002.

Abma T.A. Reflexive Dialogues. A story about the Development of Injury Prevention in Two Performing-Arts Schools, 238-252. SAGE, London, Thousand Oaks and New Delhi, 2001.

Abma T.A., J.C.Greene, O.Karlsson, K.Ryan, T.A.Schwandt, G.A.M.Widdershoven. Dialogue on Dialogue, 164-180. SAGE, London, Thousand Oaks and New Delhi, 2001.

Abma T.A. Responsief evalueren. Discoursen,controversen en allianties in het postmoderne. Delft, 1996.

Abma T.A. Variaties in beleidsevaluaties. Bestuurskunde, jrg. 6/nr2, 77-88, 1997.

Algra W.B., B.de Vries. Zorg voor ouderen. In: Trouw, 1999.

Arcares. Verzorgingshuizen in de AWBZ. Utrecht, 2000.

Arcares. Brancherapport. Verpleging en Verzorging 1998. Arcares en LVT, Utrecht, 2000.

Arcares. Ruimte voor Zorg. Toekomstverkenningen. Arcares, Utrecht, 2000.

Arcares. Uitkomst van Overleg verzorgingshuizen. Arcares, Utrecht, 2001.

Arcares. Wet Bopz voor verzorgingshuizen. Arcares Utrecht, 2001.

Arcares. In Balans: Aandacht voor levensverhalen en levensbalans in de ouderenzorg. Arcares, Utrecht, 2001.

Arcares. Kengetallen. Verpleeg- en verzorgingshuizen. Arcares, Utrecht, 2002.

Arcares. Modernisering AWBZ. De belangrijkste veranderingen voor verpleeg- en verzorgingshuizen. Arcares, Utrecht, 2003.

Arcares. Benchmarking verpleeg- en verzorgingshuizen. Arcares, Utrecht, 2004.

AWBZ, 2001, artikel 16, eerste lid

Baars J. De sociale constitutie van de ouderdom. In: C.P.M.Knipscheer, J.Baars, M.Severijns (Red.). Uitzicht op ouder worden, 21-35. Van Gorcum, Assen, Maastricht, 1988.

Baker Th.L. Doing Social Research. California State University, San Marcos, 1999.

Beauvoir de Simone. De Ouderdom. Bijleveld, Utrecht, 1975.

Becker H.M. Levenskunst op Leeftijd: Gelukbevorderende zorg in een vergrijzende wereld. Eburon, Delft, 2003. 
Berkhout A.J.M.B. Resident-Oriented Care in Nursing Homes: an evalution study of the model of resident-oriented care, the implementation and the effects. Maastricht, Universiteit Maastricht, 2000.

Berlin I. Twee opvattingen van vrijheid. Boom, Amsterdam/Meppel, 1996.

Bijsterveld H.J. Het ouderenperspectief op thuiszorg. Wensen en behoeften van ouderen ten aanzien van de thuis(zorg)situatie in Friesland. Universiteit Groningen, Groningen, 2001.

Bodt J.H.J. De werkorganisatie van verpleegafdelingen: een onderzoek naar de relatie tussen afdelingsomgeving en afdelingsstructuur. Eindhoven, 1995.

Bolscher A. Wet Geneeskundige Behandelingsovereenkomst: betekenis voor verzorgingshuizen. Zorg en Ondernemen, nr.7, 1995.

Borg ter M.B. Ouder worden in de moderne cultuur. Uit: Oud geboren om jong te sterven. Ouderenzorg en levensverhaal. Meinema, Zoetermeer, 1998.

Bosch J.G.J., H.D.Sul. Ouderenbeleid, Zorg en dienstverlening 2. Kluwer, Deventer, 1994.

Bosscher R en D.Deeg. Ouder worden:competentic, activiteit, chronische ziekte en pijn. In: Bewegen \& Hulpverlening, 183-197. 1996, 13.

Braam G.P.A, J.A.I. Coolen, J.Naafs. Ouderen in Nederland. Sociologie van bejaarden, bejaardenzorg en bejaardenbeleid. Samson, Alphen a/d Rijn, 1981.

Breed G., J.Deckers, M. den Dulk. Oud geboren om jong te sterven: Ouderenzorg en levensverhaal. Meinema, Zoetermeer, 1998.

Brink-Tjebbes van den J.A. Verplegen naar de maat. Een verplegingswetenschappelijke optiek. De Tijdstroom, Lochem, 1989.

Brugman G.M. Wijsheid en leeftijd. Het demasqué van de wijze oudere. In: Y.Quispel, L.Christ (Red.). Ouder worden: Een kwestie van leeftijd. Theorie over veroudering in relatie tot leeftijd, levensfasen en levensloop, 95-110. LBL, Utrecht, 2001.

Bussemaker J. Individualisering en sociale cohesie: een fundament voor sociale steun.TSG jaargang 80, nummer 7. Spectrum,2002.

Claessens L en F.Mertens. Nieuwe ouderen: Een pioniersrol. In: C.P.M.Knipscheer, J.Baars, M.Severijns (Red.). Uitzicht op ouder worden. Een verkenning van nieuwe rollen, 65-80. Van Gorcum, Assen/ Maastricht, 1988.

Cliënt \& Raad/LOC. Uitkomsten benchmark verpleging en verzorging. Jaargang 5, nr.3, Utrecht, 2004.

Commissie modernisering Ouderenzorg. Ouderenzorg met toekomst. Advies van de Commissie modernisering Ouderenzorg aan de minister van Welzijn, Volksgezondheid en Cultuur. Rijswijk, 1994.

Commissie Vorming en Toetsing. Aandacht voor zingeving en levensbeschouwing in het zorgplan. K.V.B./P.V.O. Joure, 1996. 
Cramer-Cornelissen L. Visie op zinvol ouder worden. In: G.Breed, J.Deckers, M. den Dulk (Red.). Oud geboren om jong te sterven: Ouderenzorg en levensverhaal. Meinema, Zoetermeer, 1998.

Deeg D.J.H. en R.J. van Zonneveld. Tot op hoge leeftijd. Tweede rapport landelijk longitudinaal gezondheidsonderzoek onder bejaarden, met medewerking van huisartsen. Leiden,1987.

Delden van J.J.M., C.M.P.M.Hertogh, H.A.M.Manschot (Red.). Ouder worden: drie ethische perspectieven. In: Morele problemen in de ouderenzorg, 49-80. Van Gorcum, Assen, 1999.

Denzin E.K., Y.S.Lincoln. Handbook of qualitative research. London: Sage P, 1994.

Dijkstra A. Care Dependency: an assessment instrument for use in long-term care facilities. Regenboog, Groningen, 1998.

Dröes R.M., E.J.Finnema, J.de Lange, C.H. van der Kooy, F.Smit, T.P.Ettema, A.Person, M.Pronk, R.Meertens, M.E.Ooms, A.Smaling, H.Rigter \& W. van Tilburg. Geïntegreerde belevingsgerichte zorg versus gangbare zorg voor dementerende ouderen in het verpleeghuis. Een klinisch experimenteel onderzoek naar de effecten en kosten. Amsterdam:VU medisch centrum; Utrecht:Trimbos-instituut en Nzi:onderzoek, informatie en opleidingen in de zorg, 2001.

Dulk den M. Het levensverhaal als erfenis. Uit: Oud geboren om jong te sterven onder red. van Breed G. J., Deckers, M. den Dulk. Meinema, Zoetermeer, 1998.

Evenhuis C. "Gij zult niet discrimineren-ook niet op grond van leeftijd". In: Y.Quispel, L.Christ (Red.). Ouder worden: Een kwestie van leeftijd. Theorie over veroudering in relatie tot leeftijd, levensfasen en levensloop, 17-30. LBL, Utrecht, 2001.

Fortuin K. Berichten uit de samenleving, Syntheserapport, Verwey-Jonker Instituut, Utrecht,1994.

Franssen J. In: G.Breed, J.Deckers, M. den Dulk (Red.). Oud geboren om jong te sterven: Ouderenzorg en levensverhaal, Meinema, Zoetermeer, 1998.

Franssen J. Van vroeger: levensverhalen schrijven met ouderen. Bohn Stafleu Van Loghum, 1995.

Frederiks C.M.A. Zorgbehoefte van en zorgverlening aan ouderen. Maastricht, 1990.

Gallé E en J.Luijten. Leven in een instituut. Handboek ouder worden. II.6.Gal. 1-30, 1992.

Gelauff M. en H.Manschot. Zingeving als funderende dimensie van zorg. In: M.Verkerk (Red.). Denken over zorg. Concepten en praktijken, 189-204. Elsevier/De Tijdstroom, Utrecht, 1997.

Gordon M. Verpleegkundige diagnostiek: proces en toepassing. Vertaling door W.Seunke. Lemma bv, Utrecht, 1995b.

Greene J.C. en T.A.Abma. Responsive Evaluation. New Directions for Evaluation, nr.92, 7-10. Jossey-Bass, San Francisco, 2001.

Handboek Lokaal Ouderenbeleid. De Tijdstroom, Utrecht, 1993. 
Heeremans J.G.M., N.P.G.Bouwmans, M.Algera, J.A.Landeweerd. Integrerende Verpleegkunde in de Praktijk: resultaten van een experiment in een algemeen ziekenhuis. (Integrated Nursing into practice: Results of an experiment in a general hospital). Rijksuniversiteit Limburg, Maastricht, 1994.

Heeswijk A. Ten geleide. Cicero en de moderne alchemisten. In: J.Munnichs, C.Knipscheer, N.Stevens, T.van Knippenberg (Red.). Ouderen en zingeving, 7-14. Ambo, Baarn, 1995.

Hertogh C. Oud en der dagen zat? Moderne doodsproblematiek en ouderdom. In: J.J.M. van Delden, C.M.P.M. Hertogh, H.A.M.Manschot (Red.). Morele problemen in de ouderenzorg, 203225. Van Gorcum, Assen, 1999.

Hesschel A.J. Het concept mens in het joodse denken. In: Adam waar ben je? De betekenis van het mensbeeld in de joodse traditie en in de psychotherapie. B.Folkertsma Stichting, Hilversum, 1983.

Heusden M.G.Widdershoven, V.Schrijnemaekers, E.v.Rossum. Een kwalitatief onderzoek naar compliance en ervaringen met belevingsgerichte zorg in verpleeghuizen. Universiteit Maastricht, Maastricht, 1999.

Hijmans E.J.S. Je moet er het beste van maken: een empirisch onderzoek naar hedendaagse zingevingssystemen. Instituut voor Toegepaste Sociale Wetenschappen. Nijmegen,1994.

Hoeksma B.H., A.H.Hulshof, M.J.M.Kardol. Onderzoek naar tijdnormstelling en verpleegkundig gedrag in een psychogeriatrisch verpleeghuis. TU Twente, 1986.

Hoogerwerf A. Denken over sterven en dood in de geneeskunde. Overwegingen van artsen bij medische beslissingen rond het levenseinde. Van der Wees, Veenendaal, 1999.

Houten van D., P.van Lieshout. De institutionalisering van de zorg. In: H.Manschot, M.Verkerk (Red). Ethiek van de de zorg. Een discussie, 11-37. Boom, Amsterdam, 1994.

Houten van D. De standaardmens voorbij. Over zorg, verzorgingstaat en burgerschap. Elsevier/De Tijdstroom, Maarssen, 1999.

Huisvesting en Verzorging Ouderen. Vuga, Den Haag, 1993.

Huijsman R. Model van voorzieningen voor ouderen. Kerckebosch, Zeist, 1990.

Huijsman R. Het Nederlandse ouderenzorgbeleid: verleden, heden en toekomst. In: J.J.M. van Delden, C.M.P.M. Hertogh, H.A.M.Manschot (Red.). Morele problemen in de ouderenzorg, 25 48. Van Gorcum, Assen, 1999.

Janmaat J.F.J. In: Uitgeschakeld? Een reeks beschouwingen over ouder worden en ouderdom onder red. van de wetenschappelijke staf van het gerontologisch centrum te Nijmegen, 40-42. Nijmegen, 1970.

Jelicic M. en P.J.Houx. Cognitieve veroudering. Patroon, determinanten en de rol van leeftijd. In: Y.Quispel, L.Christ (Red.). Ouder worden: Een kwestie van leeftijd. Theorie over veroudering in relatie tot leeftijd, levensfasen en levensloop, 83-94. LBL, Utrecht, 2001. 
Jonker J.L.M. De plaats van de bejaarde in de samenleving. In: Uitgeschakeld? Een reeks beschouwingen over ouder worden en ouderdom onder red. van de wetenschappelijke staf van het gerontologisch centrum te Nijmegen, 19-21. Nijmegen, 1970.

Kamp van der M. Praktijkgericht kwalitatief onderzoek: problemen en perspectieven. In: F.Wester, A.Smaling, L.Mulder (Red.), 173-188. Praktijkgericht kwaitatief onderzoek. Coutinho, Bussum, 2000.

Kardol M.J.M. Een reactie op de kritische analyse van de denkbeelden van Van den BrinkTjebbes. Tijdschrift voor Ziekenverpleging 35, nr.18, 593-596, 1982.

Kardol M.J.M. De registratie van verpleegprocessen. Facetten van een praktijktheorie. Tijdschrift voor Ziekenverpleging, 13, 397-403, 1985.

Kardol M.J.M. De registratie van verpleegprocessen. Dagelijkse rapportage. Tijdschrift voor Ziekenverpleging, 14, 428-432, 1985.

Kardol M.J.M. en K.Kuilman. Mythen in de ouderenzorg. In: Tijdschrift Senior, 1996.

Kardol M.J.M., H.Masselink, K.Kuilman. Verpleeghuiszorg in het verzorgingshuis: een financieel perspectief. Zorg en Ondernemen, 7, 14-18, 1997.

Kardol M.J.M. en H.Masselink. Caring for the Elderly without Residential Care Homes and Nursing Homes. World Hospitals and Health Services, Vol.36, 1, London, 2000.

Kempen G.I.J.M. Een beetje mens vergrijst niet. Oratie, Maastricht, 2003.

Keijzer J de \& C.Hertogh. Oost West, Thuis Best? Morele problemen in de thuiszorg. In: J.J.M. van Delden, C.M.P.M. Hertogh, H.A.M.Manschot (Red.). Morele problemen in de ouderenzorg, 155-171. Van Gorcum, Assen, 1999.

Knippenberg van M. Tussen naam en identiteit: Ontwerp van een model voor geestelijke begeleiding. Kok, Kampen, 1998.

Knipscheer C.P.M. Sociologie van het ouder worden sinds 1970. Onderzoek en Beleid, Nederlands Instituut voor Gerontologie, 1985.

Knipscheer C.P.M. Een samenleving vóór ouderen of met ouderen? In: H.Manschot, M.Verkerk (Red.). Ethiek van de zorg. Een discussie, 32-47.Boom, Amsterdam, 1994.

Knipscheer C.P.M., J.Baars, M.Severijns. Uitzicht op ouder worden. Een verkenning van nieuwe rollen. Van Gorcum, Assen, Maastricht, 1988.

Knipscheer C.P.M. Nieuw evenwicht in zorgverlening: matching van biografische en professionele betrokkenheid. In: J.J.M. van Delden, C.M.P.M. Hertogh, H.A.M.Manschot (Red.). Morele problemen in de ouderenzorg, 81-93. Van Gorcum, Assen, 1999.

Koene P., M.Grijpdonck, M.Th.Rodenbach, T.Windey. Integrerende Verpleegkunde: wetenschap in praktijk? De Tijdstroom, Lochem, 1982.

Kooij C.H. van der. Validation en Belevingsgerichte Zorg. Deel 1: Op zoek naar gelijkwaardigheid. Tijdschrift voor Verzorgenden, 28, 1996a, 26-31. Deel 2: Alles gebruiken wat je in huis hebt. Tijdschrift voor Verzorgenden, 28, 35-39, 1996a. 
Kooij C.H. van der. Belevingsgerichte zorg bij dementie. Denkbeeld. Tijdschrift voor Ppsychogeriatrie, 13, 16-20, 2001.

Kooij C.H. van der. Gewoon lief zijn? Het maieutisch zorgconcept en het invoeren van geïntegreerde belevingsgerichte zorg op psychogeriatrische verpleeghuisafdelingen. Lemma, Utrecht, 2003.

Kunneman H.P.J.M. Van theemutscultuur naar walkman-ego. Contouren van postmoderne individualiteit. Boom, Amsterdam/Meppel, 1996.

Leenen H.J.J. Individuele aanspraken en verdeling van schaarse middelen. In: Eigen verantwoordelijkheid in de Gezondheidszorg, 8-12. Studievereniging Jus et Sanitas, Maastricht, 1992.

Leenhouwers P. Levensverhalen, op elkaar lijken en toch totaal verschillend. Uit: Oud geboren om jong te sterven. Ouderenzorg en levensverhaal. Meinema, Zoeermeer, 1998.

Legard R, J.Keegan \& K.Ward. In-depth interviews. In: J.Ritchie \& J.Lewis (Eds.). Qualitative research practice: a guide for social science students and researchers, 138-169. London: Sage, 2003.

Landelijke Organisatie Cliëntenraden. Verantwoorde zorg, verpleeghuizen en verzorgingshuizen vanuit cliënperspectief. LOC, Utrecht, 2003.

Loveren van-Huyben C.M.S. Ontwikkeling in verzorgingshuizen? Gegevens van longitudinaal onderzoek. Beuningen/Nijmegen, 1995.

Maas van der P. Zelfstandigheid: Ideaal of ideologie. In: C.W. Aakster (Red). Oud: Beeld van ouderen en ouderenzorg, 222-225. Wolters Noordhoff, Groningen, 1987.

Maas van der P. Vergrijzing, volksgezondheid en de vraag naar zorg. In: J.J.M. van Delden, C.M.P.M. Hertogh, H.A.M.Manschot (Red.). Morele problemen in de ouderenzorg, 7-24. van Gorcum, Assen, 1999.

Malhotra N.K. Marketing Research. An Applied Orientation. Prentice Hall, Inc., Upper Saddle River, New Jersey, 1999.

Manschot H.A.M. Levenskunst of lijfsbehoud? Een humanistische kritiek op het beginsel van autonomie in de gezondheidszorg. Universiteit voor Humanistiek, Utrecht, 1992.

Manschot H.A.M. Kwetsbare autonomie: over afhankelijkheid en onafhankelijkheid in de ethiek van de zorg. In: H.Manschot, M.Verkerk (Red). Ethiek van de zorg. Een discussie, (1994a). 112 117, 1994b. Boom, Amsterdam/Meppel, 1994.

Maso I. en A.Smaling (Red). Objectiviteit in kwalitatief onderzoek. Boom, Meppel/Amsterdam, 1990.

Maso I. en A.Smaling. Kwalitatief onderzoek: praktijk en theorie. Boom, Amsterdam, 1998.

Matse J. Het Laatste Kwartier; over het leven met de dood in een bejaardenhuis. Boom, Meppel, 1977. 
Mercx R.J.M. Van traditionele verpleging naar teamverpleging. In: J.Blox, R.J.M.Mercx, I.MurVeenman, H.Nijhuis, J.Verwey (Red.). De verpleegafdeling: bedrijfskundige diagnose en therapie. De Tijdstroom, Lochem 1979.

Metaal N. Persoonlijke autonomie: een psychologische studie naar alledaagse verklaringen. Swets \& Zeitlinger B.V., Amsterdam/Lisse, 1992.

Meulen ter R.H.J. Verschraalde zorg? Over autonomie, identiteit en zingeving in de zorg voor hulpbehoevende ouderen. Rijksuniversiteit Limburg, Maastricht, 1994.

Michels J.J.M. Verpleeghuizen voor langdurig zieken. In: S.Santema (Red.). Intramurale gezondheidszorg. Beschrijving van de verschillende soorten van inrichtingen. Samsom, Alphen a/d Rijn, 1970.

Ministerie van Justitie. Handreiking voor de beoordeling van wilsbekwaamheid, 1994.

Ministerie van Onderwijs, Cultuur en Wetenschappen, Ministerie van Volksgezondheid, Welzijn en Sport. Gekwalificeerd voor de toekomst. Kwalificatiestructuur en eindtermen voor Verpleging en Verzorging. Zoetermeer/Rijswijk, 1996.

Missine L. Leven toevoegen aan de jaren. Over ouder worden. Davidsfonds, Leuven, 1996.

Muffels R.J.A. Tussen mythe en werkelijkheid: leeftijd in sociaal-economisch perspectief. In: Y.Quispel, L.Christ (Red.). Ouder worden: Een kwestie van leeftijd. Theorie over veroudering in relatie tot leeftijd, levensfasen en levensloop, 17-30. LBL, Utrecht, 2001.

Munnichs J.M.A. Psychogerontologie onder red. van Joep Munnichs, Gwenyth Uildriks. Van Loghum Slaterus, Deventer, 1989.

Munnichs J.M.A. Gerontologie, levensloop en biografie. Van Loghum Slaterus, 1990.

Munnichs J.M.A. Weg(weten) met zin. Over zinvinding en de vraag om zin bij ouderen. In: H.Manschot, M.Verkerk (Red.). Ethiek van de zorg. Een discussie, 15-30. Boom, Amsterdam, 1994.

Munnichs J.M.A., C.P.M.Knipscheer, N.L.Stevens, M.P.J. van Knippenberg. Ouderen en zingeving. AMBO, Baarn, 1995.

Nederlands Instituut voor Zorg en Welzijn. Zicht op vernieuwing. Koersbepaling voor een moderne AWBZ. NIZW, Utrecht, 2000.

Nederlands Instituut voor Zorg en Welzijn. Het verzorgingshuis in beeld: Inventarisatie vraagstukken primair proces. Discussienota. NIZW, Utrecht, 2001.

Nederlandse Zorgfederatie. Gezondheidszorg in Tel. Utrecht, 1996.

Nederlandse Zorgfederatie. Gezondheidszorg in Tel. Utrecht, 1998.

Nederlandse Zorgfederatie. Gezondheidszorg in Tel. Samenvatting, editie 6. Utrecht, 1998.

Nederlandse Zorgfederatie. Gezondheidszorg in Tel. Samenvatting, 17. Utrecht, 2001.

NP/CF. Tijd voor patiënten. Utrecht, 1993.

NP/CF. De vraag als maat. Vraaggerichtheid vanuit gebruikersperspectief, Utrecht, 2000. 
Nederlandse Vereniging voor Verpleeghuiszorg. Modelregeling zorgverleningsovereenkomst verpleeghuis-patiënt/bewoner. NVVz, Utrecht, 1994.

Nederlandse Vereniging voor Verpleeghuiszorg. Verstandig vernieuwen 2. Ouderenzorg voor eigen rekening? NVVz, Utrecht, 1995.

Nederlandse Vereniging voor Verpleeghuiszorg. Verpleeghuiszorg: een consumentenonderzoek. NSS Research \& Consultancy B.V., NVVz, Utrecht, 1996.

Nederlandse Vereniging voor Verpleeghuiszorg. Eigen leven: Omgaan met autonomie en afhankelijkheid van verpleeghuisbewoners. NVVz, Utrecht, 1996.

Nies H. Private financiering in de ouderenzorg: alle mensen zijn ongelijk. In: J.J.M. van Delden, C.M.P.M. Hertogh, H.A.M.Manschot (Red.). Morele problemen in de ouderenzorg, 95-109. Van Gorcum, Assen, 1999.

Novak J. "Concept Mapping: A Useful Tool for Science Education". Journal of Research in Science Teaching 27 (10): 937-949, 1990.

NZI. Persoonsgebonden budgetten, 7. Utrecht, 1995.

Orem D.E. Verpleegkunde: Concepten voor de Praktijk. Lemma, Utrecht, 1992.

Pincus A. The definition and measurement of the institutional environment in homes for the ages. The Gerontologist, 207-210, St.Petersburg, Florida, 1968.

Pincus A. Methodological issues in measuring the environment in institutions for the ages and its impact on residents. Aging and Human Development, 117-126. Wisconsin Milwaukee, 1970.

Pool A. Autonomie, afhankelijkheid en langdurige zorgverlening. Lemma, Utrecht, 1995.

Prétat J.R. Ouder worden: mogelijkheden van een nieuwe levensfase. Lemniscaat, Rotterdam, 1995.

Prismant. Gezondheidszorg in Tel. Van en voor de zorg, editie 8. Utrecht, 2000.

Prismant. Ruimte voor zorg. Toekomstverkenningen. Utrecht, 2000.

Raad voor de Volksgezondheid \& Zorg. Van patiënt tot klant. VWS, Zoetermeer, 2003.

Reestman K. Denken over ouder worden. Essays over de latere leeftijd. DAMON, Leende, 2000. Regelingen en werken Ouderenbeleid. Vuga, Den Haag, 1977.

Rijsselt R.J.T. Ouderen en maatschappelijke verandering: een cohortstudie naar veranderingen in de inkomenspositie, waardenoriëntaties en participatieniveaus van ouderen. Centraal Bureau De Betuwe B.V., Beusichem, 1991.

Rijksinstituut voor Volksgezondheid en Milieuhygiëne. De gezondheidstoestand van de Nederlandse bevolking in de periode 1950-2010, 1997.

RVZ. Persoonlijke levenssfeer. Zoetermeer: Voorlopige Raad voor de Volksgezondheid \& Zorggerelateerde Dienstverlening, 1996.

Schrijnemaekers V.J.J. Effects of Emotion-oriented Care in Homes for the Elderly. Universiteit Maastricht, Maastricht, 2002.

SCP. Vraagverkenning wonen en zorg voor ouderen. Rijswijk, 1997. 
SCP. Rapportage ouderen, Den Haag, 1998.

SCP. Demografische en sociaal-culturele ontwikkelingen; gevolgen voor het wonen van ouderen in de toekomst. Rijswijk, 1999.

SCP. Report on the Elderly in the Netherlands. Changes in living situation. Den Haag, 2001.

SCP. Mantelzorg: Over de hulp van en aan mantelzorgers. Den Haag, 2003.

Sevenhuysen S. Oordelen met zorg. Feministische beschouwingen over recht, moraal en politiek. Boom, Amsterdam/Meppel, 1996.

Smaling A. De methodologische kwaliteit van kwalitatief onderzoek. Verpleegkunde, nr.4, 240254, 1996-11.

Sociaal Overleg Verpleeg- en Verzorgingshuizen. Profiel Eerst Verantwoordelijk Verzorgende. Bilthoven, 2003.

Spauwen-Micka E. Het verzorgingstehuis - een woonplaats, verzorgingsinstituut of leefwereld voor oudere mensen? In: Nederlands Tijdschrift voor Gerontologie 6: 66-171, 1975.

Staatsblad. Wet BOPZ, 671, 1992.

Staatsblad. Wet BIG, 665, 1993.

Staatsblad. Wet op de geneeskundige behandelingsovereenkomst, 837, 1994.

Staatsblad. Wet van 18 januari 1996 betreffende de kwaliteit van zorginstellingen (Kwaliteitswet Zorginstellingen). Staatsblad van het Koninkrijk der Nederlanden. Sdu/ Den Haag, 1996.

Steverink N. Zolang mogelijk zelfstandig; naar een verklaring van verschillen in oriëntatie ten aanzien van opname in een verzorgingstehuis onder fysiek kwetsbare ouderen. Thesis Publishers, Amsterdam, 1996.

Stüssgen R.A.J.C. De nieuwe patiënt op weg naar autonomie. Thesis Publishers, Amsterdam, 1997.

Swanborn P.G. Objectiviteit: poging tot duidelijkheid. In: I.Maso, A.Smaling (Red.), 50-74. Objectiviteit in kwalitatief onderzoek. Boom, Meppel/Amsterdam, 1990.

Swanborn P.G. Designing Case Studies: Some Dilemmas; Het ontwerpen van case-studies: enkele keuzen, 69. Mens en Maatschappij, 1994.

Swanborn P.G. Evalueren. Boom, Amsterdam/Utrecht, 1999.

Sweere M.H.A.E., D.S.Ploeger, A.H.M. van den Bergh-Braam en A.Ph.Visser, Vakgroep Verplegingswetenschap. Motieven van ouderen bij de melding voor opname in een verzorgingstehuis. In: A.Ph.Visser (Red.). Jong over oud. Veroudering in gezondheidswetenschappelijk perspectief, 90-99. Thesis Publishers, Amsterdam, 1990.

Thiel van G., A.Huibers, K.de Haan. Met zorg besluiten. Beslissingen rond het levenseinde in de zorg voor mensen met een verstandelijke handicap. Van Gorcum, Assen, 1997.

Timmermans J.M. Rapportage Ouderen 1993. Rijswijk/Den Haag: SCP/VUGA, Cahier 106, 1993. 
Tronto J.C. Moral Boundaries: A political argument for an ethic of care. Routledge, New York, 1994.

Tronto J.C. An ethic of care. Generations, Fall98, Vol.22 Issue 3, 15-21, 1998.

Trouw. Onderzoek zorg voor ouderen. 1999.

Turksma L. Senioren in de samenleving: sociale problematiek van bejaarden. Spectrum, Utrecht, 1982.

Tweede Kamer der Staten Generaal. Nota Bejaardenbeleid. Den Haag: Staatsuitgeverij, Kamerstukken 10.934, 1970.

Tweede Kamer der Staten Generaal. Bouwstenen voor een ouderenbeleid. Den Haag: Staatsuitgeverij, Kamerstukken 17.393, 1983.

Tweede Kamer der Staten Generaal. Volksgezondheid bij beperkte middelen, 1983/1984b.

Tweede Kamer der Staten Generaal. Zorg voor ouderen. Kamerstukken I, 19434, nrs.I en 2, 1985-1986.

Tweede Kamer der Staten Generaal. Nota Ouderen in tel. Den Haag: Staatsuitgeverij, Kamerstukken 21.814, 1990.

Tweede Kamer der Staten Generaal. Ouderenbeleid 1995-1998. Den Haag: Staatsuitgeverij, Kamerstukken 24.319, 1995.

Tweede Kamer der Staten Generaal. Modernisering ouderenzorg. (Beleids)Brief van de staatssecretarissen Terpstra(VWS) en Tommel (VROM) d.d. 1 september 1995. Kamerstukken II, 1994-1995, 24.333, nr.1. Sdu, Den Haag, 1995a.

Tweede Kamer der Staten Generaal. Plan van aanpak Modernisering ouderenzorg. Bijlage 1 bij de brief van staatssecretaris Terpstra (VWS) d.d. 21 december 1995. Kamerstukken II, 19951996, 24.333, nr.6. Sdu, Den Haag, 1995b.

Tweede Kamer der Staten Generaal. Jaaroverzicht Zorg. Vergaderjaar 1996-1997, 25004, nr.1. Sdu, Den Haag, 1997.

Tweede Kamer der Staten Generaal. Jaaroverzicht Zorg. Vergaderjaar 1997-1998, 25604, nr. I en 2. Sdu, Den Haag, 1998.

Tweede Kamer der Staten Generaal. Zorgnota 2000. Den Haag: Staatsuitgeverij, Kamerstukken 26.801, nrs.1-2, 1999.

Vanderleyden L. De huisvesting van ouderen in Vlaanderen. Handboek ouder worden, afl.2. Van Loghum Sloterus, Deventer, 1989.

Verdult R. Dement worden: een kindertijd in beeld. Belevingsgerichte begeleiding van dementerende ouderen. HB uitgevers, Baarn, 2001.

Verkerk M. Zorg of contract: Een andere ethiek. H.Manschot en M.Verkerk (Red.). Ethiek van de zorg. Een discussie. Boom, Amsterdam/Meppel, 1994.

Visser A.Ph. Jong over oud. Veroudering in gezondheidswetenschappelijk perspectief. Thesis, Amsterdam, 1990. 
Vereniging van Nederlandse Gemeenten. Indicatiecommissies bejaardenoorden.Groene reeks, nr.104. 's-Gravenhage, 1988.

Vonnegut K. Welkom op de apenrots, Querido, Amsterdam, 1979.

VWS. Beleidsbrief Persoonsgebonden budgetfinanciering, 1995.

VWS. Verkenningen Ouderenzorg 1995-2010. VWS, Rijswijk, $1997^{\mathrm{e}}$.

VWS. Voortgang Modernisering ouderenzorg. Kamerbrief (DOB-U-976189). VWS, Rijswijk, $1997 \mathrm{c}$.

VWS. Jaaroverzicht Zorg 1998. Sdu/Den Haag, 1997d.

VWS. Jaaroverzicht Zorg 1999. Sdu/Den Haag, 1998.

VWS. Zicht op Zorg. Plan van aanpak modernisering AWBZ. Ministerie van Volksgezonheid, Welzijn en Sport, Den Haag, 1999.

VWS. Voortgangsrapportage Persoonsgebonden budgetfinanciering, 2001.

VWS.Aanpassingen WZV na modernisering AWBZ. Ministerie van Volksgezondheid, Welzijn en Sport, Den Haag, 2003.

VWS. Beleidsregels ex artikel 3 WZV, p.20, 2003.

VWS. Regeling DWJZ/SWW-2370326, houdende wijziging van de beleidsregels voor het ontwerpen van plannen voor ziekenhuisvoorzieningen. Staatssecretaris van Volksgezondheid, Welzijn en Sport, Den Haag, 2003.

VWS. Regeling DWJZ/SWW-2370322, houdende nieuwe begripsomschrijvingen voor de Wet ziekenhuisvoorzieningen (Regeling begripsomschrijvingen WZV). Staatssecretaris van Volksgezondheid, Welzijn en Sport, Den Haag, 2003.

VWS. Regeling DWJZ/SWW-2370320, houdende wijziging van enige regelingen ter uitvoering van de Wet ziekenhuisvoorzieningen in verband met de modernisering van de AWBZ. Staatssecretaris van Volksgezondheid, Welzijn en Sport, Den Haag, 2003.

Wais M. Biografische Verkenningen. Christofoor, Zeist, 1992.

WBO, 1963, art.7, ouderenbeleid, 30, 1994.

Werkman L. Zorg en emancipatie: een schijnbare tegenstelling? In: H.Manschot, M.Verkerk (Red.). Ethiek van de zorg. Een discussie, 38-52. Boom, Amsterdam, 1994.

Westendorp R.G.J. Veroudering is te vermijden. Over de toenemende levensverwachting. In: Y.Quispel, L.Christ (Red.). Ouder worden: Een kwestie van leeftijd. Theorie over veroudering in relatie tot leeftijd, levensfasen en levensloop, 69-82. LBL, Utrecht, 2001.

Wester F. Strategieën voor kwalitatief onderzoek. Coutinho, Bussum, 1995.

Wester F., A.Smaling en L.Mulder (Red.). Praktijkgericht kwalitatief onderzoek. Coutinho, Bussum, 2000.

Wester F. Methodische aspecten van kwalitatief onderzoek. In: F.Wester, A.Smaling, L.Mulder (Red.). Praktijkgericht kwalitatief onderzoek, 15-40. Coutinho, Busum, 2000. 
Westerhoven F.M.G.D. Zorg voor medewerkers in verpleeghuizen. Onderzoek naar de benodigde kwaliteit en kwantiteit van de medewerkers in het verpleeghuis in het jaar 2002. Van Loveren \& Partners B.V., Beuningen, 1998.

Weijs T. Zingeving en levenseis. Uit: Oud geboren om jong te sterven. Ouderenzorg en levensverhaal. Meinema, Zoetermeer, 1998.

Widdershoven G.A.M. De patiënt als geheim, 40-50. Medische Antropologie 7(1), 1995.

Widdershoven G.A.M. Principe of praktijk. Een hermeneutische visie op gezondheid en zorg. Maastricht, 1995.

Widdershoven G.A.M. Hermeneutiek als alternatief in de gezondheidsethiek. Zelfonderzoek of dialoog? Tge, 8, 38-42, 1998.

Widdershoven G.A.M. Ethiek in de kliniek: Hedendaagse benaderingen in de gezondheidsethiek. Boom, Maastricht, 2000.

Widdershoven G.A.M. Dialogue in Evaluation: A Hermeneutic Perspective, 253-263. SAGE, London, Thousand Oaks and New Delhi, 2001.

Wielink G., M.M.Y. de Klerk, R.Huijsman. Voorkeuren voor hulpverlening. Resultaten van een onderzoek onder alleenwonende ouderen, 115-122. Tijdschrift Sociale Gezondheidszorg, jaargang 73, 1995.

Wierik te M.J.M. en C.M.A.Frederiks. De hulpbehoefte en opnamewens van positief geïndiceerden; een vergelijking met verzorgingshuisbewoners. Tijdschrift Gerontologie Geriatrie, 1990.

Wijmen van F.C.B. Met minder meer of anders?, 839-842. In: Tijdschrift voor Sociale Gezondheidszorg, 1984.

Wijmen van F.C.B. Kwaliteitsverbetering in de verzorging, 351-356. De Tijdstroom, Lochem, 1984.

Wijmen van F.C.B. Eigen verantwoordelijkheid van patiënten. Studievereniging Jus et Sanitas, 40-46. Maastricht, 1992.

Wijmen van F.C.B. Vijf jaar kwaliteitsbeleid: inspiratie voor onderzoek, 109-115. Q, Maastricht, 1995-3.

Wijmen van F.C.B. Goed patiëntschap als spiegelbeeld van verantwoorde zorg (inaug.rede). Kluwer, Deventer, 1996.

Wijmen van F.C.B. Kwaliteitsbeleid in verpleeghuizen en verzorgingshuizen, 77-84. Q, Maastricht, 1996-2.

Wijmen van F.C.B. De goede patiënt. De patiënt als zorgvrager, 597-599. Medisch contact, jaargang 52, 1997.

Wijmen van F.C.B. Rollen en posities van cliënten en hun organisaties in de zorg. Vincent van Goghinstituut, Venray, 2000. 
Wijmen van F.C.B. En ik ben maar een kuip vol dromen. In: Raad voor de Volksgezondheid \& Zorg. Zorgaanbod en cliëntenperspectief, 72-104. Zoetermeer, 2003.

WVC. Flankerend Ouderenbeleid, 1983.

Wolffensperger E.W., C.P.van Linschoten, W.O.Zijlstra, Z.A.Huijsman-van den Bergh, B.P. te Velde. Substitutie en kwaliteit in de ouderenzorg in Zuidoost-Groningen. Groningen: Styx publications, 1991.

Woonzorg Federatie (WZF), Landelijke Organisatie Bewonerscommissies Bejaardenhuizen (LOBB), Ministerie van VWS. Aanpak meerjarenplan Verzorgingshuizen 2001. WZF, Zeist/LOBB, Utrecht/VWS, Rijswijk, 1997.

WRR. Ouderen voor ouderen. Demografische ontwikkelingen en beleid. SDU, Den Haag, 1993.

WRR. Rapporten aan de regering. Generatiebewust beleid. SDU, Den Haag, 1999.

WZF, LOBB. Modelreglement voor de cliëntenraad, deel $1 \mathrm{t} / \mathrm{m}$ 4, 1996, 1997. 


\section{BIJLAGEN}

1 Vragenlijst voor de bewoners van verzorgingsafdelingen

2 Vragenlijst voor het verzorgend personeel

3 Overzicht Zorgafspraken en handleiding 
Naam interviewer datum interview

\section{Persoonlijke situatie van de bewoner}

$1 \quad$ Nummer interview

2 Leeftijd Geslacht man/vrouw

3 Laatst genoten opleiding

$4 \quad$ Laatste werksituatie/functie

5 Kort omschrijven: bedrijfstak, niveau van de functie

$6 \quad$ Huidig inkomen

$\begin{array}{ll}\text { I } & \text { AOW alleen } \\ 2 & \text { AOW + pensioen } \\ 3 & \text { Anders, namelijk }\end{array}$

7 Bruto jaarlijks inkomensniveau

$\begin{array}{ll}\mathrm{I} & <\mathrm{f} 50.000 \\ 2 & 50.000-75.000 \\ 3 & 75.000-100.000 \\ 4 & >100.000\end{array}$

8 Burgerlijke staat:

1 Ongehuwd en niet eerder gehuwd geweest

2 Gehuwd/samenwonend

3 Gehuwd geweest en nu : gescheiden

4 Gehuwd geweest en nu: weduwe/weduwnaar

9 Indien gehuwd (geweest): kinderen: ja/nee

Indien ja: aantal

geslacht

leeftijd jongste: jaar

leeftijd oudste : jaar

10a Bestaan er nog contacten met de kinderen en eventuele kleinkinderen

I ja, ze komen regelmatig op bezoek

2 ja, ze bellen regelmatig

3 ze bellen of komen incidenteel

4 zee, ik zie of hoor ze nooit

5 anders, namelijk

I0b Wat vindt $\mathrm{u}$ van de contacten met uw kinderen

1 het doet me goed dat ik ze regelmatig zie of hoor

2 we zouden wat vaker contact mogen hebben 

anders, namelijk

Ila Bestaan er nog contacten van voor de verhuizing naar het verzorgingshuis

1 met andere familieleden

2 met buren

3 met vrienden

4 met oud collega's

5 anders, namelijk

Ilb Wat vindt $\mathrm{u}$ van die contacten

$1 \quad$ ik vind al die contacten prettig

2 ik stel niet alle contacten op prijs

3 sommige contacten hoeven voor mij niet meer

$4 \quad$ ik wil de contacten verbreken

6 anders, namelijk

12 In welk verzorgingshuis woont u nu:

Op welke afdeling:

Hoe lang woont u nu in dit verzorgingshuis:

0 korter dan een half jaar

0 tussen een half jaar en een jaar

0 tussen één en drie jaar

0 tussen drie en vijf jaar

0 langer dan viff jaar, $\mathrm{nl}$........jaar

13 Indien u eerder in een ander verzorgingshuis woonachtig bent geweest, in welk(e):

14 Verhuizing naar verzorgingshuis:

Op wiens initiatief was dit:

0 eigen

0 anderen: partner, kinderen, huisarts

0 anders, namelijk

15a Wat waren de redenen (omcirkel de genoemde) (meerdere antwoorden mogelijk):

1 niet meer in staat voor mijzelf te zorgen

2 onvoldoende hulp thuis van mantelzorg

3 onvoldoende professionele hulp thuis

$4 \quad$ woning niet meer geschikt (gelet op handicap)

5 behoefte aan contact met leeftijdgenoten

6 voelde me thuis niet veilig

7 anders, namelijk

$15 \mathrm{~b} \quad$ Welke van de onder 15a genoemde redenen waren (was) de belangrijkste
I
2
3
4
5
6 
Hoe goed was u op de hoogte van het verzorgingshuis voordat u er ging wonen

$1 \quad i k$ was heel goed op de hoogte

$2 \quad$ ik was redelijk goed op de hoogte

3 ik was een beetje op de hoogte

$4 \quad$ ik was tamelijk slecht op de hoogte

$5 \quad$ ik was helemaal niet op de hoogte

17 Welke informatie heeft u vooraf gekregen over het verzorgingshuis (meerdere antwoorden mogelijk):

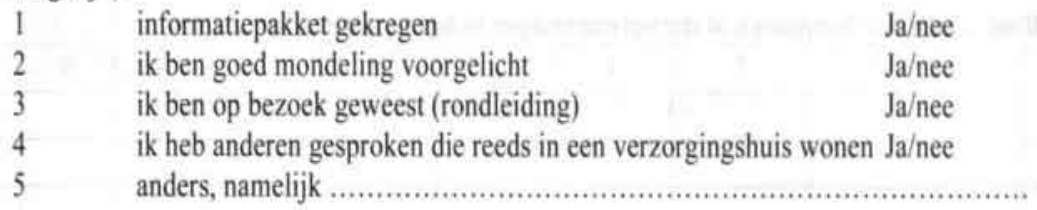

I8a Dat $\mathrm{u}$ in het verzorgingshuis bent, heeft misschien invloed gehad op uw gevoel van zelfstandigheid. Wilt $u$ uzelf een punt geven voor de mate waarin u zich momenteel afhankelijk of onafhankelijk voelt. Een I is 'volledig afhankelijk' en een 10 is 'volledig onafhankelijk'

$\begin{array}{lrllllllcr}1 & 2 & 3 & 4 & 5 & 6 & 7 & 8 & 9 & 10 \\ \text { afhankelijk } & & & & & & & \text { onafhankelijk }\end{array}$

$18 \mathrm{~b}$ Is één van de volgende punten op u van toepassing

I ik heb het gevoel dat ik volledig op anderen ben aangewezen

2 ik heb veel hulp van anderen nodig, waardoor ik me afhankelijk voel

3 ik moet regelmatig geholpen worden, wat me voor een deel afhankelijk maakt

$4 \quad$ ik moet regelmatig geholpen worden, maar toch voel ik me niet helemaal afhankelijk

5 ik heb veel hulp nodig, maar toch voel ik me niet afhankelijk

$6 \quad i k$ heb het gevoel dat ik alleen op mezelf ben aangewezen

7 anders, namelijk

18c Er volgen nu allerlei vragen over wat u van het verblijf in dit verzorgingshuis vindt. Voelt u zich vrij om te antwoorden, ook als u kritiek heeft of bent $\mathrm{u}$ bang om dit te zeggen?

$1 \quad$ ik voel me vrij om alles te zeggen wat ik vind

2 ik zal wel alles zeggen, maar ben toch bang voor eventuele gevolgen

3 sommige dingen zal ik wel zeggen, maar andere dingen niet

4 nee, ik geef geen kritiek, omdat ik bang ben voor de gevolgen

\section{Verwachtingen}

19a Kunt u zich nog herinneren wat $\mathrm{u}$ verwachtte van het verzorgingshuis toe u daar naar toe ging (meerdere antwoorden mogelijk):

$1 \quad$ hulp bij de verzorging

2 hulp bij het huishouden (eten klaarmaken, schoonmaken etc.) 


\begin{tabular}{|c|c|}
\hline 3 & contacten met medebewoners \\
\hline 4 & een aanbod aan activiteiten \\
\hline 5 & een gevoel van veiligheid \\
\hline 6 & zelfstandig kunnen wonen \\
\hline 7 & attente medewerkers om mij heen \\
\hline 8 & een gevoel van rust \\
\hline 9 & een woning die ik naar eigen smaak zou kunnen inrichten \\
\hline 10 & iets kunnen ondernemen \\
\hline II & anders, namelijk ........... \\
\hline
\end{tabular}

I9b Kunt u zich nog herinneren of die verwachtingen in het begin ook uitkwamen

\begin{tabular}{|c|c|c|c|c|c|c|c|c|c|c|c|}
\hline ta.v. & 1 & 2 & 3 & 4 & 5 & 6 & 7 & 8 & 9 & 10 & II \\
\hline n.v.t. & & & & & & & & & & & \\
\hline Ja & & & & & & & & & & & \\
\hline Nee & & & & & & & & & & & \\
\hline
\end{tabular}

19c Vindt $\mathrm{u}$ dat die verwachtingen nu uitkomen

\begin{tabular}{|l|l|l|l|l|l|l|l|l|l|l|l|}
\hline t.a.v. & 1 & 2 & 3 & 4 & 5 & 6 & 7 & 8 & 9 & 10 & 11 \\
\hline n.v.t. & & & & & & & & & & & \\
\hline Ja zeker & & & & & & & & & & & \\
\hline Ja toch wel & & & & & & & & & & & \\
\hline Soms wel,soms niet & & & & & & & & & & & \\
\hline Nee, toch niet & & & & & & & & & & & \\
\hline Zeker niet & & & & & & & & & & & \\
\hline
\end{tabular}

\section{Opvattingen over Informatievoorziening}

$20 \mathrm{a}$ Heeft u een verzorgingsovereenkomst getekend

$\mathrm{Ja} /$ nee/weet ik niet (meer)

$20 \mathrm{~b} \quad$ Zorgdossier

1 Wordt er een zorgdossier over u bijgehouden Ja/nee/weet ik niet

2 Indien er een zorgdossier wordt bijgehouden, weet u wat daar in staat

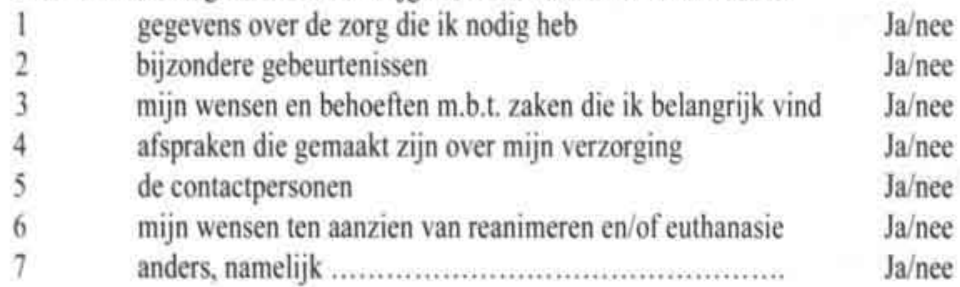

2la Op welke manier wordt $\mathrm{u}$ betrokken bij het zorgdossier (meerdere antwoorden mogelijk):

I ik word daar niet bij betrokken 
ik word regelmatig geïnformeerd over wat er in staat

3 ik weet dat ik de gegevens kan inzien

$4 \quad$ ik lees het dossier af en toe door

$5 \quad$ ik heb het met gegevens aangevuld

$6 \quad i k$ heb mijn toestemming gegeven over wat er in het zorgdossier staat

7 anders, namelijk

2Ib Bent u tevreden over de wijze waarop u bij uw zorgdossier betrokken bent

1. zeer tevreden; 2 . redelijk tevreden; 3 . noch tevreden, noch ontevreden; 4 . tamelijk ontevreden; 5 . zeer ontevreden; 6 . n.v.t.

22a Het verzorgingshuis heeft beleid op het gebied van reanimeren en euthanasie. Bent u daarover geïnformeerd

$1 \quad$ ik ben er niet van op de hoogte (verder met vraag 22c)

2 ik ben op de hoogte van het reanimeerbeleid

3 ik heb een verklaring getekend op het gebied van reanimeren/ik heb een niet-reanimeren pas

$4 \quad$ anders, namelijk

$22 \mathrm{~b}$ Indien $\mathrm{u}$ WEL op de hoogte bent van het reanimeerbeleid, wat vindt $\mathrm{u}$ daar van

1 ik praat daar liever niet over

$2 \quad$ ik kan me daar wel in vinden

3 ik vind dat mijn wens gerespecteerd moet worden

$4 \quad$ als het aan de orde is wil ik bespreken wat het beste voor mij is

$5 \quad$ als het an de orde is bepaal ik zelf wat ik wil

6 anders, namelijk

22c Indien u NIET op de hoogte bent, had u wel geïnformeerd willen worden

$1 \quad \mathrm{ja}$, want ik vind dat mijn wens gerespecteerd dient te worden

2 ja, ik wil weten hoe de instelling hier mee omgaat, zodat ik weet waar ik aan toe ben

3 nee, want als het aan de orde is wil ik bespreken wat voor mij het beste is

$4 \quad$ nee, want ik bepaal tegen die tijd zelf wel wat ik wil

5 anders, namelijk

22d Het verzorgingshuis heeft beleid op het gebied van euthanasie. Bent u daarover geïnformeerd

$1 \quad \mathrm{ik}$ ben daar niet van op de hoogte (verder met 22f)

2 ik ben op de hoogte van het euthanasiebeleid

3 ik heb een verklaring getekend over euthanasie

$4 \quad$ anders, namelijk

22e Indien u WEL op de hoogte bent van het euthanasiebeleid, wat vindt u daar van

$1 \quad$ ik praat daar liever niet over

2 ik kan me daar wel in vinden

$3 \quad i k$ vind dat mijn wens gerespecteerd moet worden

$4 \quad$ als het aan de orde is wil ik bespreken wat het beste voor mij is

5 als het aan de orde is bepaal ik zelf wat ik wil

6 anders, namelijk

$22 \mathrm{f}$ Indien $\mathrm{u}$ NIET op de hoogte bent, had u wel geïnformeerd willen worden

$1 \quad \mathrm{ja}$, want ik vind dat mijn wens gerespecteerd dient te worden 
$\mathrm{ja}$, ik wil weten hoe de instelling hier mee omgaat, zodat ik weet waar ik aan toe ben

3 nee, want als het aan de orde is wil ik het bespreken wat voor mij het beste is

$4 \quad$ nee, want ik bepaal tegen die tijd zelf wel wat ik wil

5 anders, namelijk

23a Weet u dat het verzorgingshuis een cliëntenraad heeft Ja/nee

23b Zo ja, hoe goed bent $u$ op de hoogte van wat ze doen (meerdere antwoorden mogelijk)

$1 \quad$ ik volg dat niet zo

2 ik lees de verslagen van de cliëntenraad

3 ik ga ieder jaar naar de algemene vergadering

$4 \quad$ ik draag wel eens punten aan voor het overleg van de cliëntenraad

5 anders, namelijk

23c Bent u tevreden over het functioneren van de cliëntenraad

I.zeer tevreden;2.redelijk tevreden;3.noch tevreden, noch ontevreden;4.tamelijk ontevreden;5.zeer ontevreden; 6 .n.v.t.

\section{Keuzevrijheid van bewoners bij de regels en gewoonten van het verzorgingshuis}

24a Wat vindt $u$ van de dagindeling van het verzorgingshuis

1 het is goed dat ik weet waar ik me aan te houden heb

2 ik kan hierbinnen voldoende mijn eigen gang gaan

3 deze sluit niet aan bij mijn dagritme/daginvulling

$4 \quad \mathrm{ik}$ zou graag zien dat deze meer aan mijn wensen zou worden aangepast

5 in overleg wordt deze aan mijn wensen aangepast

$6 \quad$ ik houd mij er niet aan, ik ga mijn eigen gang

7 anders, namelijk

24b Bent u tevreden over de huidige dagindeling

1.zeer tevreden; 2 .redelijk tevreden; 3 .noch tevreden,noch ontevreden; 4 .niet tevreden; 5 .zeer ontevreden;6.n.v.t.

25a Heeft het verzorgingshuis een menucommissie Ja/nee/weet ik niet

$25 \mathrm{~b}$ Indien u met ja hebt geantwoord, wat merkt $\mathrm{u}$ van de menucommissie

I de menucommissie laat nooit van zich horen

2 de menucommissie laat weten waar ze mee bezig is

3 ik heb de menucommissie wel eens ingeschakeld

4 anders, namelijk

25c Wat vindt $u$ de taak van een menucommissie

1 de menucommissie let op de kwaliteit van de voeding

2 de menucommissie doet voorstellen over de menukeuze

3 de menucommissie kiest de menu's uit

4 anders, namelijk

26a Wat vindt u van de mogelijkheid tot menukeuze 
1 het is fijn dat er keuzemogelijkheden zijn

2 binnen de menumogelijkheden vind $i k$ voldoende van mijn gading

3 in overleg kan het menu altijd aan mijn wensen worden aangepast

$4 \quad$ ik vind dat het menu meer moet zijn afgestemd op mijn wensen

5 anders, namelijk

26b Bent u tevreden over de huidige menu's

1.zeer tevreden;2.redelijk tevreden;3.noch tevreden, noch ontevreden; 4 . niet tevreden;5.zeer ontevreden;6.n.v.t.

27a Wat vindt $u$ van huisregels in het verzorgingshuis

1 doordat de instelling huisregels opstelt weten de bewoners wat kan en wat niet kan

2 de huisregels van de instelling moeten de bewoners voldoende ruimte bieden

3 de regels moeten samen met de bewoners worden opgesteld en bijgesteld

$4 \quad$ regels moeten voornamelijk door de bewoners worden opgesteld

5 er moeten geen huisregels voor bewoners worden opgesteld

6 anders, namelijk

27b Bent u tevreden over de huidige huisregels

1.zeer tevreden;2.redelijk tevreden;3.noch tevreden, noch ontevreden;4. niet tevreden;5.zeer ontevreden; 6.n.v.t.

28a Wat vindt u ervan dat de instelling een activiteitenprogramma opstelt voor de bewoners

1 het is goed dat de instelling dat voor de bewoners doet

2 het programma moet wel voldoende ruimte bieden voor speciale wensen

3 het programma moet in samenspraak met de bewoners worden opgesteld

4 het programma moet door de bewoners te worden opgesteld en niet door het verzorgingshuis

5 er moet geen programma voor bewoners worden opgesteld, ieder regelt dat maar voor zichzelf

6 anders, namelijk

28b Bent u tevreden over het huidig activiteitenprogramma

1.zeer tevreden;2.redelijk tevreden;3.noch tevreden, noch ontevreden; 4 . niet tevreden;5.zeer ontevreden;6.n.v.t.

\section{Opvattingen over de houding van verzorgende medewerkers}

29 De medewerkers benaderen mij heel attent

1: ja altijd; 2 : ja meestal wel 3 : soms wel, soms niet 4 : vaak niet 5 : nooit 6 : n.v.t.

30 De medewerkers houden rekening met mijn wensen en behoeften

1: ja altijd; 2: ja meestal wel 3 : soms wel, soms niet 4 : vaak niet 5: nooit 6 : n.v.t.

31 Als je een medewerker nodig hebt, is deze beschikbaar 
L: ja altijd; 2: ja meestal wel 3 : soms wel, soms niet 4 : vaak niet 5 : nooit 6 : n.v.t.

I: ja altijd; 2: ja meestal wel 3 : soms wel, soms niet 4 : vaak niet 5 : nooit 6 : n.v.t.

33 De medewerkers betuttelen mij

I: ja altijd; 2: ja meestal wel 3 : soms wel, soms niet 4 : vaak niet 5 : nooit 6 : n.v.t.

34 De medewerkers respecteren mij

I: ja altijd: 2: ja meestal wel 3 : soms wel, soms niet 4 : vaak niet 5 : nooit 6 : n.v.t.

35 De medewerkers bekommeren zich om $\mathrm{mij}$

1: ja altijd; 2 : ja meestal wel 3 : soms wel, soms niet 4 : vaak niet 5 ; nooit 6 : n.v.t.

36 De medewerkers hebben tijd voor mij

1: ja altijd; 2 : ja meestal wel 3 : soms wel, soms niet 4 : vaak niet 5 : nooit 6 : n.v.t.

37 De medewerkers vinden dat ik zelf moet doen wat ik zelf kan doen

I: ja altijd; 2 : ja meestal wel 3 : soms wel, soms niet 4 : vaak niet 5 : nooit 6 : n.v.t.

38 De medewerkers vragen na of ik tevreden ben over de zorg die ze bieden

1: ja altijd; 2: ja meestal wel 3 : soms wel, soms niet 4 : vaak niet 5 : nooit 6 : n.v.t.

39 De medewerkers omringen mij met veel zorg

I: ja altijd; 2: ja meestal wel 3 : soms wel, soms niet 4 : vaak niet 5: nooit 6 : n.v.t.

40 De medewerkers komen afspraken na

1: ja altijd; 2: ja meestal wel 3 : soms wel, soms niet 4 : vaak niet 5 : nooit 6 : n.v.t.

41 Er wordt rekening mee gehouden als ik het met een bepaalde medewerker moeilijk kan vinden

I: ja altijd; 2: ja meestal wel 3 : soms wel, soms niet 4 : vaak niet 5 : nooit 6 : n.v.t.

42 De medewerkers vragen of zij hulp moeten geven (helpen niet ongevraagd)

1: ja altijd; 2 : ja meestal wel 3 : soms wel, soms niet 4 : vaak niet 5 : nooit 6 : n.v.t.

43 De medewerkers weten mij te overtuigen iets tegen heug en meug te doen, waar ik achteraf blij mee ben

1: ja altijd; 2: ja meestal wel 3 : soms wel, soms niet 4 : vaak niet 5 : nooit 6 : n.v.t.

44 De medewerkers overleggen met mij op welk tijdstip ik geholpen wil worden

I: ja altijd; 2: ja meestal wel 3 : soms wel, soms niet 4 : vaak niet 5 : nooit 6 : n.v.t.

De medewerkers kennen mij zo goed dat ze soms besluiten voor mij nemen waar ik achteraf blij mee ben 
1: ja altijd; 2: ja meestal wel 3 : soms wel, soms niet 4 : vaak niet 5 ; nooit 6 : n.v.t.

46 De medewerkers gaan uit van wat ik wil doen, niet van wat ik kan doen

1: ja altijd; 2: ja meestal wel 3 : soms wel, soms niet 4 : vaak niet 5: nooit 6 : n.v.t.

47 De medewerkers houden er rekening mee dat ik me niet alle dagen hetzelfde voel

1: ja altijd; 2: ja meestal wel 3 : soms wel, soms niet 4 : vaak niet 5: nooit 6 : n.v.t.

48 De medewerkers merken tegen welke beperkingen ik aanloop in mijn woning

I: ja altijd; 2 : ja meestal wel 3 : soms wel, soms niet 4 : vaak niet 5 : nooit 6 : n.v.t.

49 De medewerkers komen ongevraagd mijn woning binnen

I: ja altijd; 2: ja meestal wel 3 : soms wel, soms niet 4 : vaak niet 5 : nooit 6 : n.v.t.

50 De medewerkers zijn vakkundig

$\mathrm{I}$ : ja altijd; 2 : ja meestal wel 3 : soms wel, soms niet 4 : vaak niet 5 : nooit 6 : n.v.t.

\section{Zorgvragen en beoordeling van het zorgaanbod}

51 Mate van zorgbehoevendheid en tevredenheid over de verleende zorg

a.I Ik heb hulp nodig bij de lichamelijke verzorging

1: ja altijd; 2 : ja meestal wel 3 : soms wel, soms niet 4 : vaak niet 5 : nooit 6 : n.v.t.

a.2 Hoe tevreden bent u over deze hulp:

1.zeer tevreden;2.redelijk tevreden;3.noch tevreden, noch ontevreden;4.niet tevreden;5.zeer ontevreden;6.n.v.t.

b.1 Ik heb hulp nodig bij het eten en drinken

1: ja altijd; 2 : ja meestal wel 3 : soms wel, soms niet 4 : vaak niet 5 : nooit 6 : n.v.t.

b.2 Hoe tevreden bent u over deze hulp:

1.zeer tevreden;2.redelijk tevreden; 3 .noch tevreden, noch ontevreden; 4 .niet tevreden;5.zeer ontevreden;6.n.v.t.

c.1 Ik heb hulp nodig bij de toiletgang

1: ja altijd; 2: ja meestal wel 3 : soms wel, soms niet 4 : vaak niet 5 ; nooit 6 : n.v.t.

c.2 Hoe tevreden bent u over deze hulp:

1.zeer tevreden;2.redelijk tevreden;3.noch tevreden, noch ontevreden; 4 .niet tevreden; 5 .zeer ontevreden;6.n.v.t.

d.I Ik heb hulp nodig bij het (voort)bewegen / ergens naar toe gaan

1: ja altijd; 2 : ja meestal wel 3 : soms wel, soms niet 4 : vaak niet 5 : nooit 6 : n.v.t.

d.2 Hoe tevreden bent u over deze hulp:

1.zeer tevreden;2.redelijk tevreden;3.noch tevreden, noch ontevreden;4.niet tevreden;5.zeer ontevreden;6.n.v.t. 
e.1 Ik heb hulp nodig bij het schoonhouden van het appartement

1: ja altijd; 2: ja meestal wel 3 : soms wel, soms niet 4 : vaak niet 5 : nooit 6 : n.v.t.

e.2 Hoe tevreden bent u over deze hulp:

1.zeer tevreden; 2 .redelijk tevreden; 3 .noch tevreden, noch ontevreden; 4 .niet tevreden;5.zeer ontevreden;6.n.v.t.

f.1 Ik heb hulp nodig bij allerhande administratieve zaken

1: ja altijd; 2: ja meestal wel 3 : soms wel, soms niet 4 : vaak niet 5 : nooit 6 : n.v.t.

f.2 Hoe tevreden bent u over deze hulp:

1.zeer tevreden;2.redelijk tevreden;3.noch tevreden, noch ontevreden;4.niet tevreden;5.zeer ontevreden;6.n.v.t.

g.I Ik heb hulp nodig bij het verwerken van de situatie waarin ik verkeer (lichamelijk, psychisch) 1: ja altijd; 2: ja meestal wel 3 : soms wel, soms niet 4 : vaak niet 5 : nooit 6 : n.v.t.

g.2 Hoe tevreden bent u over deze hulp:

I.zeer tevreden; 2 .redelijk tevreden; 3 .noch tevreden, noch ontevreden; 4 .niet tevreden; 5 .zeer ontevreden;6.n.v.t.

h.1 Ik heb hulp nodig bij het maken van contact met andere mensen

1: ja altijd; 2 : ja meestal wel 3 : soms wel, soms niet 4 : vaak niet 5 : nooit 6 : n.v.t.

h.2 Hoe tevreden bent u over deze hulp:

I.zeer tevreden;2.redelijk tevreden;3.noch tevreden, noch ontevreden; 4 .niet tevreden; 5 .zeer ontevreden;6.n.v.t.

i.I Ik heb hulp nodig bij

I: ja altijd; 2: ja meestal wel 3 : soms wel, soms niet 4 : vaak niet 5 : nooit 6 : n.v.t.

i.2 Hoe tevreden bent $u$ over deze hulp:

1.zeer tevreden;2.redelijk tevreden;3.noch tevreden, noch ontevreden;4.niet tevreden;5.zeer ontevreden;6.n.v.t.

j.1 Ik heb hulp nodig bij

I: ja altijd; 2: ja meestal wel 3 : soms wel, soms niet 4 : vaak niet 5 ; nooit 6 : n.v.t.

j.2 Hoe tevreden bent u over deze hulp:

1.zeer tevreden; 2 .redelijk tevreden; 3 .noch tevreden, noch ontevreden;4.niet tevreden;5.zeer ontevreden;6.n.v.t.

\section{Kwaliteit van leven}

$52 \quad$ Hoe kijkt u nu tegen uw leven aan

I ik ben van mening dat ik mijn leven geleefd heb en dat het voor mij niet meer hoeft

2 ondanks mijn behoefte aan verzorging wil ik nog zo veel mogelijk van het leven maken

3 dat ik voor sommige dingen afhankelijk ben betekent voor mij niet dat ik mij volledig 
afhankelijk voel

$4 \quad$ ik merk dat ik als ik meer hulp nodig heb bij de lichamelijke zorg, ik me ook op andere gebieden afhankelijker opstel

$5 \quad$ ik voel me gelukkig met mijn situatie

6 anders, namelijk

\section{Woon-leefklimaat van het verzorgingshuis}

$53 \quad$ lk voel me binnen dit huis op mijn gemak

1: ja altijd; 2 : ja meestal wel 3 : soms wel, soms niet 4 : vaak niet 5 : nooit 6 : n.v.t.

54a Ik word door medebewoners vriendelijk bejegend

1: ja altijd; 2 : ja meestal wel 3 : soms wel, soms niet 4 : vaak niet 5 : nooit 6 ; n.v.t.

54b Ik maak graag contact met medebewoners

1: ja altijd; 2: ja meestal wel 3 : soms wel, soms niet 4 : vaak niet 5 : nooit 6 : n.v.t.

$55 \quad$ Ik vind het vervelend als anderen zien dat ik geholpen moet worden bij eten etc.

1: ja altijd; 2: ja meestal wel 3 : soms wel, soms niet 4 : vaak niet 5 : nooit 6 : n.v.t.

56a Ik voel me veilig in en om het huis (stoepjes, niet bang te vallen etc.)

1: ja altijd; 2 : ja meestal wel 3 : soms wel, soms niet 4 : vaak niet 5 : nooit 6 : n.v.t.

56b Er is voldoende aandacht voor behoefte aan geestelijke zorg

I: ja altijd; 2 : ja meestal wel 3 : soms wel, soms niet 4 : vaak niet 5 : nooit 6 : n.v.t.

57 In het verzorgingshuis kom ik toe aan dingen die ik prettig vind

I: ja altijd; 2 : ja meestal wel 3 : soms wel, soms niet 4 ; vaak niet 5 : nooit 6 : n.v.t.

58 In het verzorgingshuis moet ik dingen laten die ik prettig vind

1: ja altijd; 2: ja meestal wel 3 : soms wel, soms niet 4 : vaak niet 5 : nooit 6 : n.v.t.

59 In dit huis wordt veel overleg gepleegd met de bewoners

1: ja altijd; 2: ja meestal wel 3 : soms wel, soms niet 4 : vaak niet 5 : nooit 6 : n.v.t.

$60 \quad$ Ik kan in dit huis mijn eigen gang gaan

1: ja altijd; 2 : ja meestal wel 3 : soms wel, soms niet 4 : vaak niet 5 : nooit 6 : n.v.t.

61 Al met al ben ik tevreden om in dit verzorgingshuis te leven

1: ja altijd; 2: ja meestal wel 3 : soms wel, soms niet 4 : vaak niet 5 : nooit 6 : n.v.t.

62 Ik zou dit verzorgingshuis aan anderen aanraden

1: ja altijd; 2 : ja meestal wel 3 : soms wel, soms niet 4 : vaak niet 5 : nooit 6 : n.v.t.

63 Wat ik heel plezierig vind in dit verzorgingshuis is: 
64 Wat echt anders zou moeten in dit verzorgingshuis is:

65 Welke wensen heeft u nog t.a.v.:

Aanpassingen in uw woning nee/ja, $\mathrm{nl}$.

Aandacht van de medewerkers nee/ja, $\mathrm{nl}$.

Voorzieningen in huis

Verzorging

Activiteiten

Contact met medebewoners

Dagindeling

nee/ja, nl.

nee/ja, nl.

nee/ja, nl.

nee/ja, nl.

nee/ja, nl.

Naar buiten kunnen gaan

Andere zaken

nee/ja, $\mathrm{nl}$.

namelijk: 
Vragenlijst voor het verzorgend personeel

Vragenlijst ingevuld dd:

\section{Achtergrondgegevens zorgverlener}

a wat is jouw leeftijd

b geslacht

c afdeling

d zorgcentrum

e functie

$f$ aantal jaren werkervaring

$\mathrm{g}$ omvang huidig dienstverband

h laatst genoten opleiding jaar

$\mathrm{m} / \mathrm{v}$ (omcirkel het juiste antwoord)

verzorgingshuis $\mathrm{I} /$ verzorgingshuis 2 /verzorgingshuis 3

0-1 jaar; $1-3$ jaar; 3-5 jaar; $5-10$ jaar; langer dan 10 jaar uren per week

\section{Verwachtingen van bewoners bij plaatsing in het verzorgingshuis}

Met welke verwachtingen gaan volgens jou de bewoners naar het verzorgingshuis (omcirkel die verwachtingen die naar jouw indruk het belangrijkst gevonden worden)

I hulp bij de verzorging

2 hulp bij het huishouden (eten klaarmaken, schoonmaken etc.)

3 contacten met medebewoners

$4 \quad$ een aanbod aan activiteiten

$5 \quad$ een gevoel van veiligheid

6 zelfstandig kunnen wonen

$7 \quad$ attente medewerkers om hen heen

8 een gevoel van rust

9 een woning die naar eigen smak kan worden ingericht

10 iets kunnen ondernemen

11 anders, namelijk

\section{Opvattingen over informatievoorziening}

Hoe goed zijn de bewoners geïnformeerd over de regels van het verzorgingshuis met betrekking tot de inrichting van het appartement, het al dan niet toestaan van huisdieren ed.

$1 \quad$ ze zijn goed op de hoogte

$2 \quad$ ze zijn voldoende op de hoogte

3 ze zijn onvoldoende op de hoogte

$4 \quad$ ze zijn niet op de hoogte

5 weet ik niet, omdat

b Hebben de bewoners een verzorgings- of bewonersovereenkomst getekend ja/nee weet ik niet, omdat 
c1 Weten bewoners dat een zorgdossier over hen wordt bijgehouden

weet ik niet, omdat

c 2 Weten de bewoners wat er in hun zorgdossier staat

1 ze zijn goed op de hoogte

$2 \quad$ ze zijn voldoende op de hoogte

3 ze zijn onvoldoende op de hoogte

4 ze zijn niet op de hoogte

5 weet ik niet, omdat

c 3 Worden de bewoners betrokken bij het opstellen en bijstellen van hun zorgdossier/zorgplan

1 ze worden daar niet bij betrokken

2 ze worden er wel bij betrokken, namelijk: (omcirkel de antwoorden die van toepassing zijn)

$2.1 \mathrm{ze}$ worden regelmatig geïnformeerd over wat er in staat

2.2 ze weten dat ze de gegevens kunnen inzien

2.3 ze lezen het dossier af en toe door

2.4 ze vullen het dossier af en toe zelf aan

2.5 in overleg met hen wordt het zorgdossier/zorgplan opgesteld

c 4 Wordt aan bewoners om toestemming gevraagd voordat het zorgplan wordt uitgevoerd

1: ja, altijd; 2 . ja, meestal wel; 3 . soms wel, soms niet; 4, vaak niet; 5 : nooit; 6: weet ik niet, omdat. .

c 5 Ben je tevreden over de wijze waarop de bewoners bij het zorgdossier worden betrokken

I. zeer tevreden; 2 , redelijk tevreden; 3 , noch tevreden, noch ontevreden; 4 . tamelijk ontevreden;

5. zeer ontevreden

d 1 Het verzorgingshuis heeft beleid op het gebied van reanimeren. Zijn de bewoners daarvan op de hoogte

I ze zijn goed op de hoogte

2 ze zijn voldoende op de hoogte

3 ze zijn onvoldoende op de hoogte

$4 \quad$ ze zijn niet op de hoogte

5 weet ik niet, omdat

d 2 Vind je dat de bewoners geïnformeerd moeten worden over het reanimatiebeleid

1 ja, want ik vind dat hun wens gerespecteerd dient te worden

2 ja, want zij willen tijdig weten hoe het verzorgingshuis hier mee omgaat, zodat zij weten waar ze aan toe zijn

3 nee, want pas als het aan de orde komt, willen zij bespreken wat het beste voor hen is

4 nee, want tegen de tijd dat het aan de orde komt, bepalen de bewoners zelf wel wat het beste is

5 anders, namelijk

6 weet ik niet, omdat

e 1 Het verzorgingshuis heeft beleid op het gebied van euthanasie. Zijn de bewoners daarvan op de hoogte 
ze zijn goed op de hoogte

2 ze zijn voldoende op de hoogte

3 ze zijn onvoldoende op de hoogte

4 ze zijn niet op de hoogte

5 weet ik niet, omdat

e2

Vind je dat de bewoners geïnformeerd moeten worden over het euthanasiebeleid

$1 \quad \mathrm{ja}$, want ik vind dat hun wens gerespecteerd dient te worden

2 ja, want zij willen tijdig weten hoe het verzorgingshuis hier mee omgaat, zodat zij weten waar ze aan toe zijn

3 nee, want pas als het aan de orde komt, willen zij bespreken wat het beste voor hen is

4 nee, want tegen de tijd dat het aan de orde komt, bepalen de bewoners zelf wel wat het beste is

5 anders, namelijk

6 weet ik niet, omdat

f1 Zijn de bewoners bekend met de functie van de cliëntenraad ja/nee weet ik niet, omdat

f2 Wat vind je van het functioneren van de cliëntenraad

$1 \quad$ zij slagen er in de belangen van de bewoners te behartigen

2 zij zouden nog meer moeten opkomen voor de belangen van de bewoners

3 er wordt door het verzorgingshuis te weinig naar de cliëntenraad geluisterd

$4 \quad$ zij bemoeien zich met teveel zaken

5 weet ik niet, omdat

\section{Keuzevrijheid van bewoners en de regels en gewoonten van het verzorgingshuis}

Hoe sta je tegenover kritiek van bewoners in het verzorgingshuis

1 bewoners moeten uitgenodigd worden om kritisch te zijn

2 bewoners moeten zelf kritisch durven zijn

3 bewoners moeten weten dat kritiek geven niet altijd terecht is

4 bewoners moeten weten dat het verzorgingshuis niets kan met kritiek

5 weet ik niet, omdat

b Vind je dat de bewoners invloed moeten uitoefenen op de regels van het verzorgingshuis

I ja, ik vind dat over de regels door de bewoners moet worden beslist

2 ja, ik vind dat de bewoners medezeggenschap moeten hebben over de regels van het verzorgingshuis

3 nee, ik vind dat hun invloed beperkt moet zijn

4 nee, ik vind dat het verzorgingshuis de regels moet bepalen

5 weet ik niet, omdat

c Wat vind je ervan dat het verzorgingshuis een dagindeling voor de bewoners heeft

1 ik vind het goed, omdat bewoners dan weten waar ze zich aan te houden hebben 
$i \mathrm{k}$ vind dat het verzorgingshuis de dagindeling meer aan de wensen van bewoners moet aanpassen

$3 \quad i k$ vind dat de dagindeling in overleg met de bewoners moet worden opgesteld

$4 \quad i k$ vind dat de bewoners zelf een dagindeling moeten maken en niet het verzorgingshuis

$5 \quad \mathrm{ik}$ vind dat bewoners zich niet aan de dagindeling hoeven te houden en hun eigen gang moeten kunnen gaan

weet ik niet, omdat

d Wat vind je ervan dat de instelling een activiteiten programma voor de bewoners opstelt

1 ik vind het goed dat de instelling dat voor de bewoners doet
2
3
ik vind dat de instelling het programma in samenspraak met bewoners moet opstellen
ik vind dat het programma door bewoners moet worden opgesteld en niet door het
verzorgingshuis
ik vind dat er geen programma voor bewoners moet worden opgesteld
5

\section{Opvattingen over de houding van verzorgende medewerkers}

Hieronder staan een aantal punten genoemd over de houding van verzorgende medewerkers t.o.v. de bewoners.

Als op jouw afdeling door het verzorgend personeel een houdingsaspect 'altijd' getoond wordt, omcirkel je antwoordcategorie 1, enz.

$1=$ altijd $\quad 2$ =meestal $\quad 3$ =soms wel en soms niet $\quad 4$ =vaak niet $\quad 5$ = nooit

\section{Houdingsaspect}

$I$ attent benaderen van bewoners

2 rekening houden met de wensen en behoeften van de bewoners

123345

3 direct beschikbaar zijn voor bewoners

$\begin{array}{lllll}1 & 2 & 3 & 4 & 5\end{array}$

4 steun bieden aan bewoners

5 bewoners betuttelen

6 bewoners met respect benaderen

$\begin{array}{lllll}1 & 2 & 3 & 4 & 5\end{array}$

$\begin{array}{lllll}1 & 2 & 3 & 4 & 5\end{array}$

12345

7 zich om de bewoner bekommeren

$\begin{array}{lllll}1 & 2 & 3 & 4 & 5\end{array}$

8 tijd nemen voor de bewoner

9 bij het geven van hulp uitgaan van het tempo van de bewoner

$\begin{array}{lllll}1 & 2 & 3 & 4 & 5\end{array}$

10 wat de bewoner zelf kan doen, de bewoner ook zelf laten doen

$\begin{array}{lllll}1 & 2 & 3 & 4 & 5\end{array}$

$\begin{array}{lllll}1 & 2 & 3 & 4 & 5\end{array}$

11 aan de bewoner vragen of hij tevreden is over de verleende zorg

12345

12 zorgzaam zijn voor de bewoner

$\begin{array}{lllll}1 & 2 & 3 & 4 & 5\end{array}$

13 doen voor de bewoner wat je hebt beloofd

$\begin{array}{lllll}1 & 2 & 3 & 4 & 5\end{array}$

14 er rekening mee houden als een bewoner liever niet door een collega

12345 geholpen wil worden

15 de bewoner ongevraagd helpen

$\begin{array}{lllll}1 & 2 & 3 & 4 & 5\end{array}$

16 de bewoner voor zijn bestwil overtuigen mee te werken

$\begin{array}{lllll}1 & 2 & 3 & 4 & 5\end{array}$

$\begin{array}{lllll}1 & 2 & 3 & 4 & 5\end{array}$ 
17 met de bewoner overleggen over het tijdstip waarop hulp gegeven wordt

18 besluiten voor de bewoner nemen voor zijn bestwil

$\begin{array}{lllll}1 & 2 & 3 & 4 & 5\end{array}$

19 uitgaan van wat de bewoner wil doen, niet van wat hij kan doen

$\begin{array}{lllll}1 & 2 & 3 & 4 & 5\end{array}$

20 iedere dag opnieuw nagaan hoe het met de bewoner gesteld is

21 nagaan of de bewoner aanpassingen in zijn woning nodig heeft

$\begin{array}{lllll}1 & 2 & 3 & 4 & 5\end{array}$

22 snel oplossen van mankementen of gebreken in de woning van bewoners

$\begin{array}{lllll}1 & 2 & 3 & 4 & 5\end{array}$

23 ongevraagd de woning van de bewoner binnengaan

$\begin{array}{lllll}1 & 2 & 3 & 4 & 5\end{array}$

24 de bewoner mogelijkheden aanreiken waar hij uit kan kiezen

$\begin{array}{lllll}1 & 2 & 3 & 4 & 5\end{array}$

25 de bewoner stimuleren activiteiten te ontplooien

$\begin{array}{lllll}1 & 2 & 3 & 4 & 5\end{array}$

26 de bewoner met rust laten

$\begin{array}{lllll}1 & 2 & 3 & 4 & 5\end{array}$

27 de belangen van de bewoner behartigen

$\begin{array}{lllll}1 & 2 & 3 & 4 & 5\end{array}$

28 de bewoner uitnodigen zijn wensen kenbaar te maken

$\begin{array}{lllll}1 & 2 & 3 & 4 & 5\end{array}$

\section{Zorgvragen en beoordeling van het zorgaanbod}

Hieronder staan een aantal onderwerpen genoemd over de zorg voor bewoners. Als je vindt dat er op jouw afdeling door het verzorgend personeel aan een onderwerp 'veel aandacht' wordt besteed, omcirkel je antwoordcategorie I, enz.

$1=$ veel aandacht $\quad 2$ = voldoende aandacht $\quad 3$ = weinig aandacht $\quad 4=$ geen aandacht "nvt" omcirkel je als het onderwerp niet van toepassing is op jouw afdeling, bijvoorbeeld omdat om de zorg of dienst niet gevraagd wordt

I aandacht voor hulpvragen bij de lichamelijke verzorging

2 aandacht voor hulpvragen bij het eten en drinken

3 aandacht voor hulpvragen bij de toiletgang

4 aandacht voor hulpvragen bij het (voort)bewegen / het zich verplaatsen

5 aandacht voor de vraag om hulp bij het schoonhouden van het appartement

6 aandacht voor de vraag om hulp bij allerhande administratieve zaken

7 aandacht voor de vraag om hulp bij het verwerken van de (lichamelijke, geestelijke) situatie waarin bewoners verkeren

8 aandacht voor de vraag om vertrouwde contacten

$\begin{array}{lllll}1 & 2 & 3 & 4 & \mathrm{nvt}\end{array}$

9 aandacht voor de behoefte om zelf invulling te kunnen geven aan het leven in het verzorgingshuis

10 aandacht voor ondersteuning bij het omgaan met afhankelijkheid

11 aandacht voor ondersteuning bij vragen op het gebied van zingeving

\section{Opvattingen over het leven van de bewoners in het verzorgingshuis}

Onder a $t / m$ t kun je aangeven hoe jij aankijkt tegen het leven van de bewoners die in dit verzorginghuis wonen 
Ik heb de indruk dat de bewoners, ondanks bun eventuele behoefte aan verzorging nog zo veel mogelijk van het leven willen maken

I: ja zeker; 2: ja toch wel $\quad 3$ : soms wel, soms niet $\quad 4$ : vaak niet 5 : zeker niet

Ik heb de indruk dat het afhankelijk zijn voor de bewoners niet betekent dat zij zich ook afhankelijk voelen
1: ja zeker; 2 : ja toch wel
3: soms wel, soms niet
4: vaak niet 5 : zeker niet

d Ik heb de indruk dat wanneer bewoners meer hulp nodig hebben bij de lichamelijke zorg, zij zich ook op andere gebieden afhankelijker opstellen

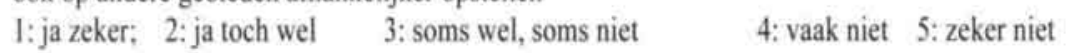

e Ik heb de indruk dat de bewoners zich gelukkig voelen met hun situatie

1: ja zeker; 2: ja toch wel $\quad 3$ : soms wel, soms niet $\quad 4$ : vaak niet 5 : zeker niet

f I heb de indruk dat bewoners in dit verzorgingshuis zich op hun gemak voelen

1: ja zeker; 2: ja toch wel 3 : soms wel, soms niet $\quad 4$ : vaak niet 5 : zeker niet

g Ik heb de indruk dat bewoners door medebewoners vriendelijk bejegend worden

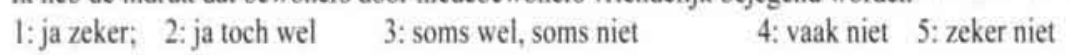

$\mathrm{h} \quad$ Ik heb de indruk dat bewoners graag contact maken met medebewoners

1: ja zeker; 2: ja toch wel 3: soms wel, soms niet 4: vaak niet 5 : zeker niet

i lk heb de indruk dat het voor bewoners vervelend is als anderen zien dat zij geholpen moeten worden bij het eten ed.

1: ja zeker; 2: ja toch wel $\quad 3$ : soms wel, soms niet $\quad 4$ : vaak niet 5 : zeker niet

j I $\quad$ heb de indruk dat de bewoners zich veilig voelen in en het verzorgingshuis

1: ja zeker; 2: ja toch wel $\quad 3$ : soms wel, soms niet $\quad 4$ : vaak niet 5 : zeker niet

k Ik heb de indruk dat de bewoners behoefte hebben aan geestelijke zorg

1: ja zeker; 2: ja toch wel $\quad 3$ : soms wel, soms niet $\quad 4$ : vaak niet 5 : zeker niet

$1 \quad$ lk heb de indruk dat de bewoners in het verzorgingshuis toekomen aan dingen die zij prettig vinden

1: ja zeker; 2: ja toch wel 3: soms wel, soms niet 4: vaak niet 5 : zeker niet

$\mathrm{m} \quad \mathrm{lk}$ heb de indruk dat de bewoners in het verzorgingshuis dingen moeten laten die zij prettig vinden

1: ja zeker; 2: ja toch wel 3: soms wel, soms niet $\quad 4$ : vaak niet 5 : zeker niet

$\mathrm{n} \quad \mathrm{lk}$ heb de indruk dat de bewoners er behoefte aan hebben dat er met hen overlegd wordt 


\section{1: ja zeker; 2 : ja toch wel $\quad 3$ : soms wel, soms niet $\quad 4$ : vaak niet 5 : zeker niet}

I k heb de indruk dat de bewoners in het verzorgingshuis hun eigen gang willen gaan

1: ja zeker; 2: ja toch wel 3: soms wel, soms niet $\quad 4$ : vaak niet 5 : zeker niet

Ik heb de indruk dat bewoners al met al een plezierig leven hebben in dit verzorgingshuis
1: ja zeker; 2: ja toch wel
3: soms wel, soms niet
4: vaak niet 5 ; zeker niet

Ik zou het verzorgingshuis aan zorgbehoevende ouderen aanraden
1: ja zeker; 2: ja toch wel
3: soms wel, soms niet
4: vaak niet 5 : zeker niet

Zou je als je later veel zorg nodig hebt in zo'n verzorgingshuis willen wonen als waar je nu werkt

1. ja, want het leven en wonen in zo'n verzorgingshuis is plezierig

2. nee, want het leven en wonen in zo'n verzorgingshuis is geen pretje

3. anders, namelijk.

Wil je hieronder een paar zaken noemen die volgens jou heel plezierig zijn in dit verzorgingshuis:

Wil je hieronder een paar zaken noemen die volgens jou echt anders moeten in dit verzorgingshuis

\section{Opvattingen over het werken in het verzorgingshuis}

Wat is jouw algemene indruk van het beroep dat de bewoners doen op de zorgverleners

1 bewoners vragen veel te snel om hulp

2 bewoners doen zoveel mogelijk zelf wat ze zelf kunnen

3 bewoners vragen vaak te weinig om hulp

4 anders, namelijk.

b Het verzorgingshuis is volgens een contract met de zorgverzekeraar verplicht de autonomie van de bewoner te respecteren en te beschermen. Weet je wat daar mee bedoeld wordt en vind je dat het verzorgingshuis die opdracht goed, voldoende, onvoldoende of slecht nakomt. Licht jouw antwoord toe. 
mee bedoeld wordt en vind je dat het verzorgingshuis die opdracht goed, voldoende, onvoldoende of slecht nakomt. Licht jouw antwoord toe.

Vind je dat er organisatorische omstandigheden zijn die jouw werk moeilijk maken. Licht jouw antwoord toe.

Vind je dat er organisatorische omstandigheden zijn die een positieve invloed hebben op jouw werk. Licht jouw antwoord toe. 
In het Overzicht Zorgafspraken worden gegevens genoteerd die van belang zijn voor een plezierig, waardevol en zinvol verblijf van de bewoner in het verzorgingshuis. Wat plezierig, waardevol en zinvol is, is voor ieder mens verschillend. Elk Overzicht Zorgafspraken bevat dan ook andere informatie.

Het Overzicht Zorgafspraken wordt ingevuld naar aanleiding van een gesprek dat de e.v.v.er met de bewoner voert. Daarbij is het de bedoeling dat het gesprek zo open mogelijk gevoerd wordt; een gesprek van mens tot mens. Het Overzicht Zorgafspraken wordt ingevuld op basis van dit gesprek en niet omgekeerd; het gesprek moet niet gevoerd worden op basis van het Overzicht. Het moet met ander woorden geen 'vraag en antwoord sessie' zijn waarbij het Overzicht punt voor punt wordt ingevuld. Als dat wel gedaan wordt, is de kans groot dat in de Overzichten Zorgafspraken toch steeds dezelfde gegevens staan en dat 'een plezierig, waardevol en zinvol leven' op papier voor iedere persoon hetzelfde gaan inhouden.

Het Overzicht Zorgafspraken is ook geen anamnese - formulier, waarin je alleen gegevens noteert over ziektes of beperkingen die de bewoner heeft of ondervindt. Het is ook geen 'zorglijstje' of 'zorgkaart' waarop vooral staat beschreven welke lichamelijke zorg je moet geven en welke medicijnen de bewoner heeft. Als je het wel ziet als een anamnese - formulier of een zorgkaart, zul je ook zien dat de Overzichten Zorgafspraken veel op elkaar gaan lijken.

In het Overzicht Zorgafspraken vul je gegevens in die een goed beeld geven van wie de bewoner is. Om daar achter te komen kun je vragen aan de bewoner stellen, zoals wat hem bezighoudt; wat hij van belang vindt in zijn leven in het verzorgingshuis en wat er voor hem te beleven valt; hoe hij zijn leven indeelt; met wie hij graag contact onderhoudt; wat voor belangrijke gebeurtenissen of belevenissen hij heeft meegemaakt; waar hij tegen op ziet en waar hij naar uitkijkt; welke houding van personeelsleden hij op prijs stelt en welke niet; hoe hij het ervaart dat hij op anderen is aangewezen; of hij het op prijs stelt zoveel mogelijk met rust gelaten te worden of juist in contact met anderen wil komen; met wie hij graag in contact zou willen komen; waar hij van geniet en wat hem verdrietig maakt; of hij zichzelf kan zijn in het verzorgingshuis; of zijn woonruimte hem aanstaat en aan welke materiële zaken of spullen hij belang hecht; wat hij nog zou willen doen in zijn leven enz. enz. enz.

De antwoorden en reacties op dit soort vragen geven een goed beeld van de gedachtes van de bewoner, van zijn ervaringen en van dingen die hem aanspreken en beroeren, met ander woorden van wat voor mens hij is. Ze laten zien wat kenmerkend of karakteristiek is voor deze bewoner.

Misschien wil de bewoner niet graag te koop lopen met zijn levensgeschiedenis, maar hij zal gevoelig zijn voor het argument dat het verstrekken van informatie belangrijk is. Deze informatie geeft het personeel de kans om de bewoner zichzelf te laten zijn, om hem zijn waardigheid en eigenheid te kunnen laten houden. Het personeel weet daardoor waar het rekening mee kan houden in het contact met de bewoner. Ook als de bewoner minder in staat wordt voor zichzelf op te komen, wijst de informatie de zorgverlener de weg om de bewoner te beschermen en verantwoord handelingen of beslissingen van de bewoner over te nemen.

In onze visie op zorg proberen wij uit te gaan van keuzevrijheid en keuzemogelijkheden voor de bewoner. Daarom is het nodig te weten welke keuzes de bewoner wil maken. Bij het opstellen van het Overzicht Zorgafspraken vraagt de e.v.v.-er aan de bewoner welke keuzes hij wil maken. Daarbij gaat het om de vraag wat de bewoner graag zou willen. Onder de kop 'keuzes' staan bij de rubrieken in het Overzicht 
Zorgafspraken voorbeelden genoemd waar zoal aan gedacht kan worden, maar ook hier moet je er voor oppassen dat de voorbeelden geen eigen leven gaan leiden. Ook in de keuzes die iemand maakt, onderscheidt de ene persoon zich van de andere.

Zo kan een bewoner het van belang vinden er goed verzorgd uit te zien (=karakteristiek) en hij kan de keuze maken éénmaal per maand naar de kapper van het verzorgingshuis te gaan. Hij heeft ook de vrijheid en mogelijkheid om die keuze te maken en hij is niet afhankelijk van de medewerking van de zorgverlener om naar de kapper te gaan als hij voldoende mobiel is of als hij er door anderen naar toe wordt gebracht. Deze bewoner kan ook de keuze willen maken om eenmaal per week in bad te gaan. De bewoner heeft uiteraard de vrijheid om die keuze te maken, maar of de keuze ook mogelijk gemaakt kan worden, is de vraag. Het kan zijn dat de bewoner hulp nodig heeft bij het baden en dat de totale zorgvraag op de afdeling zo groot is, dat de e.v.v.-er het niet georganiseerd krijgt aan die keuze tegemoet te komen. Dat betekent niet dat de keuze dan maar niet wordt opgenomen in het Overzicht Zorgafspraken. Gezien de waarde die de bewoner toekent aan een goede lichaamsverzorging is de keuze te begrijpen. Er zal met de bewoner moeten worden overlegd hoe deze keuze zoveel mogelijk gehonoreerd kan worden.

In het Overzicht Zorgafspraken moeten ook de keuzes worden vermeld die de bewoner van het huis moet maken vanwege regelingen waar het huis aan gehouden is. Zo wil Vughterstede weten of de bewoner zijn was zelf verzorgt, of ze laat verzorgen. Wil hij de broodmaaltijden zelf regelen of ze door het huis laten aanreiken? Neemt hij graag aan activiteiten deel?

Veel bewoners willen bij een aantal zaken ondersteund worden. Onder de rubriek ondersteuningsbehoeften kan worden vermeld welke ondersteuning gevraagd wordt. Zo kan een bewoner het op prijs stellen dat de zorgverlener toeziet en in de buurt blijft als hij gast wandelen; het kan ook zijn dat hij de zorg voor het schoonhouden van het appartement aan de huishoudelijk medewerker moet overlaten. In het voorbeeld van hierboven kan de bewoner die er graag goed verzorgd uitziet behoefte hebben aan hulp bij het wassen en bij het aankleden. Een ondersteuningsbehoefte kan ook betrekking hebben op beslissingen die de bewoner wil maken. Zo kan een bewoner willen dat hij wordt aangespoord om zich tussen de andere bewoners te begeven; hij kan er van overtuigd willen worden dat hij zich aan een dieet houdt of hij kan het op prijs stellen dat de verzorging het contact met de familie onderhoudt en beslissingen neemt over de financiën van bewoner of over de verzorging van de was ed.

Bij het invullen van het Overzicht Zorgafspraken, en met name bij het invullen van de ondersteuningsbehoeften, moet de zorgverlening er zich goed van bewust zijn dat afspraken kunnen veranderen. Zo kan een bewoner die zich niet lekker voelt een paar dagen volledig op de zorg van de verzorgenden zijn aangewezen, terwijl die bewoner die steun anders niet nodig heeft. Het is daarom van belang om je steeds af te vragen of de behoefte aan ondersteuning veranderd is en of eerder gemaakte keuzes nog gelden.

De bewoner kan naast behoefte aan ondersteuning door de zorgverleners ook behoefte hebben aan inbreng van andere hulpverleners. Zo kan de bewoner zijn aangewezen op geneesmiddelen, therapie of therapeutische hulpmiddelen. Als daar bij éen of meer aspecten sprake van is, kan dat worden vermeld onder de rubriek interventiebehoefte/ behandelbehoefte. Voorbeelden zijn: het verzorgen van een stoma; het toedienen van oogdruppels, of van insuline; het ondersteunen van fysiotherapie; het geven van medicijnen tegen depressie en het raadplegen van de pastor.

Mochten bepaalde gegevens van de bewoner nog niet vermeld zijn, maar wel de aandacht verdienen, dan is het bij elk aspect mogelijk de rubriek verdere aandachtspunten in te vullen. 
Wanneer een bewoner mantelzorg heeft, dient dit op het daartoe ingericht deel van het overzicht zorgafspraken vermeld te worden.

Het overzicht zorgafspraken bevat ook een rubriek organisatorische belemmeringen. Hier worden die zorgafspraken (keuzes, ondersteuningsbehoeften, of interventie-/ behandelbehoeften) vermeld die niet gerealiseerd kunnen worden, omdat organisatorische of andere voorwaarden ontbreken. Bijvoorbeeld de keuze van de bewoner om éénmaal per week in bad te gaan.

In samenspraak met het management zal worden nagegaan of, hoe en wanneer de organisatorische belemmeringen kunnen worden opgeheven.

Het overzicht zorgafspraken wordt ondertekend door zowel de verzorgende (e.v.v.-er) als de bewoner. Met de ondertekening geeft de bewoner toestemming om die zorg te verlenen die in het overzicht staat vermeld. 


\section{Overzicht Zorgafspraken}

\section{Persoonlijke verzorging}

Wat is karakteristiek voor de bewoner met betrekking tot de persoonlijke verzorging of lichamelijke verschijning?

Welke keuzes wil de bewoner maken m.b.t. de persoonlijke verzorging (bijv. ta.v. het tijdstip van verzorging; douchen en baden; bezoek aan kapper of van pedicure ed.) ?

Wil de bewoner geholpen worden bij de persoonlijke verzorging?

ondersteuningsbehoefte

$\begin{array}{llllll}0 & 1 & 2 & 3 & 4^{*}\end{array}$

wassen

ankleden

overige lichamelijke verzorging

(haren kammen, make-up opbrengen, incontinentiemateriaal

aanbrengen/verwisselen)

Toelichting op de ondersteuningsbehoefte

Heeft de bewoner een interventiebehoefte/behandelbehoefte

Heeft de bewoner speciale aandoeningen of lichamelijke klachten waardoor medicatie, hulpmiddelen of therapieẻn nodig zijn (bijv. t.a.v. de huid, het gehoor, het gezichtsvermogen of de uitscheiding)

Zijn er nog verdere aandachtspunten m.b.t. de persoonlijke verzorging?

\section{Beweging}

Wat is karakteristiek voor de bewoner m.b.t. diens beweging? 
Welke keuzes wil de bewoner maken m.b.t. beweging (bijv. deelname aan meer bewegen voor ouderen; graag naar buiten voor een wandeling; aanschaffgebruik van hulpmiddelen)?

Wil de bewoner geholpen worden bij de beweging of lichaamshouding?

ondersteuningsbehoefte

$\begin{array}{lllll}0 & 1 & 2 & 3 & 4\end{array}$

beweging

lichaamshouding

Toelichting op de ondersteuningsbehoefte

interventiebehoefte/behandelbehoefte

Heeft de bewoner speciale aandoeningen of klachten waardoor medicatie, hulpmiddelen of therapieën nodig zijn om de bewegingsmogelijkheden te beïnvloeden

Zijn er nog verdere aandachtspunten m.b.t. de beweging of houding

3. Voeding

Wat is karakteristiek voor de bewoner m.b.t. diens voeding?

Welke keuzes wil de bewoner maken m.b.t. de voeding (bijv. tijdstip voor de warme maaltijd; zelf broodmaaltijden verzorgen; vegetarisch eten ed.)?

Wil de bewoner geholpen worden bij de voeding?

ondersteuningsbehoefte

$\begin{array}{lllll}0 & 1 & 2 & 3 & 4\end{array}$

voeding

Toelichting op de ondersteuningsbehoefte

interventiebehoefte/behandelbehoefte

Heeft de bewoner nog speciale wensen m.b.t. voeding in verband met lichamelijke aandoeningen of klachten 
(bijv, behoefte aan dieet; allergisch voor bepaalde producten )?

Zijn er nog verdere aandachtspunten m.b.t. voeding

\section{Daginvulling en levensritme}

Wat is karakteristiek voor de bewoner m.b.t. diens daginvulling of levensritme (bijv. bij de dagindeling en vrijetijdsbesteding; de vroegere werksituatie ed.)

Welke keuzes wil de bewoner maken m.b.t daginvulling of levensritme (bijv. t.a.v. rusttijden, deelname aan activiteiten (begeleiding), uitoefening van een hobby, ed.).

Wil de bewoner geholpen worden bij de daginvulling of het levensritme? ondersteuningsbehoefte

$\begin{array}{lllll}0 & 1 & 2 & 3 & 4\end{array}$

daginvulling / levensritme

Toelichting op de ondersteuningsbehoefte

interventiebehoefte/behandelbehoefte

Heeft de bewoner speciale aandoeningen of klachten waardoor medicatie, hulpmiddelen of therapieën nodig zijn om de daginvulling of het levensritme te beïnvloeden (bijv. behoefte aan slaapmedicatie)?

Zijn er nog verdere aandachtspunten m.b.t. daginvulling of levensritme 


\section{Psychisch functioneren}

Wat is karakteristiek voor de bewoner m.b.t. diens psychisch functioneren (zijn er onderwerpen die de bewoner bezighouden; bijv. over hoe de plaatsing in het verzorgingshuis is ervaren en het verblijf nu beleefd wordt, of t.a.v. zijn verleden; zijn er zaken waar de bewoner erg gevoelig voor is of erg prijs op stelt; spant de bewoner zich in om 'bij de tijd te blijven'; wat is doorgaans zijn stemming ed. )

Welke keuzes wil de bewoner maken m.b.t. het psychisch functioneren (bijv. deelname aan het gezamenlijk lezen van de krant)

Wil de bewoner geholpen worden bij zijn psychisch functioneren?

ondersteumingsbehoefte

$\begin{array}{lllll}0 & 1 & 2 & 3 & 4\end{array}$

psychisch functioneren

(... $\quad \cdots \quad \cdots \quad \cdots \quad \ldots$

Toelichting op de ondersteuningsbehoefte

interventiebehoefte/behandelbehoefte

Heeft de bewoner speciale aandoeningen of klachten waarvoor hij medicatie, hulpmiddelen of therapieën nodig heeft om het psychisch functioneren te beïnvloeden? (bijv. geheugenverlies; depressiviteit ed.)

Zijn er nog verdere aandachtspunten m.b.t. het psychisch functioneren?

\section{Sociaal functioneren}

Wat is karakteristiek voor de bewoner m.b.t. diens sociaal functioneren? (bijv. inzake contacten/relaties met familieleden en in het verzorgingshuis; ervaring van eenzaamheid: intimiteit ed.)

Welke keuzes wil de bewoner maken m.b.t. het sociaal functioneren? (bijv. inzake ontvangst van bezoek; contact met contactfunctionaris van het verzorgingshuis; deelname aan sociale activiteiten: wie de contactpersoon is; diensten verrichten voor medebewoners; deelnemen aan de menucommissie en/of de cliëntenraad) 
Wil de bewoner geholpen worden bij het sociaal functioneren? (bijvoorbeeld bij de kennismaking met medebewoners) ondersteuningsbehoefte $\begin{array}{lllll}0 & 1 & 2 & 3 & 4\end{array}$

sociaal functioneren

Toelichting op de ondersteuningsbehoefte

interventiebehoefte/behandelbehoefie

Heeft de bewoner bepaalde problemen bij het sociaal functioneren of met relaties waarvoor hij professionele steun nodig heeft? (bijv. behoefte aan mediator voor familieconflict; behoefte aan mentorschap ed.)

Zijn er nog verdere aandachtspunten m.b.t. het sociaal functioneren?

\section{Woon-leefomgeving}

Wat is karakteristiek voor de bewoner m.b.t. het omgaan met zijn woon-leefomgeving ( bijv. inzake schoonmaken en opruimen van het appartement, gehecht zijn aan bepaalde spullen; de behoefte aan privacy ed.)

Welke keuzes wil de bewoner maken m.b.t. zijn woon-leefomgeving (bijv. t.a.v. frequentie en intensiteit van hulp bij schoonmaken; t.a.v. het niet zonder kloppen of bellen laten betreden van zijn appartement door medewerkers; het houden van een huisdier; het doen van klusjes voor het huis ed.)

Wil de bewoner geholpen worden bij de zorg voor de woon-leefomgeving? ondersteuningsbehoefte

$\begin{array}{lllll}0 & 1 & 2 & 3 & 4\end{array}$

zorg voor de woonleefomgeving

$\begin{array}{lllllllll} & \ldots & \ldots & \ldots & \cdots & \ldots\end{array}$

Toelichting op de ondersteuningsbehoefte

interventiebehoefte/behandelbehoefte

Heeft de bewoner speciale aandoeningen of klachten die van invloed zijn op zijn omgang met de woonleefomgeving? (bijvoorbeeld allergieën voor stoffen of schoonmaakmiddelen; zuurstoftekort waardoor extra 
ventilatie van belang is; hoogtevrees, waardoor er voorkeur is voor bepaalde etages in zorgcentrum ed.)

Zijn er nog verdere aandachtspunten m.b.t. de woon-leefomgeving

\section{Levensbeschouwelijk functioneren}

Wat is karakteristiek voor de bewoner m.b.t. diens levensbeschouwelijk functioneren (bijv. inzake normen en waarden van de bewoner; kijk op het leven en de dood; verwerking van verdriet; betekenis van religie; omgaan met eigen beperkingen en mogelijkheden ed.)

Welke keuzes wil de bewoner maken m.b.t. het levensbeschouwelijk functioneren (bijv. t.a.v. contact met pastor/dominee; t.a.v. het ontvangen van sacramenten; deelname aan gebedsdiensten, of aan gespreksgroepen; willen beschikken over een niel-reanimeren pas en/of over een euthanasieverklaring.)

Wil de bewoner geholpen worden bij het levensbeschouwelijk functioneren? ondersteuningsbehoefte

$\begin{array}{lllll}0 & 1 & 2 & 3 & 4\end{array}$

levensbeschouwelijk functioneren

Toelichting op de ondersteuningsbehoefte

interventiebehoefte/behandelbehoefte

Heeft de bewoner bepaalde behoeften bij het levensbeschouwelijk functioneren waarvoor hij om steun vraagt? (bijv. bij het niet kunnen verwerken van de lichamelijke beperkingen waarmee hij te maken heeft; bij het omgaan met het naderend levenseinde ed.)

Zijn er nog verdere aandachtspunten m.b.t. het levensbeschouwelijk functioneren?

\section{Inzet mantelzorger van bewoner}

naam, adres en telefoonnummer mantelzorger: 
Activiteit afspraak mantelzorg

1 persoonlijke verzorging (bijv: gaat eenmaal per drie weken met bewoner naar de kapper)

2 beweging

3 voeding

4 daginvulling / levensritme

5 psychisch functioneren

6 sociaal functioneren

7 woon-leef omgeving

8 levensbeschouwelijk functioneren

Organisatorische belemmeringen

(behoeftes, keuzes, verwachtingen of wensen van bewoner die niet kunnen worden gerealiseerd vanwege organisatorische belemmeringen).

Gemeld bij clusterhoofd / zorgcoördinator

Reactie ontvangen dd:

\section{Ondertekening zorgafspraken}

Overzicht Zorgafspraken opgesteld dd:

Door teamlid:

Handtekening bewoner voor toestemming uitvoering zorgafspraken

Datum ondertekening bewoner.

Wenst de bewoner over dit Overzicht Zorgafspraken te beschikken, of een exemplaar in het eigen appartement te bewaren $\mathrm{ja} /$ nee

Dit overzicht is bijgesteld dd:

( zie volgende Overzicht Zorgafspraken)

* ondersteuningsbehoeften

0 .de bewoner gaat zijn eigen gang; 1.in de buurt blijven;aandacht geven /observeren of bewoner zelf tot de activiteit of keuze/beslissing in staat is; 2.de bewoner aansporen of adviseren de activiteit te verrichten, de keuze te maken of de beslissing te nemen; 3.de bewoner helpen bij de activiteit , bijvoorbeeld door de activiteit gedeeltelijk overnemen/ de bewoner helpen bij het maken van keuzes of het nemen van beslissingen, bijvoorbeeld door aanwijzingen te geven of door te overtuigen 4.de activiteit geheel overnemen/voor de bewoner kiezen of beslissen . 

